\title{
CARBON DIOXIDE, HYDROGRAPHIC, AND CHEMICAL DATA OBTAINED IN THE CENTRAL SOUTH PACIFIC OCEAN (WOCE SECTIONS P17S AND P16S) DURING THE TUNES-2 EXPEDITION OF THE R/V THOMAS WASHINGTON, JULY-AUGUST, 1991
}

Contributed by

Taro Takahashi*, John G. Goddard*, Stephany Rubin*, David W. Chipman*, Stewart C. Sutherland", and Catherine Goyet

"Lamont-Doherty Earth Observatory of Columbia University Palisades, New York

"Woods Hole Oceanographic Institution Woods Hole, Massachusetts

Prepared by Alexander Kozyr ${ }^{* *}$ Carbon Dioxide Information Analysis Center Oak Ridge National Laboratory Oak Ridge, Tennessee

***Energy, Environment, and Resources Center The University of Tennessee, Knoxville

Environmental Sciences Division Publication No. 4465

Date Published: March 1996

Prepared for the Global Change Research Program Environmental Sciences Division Office of Health and Environmental Research U.S. Department of Energy

Budget Activity Number KP 0502000

Prepared by the Carbon Dioxide Information Analysis Center OAK RDGE NATIONAL LABORATORY

Oak Ridge, Tennessee 37831-6335 managed by LOCKHEED MARTIN ENERGY RESEARCH CORP. for the U.S. DEPARTMENT OF ENERGY under contract DE-AC05-96OR22464 
$\because \because+\infty$ 


\section{CONTENTS}

Page

LIST OF FIGURES $\ldots \ldots \ldots \ldots \ldots \ldots \ldots \ldots \ldots \ldots \ldots \ldots \ldots \ldots \ldots \ldots \ldots \ldots \ldots \ldots$

LIST OF TABLES $\ldots \ldots \ldots \ldots \ldots \ldots \ldots \ldots \ldots \ldots \ldots \ldots \ldots \ldots \ldots \ldots \ldots \ldots \ldots$ vii

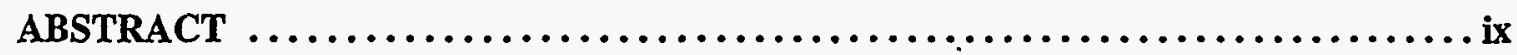

PART 1: OVERVIEW $\ldots \ldots \ldots \ldots \ldots \ldots \ldots \ldots \ldots \ldots \ldots \ldots \ldots \ldots \ldots \ldots \ldots \ldots \ldots$

1. BACKGROUND INFORMATION $\ldots \ldots \ldots \ldots \ldots \ldots \ldots \ldots \ldots \ldots \ldots \ldots \ldots \ldots$

2. DESCRIPTION OF THE EXPEDITION $\ldots \ldots \ldots \ldots \ldots \ldots \ldots \ldots \ldots \ldots \ldots \ldots$

2.1 R/V Thomas Washington TUNES-2 Expedition Information $\ldots \ldots \ldots \ldots \ldots$

2.2 Brief Cruise Summary $\ldots \ldots \ldots \ldots \ldots \ldots \ldots \ldots \ldots \ldots \ldots \ldots \ldots \ldots$

3. DESCRIPTION OF VARIABLES AND METHODS $\ldots \ldots \ldots \ldots \ldots \ldots \ldots \ldots \ldots$

3.1 Hydrographic Measurements $\ldots \ldots \ldots \ldots \ldots \ldots \ldots \ldots \ldots \ldots \ldots \ldots \ldots \ldots$

3.2 CFC-11 and CFC-12 Measurements $\ldots \ldots \ldots \ldots \ldots \ldots \ldots \ldots \ldots \ldots \ldots$

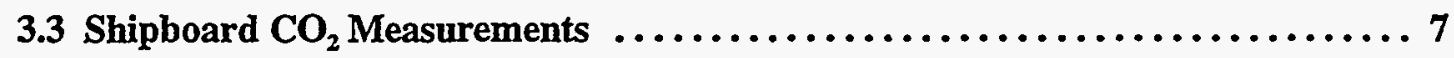

3.4 Shore-based $\mathrm{CO}_{2}$ Analyses $\ldots \ldots \ldots \ldots \ldots \ldots \ldots \ldots \ldots \ldots \ldots \ldots \ldots \ldots$

4. DATA CHECKS AND PROCESSING PERFORMED BY CDIAC $\ldots \ldots \ldots \ldots \ldots$

5. HOW TO OBTAIN THE DATA AND DOCUMENTATION $\ldots \ldots \ldots \ldots \ldots \ldots 17$

6. REFERENCES $\ldots \ldots \ldots \ldots \ldots \ldots \ldots \ldots \ldots \ldots \ldots \ldots \ldots \ldots \ldots \ldots \ldots \ldots \ldots$

PART 2: CONTENT AND FORMAT OF DATA FILES $\ldots \ldots \ldots \ldots \ldots \ldots \ldots \ldots$

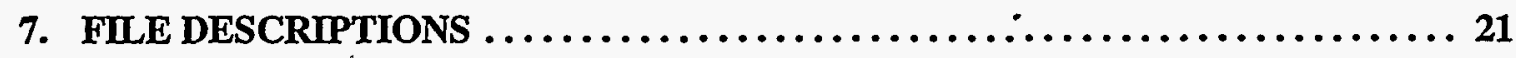

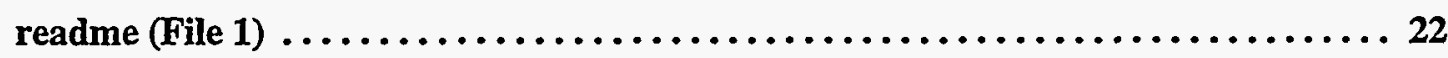

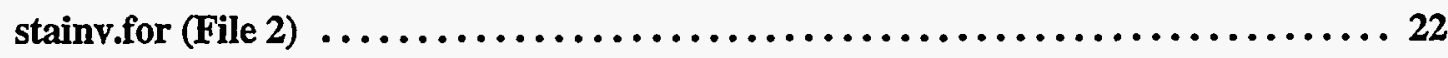

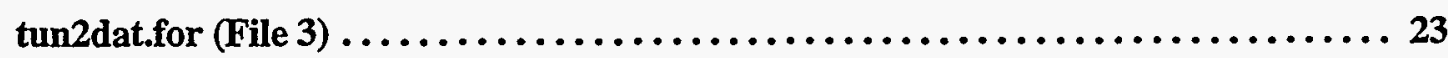




\section{Page}

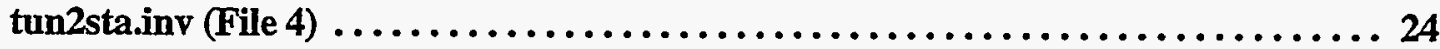

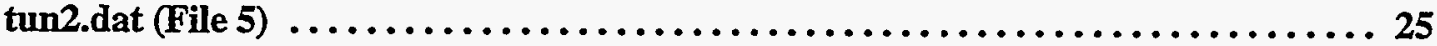

8. VERIFICATION OF DATA TRANSPORT $\ldots \ldots \ldots \ldots \ldots \ldots \ldots \ldots \ldots \ldots \ldots$

APPENDIX A: STATION INVENTORY $\ldots \ldots \ldots \ldots \ldots \ldots \ldots \ldots \ldots \ldots \ldots \ldots \ldots \ldots$

APPENDIX B: REPRINT OF PERTINENT LITERATURE $\ldots \ldots \ldots \ldots \ldots \ldots \ldots . .$. 


\section{LIST OF FIGURES}

Figure

$\underline{\text { Page }}$

1 Station locations during R/V Thomas Washington TUNES-2 Expedition ......... 4

2 Sampling depths at all hydrographic stations occupied during RV Thomas

Washington TUNES-2 Expedition $\ldots \ldots \ldots \ldots \ldots \ldots \ldots \ldots \ldots \ldots \ldots$

3 Shipboard total $\mathrm{CO}_{2}$ minus shore-based total $\mathrm{CO}_{2}$ versus depth for Station $180 \ldots \ldots 9$

4 Nested profiles: total $\mathrm{CO}_{2}(\mu \mathrm{mol} / \mathrm{kg})$ vs pressure $(\mathrm{dbar}) \ldots \ldots \ldots \ldots \ldots \ldots \ldots$

5 Nested profiles: total alkalinity $(\mu \mathrm{mol} / \mathrm{kg})$ vs pressure $(\mathrm{dbar}) \ldots \ldots \ldots \ldots \ldots \ldots$

6 Nested profiles: partial pressure of $\mathrm{CO}_{2}(\mu \mathrm{atm})$ vs pressure (dbar) $\ldots \ldots \ldots \ldots \ldots$

\section{DISCLAIMER}

This report was prepared as an account of work sponsored by an agency of the United States Government. Neither the United States Government nor any agency thereof, nor any of their employees, makes any warranty, express or implied, or assumes any legal liability or responsibility for the accuracy, completeness, or usefulness of any information, apparatus, product, or process disclosed, or represents that its use would not infringe privately owned rights. Reference herein to any specific commercial product, process, or service by trade name, trademark, manufacturer, or otherwise does not necessarily constitute or imply its endorsement, recommendation, or favoring by the United States Government or any agency thereof. The views and opinions of authors expressed herein do not necessarily state or reflect those of the United States Government or any agency thereof. 


\section{LIST OF TABLES}

Table

Page

1 Summary of total $\mathrm{CO}_{2}$ replicate data collected during $\mathrm{R} N \mathrm{~V}$ Thomas Washington

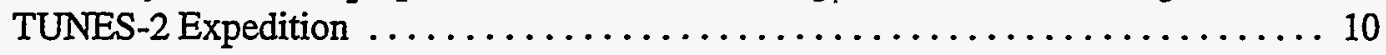

2 Summary of total alkalinity replicate data collected during $\mathrm{R} / \mathrm{V}$ Thomas

Washington TUNES-2 Expedition $\ldots \ldots \ldots \ldots \ldots \ldots \ldots \ldots \ldots \ldots \ldots \ldots \ldots \ldots \ldots \ldots \ldots$

3 Content, size, and format of data files $\ldots \ldots \ldots \ldots \ldots \ldots \ldots \ldots \ldots \ldots \ldots \ldots \ldots$

4 Partial listing of "tun2sta.inv" (File 4) $\ldots \ldots \ldots \ldots \ldots \ldots \ldots \ldots \ldots \ldots \ldots \ldots \ldots \ldots \ldots \ldots$

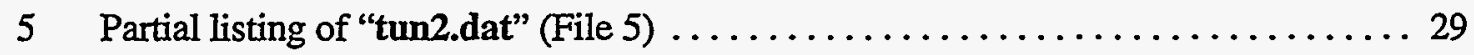

A.1 Station inventory information for the 97 sites occupied during $\mathrm{R} / \mathrm{V}$ Thomas

Washington TUNES-2 Expedition ....................... 


\begin{abstract}
Takahashi, T., J. G. Goddard, S. Rubin, D. W. Chipman, S. C. Sutherland, and C. Goyet. 1995. Carbon Dioxide, Hydrographic, and Chemical Data Obtained in the Central South Pacific Ocean (WOCE Sections P17S and P16S) During the TUNES-2 Expedition of the R/V Thomas Washington, July-August, 1991. ORNL/CDIAC-86, NDP-054. Carbon Dioxide Information Analysis Center, Oak Ridge National Laboratory, Oak Ridge, Tennessee. $210 \mathrm{pp}$.
\end{abstract}

This data documentation discusses the procedures and methods used to measure total carbon dioxide $\left(\mathrm{TCO}_{2}\right)$, discrete partial pressure of $\mathrm{TCO}_{2}\left(\mathrm{pCO}_{2}\right)$, and total alkalinity (TALK), during the Research Vessel (R/V) Thomas Washington TUNES Leg 2 Expedition in the central South Pacific Ocean. Conducted as part of the World Ocean Circulation Experiment (WOCE), the cruise began in Papeete, Tahiti, French Polynesia, on July 16, 1991, and returned to Papeete on August 25, 1991. WOCE Meridional Sections P17S along $135^{\circ} \mathrm{W}$ and $\mathrm{P} 16 \mathrm{~S}$ along $150^{\circ} \mathrm{W}$ were completed during the 40-day expedition. A total of 97 hydrographic stations were occupied. Hydrographic and chemical measurements made along WOCE Sections P17S and P16S included pressure, temperature, salinity, and oxygen measured by conductivity, temperature and depth sensor; bottle salinity; oxygen; phosphate; nitrate; nitrite; silicate; CFC-12; CFC-11; $\mathrm{TCO}_{2} ; \mathrm{TALK}$; and $\mathrm{pCO}_{2}$ measured at $20^{\circ} \mathrm{C}$.

The $\mathrm{TCO}_{2}$ concentration in 1000 seawater samples was determined with a coulometric analysis system, the $\mathrm{pCO}_{2}$ in 940 water samples was determined with an equilibrator/gas chromatograph system, while the TALK concentration in 139 samples was determined on shore at the laboratory of C. Goyet of Woods Hole Oceanographic Institution with an alkalinity titration system. In addition, 156 coulometric measurements for the Certified Reference Material (Batch \#6) were made and yielded a mean value of $2303.2 \pm 1.5 \mu \mathrm{mol} / \mathrm{kg}$. This mean value agrees within a standard deviation of the $2304.6 \pm 1.6 \mu \mathrm{mol} / \mathrm{kg}(\mathrm{N}=9)$ value determined with the manometer of C. D. Keeling at Scripps Institution of Oceanography (SIO). Replicate samples from 11 Niskin bottles at 4 stations were also collected for later shore-based reference analyses of $\mathrm{TCO}_{2}$ and TALK by vacuum extraction and manometry in the laboratory of C. D. Keeling of SIO.

The RN Thomas Washington TUNES-2 Expedition data set is available free-of-charge as a numeric data package (NDP) from the Carbon Dioxide Information Analysis Center. The NDP consists of two oceanographic data files, two FORTRAN 77 data-retrieval routine files, a readme file, and this printed documentation, which describes the contents and format of all files and the procedures and methods used to obtain the data.

Keywords: carbon dioxide; World Ocean Circulation Experiment; South Pacific Ocean; hydrographic measurements; carbon cycle; carbonate chemistry; coulometer 


\section{PART 1:}

\section{OVERVIEW}





\section{BACKGROUND INFORMATION}

The World Ocean plays a dynamic role in the Earth's climate: it captures heat from the sun, transports it, and releases it thousands of miles away. These oceanic-solar-atmospheric interactions affect winds, rainfall patterns, and temperatures on a global scale. The oceans also play a major role in global carbon-cycle processes. Carbon is unevenly distributed in the oceans because of complex circulation patterns and biogeochemical cycles, neither of which is completely understood, as well as the biological processes of photosynthesis and respiration. The oceans are estimated to hold 38,000 gigatons of carbon, 50 times more than that in the atmosphere and 20 times more than that held by plants, animals, and the soil. If only $2 \%$ of the carbon stored in the oceans were released, the level of atmospheric carbon dioxide $\left(\mathrm{CO}_{2}\right)$ would double. Every year, more than 15 times as much $\mathrm{CO}_{2}$ is exchanged across the sea surface than the amount produced by buming of fossil fuels, deforestation, and other human activities (Williams 1990).

To better understand the ocean's role in climate and climatic changes, several large experiments have already been conducted, and others are currently under way. The largest oceanographic experiment ever attempted is the World Ocean Circulation Experiment (WOCE). A major component of the World Climate Research Program, WOCE brings together the expertise of scientists and technicians from more than 30 nations. In the United States, WOCE is supported by the federal government under the Global Change Research Program. The multi-agency U.S. effort is led by the National Science Foundation and supported by major contributions from the National Oceanic and Atmospheric Administration, the U.S. Department of Energy (DOE), the Office of Naval Research, and the National Aeronautics and Space Administration. Although total carbon dioxide $\left(\mathrm{TCO}_{2}\right)$ is not an official WOCE measurement, a coordinated effort, supported in the United States by the DOE, is being made on WOCE cruises to measure the global, spatial, and temporal distributions of $\mathrm{TCO}_{2}$ and other carbon-related parameters. The goal of the $\mathrm{CO}_{2}$ survey include estimation of the meridional transport of inorganic carbon in the Pacific Ocean in a manner analogous to the oceanic heat transport (Bryden and Hall 1980; Brewer et al. 1989; Roemmich and Wunsch 1985), evaluation of the exchange of $\mathrm{CO}_{2}$ between the atmosphere and the ocean, and preparation of a database suitable for carbon-cycle modeling and the subsequent assessment of the anthropogenic $\mathrm{CO}_{2}$ increase in the oceans. The final data set is expected to cover $\sim 23,000$ stations.

This report presents $\mathrm{CO}_{2}$-related measurements obtained during the 40-day Leg 2 of the Research Vessel (R/V) Thomas Washington TUNES Expedition (TUNES-2) along the WOCE Sections P17S and P16S, which are located in the central part of the South Pacific Ocean along the $135^{\circ} \mathrm{W}$ (between $6^{\circ} \mathrm{S}$ and $33^{\circ} \mathrm{S}$ ) and $150^{\circ} \mathrm{W}$ (between $17.5^{\circ} \mathrm{S}$ and $37.5^{\circ} \mathrm{S}$ ) meridians respectively (Fig. 1).

In addition to $\mathrm{TCO}_{2}$, parameters measured include total alkalinity (TALK); discrete partial pressure of $\mathrm{CO}_{2}\left(\mathrm{pCO}_{2}\right)$ measured at $20^{\circ} \mathrm{C}$; pressure, temperature, salinity, and oxygen measured by conductivity, temperature, and depth sensor (CTD); bottle salinity; oxygen; nutrients; chlorofluorocarbons (CFCs); tritium; and helium.

Scientists from the following institutions participated in the cruise: Scripps Institution of Oceanography (SIO), Woods Hole Oceanographic Institution (WHOI), Lamont-Doherty Earth Observatory (LDEO), Rosenstiel School of Marine and Atmospheric Science (RSMAS), University of Hawaii (UH), and Princeton University (PU).

The $\mathrm{CO}_{2}$ investigation during the TUNES-2 Expedition was supported by a grant (No. DEFGO2-90-ER60983) from the U.S. DOE. 


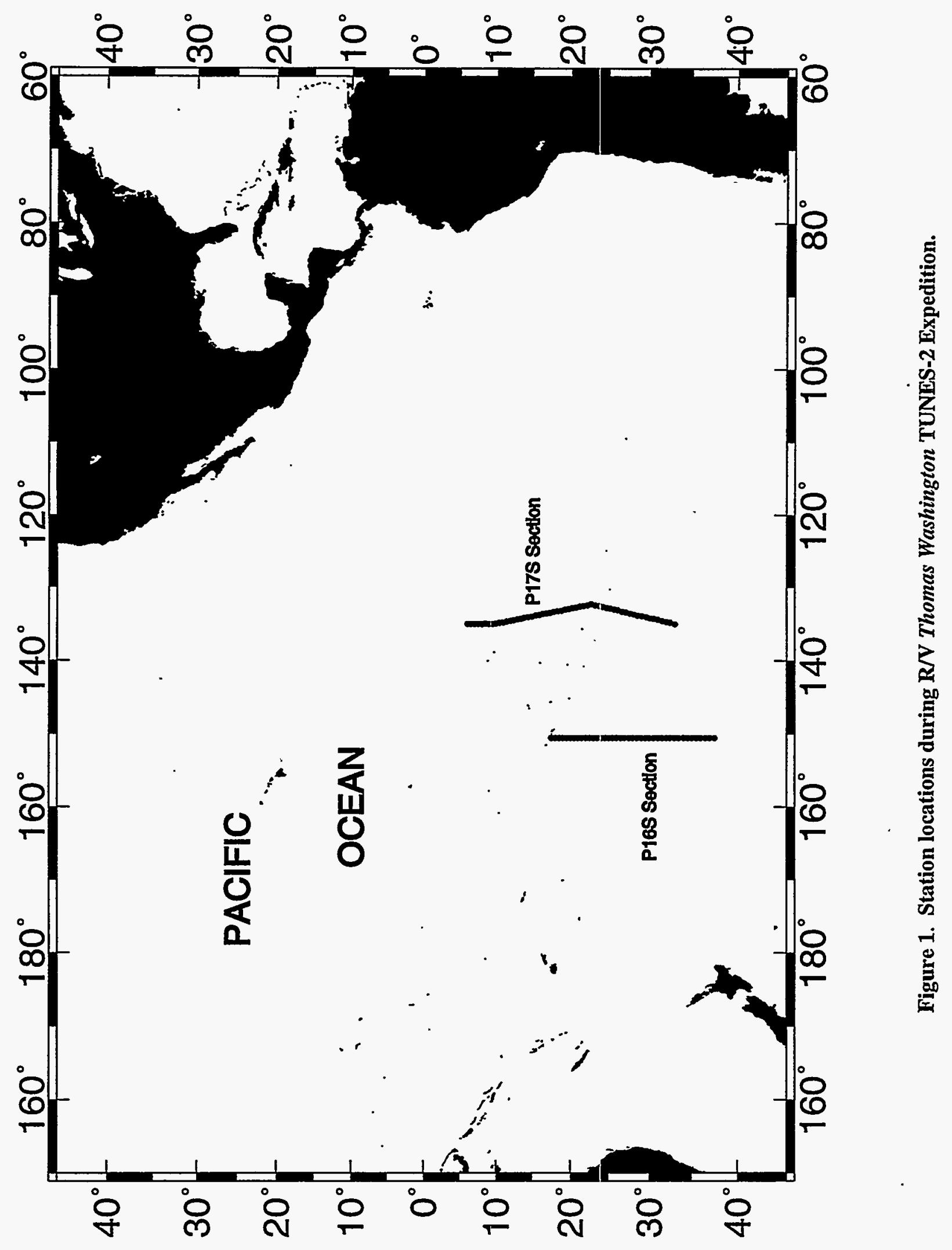




\section{DESCRIPTION OF THE EXPEDITION}

\subsection{R/V Thomas Washington TUNES-2 Expedition Information}

R/V Thomas Washington TUNES-2 Expedition information is as follows:

$\begin{array}{ll}\text { Ship name } & \text { Thomas Washington } \\ \text { Cruise/leg } & \text { TUNES/2 } \\ \text { Expocode } & \text { 31WTTUNES/2 } \\ \text { WOCE Sections } & \text { P17S/P16S } \\ \text { Ports of call } & \text { Papeete, Tahiti, French Polynesia (round trip) } \\ \text { Dates } & \text { July 16-August 25, 1991 } \\ \text { Chief Scientist } & \text { James H. Swift, (SIO) } \\ \text { Master } & \text { A. Arsenault }\end{array}$

\section{Parameters measured}

CTD, oxygen, and nutrients (P17S)

CTD, oxygen, and nutrients (P16S)

Drifters

ALACE floats

Tritium and helium

$\mathrm{TCO}_{2}$ and $\mathrm{pCO}_{2}$ (shipboard)

$\mathrm{TCO}_{2}$ and TALK (shore)

TALK (shore)

$\mathrm{pCO}_{2}$ (underway)

CFCs

$\mathrm{ADCP}$

${ }^{14} \mathrm{C},{ }^{226} \mathrm{Ra} 2{ }^{228} \mathrm{Ra}$, and $\mathrm{Ba}$

\section{Institution Principal investigators}

$\begin{array}{ll}\text { SIO } & \text { L. Talley, M Tsuchiya } \\ \text { SIO } & \text { J. Swift } \\ \text { SIO } & \text { Pearn Niiler } \\ \text { SIO } & \text { R. Davis } \\ \text { WHOI } & \text { W. Jenkins } \\ \text { LDEO } & \text { D. Chipman, T Takahashi } \\ \text { SIO } & \text { C. Keeling } \\ \text { WHOI } & \text { C. Goyet } \\ \text { SIO } & \text { R. Weiss } \\ \text { RSMAS } & \text { R. Fine } \\ \text { UH } & \text { P. Hacker } \\ \text { PU } & \text { R. Key }\end{array}$

\section{Participating Institutions}

SIO

WHOI

LDEO

RSMAS

UH

PU
Scripps Institution of Oceanography (University of California, San Diego)

Woods Hole Oceanographic Institution

Lamont-Doherty Earth Observatory (Columbia University)

Rosenstiel School of Marine and Atmospheric Science (University of Miami)

University of Hawaii

Princeton University 


\subsection{Brief Cruise Summary}

Scientific work for the first portion of the TUNES-2 Expedition (Section P17S) was proposed by Lynne Talley and Mizuki Tsuchiya (both SIO); the second portion (P16S) was planned by James Swift (SIO). The overall purpose of both sections was to contribute to a planned WOCE Hydrographic Program multi-cruise examination of the meridional circulation and water mass transportation in the Pacific Ocean, in this case emphasizing the central subtropical gyros of the North and South Pacific.

After departure from Papeete, Tahiti, on July 16, 1991, WOCE Section P17S began on July 21, 1991 , with the occupation of Station 124 at $6^{\circ} \mathrm{S}$ and $135^{\circ} \mathrm{W}$ and continued south along $135^{\circ} \mathrm{W}$ meridian with stations every $30 \mathrm{~nm}$. The P17S track, which followed the ridge extending from the East Pacific Rise to the Tuanotu Islands, was shifted slightly to the east, then back again, in order to cross the rise at a saddle (see Fig. 1). The planned southern Station $179\left(33^{\circ} 03^{\prime} \mathrm{S}\right.$ and $135^{\circ} 01^{\prime} \mathrm{W}$ ) of the P17S line was reached without major problems on August 8,1991, and the vessel steamed for 83 hours to the southern end of the P16S line. In general, the weather was relatively good during the work on the P17S line. A total of 56 stations were occupied.

WOCE Section P16S began on August 11, 1991, with the occupation of Station 180 at $37^{\circ} 30^{\prime}$ $S$ and $150^{\circ} 28^{\prime} \mathrm{W}$, and continued north along $150^{\circ} \mathrm{W}$ meridian with stations spaced every $30 \mathrm{~nm}$. The weather was still remarkably favorable considering that operations were being carried out during the middle of the austral winter. Although some instrument problems that could potentially affect CTD data quality occurred during this section of the cruise, researchers managed to complete every planned station. The last station of the TUNES-2 Expedition, station 210, was occupied on August 25,1991 , at $17^{\circ} 31^{\prime} \mathrm{S}$ and $150^{\circ} 30^{\prime} \mathrm{W}$, and the same day R/V Thomas Wáshington arrived back at Papeete, Tahiti. A total of 41 stations were occupied during Section P16S.

\section{DESCRIPTION OF VARIABLES AND METHODS}

The data file tun2.dat (see description in Part 2) in this numeric data package (NDP) contains the following variables: station numbers; cast numbers; sample numbers; bottle numbers; CTD pressure, temperature, salinity, and oxygen; potential temperature; bottle salinity; concentration of dissolved oxygen, silicate, nitrate, nitrite, and phosphate; CFC-11; CFC-12; $\mathrm{TCO}_{2}$ and TALK concentration; $\mathrm{pCO}_{2}$ measured at $20^{\circ} \mathrm{C}$; and data quality flags. The station inventory file tun 2 sta.inv (see Part 2) contains the expocode, section number, station number, latitude, longitude, sampling date (i.e., month, day, year), sampling time, and bottom depth for each station.

\subsection{Hydrographic Measurements}

The hydrographic measurements and water sampling were conducted by the staff of the SIO Oceanographic Data Facility (ODF). During the expedition, a 24/12 double-ring 36-bottle CTD/rosette sampler was used for sampling. An ODF-modified Neil Brown Mark III CTD, a Benthos altimeter, and a Sea Tech transmissometer were mounted on the rosette frame. Seawater samples were collected in PVC 10-L Niskin and ODF bottles.

A full description of CTD and bottle hydrographic measurements is provided in Takahashi et al. (1993 - a reprint is provided in Appendix B). 


\subsection{CFC-11 and CFC-12 Measurements}

Concentrations of the dissolved chlorofluorocarbons (CFC-11 and CFC-12) were measured by shipboard electron-capture gas chromatography using the methods described by Bullister and Weiss (1988). The measurements were carried out by the group at the University of Miami under the direction of Dr. Rana A. Fine with the assistance of a technician from LDEO, Columbia University. A total of 1847 water analyses were carried out, 23 of which were duplicate analyses. The mean values of duplicate analyses are reported in the data file and are assigned a quality flag of 6 according to the WOCE Operations Manual (Joyce and Corry, 1994).

\subsection{Shipboard $\mathrm{CO}_{2}$ Measurements}

The $\mathrm{TCO}_{2}$ concentration in 1000 seawater samples (Fig. 2) was determined with a coulometric analysis system similar to the one described by Johnson et al. (1985). This system consists of a coulometer (Model 5011) manufactured by UIC, Inc. (Jolliet, III.) and a sample introduction/ $/ \mathrm{CO}_{2}$ extraction system of LDEO design.

The $\mathrm{pCO}_{2}$ in 940 water samples was determined with a fully automated equilibrator-gas chromatograph system that has been described by Chipman et al. (1993).

A full description of shipboard $\mathrm{TCO}_{2}$ and $\mathrm{pCO}_{2}$ measurements is provided in Appendix $\mathrm{B}$.

\subsection{Shore-based $\mathrm{CO}_{2}$ Analyses}

The TALK concentration in 139 samples was determined on shore at the laboratory of C. Goyet of WHOI. Samples were collected in $250-\mathrm{mL}$, standard borosilicate glass, screw-cap bottles and poisoned with $50 \mu \mathrm{L}$ of saturated solution of $\mathrm{HgCl}_{2}$. The samples were stored at room temperature and sent to WHOI for TALK analysis. TALK was determined by potentiometric titration; the method used was derived from one first described by Dyrssen (1965) and later modified by Bradshaw et al. (1981). The automated titration was performed in a closed cell maintained at constant temperature $\left(25 \pm 0.1^{\circ} \mathrm{C}\right)$. To be similar to seawater, the ionic strength of the hydrochloric acid solution $(0.1 \mathrm{~N})$ was adjusted with $\mathrm{NaCl}$. The ratio of the acid normality over the cell volume was calibrated before and after the sample analysis. The calibration consisted of preparing solutions of known TALK concentration and measuring them as described by Brewer et al. (1986). The precision of the measurements was estimated to be better than $0.1 \%$. 


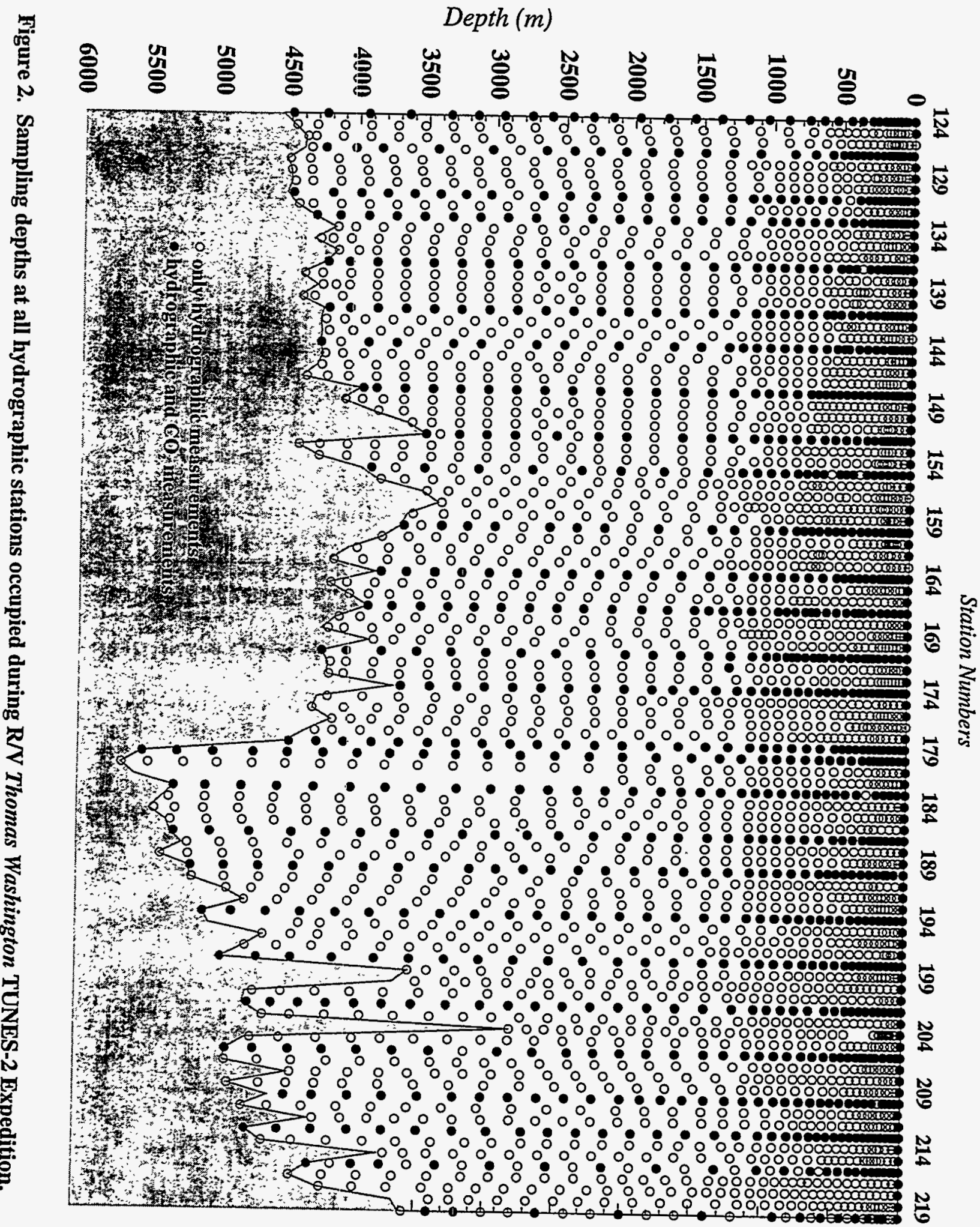


The replicate samples from 11 Niskin bottles at 4 stations were collected for shore-based reference analyses at the laboratory of $\mathrm{C}$. D. Keeling of SIO. The $\mathrm{TCO}_{2}$ measurements were produced by vacuum extraction/manometric analysis and the TALK values by potentiometric titration. Both meäsurements were performed in controlled laboratory conditions using standards. Samples were collected from the same Niskin bottles used to collect samples for shipboard analyses of $\mathrm{TCO}_{2}$. The shore laboratory analyses of $\mathrm{TCO}_{2}$ and TALK employed a precise and proven methodology to provide information on the quality of the shipboard analyses (Guenther et al. 1994). For all shore-based analyses, a replicate $s$ of $1.43 \mu \mathrm{mol} / \mathrm{kg}$ for eleven unflagged pairs was calculated, with no deltas greater than $3 s$. The average difference for eleven comparisons of single replicate samples comparing ship and shore $\mathrm{TCO}_{2}$ values was $-3.5 \pm 2.0 \mu \mathrm{mol} / \mathrm{kg}$. Only two surface water and two deep water comparisons exist for the TUNES-2 Expedition. These represent too few data points for meaningful comparative analysis.

Figure 3 displays the one set of profile differences from Station 180 of the TUNES-2 Expedition. There are eight comparisons from Niskin bottles at $300 \mathrm{~m}$ and deeper. After the one shallowest comparison (a replicate singlet) was omitted, the remaining seven are characterized by an average difference of $-4.3 \pm 1.6 \mu \mathrm{mol} / \mathrm{kg}$. The consistency of the four deeper comparisons, all with excellent bottle pair agreement, is striking. Tables 1 and 2 summarize the replicate shore-based measurements of $\mathrm{TCO}_{2}$ and TALK.

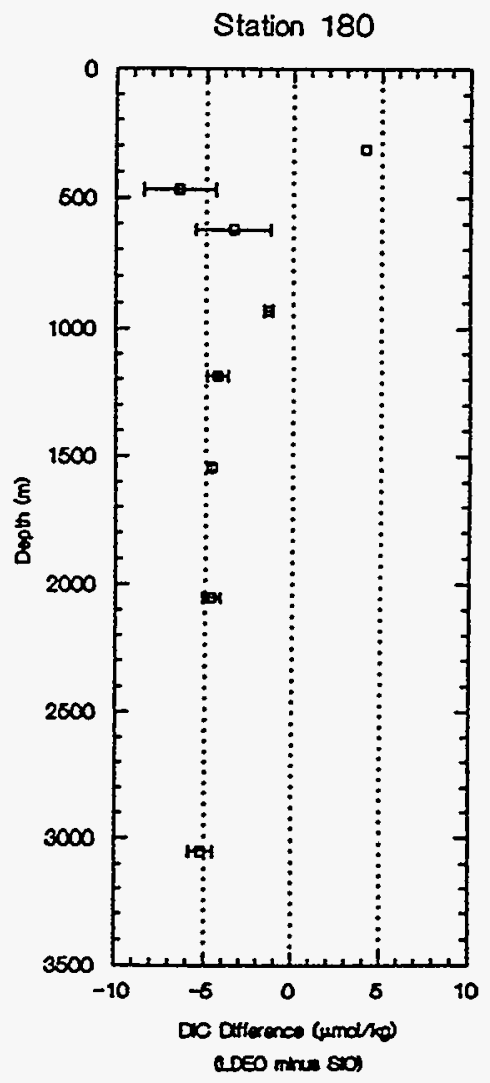

Figure 3. Shipboard total $\mathrm{CO}_{2}$ minus shore-based total $\mathrm{CO}_{2}$ versus depth for Station 180 . Open squares represent shipboard minus average shore-based $\mathrm{TCO}_{2}$. Horizontal bracketed lines indicate replicate pair deltas. 
Table 1. Summary of total $\mathrm{CO}_{2}$ replicate data collected during $\mathrm{R} / \mathrm{V}$ Thomas Washington TUNES-2 Expedition

THE CARBOH DIOXIDE PROJECT OF THE SCRIPPS IIISTITUTIOH OF OCEANOGRAPHY TUHES LEg 2 1991 Paciflc WOCE Lines P17S/P16S

\begin{tabular}{|c|c|c|c|c|c|c|c|c|c|c|c|c|c|c|c|c|c|}
\hline $\begin{array}{l}\text { LEG } \\
\text { STN }\end{array}$ & $\begin{array}{l}\text { LAT. } \\
\text { LONG. }\end{array}$ & $\begin{array}{l}\text { CAST } \\
\text { WISK }\end{array}$ & $\begin{array}{l}\text { DEPTH } \\
\text { (b) }\end{array}$ & $\begin{array}{l}\text { SAHPLEE } \\
\text { DATE }\end{array}$ & $\begin{array}{c}\text { EXTRAC } \\
\text { DATE }\end{array}$ & $\begin{array}{l}\text { AlJALYSIS } \\
\text { DATE }\end{array}$ & $\begin{array}{l}\text { HANO } \\
\text { TYPE }\end{array}$ & $\begin{array}{l}\text { SAMPLE } \\
\text { BO'TTLE }\end{array}$ & RUN & FLAG & $\begin{array}{l}\text { S.I.O. } \\
\text { RUN }\end{array}$ & $\begin{array}{c}\text { RUIN } \\
\text { DELTA }\end{array}$ & $\begin{array}{c}\text { BOTTLE } \\
\text { TCO } \\
-\quad\left(\mu B_{2} L E\right.\end{array}$ & $\begin{array}{l}\text { BOTTLE " } \\
\text { DELTA } \\
\text { ES/KG S.II) }\end{array}$ & $\begin{array}{c}\text { "MISKIII" } \\
\text { AVG }\end{array}$ & $\begin{array}{c}\text { LDEO } \\
\mathrm{TCO}_{2}\end{array}$ & $\begin{array}{r}\text { LDEO } \\
- \text { S.I.O. } \\
\end{array}$ \\
\hline $\begin{array}{c}2 \\
160\end{array}$ & $\begin{array}{r}23-435 \\
132-33 w\end{array}$ & 119 & 909 & 01AUG91 & $\begin{array}{l}11 \text { DEC91 } \\
11 \text { DEC91 } \\
11 \text { DEC91 } \\
11 \text { DEC91 }\end{array}$ & $\begin{array}{l}11 \text { DEC } 91 \\
20 \text { DEC91 } \\
12 \text { DEC } 91 \\
20 \text { DEC } 91\end{array}$ & $\begin{array}{l}\text { M } \\
\text { S } \\
\text { H } \\
\text { S }\end{array}$ & $\begin{array}{l}\text { S4158 } \\
\text { S4158 } \\
\text { S4159 } \\
\text { S4159 }\end{array}$ & $\begin{array}{l}001 \\
001 \\
001 \\
001\end{array}$ & & $\begin{array}{l}2208.25 \\
2208.73 \\
2207.96 \\
2208.23\end{array}$ & & $\begin{array}{l}2208.25 \\
2208.73 \\
2207.96 \\
2208.23\end{array}$ & $\begin{array}{l}-0.29 \\
-0.50\end{array}$ & $\begin{array}{l}2208.10 \\
2208.48\end{array}$ & $\begin{array}{l}2206.1 \\
2206.1\end{array}$ & $\begin{array}{l}-2.00 \\
-2.38\end{array}$ \\
\hline \multirow[t]{2}{*}{$\stackrel{2}{174}$} & $\begin{array}{r}30-32 S \\
134-20 W\end{array}$ & 161 & 4 & 06AUG91 & $\begin{array}{l}\text { 03DEC91 } \\
\text { 03DEC91 } \\
03 \mathrm{DEC91} \\
\text { 03DEC91 }\end{array}$ & $\begin{array}{l}\text { 04DEC91 } \\
\text { 09DEC91 } \\
\text { 04DEC91 } \\
\text { 09DEC91 }\end{array}$ & $\begin{array}{l}M \\
S \\
M \\
S\end{array}$ & $\begin{array}{l}\text { R4548 } \\
\text { R4548 } \\
\text { R4549 } \\
\text { R4549 }\end{array}$ & $\begin{array}{l}001 \\
001 \\
001 \\
001\end{array}$ & & $\begin{array}{l}2023.46 \\
2022.97 \\
2023.77 \\
2024.61\end{array}$ & & $\begin{array}{l}2023.46 \\
2022.97 \\
2023.77 \\
2024.61\end{array}$ & $\begin{array}{l}+0.31 \\
+1.64\end{array}$ & $\begin{array}{l}2023.61 \\
2023.79\end{array}$ & $\begin{array}{l}2024.2 \\
2024.2\end{array}$ & $\begin{array}{l}0.59 \\
0.41\end{array}$ \\
\hline & & 133 & 3081 & & $\begin{array}{l}\text { 03DEC91 } \\
03 \text { DEC91 } \\
03 \text { DEC91 } \\
03 \text { DEC91 }\end{array}$ & $\begin{array}{l}\text { 03DEC91 } \\
\text { 06DEC91 } \\
\text { 03DEC91 } \\
\text { 06DEC91 }\end{array}$ & $\begin{array}{l}M \\
S \\
M \\
S\end{array}$ & $\begin{array}{l}\text { R4546 } \\
\text { R4546 } \\
\text { R4547 } \\
\text { R4547 }\end{array}$ & $\begin{array}{l}001 \\
001 \\
001 \\
001\end{array}$ & & $\begin{array}{l}2301.42 \\
2303.27 \\
2302.64 \\
2302.94\end{array}$ & & $\begin{array}{l}2301.42 \\
2303.27 \\
2302.64 \\
2302.94\end{array}$ & $\begin{array}{l}+1.22 \\
-0.33\end{array}$ & $\begin{array}{l}2302.03 \\
2303.10\end{array}$ & $\begin{array}{l}2299.0 \\
2299.0\end{array}$ & $\begin{array}{l}-3.03 \\
-4.10\end{array}$ \\
\hline \multirow{6}{*}{$\stackrel{2}{180}$} & $\begin{array}{r}37-30 \mathrm{~s} \\
150-30 \mathrm{~W}\end{array}$ & 269 & 315 & 12AUG91 & $04 \mathrm{DEC} 91$ & 06DEC91 & $s$ & R4565 & 001 & & 2121.42 & & 2121.42 & & 2121.42 & 2125.5 & 4.08 \\
\hline & & 211 & 469 & & $\begin{array}{l}\text { 11DEC91 } \\
11 \text { DEC91 } \\
11 \text { DEC91 } \\
11 \text { DEC91 }\end{array}$ & $\begin{array}{l}\text { 11DEC91 } \\
19 D E C 91 \\
11 D E C 91 \\
19 D E C 91\end{array}$ & $\begin{array}{l}M \\
S \\
M \\
S\end{array}$ & $\begin{array}{l}\text { R4562 } \\
\text { R4562 } \\
\text { R4563 } \\
\text { R4563 }\end{array}$ & $\begin{array}{l}001 \\
001 \\
001 \\
001\end{array}$ & & $\begin{array}{l}2134.64 \\
2133.70 \\
2130.68 \\
2129.14\end{array}$ & & $\begin{array}{l}2134.64 \\
2133.70 \\
2130.68 \\
2129.14\end{array}$ & $\begin{array}{l}-3.96 \\
-4.56\end{array}$ & $\begin{array}{l}2132.66 \\
2131.42\end{array}$ & $\begin{array}{l}2126.2 \\
2126.2\end{array}$ & $\begin{array}{l}-6.46 \\
-5.22\end{array}$ \\
\hline & & 213 & 622 & & $\begin{array}{l}\text { 16DEC91 } \\
16 \mathrm{DEC} 91 \\
16 \mathrm{DEC} 91 \\
16 \mathrm{DEEC} 91\end{array}$ & $\begin{array}{l}\text { 17DEC91 } \\
\text { 20DEC91 } \\
\text { 17DEC91 } \\
\text { 20DEC91 }\end{array}$ & $\begin{array}{l}M \\
S \\
M \\
S\end{array}$ & $\begin{array}{l}\text { R4560 } \\
\text { R4560 } \\
\text { R4561 } \\
\text { R4561 }\end{array}$ & $\begin{array}{l}001 \\
001 \\
001 \\
001\end{array}$ & & $\begin{array}{l}2138.07 \\
2137.74 \\
2133.80 \\
2134.91\end{array}$ & & $\begin{array}{l}2138.07 \\
2137.74 \\
2133.80 \\
2134.91\end{array}$ & $\begin{array}{l}-4.27 \\
-2.83\end{array}$ & $\begin{array}{l}2135.94 \\
2136.32\end{array}$ & $\begin{array}{l}2132.5 \\
2132.5\end{array}$ & $\begin{array}{l}-3.44 \\
-3.82\end{array}$ \\
\hline & & 216 & 931 & & $\begin{array}{l}\text { 06MAY92 } \\
\text { 06MAY92 } \\
\text { 06MAY92 } \\
\text { 06MAY92 }\end{array}$ & $\begin{array}{l}\text { 17JUL92 } \\
\text { 17JUL92 } \\
\text { 17JUL92 } \\
\text { 17JUL92 }\end{array}$ & $\begin{array}{l}\mathrm{E} \\
\mathrm{E} \\
\mathrm{E} \\
\mathrm{E}\end{array}$ & $\begin{array}{l}\text { R4558 } \\
\text { R4558 } \\
\text { R4559 } \\
\text { R4559 }\end{array}$ & $\begin{array}{l}001 \\
002 \\
001 \\
002\end{array}$ & & $\begin{array}{l}2169.51 \\
2168.19 \\
2168.22 \\
2168.53\end{array}$ & $\begin{array}{l}-1.32 \\
+0.31\end{array}$ & $\begin{array}{l}2168.85 \\
2168.38\end{array}$ & -0.17 & 2168.61 & 2167.2 & -1.41 \\
\hline & & 218 & 1188 & & $\begin{array}{l}\text { 05MAY92 } \\
\text { 05MAY92 } \\
05 \text { MAY92 } \\
05 \text { MAY92 }\end{array}$ & $\begin{array}{l}\text { 17JUL92 } \\
\text { 17JUL92 } \\
\text { 17JUL92 } \\
\text { 17JUL92 }\end{array}$ & $\begin{array}{l}\mathrm{E} \\
\mathrm{E} \\
\mathrm{E} \\
\mathrm{E}\end{array}$ & $\begin{array}{l}\text { R4556 } \\
\text { R4556 } \\
\text { R4557 } \\
\text { R4557 }\end{array}$ & $\begin{array}{l}001 \\
002 \\
001 \\
002\end{array}$ & & $\begin{array}{l}2207.85 \\
2207.82 \\
2207.12 \\
2206.20\end{array}$ & $\begin{array}{l}-0.03 \\
-0.92\end{array}$ & $\begin{array}{l}2207.84 \\
2206.66\end{array}$ & -1.18 & 2207.25 & 2202.9 & -4.35 \\
\hline & & 220 & 1543 & & $\begin{array}{l}\text { 04DEC91 } \\
04 \mathrm{DEC} 91 \\
04 \mathrm{DEC} 91 \\
04 \mathrm{DEC} 91\end{array}$ & $\begin{array}{l}\text { 04DEC91 } \\
\text { 09DEC91 } \\
\text { 05DEC91 } \\
\text { 09DEC91 }\end{array}$ & $\begin{array}{l}M \\
S \\
M \\
S\end{array}$ & $\begin{array}{l}\text { R4554 } \\
\text { R4554 } \\
\text { R4555 } \\
\text { R4555 }\end{array}$ & $\begin{array}{l}001 \\
001 \\
001 \\
001\end{array}$ & & $\begin{array}{l}2258.59 \\
2259.74 \\
2258.58 \\
2257.71\end{array}$ & & $\begin{array}{l}2258.59 \\
2259.74 \\
2258.58 \\
2257.71\end{array}$ & $\begin{array}{l}-0.01 \\
-2.03\end{array}$ & $\begin{array}{l}2258.59 \\
2258.73\end{array}$ & $\begin{array}{l}2253.9 \\
2253.9\end{array}$ & $\begin{array}{l}-4.69 \\
-4.83\end{array}$ \\
\hline
\end{tabular}

MANOMETER TYPE

$M=$ CONSTANT VOLUME MERCURY MANOMETER DATUM

$S=$ QUARTZ SPIRAL MANOMETER DATUM
$E=$ ELECTRONIC CONSTANT-VOLUME MANOMETER DATUM

FLAGS

F: No $\mathrm{Hg}$ found in bottle

RTE TYPE:

$S=S$ TYPE

EX: Data excluded from analysis 
Table 1 (continued)

THE CARBOI DIOXIDE PROJECT OE THE SCRIPPS IIISTITUTIOI OF OCEANOGRAPHY

\begin{tabular}{|c|c|c|c|c|c|c|c|c|c|c|c|c|c|c|c|c|c|}
\hline $\begin{array}{l}\text { LEG } \\
\text { ST\%1 }\end{array}$ & $\begin{array}{l}\text { LAT. } \\
\text { LONG. }\end{array}$ & $\begin{array}{l}\text { CAST } \\
\text { NISK }\end{array}$ & $\begin{array}{c}\text { DEPTH } \\
\text { (H) }\end{array}$ & $\begin{array}{l}\text { SALAPLE } \\
\text { DATE }\end{array}$ & $\begin{array}{c}\text { EXTRAC } \\
\text { DATE }\end{array}$ & $\begin{array}{l}\text { ANALYSIS } \\
\text { DATE }\end{array}$ & $\begin{array}{l}\text { HAINO } \\
\text { TYPE }\end{array}$ & $\begin{array}{l}\text { SALHPLE } \\
\text { BOTTLE }\end{array}$ & RUN & FLAG & S.I.O. & $\begin{array}{c}\text { RUN } \\
\text { DELTA }\end{array}$ & $\begin{array}{l}\text { BOTTLE } \\
\text { TCO } \\
-\quad-\quad \text { ' } \mu \text { HOLE }\end{array}$ & $\begin{array}{l}\text { BOTTLE " } \\
\text { DELTA } \\
\text { S/KG S(f) }\end{array}$ & "NI SKIII" & $\begin{array}{c}\mathrm{LDEO} \\
\mathrm{TCO}\end{array}$ & $\begin{array}{r}\text { LDEO } \\
- \text { S.I.O. }\end{array}$ \\
\hline \multirow[t]{2}{*}{${ }_{180}^{2}$} & $\begin{array}{r}37-305 \\
150-30 w\end{array}$ & 22 & 22052 & 12AUG91 & $\begin{array}{l}\text { 051SAY92 } \\
\text { 05 MAY92 } \\
\text { 05 MAY92 } \\
\text { 05MAY92 }\end{array}$ & $\begin{array}{l}\text { 10JUL92 } \\
\text { 10JUL92 } \\
10 \text { JUL92 } \\
\text { 10JUL92 }\end{array}$ & $\begin{array}{l}E \\
E \\
E \\
E\end{array}$ & $\begin{array}{l}\text { R4552 } \\
\text { R4552 } \\
\text { R4553 } \\
\text { R4553 }\end{array}$ & $\begin{array}{l}001 \\
002 \\
001 \\
002\end{array}$ & EX & $\begin{array}{l}2299.71 \\
2294.57 \\
2295.61 \\
2295.46\end{array}$ & -0.15 & $\begin{array}{l}2294.57 \\
2295.54\end{array}$ & +0.97 & 2295.06 & 2290.4 & -4.66 \\
\hline & & 22 & 63051 & & $\begin{array}{l}\text { 04MAY92 } \\
\text { 04MAY92 } \\
\text { 04MAY92 } \\
\text { 04MAY92 }\end{array}$ & $\begin{array}{l}\text { 10JUL92 } \\
\text { 10JUL92 } \\
\text { 10JUL92 } \\
\text { 10JUL92 }\end{array}$ & $\begin{array}{l}E \\
E \\
E \\
E\end{array}$ & $\begin{array}{l}\text { R4550 } \\
\text { R4550 } \\
\text { R4551 } \\
\text { R4551 }\end{array}$ & $\begin{array}{l}001 \\
002 \\
001 \\
002\end{array}$ & EX & $\begin{array}{l}2309.37 \\
2309.74 \\
2308.23 \\
2299.35\end{array}$ & +0.37 & $\begin{array}{l}2309.56 \\
2308.23\end{array}$ & -1.33 & 2308.90 & 2303.7 & -5.20 \\
\hline$\underset{213}{2}$ & $\begin{array}{r}21-0 S \\
150-30 \mathrm{~W}\end{array}$ & 1 & 62 & 23AUG91 & $\begin{array}{l}12 \text { DEC91 } \\
12 \text { DEC91 } \\
12 D E C 91 \\
12 D E C 91\end{array}$ & $\begin{array}{l}\text { 13DEC91 } \\
19 \mathrm{DEC91} \\
13 \mathrm{DEC91} \\
\text { 20DEC91 }\end{array}$ & $\begin{array}{l}M \\
S \\
M \\
S\end{array}$ & $\begin{array}{l}\text { S4118 } \\
\text { S4118 } \\
\text { S4119 } \\
\text { S4119 }\end{array}$ & $\begin{array}{l}001 \\
001 \\
001 \\
001\end{array}$ & & $\begin{array}{l}1997.57 \\
1998.22 \\
1995.37 \\
1995.98\end{array}$ & & $\begin{array}{l}1997.57 \\
1998.22 \\
1995.37 \\
1995.98\end{array}$ & $\begin{array}{l}-2.20 \\
-2.24\end{array}$ & $\begin{array}{l}1996.47 \\
1997.10\end{array}$ & $\begin{array}{l}1992.9 \\
1992.9\end{array}$ & $\begin{array}{l}-3.57 \\
-1.20\end{array}$ \\
\hline
\end{tabular}

MANOMETER TYPE:

$B I=$ CONSTANT VOLUME MERCURY MANOMETER DATUM

FLAGS:

$\begin{aligned} S & =\text { QUARTZ SPIRAL MANONETER DATUM } \\ E & =\text { ELECTRRONIC CONSTANT-VOLUME MANOMETER DATUM }\end{aligned}$

$\mathrm{F}$ : No $\mathrm{Hg}$ found in bottle

G: Severe bottele leak

EX: Data excluded from analysis

$S=S$ TYPE

NOTE: Dilution factor of 1.000170 has been applied. 
Table 2. Summary of total alkalinity replicate data collected during R/V Thomas Washington TuNES-2 Expedition

THE CARBOI DIOXIDE PROJECT OF THE SCRIPPS INSTITUTION OF OCEAMOGPAPH $i$

TUHES Leg 2 1991 WOCE Pacific Line P17S/P16S

\begin{tabular}{|c|c|c|c|c|c|c|c|c|c|c|c|c|c|c|}
\hline $\begin{array}{l}\text { LEG } \\
\text { STM }\end{array}$ & $\begin{array}{l}\text { LAT. } \\
\text { LONG. }\end{array}$ & $\begin{array}{l}\text { CAST } \\
\text { NISK }\end{array}$ & $\begin{array}{l}\text { DEPTH } \\
(\mathrm{H})\end{array}$ & $\begin{array}{c}\text { SALPLE } \\
\text { DATE }\end{array}$ & $\begin{array}{c}\text { ANALYSIS } \\
\text { DATE }\end{array}$ & $\begin{array}{l}\text { TITR } \\
\text { SYST }\end{array}$ & $\begin{array}{l}\text { SAMPLE } \\
\text { BOTTLE }\end{array}$ & TRIAL & FLAG & $\begin{array}{l}\text { S.I.O. } \\
\text { TRIAL }\end{array}$ & $\begin{array}{l}\text { TRIAL } \\
\text { DELTA }\end{array}$ & $\begin{array}{l}\text { BOTTLE } \\
\quad \text { ALK } \\
--\quad(\mu \mathrm{EQUI}\end{array}$ & $\begin{array}{l}\text { BOTTLE " } \\
\text { DELTA } \\
\text { IV/KG SWI) }\end{array}$ & $\begin{array}{c}\text { "NISKIN" } \\
\text { AVG }\end{array}$ \\
\hline$\frac{2}{160}$ & $\begin{array}{r}23-43 s \\
132-33 w\end{array}$ & 11 & 909 & 01AUG91 & $\begin{array}{l}\text { 20JAN92 } \\
\text { 20JAN92 }\end{array}$ & $\begin{array}{l}\mathrm{V} \\
\mathrm{V}\end{array}$ & $\begin{array}{l}\text { S4158 } \\
\text { S4159 }\end{array}$ & 1 & & $\begin{array}{l}2300.18 \\
2302.05\end{array}$ & & $\begin{array}{l}2300.18 \\
2302.05\end{array}$ & +1.87 & 2301.11 \\
\hline$\stackrel{2}{174}$ & $\begin{array}{r}30-325 \\
134-20 \mathrm{~W}\end{array}$ & 16 & 4 & 06AUG92 & $\begin{array}{l}\text { 10JAN92 } \\
\text { 10JAN92 }\end{array}$ & $\begin{array}{l}\mathrm{v} \\
\mathrm{v}\end{array}$ & $\begin{array}{l}\text { R4548 } \\
\text { R4549 }\end{array}$ & $\begin{array}{l}1 \\
1\end{array}$ & & $\begin{array}{l}2318.15 \\
2324.19\end{array}$ & & $\begin{array}{l}2318.15 \\
2324.19\end{array}$ & +6.04 & 2321.17 \\
\hline & & 135 & 3081 & & $\begin{array}{l}\text { 10JAN92 } \\
\text { 10JAN92 }\end{array}$ & $\begin{array}{l}\mathrm{V} \\
\mathrm{V}\end{array}$ & $\begin{array}{l}\text { R4546 } \\
\text { R4547 }\end{array}$ & $\begin{array}{l}1 \\
1\end{array}$ & & $\begin{array}{l}2395.78 \\
2396.62\end{array}$ & & $\begin{array}{l}2395.78 \\
2396.62\end{array}$ & +0.84 & 2396.20 \\
\hline $\begin{array}{c}2 \\
180\end{array}$ & $\begin{array}{r}37-30 \mathrm{~S} \\
150-30 \mathrm{~W}\end{array}$ & 26 & 315 & 12AUG91 & $\begin{array}{l}\text { 14JAN92 } \\
\text { 14JAN92 }\end{array}$ & $\begin{array}{l}\mathrm{V} \\
\mathrm{V}\end{array}$ & $\begin{array}{l}\text { R4564 } \\
\text { R4565 }\end{array}$ & $\begin{array}{l}1 \\
1\end{array}$ & & $\begin{array}{l}2277.74 \\
2280.79\end{array}$ & & $\begin{array}{l}2277.74 \\
2280.79\end{array}$ & +3.05 & 2279.27 \\
\hline & & 21 & 469 & & $\begin{array}{l}\text { 14JAN92 } \\
\text { 14JAN92 }\end{array}$ & $\begin{array}{l}\mathrm{v} \\
\mathrm{v}\end{array}$ & $\begin{array}{l}\text { R4562 } \\
\text { R4563 }\end{array}$ & $\begin{array}{l}1 \\
1\end{array}$ & & $\begin{array}{l}2275.55 \\
2273.45\end{array}$ & & $\begin{array}{l}2275.55 \\
2273.45\end{array}$ & -2.10 & 2274.50 \\
\hline & & 213 & 622 & & $\begin{array}{l}\text { 17JAN92 } \\
\text { 17JAN92 }\end{array}$ & $\begin{array}{l}\mathrm{V} \\
\mathrm{V}\end{array}$ & $\begin{array}{l}\text { R4560 } \\
\text { R4561 }\end{array}$ & $\begin{array}{l}1 \\
1\end{array}$ & & $\begin{array}{l}2275.23 \\
2281.82\end{array}$ & & $\begin{array}{l}2275.23 \\
2281.82\end{array}$ & +6.59 & 2278.53 \\
\hline & & 21 & 931 & & $\begin{array}{l}\text { 22JUN92 } \\
\text { 22JUN92 }\end{array}$ & $\begin{array}{l}\mathrm{V} \\
\mathrm{v}\end{array}$ & $\begin{array}{l}\text { R4558 } \\
\text { R4559 }\end{array}$ & $\begin{array}{l}1 \\
1\end{array}$ & & $\begin{array}{l}2290.65 \\
2285.23\end{array}$ & & $\begin{array}{l}2290.65 \\
2285.23\end{array}$ & -5.42 & 2287.94 \\
\hline & & 218 & 1188 & & $\begin{array}{l}\text { 22JUN92 } \\
\text { 22JUN92 }\end{array}$ & $\begin{array}{l}\mathrm{v} \\
\mathrm{v}\end{array}$ & $\begin{array}{l}\text { R4556 } \\
\text { R4557 }\end{array}$ & $\begin{array}{l}1 \\
1\end{array}$ & & $\begin{array}{l}2304.57 \\
2304.45\end{array}$ & & $\begin{array}{l}2304.57 \\
2304.45\end{array}$ & -0.12 & 2304.51 \\
\hline & & 226 & 1543 & & $\begin{array}{l}\text { 13JAN92 } \\
\text { 13JAN92 }\end{array}$ & $\mathrm{v}$ & $\begin{array}{l}\text { R4554 } \\
\text { R4555 }\end{array}$ & $\begin{array}{l}1 \\
1\end{array}$ & & $\begin{array}{l}2343.31 \\
2343.93\end{array}$ & & $\begin{array}{l}2343.31 \\
2343.93\end{array}$ & +0.62 & 2343.62 \\
\hline & & 222 & 2052 & & $\begin{array}{l}\text { 18JUN92 } \\
\text { 18JUN92 }\end{array}$ & $\begin{array}{l}\mathrm{v} \\
\mathrm{v}\end{array}$ & $\begin{array}{l}\text { R4552 } \\
\text { R4553 }\end{array}$ & $\begin{array}{l}1 \\
1\end{array}$ & & $\begin{array}{l}2380.77 \\
2382.52\end{array}$ & & $\begin{array}{l}2380.77 \\
2382.52\end{array}$ & +1.75 & 2381.65 \\
\hline & & 226 & 3051 & & $\begin{array}{l}\text { 18JUN92 } \\
\text { 18JUN92 }\end{array}$ & $\begin{array}{l}\mathrm{V} \\
\mathrm{V}\end{array}$ & $\begin{array}{l}\text { R4550 } \\
\text { R4551 }\end{array}$ & $\begin{array}{l}1 \\
1\end{array}$ & & $\begin{array}{l}2403.47 \\
2404.50\end{array}$ & & $\begin{array}{l}2403.47 \\
2404.50\end{array}$ & +1.03 & 2403.99 \\
\hline 213 & $\begin{array}{r}21-0 \mathrm{~S} \\
150-30 \mathrm{~W}\end{array}$ & 13 & 62 & 23AUG91 & $\begin{array}{l}\text { 20JAN92 } \\
\text { 20JAN92 }\end{array}$ & $\begin{array}{l}v \\
v\end{array}$ & $\begin{array}{l}\text { S4118 } \\
\text { S4119 }\end{array}$ & $\begin{array}{l}1 \\
1\end{array}$ & & $\begin{array}{l}2365.81 \\
2366.34\end{array}$ & & $\begin{array}{l}2365.81 \\
2366.34\end{array}$ & +0.53 & 2366.08 \\
\hline $\begin{array}{l}\text { TITRAT } \\
\mathrm{G}=\mathrm{Gl} \\
\mathrm{V}=\mathrm{V} \\
\mathrm{BOTTLE} \\
\mathrm{R}=\mathrm{I}\end{array}$ & $\begin{array}{l}\text { PION SYST } \\
\text { GRAVIMETR } \\
\text { IOLUMETRI } \\
\text { EYYPE: } \\
\text { RODAVISS }\end{array}$ & EM: & $s \mathrm{Ty}$ & & \multicolumn{10}{|c|}{$\begin{array}{l}\text { FLAGS: } \\
\text { F: No Hg found in bottle } \\
\text { X: Titrator malfunction } \\
\text { EX: Data excluded from analysis }\end{array}$} \\
\hline
\end{tabular}

NOTE: Dilution factor of 1.000170 has been applied. 


\section{DATA CHECKS AND PROCESSING PERFORMED BY CDIAC}

An important part of the NDP process at the Carbon Dioxide Information Analysis Center (CDIAC) involves the quality assurance (QA) of data before distribution. Data received at CDIAC are rarely in a condition that would permit immediate distribution, regardless of the source. To guarantee data of the highest possible quality, CDIAC conducts extensive QA reviews that involve examining the data for completeness, reasonableness, and accuracy. Although they have common objectives, these reviews are tailored to each data set and often require extensive programming efforts. In short, the QA process is a critical component in the value-added concept of supplying accurate, usable data for researchers.

The following information summarizes the data-processing and QA checks performed by CDIAC on the data obtained during the RN Thomas Washington TUNES-2 Expedition in the South Pacific Ocean (WOCE Sections P17S and P16S).

1. Carbon-related data and preliminary hydrographic measurements were provided to CDIAC by Taro Takahashi and Stewart Sutherland of LDEO. The final hydrographic and chemical measurements and the station information files were provided by the WOCE Hydrographic Program Office after quality evaluation. A FORTRAN 77 retrieval code was written and used to merge and reformat all data files.

2. The designation for missing values, given as -9.0 in the original files, was changed to -999.9 .

3. To check for obvious outliers, all data were plotted with a PLOTNEST.C program written by Stewart C. Sutherland (LDEO). The program plots a series of nested profiles, using the station number as an offset; the first station is defined at the beginning, and subsequent stations are offset by a fixed interval (Figs. 4-6). Several outliers were identified and removed after consultation with the principal investigators.

4. To identify "noisy" data and possible systematic, methodological errors, property-property plots for all parameters were generated, carefully examined, and compared with plots from previous expeditions in the South Pacific Ocean.

5. All variables were checked for values exceeding physical limits, such as sampling depth values that are greater than the given bottom depths.

6. Dates and times were checked for bogus values (e.g., values of MONTH $<1$ or $>12$, DAY $<1$ or $>31$, YEAR $<$ or $>1991$, TIME $<0000$ or $>2400$.

7. Station locations (latitudes and longitudes) and sampling times were examined for consistency with maps and cruise information supplied by Takahashi et al. (1993). 
R/V Thomas Washington TUNES-2 Expedition.

Only profiles which exist in this pressure (dbar) range are plotted. plotted parameter ranges from 1900 to 2400

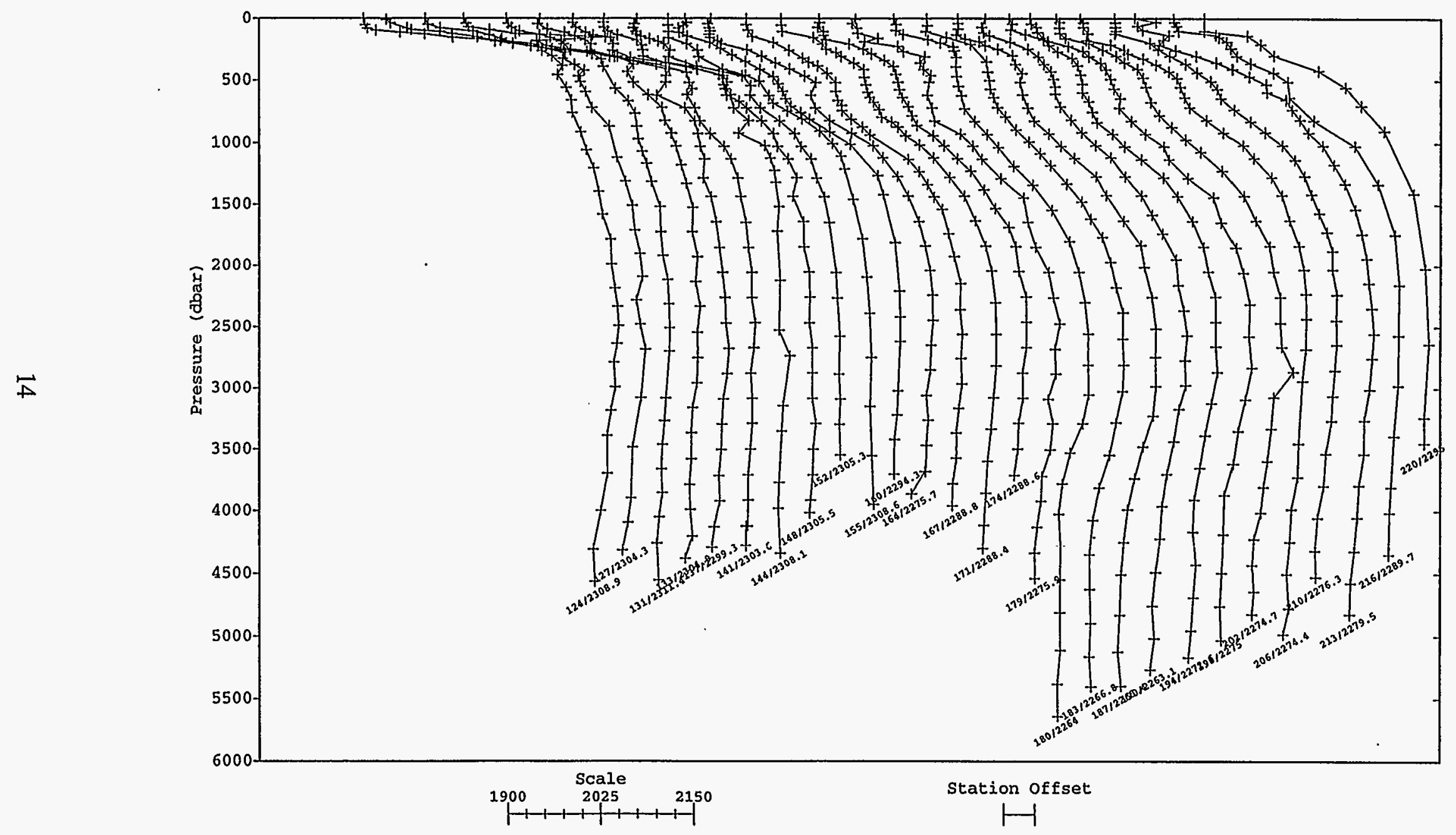

Figure 4. Nested profiles: total $\mathrm{CO}_{2}(\mu \mathrm{mol} / \mathrm{kg})$ vs pressure (dbar). 
R/V Thomas Washington TUNES-2 Expedition.

only profiles which exist in this Pressure (dbar) range are plotted.

plotted parameter ranges from 2250 to 2450

$\vec{u}$

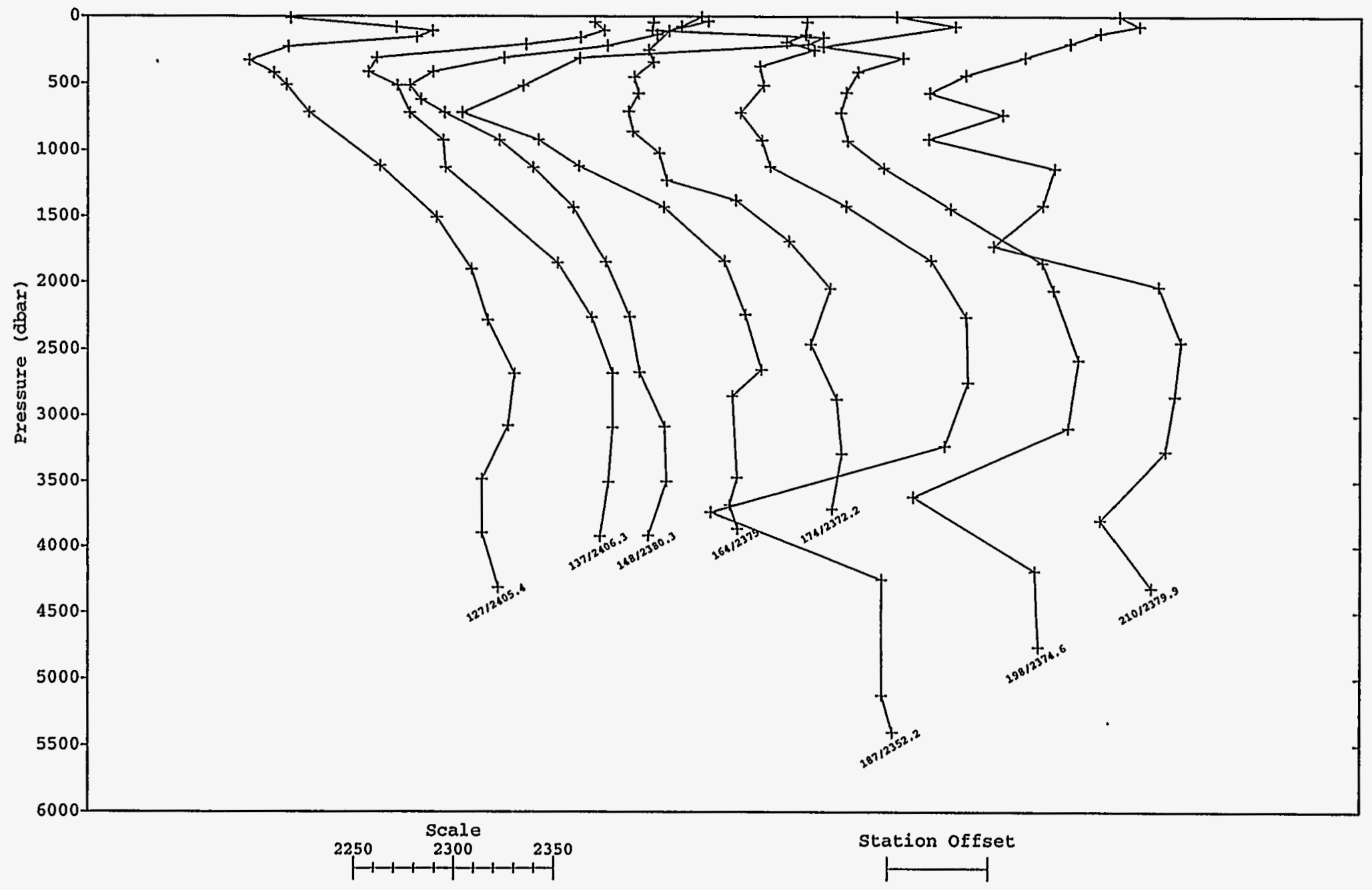

Figure 5. Nested profiles: total alkalinity ( $\mu \mathrm{mol} / \mathrm{kg}$ ) vs pressure (dbar). 


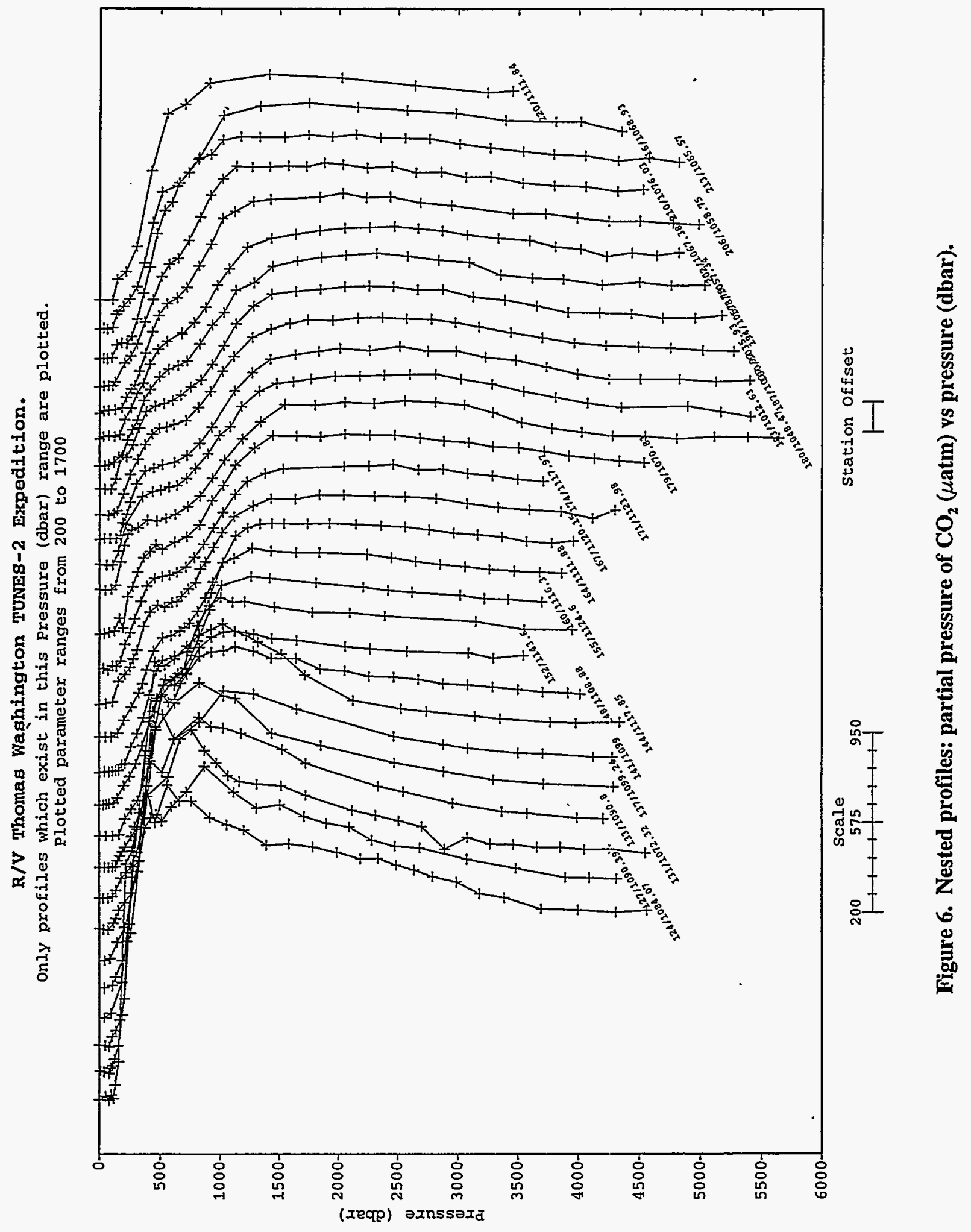




\section{HOW TO OBTAIN THE DATA AND DOCUMENTATION}

This database is available on request in machine-readable form, without charge, from CDIAC. CDIAC will also distribute subsets of the database as needed. It can be acquired on 9-track magnetic tape; on 8-mm tape; on 150-mB, quarter-inch tape cartridge; on MAC- or IBM-formatted floppy diskettes; or from CDIAC's anonymous File Transfer Protocol (FTP) area via Internet (see FTP address below). Requests should include any specific media instructions required by the user to access the data (e.g., 1600 or $6250 \mathrm{BPI}$, labeled or nonlabeled, ASCII or EBCDIC characters, and variable- or fixed-length records; 3.5- or 5.25-in. floppy diskettes, high or low density; and 8200 or 8500 format, 8 -mm tape). Magnetic tape requests not accompanied by specific instructions will be filled on 9-track, 6250-BPI, non-labeled tapes with ASCII characters. Requests should be addressed to

Carbon Dioxide Information Analysis Center

Oak Ridge National Laboratory

Post Office Box 2008

Oak Ridge, Tennessee 37831-6335

U.S.A.

Telephone: (423) $574-0390$ or (423) $574-3645$

Fax: (423) $574-2232$

Electronic Mail:

INTERNET: cdiac@ornl.gov

The data files can also be acquired from CDIAC's anonymous FTP account via Internet:

- FTP to cdiac.esd.ornl.gov (128.219.24.36),

- Enter "ftp" or "anonymous" as the user ID,

- Enter your electronic mail address as the password (e.g.,"alex@alex.esd.oml.gov")1,

- Change to the directory "/pub/ndp054", and

- Acquire the files using the FTP "get" or "mget" command.

or

World Wide Web URL: http://cdiac.esd.ornl.gov/cdiac/

'Please enter your correct address. This address is used by CDIAC to inform data recipients of data revisions and updates. 


\section{REFERENCES}

Bradshaw A. L., P. G. Brewer, D. K. Shafer, and R. T. Williams. 1981. Measurements of total carbon dioxide and alkalinity by potentiometric titration in the GEOSECS program. Earth Planet. Sci. Lett. 55:99-115.

Brewer, P. G., A. L. Bradshaw, and R. T. Williams. 1986. Measurements of total carbon dioxide and alkalinity in the North Atlantic Ocean in 1981. pp. 358-81. In D. Reiche (ed.), The Global Carbon Cycle: Analysis of the Natural Cycle and Implications of Anthropogenic Alterations for the Next Century. Springer, New York.

Brewer, P. G., C. Goyet, and D. Dyrssen. 1989. Carbon dioxide transport by ocean currents at $25^{\circ} \mathrm{N}$ latitude in the Atlantic Ocean. Science 246:477-79.

Bryden, H. L., and M. M. Hall. 1980. Heat transport by ocean currents across $25^{\circ} \mathrm{N}$ latitude in the North Atlantic Ocean. Science 207:884.

Bullister, J.L. and R.F. Weiss. 1988. Determination of CCl3F and CCl2F2 in seawater and air. Deep-Sea Res. 35:839-53.

Chipman, D. W., J. Marra, and T. Takahashi. 1993. Primary production at $47^{\circ} \mathrm{N}$ and $20^{\circ} \mathrm{W}$ in the North Atlantic Ocean: A comparison between the ${ }^{14} \mathrm{C}$ incubation method and the mixed layer carbon budget. Deep-Sea Res. 40:151-69.

Dyrssen D. 1965. A gran titration of sea water on board SAGTTA. Acta Chemica Scand. 19:1265.

Guenther, P. R., C. D. Keeling, and G. Emanuele III. 1994. Oceanic $\mathrm{CO}_{2}$ Measurements for the WOCE Hydrographic Survey in the Pacific Ocean, 1990-1991: Shore Based Analyses. SIO Reference Series, Ref. No. 94-28. University of California.

Johnson, K. M., A. E. King, and J. McN. Sieburth. 1985. Coulometric $\mathrm{TCO}_{2}$ analyses for marine studies: An introduction. Mar. Chem. 16:61-82.

Joyce, T., and C. Corry (eds.). 1994. Requirements for WOCE Hydrographic Programme Data Reporting. Rew. 2. Woods Hole Oceanographic Institution, Woods Hole, Mass.

Roemmich, D., and C. Wunsch. 1985. Two transatlantic sections: Meridional circulation and heat flux in the subtropical North Atlantic Ocean. Deep-Sea Res. 32:619-64.

Takahashi, T., J. G. Goddard, S. Rubin, D. W. Chipman, and S. C. Sutherland. 1993. Investigation of Carbon Dioxide in the Central South Pacific Ocean (WOCE Sections P-16C and $P-17 C)$ during the TUNES/2 Expedition of the RN Thomas Washington, July-August, 1991. Final Technical Report for grant DE-FGO2-90-ER60983,. LDEO of Columbia University, Palisades, N.Y.

Williams, P. J. 1990. Oceans, carbon, and climate change. Scientific Committee on Oceanic Research (SCOR), Halifax, Canada. 
PART 2:

CONTENT AND FORMAT OF DATA FILES 
. 


\section{FILE DESCRIPTIONS}

This section describes the content and format of each of the five files that comprise this NDP (see Table 3). Because CDIAC distributes the data set in several ways (e.g., via anonymous FTP, on floppy diskette, and on 9-track magnetic tape), each of the five files is referenced by both an ASCII file name, which is given in lower-case, bold-faced type (e.g., readme), and a file number. The remainder of this section describes (or lists, where appropriate) the contents of each file. The files are discussed in the order in which they appear on the magnetic tape.

Table 3. Content, size, and format of data files

File number, name, and description
Logical

records
File size

in bytes
Block

size

\section{Record} length

1. readme:

1,008

60,305

8,000

80

a detailed description

of the cruise network, the

two FORTRAN 77 data

retrieval routines, and the

two oceanographic data

files

2. stainv.for:

32

1,006

8,000

80

a FORTRAN 77 data retrieval

routine to read and print

tun2sta.inv (File 4)

3. tun2dat.for:

a FORTRAN 77 data retrieval

routine to read and print

tun2.dat (File 5)

4. tun2sta.inv:

7,850

4,100

41

a listing of the station locations,

sampling dates, and sounding

bottom depths for each of the

97 stations

5. tun2.dat:

hydrographic, carbon dioxide,

50

2,239

8,000

80

and chemical data from 97 stations

653,054

16,000

160

\section{Total}




\section{readme (File 1)}

This file contains a detailed description of: the data set, the two FORTRAN 77 data retrieval routines, and the two oceanographic data files. It exists primarily for the benefit of individuals who acquire this database as machine-readable data files from CDIAC.

\section{stainv.for (File 2)}

This file contains a FORTRAN 77 data retrieval routine to read and print tun2sta.inv (File 4). The following is a listing of this program. For additional information regarding variable definitions, variable lengths, variable types, units, and codes, please see the description for tun2sta.inv.

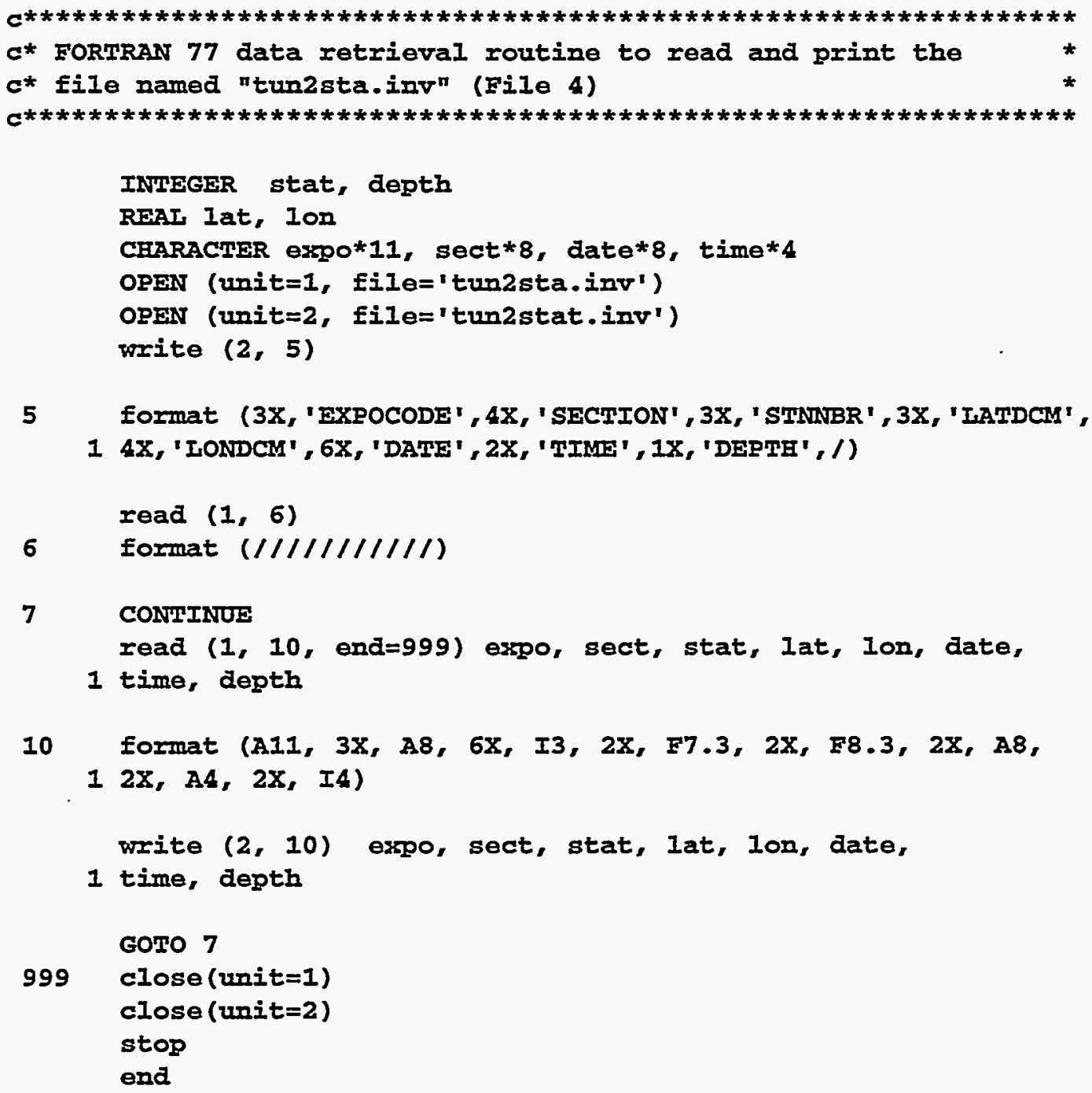




\section{tun2dat.for (File 3)}

This file contains a FORTRAN 77 data retrieval routine to read and print tun2.dat (File 5). The following is a listing of this program. For additional information regarding variable definitions, variable lengths, variable types, units, and codes, please see the description for tun2.dat.

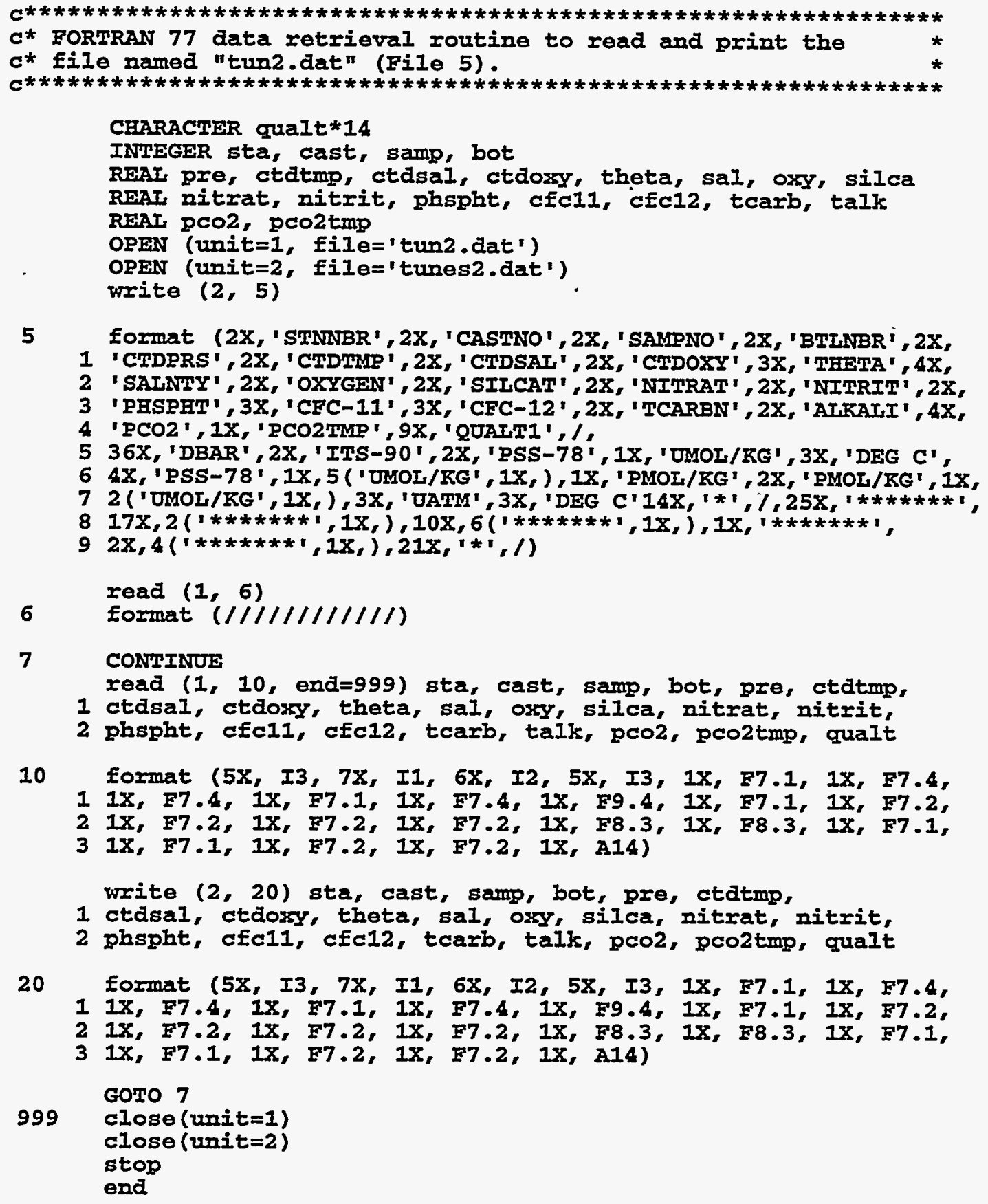

5 Format (2X, 'STNNBR', 2X, 'CASTNO', 2X, 'SAMPNO', 2X, 'BTINBR', 2X, 1 'CTDERS', 2X, 'CTDTMP', 2X, 'CTDSAI', 2X, 'CTDOXY', 3X, ' THETA', $4 \mathrm{X}$, 


\section{tun2sta.inv (File 4)}

This file provides station inventory information for each of the 97 stations occupied during the RN Thomas Washington TUNES-2 Expedition. Each record of the file contains an expocode, section number, station number, coordinate, sampling date, sampling time, and sounding depth. The file is sorted by station number and can be read by using the following FORTRAN 77 code (contained in stainv.for, File 2):

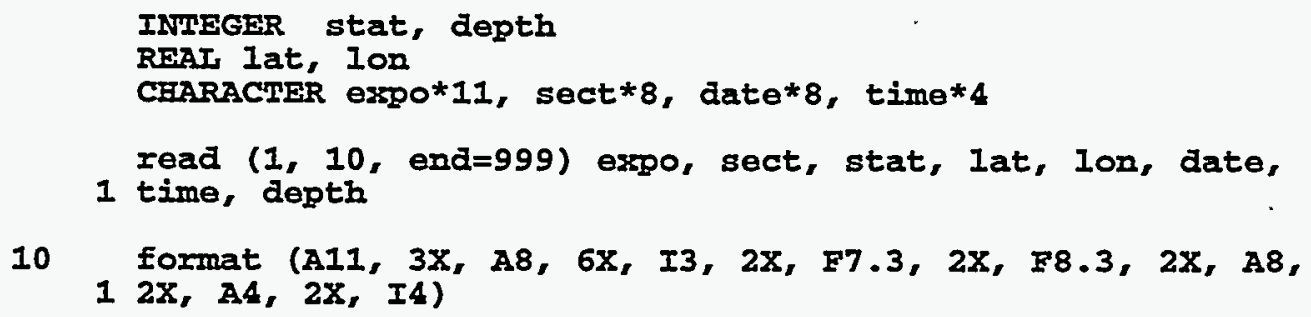

Stated in tabular form, the contents include the following:

\begin{tabular}{llccc}
\hline Variable & $\begin{array}{l}\text { Variable } \\
\text { type }\end{array}$ & $\begin{array}{c}\text { Variable } \\
\text { width }\end{array}$ & $\begin{array}{c}\text { Starting } \\
\text { column }\end{array}$ & $\begin{array}{c}\text { Ending } \\
\text { column }\end{array}$ \\
\hline expo & Character & 11 & 1 & 11 \\
sect & Character & 8 & 15 & 22 \\
stat & Numeric & 3 & 29 & 31 \\
lat & Numeric & 7 & 34 & 40 \\
lon & Numeric & 8 & 43 & 50 \\
date & Character & 8 & 53 & 60 \\
time & Character & 4 & 63 & 72 \\
depth & Numeric & 4 & 69 & \\
\hline
\end{tabular}

where

expo is the expocode of the cruise;

sect is the WOCE section number;

stat is the station number (values range from 124 to 220);

lat is the latitude of the station (in decimal degrees; negative values indicate the Southern Hemisphere);

Ion is the longitude of the station (in decimal degrees; negative values indicate the Western Hemisphere);

date is the sampling date (month/day/year); 
time is the sampling time (GMT);

depth is the sounding depth of the station (in meters).

\section{tun2.dat (File 5)}

This file provides hydrographic, carbon dioxide, and chemical data for the 97 stations occupied during the RV Thomas Washington TUNES-2 Expedition. Each record contains a station number; cast number; sample number; bottle number; CTD pressure, temperature, salinity, and oxygen; potential temperature; bottle salinity; concentrations of oxygen, silicate, nitrate, nitrite, phosphate, CFC-11, CFC-12, and $\mathrm{TCO}_{2} ; \mathrm{TALK} ; \mathrm{pCO}_{2} ; \mathrm{PCO}_{2}$ temperature; and data quality flags. The file is sorted by station number and pressure and can be read by using the following FORTRAN 77 code (contained in tun2dat.for, File 3):

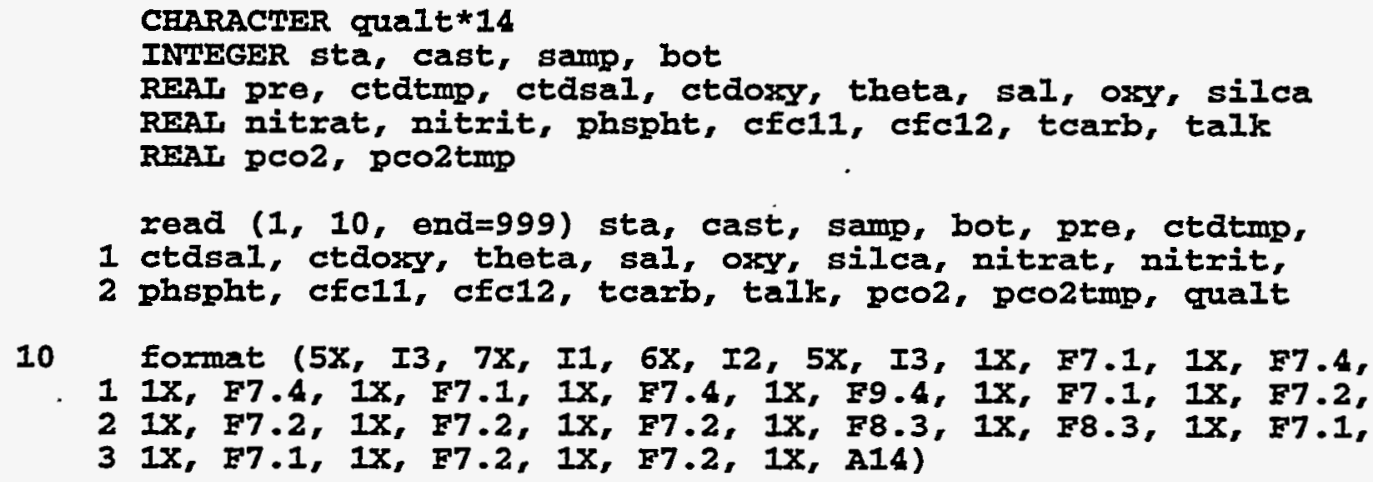

Stated in tabular form, the contents include the following:

\begin{tabular}{llccc}
\hline Variable & $\begin{array}{c}\text { Variable } \\
\text { type }\end{array}$ & $\begin{array}{c}\text { Variable } \\
\text { width }\end{array}$ & $\begin{array}{c}\text { Starting } \\
\text { column }\end{array}$ & $\begin{array}{c}\text { Ending } \\
\text { column }\end{array}$ \\
\hline sta & Numeric & 3 & 6 & 8 \\
cast & Numeric & 1 & 16 & 16 \\
samp & Numeric & 2 & 23 & 24 \\
bot & Numeric & 3 & 30 & 32 \\
pre & Numeric & 7 & 35 & 40 \\
ctdtmp & Numeric & 7 & 42 & 48 \\
ctdsal & Numeric & 7 & 50 & 56 \\
ctdoxy & Numeric & 7 & 58 & 64 \\
theta & Numeric & 7 & 66 & 72 \\
sal & Numeric & 9 & 74 & 82 \\
oxy & Numeric & 7 & 84 & 98 \\
silca & Numeric & 7 & 92 & 106 \\
nitrat & Numeric & 7 & 100 &
\end{tabular}




\begin{tabular}{llccc} 
nitrit & Numeric & 7 & .108 & 114 \\
phspht & Numeric & 7 & 116 & 122 \\
cfc11 & Numeric & 8 & 124 & 131 \\
cfc12 & Numeric & 8 & 133 & 140 \\
tcarb & Numeric & 7 & 142 & 148 \\
talk & Numeric & 7 & 150 & 156 \\
pco2 & Numeric & 7 & 158 & 164 \\
pco2tmp & Numeric & 7 & 166 & 172 \\
qualt & Character & 14 & 174 & 187 \\
\hline
\end{tabular}

where

\begin{tabular}{|c|c|}
\hline sta & is the station number; \\
\hline cast & is the cast number; \\
\hline samp & is the sample number; \\
\hline bot $^{*}$ & is the bottle number; \\
\hline pre & is the CTD pressure (in dbar); \\
\hline ctdtmp & is the CTD temperature $\left(\right.$ in $^{\circ} \mathrm{C}$ ); \\
\hline ctdsaI* & is the CTD salinity [on the Practical Salinity Scale (PSS)]; \\
\hline ctdoxy & is the CTD oxygen concentration (in $\mu \mathrm{mol} / \mathrm{kg}$ ); \\
\hline theta & is the potential temperature (in ${ }^{\circ} \mathrm{C}$ ); \\
\hline $\operatorname{sal}^{*}$ & is the bottle salinity; \\
\hline osxy* & is the oxygen concentration (in $\mu \mathrm{mol} / \mathrm{kg}$ ); \\
\hline silca* & is the silicate concentration (in $\mu \mathrm{mol} / \mathrm{kg}$ ); \\
\hline nitrat & is the nitrate concentration (in $\mu \mathrm{mol} / \mathrm{kg}$ ); \\
\hline nitrit* & is the nitrite concentration (in $\mu \mathrm{mol} / \mathrm{kg}$ ); \\
\hline phspht & is the phosphate concentration (in $\mu \mathrm{mol} / \mathrm{kg}$ ); \\
\hline $\operatorname{cfc} 11^{*}$ & is the trichlorofluoromethane- 11 concentration $\left(\mathrm{CCl}_{3} \mathrm{~F}\right)$ (in pmol/kg); \\
\hline $\operatorname{cfc} 12^{*}$ & is the dichlorodifluoromethane- 12 concentration $\left(\mathrm{CCl}_{2} \mathrm{~F}_{2}\right)$ (in pmol/kg); \\
\hline tcarb ${ }^{*}$ & is the total carbon dioxide concentration (in $\mu \mathrm{mol} / \mathrm{kg}$ ); \\
\hline $\operatorname{talk}{ }^{*}$ & is the total alkalinity (in $\mu \mathrm{mol} / \mathrm{kg}$ ); \\
\hline $\operatorname{pco2} 2^{*}$ & is the partial pressure of $\mathrm{CO}_{2}$ (in $\mu$ atm and measured at pco2tmp); \\
\hline pco2tmp & $\begin{array}{l}\text { is the temperature of equilibration of the } \mathrm{pCO}_{2} \text { samples in the equilibrator } \\
\text { (in }{ }^{\circ} \mathrm{C} \text { ); }\end{array}$ \\
\hline
\end{tabular}


qualt

is a 14-digit character variable that contains data-quality flag codes for parameters marked with an asterisk (") in the output file.

Quality flags are defined as follows:

1 = Sample for this measurement was drawn from water bottle but results of analyses were not received;

2 = Acceptable measurement;

3 = Questionable measurement;

4 = Bad measurement;

5 = Not reported;

6 = Mean of replicate measurements;

7 = Manual chromatographic peak measurement;

8 = Iregular digital chromatographic peak integration;

$9=$ Sample was not drawn for this measurement from this bottle. 


\section{VERIFICATION OF DATA TRANSPORT}

The data files contained in this numeric data package can be read by using the FORTRAN 77 data retrieval programs provided. Users should visually examine each data file to verify that the data were correctly transported to their systems. To facilitate the visual inspection process, partial listings of each data file are provided in Tables 4 and 5. Each of these tables contains the first and last five lines of a data file.

Table 4. Partial listing of "tun2sta.inv" (File 4)

First five lines of the file:

$\begin{array}{llllllll}\text { 31WTIUNES-2 } & \text { WOCE_P17 } & 124 & -6.005 & -135.003 & 07 / 21 / 91 & 2322 & 4562 \\ \text { 31WTTUNES-2 } & \text { WOCE_P17 } & 125 & -6.498 & -135.000 & 07 / 22 / 91 & 0550 & 4475 \\ \text { 31WTPUNES-2 } & \text { WOCE_P17 } & 126 & -6.998 & -135.003 & 07 / 22 / 91 & 1227 & 4393 \\ \text { 31WTTUNES-2 } & \text { WOCE_P17 } & 127 & -7.503 & -135.002 & 07 / 22 / 91 & 1929 & 4400 \\ \text { 31WTHONES-2 } & \text { WOCE_P17 } & 128 & -7.998 & -135.000 & 07 / 23 / 91 & 0208 & 4525\end{array}$

Last five lines of the file:

$\begin{array}{ll}\text { 31WTIUNES-2 } & \text { WOCE_P16 } \\ \text { 31WTTUNES-2 } & \text { WOCE_P16 } \\ \text { 31WTIUNES-2 } & \text { WOCE_P16 } \\ \text { 31WTIUNES-2 } & \text { WOCE_P16 } \\ \text { 31WTITUNES-2 } & \text { WOCE_P16 }\end{array}$

$\begin{array}{llllll}216 & -19.500 & -150.498 & 08 / 24 / 91 & 0811 & 4264 \\ 217 & -19.000 & -150.500 & 08 / 24 / 91 & 1433 & 3356 \\ 218 & -18.508 & -150.497 & 08 / 24 / 91 & 2027 & 4201 \\ 219 & -18.002 & -150.498 & 08 / 25 / 91 & 0215 & 3659 \\ 220 & -17.502 & -150.498 & 08 / 25 / 91 & 0804 & 3604\end{array}$


Table 5. Partial listing of "tun2.dat" (File 5)

First five lines of the file:

\begin{tabular}{|c|c|c|c|c|c|c|c|c|c|c|c|}
\hline \multicolumn{2}{|c|}{124} & 1 & 2 & 53.2 & 27.3959 & 35.1756 & 216.427 .3836 & 35.1817 & 214.8 & 2.73 & 4.81 \\
\hline 0.08 & 0.53 & 1.673 & 0.888 & 2000.6 & -999.9 & 313.20 & \multicolumn{5}{|c|}{$20.00 \quad 22622222228292$} \\
\hline \multicolumn{2}{|c|}{124} & 1 & 3 & 78.5 & 27.4009 & 35.1940 & 213.627 .3827 & 35.1999 & 213.8 & 2.71 & 4.91 \\
\hline 0.08 & 0.54 & 1.539 & 0.839 & 2003.4 & -999.9 & 297.66 & \multicolumn{2}{|c|}{20.0022622222228292} & & & \\
\hline \multicolumn{2}{|c|}{1.24} & 1 & 4 & 98.0 & 27.3409 & 35.4125 & 206.327 .3182 & 35.4790 & 209.2 & 2.69 & 4.56 \\
\hline 0.08 & 0.59 & 1.564 & 0.837 & 2015.1 & -999.9 & 318.35 & \multicolumn{2}{|c|}{$20.00 \quad 22622222228292$} & & & \\
\hline \multicolumn{2}{|c|}{124} & 1 & 5 & 114.0 & 25.9565 & 35.9781 & 193.425 .9310 & 35.9803 & 196.4 & 2.48 & 3.08 \\
\hline .11 & 0.63 & 1.768 & 0.993 & 2047.4 & -999.9 & 304.50 & \multicolumn{2}{|c|}{20.0022222222228292} & & & \\
\hline \multicolumn{2}{|c|}{124} & 1 & 6 & 128.9 & 24.2842 & 36.0574 & 185.124 .2567 & 36.0313 & 186.6 & 2.27 & 2.52 \\
\hline .02 & 0.67 & 0.794 & 0.431 & 2080.4 & -999.9 & 359.24 & 20.002222222224 & 292 & & & \\
\hline
\end{tabular}

Last five lines of the file:

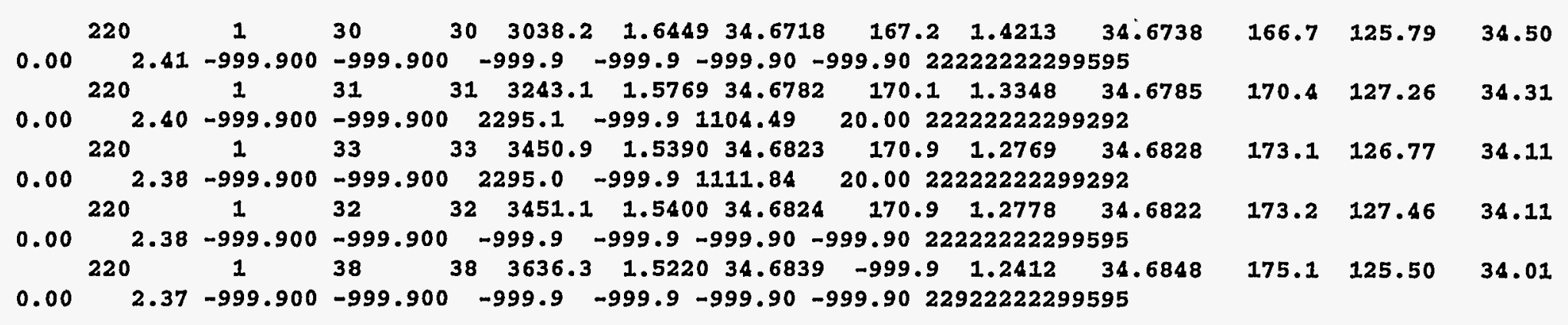




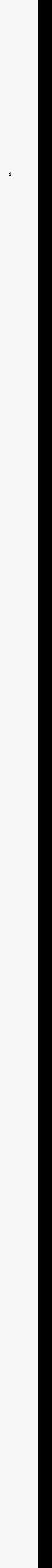


APPENDIX A:

STATION INVENTORY 


\section{APPENDIX A: STATION INVENTORY}

This appendix lists station inventory information for the 97 sites occupied during the $R / V$ Thomas Washington TUNES-2 Expedition in the South Pacific Ocean. The meanings of the column headings in Table A-1 are as follows:

EXPOCODE is the expocode of the cruise;

SECTION is the WOCE section number;

STNNBR is the station number;

LATDCM is the latitude of the station (in decimal degrees). Stations in the Southern Hemisphere have negative latitudes;

LONDCM is the longitude of the station (in decimal degrees). Stations in the Western Hemisphere have negative longitudes;

DATE is the sampling date (month/day/year);

TIME - is the sampling time (GMT);

DEPTH is the sounding bottom depth of each station (in meters). 


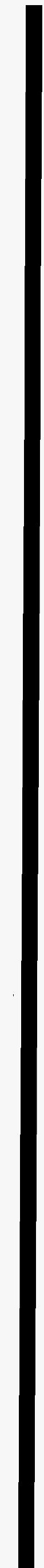


Table A.1 Station inventory information for the 97 sites occupied during R/V Thomas Washington TUNES-2 Expedition

\begin{tabular}{|c|c|c|c|c|c|c|c|}
\hline EXPOCODE & SECMION & STNNBR & IATPDCM & IONDCM & DATE & TIME & DEPTH \\
\hline 31WTHUNES-2 & WOCE_P17 & 124 & -6.005 & -135.003 & $07 / 21 / 91$ & 2322 & 4562 \\
\hline 31WTIUNES-2 & WOCE_P17 & 125 & -6.498 & -135.000 & $07 / 22 / 91$ & 0550 & 4475 \\
\hline 31WTHUNES-2 & WOCE_P17 & 126 & -6.998 & -135.003 & $07 / 22 / 91$ & 1227 & 4393 \\
\hline 31WTTUNES-2 & WOCE_P17 & 127 & -7.503 & -135.002 & $07 / 22 / 91$ & 1929 & 4400 \\
\hline 31WTIUNES-2 & WOCE_P17 & 128 & -7.998 & -135.000 & $07 / 23 / 91$ & 0208 & 4525 \\
\hline 31WTTUNES-2 & WOCE_P17 & 129 & -8.507 & -134.988 & $07 / 23 / 91$ & 0950 & 4449 \\
\hline 31WTIONES-2 & WOCE_P17 & 130 & -9.000 & -135.002 & $07 / 23 / 91$ & 1629 & 4494 \\
\hline 31WTIUNES-2 & WOCE_P17 & 131 & -9.502 & -135.000 & $07 / 23 / 91$ & 2312 & 4527 \\
\hline 31WTTUNES-2 & WOCE_P17 & 132 & -10.040 & -134.960 & $07 / 24 / 91$ & 1133 & 4450 \\
\hline 31WTIUNES-2 & HOCE_P17 & 133 & -10.483 & -134.898 & $07 / 25 / 91$ & 0122 & 4320 \\
\hline 31WTWUNES-2 & WOCE_P17 & 134 & -10.987 & -134.802 & $07 / 25 / 91$ & 0739 & 4167 \\
\hline 31WTTUNES-2 & WOCE_P17 & 135 & -11.470 & -134.698 & $07 / 25 / 91$ & 1402 & 4319 \\
\hline 31WTTUNES-2 & WOCE_P17 & 136 & -11.970 & -134.597 & $07 / 25 / 91$ & 2042 & 4140 \\
\hline 31WTIUNES-2 & HOCE_P17 & 137 & -12.448 & -134.500 & $07 / 26 / 91$ & 0246 & $\$ 237$ \\
\hline 31WTTUNES-2 & WOCE_P17 & 138 & -12.932 & -134.397 & $07 / 26 / 91$ & 0858 & 4414 \\
\hline 1FTIUNES-2 & WOCE_P17 & 139 & -13.433 & -134.280 & $07 / 26 / 91$ & 1535 & 4294 \\
\hline 31FTTUNES-2 & WOCE_P17 & 140 & -13.920 & -134.185 & $07 / 26 / 91$ & 2157 & 4423 \\
\hline 31WTIUNES-2 & WOCE_P17 & 141 & -14.418 & -134.083 & $07 / 27 / 91$ & 0426 & 4245 \\
\hline 31WWMUNES-2 & WOCE_P17 & 142 & -14.898 & -133.983 & $07 / 27 / 91$ & 1105 & 4270 \\
\hline 31FTTUNES-2 & WOCE_P17 & 143 & -15.382 & -133.882 & $07 / 28 / 91$ & 0203 & 4258 \\
\hline 31FTTUNES-2 & WOCE_PI7 & 144 & -15.882 & -133.785 & $07 / 28 / 91$ & 1141 & 4260 \\
\hline 31WTMUNES-2 & WOCE_P17 & 145 & -16.367 & -133.663 & $07 / 28 / 91$ & 1806 & 4252 \\
\hline IWTTUNES-2 & WOCE_P17 & 146 & -16.867 & -133.565 & $07 / 29 / 91$ & 0004 & 4293 \\
\hline 31WTMUNES-2 & HOCE_P17 & 147 & -17.348 & -133.467 & $07 / 29 / 91$ & 0553 & 4404 \\
\hline 31WTIUNES-2 & WOCE_P17 & 148 & -17.833 & $-133 \cdot 367$ & 191 & 1145 & 3970 \\
\hline 31WTTUNES-2 & WOCE_P17 & 149 & -18.330 & -133.250 & $07 / 29 / 91$ & 1735 & 4107 \\
\hline 31 WTPUNES-2 & WOCE_R17 & 150 & -18.815 & $-133 \cdot 150$ & $07 / 29 / 91$ & 2313 & 3884 \\
\hline 31WTTUNES-2 & WOCE_P17 & 151 & -19.312 & -133.052 & $07 / 30 / 91$ & 0449 & 3629 \\
\hline 31WTIONES-2 & WOCE_P17 & 152 & -19.798 & -132.950 & $07 / 30 / 91$ & 1011 & 3414 \\
\hline 31WTIUNES-2 & WOCE_R17 & 153 & -20.283 & -132.833 & $07 / 30 / 91$ & 2220 & 4430 \\
\hline 31WTTUNES-2 & WOCE_P17 & 154 & -20.787 & -132.733 & $07 / 31 / 91$ & 0954 & 4250 \\
\hline 31WTIUNES-2 & WOCE_P17 & 155 & -21.263 & $-132 \cdot 618$ & 07/31/91 & 1611 & 3959 \\
\hline 31WTTUNES-2 & WOCE_P17 & 156 & -21.767 & -132.518 & $07 / 31 / 91$ & 2215 & 3837 \\
\hline 31WTTUNES-2 & WOCE_P17 & 157 & -22.255 & -132.418 & $08 / 01 / 91$ & 0433 & 3512 \\
\hline 31WTTUNES-2 & WOCE_P17 & 158 & -22.708 & -132.285 & $08 / 01 / 91$ & 1103 & 3398 \\
\hline 31WTITURES-2 & WOCE_217 & 159 & -23.233 & -132.435 & $08 / 01 / 91$ & 1653 & 3619 \\
\hline 31WTIULES-2 & WOCE_P17 & 160 & -23.722 & -132.550 & $08 / 01 / 91$ & 2244 & 3664 \\
\hline 31 WTTUNES - 2 & WOCE_P17 & 161 & -24.202 & -132.668 & $08 / 02 / 91$ & 0500 & 3777 \\
\hline 31WTMULES-2 & WOCE_P17 & 162 & -24.688 & $-132 \cdot 800$ & $08 / 02 / 91$ & 1106 & 4047 \\
\hline 31WTPUNES-2 & WOCE_P17 & 163 & -25.182 & $-132 \cdot 920$ & $08 / 02 / 91$ & 1708 & 4178 \\
\hline 31WTHUNES-2 & WOCE_P17 & 164 & -25.673 & -133.045 & $08 / 02 / 91$ & 2309 & 3845 \\
\hline 31FTMUNES-2 & WOCE_P17 & 165 & -26.110 & -133.088 & $08 / 03 / 91$ & 0932 & 4187 \\
\hline 31 WTWUNES-2 & WOCE_E17 & 166 & -26.632 & -133.300 & $08 / 03 / 91$ & 2217 & 4028 \\
\hline 31FTTUNES-2 & WOCE_P17 & 167 & -27.118 & $-133 \cdot 435$ & $08 / 04 / 91$ & 1203 & 3758 \\
\hline 31FTMUNES-2 & WOCE_P17 & 168 & -27.618 & -133.540 & $08 / 04 / 91$ & 1839 & 4130 \\
\hline 31WTIOLES-2 & WOCE_P17 & 169 & -28.097 & -133.682 & $08 / 05 / 91$ & 0031 & 4230 \\
\hline 31 WTIONES-2 & WOCE_P17 & 170 & -28.582 & -133.817 & $08 / 05 / 91$ & 0623 & 3885 \\
\hline 31WITUNES-2 & WOCE_E17 & 171 & -29.068 & -133.932 & $08 / 05 / 91$ & 1201 & 4206 \\
\hline 31WTITUNES-2 & HOCE_P17 & 172 & -29.567 & -134.070 & $08 / 05 / 91$ & 2322 & 4183 \\
\hline 3 IWTIONES - 2 & WOCE_P17 & 173 & -30.048 & -134.203 & $08 / 06 / 91$ & 0935 & 4190 \\
\hline
\end{tabular}


Table A.1 (continued)

\begin{tabular}{|c|c|c|c|c|c|c|c|}
\hline EXPOCODE & SECTION & STMNBR & IATDCM & LONDCM & DATE & TIME : & EPTH \\
\hline LWTIUNES-2 & OCE_P17 & 174 & .30 .532 & 134.333 & $6 / 91$ & 1544 & \\
\hline 1WIIUNES-2 & OCE_P17 & 175 & 31.022 & -134.465 & $03 / 06 / 91$ & 2135 & 258 \\
\hline 31WTTUNES-2 & OCE_P17 & 176 & 31.500 & -134.600 & $03 / 07 / 91$ & 0340 & 1208 \\
\hline LWTHUNES-2 & OCE_P17 & 177 & -32.003 & -134.715 & $08 / 07 / 91$ & 1010 & \\
\hline LWTHUNES-2 & OCE_P17 & 178 & -32.482 & -134.848 & /3/07/91 & 1630 & 4337 \\
\hline LWTITUNES-2 & OCE_P17 & 179 & -33.010 & -135.022 & /8/08/91 & 0430 & 14 \\
\hline LWTIUNES-2 & OCE_P16 & 180 & -37.498 & -150.502 & $03 / 12 / 91$ & 0333 & 553 \\
\hline LWTTIUNES-2 & OCE_P16 & 181 & -36.998 & -150.498 & 03/12/91 & 1528 & 568 \\
\hline WITUNES-2 & TOCE_P16 & 182 & -36.500 & -150.500 & 3/13/91 & 0324 & \\
\hline WTIONES-2 & OCE_P16 & 183 & -36.000 & -150.497 & 3/91 & 1534 & \\
\hline LWTIONES-2 & OCE_P16 & 184 & -35.497 & -150.498 & $08 / 13 / 91$ & 2217 & 5383 \\
\hline 1WTIUUNES-2 & 10CE_P16 & 185 & -35 & 498 & 4/91 & 0457 & $\mathbf{5 4 7 0}$ \\
\hline WTHONES-2 & WOCE_P16 & 186 & -34.497 & -150.505 & 191 & 1146 & $348>-2$ \\
\hline WITIONES-2 & OOCE_P16 & 187 & -34.002 & -150.500 & $.5 / 91$ & 028 & \\
\hline WTTUNES-2 & OCE_P16 & 188 & -33.497 & -150.505 & $.5 / 91$ & 1135 & 5236 \\
\hline LWTTUNES-2 & WOCE_P16 & 189 & -32.995 & 492 & 5/91 & 0332 & 5401 \\
\hline WTIUNES-2 & TOCE_P16 & 190 & -32.498 & -150.500 & $6 / 91$ & 1025 & 5179 \\
\hline WTTUNES-2 & OCE_P16 & 191 & -32.000 & -150.502 & 6/91 & 659 & 170 \\
\hline WTTUNES-2 & OCE_P16 & 192 & -31.500 & -150.503 & $6 / 91$ & 325 & 920 \\
\hline WITUNES-2 & OOCE_P16 & 193 & $-3 c$ & 510 & & 634 & 4547 \\
\hline LWTYTUNES-2 & WOCE_P16 & 194 & -30.503 & -150.505 & $7 / 91$ & 555 & 4939 \\
\hline WITUNES-2 & TOCE_P16 & 195 & -30.003 & -150.512 & 7/91 & 225 & 029 \\
\hline WITONES-2 & OCE_P16 & 196 & -29.503 & -150.503 & 91 & 449 & 4579 \\
\hline WITUNES-2 & WOCE_P16 & 197 & 998 & .503 & & 111 & 4772 \\
\hline WTHTUNES-2 & WOCE_P16 & 198 & -28.500 & -150.497 & 191 & 321 & 4897 \\
\hline WITUNES-2 & WOCE_P16 & 199 & -27.997 & -150.497 & $.9 / 91$ & 2917 & 3452 \\
\hline WTTUNES-2 & $O C E \_P 16$ & 200 & -27.502 & -150.492 & $1 / 91$ & 545 & 678 \\
\hline WTIUNES-2 & OCE_P16 & 201 & -27.000 & .495 & 191 & 157 & 4753 \\
\hline WTTUNES-2 & 6 & & & 503 & & 18 & 777 \\
\hline WTTUNES-2 & WOCE_P16 & 203 & -25.998 & -150.498 & 0/91 & 1101 & 628 \\
\hline WITIUNES-2 & WOCE_P16 & 204 & -25.503 & -150.497 & $0 B / 20 / 91$ & .753 & 2541 \\
\hline WTIUNES-2 & OCE_P16 & 205 & -25.000 & .498 & $1 / 91$ & 000 & 4749 \\
\hline WTTUNES-2 & DCE_P16 & 206 & -2 & 498 & 91 & 557 & 900 \\
\hline WITUNES-2 & TOCE_P & 207 & & 500 & & 1220 & 4910 \\
\hline WTITUNES-2 & TOCE_P16 & 208 & -23.505 & -150.500 & 191 & 1842 & 4439 \\
\hline LWT-TUNES-2 & OCE_P16 & 209 & -23.000 & -150.500 & $08 / 22 / 91$ & 0102 & 4843 \\
\hline LWTTUNES-2 & WOCE_P16 & 210 & -22.502 & -150.502 & $08 / 22 / 91$ & 1206 & 4578 \\
\hline WTTUNES-2 & WOCE_P16 & 1 & & .495 & 91 & 0013 & 4788 \\
\hline WTHUNES-2 & $O C E \_P 16$ & 212 & 98 & .507 & 191 & 0650 & 285 \\
\hline WITIUNES-2 & CE_P16 & 213 & -21.000 & 498 & $3 / 91$ & 1315 & 471 \\
\hline WTHONES-2 & CE_P16 & 214 & -20.497 & -150.497 & $08 / 23 / 91$ & 1948 & 4619 \\
\hline 31WTTUNES-2 & WOCE_P16 & 215 & -20.000 & -150.498 & $08 / 24 / 91$ & 0156 & $\mathbf{3 7 7 7}$ \\
\hline LWTTUNES-2 & WOCE_P16 & 216 & 300 & 0.498 & 91 & 811 & 26 \\
\hline WTIIUNES-2 & EE_P16 & 2.18 & & 500 & & 433 & $3=-7+2+3$ \\
\hline PTIONES-2 & CE_EI6 & 218 & & & & 2027 & 420 \\
\hline & & 219 & -18.002 & -150.498 & $08 / 25 / 91$ & 0215 & 365 \\
\hline$x=5$ & $C E P 16$ & 20 & -17.502 & 150,498 & $08 / 25$ & 0804 & \\
\hline
\end{tabular}


APPENDIX B:

REPRINT OF PERTINENT LITERATURE 

FINAL TECHNICAL REPORT

FOR GRANT DE-FGO2-90-ER60983

submitted to

CARBON DIOXIDE RESEARCH DIVISION

OFFICE OF HEALTH AND ENVIRONMENTAL RESEARCH

U.S. DEPARTMENT OF ENERGY

WASHINGTON, D. C. 20545

INVESTIGATION OF CARBON DIOXIDE

IN THE CENTRAL SOUTH PACIFIC OCEAN

(WOCE SECTIONS P-16C and P-17C)

DURING THE TUNES/2 EXPEDITION OF

THE R/V THOMAS WASHINGTON,

JULY-AUGUST, 1991

by

Taro Takahashi, John G. Goddard, Stephany Rubin,

David W. Chipman and Stewart C. Sutherland

Lamont-Doherty Earth Observatory of Columbia University

Palisades, NY 10964

December, 1993 


\section{TABLE OF CONTENTS}

ACKNOWLEDGMENTS

I. INTRODUCTION

II. SAMPLING AND EXPERIMENTAL METHODS $\quad \ldots \ldots \ldots \ldots \ldots \ldots \ldots \ldots \ldots \ldots \ldots$

II-a) Sampling Locations and Methods $\quad$.................................... 5

II-b) Determination of Total $\mathrm{CO}_{2}$ Concentration in Seawater ................ 7

II-c) Determination of $\mathrm{pCO}_{2}$ in Seawater and Air Samples $\quad$................ 13

II-d) Computation of the Alkalinity in Seawater $\quad$........................... 20

II-e) Measurements of Hydrographic Variables $\quad$.......................... 21

III. DISTRIBUTION OF HYDROGRAPHIC AND $\mathrm{CO}_{2}$ PROPERTIES .......... 24

III-a) Distribution of Properties in Surface Waters .......................... 24

III-b) Property Distribution along the WOCE Sections P-16C and P-17C ..... 26

III-c) Distribution of Property Maxima and Minima $\quad$............................77

VI. PROPERTY-PROPERTY RELATIONSHIPS $\quad$..........................82

VI-a) $\theta$-S Relationships $\quad$............................................82

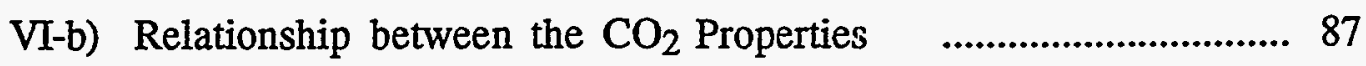

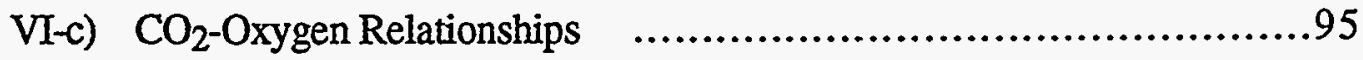

VI-d) Relationships between Alkalinity and Silicate $\quad$........................... 95

VI-e) Relationships between Phosphate and Nitrate $\quad$........................... 96

V. SUMMARY AND CONCLUSIONS $\quad$.............................105

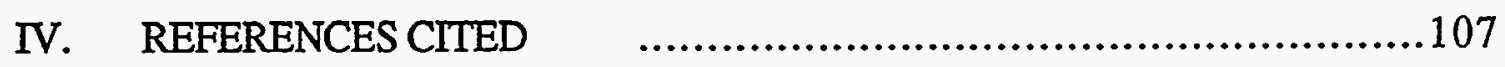

IIV. DATA TABLES $\quad$....................................................110

IIV-a) Surface Water Data $\quad$.............................................. 110

IIV-b) Hydrographic and $\mathrm{CO}_{2}$ Chemistry Data $\quad$............................. 114 


\section{ACKNOWLEDGEMENTS}

This investigation has been supported by a grant from the U.S. Department of Energy (No. DE-FGO2-90ER60983). We thank Drs. Michael Riches and John Downing for their support and encouragements. The field work was conducted aboard the $R / V$ Thomas Washington of Scripps Institution of Oceanography. We are thankful for the help and advice provided by Drs. James Swift and Ray Peterson of Scripps Institution of Oceanography, Chief Scientists of the expedition, and by the staff of the Oceanographic Data Facility, Scripps Institution of Oceanography, who obtained the hydrographic data used in this report. We also thank the US WOCE Office and the WOCE Hydrographic Program for inviting us to participate in the expedition. 


\section{ABSTRACT}

This report summarizes the results of $\mathrm{CO}_{2}$ and associated hydrographic measurements made during the oceanographic expedition, TUNES/2, aboard the R/V Thomas Washington in the central South Pacific Ocean. The expedition started on July 16, 1991, from Papeete, Tahiti, and returned to Tahiti on August 25, 1991, after completing the WOCE hydrographic sections $\mathrm{P}-16 \mathrm{C}$ along $150^{\circ} \mathrm{W}$ and $\mathrm{P}-17 \mathrm{C}$ along $135^{\circ} \mathrm{W}$. During the 40 -day expedition, the total $\mathrm{CO}_{2}$ concentration in 1000 seawater samples were determined using a coulometer system and the $\mathrm{pCO}_{2}$ in 940 seawater samples were determined using an equilibrator/gas chromatograph system. The alkalinity values in 900 water samples were computed using these measurements. In addition, 156 coulometric measurements were made for the Certified Reference Solutions (Batch \#6) and yielded a mean value of $2303.2 \pm 1.5 \mu \mathrm{mol} / \mathrm{kg}$. This agrees within a standard deviation with $2304.6 \pm 1.6 \mu \mathrm{mol} / \mathrm{kg}(\mathrm{N}=9)$ determined using the manometer of $\mathrm{C}$. D. Keeling of SIO.

The tropical waters located north of about $12^{\circ} \mathrm{S}$ were sources for atmospheric $\mathrm{CO}_{2}$ (positive $\Delta \mathrm{pCO}_{2}$ values), whereas the waters south of this latitude, especially those located south of about $25^{\circ} \mathrm{S}$, were strong $\mathrm{CO}_{2}$ sinks with negative $\triangle \mathrm{pCO}_{2}$ values ranging between -40 and $-50 \mu \mathrm{atm}$. This indicates that the oceanic area south of about $25^{\circ} \mathrm{S}$ between $135^{\circ} \mathrm{W}$ and $150^{\circ} \mathrm{W}$ was a strong $\mathrm{CO}_{2}$ sink during the austral winter, July-August, 1991. The chemical characteristics for the major water masses including the Antarctic Intermediate Water (AAIW), the North Pacific Deep Water (NPDW), the Circumpolar Deep Water (CPDW) and the Antarctic Bottom Water (AABW) have been determined. The NPDW located at depths between 2500 and 3500 meters north of the Tuamotu Archipelago is found to have different $\mathrm{CO}_{2}$, alkalinity and silicate properties from that located south of it. Because of the presence of the high topographic barrier, these waters have taken different circulation paths and hence reflect different biogeochemical histories. The Revelle factor for waters throughout the main thermocline south of about $20^{\circ} \mathrm{S}$ has been found to be uniformly 10 . This suggests that $\mathrm{CO}_{2}$ was added to these waters with a ratio of 8 parts from the oxidation of organic debris and 1 part from the dissolution of calcareous tests. 


\section{INTRODUCTION}

The global oceans contain about 50 times as much $\mathrm{CO}_{2}$ as the atmosphere and actively exchange $\mathrm{CO}_{2}$ with it. Accordingly, the atmospheric $\mathrm{CO}_{2}$ concentration, which affects the heat balance of the earth and hence the climate, is sensitively affected by changes in the oceans' holding capacity for $\mathrm{CO}_{2}$. In 1989, it was realized that no definitive set of $\mathrm{CO}_{2}$ measurements for the global oceans exists. To remedy the situation, the DOE announced in the Federal Register Notice \#89-7 the initiation of the Ocean $\mathrm{CO}_{2}$ Program in collaboration with the WOCE Hydrographic and JGOFS Programs. The main purpose of the DOE program is to determine the concentration of $\mathrm{CO}_{2}$ and associated properties in the global oceans, so that a) the data may be used to establish an accurate inventory of $\mathrm{CO}_{2}$ in the oceans and 2) the data may be used to constrain and/or validate the global ocean carbon cycle models.

The investigation described in this report was funded by DOE under the original title of " $\mathrm{CO}_{2}$ Measurements along the WOCE P-16 and P-19 Sections in the South Pacific Ocean: A joint LDGO/WHOI Program". After the grant was awarded in 1990, the original program was modified because of the following two events. First, the original WOCE oceanographic expedition schedule was delayed by a year or more due to delays in the major structural modifications of the R/V Knorr and R/V Melville, which had been selected for the WOCE expeditions. Second, Dr. Peter G. Brewer who was one of the co-principal investigators of the original proposal left the Woods Hole Oceanographic Institution (WHOI) to accept the chief administrative position at the Monterey Bay Aquarium and Research Institute. For this reason, the joint LDGO/WHOI program was reformulated to be operated as two independent investigations. Accordingly, our group from Lamont investigated the two WOCE sections, $P-16 C$ and $P-17 C$, instead of the P-16 and P-19 Sections proposed originally in the South Pacific Ocean. This report summarizes the results of $\mathrm{CO}_{2}$ measurements obtained during the 40-day long TUNES/ 2 Expedition aboard the R/V Thomas Washington along the WOCE P-16C and P-17C Sections, which are located in the central South Pacific Ocean along the $150^{\circ} \mathrm{W}$ (between $17.5^{\circ} \mathrm{S}$ and $37.5^{\circ} \mathrm{S}$ ) and $135^{\circ} \mathrm{W}$ meridians (between $6^{\circ} \mathrm{S}$ and $33^{\circ} \mathrm{S}$ ) respectively. These two sections were extended as far south as $65^{\circ} \mathrm{S}$ during the investigations in the following years. The WOCE Section $\mathrm{P}-17 \mathrm{~N}$ in the North and equatorial Pacific, which constitutes the northern extension of our P-17C Section, was investigated by the WHOI group (Catherine Goyet), and the P-16N Section, which constitutes the northern extension of our 
P-17C Section to about $20^{\circ} \mathrm{N}$ (Hawaii), was investigated by Keeling's group from the Scripps Institution of Oceanography (SIO) and the WHOI group.

\section{SAMPLING AND EXPERIMENTAL METHODS}

The TUNES/2 Expedition aboard the R/V Thomas Washington started from Papeete, Tahiti, on July 16, 1991, and returned to the same port on August 25, after 40 days at sea. During the expedition, the total $\mathrm{CO}_{2}$ concentration in 1000 ocean water samples and the $\mathrm{pCO}_{2}$ in 940 discrete water samples were determined aboard the ship. Many of the total $\mathrm{CO}_{2}$ determinations were made in duplicate; the $\mathrm{pCO}_{2}$ measurements were made in duplicate for all the samples and in quadruplicate for some samples. In addition, about 160 total $\mathrm{CO}_{2}$ determinations were made for the Certified Reference Water Samples provided by A. G. Dickson of SIO, and about 20 determinations for the atmospheric $\mathrm{CO}_{2}$ concentration. All the hydrographic measurements including pressure, temperature, salinity, the concentrations of dissolved oxygen and nutrients were made by the staff of the SIO's Oceanographic Data Facility.

\section{II-a) Sampling Locations and Methods:}

A total of 96 hydrographic stations were occupied during the TUNES/2 Expedition. Stations 124 through 179, which constitute the P-17C Section, were located approximately along the $135^{\circ} \mathrm{W}$ meridian between $6^{\circ} \mathrm{S}$ and $33^{\circ} \mathrm{S}$; and Stations 180 through 220 , which constitute the P-16C Section, were located along the $150^{\circ} \mathrm{W}$ meridian between $17.5^{\circ} \mathrm{S}$ and 37.5'S. Figure 1 shows the station locations and numbers. The hydrographic measurements and water sampling were conducted by the staff of the Oceanographic Data Facility of the Scripps Institution of Oceanography (ODF/SIO), and the descriptions of the shipboard equipment and procedures are based on the Chief Scientists' Report provided by James Swift of Sio.

Throughout the expedition, a 24/12 double-ring 36-bottle CTD/rosette sampler was used for sampling by the staff of ODF/SIO. An ODF-modified NBIS Mark 3 CTD, a Benthos altimeter and a SeaTech transmissometer were mounted on the rosette frame. Seawater samples were collected in PVC 10-liter Niskin and ODF bottles mounted on the rosette frame. 
Fig. 1 - The locations of hydrographic stations occupied during the TUNES/2 Expedition for the WOCE Sections P-16C and P-17C during July-August, 1991.

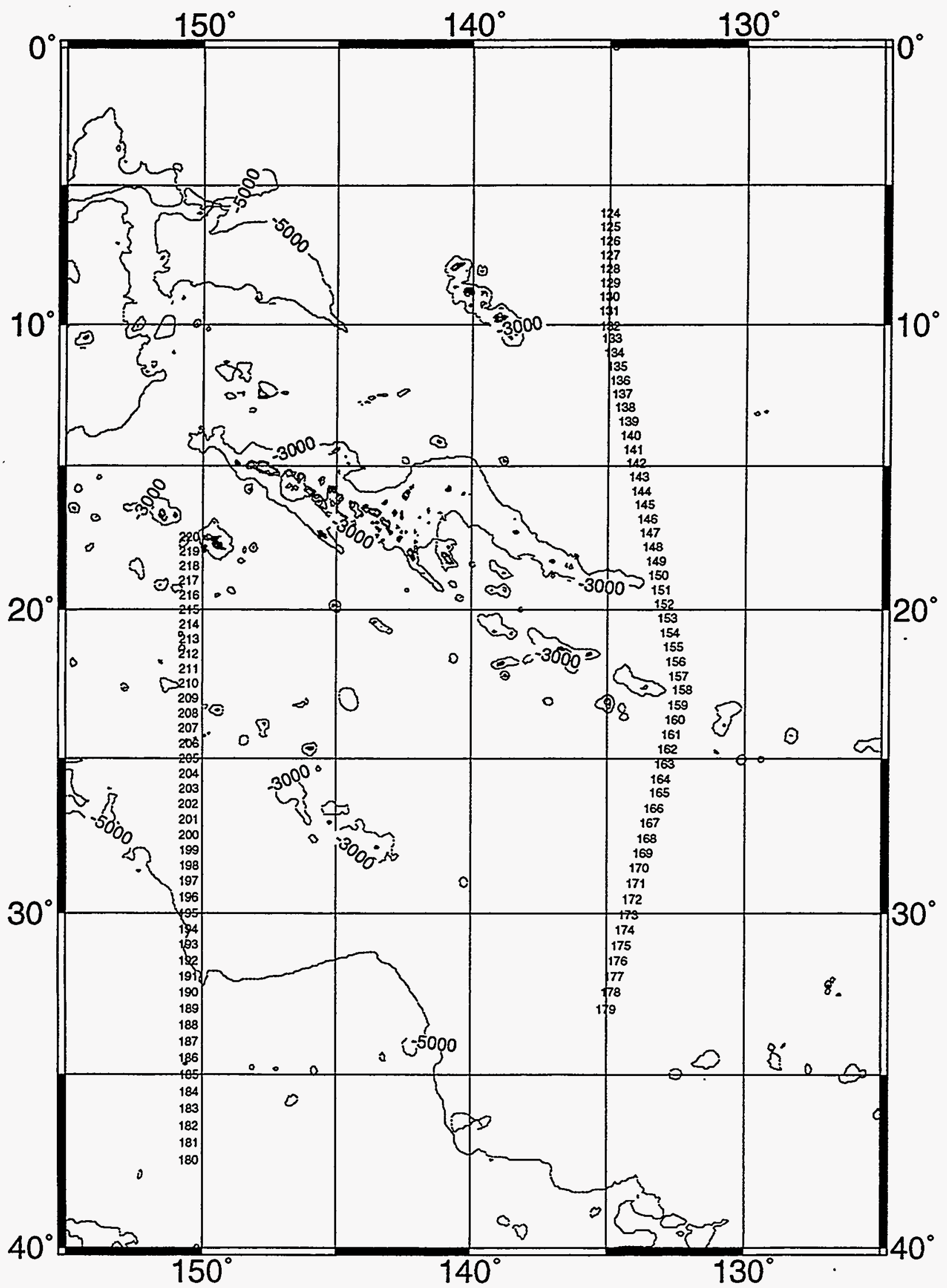


The rosette/CTD was lowered into the ocean using a three-conductor cable which provided power to the CTD and transmitted the CTD signals to the laboratory, where the signals were recorded and processed with an on-board computer and displayed on CRTs in real time.

As soon as each rosette cast was brought on board, water samples were drawn into respective containers in the following order: $\mathrm{CFCs}$, helium-3, oxygen, total $\mathrm{CO}_{2}, \mathrm{pCO}_{2}$, alkalinity, AMS carbon-14, tritium, nutrients and salinity. Status of the water sample (e.g. valve leaking, incomplete closing of lid, lanyard caught in lid etc.) was noted on the Sample Log Sheet.

II-b) Determination of Total $\mathrm{CO}_{2}$ Concentration in Seawater:

The coulometric analysis system which was used to measure the total $\mathrm{CO}_{2}$ concentration in seawater samples $\left(\mathrm{TCO}_{2}\right)$ during the expedition is similar to the one described by Johnson et al. (1985) and is briefly summarized below. This system consists of a coulometer (Model 5011) manufactured by the UIC Inc. (Jolliet, IL) and a sample introduction $/ \mathrm{CO}_{2}$ extraction system of the LDEO design, which differs from the Single Operator Multiparameter Metabolic Analyzer (SOMMA) system used by most of the other participants of the $\mathrm{DOE} / \mathrm{CO}_{2}$ program. In the LDEO system (Chipman et al., 1993), a precisely known volume of seawater sample is introduced manually into an $\mathrm{CO}_{2}$ extraction vessel using a calibrated syringe, instead of an automated pipette used by the SOMMA system.

Samples for $\mathrm{TCO}_{2}$ analysis were drawn from the Niskin samplers of the rosette casts directly into $250 \mathrm{ml}$ glass reagent bottles with ground standard-taper stoppers, sealed with silicone vacuum grease. All samples were poisoned with $200 \mu \mathrm{l}$ of $50 \%$ saturated mercuric chloride solution to prevent biological alteration of the $\mathrm{TCO}_{2}$, and were analyzed within 24 hours of collection. For analysis, a calibrated volume (ranging between 19 and $20 \mathrm{ml}$ ) of water sample was introduced into a $\mathrm{CO}_{2}$ extraction chamber through a Hamilton valve. The mass of the seawater sample delivered was calculated using the density of the seawater at the temperature of injection using the International Equation of State of Seawater (Millero et al., 1980). Prior to the expedition, the volume of each sampling syringe between the two reference stops was determined by repeatedly weighing it "empty" and "filled" with distilled water. The measurements were corrected for the buoyancy due to the air displaced by the water, which amounted to approximately $0.1 \%$ of the weight of the water, and the volume was computed using the density of pure water at the temperature of the measurement. Repeated 
measurements yielded a precision of $\pm 0.03 \%$. The seawater sample in the extraction vessel was acidified with $1 \mathrm{ml}$ of $8.5 \%$ phosphoric acid introduced through the Hamilton valve into an extraction chamber where the evolved $\mathrm{CO}_{2}$ was removed from the sample and transferred into the electrochemical cell of the $\mathrm{CO}_{2}$ coulometer by a stream of $\mathrm{CO}_{2}$-free air generated by a pure air generator. In the coulometer cell, the $\mathrm{CO}_{2}$ was quantitatively absorbed by a solution of ethanolamine in dimethylsulf oxide (DMSO). Reaction between the $\mathrm{CO}_{2}$ and the ethanolamine formed the weak hydroxyethylcarbamic acid. The $\mathrm{pH}$ change of the solution associated with the formation of this acid resulted in a color change of thymolphthalein $\mathrm{pH}$ indicator in the solution. The color change, from deep blue to colorless, was detected by a photodiode, which continually monitored the transmissivity of the solution. The electronic circuitry of the coulometer, on detecting the change in the color of the $\mathrm{pH}$ indicator, caused a current to be passed through the cell, electro-generating hydroxyl $(\mathrm{OH})$ ions fromed a small amount of water in the solution. The $\mathrm{OH}^{-}$generated titrated the acid, returning the solution to its original $\mathrm{pH}$ (and hence color), at which point the circuitry interrupted the current flow. The product of current passed through the cell and time was related by the Faraday constant to the number of moles of $\mathrm{OH}$ generated to titrate the acid and hence to the number of moles of $\mathrm{CO}_{2}$ absorbed to form the acid. A thermostated foot-bath mounted on the base of the titration cell was used to extract the heat generated in the cell during titration, to eliminate the shifting of the endpoint of the titration due to change in temperature of the cell solutions.

The coulometer was calibrated using research grade $\mathrm{CO}_{2}$ gas ( $99.998 \%$ pure) introduced into the carrier gas line upstream of the extraction tube, using alternately two fixed-volume sample loops on a gas sampling valve and measuring the pressure of the gas in the loops by venting them to the atmosphere and determining the barometric pressure using the same electronic barometer used with the $\mathrm{pCO}_{2}$ system; the loop temperatures were measured to $\pm 0.05^{\circ} \mathrm{C}$ with a thermometer calibrated against one traceable to the NBS, and the non-ideality of $\mathrm{CO}_{2}$ was incorporated in the computation of the loop contents. Prior to the expedition, the volume of the loops was determined by the weight difference between the loop/injection valve assembly empty and that filled with water. Repeated measurements indicated that the volumes of those loops were precise to $\pm 0.02 \%$. During the expedition, the coulometer was calibrated several times daily using the gas sampling system described above. The calibration factor, which represents the ratio between the number of moles of $\mathrm{CO}_{2}$ in the loop and the 
reading of coulometer, changed during the use of a titration cell above or below the ideal ratio of unity by a few tenths of percent depending upon the condition of the coulometric solution in the titration cell. Fig. 2 shows the typical variation of the calibration factor as a function of the cumulative amount of $\mathrm{CO}_{2}$ titrated by a cell and indicates that it may be represented by a quadratic form. Accordingly, the $\mathrm{CO}_{2}$ concentration in each seawater sample was determined using a calibration factor estimated using an equation fitted to the calibration data obtained several times for each titration cell. Generally, a titration cell had to be cleaned and filled with new solution after about 40 samples were analyzed. Beyond this number of analyses, the cell began to behave erratically yielding unreliable analytical results. The working equation used for computing the coulometer/cell calibration factor (CF) is as follows.

$$
\begin{aligned}
& \mathrm{CF}=\left(12.011^{*} 10^{6}\right) * \mathrm{PA}^{*}\left[\mathrm{LPV}^{*}\left(1+3^{*} \alpha\right)^{*}(\mathrm{TK}(\text { calib })-\mathrm{TK}(\mathrm{lp}))\right] /\left\{\mathrm{MV}\left(\mathrm{CO}_{2}\right)^{*}\left[\mathrm{RD}-\left(\mathrm{TM}^{*} \mathrm{BL}\right)\right]\right\} \\
& \text { where } 12.011 * 10^{5}=\text { Atomic weight (in } \mu \mathrm{gm} \text { ) of carbon, } \\
& \text { PA = Pressure (in atm) of } \mathrm{CO}_{2} \text { gas in loop at time of calibration, } \\
& \text { LPV } \quad \text { = Volume of calibration valve loop (in } \mathrm{ml} \text { ) at TK(lp), } \\
& \alpha \quad=\quad \text { Linear thermal expansion coefficient of stainless steel, } \\
& 1.73 * 10^{-5} \circ \mathrm{K}^{-1} \text {, } \\
& \text { TK(lp) = Temperature (in }{ }^{\circ} \mathrm{K} \text { ) at which loop volume was determined, } \\
& \text { TK(calib) = Temperature (in }{ }^{\circ} \mathrm{K} \text { ) of } \mathrm{CO}_{2} \text { in loop at time of calibration, } \\
& \mathrm{MV}\left(\mathrm{CO}_{2}\right)=\text { Molar volume of } \mathrm{CO}_{2} \text { (in } \mathrm{ml} \text { ) at temperature at which loop } \\
& \text { volume was determined, } \\
& \text { RD = Coulometer reading (in } \mu \mathrm{gm} \text {-Carbon), } \\
& \text { TM = Length of calibration run (in minutes), and } \\
& \text { BL = Instrumental blank (or background) rate (in } \\
& \text { Hgm-Carbon/minute). }
\end{aligned}
$$

The following relationships were used for the computation of the total $\mathrm{CO}_{2}$ concentration in seawater samples using the coulometer;

$\mathrm{TCO}_{2}(\mu \mathrm{mol} / \mathrm{kg})=\mathrm{CF}{ }^{*} \mathrm{DF}{ }^{*}\left[\mathrm{RD}-\mathrm{AB}-\left(\mathrm{TM}^{*} \mathrm{BL}\right)\right] /\left(12.011^{*} \mathrm{VL} * \mathrm{RHO}\right)$ 
Fig. 2 - Change in the coulometer calibration factor as a function of the amount of $\mathrm{CO}_{2}$ titrated. The change is expressed in terms of the percentage deviation from the ideal ratio of unity.

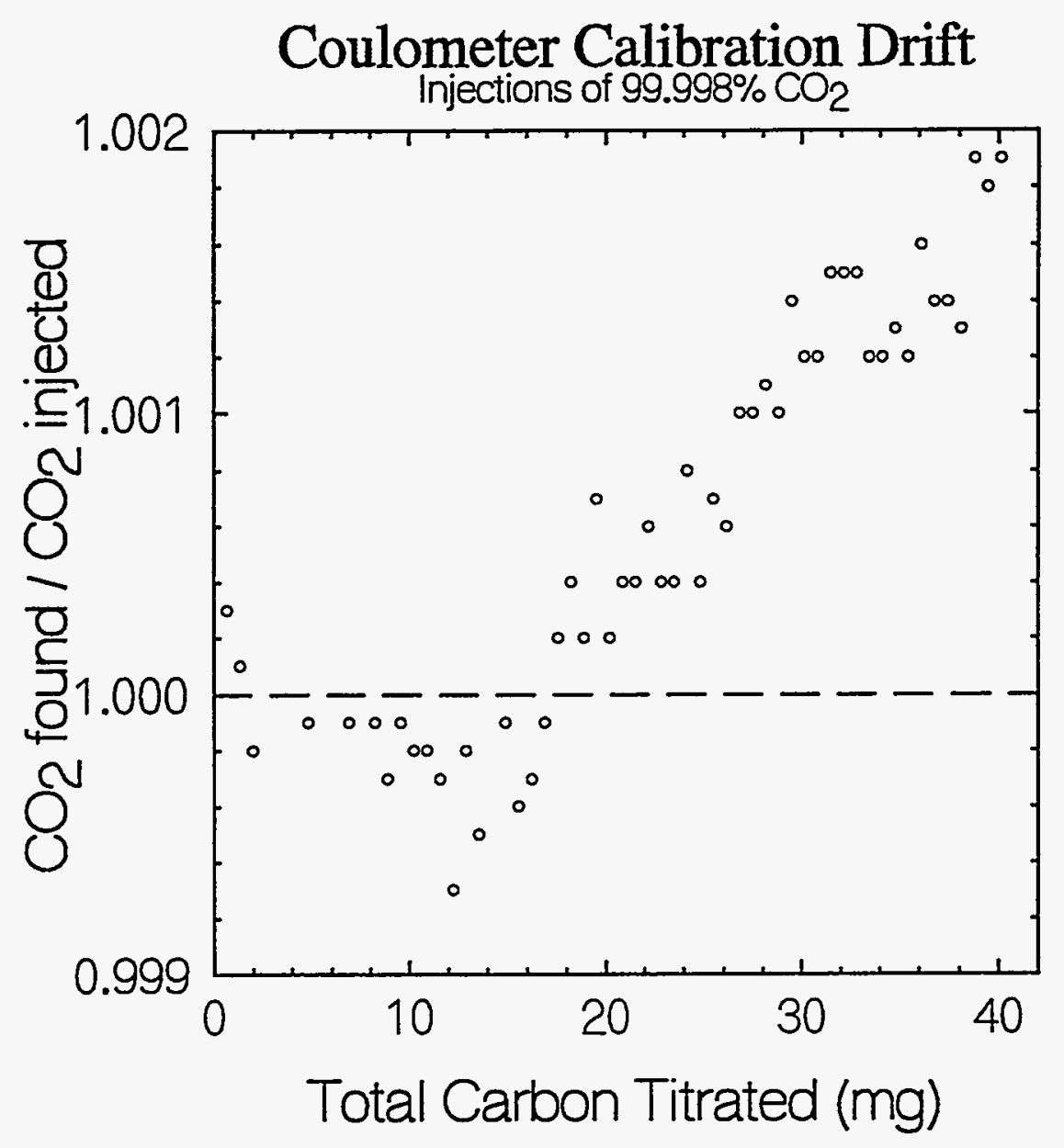


where CF = Calibration factor of coulometer/cell combination interpolated to the time when the measurement was made,

$\mathrm{DF}=$ Dilution factor to account for dilution of seawater sample by $\mathrm{CO}_{2}$-f ree mercuric chloride poisoning solution, $D F=[$ (sample volume $)+$ (poisonvolume) $] /($ sample volume $)=1.0004$ for $100 \mu$ of mercuric chloride solution in $250 \mathrm{ml}$ sample,

RD = Coulometer reading (in $\mu$ gm-Carbon),

$\mathrm{AB}=$ Acid blank (in $\mu \mathrm{gm}$-Carbon) to account for small amount of $\mathrm{CO}_{2}$ in phosphoric acid solution added to sample; determined by measuring $\mathrm{CO}_{2}$ stripped from larger volume of acid, typically less than $0.03 \%$ of amount of $\mathrm{CO}_{2}$ in seawater sample,

$\mathrm{TM}=$ Length of analytical run (in minutes),

$\mathrm{BL}=$ Instrumental blank rate (in $\mu \mathrm{gm}-$ Carbon $/ \mathrm{min}$ ), typical blank rate being 0.01 to $0.02 \mu \mathrm{gm}$-Carbon/min; the maximum acceptable blank rate of $0.05 \mu \mathrm{gm}$-Carbon $/ \mathrm{min}$ results in a correction of approximately $0.1 \%$ over the normal length of an analytical run,

$\mathrm{VL}=$ Volume of seawater sample (in liters) injected into stripping chamber, determined by use of pre-calibrated fixed-volume syringes, typical sample volume being 0.019 to 0.020 liters,

RHO = Density of seawater sample at the temperature of injection into stripping chamber, calculated using the UNESCO equation of state for seawater, the salinity, and the temperature measured on the water remaining in the syringe immediately af ter injecting sample,

$12.011=\quad$ Atomic weight (in grams) of carbon.

The precision of the total $\mathrm{CO}_{2}$ measurements was further tested by analyzing the Certified Reference Solutions each day along with the seawater samples. These Reference Solutions were provided by Dr. A. G. Dickson of SIO and their total $\mathrm{CO}_{2}$ concentration was determined by the staff of C. D. Keeling, SIO, using his manometric method. Fig. 3 shows a comparison between the results of our ship board measurements of these Reference Solutions during the expedition. Our shipboard measurements yielded a mean value of $2303.2 \pm 1.5$ $\mu \mathrm{mol} / \mathrm{kg}(\mathrm{N}=156)$, which compares with $2304.6 \pm 1.6 \mu \mathrm{mol} / \mathrm{kg}(\mathrm{N}=9)$ determined 
Fig. 3 - Comparison between the results of the coulometric determinations of total $\mathrm{CO}_{2}$ concentration in the SIO Reference Solutions (Batch \#6) obtained during this expedition and the manometric determinations obtained by the staff of $C$. $D$. Keeling, SIO. The 158 measurements made during the expedition yield $2303.2 \pm 1.5 \mu \mathrm{mol} / \mathrm{kg}$, which compares with the mean manometric value of $2304.6 \pm 1.6 \mu \mathrm{mol} / \mathrm{kg}(\mathrm{N}=9)$. The mean values for each set of measurements agree with each other within respective standard deviations.

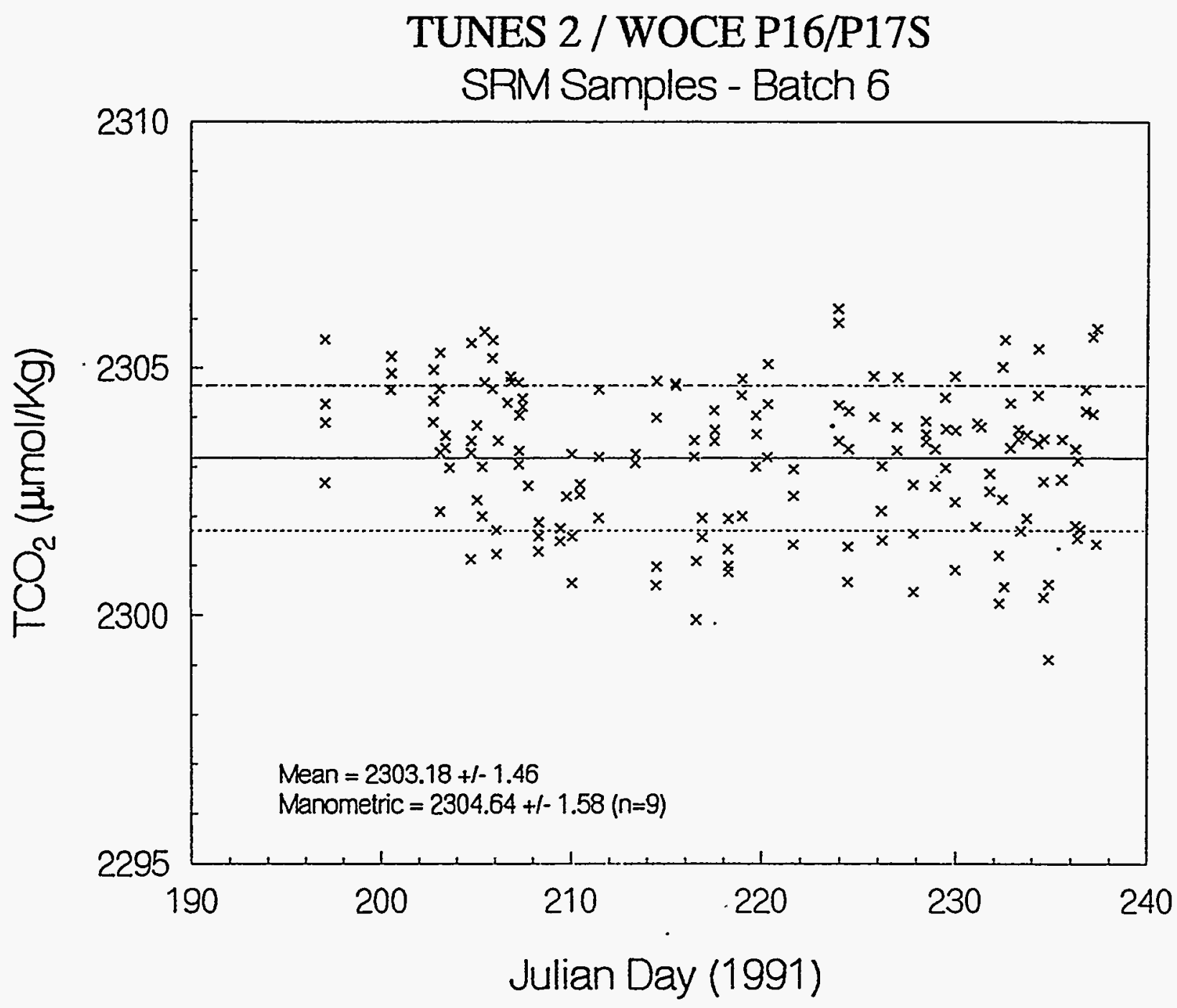


manometrically by the staff of C. D. Keeling. Although our value is smaller than the Keeling value by $1.4 \mu \mathrm{mol} / \mathrm{kg}$, these mean values overlap within one standard deviation. Thus, the total $\mathrm{CO}_{2}$ concentration values reported in this report are consistent with the manometric values within $\pm 1.5 \mu \mathrm{mol} / \mathrm{kg}$. The total $\mathrm{CO}_{2}$ values listed in this report are not corrected for the systematic difference of $1.4 \mu \mathrm{mol} / \mathrm{kg}$.

The water samples for total $\mathrm{CO}_{2}$ analyses were collected from Niskin samplers after 1 to 2 liters of headspace was formed by the withdrawal of other water samples. Since the marine air introduced into the headspace had lower $\mathrm{pCO}_{2}$ values than those for the seawater in the samplers, especially after several degrees of warming occurred during hoisting, it is likely that $\mathrm{CO}_{2}$ was lost from the sample waters to the headspace. During the South Atlantic Ventilation Experiment (SAVE) program, the loss has been estimated by comparing the total $\mathrm{CO}_{2}$ concentrations determined for those from the 10-liter Niskin samplers with that drawn from the 280-liter Gerard samplers. Because of its large mass, the water temperature in a Gerard sampler changed little during hoisting from the sampling depth. In addition, because of the height (about 1.5 meters), an water sample drawn from the base of the sampler was thought to be unaffected by the air introduced into the headspace. For these reasons, it was considered that little or no $\mathrm{CO}_{2}$ had been lost from the water samples withdrawn from Gerard samples. The results of nearly 40 pairs of comparison indicate that the deep water samples collected from the Niskin samplers appear to have lost no more than $2 \mu \mathrm{mol} / \mathrm{kg}$ of $\mathrm{CO}_{2}$ bef ore the seawater samples were transferred into the sample bottles for analysis.

II-c) Determination of $\mathrm{pCO}_{2}$ in Seawater and Air Samples:

A fully automated equilibrator-gas chromatograph system was used during the expedition for the determination of partial pressure of $\mathrm{CO}_{2}$ exerted by the seawater samples, and its design has been described by Chipman et al. (1993). Fig. 4 gives a schematic diagram of this system.

The system consists of a pair of air circulation pumps (Spectrex Model AS-300-SS) plumbed to recirculated air through porous plastic gas dispersers which are immersed in two separate seawater samples. Electrically driven Valco 4-port valves were used to isolate each of the equilibrators during the initial equilibration prior to analysis of the equilibrated air. Manually operated 2-way and 3-way Whitey valves allowed part of the water in each 
Fig. 4 - Schematic diagram of the automated GClequilibrator system used for the $\mathrm{pCO}_{2}$ measurements in discrete seawater samples $(500 \mathrm{ml})$ during this expedition (Chipman et al., 1993).

\section{LDGO pCO2 Gas Chromatograph}

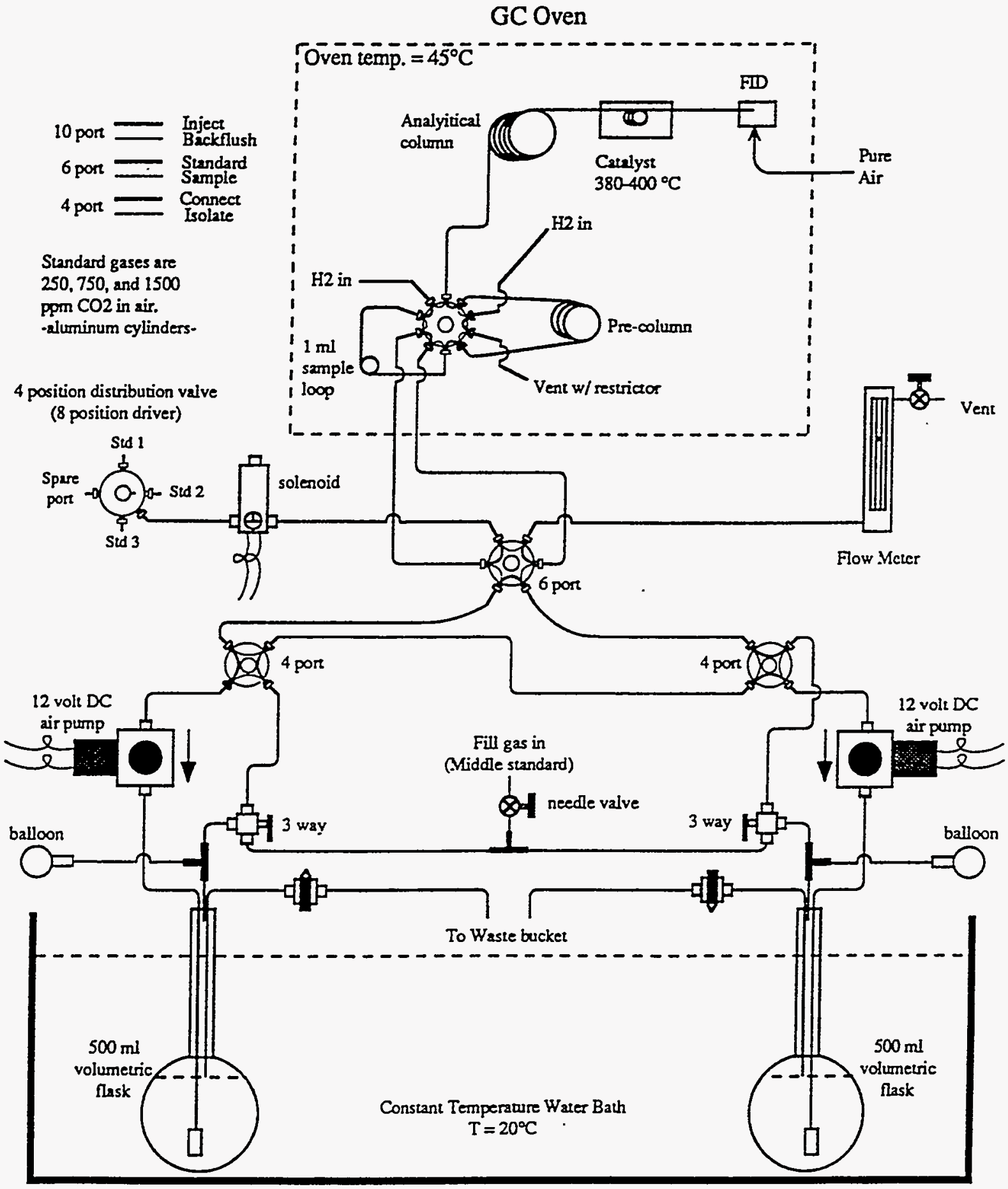


equilibrator to be replaced with air of known initial $\mathrm{CO}_{2}$ concentration, to create the necessary headspace for equilibration. A drain line in each equilibrator insured that the ratio of water to air in each equilibrator was constant, allowing accurate corrections to be made for the effect of the perturbation of the sample seawater by the headspace air. Diaphragms (thin rubber balloons) were plumbed to each equilibrator to provide "soft walls" to the system, so that the pressure in the equilibrators was kept close to the ambient laboratory atmospheric pressure which was measured with a high precision electronic barometer. Since the partial pressure of $\mathrm{CO}_{2}$ is strongly affected by temperature changes, the equilibration flasks were kept immersed in a constant temperature water bath, held at a temperature of $20.00^{\circ} \mathrm{C}$. An electrically driven Valco 6-port valve allowed the entire equilibration system to be isolated, simultaneously connecting a calibration gas selection valve (also electrically driven Valco, Model 4SD, with 4 input ports but with an eight-position driver, so that all gas flows were blocked at the four intermediate positions). A 2-way normally-closed Skinner solenoid valve on the output of the calibration selection valve allowed the gas flows to be controlled by the system controller, and provided a necessary second means of stopping the flow of the calibration gases to prevent the accidental loss of calibration gases in the event of control malfunction.

The analysis of the $\mathrm{CO}_{2}$ in the equilibrated air or calibration gases was performed using a Shimadzu Mini-2 gas chromatograph, which was equipped with a flame ionization detector. A one-ml sample loop and a pre-column and analytical column (both packed with Chromosorb 102, of 0.2 and $2.0 \mathrm{~m}$ lengths respectively) were attached to an electrically driven Valco 10-port valve within the column oven of the gas chromatograph. Ultra-high purity hydrogen gas (electrolytically generated by an Aadco hydrogen generator and purified by means of diffusion through a palladium foil using an Aadco hydrogen purifier) served as the carrier gas for the chromatographic separation of $\mathrm{CO}_{2}$ from the other components of the air. The use of hydrogen for carrier gas also allowed the $\mathrm{CO}_{2}$ to be converted to methane in an attached catalytic converter prior to quantification by the flame ionization detector. Unlike the method described by Weiss (1981), our system used a catalyst of ruthenium metal on Chromosorb W support and did not require a palladium pre-catalyst to remove oxygen from the carrier gas stream. Hydrocarbon-free air to support the combustion in the flame ionization detector was provided by means of a chromatographic air purifier (Aadco Model 737). 
Integration of the output signal from the gas chromatograph and control of the entire equilibration and calibration procedure was provided by means of a Shimadzu Chromatopac (Model C-R6A) computing integrator.

The analytical procedure is as follows. Water samples for analysis were drawn from the 10-liter Niskin samplers of a rosette cast directly into 500-ml narrow-necked Pyrex flasks which serve both as sample containers and equilibration vessels. The samples were poisoned with $200 \mu \mathrm{l}$ of $50 \%$ saturated mercuric chloride solution to prevent biological modification of the $\mathrm{pCO}_{2}$, and were stored in the dark until measurement, which normally was performed within 24 hours of sampling. A headspace of 3 to $5 \mathrm{ml}$ was left above the water in the flask to allow for thermal expansion during storage. The flasks were sealed air-tight using screw-caps with conical plastic liners.

The equilibrated air samples were saturated with water-vapor at the temperature of equilibration and had the same $\mathrm{pCO}_{2}$ as the water sample. By injecting the air aliquot without removing the water vapor, the partial pressure of $\mathrm{CO}_{2}$ was determined directly, without the need to know the water vapor pressure (Takahashi et al., 1982) using the relationship below:

$$
\mathrm{pCO}_{2}(\mu \mathrm{atm})=[\mathrm{Cmeas}(\mathrm{ppm})]^{*}[\text { Total pressure of equilibration }(\mathrm{atm})]
$$

where Cmeas is the mole fraction concentration of $\mathrm{CO}_{2}$ in equilibrated moist air. The total pressure of equilibrated air was measured by having the head space in the equilibrator flask always at atmospheric pressure which was, in turn, measured with the electronic barometer at the time each equilibrated air sample was injected into the gas chromatograph.

Corrections were made to account for the change in $\mathrm{pCO}_{2}$ of the sample water due to the transfer of $\mathrm{CO}_{2}$ to or from the water during equilibration with the recirculating air. The analytical steps yielding Cmeas, which have been programmed in the on-line computer, are schematically shown in Fig. 5-A; the $\mathrm{pCO}_{2}$ correction routines in Fig. 5-B; and a list of variables in Fig. 5-C. The overall precision of the $\mathrm{pCO}_{2}$ measurement has been estimated to be about $\pm 0.10 \%$ based on the reproducibility of replicate equilibrations.

The air samples for $\mathrm{pCO}_{2}$ analysis were collected in a $50 \mathrm{ml}$ glass syringe equipped with a plastic shut-off valve. The syringe was flushed with several volumes of air from a point 
Fig. 5 - Analytical steps for (A) the measurement of $\mathrm{pCO}_{2}$ in discrete seawater samples using the LDEO GC/equilibrator system, (B) the correction procedures and equations and (C) a list of variables used in (A) and (B).

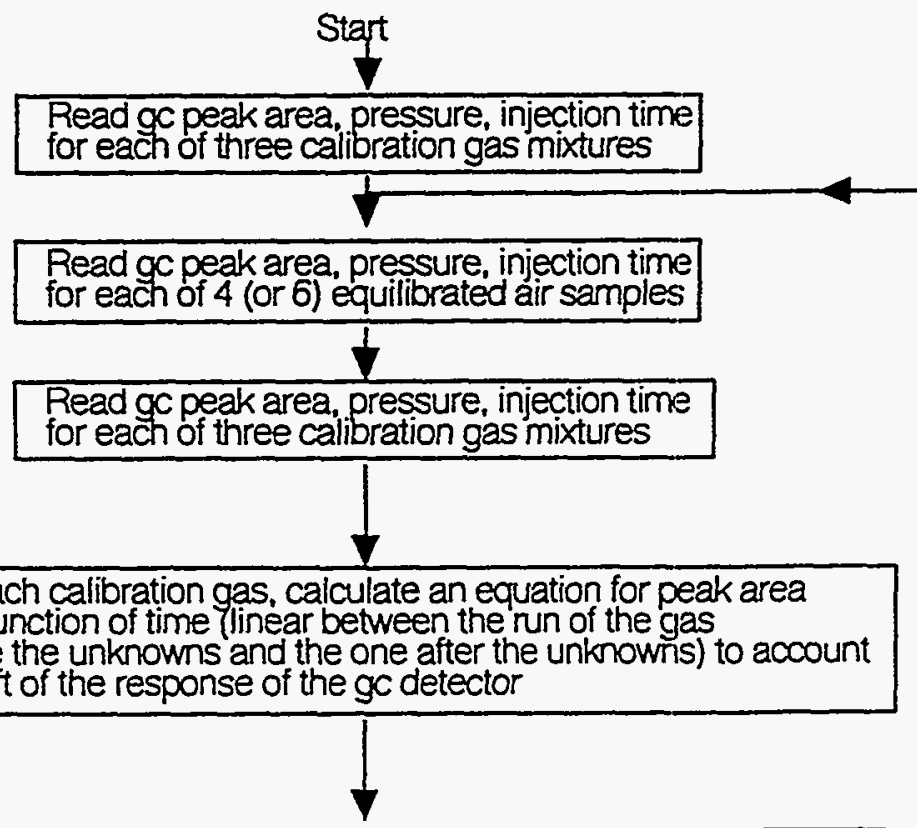

For each equilibrated air sample, calculate the peak area each of the calibration gases would have had at the time the air sample was injected, from the equations calculated above. Using these three peak areas and the calibration gas concentrations, calculate the gc response (as a parabola) and from the peak area of the air sample, calculate its $\mathrm{CO}_{2}$ concentration ( $\mathrm{C}_{\text {meas }}$ )

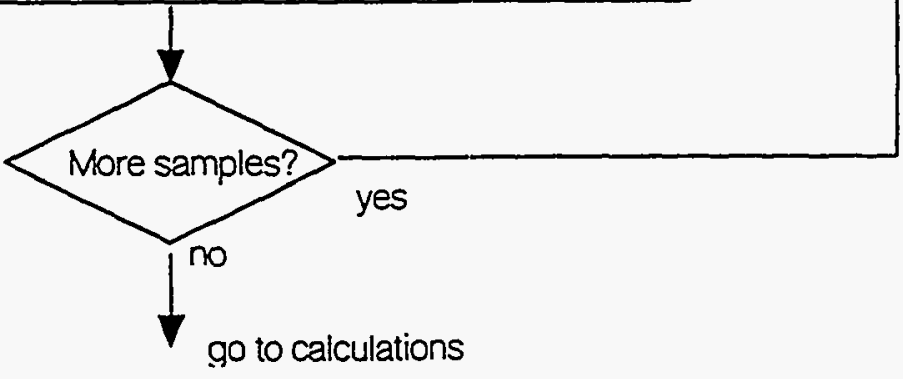


5 (B)

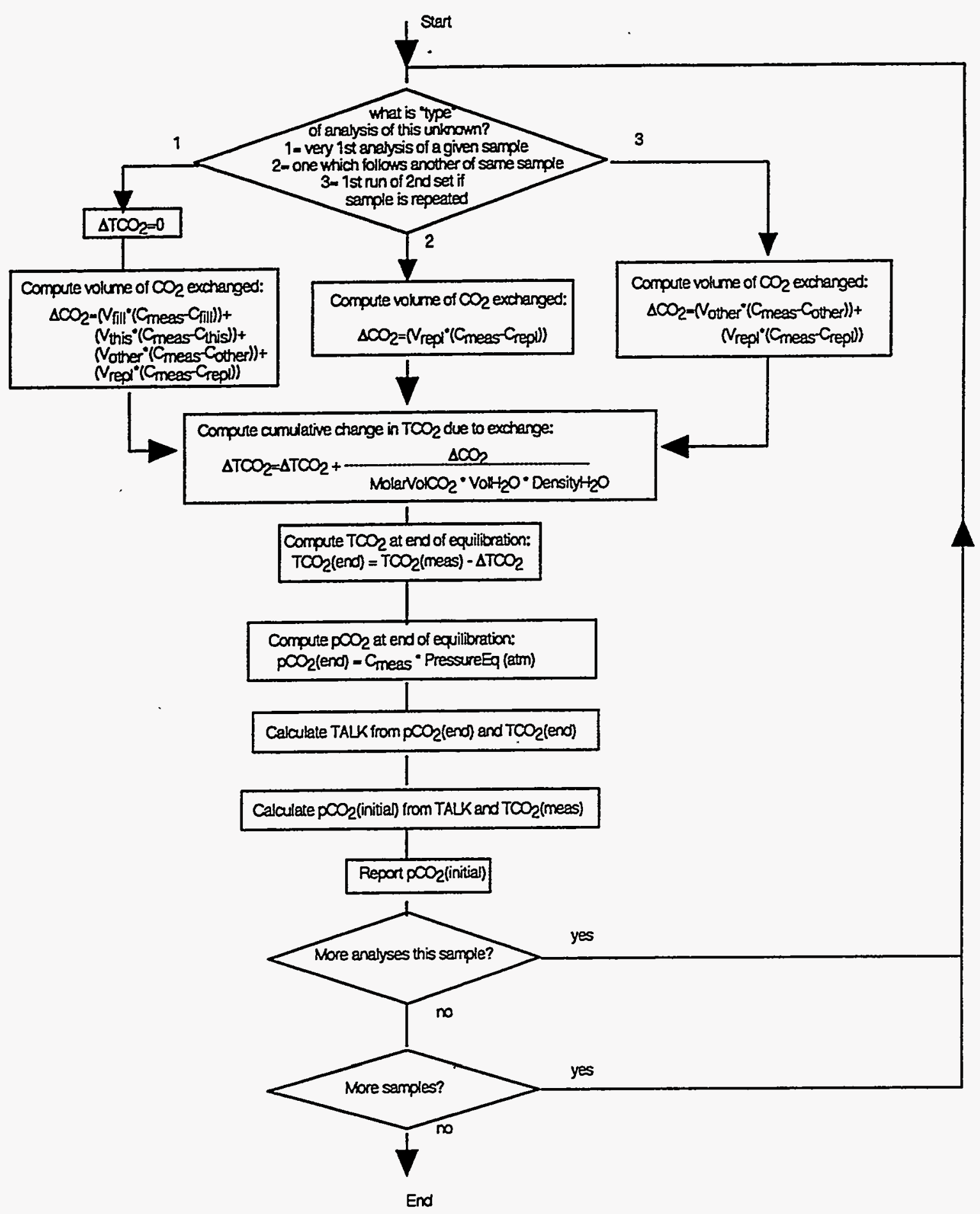


$\Delta \mathrm{TCO}_{2}=$ change in $\mathrm{TCO}_{2}$ concentration due to equilibration $\Delta \mathrm{CO}_{2}=$ volume of $\mathrm{CO}_{2}$ exchanged between water and headspace $\mathrm{C}_{\text {meas }}=$ mole fraction of $\mathrm{CO}_{2}$ in equilibrated air

$V_{\text {fill }}=$ Volume of headspace created by displacing water in equilibrator

$V_{\text {this }}=$ Volume of tubing \& pump not swept while creating headspace

$V_{\text {other }}=$ Volume of tubing connecting equilibrator to 6-port valve (filled with air from "other" equilibrator)

$V_{\text {repl }}=$ Volume of tubing connecting 6-port and 10-port valves \& sample loop (air "replaced" with calibration gas before each analysis)

$\mathrm{C}_{\text {fill }}=$ mole fraction of $\mathrm{CO}_{2}$ in air used to create headspace

$\mathrm{C}_{\text {this }}=$ mole fraction of $\mathrm{CO}_{2}$ in residual air in tubing \& pump

$\mathrm{C}_{\text {other }}=$ mole fraction of $\mathrm{CO}_{2}$ in preceeding sample in "other" equilibrator

$\mathrm{C}_{\text {repl }}=$ mole fraction of $\mathrm{CO}_{2}$ in "replacement" air

MolarVolCO $2=$ molar volume of $\mathrm{CO}_{2}$ at temperature of equilibration

$\mathrm{VolH}_{2} \mathrm{O}=$ volume of water sample in equilibrator

Density $\mathrm{H}_{2} \mathrm{O}=$ density of water sample at temperature of equilibrator

$\mathrm{TCO}_{2}$ (end) = concentration of $\mathrm{TCO}_{2}$ in sample after equilibrating with headspace

$\mathrm{TCO}_{2}$ (meas) = concentration of $\mathrm{TCO}_{2}$ measured colulometrically in fresh sample $\mathrm{pCO}_{2}$ (end) = partial pressure of $\mathrm{CO}_{2}$ measured after equilibration

PressureEq = pressure of equilibration (in atmospheres)

TALK = Total alkalinity of sample (unchanged during equilibration) $\mathrm{pCO}_{2}$ (initial) $=$ partial pressure of $\mathrm{CO} 2$ of sample water PRIOR TO equilibration (at temperature of equilibration) 
at the ship's rail facing into the wind, and the valve was closed to isolate the final volume of air. The syringe was then connected to the sampling loop (about $1 \mathrm{ml}$ ) of the gas chromatograph, and the loop was flushed with at least $40 \mathrm{ml}$ of the sample air about 30 seconds before the loop contents were injected into the GC for analysis. The over-all precision for the atmospheric $\mathrm{CO}_{2}$ measurements, including the effects of the sampling and analytical procedures, has been estimated to be about $\pm 0.2 \mathrm{ppm} \mathrm{CO}_{2}$ mole fraction in dry air.

The $\mathrm{pCO}_{2}$ values in air have been computed assuming that the air is saturated with water vapor at the seawater temperature. The following equation was used for this purpose:

$$
\left(\mathrm{pCO}_{2}\right)_{\text {air }}=\left(\mathrm{VCO}_{2}\right)_{2 \mathrm{ir}}^{*}(\mathrm{~Pb}-\mathrm{Pw})
$$

where $\left(\mathrm{VCO}_{2}\right)_{2 \mathrm{r}}$ is the mole fraction concentration of $\mathrm{CO}_{2}$ in dry air, $\mathrm{Pb}$ is the barometric pressure measured at each station and $\mathrm{Pw}$ is the equilibrium water vapor pressure at sea surface temperature and salinity. The following empirical expression was used to compute the equilibrium water vapor pressure, $\mathrm{Pw}$ :

$$
\begin{aligned}
\text { Pw }(\mathrm{atm})=(1 / 760)^{*}\left(1-5.3684 \times 10^{-4} . \mathrm{Sal}\right) * \\
\operatorname{EXP}\left\{[0.0039476-(1 / \mathrm{TK})] / 1.8752 \times 10^{-4}\right\}
\end{aligned}
$$

where Sal is salinity in PSU, and TK is the temperature in ${ }^{\circ} \mathrm{K}$.

Since the variability of atmospheric $\mathrm{CO}_{2}$ concentrations was expected to be small in the study area, 20 determinations were made during the expedition. The measurements yielded a mean atmospheric $\mathrm{CO}_{2}$ concentration of $351.3 \pm 1.0 \mathrm{ppm}$ (in mole fraction of $\mathrm{CO}_{2}$ in dry air). This mean value has been used to compute the atmospheric $\mathrm{pCO}_{2}$, and the sea-air $\mathrm{pCO}_{2}$ difference reported in this report was computed assuming the mean barometric pressure $(\mathrm{Pb})$ of $1.000 \mathrm{~atm}$ for the atmospheric $\mathrm{pCO}_{2}$.

II-d) Computation of the Alkalinity in Seawater:

The alkalinity of seawater has been computed using the observed values of $\mathrm{pCO}_{2}$, total $\mathrm{CO}_{2}$ concentration, phosphate concentration, temperature and salinity. For our computation, the total alkalinity (TALK) in seawater is defined by: 


$$
\mathrm{TALK}=\mathrm{Ac}+\mathrm{Ab}+\mathrm{Asi}+\mathrm{Ap}+\mathrm{Aw}
$$

$$
\begin{aligned}
& \text { where Ac = Carbonate alkalinity }=\left[\mathrm{HCO}_{3}^{-}\right]+2\left[\mathrm{CO}_{3}{ }^{-}\right] \\
& \mathrm{Ab}=\text { Borate alkalinity }=\left[\mathrm{H}_{2} \mathrm{BO}_{3}^{-}\right] \text {, } \\
& \text { Asi = Silicate alkalinity }=\left[\mathrm{H}_{3} \mathrm{SiO}_{4}^{-}\right] \text {, } \\
& \text { Ap = Phosphate alkalinity }=\left[\mathrm{H}_{2} \mathrm{PO}_{4}^{-}\right]+2\left[\mathrm{HPO}_{4}=\right]+3\left[\mathrm{PO}_{4}^{-3}\right] \text {, } \\
& \text { Aw }=\text { Water alkalinity }=[\mathrm{OH}]-\left[\mathrm{H}^{+}\right] \text {. }
\end{aligned}
$$

The total concentration of borate (TB) has been assumed to be proportional to salinity: TB $(\mu \mathrm{mol} / \mathrm{kg})=410.6^{*}(\mathrm{Sal} / 35)$. The borate alkalinity ranges between about $40 \mu \mathrm{eq} / \mathrm{kg}$ for deep waters and $100 \mu \mathrm{eq} / \mathrm{kg}$ for surface waters. Since the silicate concentration may be as high as $150 \mu \mathrm{mol} / \mathrm{kg}$ in deep waters, the silicate alkalinity is as high as $6 \mu \mathrm{eq} / \mathrm{kg}$ for deep water but it is negligibly small for surface waters. The phosphate alkalinity ranges from $0.5 \mu \mathrm{eq} / \mathrm{kg}$ for surface waters to about $5 \mu \mathrm{eq} / \mathrm{kg}$ in deep waters. The following apparent dissociation constants of acid in seawater were used; Merhbach et al. (1973) for carbonic acid; Lyman (1956) for boric acid; Kester and Pytkowicz (1967) for phosphoric acid; Ingri (1959) for silicic acid; and Millero (1979) and Culberson and Pytkowicz (1973) for water. The expressions used to compute these constants as a function of temperature and salinity and the computational scheme are described in Peng et al. (1987).

\section{II-e) Measurements of Hydrographic Variables:}

Pressure and Temperature: All pressure and temperature values for the bottle data tabulations were obtained by averaging CTD data for a brief interval at the time the bottle was closed on the rosette. All reported CTD values were calibrated with reference to the International Temperature Scale of 1990 and processed with the methodology described in the documentation accompanying the final CTD data report.

Salinity: Salinity samples were drawn into $200 \mathrm{ml}$ K.imax high alumina borosilicate glass bottles with custom-made plastic insert thimbles and Nalgene screw caps. This provided low container dissolution and sample evaporation. These bottles were rinsed three times before filling, and measurements were made usually within 8 to 36 hours of collection. Salinity 
was determined on the basis of electrical conductivity measured with an ODF-modified Guildline Autosal Model $8400 \mathrm{~A}$ salinometer, and the values were obtained according to the equations of the Practical Salinity Scale of 1978 (UNESCO, 1981). For the samples from Stations 124 through 140, the salinometer was calibrated using a batch of Wormley IAPSO standard seawater, P-114, with at least one fresh vial opened per cast. For the samples from Stations 141 through 220, the standard seawater from batch P-108 was used. A single comparison at sea during TUNES/2 yielded a salinity value for $\mathrm{P}-114$ about 0.002 PSU higher than that of P-108, when standardized against P-108. This compares with the estimated precision of about 0.001 PSU of this instrument operated at sea under normal conditions.

Oxygen: Water samples for oxygen analyses were collected shortly after the rosette sampler was brought on board and after the samples for CFC's and helium-3 were drawn. Sampling flasks (100 to $125 \mathrm{ml}$ ), whose volumes (with a stopper in place) were calibrated prior to the expedition, were rinsed carefully with minimal agitation, then filled using a drawing tube after allowing to overflow for at least two flask volumes. Reagents were added to fix the oxygen before stoppering. The flasks were shaken immediately after the stoppers were placed to seal them, and then again after 20 minutes, to assure thorough dispersion of the $\mathrm{Mn}(\mathrm{OH})_{2}$ precipitate. The oxygen concentration in these solutions were determined within 4 to 36 hour using the Winkler titration methods of Carpenter (1965) with modifications by Culberson and Williams (1991). The titrator was calibrated with $0.01 \mathrm{~N}$ potassium iodate standard solutions prepared using pre-weighed potassium iodate crystals. Standards were run at the beginning of each session of analyses, which typically included samples from one to three stations. Several batches of standard solutions were made up and compared to assure that the results were reproducible. A correction was made for the amount of oxygen added with the reagents, and combined reagent/distilled water blanks were determined to account for oxidizing or reducing materials in the reagents.

Oxygen concentrations were converted from milliliter per liter to micromoles per kilogram of seawater using the in-situ temperature. A molar volume at STP of 22.385 liter/mole (Kester, 1975) was used for this purpose. Ideally, the temperature at which a liter of seawater is converted to kilograms should be the temperature of the water when samples were collected in the sampling flasks. However, in-flask temperatures were measured and found to be 4 to $7^{\circ} \mathrm{C}$ warmer than the in-situ temperatures for mid-depths water samples. 
Accordingly, the magnitude of errors induced by using about $6^{\circ} \mathrm{C}$ colder temperature would be about $+0.08 \%$ or $+0.2 \mu \mathrm{mol} / \mathrm{kg}$.

The Apparent Oxygen Utilization (AOU) value was obtained by subtracting the measured value from the saturation value. The latter was computed at the potential temperature of water and $1 \mathrm{~atm}$ total pressure using the following expression based on the data of Murray and Riley (1969):

$$
\begin{aligned}
& \ln \left(\mathrm{O}_{2} \text { in } \mu \mathrm{mol} / \mathrm{kg}\right)=-173.9894+255.5907(100 / \mathrm{TK})+146.4813 \ln (\mathrm{TK} / 100) \\
& -22.2040(\mathrm{TK} / 100)+\operatorname{Sal}[-0.037362+0.016504(\mathrm{TK} / 100) \\
& \left.-0.0020564(\mathrm{TK} / 100)^{2}\right]
\end{aligned}
$$

where TK is temperature in ${ }^{\circ} \mathrm{K}$ and Sal in PSU.

Nutrients: The concentrations of phosphate, nitrate, nitrite and silicate in seawater were determined using a Technicon AutoAnalyzer based on the procedures described by Hager et al. (1972) and Atlas et al. (1971). The analyzer was calibrated using the standard solutions prepared aboard ship from pre-weighed standards. These solutions were used before and after the analyses for each cast consisting of about 36 samples to correct for instrumental drift. Sets of 4-6 different standard solutions having different concentrations were used periodically to determine the non-linear colorimeter response and the resulting corrections. The phosphate concentration was determined using the hydrazine reduction of phosphomolybdic acid (Bernhardt and Wilhelms, 1967). The silicate concentration was determined using stannous chloride reduction of silicomolybdic acid (Armstrong et al., 1967). The nitrite concentration was determined using diazotization and coupling to form dye; the nitrate concentration was determined as nitrite after nitrate was reduced by copperized cadmium (Armstrong et al., 1967). The precision of measurements has been estimated to be $\pm 0.1 \mu \mathrm{mol} / \mathrm{kg}$ for nitrate and silicate and $\pm 0.01 \mu \mathrm{mol} / \mathrm{kg}$ for phosphate. 


\section{DISTRIBUTION OF HYDROGRAPHIC AND $\mathrm{CO}_{2}$ PROPERTIES}

III-a) Distribution of $\mathrm{CO}_{2}$ and Other Properties in Surface Waters:

The distribution of 9 properties along the P-16C and P-17C sections are shown in Fig. 6. The data for $\mathrm{P}-16 \mathrm{C}$ along $150^{\circ} \mathrm{W}$ are shown with filled circles, and those for $\mathrm{P}-17 \mathrm{C}$ along $135^{\circ} \mathrm{W}$ with open circles. The surface water temperature varied from $28^{\circ} \mathrm{C}$ at $6^{\circ} \mathrm{S}$ to $13^{\circ} \mathrm{C}$ at $37.5^{\circ} \mathrm{S}$. Over the latitudinal range between $17.5^{\circ} \mathrm{S}$ and $32.5^{\circ} \mathrm{S}$ investigated by both sections, the temperature and the concentrations of nitrate, phosphate and silicate were similar, whereas $\mathrm{pCO}_{2}$ and the concentrations of oxygen and $\mathrm{CO}_{2}$ observed along $150^{\circ} \mathrm{W}$ were higher than those observed along $135^{\circ} \mathrm{W}$. The concentrations of nutrients in the subtropical gyre water located between $15^{\circ} \mathrm{S}$ and $34^{\circ} \mathrm{S}$ were very small as expected (nitrate $=0.1 \mu \mathrm{mol} / \mathrm{kg}$, phosphate $=0.07$ $\mu \mathrm{mol} / \mathrm{kg}$ and silicate $=1.0 \mu \mathrm{mol} / \mathrm{kg}$ ). North of $15^{\circ} \mathrm{S}$, these concentrations increased gradually to the northern limit of the present investigation at $6^{\circ} \mathrm{S}$ where nitrate $=6 \mu \mathrm{mol} / \mathrm{kg}$, phosphate $=0.6 \mu \mathrm{mol} / \mathrm{kg}$, and silicate $=2.5 \mu \mathrm{mol} / \mathrm{kg}$ were observed. Only a minor increase in nutrient concentrations was observed in the waters south of $34^{\circ} S$ to the southern limit of this investigation at $37.5^{\circ} \mathrm{S}$.

The total $\mathrm{CO}_{2}$ concentration increased southward from about $1990 \mu \mathrm{mol} / \mathrm{kg}$ at $6^{\circ} \mathrm{S}$ to $2050 \mu \mathrm{mol} / \mathrm{kg}$ at $37.5^{\circ} \mathrm{S}$, whereas the $\mathrm{pCO}_{2}$ in surface waters decreased southward from about $410 \mu \mathrm{atm}$ at $6^{\circ} \mathrm{S}$ to $290 \mu \mathrm{atm}$ at $27^{\circ} \mathrm{S}$ and increased to $310 \mu \mathrm{atm}$ at $37.5^{\circ} \mathrm{S}$. The greater $\mathrm{pCO}_{2}$ values in lower latitudes are mainly attributed to the effect of increased temperature. As indicated in the lowermost panel in Fig. 6, the tropical waters north of about $12^{\circ} \mathrm{S}$ were sources for atmospheric $\mathrm{CO}_{2}$ (positive $\Delta \mathrm{pCO}_{2}$ values), whereas the waters south of this latitude, especially those located south of about $25^{\circ} \mathrm{S}$, were strong sinks for atmospheric $\mathrm{CO}_{2}$ with negative $\Delta \mathrm{pCO}_{2}$ values ranging between -40 and $-50 \mu \mathrm{atm}$. This indicates that the oceanic area south of about $25^{\circ} \mathrm{S}$ between $135^{\circ} \mathrm{W}$ and $150^{\circ} \mathrm{W}$ was a strong $\mathrm{CO}_{2}$ sink during the austral winter, July-August, 1991. Murphy et al. (1991) measured the surface water $\mathrm{pCO}_{2}$ along $105^{\circ} \mathrm{W}$ and $130-140^{\circ} \mathrm{W}$ during the austral autumn of 1989 and that along $150^{\circ} \mathrm{W}$ and $170^{\circ} \mathrm{W}$ during the austral autumn of 1984 in the South Pacific. They reported that surface between $20^{\circ} \mathrm{S}$ and $35^{\circ} \mathrm{S}$ waters along $150^{\circ} \mathrm{W}$ were undersaturated with respect to atmospheric $\mathrm{CO}_{2}$ by -10 to $-20 \mu \mathrm{atm}$, whereas those between $20^{\circ} \mathrm{S}$ and $30^{\circ} \mathrm{S}$ along $135^{\circ} \mathrm{W}$ were supersaturated by +15 to $0 \mu$ atm (see their Plate 1 in page 20,458 ). On the other hand, our data show a greater degree of undersaturation by as much as -21 to $-56 \mu$ atm between $20^{\circ} \mathrm{S}$ and $37.5^{\circ} \mathrm{S}$ along $150^{\circ} \mathrm{W}$ and +1 to 
Fig. 6 - Meridional distribution of surface water properties along the P-16C and P-17C Sections. The open circles indicate the data along the $135^{\circ} \mathrm{W}$ meridian $(\mathrm{P}-17 \mathrm{C})$, and the filled circles those along the $150^{\circ} \mathrm{W}$ meridian $(\mathrm{P}-16 \mathrm{C})$.

Open Circle $=P 17 C \quad 135 \% \quad$ Surface Data Filled Circle $=P 16 C 150^{\circ} \mathrm{W}$

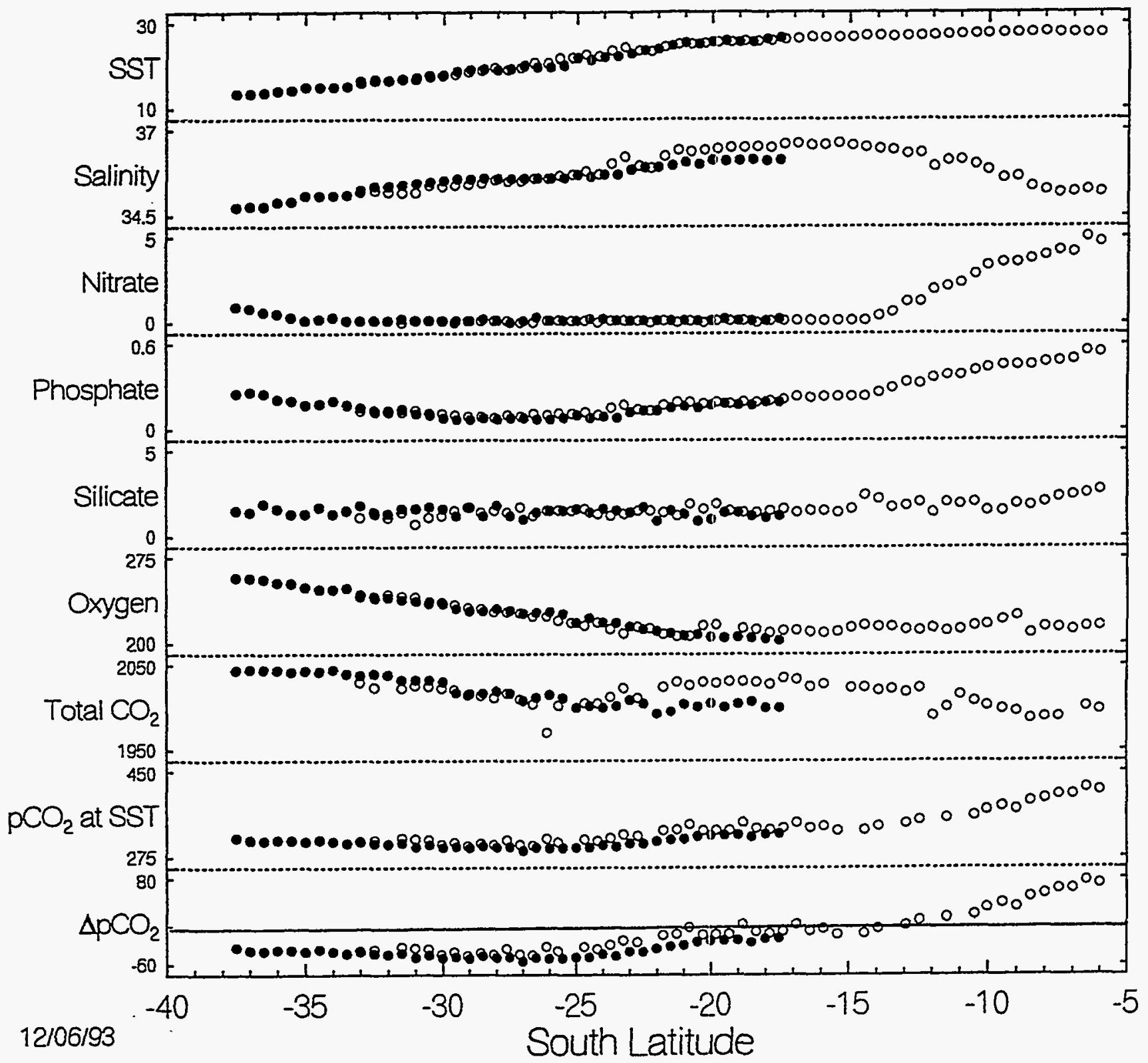


$-45 \mu \mathrm{atm}$ between $20^{\circ} \mathrm{S}$ and $30^{\circ} \mathrm{S}$ along $135^{\circ} \mathrm{W}$. This means that our $\mathrm{pCO}_{2}$ values measured in July through August are 15 to $45 \mu$ atm lower than those observed by Murphy et al. in the same areas about four months earlier in season (March-April, 1984 along 150 $\mathrm{W}$; March, 1989 along $130^{\circ} \mathrm{W}-140^{\circ} \mathrm{W}$ ). These $\mathrm{pCO}_{2}$ differences correspond to temperature differences of 1 to $3.5^{\circ} \mathrm{C}$. Although their temperature data have not been compared with ours as yet, these temperature differences are considered to be reasonable in view of the differences in the time of respective measurements: ours during the austral mid-winter whereas those of Murphy et al. during late austral summer. Thus, the observed differences between Murphy et al. and ours appear to represent seasonal changes.

III-b) Distribution of Properties along the WOCE Sections P-16C and P-17C:

In Figs. 7 through 28, the distribution along the WOCE Sections P-16C and P-17C are shown for the following properties; potential temperature, salinity, potential density, total $\mathrm{CO}_{2}$ concentration, $\mathrm{pCO}_{2}$ in seawater at $20^{\circ} \mathrm{C}$, alkalinity, the concentrations of dissolved oxygen, phosphate, nitrate and silicate and the apparent oxygen utilization (AOU). Each figure consists of two panels: (A) the upper 1000 meters and (B) the entire water column. The potential density values computed for at sea surface (sigma- $\theta$ ) are used for the upper 1000 meter section, and those at $2000 \mathrm{db}$ (sigma-2) are used for the section below 1000 meters.

\section{Potential Temperature}

Figs. 7-A \& B show the distribution of potential temperature along $150^{\circ} \mathrm{W}$ (WOCE Section P-16C) down to 1000 meters and to the sea floor respectively. The highest temperature of $26.5^{\circ} \mathrm{C}$ was found at the sea surface at $17.5^{\circ} \mathrm{S}$, and the lowest temperature of $0.6^{\circ} \mathrm{C}$ along the sea floor ( 5250 meters deep) at about $36^{\circ} \mathrm{S}$. Figs. 8-A \& B show a section along $135^{\circ} \mathrm{W}$ (WOCE Section P-17C). Since this section covered a latitudinal range further north between $6^{\circ} \mathrm{S}$ and $33^{\circ} \mathrm{S}$, higher surface water temperatures as high as $27.7^{\circ} \mathrm{C}$ were observed in the tropical waters. The lowest temperature of $0.9^{\circ} \mathrm{C}$ was observed in the abyssal waters near the southern extreme of this section.

\section{Salinity}

Figs. 9-A \& B show the distribution of salinity along $150^{\circ} \mathrm{W}$ down to 1000 meters and to the sea floor respectively. The highest salinity values, as high as 36.12 PSU, were observed in 


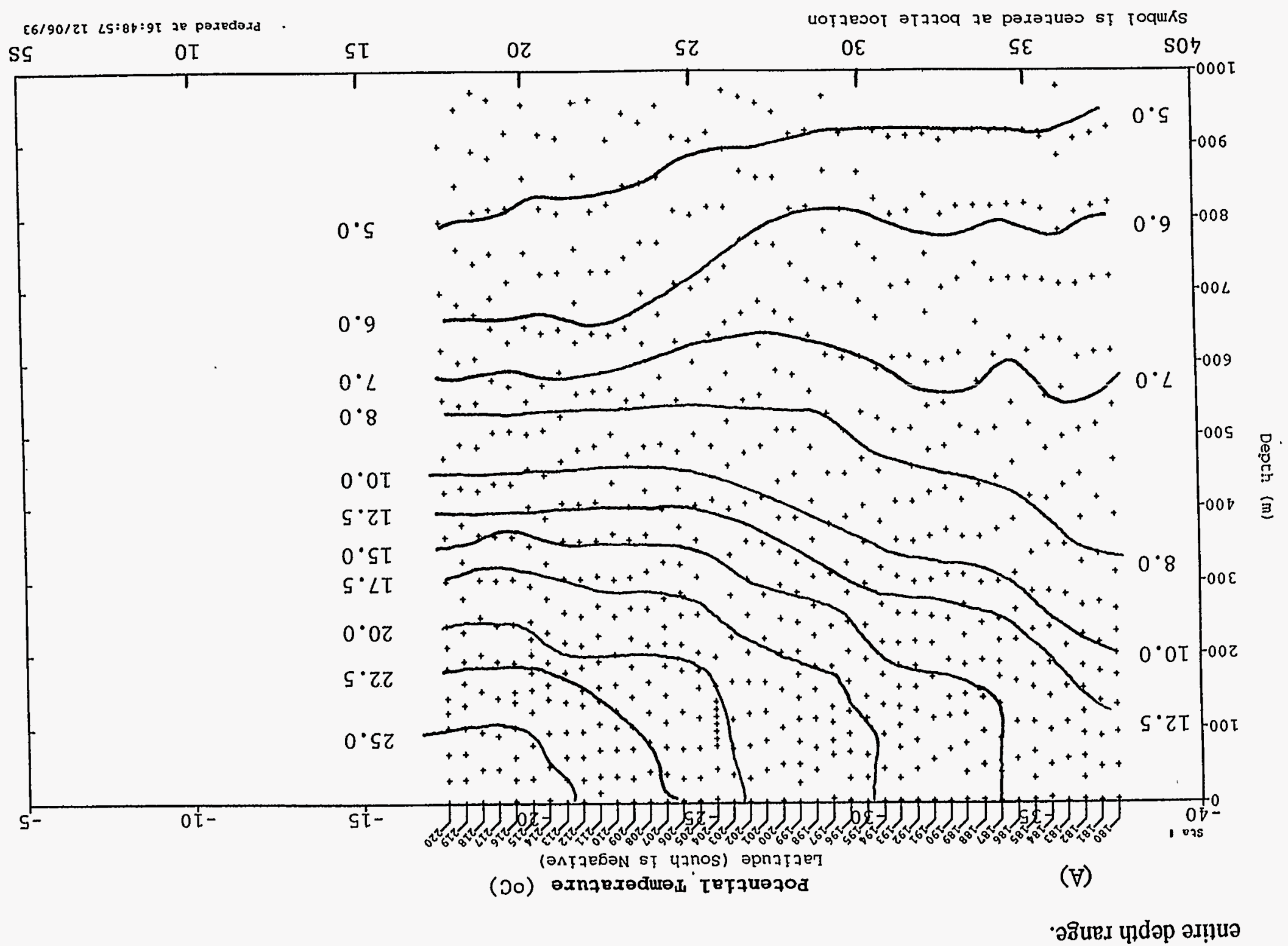

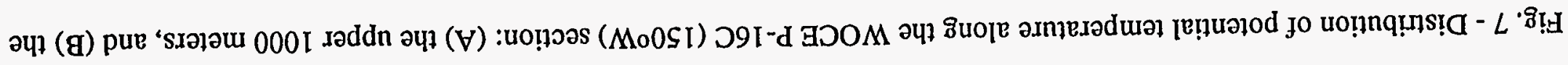




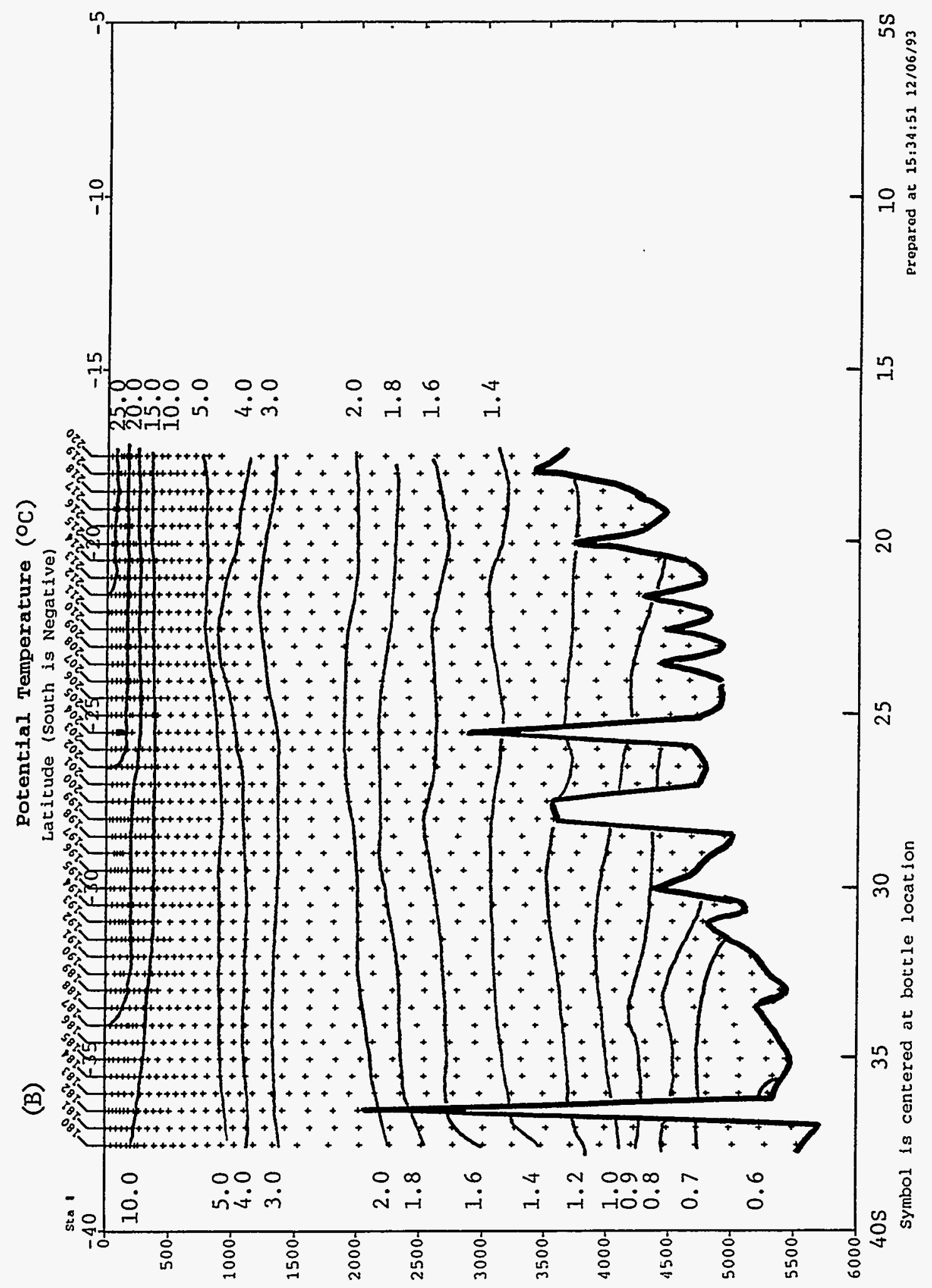

(u) 420อC 


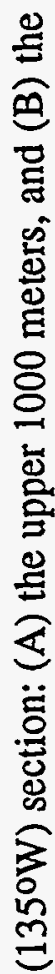

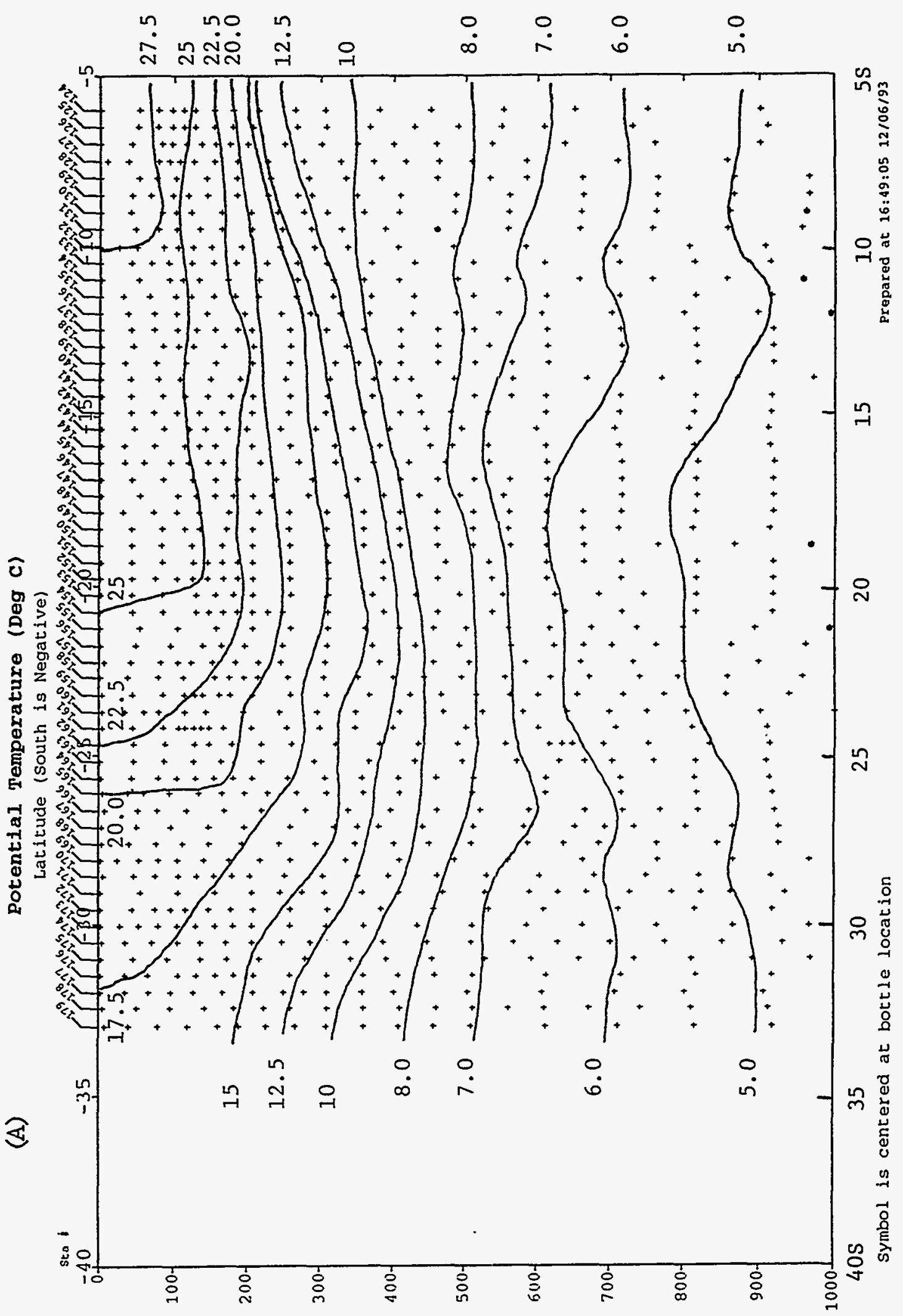

(ii) บวdอด 


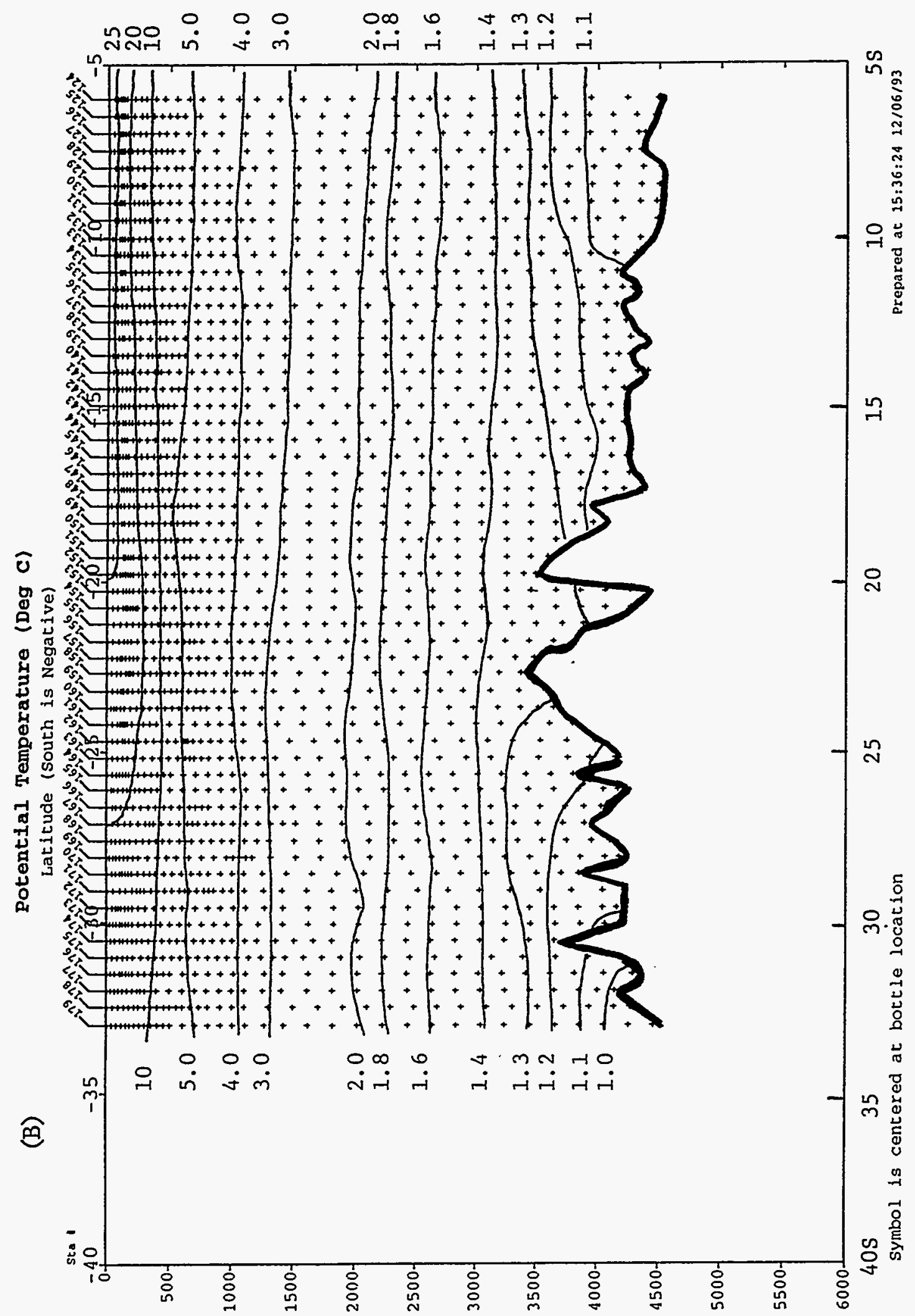

(w) पวดฮอс 
(4)
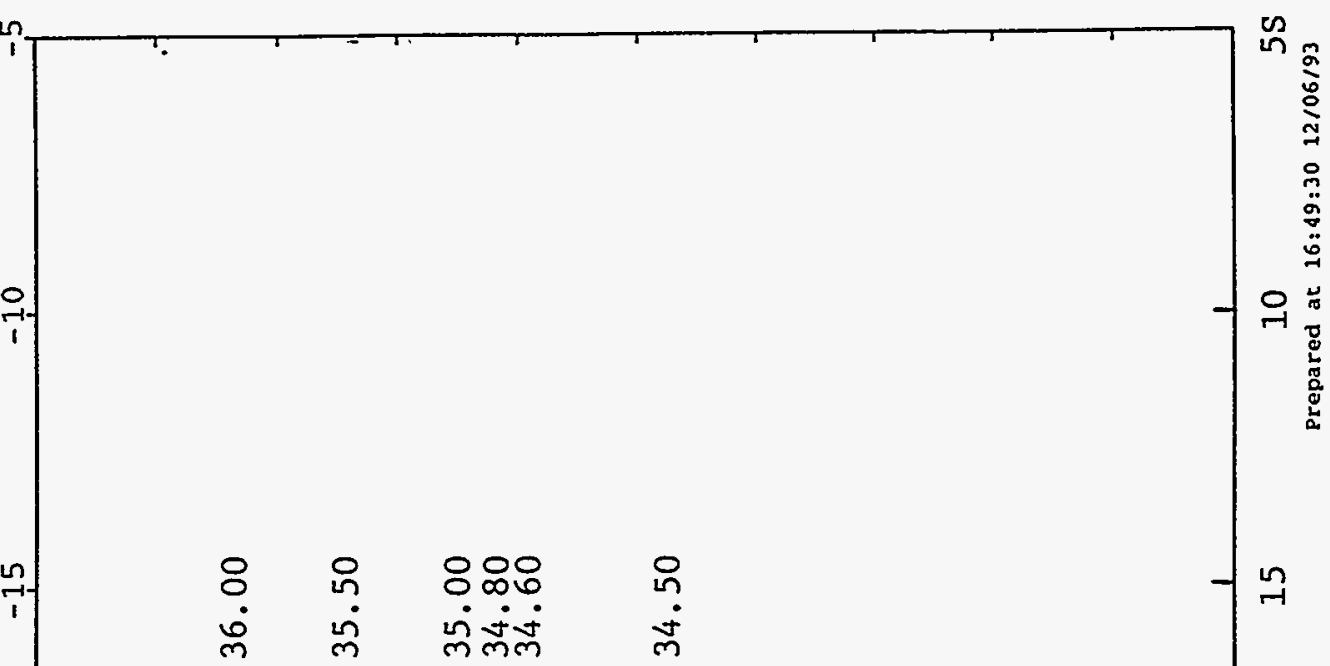

을
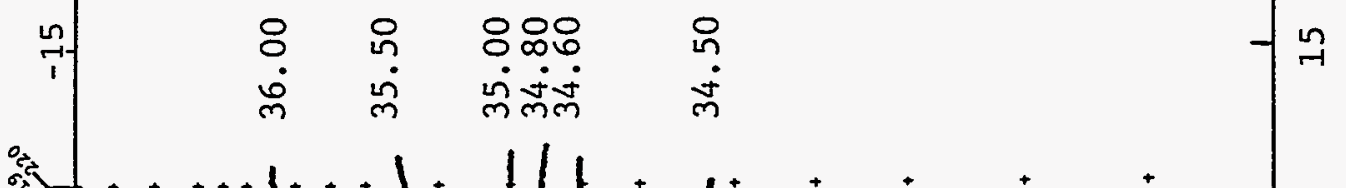

$\$$

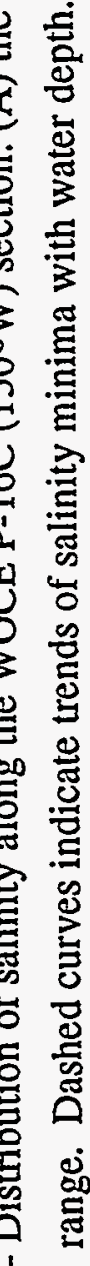

a

in

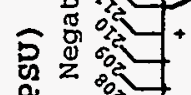

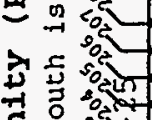

मี 0 of

吹 옥
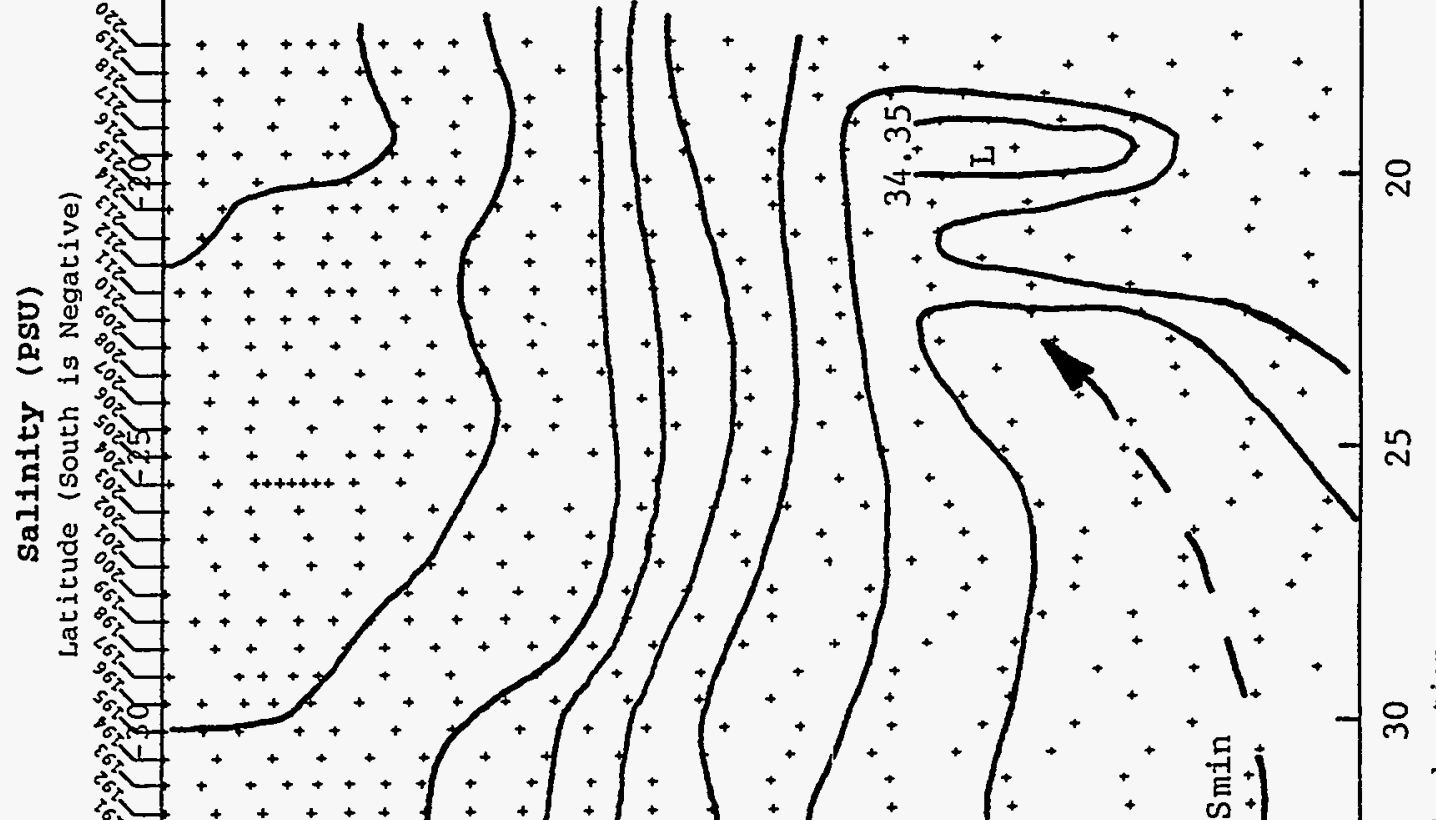

$\overparen{4}$
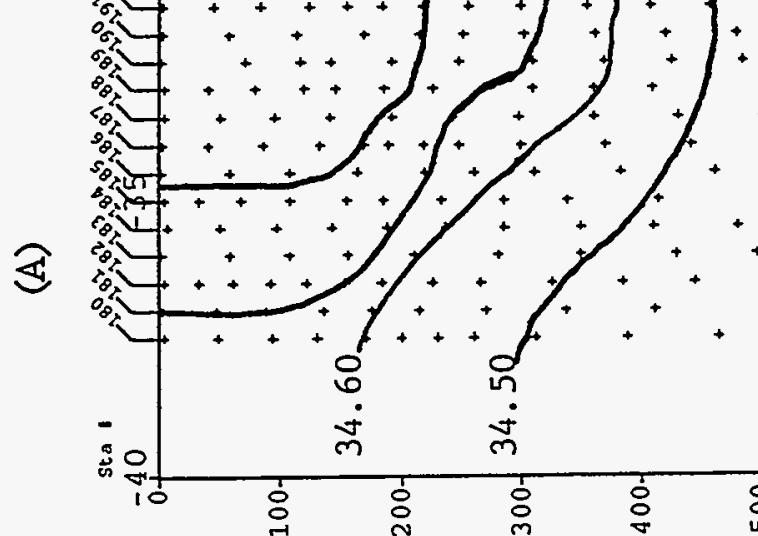

(w) บวवวอ

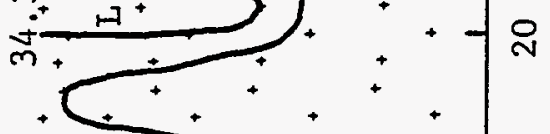




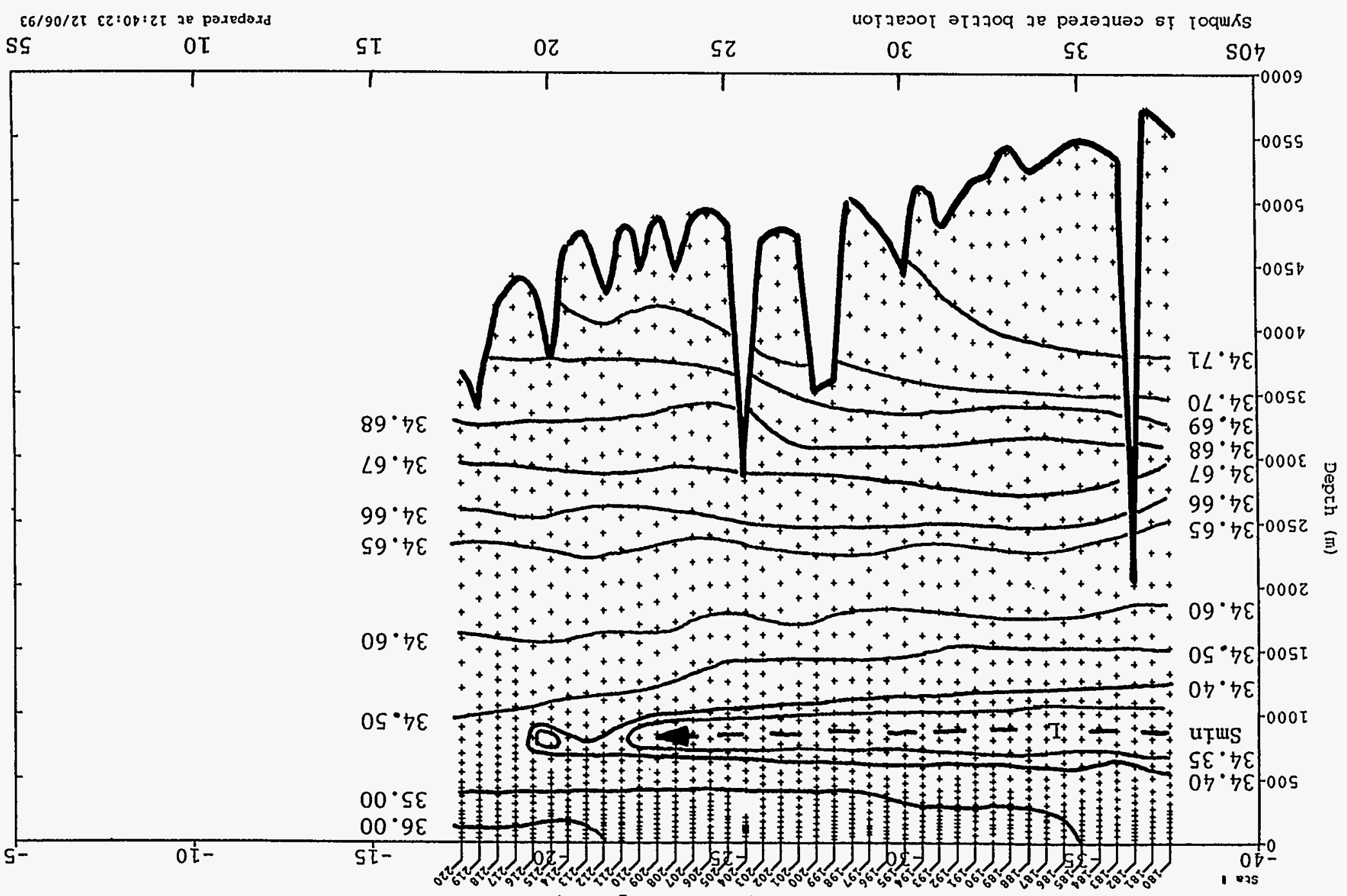

(anțJEEON ST yanos) әpnatวeT

(nSd) XafuFTES

(g) 
Fig. 10 - Distribution of salinity along the WOCE P-17C $\left(135^{\circ} \mathrm{W}\right)$ section: (A) the upper 1000 meters, and (B) the entire depth range. Dashed curves indicate trends of salinity minima with water depth.

(A) Salinity (PSU)

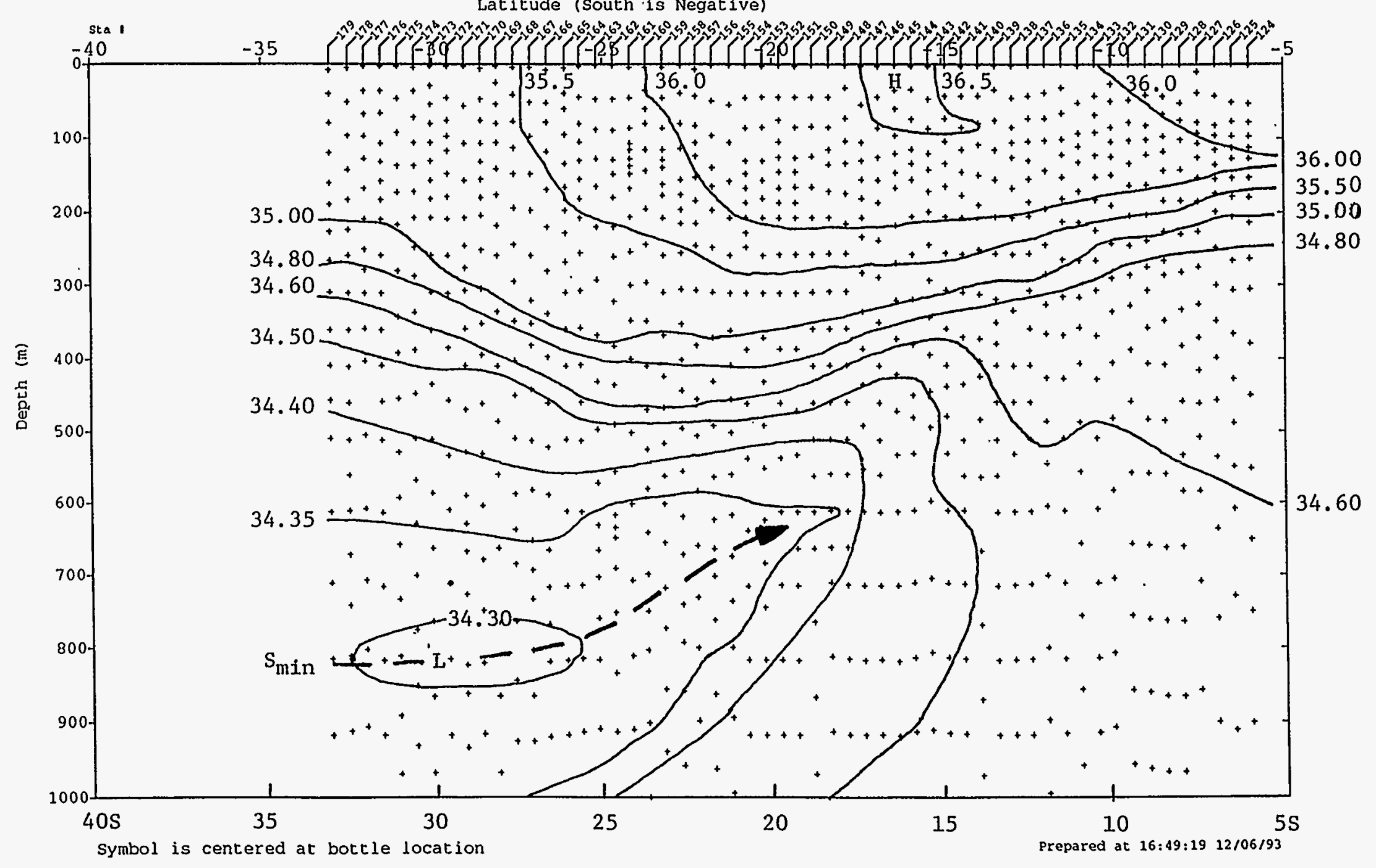




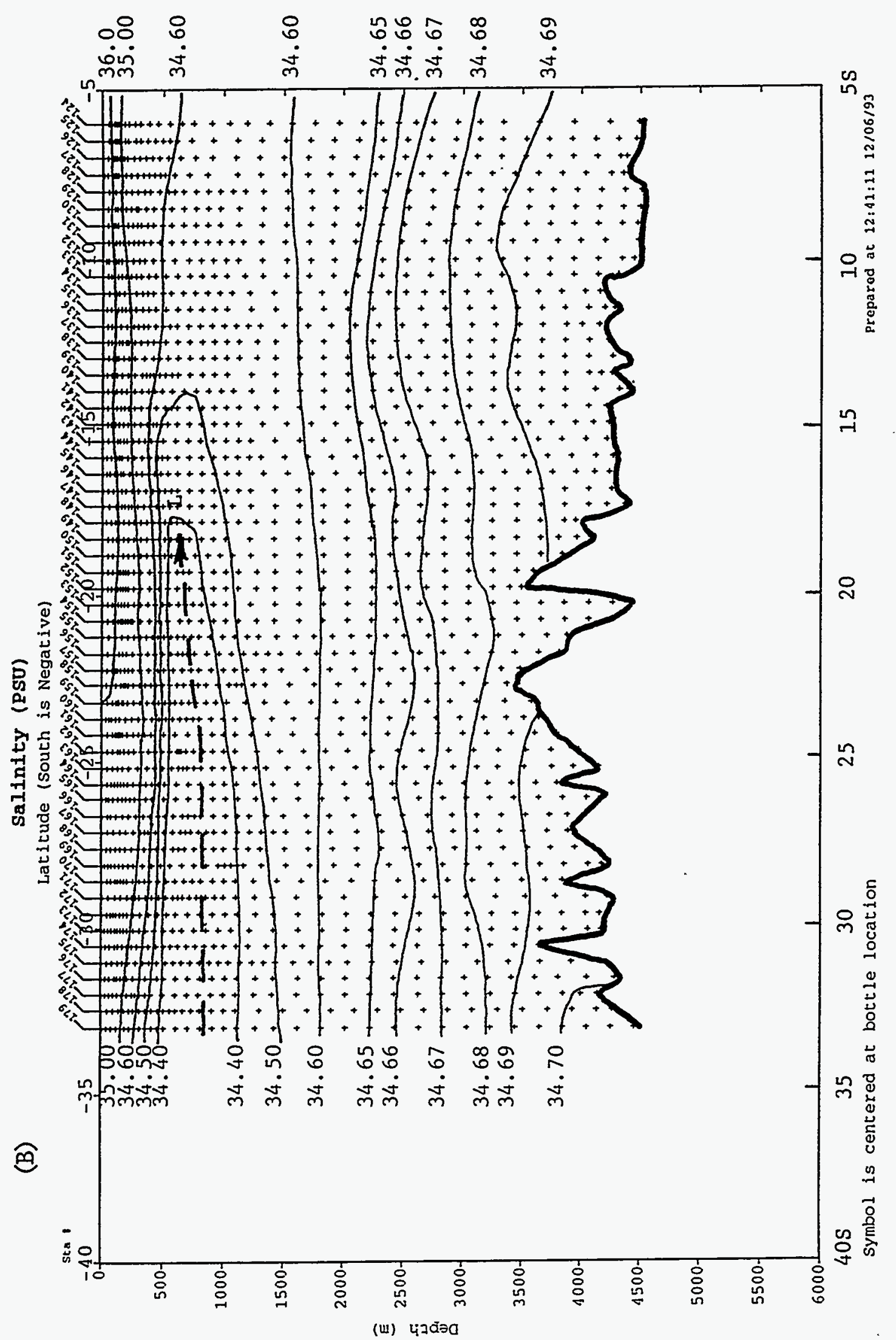


Fig. 11 - Distribution of potential density along the WOCE P-16C (150\%) section: (A) sigma- $\theta$ for the upper 1000 meters, and (B) sigma-2 from 1000 meters to the sea floor.

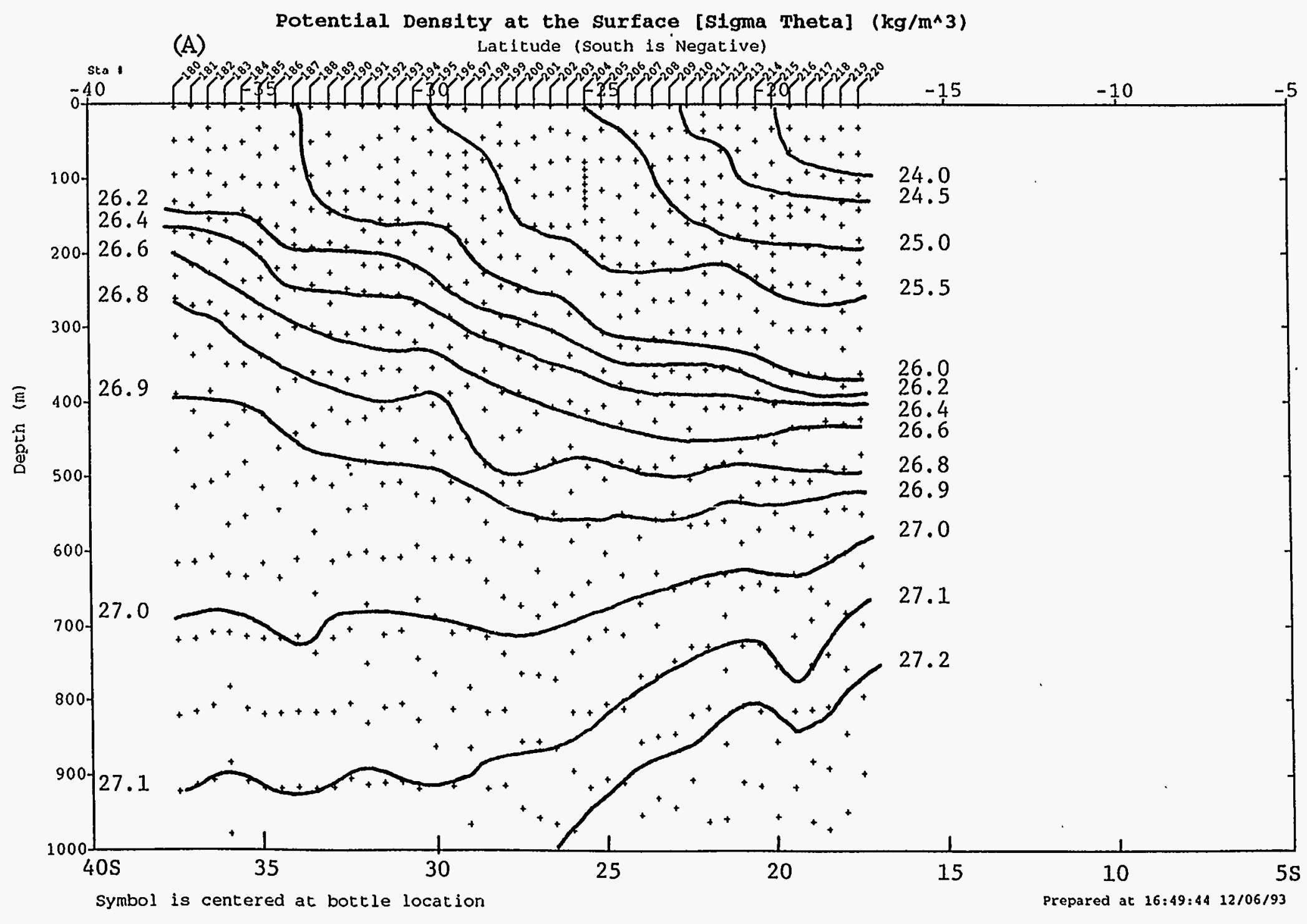




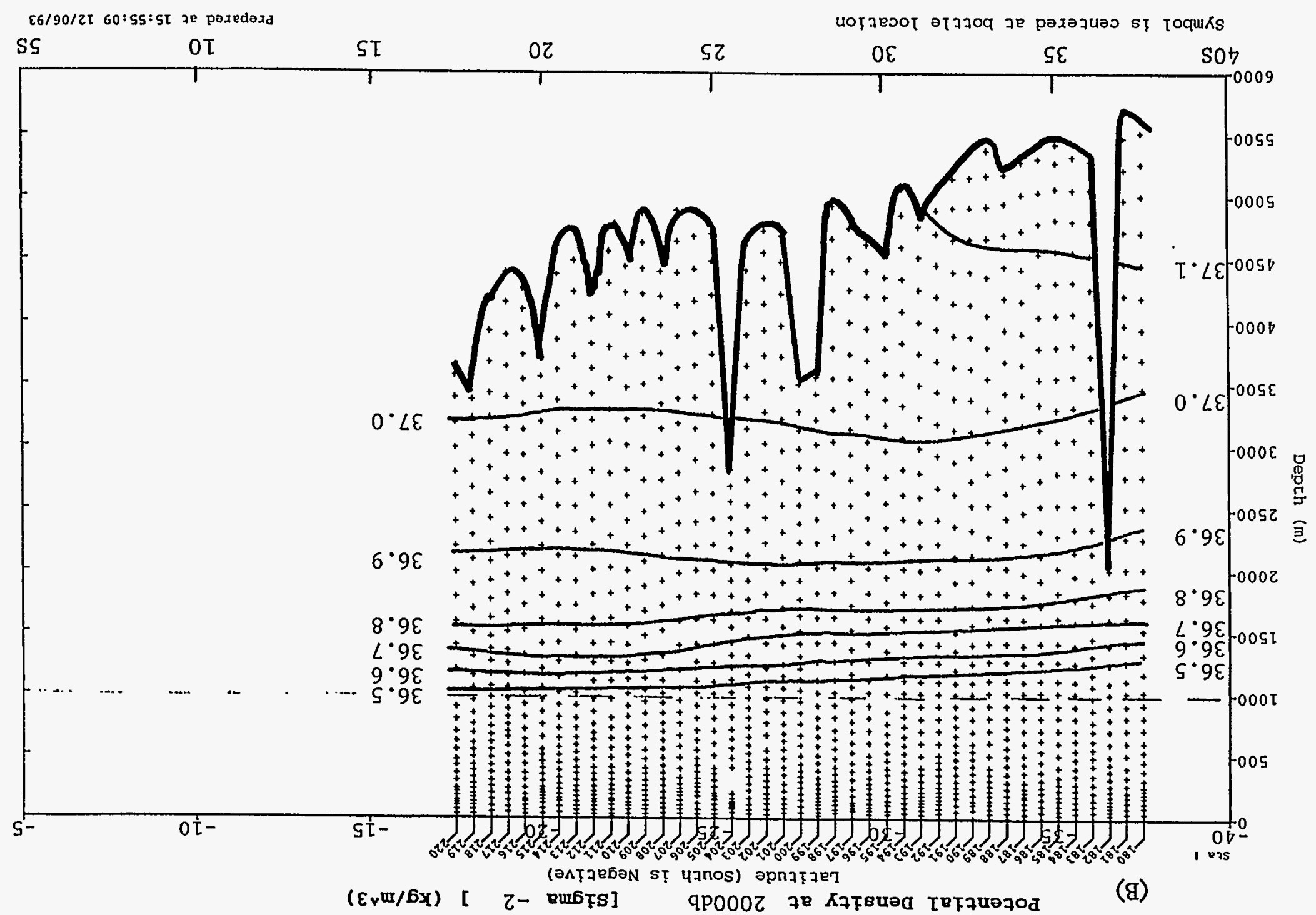




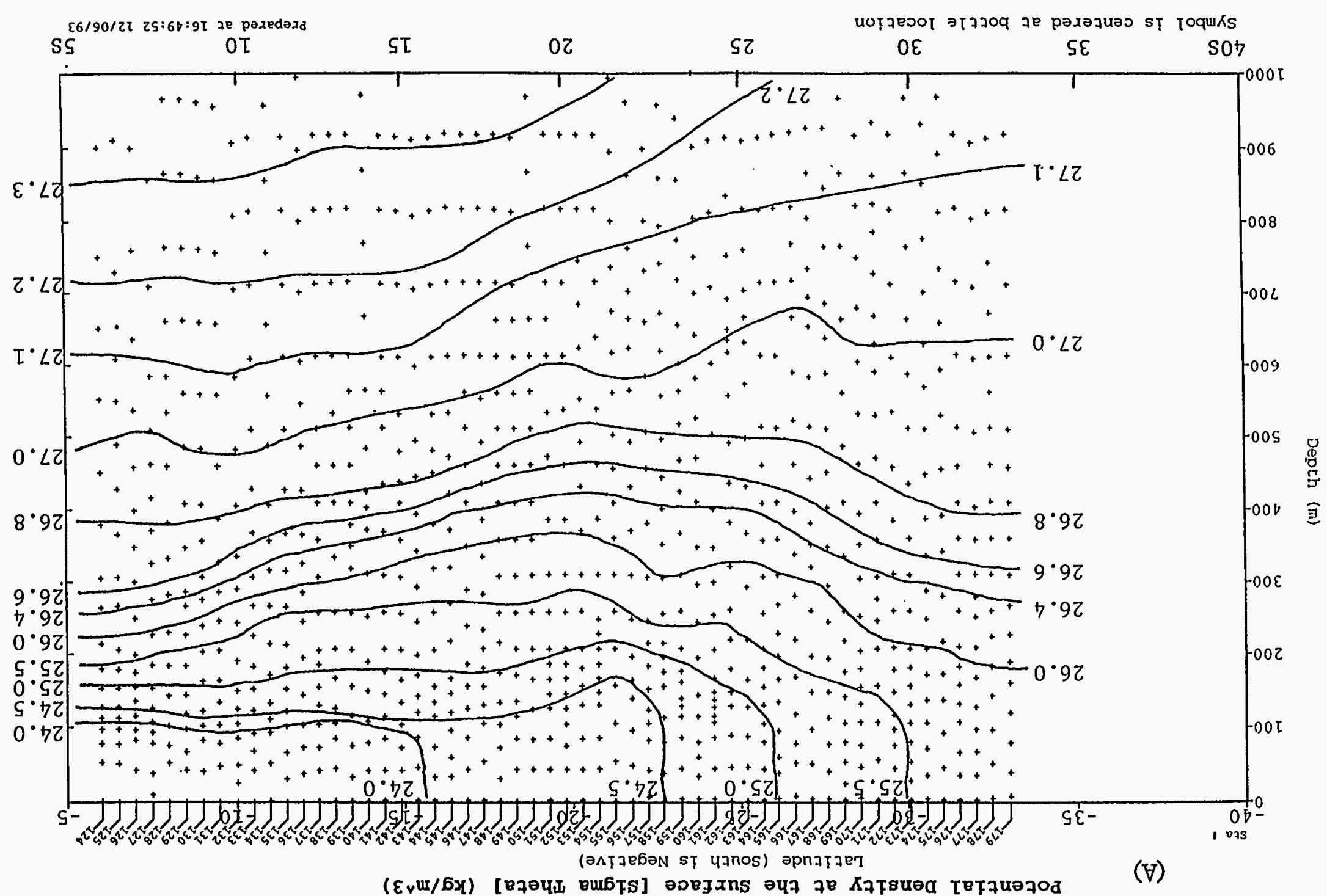

'.

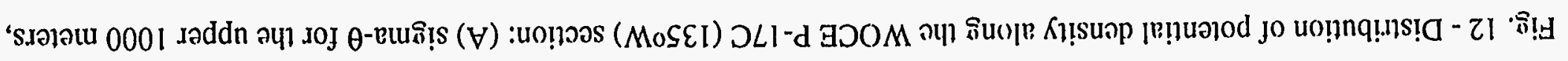




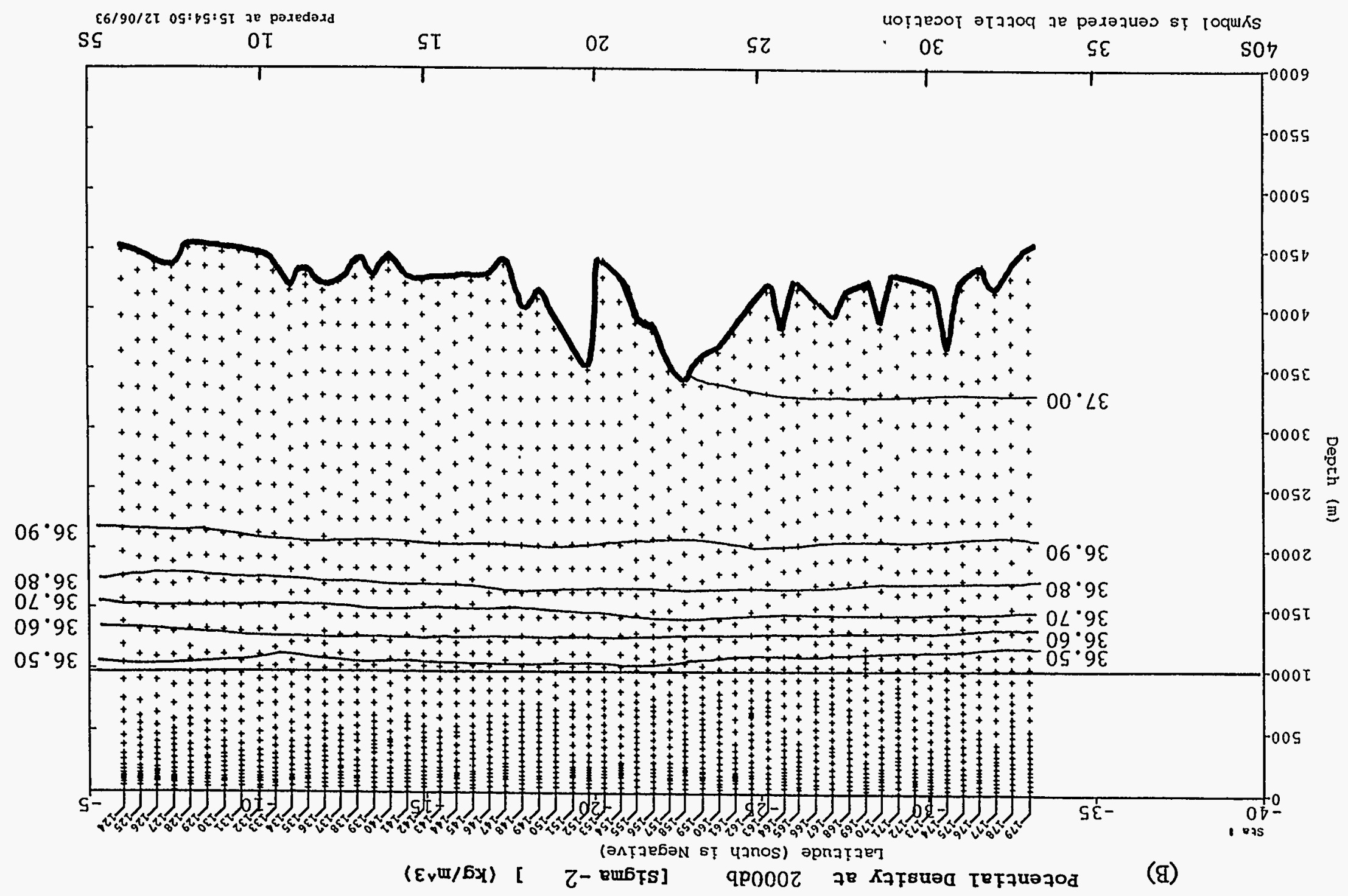


Fig. 13 - Distribution of the total $\mathrm{CO}_{2}$ concentration in scawater along the WOCE P-16C (150\%) section: (A) the upper 1000 meters, and $(B)$ the entire depth range. Dashed curves indicate trends of total $\mathrm{CO}_{2}$ maxima or minima.

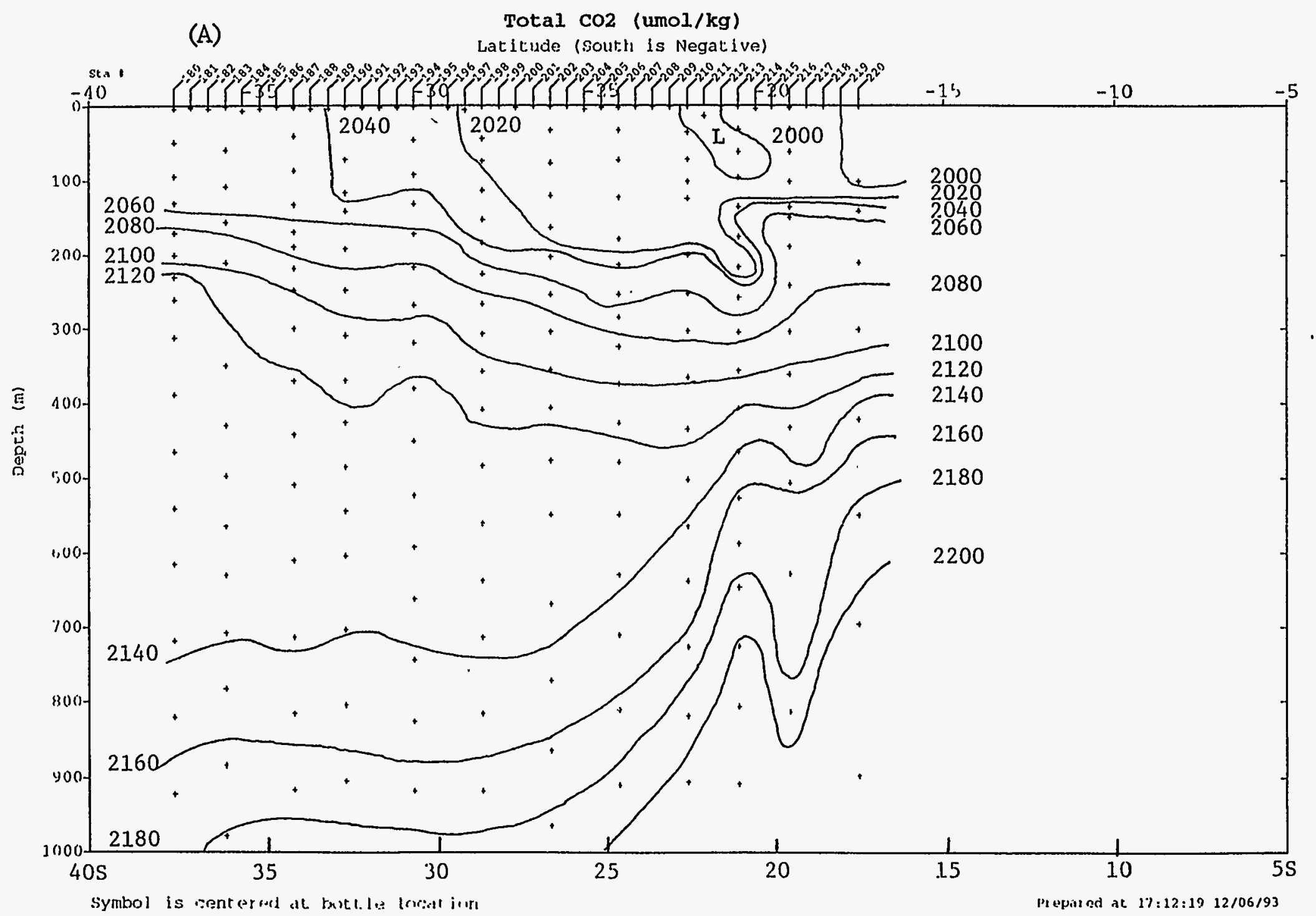




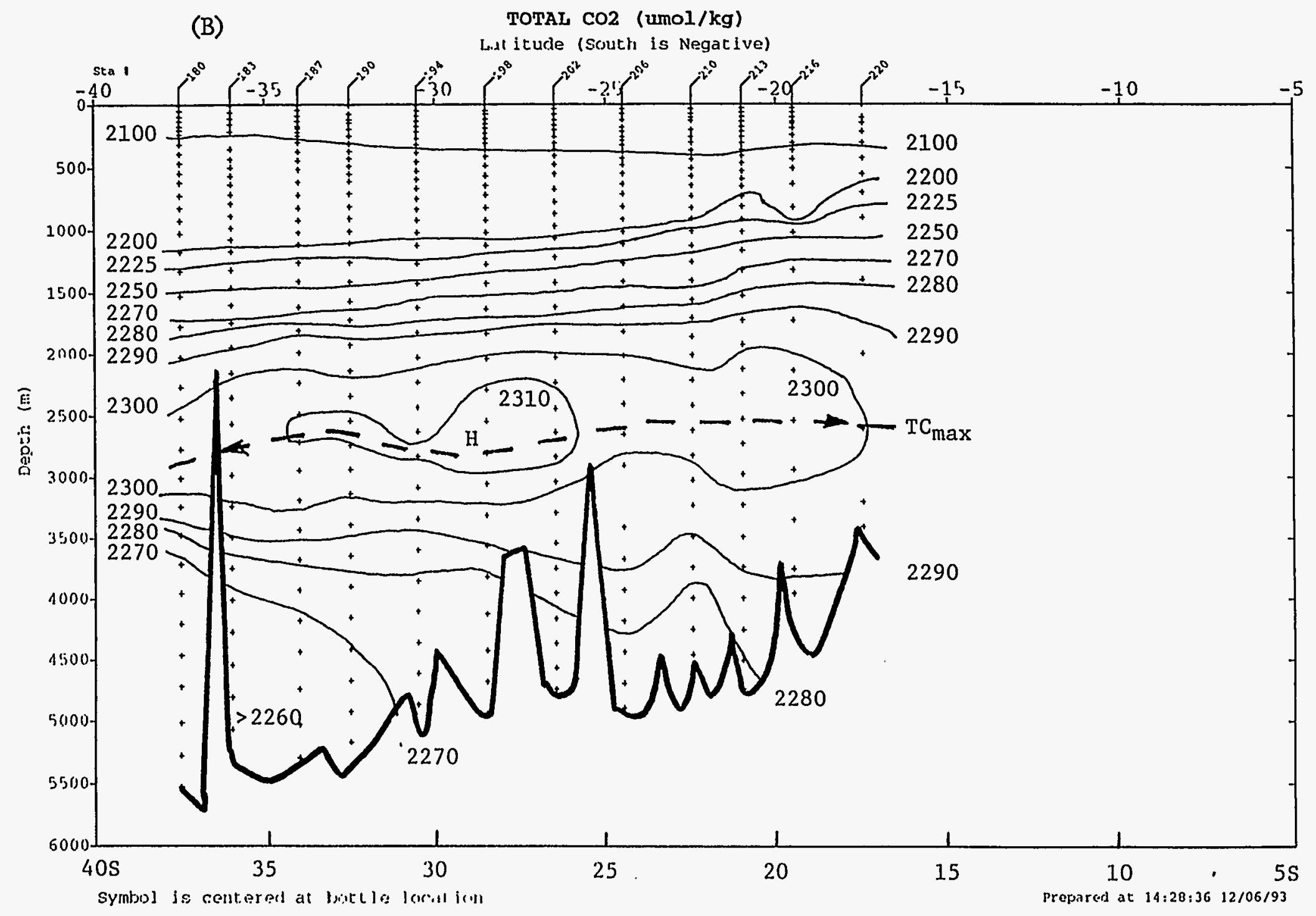


the surface layer at $17.5^{\circ} \mathrm{S}$, and the lowest values, as low as $34.31 \mathrm{PSU}$, in a salinity minimum layer between 800 and 900 meters representing the Antarctic Intermediate Water (AAIW). The position of the salinity minimum is indicated with a dashed curve with an arrow. Below this depth, the salinity increased with depth to 34.71 PSU, a typical value for the Antarctic Bottom Water (AABW), which was found below about 4000 meters south of about $30^{\circ} \mathrm{S}$. Figs. $10-\mathrm{A} \& \mathrm{~B}$ show the sections along $135^{\circ} \mathrm{W}$. The distribution of salinity along this section is basically identical to that along $150^{\circ} \mathrm{W}$, with an exception that the minimum salinity in the AAIW was $34.29 \mathrm{PSU}$, slightly lower than the minimum value observed along the $150^{\circ} \mathrm{W}$ section. This suggests that the AAIW observed along $135^{\circ} \mathrm{W}$ was closer to the source region of the water mass than that observed further west along $150^{\circ} \mathrm{W}$.

\section{Potential Density}

Figs. 11-A \& B show the distribution of the potential density along $150^{\circ} \mathrm{W}$ down to 1000 meters and to the sea floor respectively. The potential density at the sea surface ( $\operatorname{sigma}-\theta$ ) is used for waters above 1000 meters and that at $2000 \mathrm{db}$ (Sigma-2) for waters below 1000 meters. The density of the core of AATW represented by salinity minima corresponds to a sigma- $\theta$ density of about 27.1. The most dense water found in this section was 37.11 sigma-2. Figs. 12-A \& B show the sections along $135^{\circ} \mathrm{W}$. The densest water found in this section was sigma-2 37.07, which was slightly smaller than that observed in the $150^{\circ} \mathrm{W}$ section. This suggests a greater contribution of denser southern waters in the abyssal waters of the $150^{\circ} \mathrm{W}$ section.

\section{Total $\mathrm{CO}_{2}$ Concentration}

Figs. 13-A \& B show the distribution of the total $\mathrm{CO}_{2}$ concentration along $150^{\circ} \mathrm{W}$ down to 1000 meters and to the sea floor respectively. In the upper 1000-meter section, the lowest $\mathrm{CO}_{2}$ concentration of $2000 \mu \mathrm{mol} / \mathrm{kg}$ was found in subtropical waters located between $17.5^{\circ} \mathrm{S}$ and $30^{\circ} \mathrm{S}$. North of about $25^{\circ} \mathrm{S}$, the total $\mathrm{CO}_{2}$ concentration increased much more rapidly with depth to 1000 meters than south of this latitude, reflecting the influence of the strongly bio-mediated layers of the eastern tropical Pacific. Below 1.000 meters, the $\mathrm{CO}_{2}$ concentration increased with depth to a $\mathrm{CO}_{2}$ maximum layer located between 2500 and 3000 meters, in which $\mathrm{CO}_{2}$ values as high as $2314 \mu \mathrm{mol} / \mathrm{kg}$ were observed. As will be shown in Fig. 27-B, this $\mathrm{CO}_{2}$ maximum is closely associated with a silicate maximum. This suggests that this layer 
represents the southward flowing water from the North Pacific Ocean. The maximal values for both $\mathrm{CO}_{2}$ and silicate within this layer tended to decrease both southward and northward away from $28^{\circ} \mathrm{S}$ suggesting that a tongue of the high $\mathrm{CO}_{2}$ North Pacific water intruded into the southern water which had lower $\mathrm{CO}_{2}$ and silicate concentrations. Below this layer, the total $\mathrm{CO}_{2}$ concentration gradually decreased to the lowest value of about $2262 \mu \mathrm{mol} / \mathrm{kg}$ which was found in the bottom waters in the southern end of this section.

Figs. 14-A \& B show the distribution along $135^{\circ} \mathrm{W}$. The distribution in the upper 1000 meters was similar to that observed along $150^{\circ} \mathrm{W}$. On the other hand, substantial differences were observed in waters below about 2000 meters. North of about $20^{\circ} \mathrm{S}$, a tongue of the $\mathrm{CO}_{2}$ maximum became more prominent with the maximum value reaching as high as $2339 \mu \mathrm{mol} / \mathrm{kg}$ at $6^{\circ} \mathrm{S}$. The outline of this maximum shows clearly that it came from the North Pacific. Although a $\mathrm{CO}_{2}$ maximum layer is observed at about 2500 meters south of about 23"S, its outline does not clearly show from which direction this feature was derived.

\section{$\mathrm{CO}_{2}$ Partial Pressure at $20^{\circ} \mathrm{C}$}

Figs. 15- $\mathrm{A} \& \mathrm{~B}$ show the distribution of $\mathrm{pCO}_{2}$ at $20^{\circ} \mathrm{C}$ along $150^{\circ} \mathrm{W}$ down to 1000 meters and to the sea floor respectively. Low $\mathrm{pCO}_{2}$ values as low as $245 \mu \mathrm{atm}$ (at $20^{\circ} \mathrm{C}$ ) were found in subtropical surface waters, and they increased more rapidly with depth north of $25^{\circ} S$ than south of it, reflecting the effect of the high $\mathrm{pCO}_{2}$ tropical waters. Near the southern end of this section, a broad $\mathrm{pCO}_{2}$ maximum layer with values as high as $1203 \mu$ atm was found in a depth range between 1500 and 3000 meters. Since the maximum values tend to decrease northward, this feature appears to have originated in the south. As seen in Fig. 13-B, the total $\mathrm{CO}_{2}$ concentration is nearly constant near the depth of 2500 meters. The observed southward increase in $\mathrm{pCO}_{2}$ indicates a southward decrease in the total alkalinity, which may be accounted for by an influx of lower alkalinity waters from the south. The $\mathrm{pCO}_{2}$ maximum layer was not clearly defined between $32^{\circ} \mathrm{S}$ and $36^{\circ} \mathrm{S}$. It was clearly definable north of $32^{\circ} \mathrm{S}$ at about 2300 meters and shallowed to about 1300 meters at the northern end of the section at $17.5^{\circ} \mathrm{S}$. No meridional trend was observed along this section of the $\mathrm{pCO}_{2}$ maximum layer. This may be attributed to the fact that the total $\mathrm{CO}_{2}$ concentration and alkalinity decreased northward with a similar proportion. The $\mathrm{pCO}_{2}$ maximum layer was located shallower than the total $\mathrm{CO}_{2}$ concentration maximum layer by about 400 meters near the southern end of the section and by more than 1000 meters at the northern end of the section. Shallowing of the $\mathrm{pCO}_{2}$ maximum 
Fig. 14 - Distribution of the total $\mathrm{CO}_{2}$ concentration in seawater along the WOCE P-17C (135०W) section: (A) the upper 1000 meters, and $(B)$ the entire depth range. Dashed curves indicate trends of total $\mathrm{CO}_{2}$ maxima.

(A)

Total $\mathrm{CO} 2$ (umol/ $/ \mathrm{kg}$ )

Latitude (South is Negative)

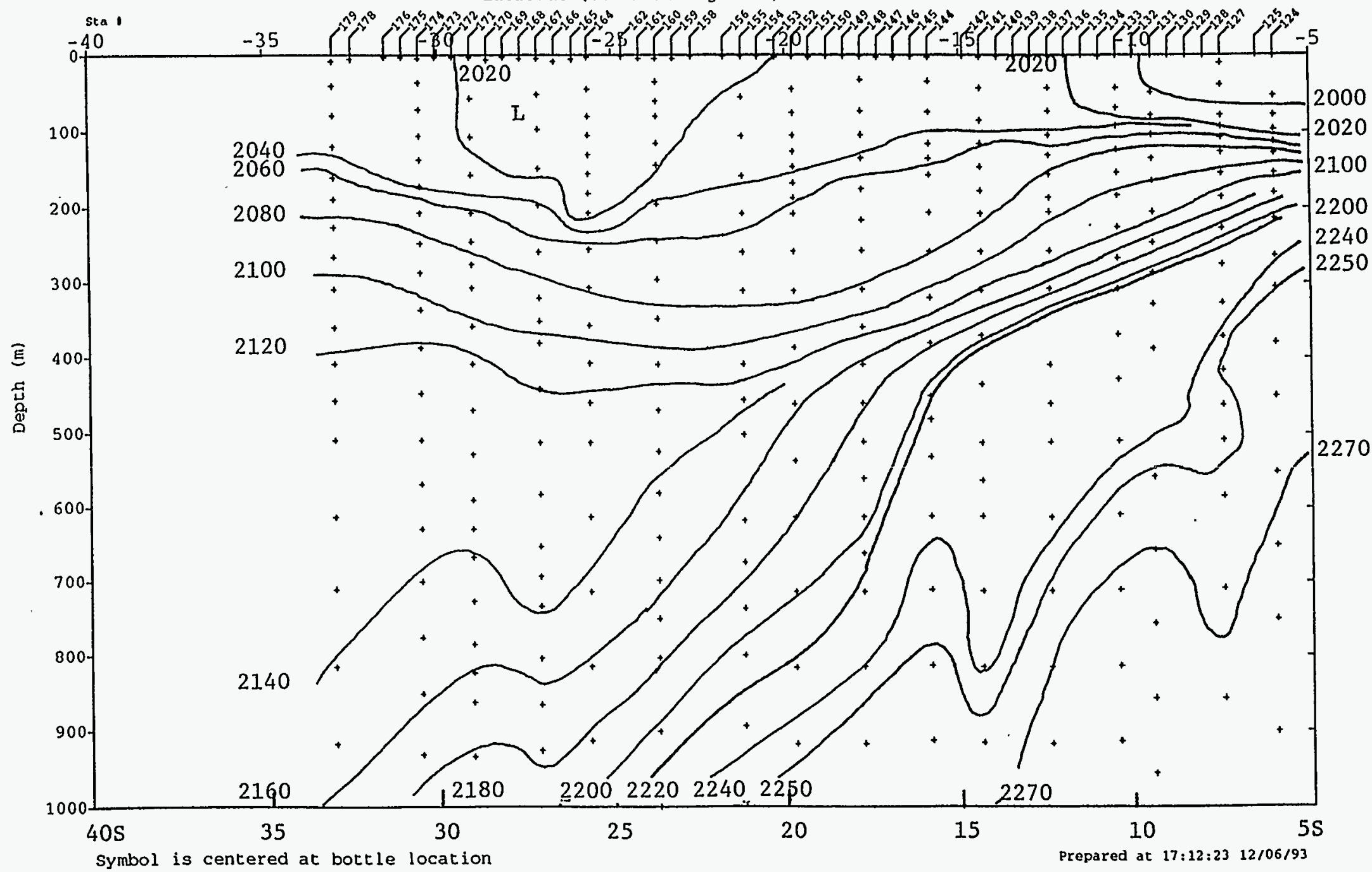


(B)

TOTAL $\mathrm{CO} 2$ (umol/kg)

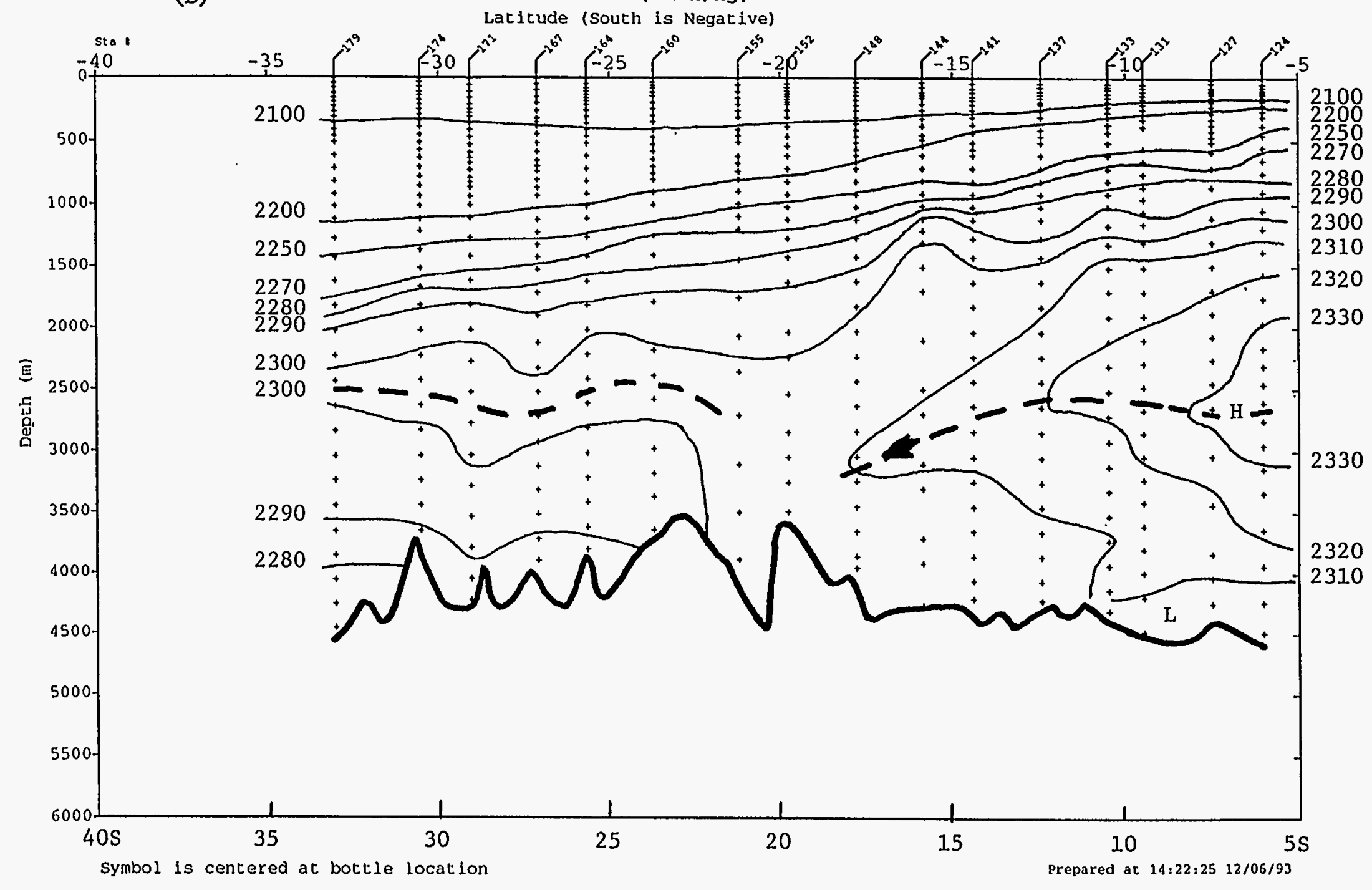




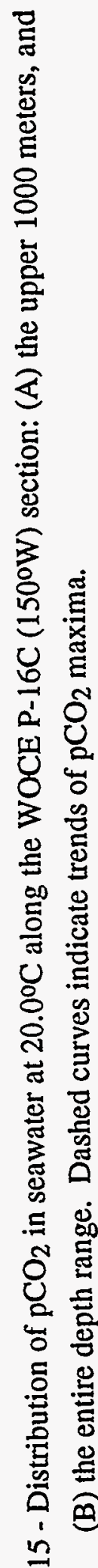

定

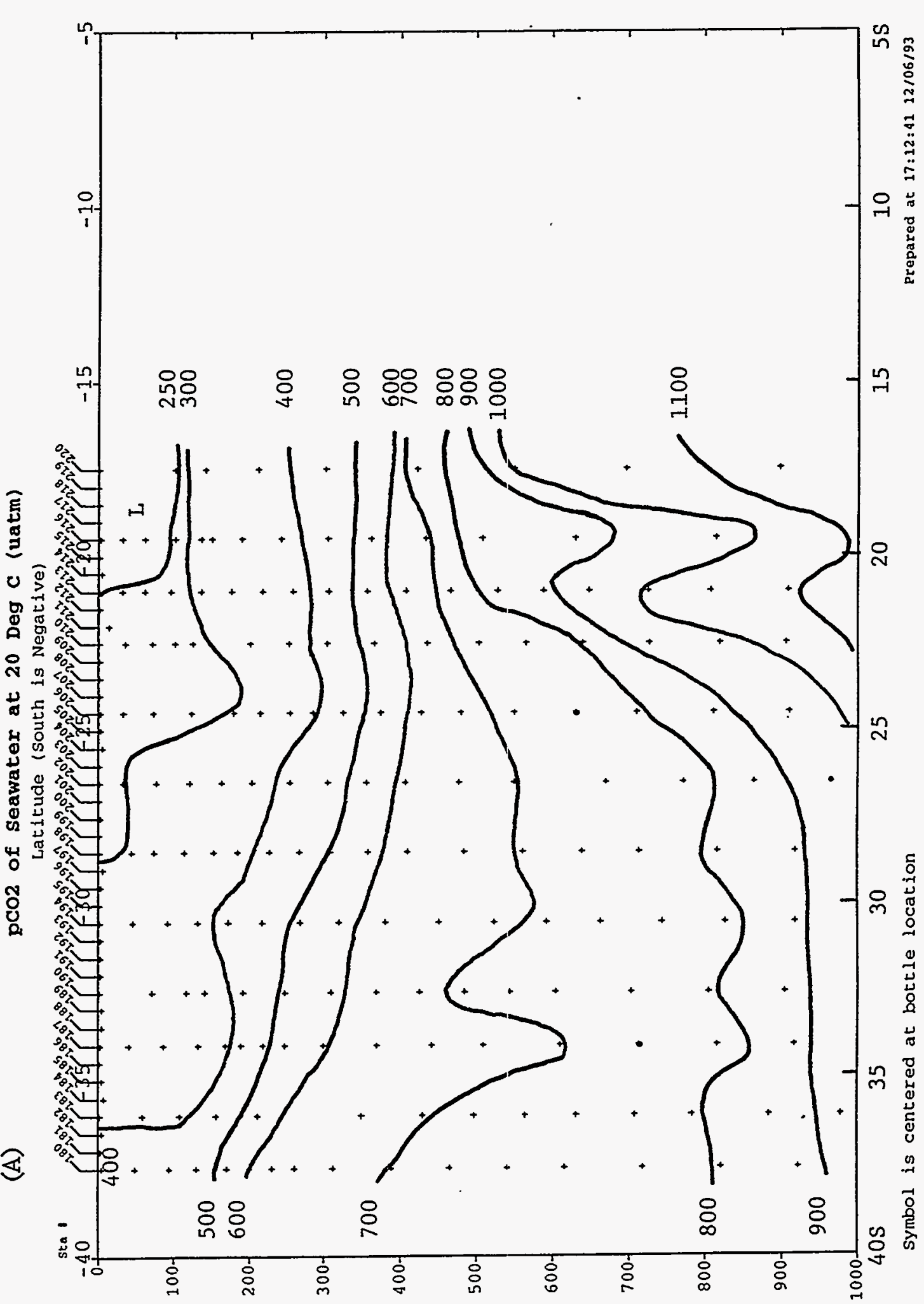

(w) yวवृอव 


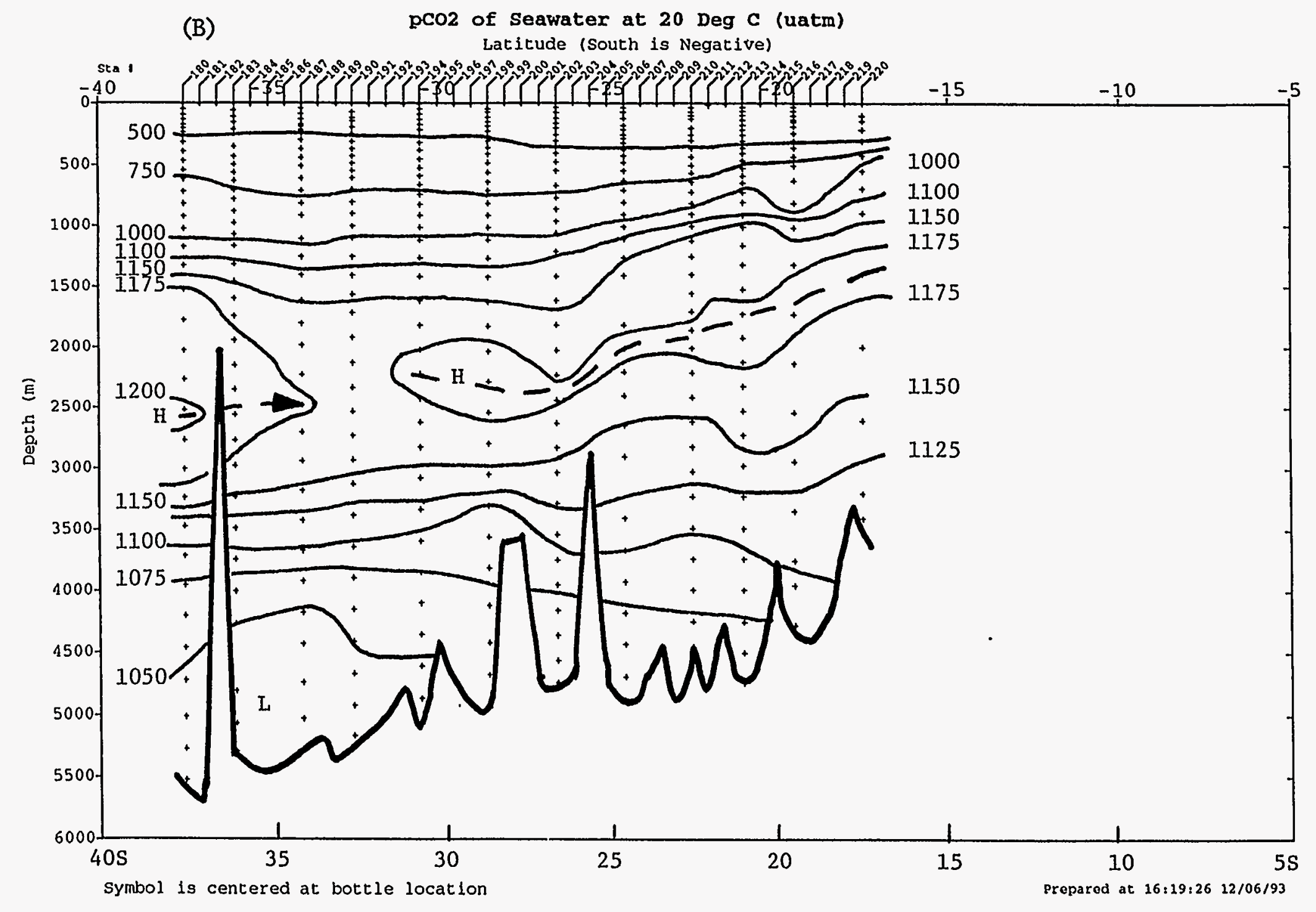


layer may be attributed to the effect of the overlying low oxygen water of tropical origin. Below the maximum layer; the $\mathrm{pCO}_{2}$ vălues decreased with depth to 1033 and $1075 \mu$ atm respectively in the bottom waters near the southern and northern end of this section.

Figs. 16-A and -B show the distribution along $135^{\circ} \mathrm{W}$. In the upper 1000 meters, a strong $\mathrm{pCO}_{2}$ maximum (as high as $1604 \mu \mathrm{atm}$ ) was observed at about 500 meters deep near the northern end, $6^{\circ} \mathrm{S}$. It deepened southward rapidly to about 1500 meters at $27^{\circ} \mathrm{S}$, then to below 2000 meters near the southern end of this section.

\section{Total Alkalinity}

Figs. 17-A \& B show the distribution of the total alkalinity along $150 \% \mathrm{~W}$ down to 1000 meters and to the sea floor respectively. These alkalinity values were computed using the measured values of $\mathrm{pCO}_{2}$ and the total $\mathrm{CO}_{2}$ concentration in seawater. Alkalinity values as high as $2392 \mu \mathrm{eq} / \mathrm{kg}$ were found in the warm subtropical surface waters. The alkalinity decreased with increasing depth down to a minimum layer $(2290 \mu \mathrm{eq} / \mathrm{kg})$ located at about 600 meters. Although this is shallower than the salinity minimurn layer for the AAIW by 300 meters, this appears to be derived from the Southern Ocean. Below this, the alkalinity increased to the alkalinity maximum layer centered around 2700 meters at the northern end, where values as high as $2430 \mu \mathrm{eq} / \mathrm{kg}$ were observed. This layrer deepened gradually to 3000 meters deep at the southern end of the section. The maximum value in this layer was found at about $30^{\circ} \mathrm{S}$ and decreased northward and southward away from this point. This appears to represent high alkalinity North Pacific water flowing across the meridional section. Below this maximum layer, the alkalinity decreased gradually to 2375 and $2900 \mu \mathrm{eq} / \mathrm{kg}$ near the sea floor respectively at the southern and north ends of the section.

Figs. 18-A \& B show the sections along $135^{\circ} \mathrm{W}$. In the upper 1000 meters, an alkalinity minimum layer was observed between 300 meters near the northern end and 600 meters near the southern end of the section. The magnitude of this alkalinity minimum layer is similar to that observed along $150^{\circ} \mathrm{W}$. Below these depths, the alkalinity increased with depth to the alkalinity maximum layer which was centered at 2600 meters near the northern end of the section. Since the intensity of the maximum layer decreases southward, this layer is considered to represent the North Pacific water spreading southward. However, south of about $25^{\circ} \mathrm{S}$, the maximum layer became more diffuse and the trend could not be clearly 
defined, suggesting a greater degree of mixing with southern waters. This feature is consistent with that observed with the total $\mathrm{CO}_{2}$ concentration in Fig. 14-B.

\section{Dissolved Oxygen}

Figs. 19-A \& B show the distribution of the oxygen concentration dissolved in seawater along $150^{\circ} \mathrm{W}$ down to 1000 meters and to the sea floor respectively. Two oxygen minimum layers were found: the upper layer was located at about 250 meters deep while the deeper layer was at about 1500 meters at the northern end of the section at $17.5^{\circ} \mathrm{S}$ and deepened to about 2500 meters at about $30^{\circ} \mathrm{S}$. Both of these layers appear to have originated from the eastern tropical Pacific. Between these two layers, an oxygen maximum layer is found at a depth of about 600 meters. This appears to be derived from the Southern Ocean. Below the deep oxygen minimum layer, the oxygen concentration increased with depth of water to about 205 $\mu \mathrm{mol} / \mathrm{kg}$, indicating that younger abyssal waters originated in the Southern Ocean were entering from the southern end of this section.

Figs. 20-A \& B show the distribution along $135^{\circ} \mathrm{W}$. Similar to the $150^{\circ} \mathrm{W}$ section, two oxygen minimum layers and one oxygen maximum layer between these two were observed. Since the observations were made further north to $6^{\circ} \mathrm{S}$ along this section, much lower oxygen values, as low as $20 \mu \mathrm{mol} / \mathrm{kg}$, were observed in the upper oxygen minimum layer at about 300 meters deep. The deeper oxygen minimum layer was observed from 350 meters near the northern end to about 2000 meters near the southern end of the section. The oxygen concentrations observed in the oxygen maximum layer in the $135^{\circ} \mathrm{W}$ section were similar to those found in the $150^{\circ} \mathrm{W}$ section.

\section{Apparent Oxygen Utilization}

Figs. 21-A \& B show the distribution of AOU along $150^{\circ} \mathrm{W}$ down to 1000 meters and to the sea floor respectively. South of about $23^{\circ} \mathrm{S}$, the AOU values remained nearly constant at $60 \pm 20$ over a depth range between 300 and 800 meters. This broad area corresponds to that ventilated by the high oxygen Southern Ocean water. Below this layer, the AOU increased with depth to an AOU maximum layer at about 2750 meters deep at the southern end of the section. This layer shoaled gradually to about 1750 meters at the northern end. In the AOU maximum layer, about $50 \%$ of the original oxygen concentration was consumed. Its position 
Fig. 16 - Distribution of $\mathrm{pCO}_{2}$ in seawater at $20.0{ }^{\circ} \mathrm{C}$ along the WOCE P-17C $\left(135^{\circ} \mathrm{W}\right)$ section: (A) the upper 1000 meters, and (B) the entire depth range. Dashed curves indicate trends of $\mathrm{pCO}_{2}$ maxima.

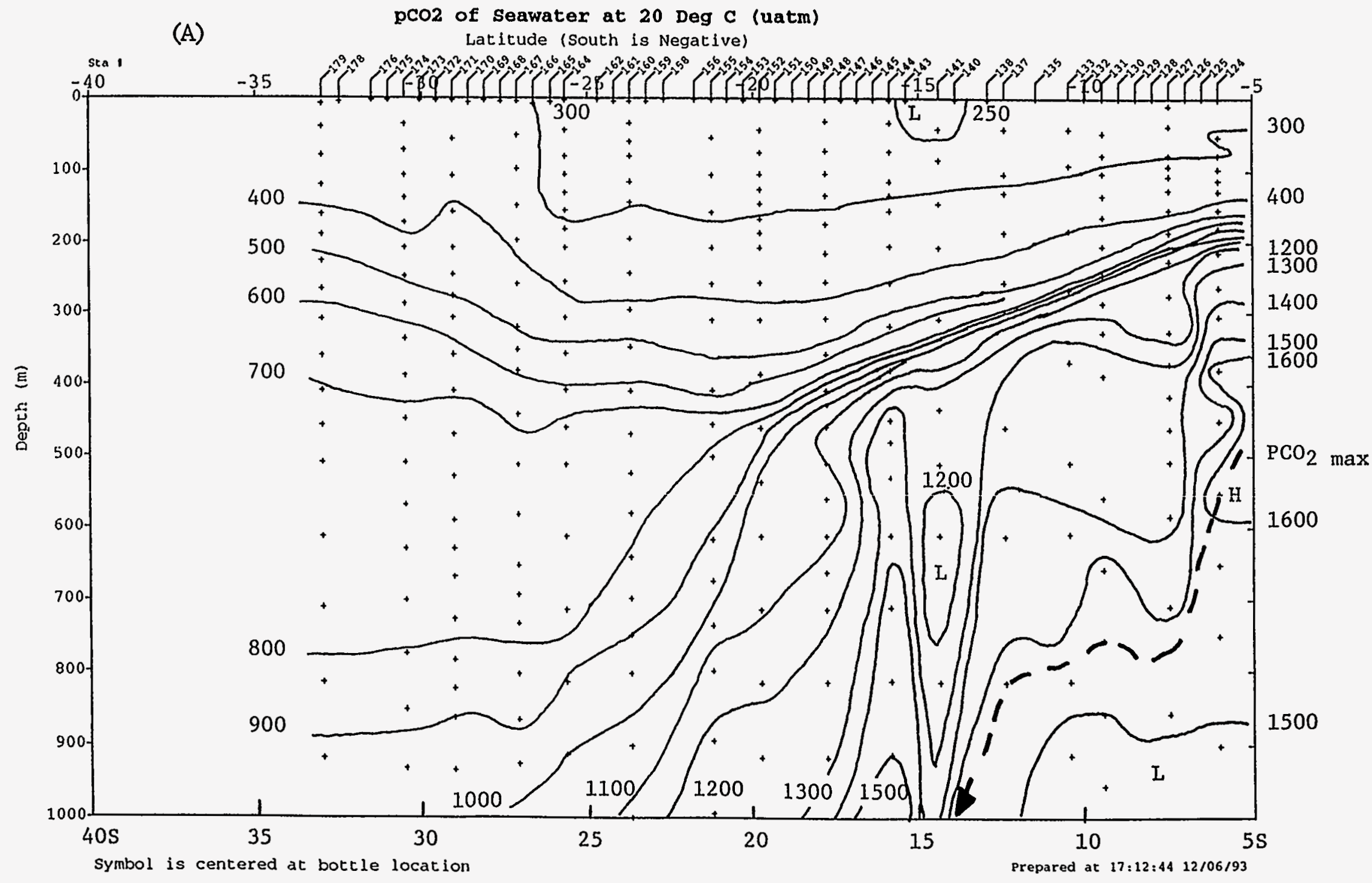


(B)

pCO2 of Seawater at 20 Deg C (uatm) Latitude (South is Negative)

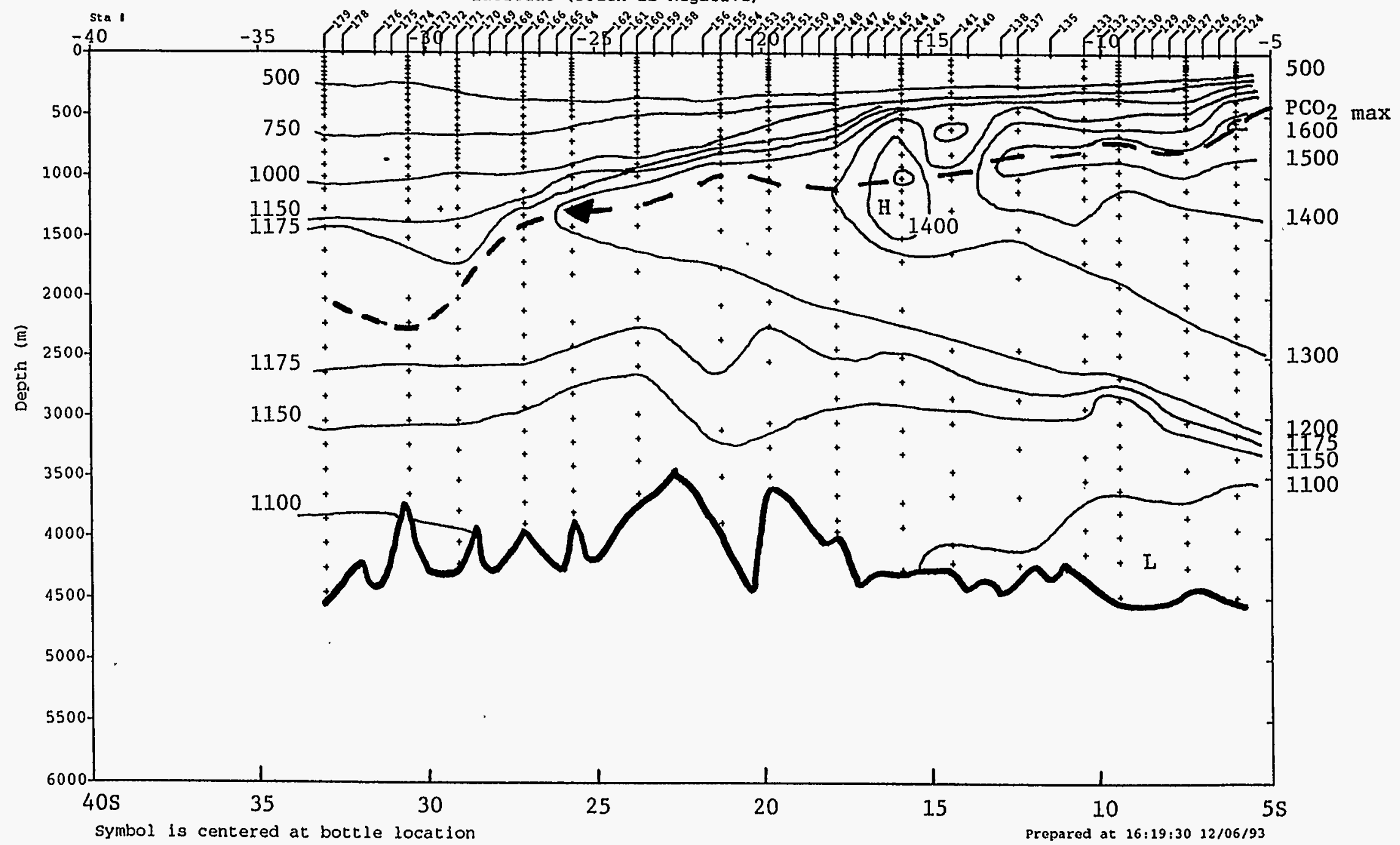


象

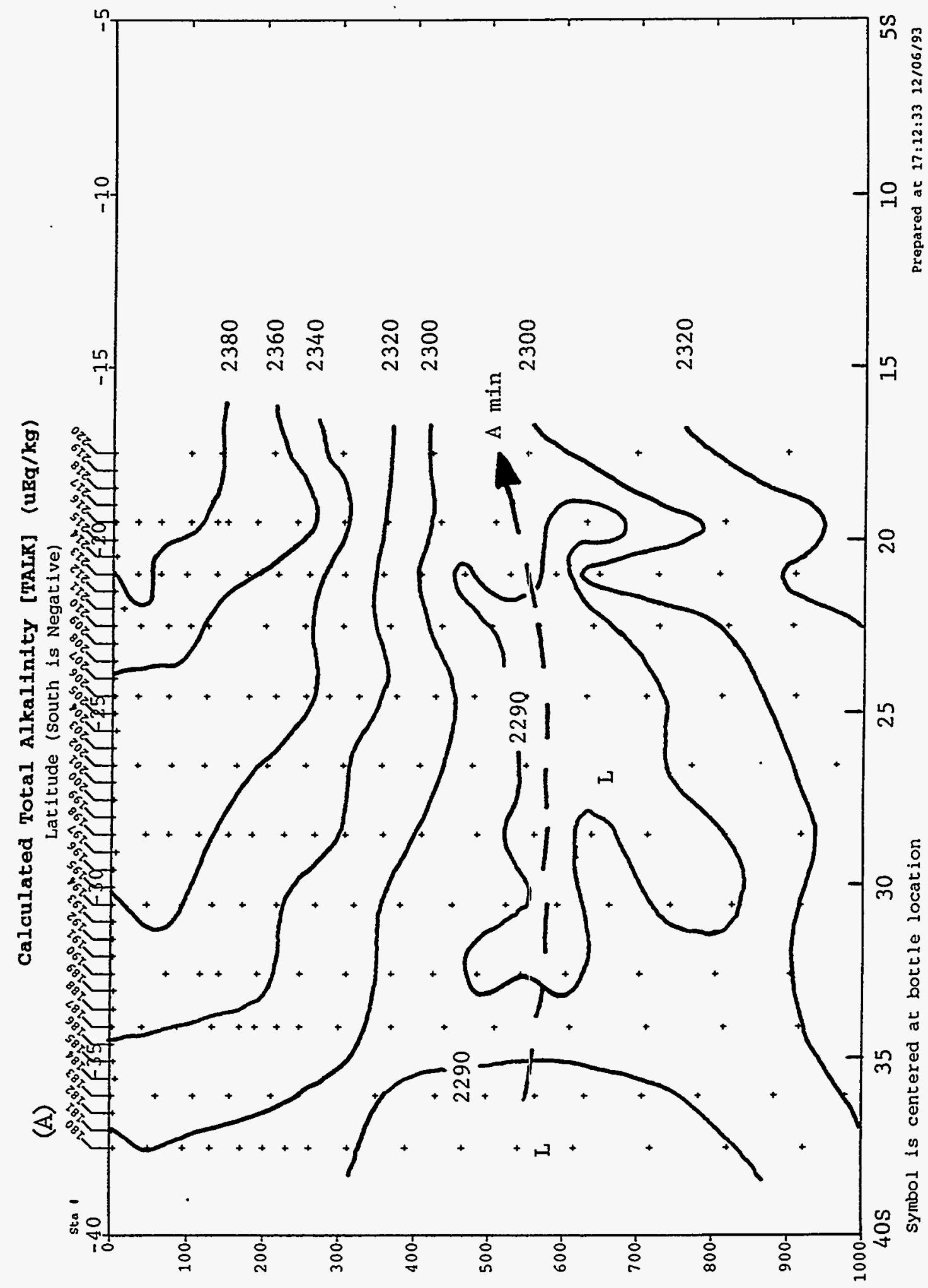

I

3

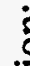

ํํㄹ

点

닝

ช



옹

敢

홍

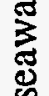

.

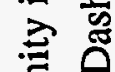

哥

光

흘

$\therefore$

i.

(Ui) 4วव๋อ 
(B)

Calculated Total Alkalinity [TALK] (uBq/kg) Latitude (South is Negative)

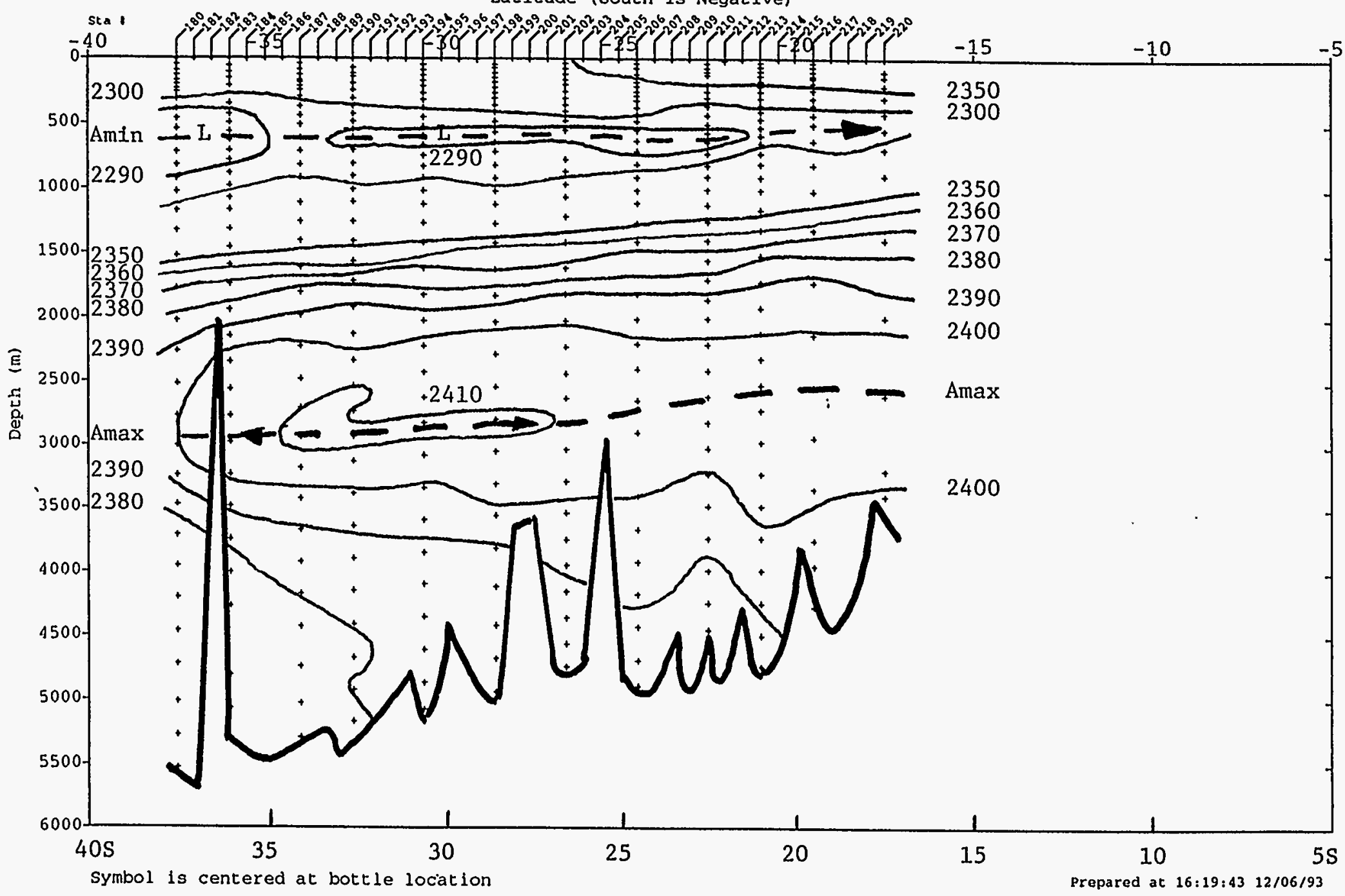


Fig. 18 - Distribution of alkalinity in seawater along the WOCE P-17C (1350W) section: (A) the upper 1000 meters, and (B) the entire depth range. Dashed curves indicate trends of alkalinity maxima or minima with water depth.

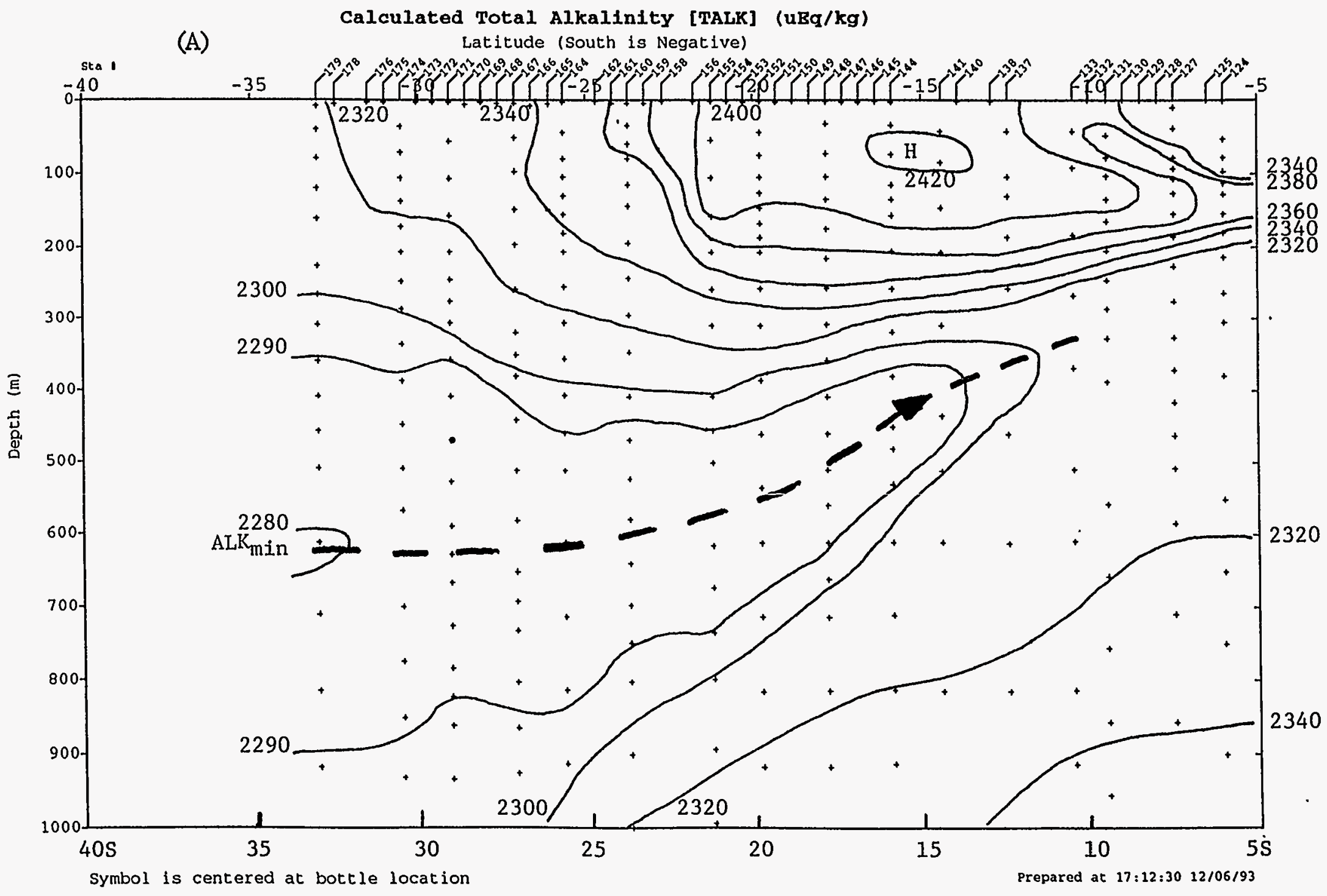




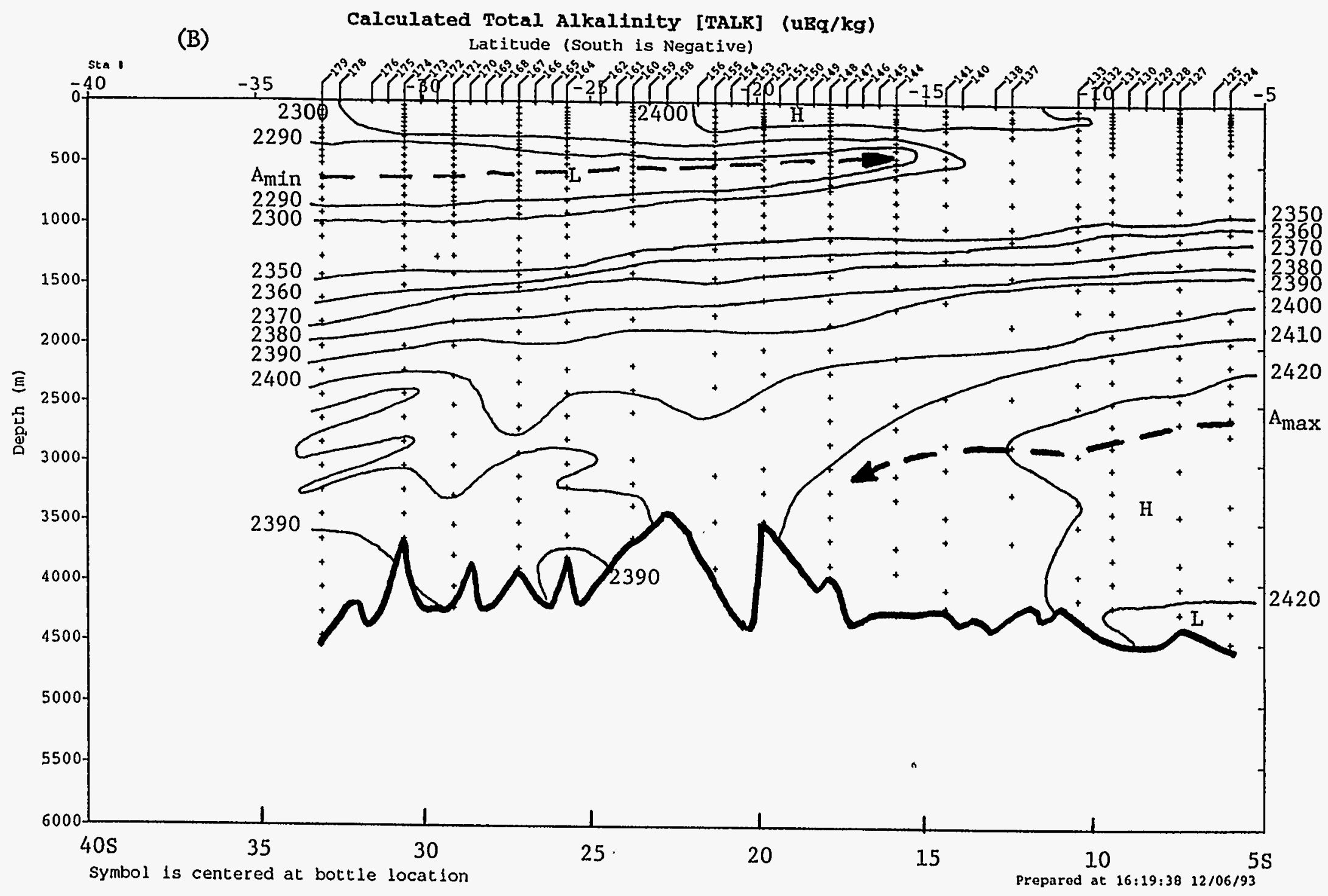




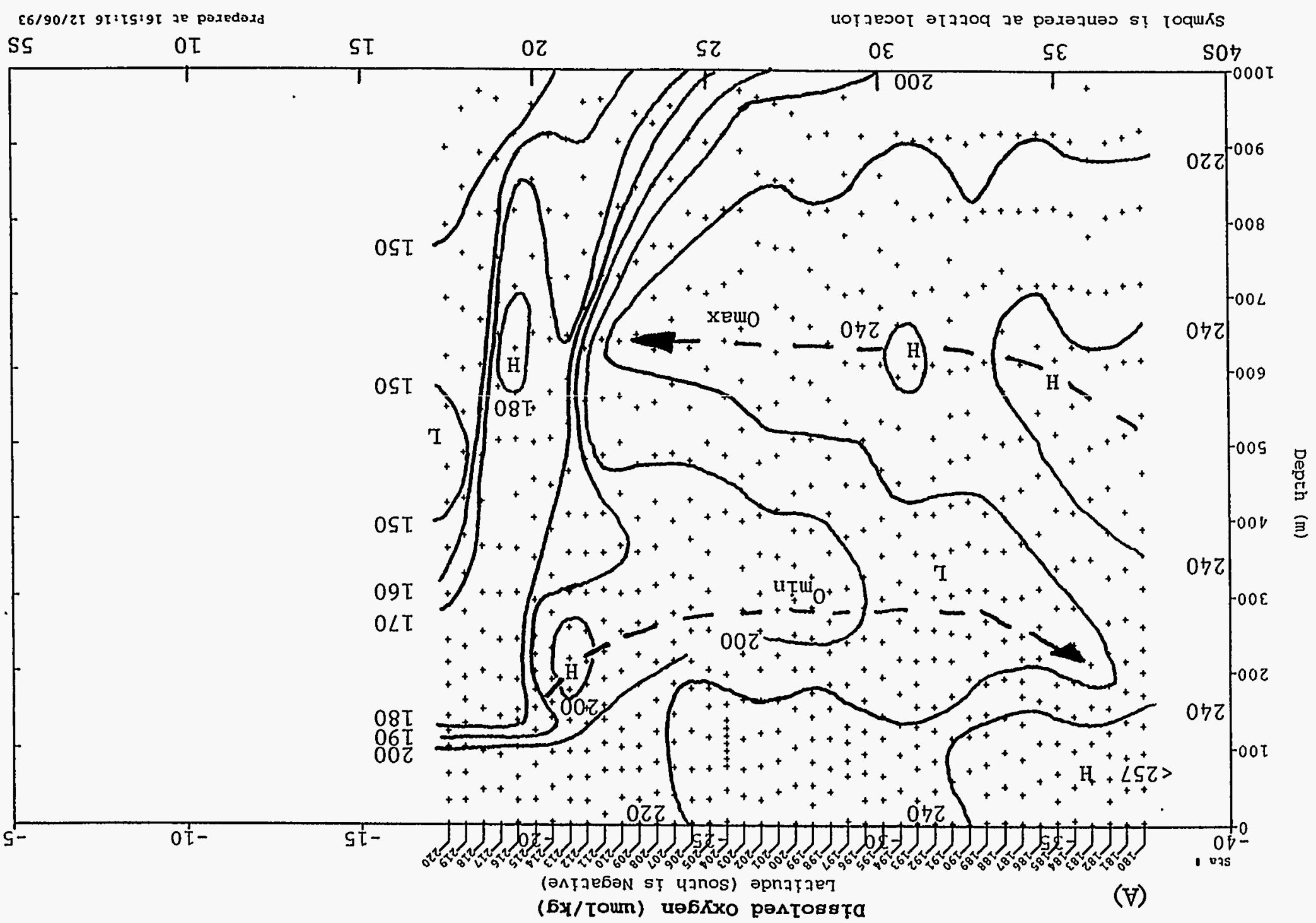

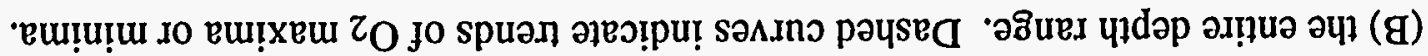

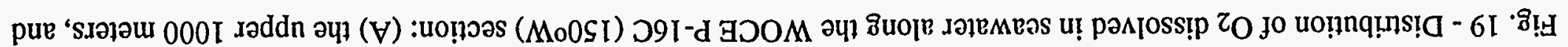




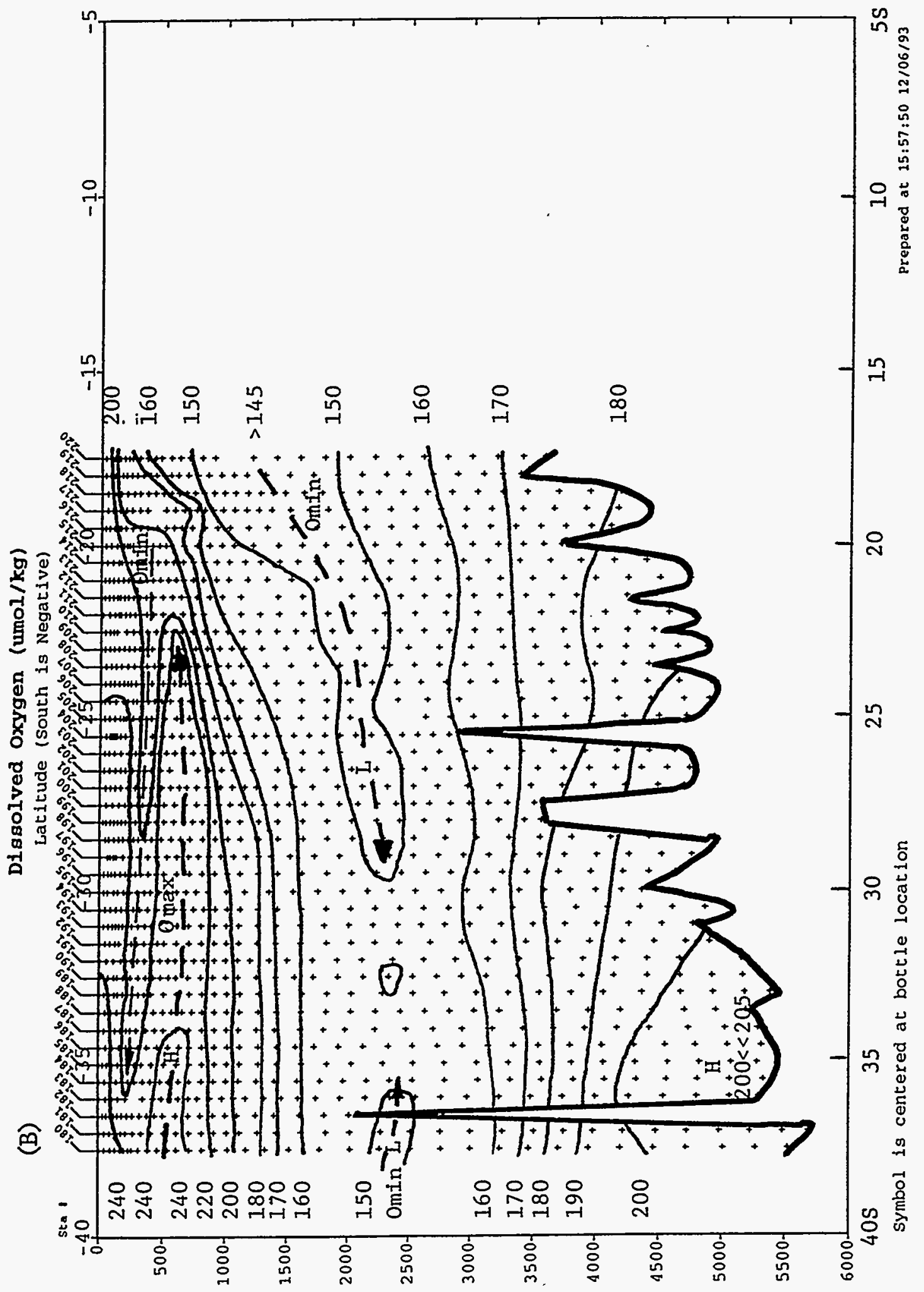

(ui) प3dəa 


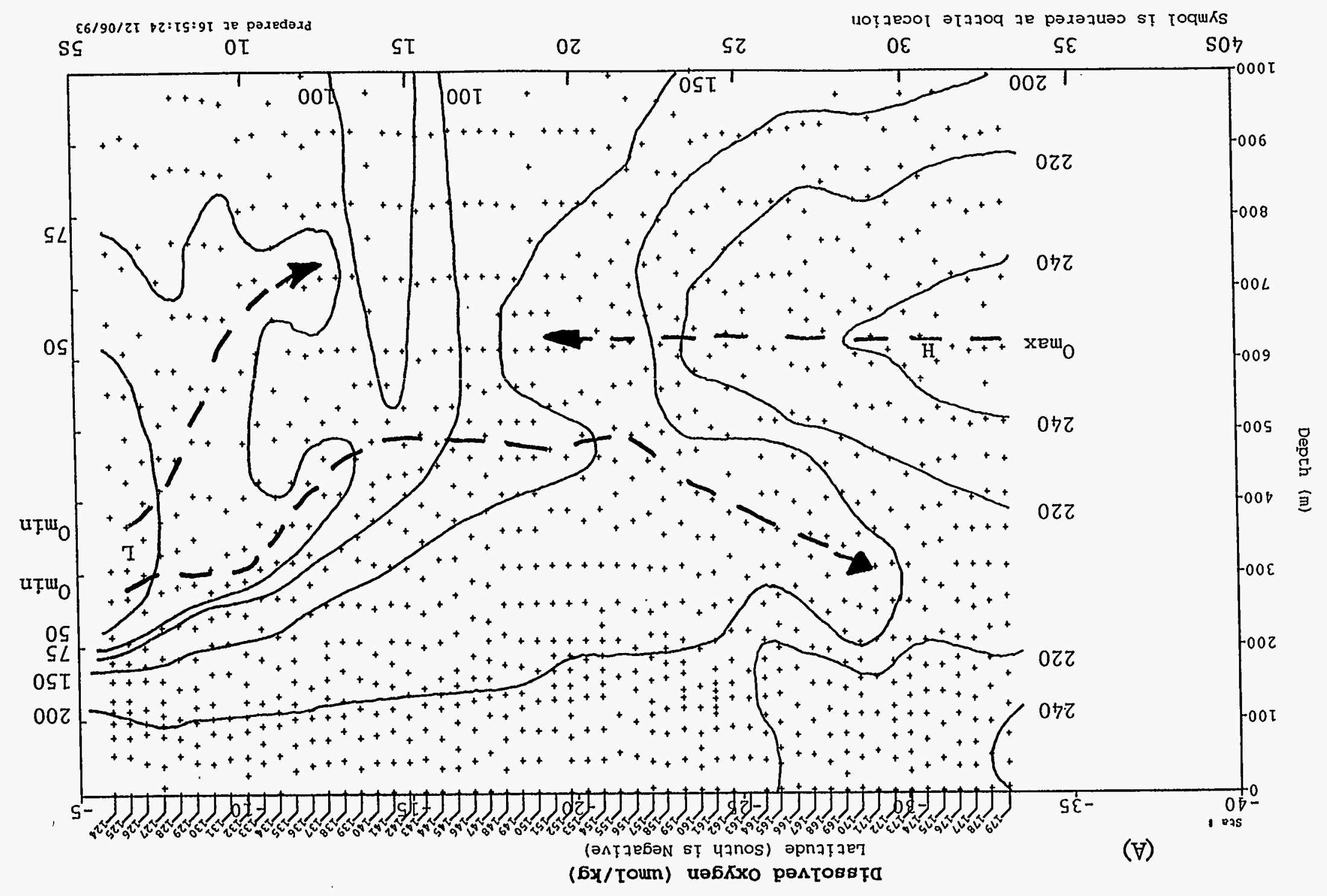

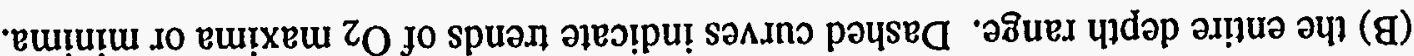

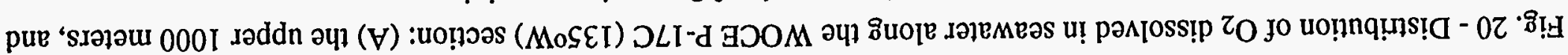




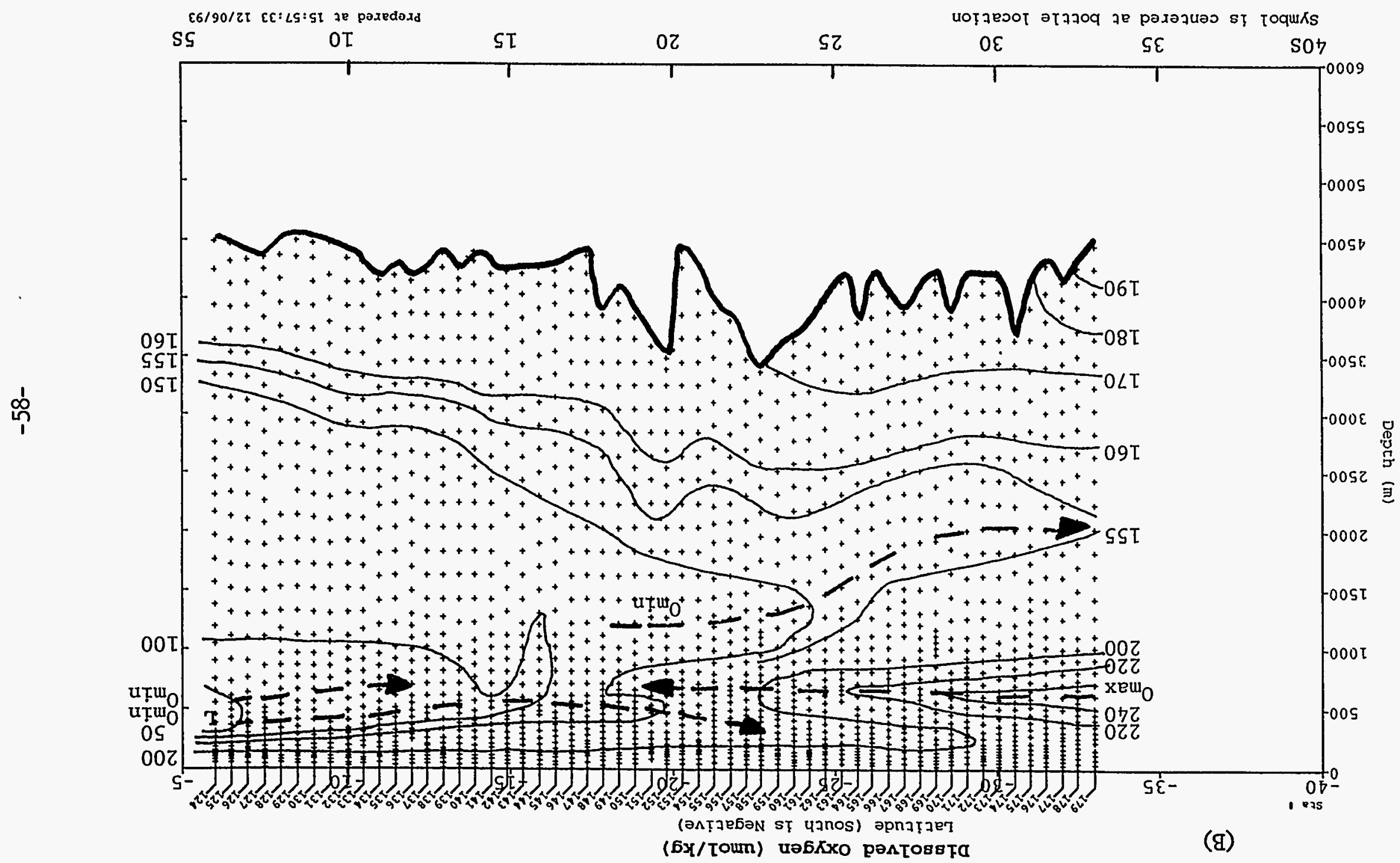


Fig. 21 - Distribution of the apparent oxygen utilization (AOU) in seawater along the WOCE P-16C (150\%) section: (A) the upper 1000 meters, and (B) the entire depth range. Dashed curves indicate trends of AOU maxima.

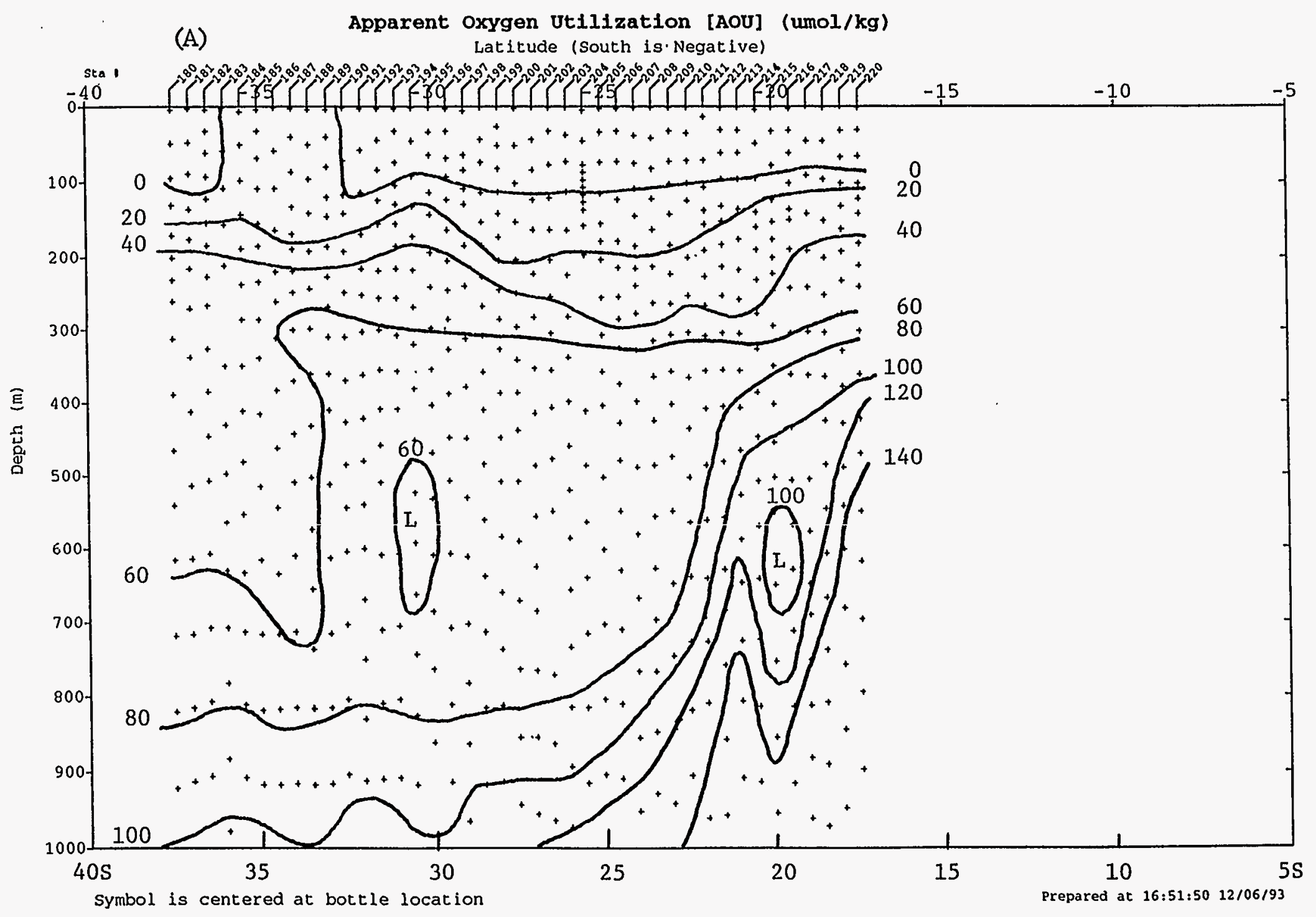




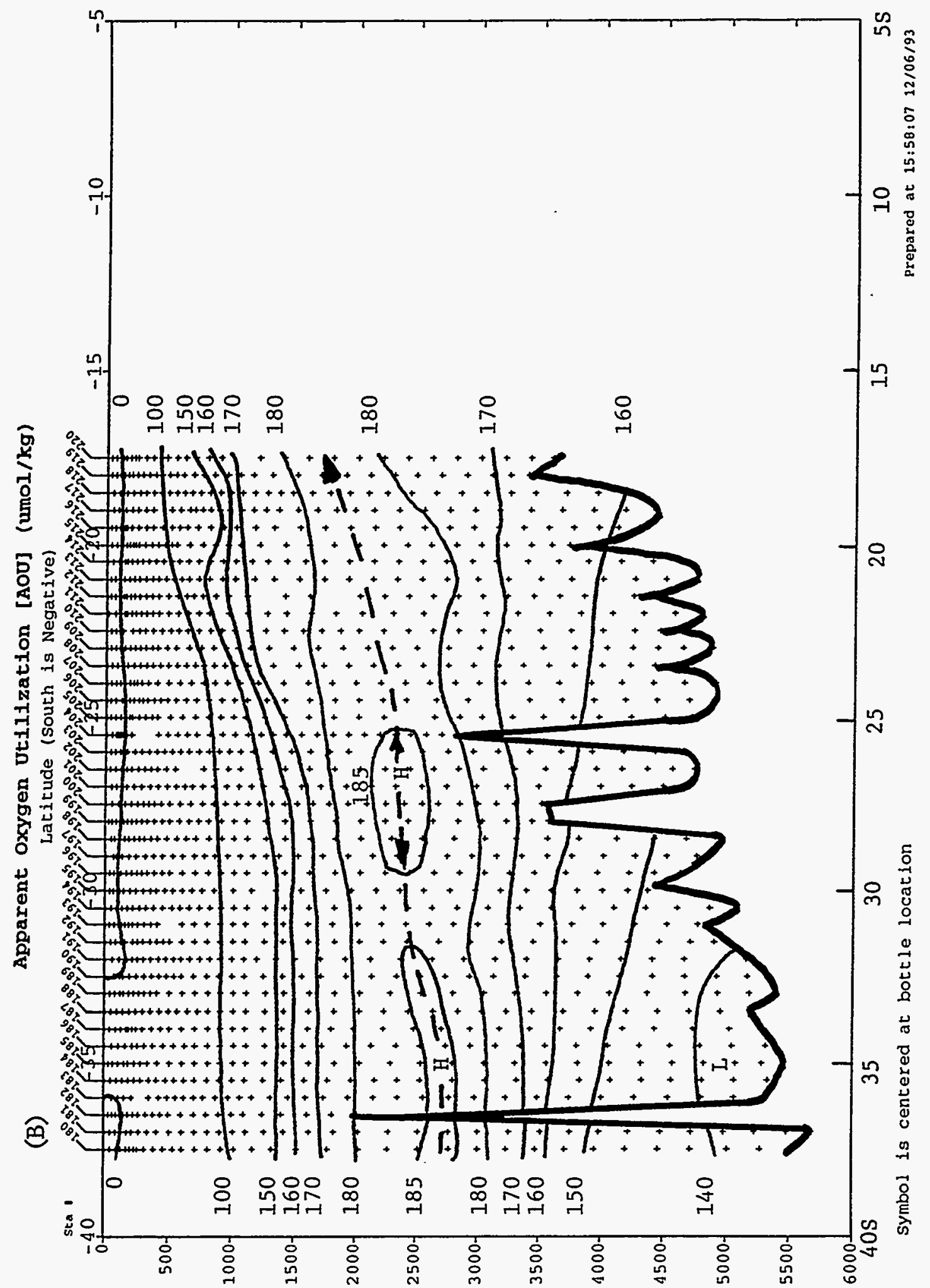

(ii) บวฮัวด 
$\pm$

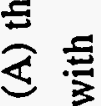

:

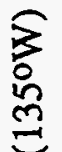



궁

딘

3

\&

की

范

密

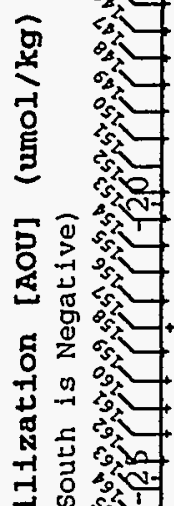

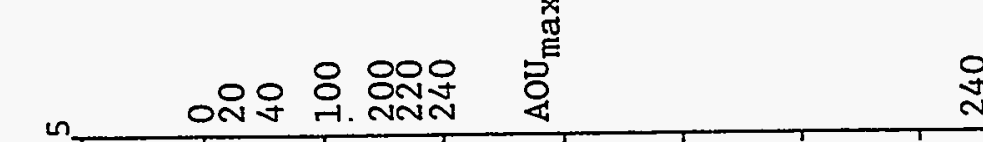

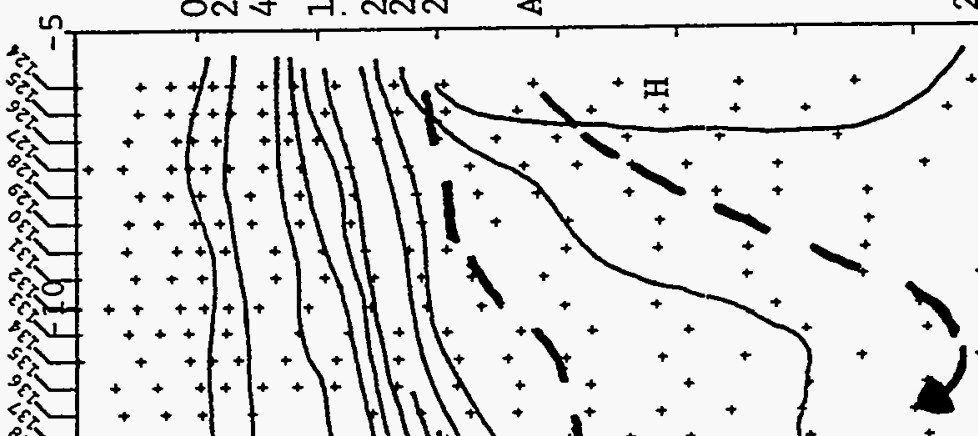

हो

$0^{2}+^{+}++^{+}++1$ f

$+\div+\div+\div+\div++$

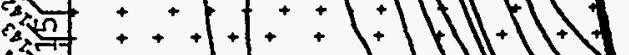

$+$

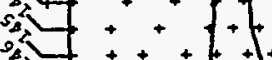

$+++++$
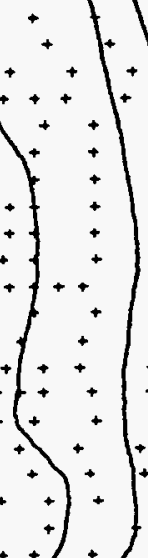

i

을

至

空

$+1+1$

$\div+1+1$

$1 .+4+4$

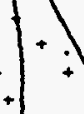

$+$
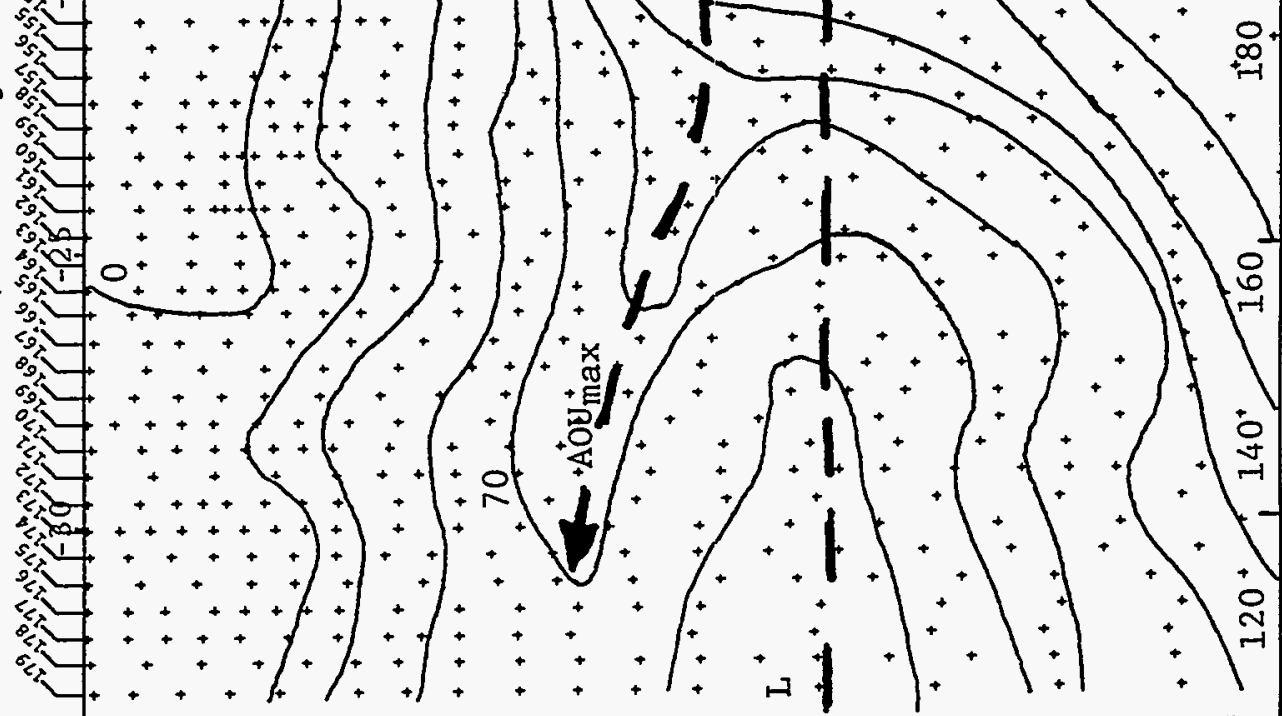

范

n.

$+++++4$
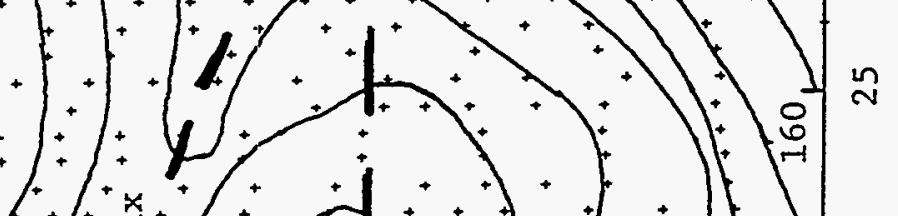

$+t_{+}^{+}+0^{+}$
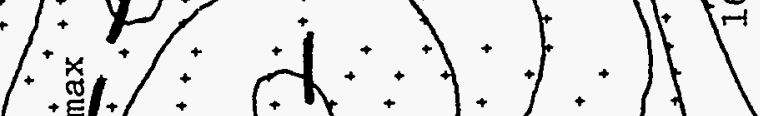

눅

오

윽 뭄

总

言

สิ

定

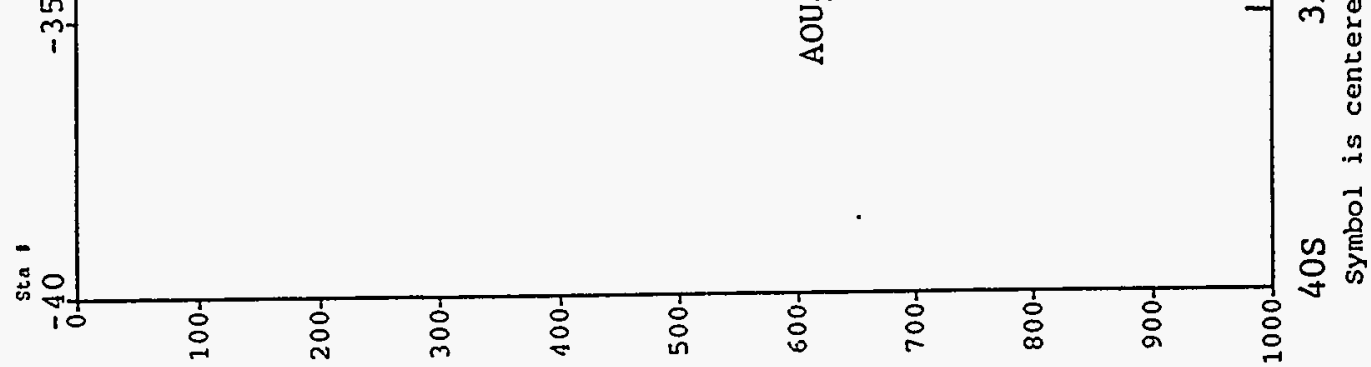

(ii) पวवือव 


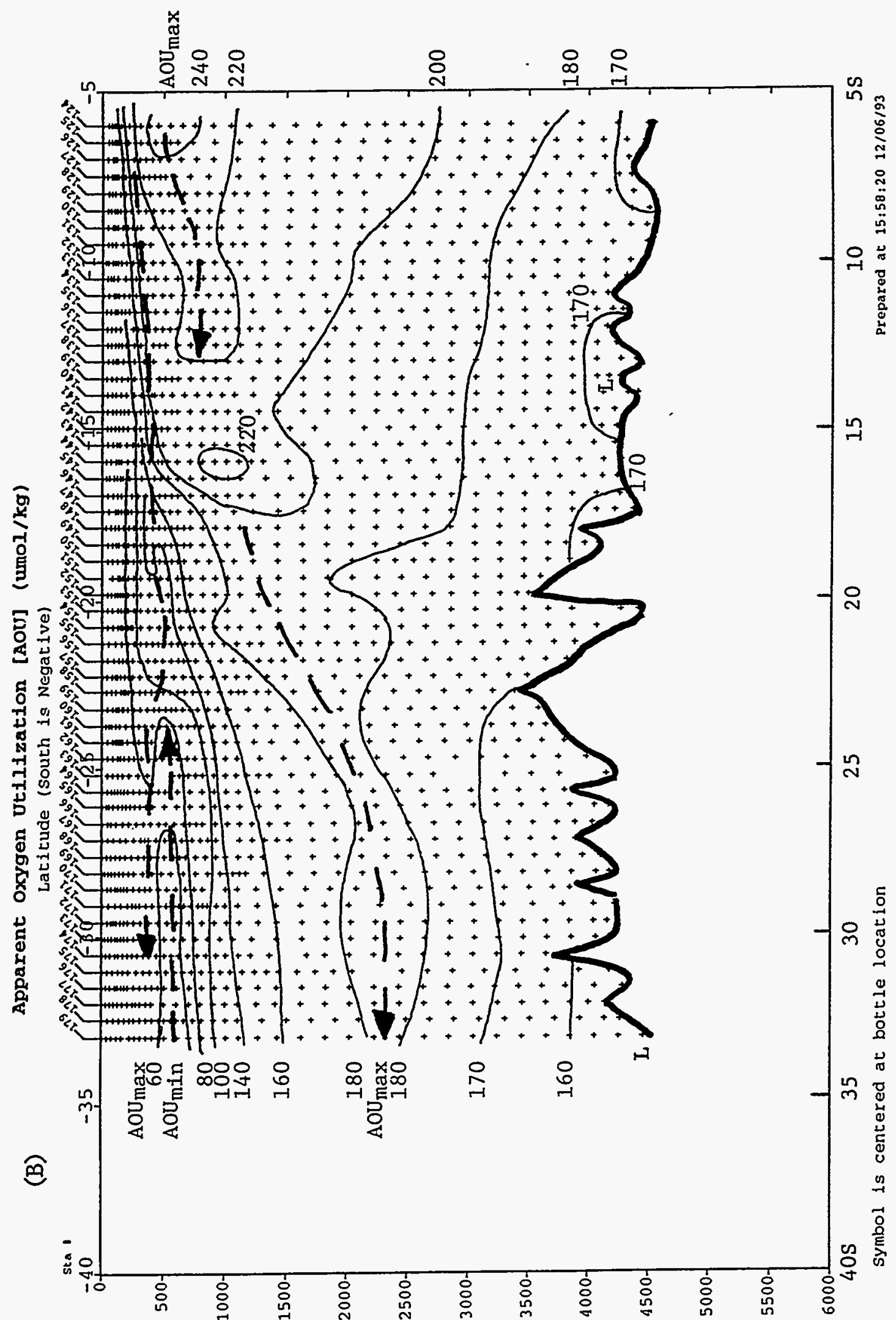

(ui) yzdaa 
Fig. 23 - Distribution of phosphate dissolved in seawater along the WOCE P-16C (150\%W) section: (A) the upper 1000 meters, and $(B)$ the entire depth range. Dashed curves indicate trends of phosphate maxima.

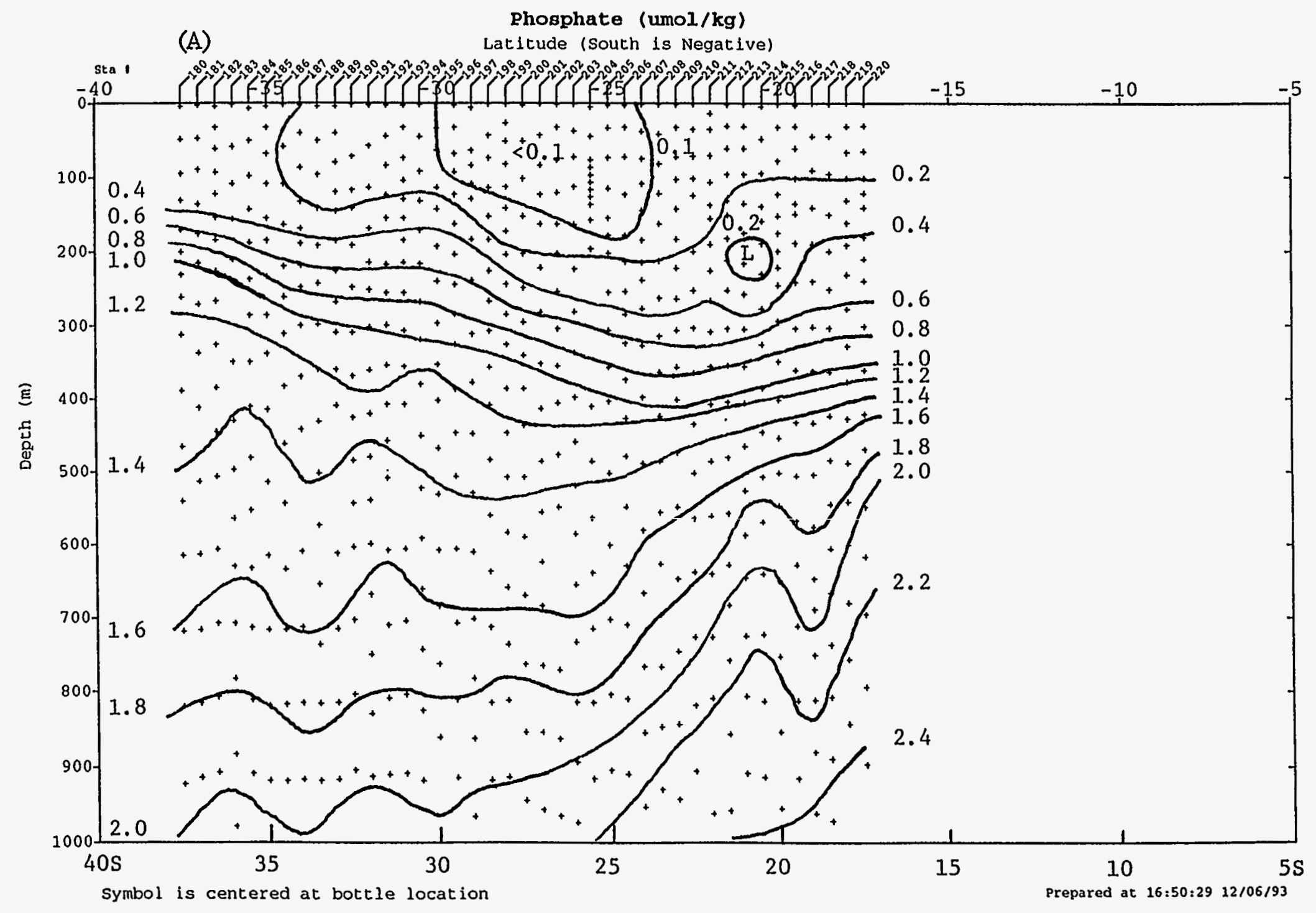




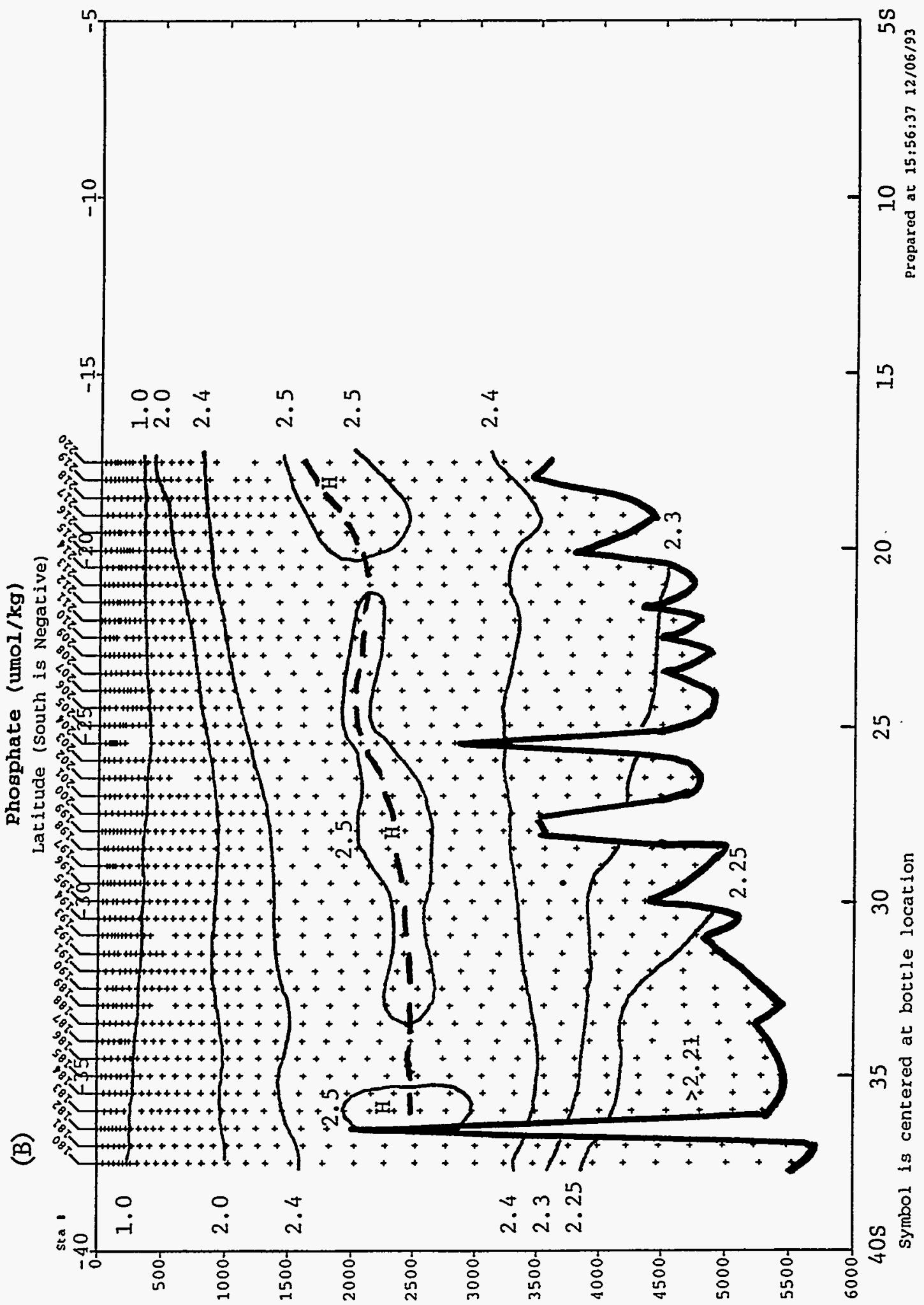

(ui) $43 d 20$ 


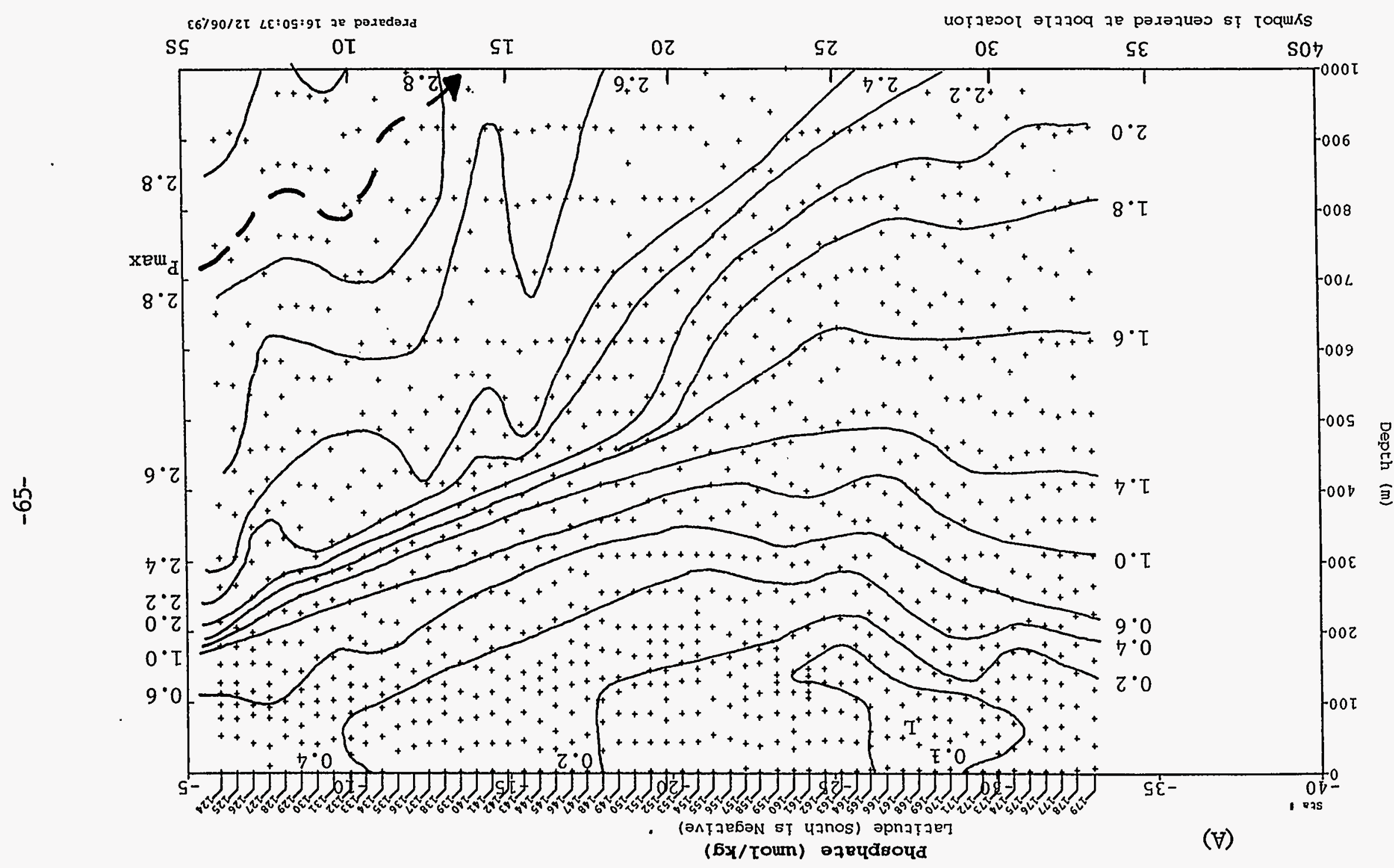

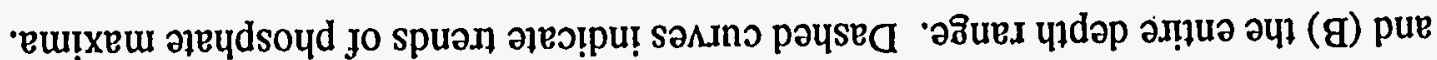

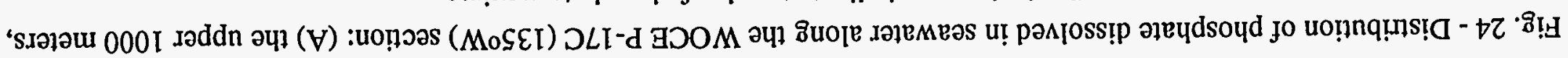




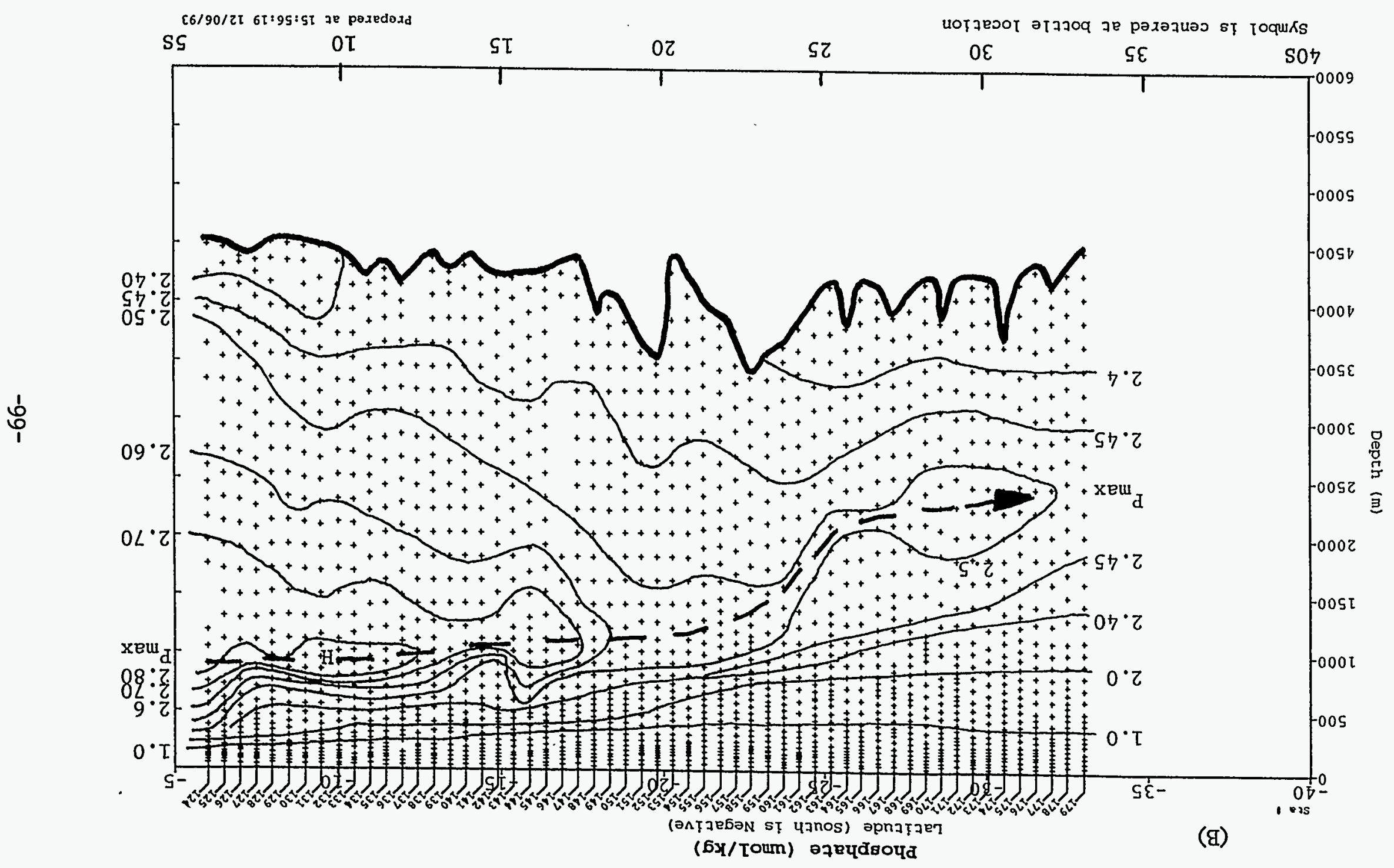


름

응

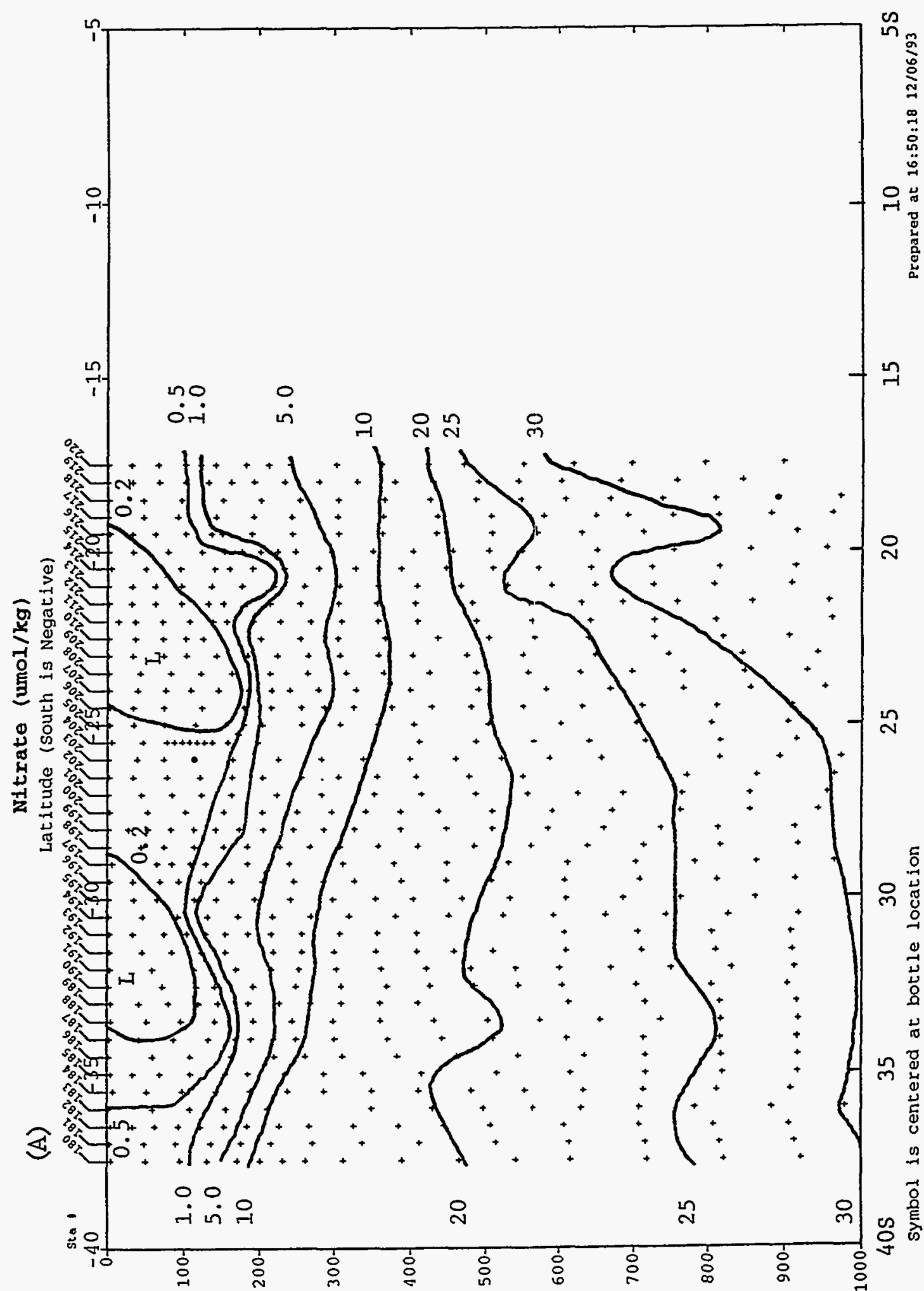

$\$$

芦



옹

는

a

0

远

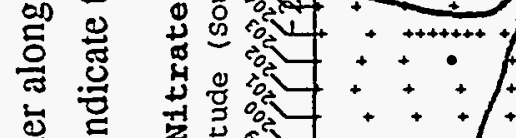

选

ฮี

.

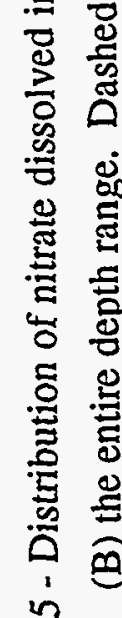

ก

is

(w) บุวฮəด 


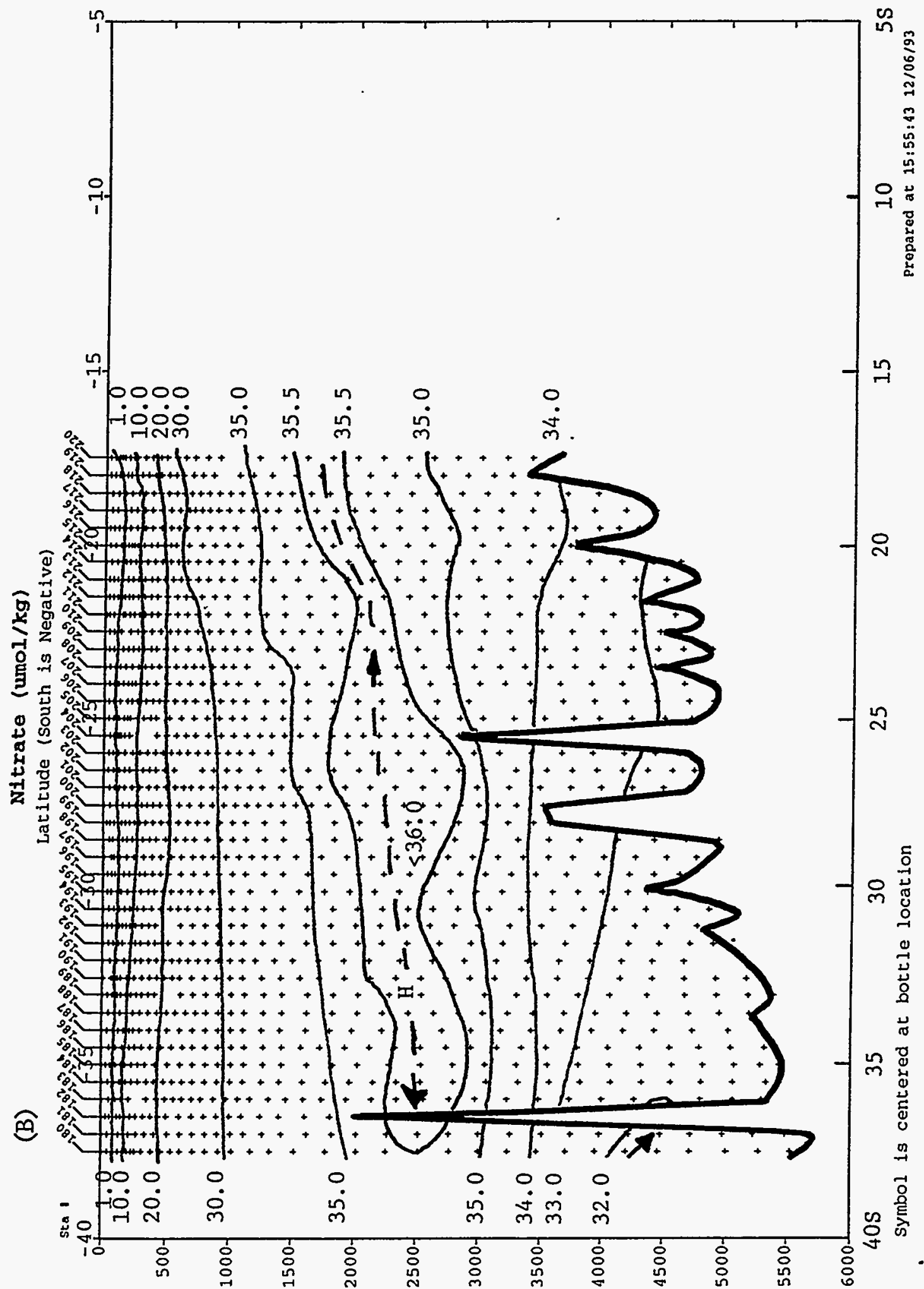

(ui) पวdəa 
nearly coincided with that for the $\mathrm{pCO}_{2}$ maximum layer, but was located a few hundred meters below the deeper oxygen minimum layer.

Figs. 22-A \& B show the distribution along $135^{\circ} \mathrm{W}$. In the upper 1000 meters, two AOU maximum layers and a minimum layer can be seen due mainly to the more intensified influence of the low oxygen waters of the eastern tropical Pacific over-riding and under-cutting the high oxygen southern water centered around 600 meters. The deeper AOU maximum layer started at a depth of about 500 meters near the northern end of the section and deepened to about 2800 meters near the southern end, where the magnitude was similar to that observed along the $150^{\circ} \mathrm{W}$ meridian.

\section{Phosphate}

Figs. 23-A \& B show the distribution of phosphate dissolved in seawater along $150^{\circ} \mathrm{W}$ down to 1000 meters and to the sea floor respectively. Phosphate in surface layers of the subtropical ocean was nearly depleted, less than $0.2 \mu \mathrm{mol} / \mathrm{kg}$. It increased with depth to the phosphate maximum layer located at a depth of 2500 meters in the southern end of the section at $37.5^{\circ} \mathrm{S}$, and 1600 meters at the northern end at $17.5^{\circ} \mathrm{S}$. Since the maximum values for phosphate were similar along this layer at about $2.5 \mu \mathrm{mol} / \mathrm{kg}$, the direction of its source could not be identified. The position of the phosphate maximum was several hundred meters below that for the oxygen minimum layer north of about $23^{\circ} \mathrm{S}$, but coincided with it south of the latitude. Below the maximum layer, phosphate decreased gradually to $2.2 \mu \mathrm{mol} / \mathrm{kg}$ at the southern end and to $2.3 \mu \mathrm{mol} / \mathrm{kg}$ at the northern end. Figs. 24-A \& B show the distribution along $135^{\circ} \mathrm{W}$. In the northern half of this section between $6^{\circ} \mathrm{S}$ and $23^{\circ} \mathrm{S}$, the phosphate maximum layer was found at about 1200 meters. South of about $25^{\circ} \mathrm{S}$, it was observed much deeper at about 2300 meters. Along the layer, the phosphate concentration decreased southward from $2.88 \mu \mathrm{mol} / \mathrm{kg}$ at the northern end to $2.5 \mu \mathrm{mol} / \mathrm{kg}$ at the southern end of the section, indicating a northern origin of this signal.

\section{Nitrate}

Figs. 25-A \& B show the distribution of nitrate dissolved in seawater along $150^{\circ} \mathrm{W}$ down to 1000 meters and to the sea floor respectively. The nitrate concentration in surface waters'was generally less than $0.5 \mu \mathrm{mol} / \mathrm{kg}$ and was of ten less than $0.2 \mu \mathrm{mol} / \mathrm{kg}$. It increased to a nitrate maximum layer, which was located at 2500 meters near the southern end and at 
1700 meters near the northern end of the section. The highest nitrate concentration as high as $36.0 \mu \mathrm{mol} / \mathrm{kg}$ was found in this layer at about $26^{\circ} \mathrm{S}$, and the value decreased north and south of this latitude as observed for the total $\mathrm{CO}_{2}$ concentration (Fig. 13-B) and alkalinity (Fig. 17-B). This suggests that a tongue of the North Pacific water was cut across by this section. The concentration decreased with depth to the lowest value of $32.0 \mu \mathrm{mol} / \mathrm{kg}$ in the bottom water in the southern end of the section. The low values for the concentrations of total $\mathrm{CO}_{2}$, phosphate and nitrate and the high values for oxygen found in bottom waters in the southern end are indicative of their southern high-latitude origin.

Figs. 26-A \& B show the distribution along $135^{\circ} \mathrm{W}$. Nitrate maximum layer may be traced from about 800 meters at the northern end and to 2300 meters at the southern end of the section. Values as high as $40 \mu \mathrm{mol} / \mathrm{kg}$ were observed near the northern end. The meridional change of the maximum nitrate layer depth along $135^{\circ} \mathrm{W}$ differed substantially from that along $150^{\circ} \mathrm{W}$ due mainly to the stronger influence of the eastern tropical waters with low-oxygen and high-nutrient concentrations.

\section{Silicate}

Figs. 27-A \& B show that the distribution of silicate dissolved in seawater along $150^{\circ} \mathrm{W}$ down to 1000 meters and to the sea floor respectively. The silicate concentration in surface waters was less than $2.0 \mu \mathrm{mol} / \mathrm{kg}$, and it increased with depth to the silicate maximum layer which was located at about 3000 meters. In this layer, silicate values as high as $133.3 \mu \mathrm{mol} / \mathrm{kg}$ were observed near $28^{\circ} \mathrm{S}$. The maximum value tended to fall north and south of this latitude similar to the trends observed for the total $\mathrm{CO}_{2}$ concentration (Fig. 13-B), alkalinity (Fig. 17-B) and nitrate (Fig. 25-B). This suggests that a tongue of the North Pacific water was crossed by this section. Below this maximum layer, a silica minimum layer was found between 4000 and 4300 meters deep in the areas south of $30^{\circ} \mathrm{S}$. This silicate minimum layer is considered to represent the Antarctic Circumpolar Deep Water, which is characterized by high-salinity and low-silicate values reflecting the contribution of the NADW, and intrude under the silicate maximum layer of the northern origin. Reid (1986) observed along $170^{\circ} \mathrm{W}$ a deep silicate minimum layer which was associated with a salinity maximum (with a maximum value of $34.74 \mathrm{PSU}$ ) and interpreted that these features were due to the influence of the high-salinity, low-silicate North Atlantic Deep Water (NADW). However, the salinity data obtained during this expedition along $150^{\circ} \mathrm{W}$ did not show a maximum in association of the 
Fig. 26 - Distribution of nitrate dissolved in seawater along the WOCE P-17C (135\% W) section: (A) the upper 1000 meters, and (B) the entire depth range. Dashed curves indicate trends of nitrate maxima.

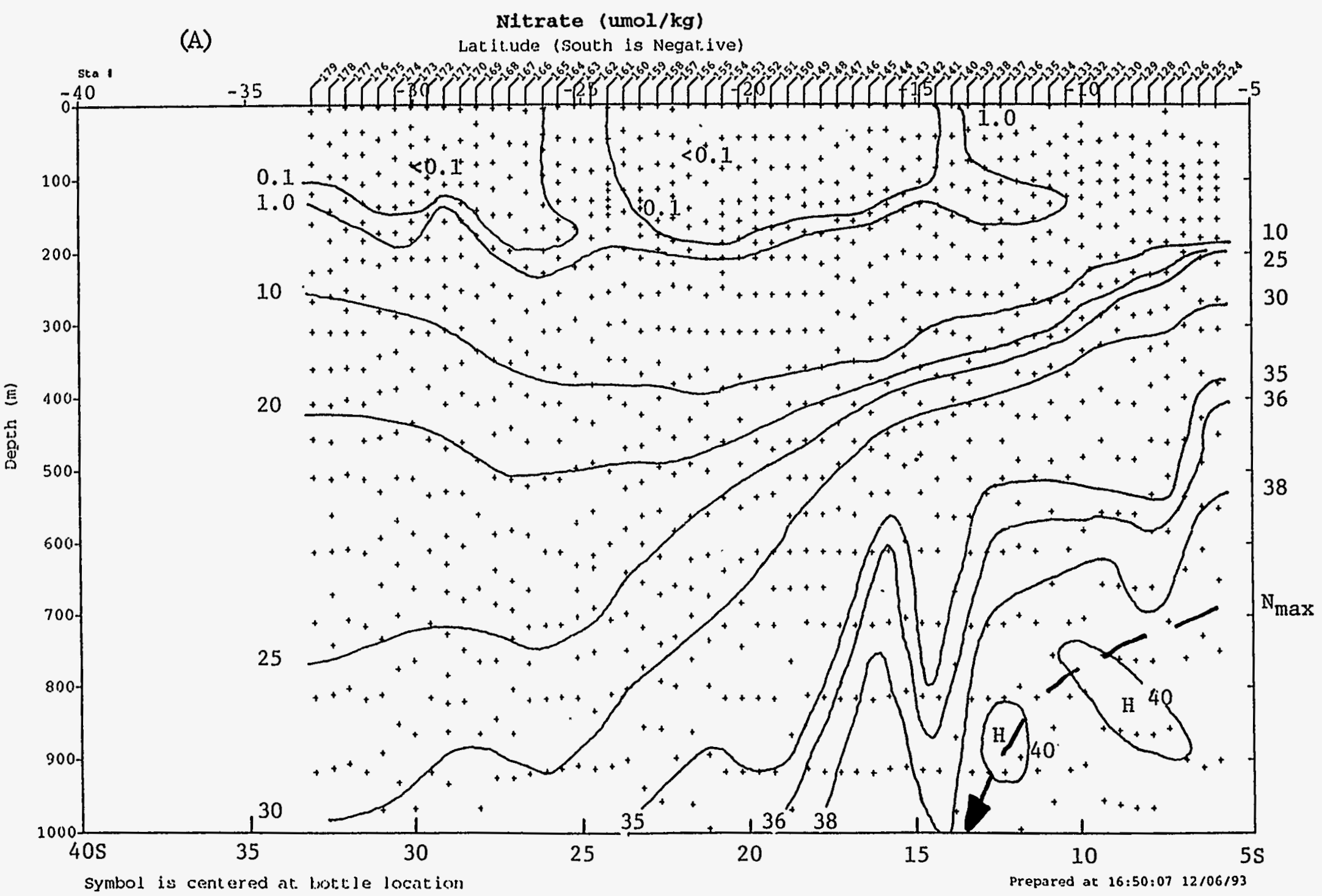




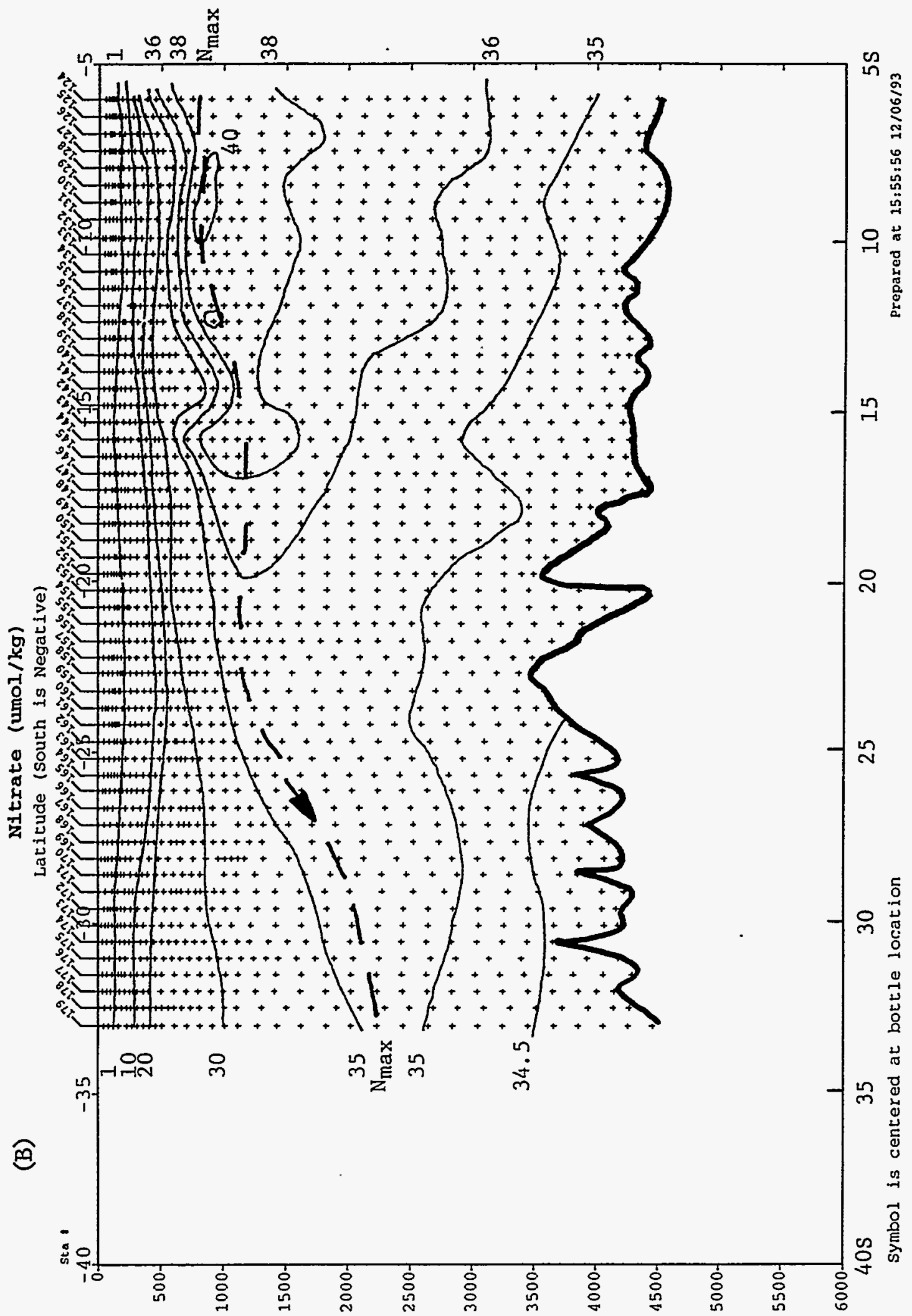

(ui) पวdəa 
Fig. 27 - Distribution of silicate dissolved in seawater along the WOCE P-16C (150\%) section: (A) the upper 1000 meters, and $(B)$ the entire depth range. Dashed curves indicate trends of silicate maxima or minima.

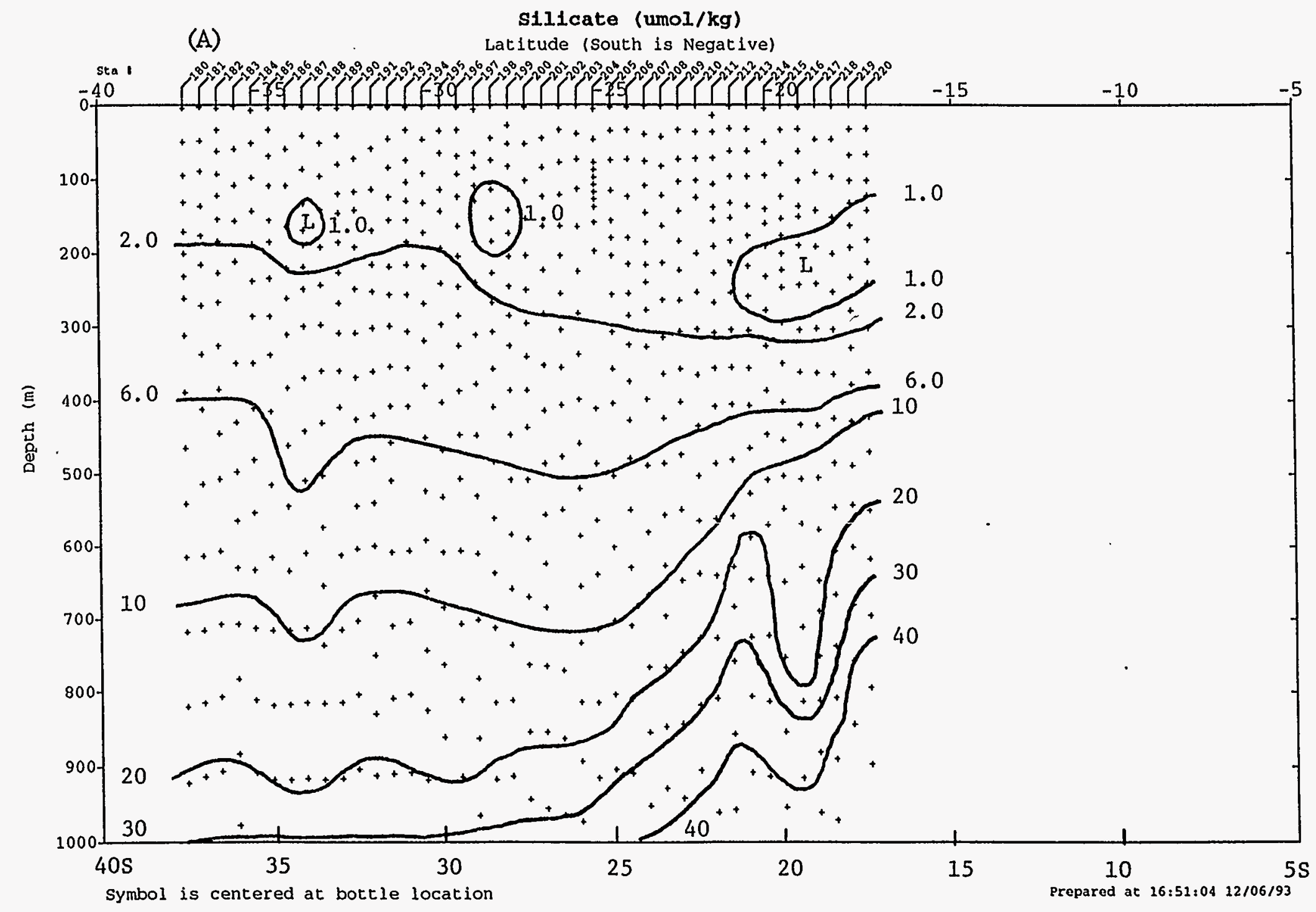




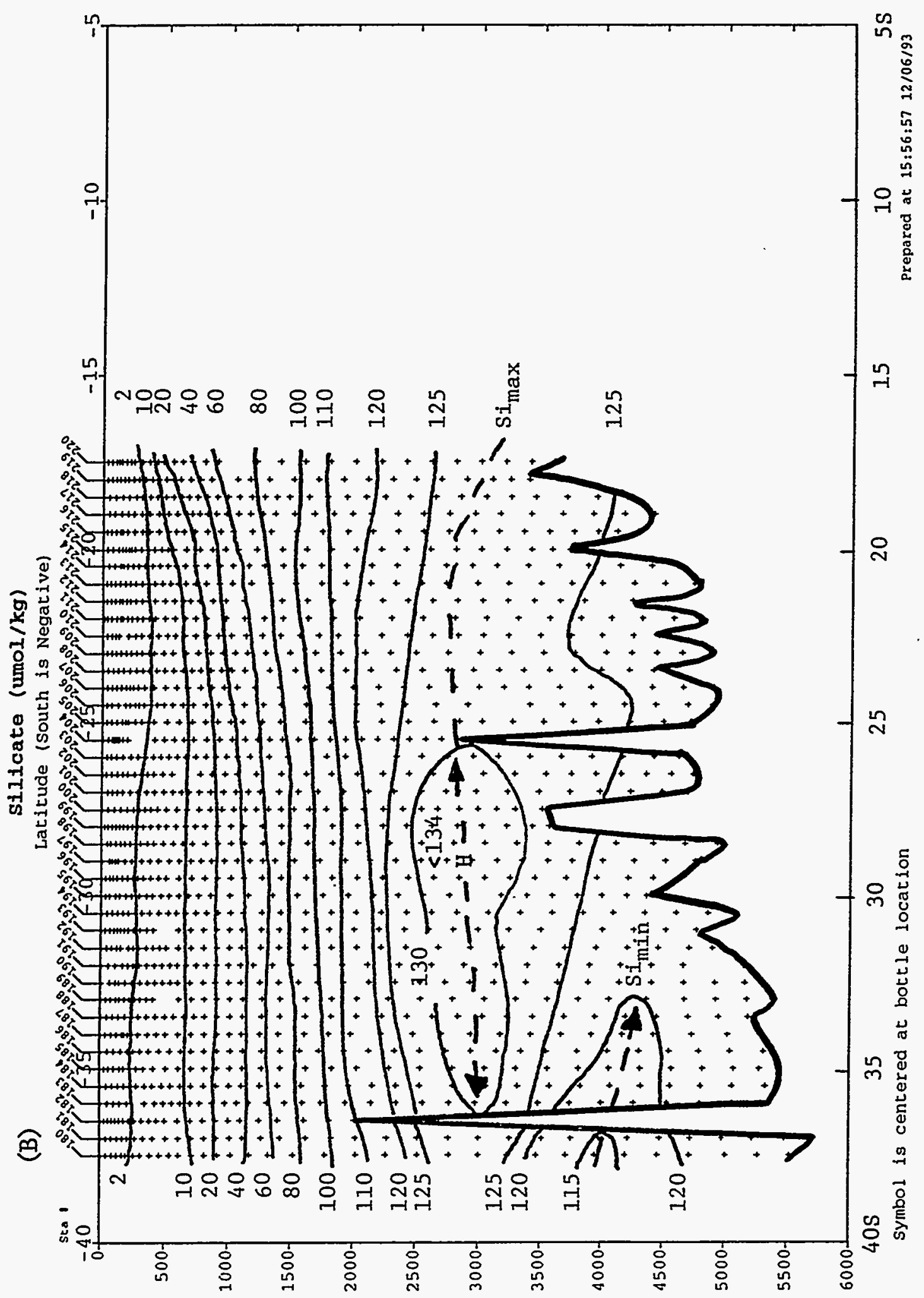

(ii) 4adac 
Fig. 28 - Distribution of silicate dissolved in seawater along the WOCE P-17C (135 $\mathrm{W})$ section: (A) the upper 1000 meters, and $(B)$ the entire depth range. Dashed curves indicate trends of silicate maxima with water depth.

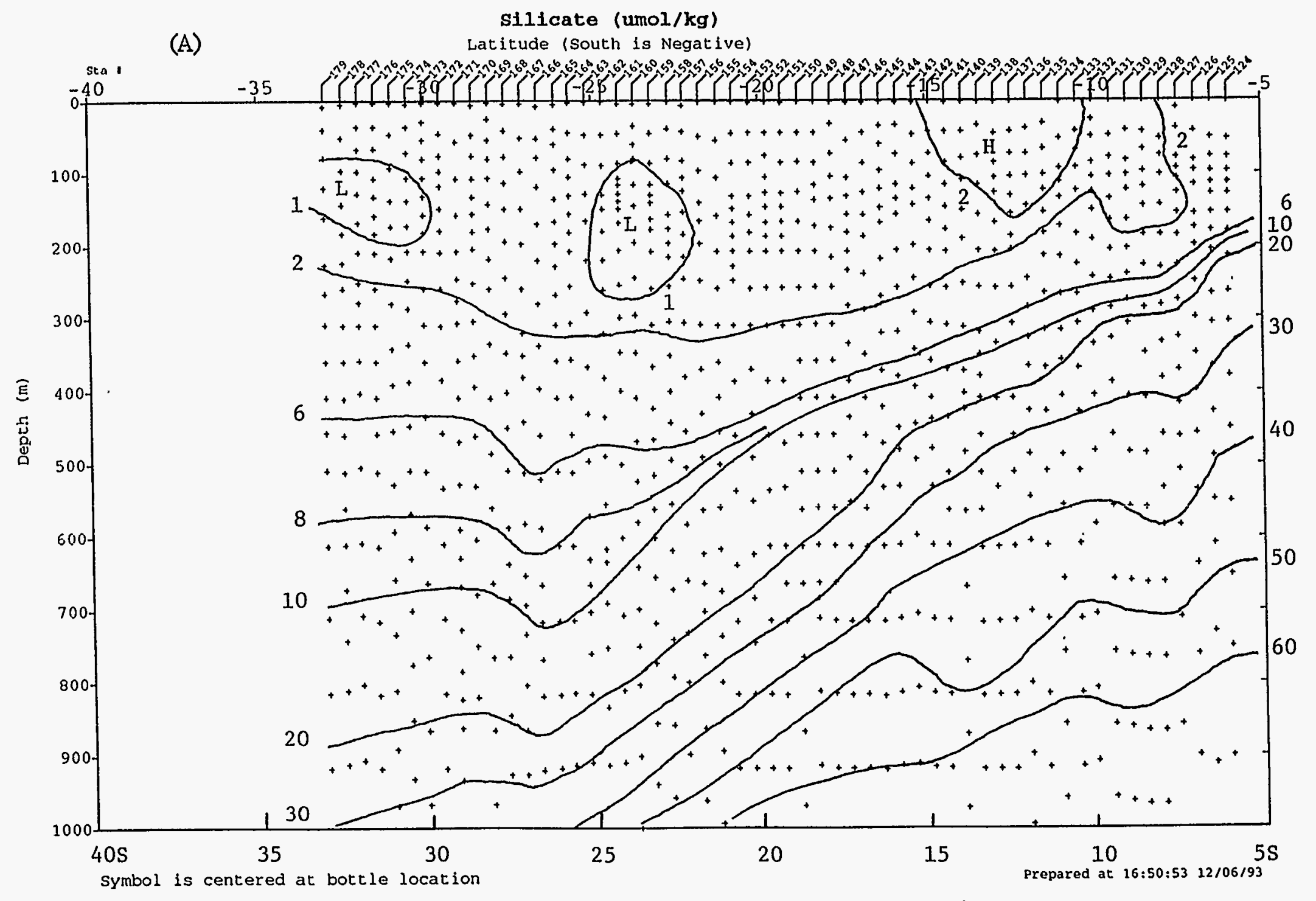




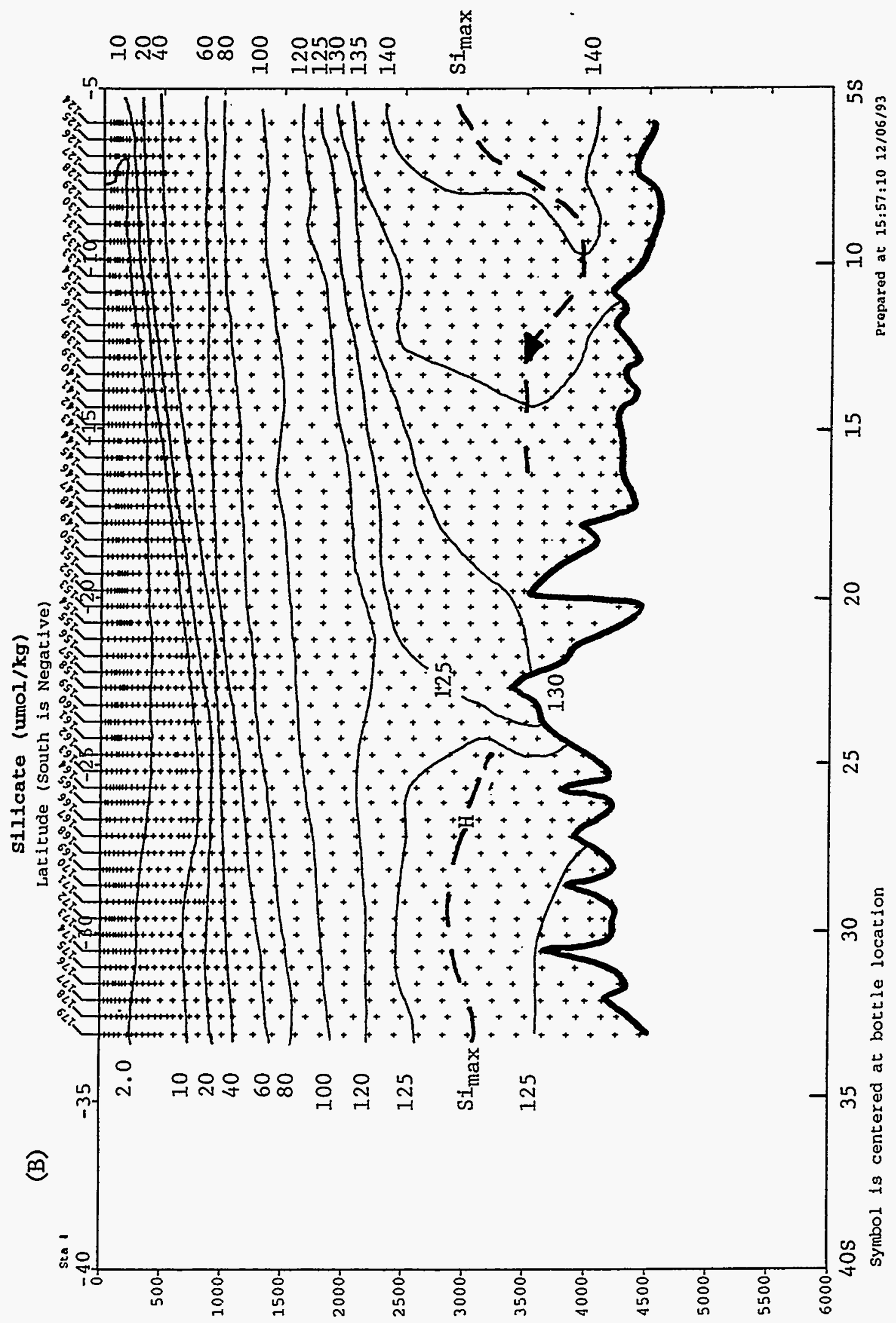

(Ui) पวवृอ 
silicate minimum presumably due to that the section did not extend beyond $37.5^{\circ} \mathrm{S}$. Figs. $28-\mathrm{A}$ and $-\mathrm{B}$ show the distribution along $135^{\circ} \mathrm{W}$. North of about $16^{\circ} \mathrm{S}$, a silicate maximum layer representing the North Pacific water was observed between 3000 and 4000 meters deep. Although this layer could not be clearly defined between $16^{\circ} \mathrm{S}$ and $25^{\circ} \mathrm{S}$, it became clear south of $25^{\circ} \mathrm{S}$, where the meridional trend of the maximum layer was too weak to be identified. The silicate minimum layer observed near the southern end of the $150^{\circ} \mathrm{W}$ section could not be seen in this section since this section was not extended beyond $33.5^{\circ} \mathrm{S}$.

III-c) Distribution of Property Maxima and Minima:

The maxima and minima in the property distributions observed along the WOCE $\mathrm{P}-16 \mathrm{C}\left(150^{\circ} \mathrm{W}\right)$ and $\mathrm{P}-17 \mathrm{C}\left(135^{\circ} \mathrm{W}\right)$ sections (Figs. 7 through 28$)$ are summarized in Figs. 29-A and -B. Two isopycnals of 27.00 sigma- $\theta$ and 36.90 sigma-2 are also indicated in both panels for the references using dashed curves. The sea floor topography is indicated with the heavy curves closest to the bottom of each panel.

In the upper 1000 meters, the following four features were observed along both the $150^{\circ} \mathrm{W}$ and $135^{\circ} \mathrm{W}$ sections; from the shallowest to the deepest, an oxygen minimum trend (Omin) between 200 and 400 meters, an alkalinity minimum trend (Amin) between 500 and 600 meters, an oxygen maximum trend (Omax) at about 600 meters and a salinity minimum trend (Smin) between 700 and 1000 meters. The arrows are drawn to indicate the direction, towards which the intensity of a maximum or minimum tends to be subdued and hence indicate the direction away from the source area for each trend. Accordingly, the shallow oxygen minimum trend propagated southward from tropical areas, whereas the deeper three features were originated in the Southern Ocean and propagated equatorward. The salinity minimum represents the Antarctic Intermediate Water (AAIW) with a sigma- $\theta$ density of about 27.10. In addition to these common features, several additional trends are observed in the $135^{\circ} \mathrm{W}$ section north of $17.5^{\circ} \mathrm{S}$. These are an oxygen minimum trend (Omin) between 400 and 700 meters, and a $\mathrm{pCO}_{2}$ maximum trend $\left(\mathrm{PcO}_{2}\right.$ max), a phosphate maximum trend ( $\mathrm{Pmax}$ ) and a nitrate maximum trend ( $N$ max), all which nearly coincide each other between 500 and 1000 meters. These features propagated southward from tropicall areas, presumably from the eastern tropical Pacific. These features are missing from the $150^{\circ} \mathrm{W}$ section mainly because the section did not extend beyond north of $17.5^{\circ} \mathrm{S}$. 
Fig. 29 - Summary of the property maxima and minima observed along (A) the $150^{\circ} \mathrm{W}$ (P-16C) and (B) $135^{\circ} \mathrm{W}$ (P-17C) sections. The heavy curves indicate the property maxima or minima along water columns. The arrows indicate the direction toward which the intensity of a maximum or minimum is reduced and hence the direction away from the source. The heavy curves without arrows indicate that no increasing or decreasing trend was observed in maximum or minimum values. Filled circles on the heavy curves indicate the maximum position along a maximum curve. The dashed curves indicate isopycnals.

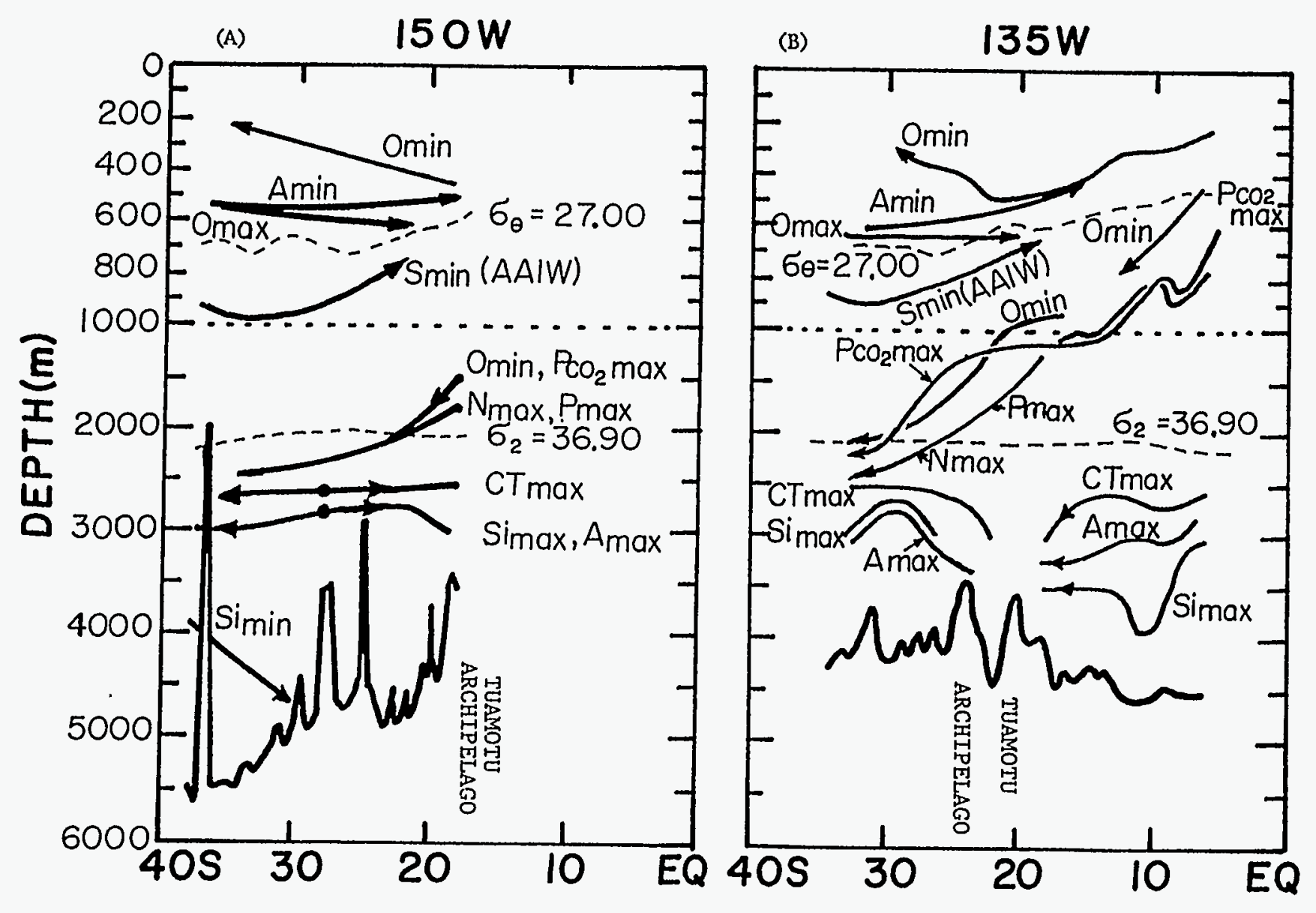


Between 1000 and 2500 meters, the following four features were observed; an oxygen minimum trend (Omin), a $\mathrm{pCO}_{2}$ maximum trend $\left(\mathrm{PCO}_{2} \mathrm{max}\right)$, a phosphate maximum trend (Pmax) and a nitrate maximum trend (Nmax). All these trends appear to propagate southward from the tropical Pacific. Although they appear to coincide in the $150^{\circ} \mathrm{W}$ section while they are separated in the $135^{\circ} \mathrm{W}$ section, it is not certain whether the differences are real or due to the artifacts of sample distributions and imperfections of the measurements.

Below about 2500 meters to the sea floor, the following trends were observed; a total $\mathrm{CO}_{2}$ maximum trend (CTmax) between 2500 and 3000 meters, a total alkalinity maximum trend (Amax) centered around 3000 meters, a silicate maximum trend (Si max) between 3000 and 4000 meters and a silicate minimum trend ( $\mathrm{Si} \mathrm{min)}$ ) below 4000 meters south of about $32^{\circ} \mathrm{S}$ in the $150^{\circ} \mathrm{W}$ section. Since the direction of meridional changes for the maxima in the alkalinity and the concentrations of total $\mathrm{CO}_{2}$ and silicate in the southern half of the $135^{\circ} \mathrm{W}$ section was not obvious, no arrow was attached to these maximum trend lines. The depth profiles observed during the GEOSECS Program in the North Pacific Ocean (Takahashi et al., 1981-a; Takahashi et al., 1981-b) indicate a maximum concentration in total $\mathrm{CO}_{2}$ at depths between 1500 and 2000 meters, and that for the alkalinity and silicate both at depths between 2000 and 3000 meters. This suggests that these maxima observed in the $150^{\circ} \mathrm{W}$ and $135^{\circ} \mathrm{W}$ sections represent deep waters transported southward from the North Pacific Ocean. Along the $150^{\circ} \mathrm{W}$ section, the total $\mathrm{CO}_{2}$, alkalinity and silicate values in the maximum layers decreased away from $28^{\circ} \mathrm{S}$ (shown with the filled dots). This suggests that a tongue of the North Pacific water was flowing across the section and surrounded by the southern waters which had lower values for these properties. Since a well defined tongue was not observed further east along $135^{\circ} \mathrm{W}$, it is deduced that the tongue of the North Pacific water came from the northwest rather than directly from the north. This is because the topographic high of the Tuamotu Archipelago lies from $15^{\circ} \mathrm{S}, 152^{\circ} \mathrm{W}$ to $22^{\circ} \mathrm{S}, 138^{\circ} \mathrm{W}$ and blocks the southward flow of the North Pacific waters along $150^{\circ} \mathrm{W}$, but does not impede it along $135^{\circ} \mathrm{W}$. Along the $135^{\circ} \mathrm{W}$ section, the maximum values in the total $\mathrm{CO}_{2}$, alkalinity and silicate maximum layers decreased southward from $6^{\circ} \mathrm{S}$ to $18^{\circ} \mathrm{S}$, suggesting a more or less southward flow of the North Pacific waters between 2500 and 3500 meters. Thus, north of the Tuamotu Archipelago, strong and clear signals for the North Pacific waters were present. On the other hand, south of the Archipelago, the maximum values for these properties were found to be nearly constant south of $22^{\circ} \mathrm{S}$. This feature may correspond to the more. strongly defined maximum layer 
observed in the $150^{\circ} \mathrm{W}$ section. Based upon the property distributions, regional circulation patterns of the waters between 2500 and 3500 meters have been deduced and compared with the geostrophic flow at $2000 / 3500 \mathrm{db}$ estimated by Reid (1986) in Fig. 30. An eastward flow of the North Pacific waters between $20^{\circ} \mathrm{S}$ and $30^{\circ} \mathrm{S}$ is a dominant feature in this area, and is well reflected in the flow patterns estimated on the basis of the property distributions. Thus, Reid's geostrophic flow patterns are consistent with the distribution of the properties observed during this work.

Below about 4000 meters to the sea floor along $150^{\circ} \mathrm{W}$, the southern waters which are represented by a silicate minimum layer appear to flow northward. These waters were not observed along the $135^{\circ} \mathrm{W}$ section presumably because the section did not extend far enough south beyond $33^{\circ} \mathrm{S}$ and the ocean was no deeper than 4200 meters. As discussed earlier, this silicate minimum represents the effect of NADW which was transported to the South Pacific via the circumpolar currents (Reid, 1986). 
Fig. 30 - Flow patterns of water in a depth range between 3000 and 3500 meters. (A) Those deduced on the basis of the distribution of chemical properties observed during this work. The 3000 meter isobaths are indicated with dashed curves. (B) The 2000/3500 db geostrophic flow estimated by Reid (1986). Our study area shown in (A) is outlined with heavy lines in (B).

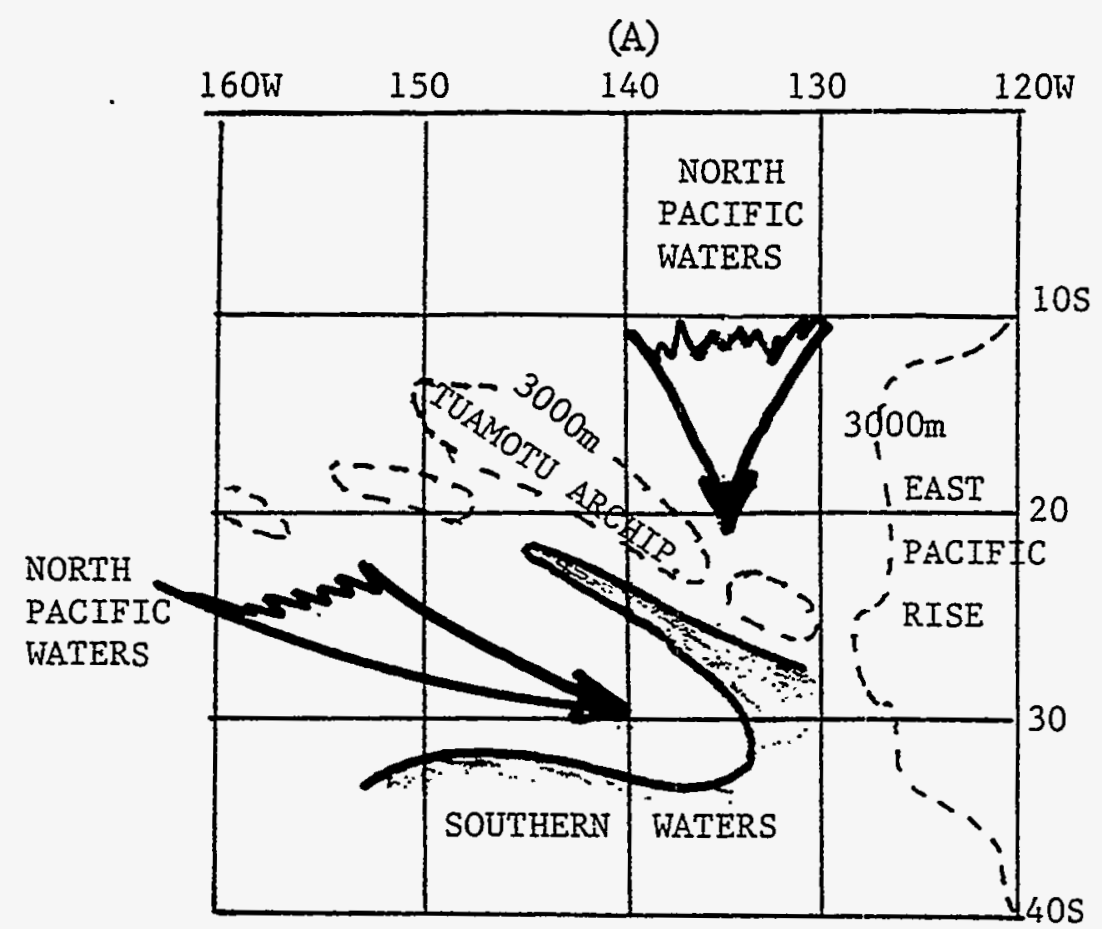

(B)

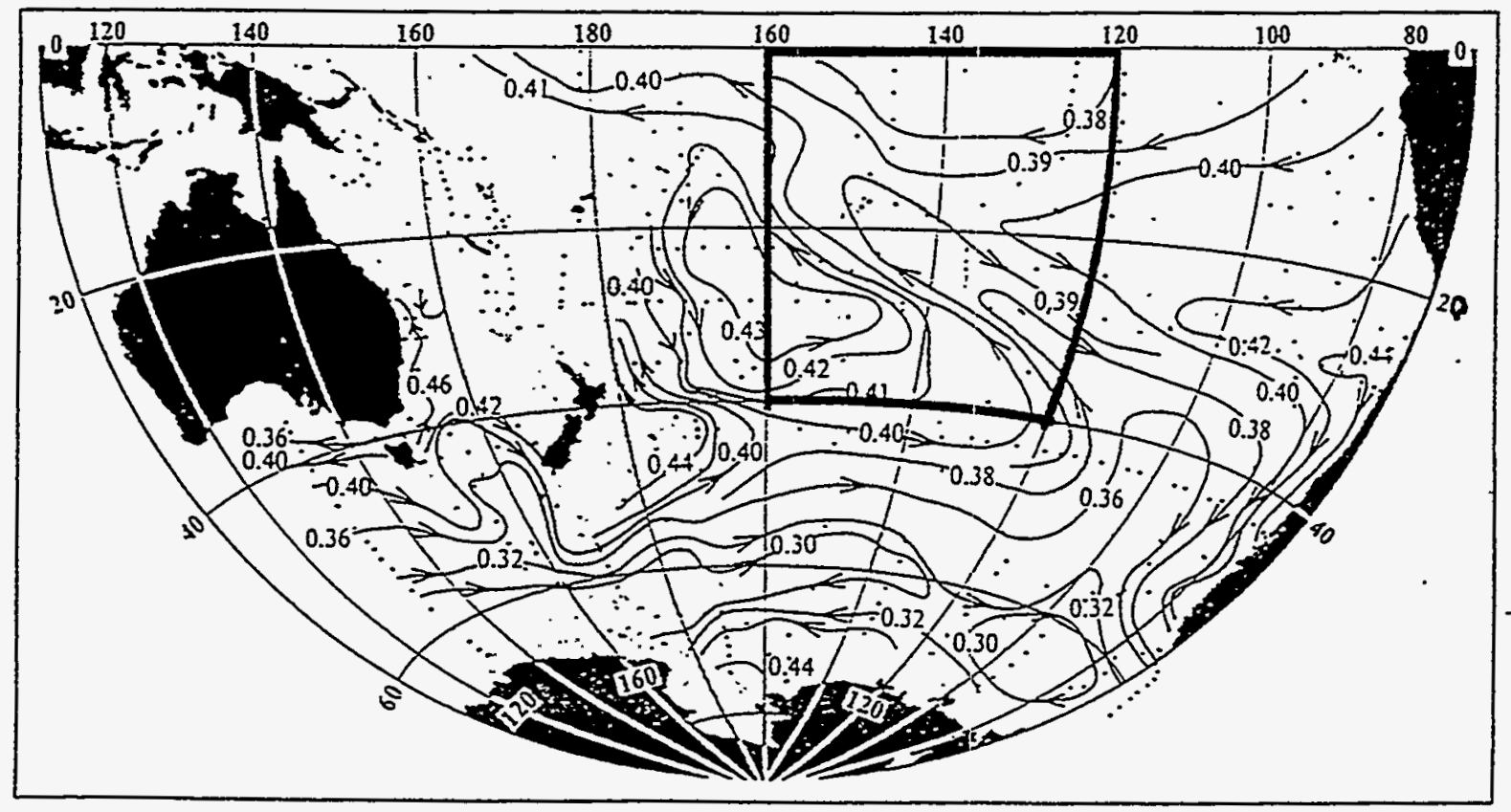




\section{PROPERTY-PROPERTY RELATIONSHIPS}

In Figs. 31 through 39 presented in this section, the data for the upper 100 meters representing surface mixed layer waters are indicated with open circles; those between 100 and 800 meters are indicated with the " $x$ " symbols; and those below 800 meters are indicated with the "+" symbols.

\section{VI-a) $\theta-S$ Relationships:}

Figs. 31-A \& B show the $\theta-S$ relationships observed along $150^{\circ} \mathrm{W}$ (P-16C Section) and $135^{\circ} \mathrm{W}$ (P-17C Section) respectively. The latitudes shown refer only to the surface data indicated with open circles. The meridional distribution of the mixed layer temperature is shown in Fig. 32 and indicates that the temperature decreased almost linearly with latitude from $25^{\circ} \mathrm{C}$ at $19^{\circ} \mathrm{S}$ to $13^{\circ} \mathrm{C}$ at $37.5^{\circ} \mathrm{S}$. The sigma- $\theta$ potential density ranging between 23 and 28 are indicated with the solid curves, and selected water depths are indicated with the dashed curves.

\section{Near Surface Layers:}

Along $150^{\circ} \mathrm{W}$ (Fig. 31-A), the surface mixed layer data (open circles) indicate three meridional regimes. Between $17.5^{\circ} \mathrm{S}$ and $26^{\circ} \mathrm{S}$, the density increased from 23.7 to 24.8 as both the temperature and salinity decreased linearly with increasing latitude. Between $26^{\circ} S$ and $30^{\circ}$ S, the density increased more rapidly from 24.8 to 25.7 due to a small decrease in the salinity from 35.64 to 35.53 PSU accompanied with a linear decrease in temperature with latitude. The small change in salinity may be a result of excess evaporation over the subtropical gyre. Between $32^{\circ} \mathrm{S}$ and $37.5^{\circ} \mathrm{S}$, where the southernmost observation was made along this section, the density was nearly constant and only increased from 25.9 to 26.1 while the temperature decreased from $17^{\circ} \mathrm{C}$ to $13^{\circ} \mathrm{C}$ and the salinity from 35.45 to 34.73 PSU. Since the $135^{\circ} \mathrm{W}$ section sampled waters further north and east, Fig. 31-B shows considerably different features for temperatures above $22^{\circ} \mathrm{C}$ (or locations north of about $26^{\circ} \mathrm{S}$ ). From $6^{\circ} \mathrm{S}$ to $16^{\circ} \mathrm{S}$, the surface water temperature decreased slowly from $28^{\circ} \mathrm{C}$ to $27^{\circ} \mathrm{C}$ (Fig. 32), while the salinity increased rapidly from 35.1 to 36.7 PSU resulting in a rapid southward increase in density of surface waters. This appears to represent a mixing regime for the warm and fresher South Equatorial Current water with the high-salinity subtropical gyre waters. From $16^{\circ} \mathrm{S}$ to 
Fig. 31 - The $\theta-S$ relationships observed $(\mathrm{A})$ along the $150^{\circ} \mathrm{W}(\mathrm{P}-16 \mathrm{C})$ and $(\mathrm{B})$ the $135^{\circ} \mathrm{W}(\mathrm{P}-17 \mathrm{C})$ sections. The open circles, " $\mathrm{x}$ " and " + "symbols indicate respectively the data down to 100 meters, between 100 and 800 meters and below 800 meters. The potential density at surface is indicated with the solid curves.

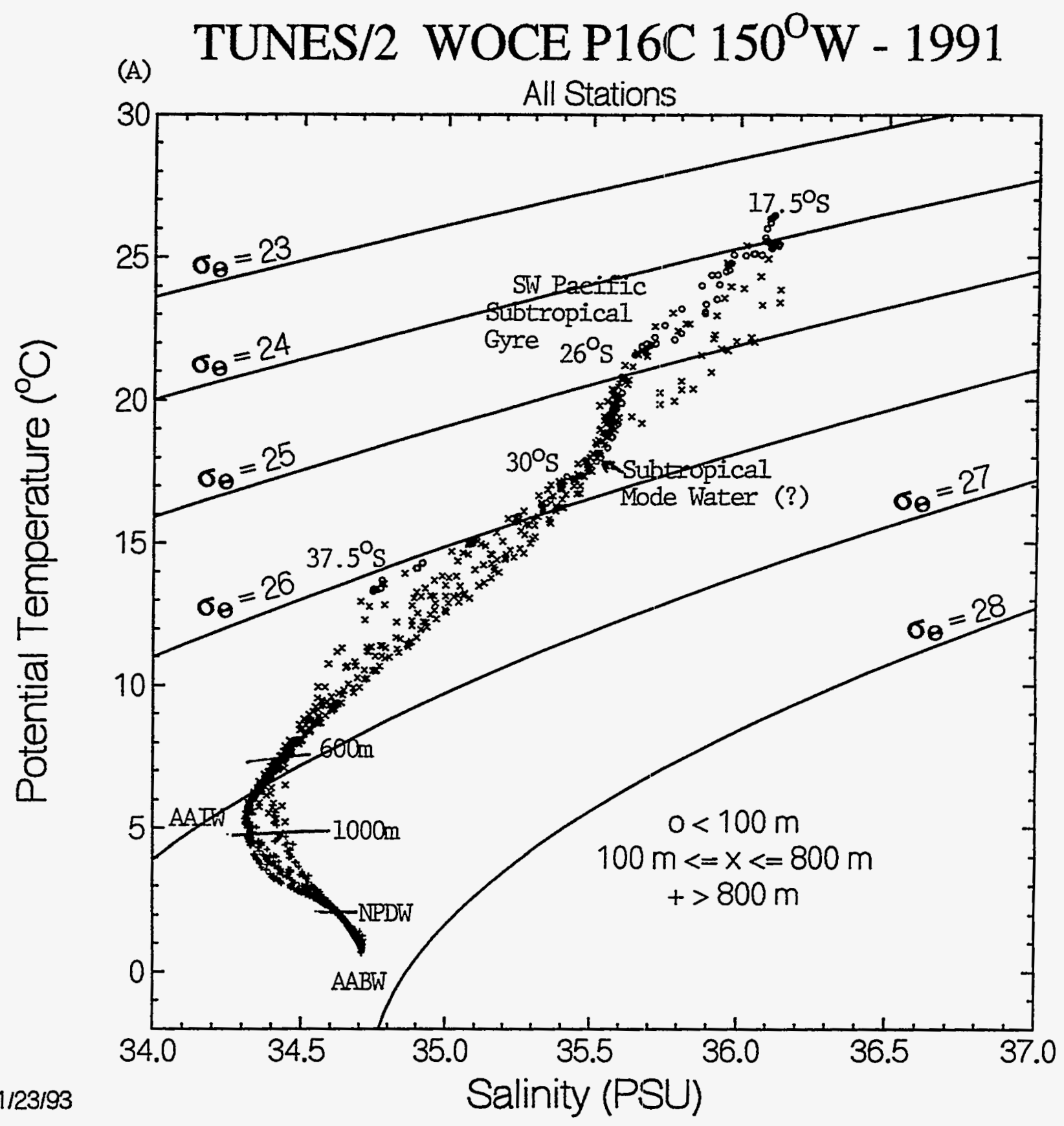




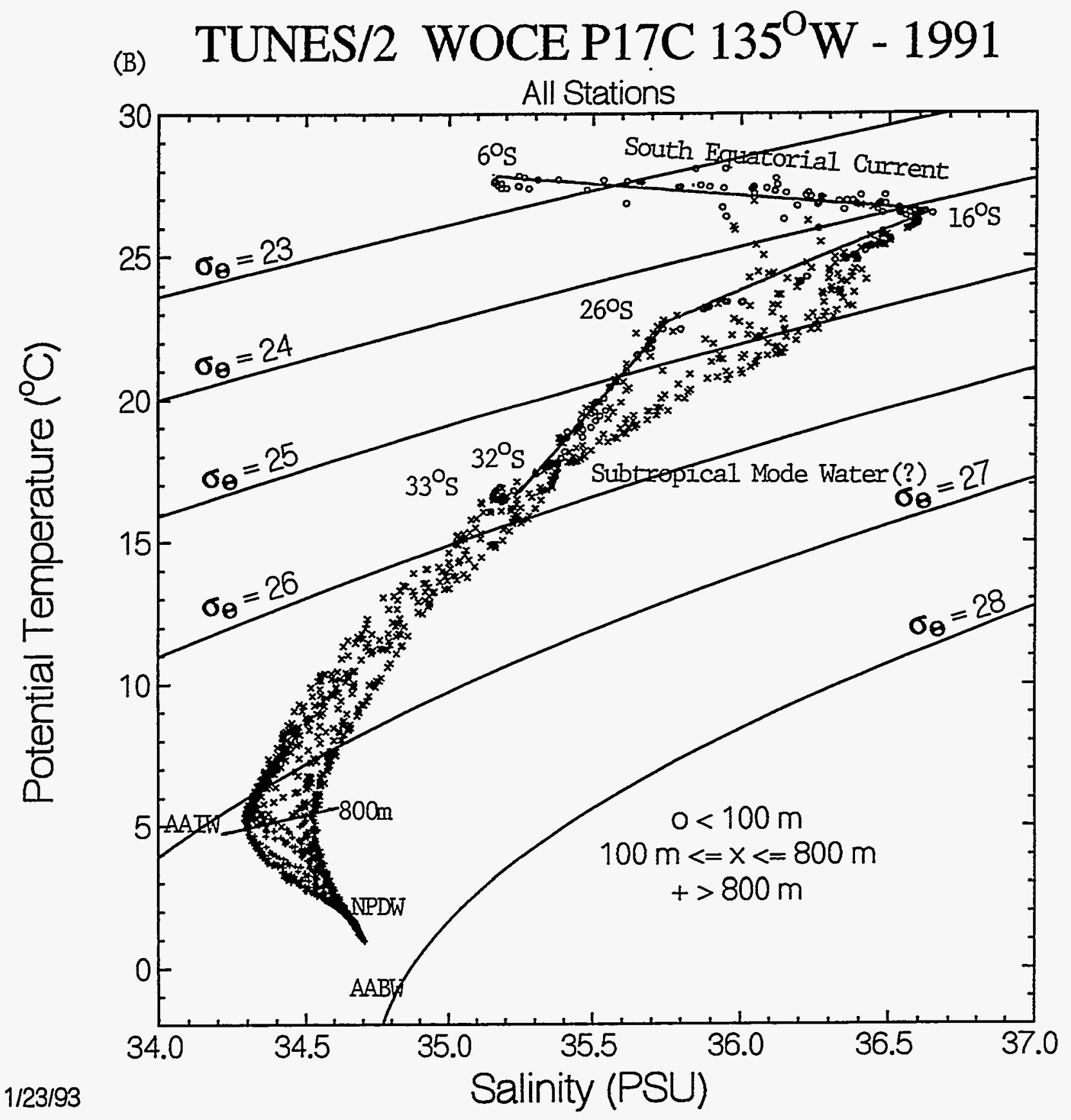


Fig. 32 - The mixed layer temperature as a function of latitude, observed during this study.

\section{TUNES/2 WOCE P16C/P17C - 1991 SURFACE DATA}

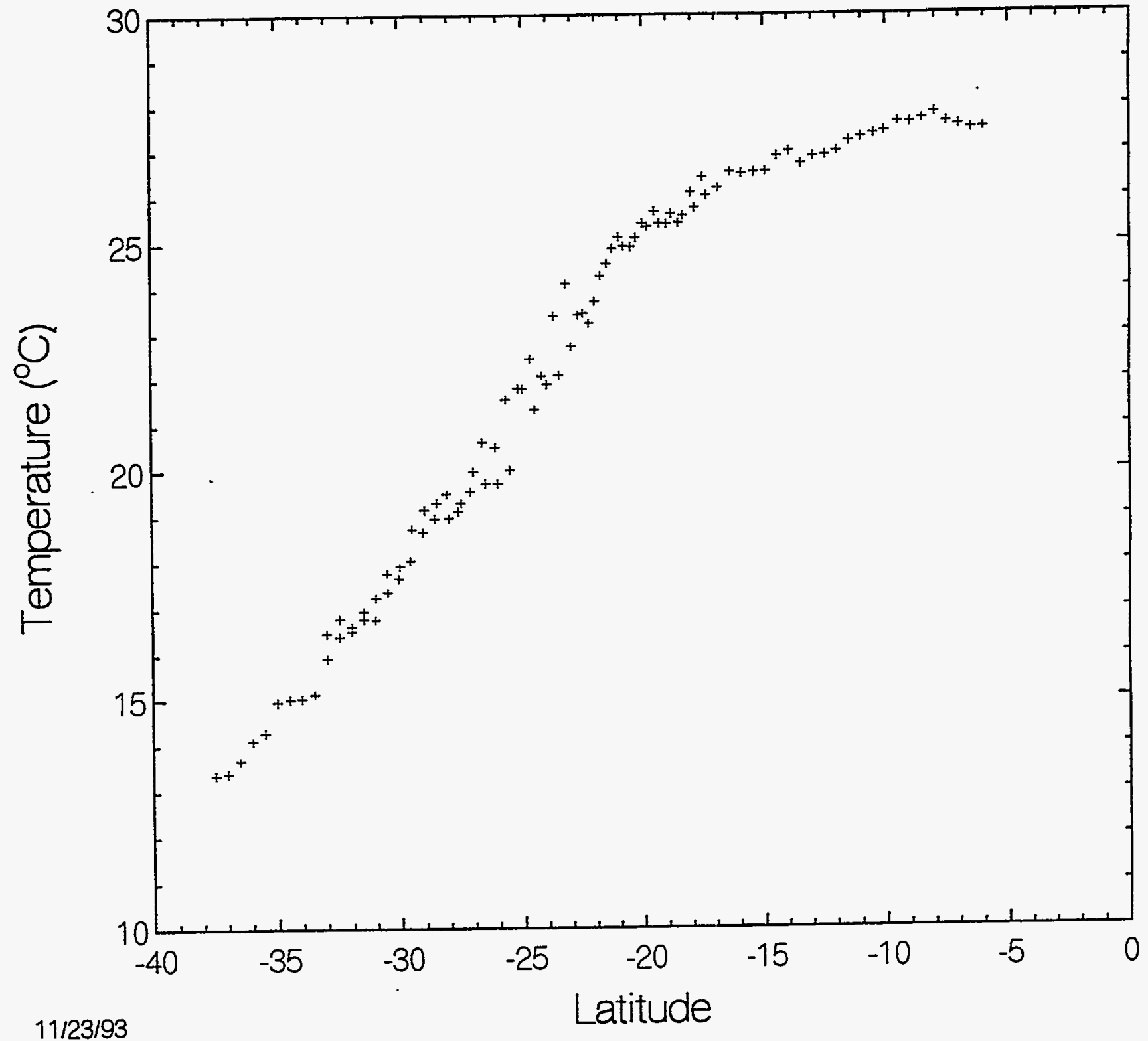


$26^{\circ}$ S, the surface water salinity decreased southward from 36.7 to 35.75 PSU, while its temperature decreased linearly with latitude (Fig. 32). As a result, the density of surface waters increased slightly from about 24.2 to 24.6 . The salinities in this latitudinal range along $135^{\circ} \mathrm{W}$ were much greater than those observed in the same latitudes along $150^{\circ} \mathrm{W}$. This suggests that the high salinity water's centered around $16^{\circ} \mathrm{S}$ were transported from east to west. From $26^{\circ} \mathrm{S}$ to $33^{\circ} \mathrm{S}$ (the southern end of this section), the surface water density increased rapidly from 24.6 to 25.8 due mainly to cooling while the salinity decreased from 35.5 to 35.3 PSU.

\section{Main Thermocline:}

Main thermocline waters below the surface mixed layer down to about 600 meters deep are represented by a broadly linear $\theta-S$ relationship, which corresponds to a water type categorized as the "Eastern South Pacific Central Water" by Sverdrup et al. (1942). Data for both surface and subsurface water appear to converge to $18^{\circ} \mathrm{C}$ and $35.52 \mathrm{PSU}$ along $150^{\circ} \mathrm{W}$ (Fig. 31-A) and to $17.5^{\circ} \mathrm{C}$ and $35.4 \mathrm{PSU}$ along $135^{\circ} \mathrm{W}$ (Fig. 31-B). Above and below these points, the data points tend to diverge. This indicates that, north of $30^{\circ} \mathrm{S}$, waters with this temperature and salinity and hence with a constant density of about 25.8 were present at every station. Figs. 7-A and 9-A show that, along $150^{\circ} \mathrm{W}$, the $17.5^{\circ} \mathrm{C}$ isothermal and 35.5 PSU isohaline curves are located nearly at the same locations (i. e. at the sea surface at about $30^{\circ} \mathrm{S}$ and 300 meters between $17.5^{\circ} \mathrm{S}$ and $25^{\circ} \mathrm{S}$ ). Similar distribution of temperature and salinity was found along $135^{\circ} \mathrm{W}$, although a 35.4 isohaline curve was not shown in Fig. 10-B. Therefore, these convergent points appear to indicate the formation and spreading of a subtropical Mode Water in the central South Pacific Ocean. No distinctive feature in the distribution of $\mathrm{CO}_{2}$, oxygen and nutrients was observed at this temperature and salinity range. The sigma- $\theta$ potential density for this water mass is much smaller than $27.0 \pm 0.1$ observed along the $28^{\circ} \mathrm{S}$ and $43^{\circ} \mathrm{S}$ sections in the South Pacific by McCartney (1982) in his Fig. 7 for the subantarctic Mode Water. Although the Eighteen Degree Water in the North Atlantic, a subtropical Mode Water described by Worthington (1959 and 1972), has a similar temperature as this water, it has a density of about 26.5 , which is also greater than that for the subtropical water described above. 
Intermediate Water Regime:

The salinity minimum water centered at a depth of about 800 meters represents the Antarctic Intermediate Water (AATW). It has a sigma- $\theta$ density of about 27.1 with a temperature of about $5^{\circ} \mathrm{C}$ and a salinity ranging between 34.3 and 34.6. The salinity increases northward along both sections, but no significant difference was observed between the $150^{\circ} \mathrm{W}$ and $135^{\circ} \mathrm{W}$ sections.

\section{Deep and Abyssal Water Regimes:}

Figs. 33-A \& B show detailed views of the $\theta$-S relationships in the deep and abyssal regimes for the $150^{\circ} \mathrm{W}$ and $135^{\circ} \mathrm{W}$ sections respectively. The North Pacific Deep Water is indicated by a minor inflexion point on the $\theta-S$ plots located at about $2.0^{\circ} \mathrm{C}$ and $34.63 \mathrm{PSU}$. The inflexion point may be obscured depending on the temperature and salinity values of the AAIW overlying and mixing with the North Pacific Deep Water, but it is clearly seen in Fig. 33-A. This water mass, which represents a southward return flow from the North Pacific of the Southern Ocean abyssal water flowing northward into the North Pacific basin, dominates the depth range between about 2500 meters and 3500 meters along these sections. Because of its long travel time, this water has accumulated $\mathrm{CO}_{2}$ and silicate especially during its circulation through the North Pacific, and hence is characterized by maximum concentrations of total $\mathrm{CO}_{2}$, silicate and alkalinity as shown in Fig. 29.

Along $150^{\circ} \mathrm{W}$, the Circumpolar Deep Water (CPDW) is seen at a temperature of about $1.3^{\circ} \mathrm{C}$ and a salinity of $34.71 \mathrm{PSU}$. Since the $135^{\circ} \mathrm{W}$ section did not extend beyond $33^{\circ} \mathrm{S}$, it is not clearly seen. As shown in Fig. 27-B, this water has lower silicate concentrations. This is attributed to the mixing of NADW which has higher salinity and low silicate concentrations (Reid, 1986). The densest water observed in the abyssal depths along these sections has a potential temperature of $0.6^{\circ} \mathrm{C}$ and a salinity of $34.71 \mathrm{PSU}$ and represents $\mathrm{AABW}$.

VI-b) Relationship between the $\mathrm{CO}_{2}$ Properties:

Figs. 34- $\mathrm{A} \& \mathrm{~B}$ show the relationships between the natural logarithm of $\mathrm{pCO}_{2}$ at $20^{\circ} \mathrm{C}$ and that of the total $\mathrm{CO}_{2}$ concentration normalized to 35.00 salinity along $150^{\circ} \mathrm{W}$ and $135^{\circ} \mathrm{W}$ respectively. Major water masses and other oceanographic features are indicated by letters. Three iso-alkalinity curves computed using the LDEO algorithm (Peng et al., 1989) are indicated by the solid curves. 
salinity and temperature, the constant Revelle factor trend cannot be due simply to the mixing between surface water and AAIW. An additional study is being made to understand the oceanographic implications of the constant Revelle factor trend.

\section{Intermediate and Deep Waters:}

Below AAIW, the relationships become more complicated because of the presence of a number of different water masses which have different chemical characteristics. Along $135^{\circ} \mathrm{W}$ (Fig. 34-B), the Lower Oxygen Minimum water, which has $\mathrm{pCO}_{2}$ and $\mathrm{TCO}_{2}$ values as high as $1650 \mu \mathrm{atm}$ and $2300 \mu \mathrm{mol} / \mathrm{kg}$ respectively, is observed at $6^{\circ} \mathrm{S}$ in a depth range between 400 and 500 meters, whereas, south of $20^{\circ} \mathrm{S}$, it is found below AATW at depths between 1000 and 2500 meters (Figs. 29-A \& B). The chemical characteristics of the Lower Oxygen-Minimum water found north of the Tuamotu Archipelago $\left(23^{\circ} \mathrm{S}\right.$ along $\left.135^{\circ} \mathrm{W}\right)$ differ in the magnitude in $\mathrm{pCO}_{2}$; in the areas south of the Archipelago, it has a $\mathrm{pCO}_{2}$ value of about $1200 \mu$ atm (Figs. 34-A \& B), whereas in the areas north of it, it has about $1600 \mu$ atm (Fig. 34-B). These waters are marked in Figs. 34-A \& B as "Lower Omin (S)" and "Lower Omin $(N)^{n}$ respectively. This chemical difference suggests different circulation and mixing histories for these waters. The waters located south of the Archipelago were likely to have mixed with a greater proportion of the southern waters.

Between 2500 and 3000 meters, the North Pacific Deep Water (NPDW) is found. This water is characterized by the maximum concentrations in silicate, total $\mathrm{CO}_{2}$ and alkalinity as discussed earlier. Two distinct types of the NPDW are identified in Fig. 34-A \& B; NPDW (S), which is found south of the Tuamotu Archipelago and is represented by a sharp point in the $150^{\circ} \mathrm{W}$ section (Fig. 34-A) at the maximum total $\mathrm{CO}_{2}$ concentration (extreme right); and NPDW (N), which is observed north of the Archipelago and is represented by the maximum total $\mathrm{CO}_{2}$ concentration in the $135^{\circ} \mathrm{W}$ section (Fig. 34-B). These chemical differences represent differences in the circulation, mixing and biogeochemical history of the waters.

Below the NPDW, the observed trend indicates mixing with the AADW. The point marked AABW in each of Figs. 34-A \& B represents a set of values observed at $677^{\circ} \mathrm{S}$ and 139.6 $6^{\circ} \mathrm{W}$ along the WOCE S-4 section: $\theta=0.6^{\circ} \mathrm{C}$, Sal $=34.705 \mathrm{PSU}, \mathrm{TCO}_{2}=2262$ and 2280 $\mu \mathrm{mol} / \mathrm{kg}$ (respectively at the observed salinity and 35.00 salinity), $\mathrm{pCO}_{2}=1127 \mu \mathrm{atm}$ at $20^{\circ} \mathrm{C}$, $\mathrm{SiO}_{3}=127.1 \mu \mathrm{mol} / \mathrm{kg}$. 
Fig. 33 - The $\theta-S$ relationships between 0.0 and $4.0^{\circ} \mathrm{C}$ observed (A) along the $150^{\circ} \mathrm{W}$ (P-16C) and (B) $135^{\circ} \mathrm{W}$ (P-17C) sections. The North Pacific Deep Water, Circumpolar Deep Water and Antarctic Bottom Water are indicated.

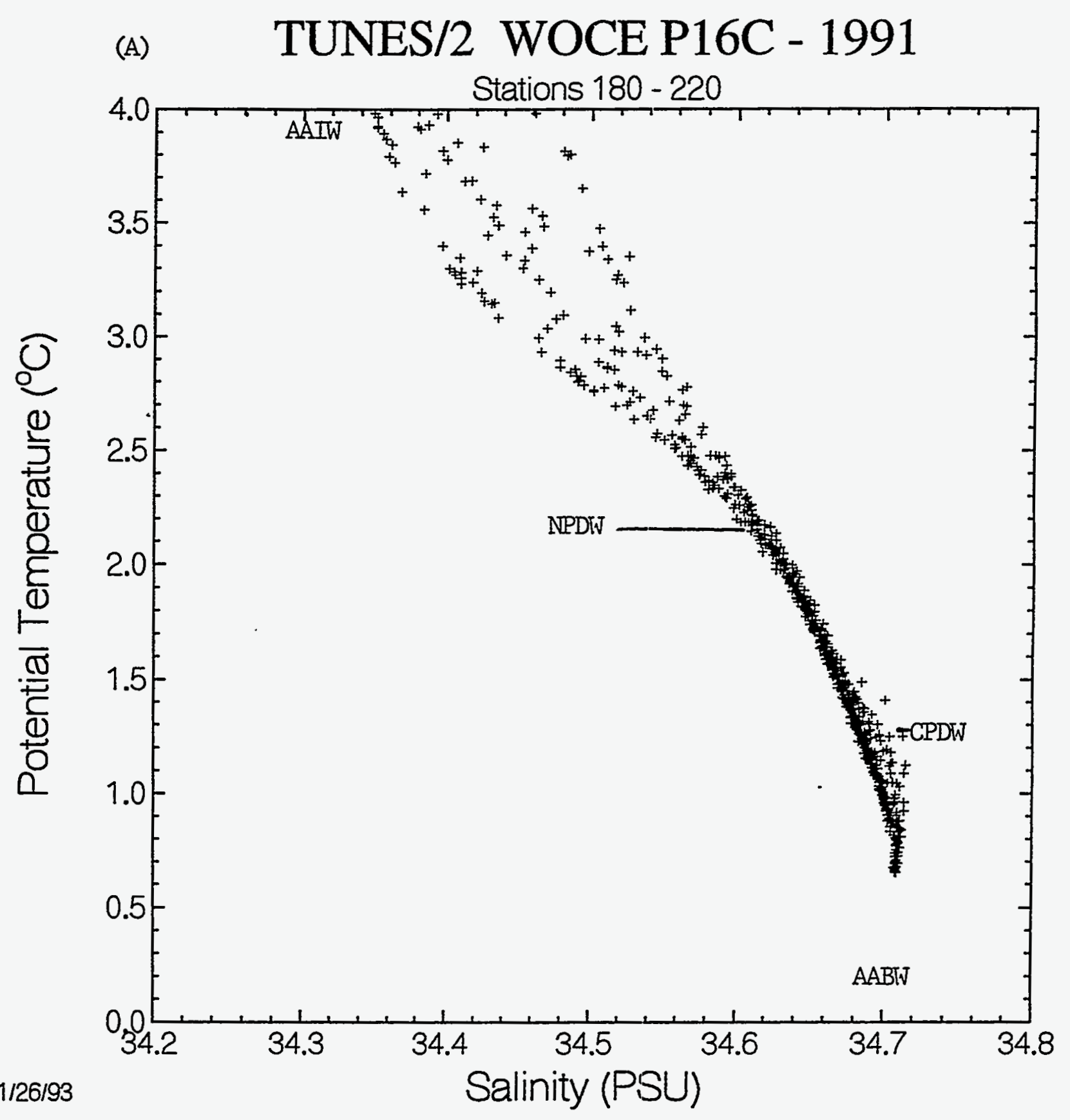


(B) TUNES/2 WOCE P17C - 1991

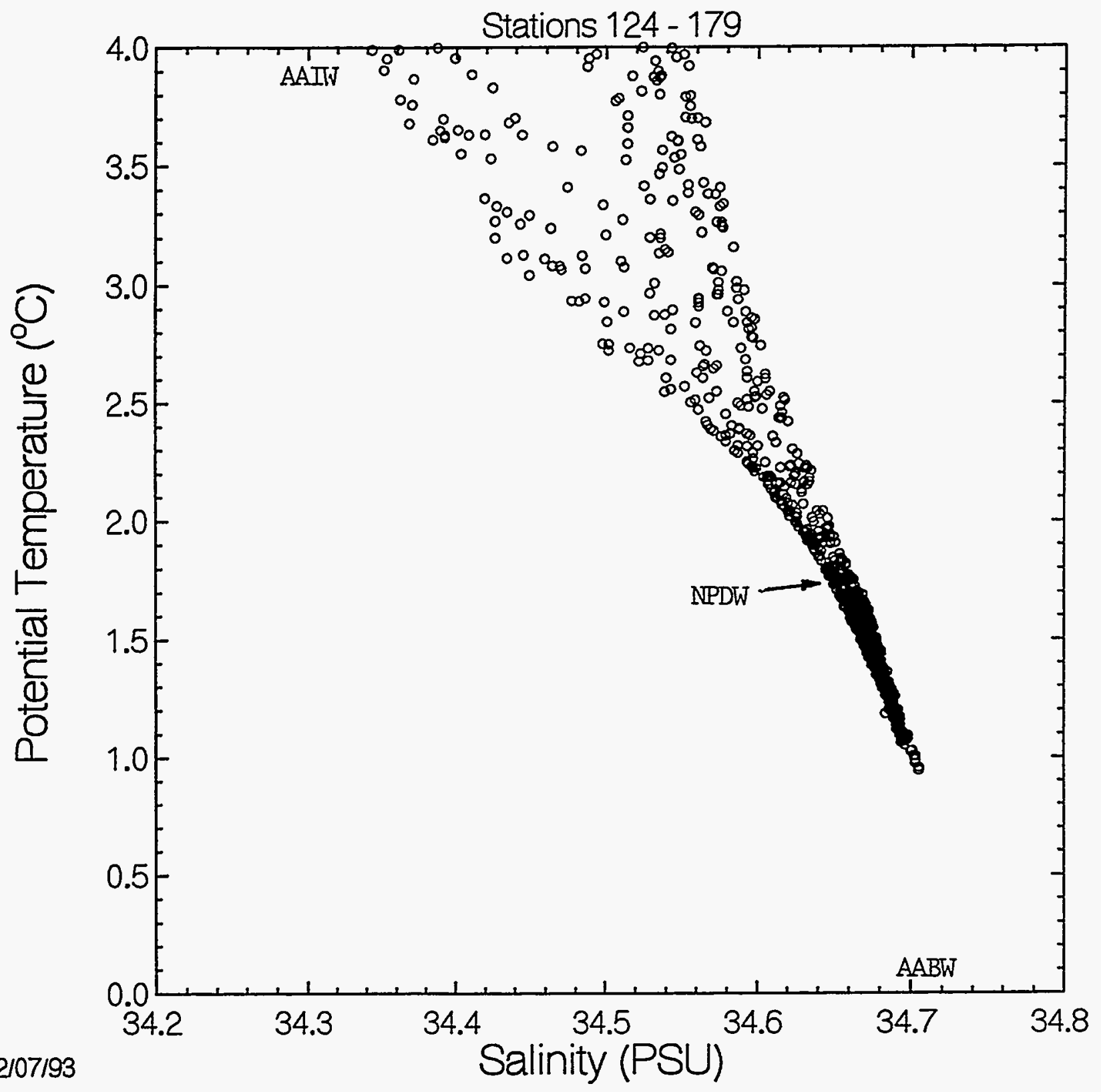


Fig. 34 - The relationships between the natural logarithm of $\mathrm{pCO}_{2}$ at $20^{\circ} \mathrm{C}$ and that of the total $\mathrm{CO}_{2}$ concentration in seawater normalized to a salinity of $35 \mathrm{PSU}$, observed along the $150^{\circ} \mathrm{W}(\mathrm{P}-16 \mathrm{C})$ and $(\mathrm{B}) 135^{\circ} \mathrm{W}(\mathrm{P}-17 \mathrm{C})$ sections. The three solid curves indicate respectively iso-alkalinity lines for 2300,2400 and $2500 \mu \mathrm{eq} / \mathrm{kg}$. The dashed line indicates a constant Revelle factor of 10.0 .

(A)

TUNES/2 WOCE P16C - 1991

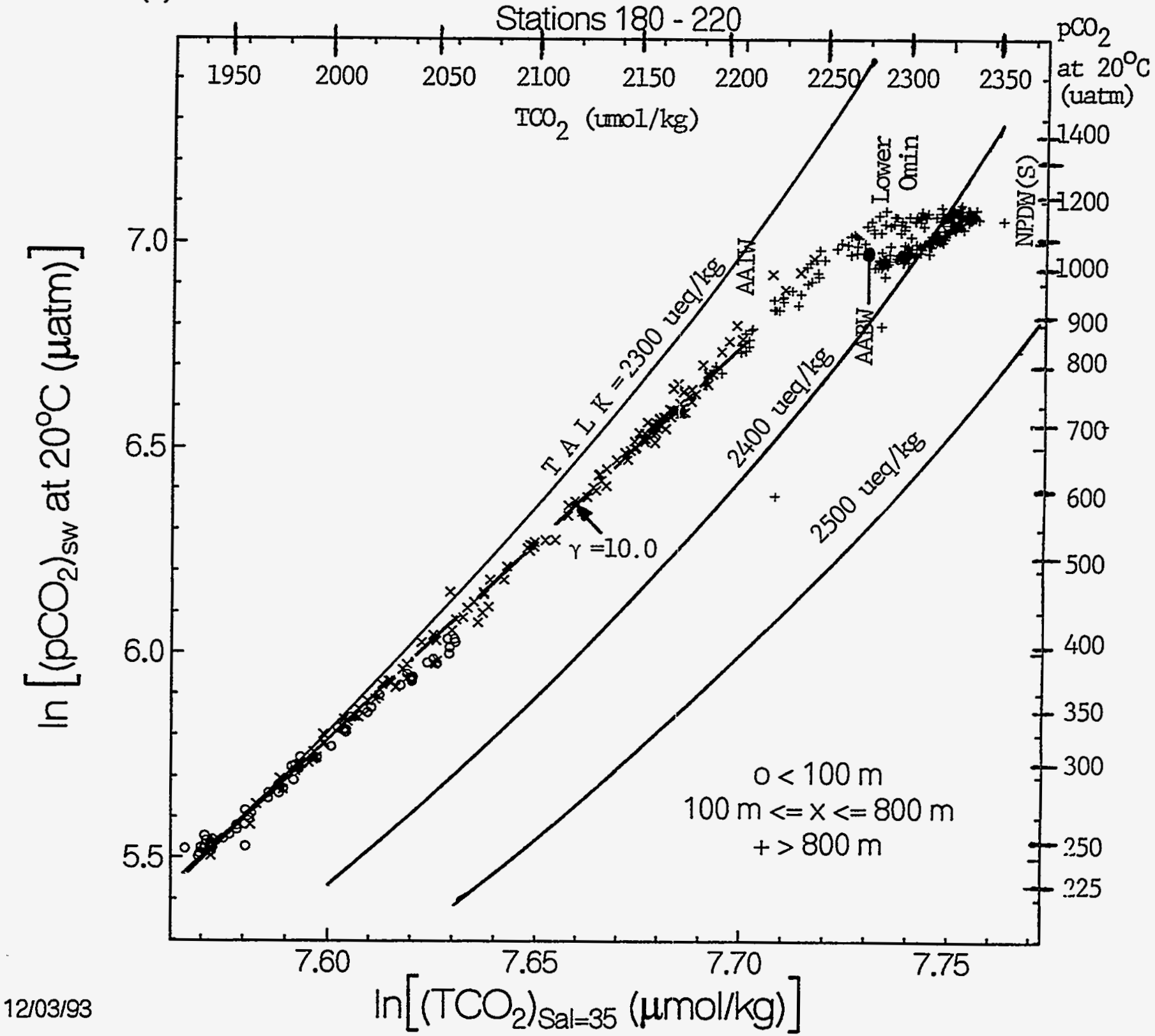




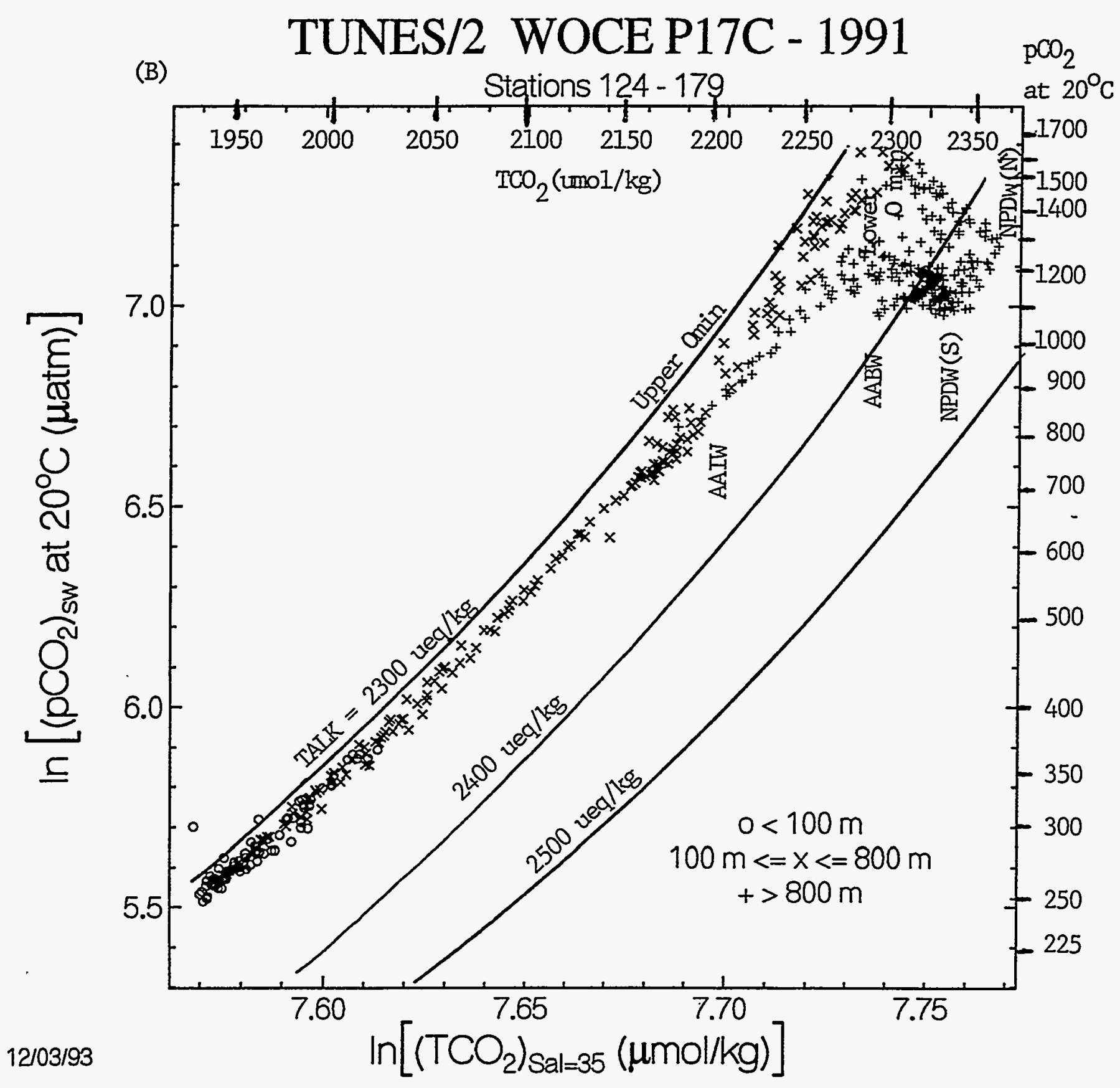


Upper Layer and Main Thermocline Waters:

A linear relationship with a slope of 10.0 is found for the data from the upper 800 meters south of about $20^{\circ} \mathrm{S}$ in both sections. The linear trend observed in surface waters (defined by the open circles) is indistinguishable from that observed in subsurface waters (defined by the " $x$ " symbols). However, north of $20^{\circ} \mathrm{S}$, the Upper Oxygen-Minimum/ AOU-Maximum water ( 300 - 500 meters) and the Lower Oxygen-Minimum/AOU-Maximum water (400 meters and deeper) (see Figs. 20-A \& B and 22-A \& B) which have very high $\mathrm{pCO}_{2}$ values between 800 and 1650 ratm (see a group of " $x$ " symbols located in the uppermost sector) fall above the Revelle factor 10 trend. These waters appear to have originated in the eastern tropical Pacific and have been subjected to different biogeochemical processes than those in the waters from the Southern Ocean. These differences may be manifested in the different slopes.

Since the Revelle factor is defined as $\left(\delta \operatorname{lnp} \mathrm{CO}_{2} / \delta \ln \mathrm{TCO}_{2}\right)$, the linear trend observed south of $20^{\circ} \mathrm{S}$ corresponds to a constant Revelle factor of 10 from the surface mixed layer down to the AAIW. Since the $\mathrm{pCO}_{2}$ values represent those at a constant temperature of $20^{\circ} \mathrm{C}$ and the total $\mathrm{CO}_{2}$ concentration at a constant salinity of $35 \mathrm{PSU}$, a constant Revelle factor of 10 defines a specific relationship between the total alkalinity and total $\mathrm{CO}_{2}$ concentration. The relationship computed using the thermodynamic relationships in carbonate chemistry (Peng. et al, 1987) is presented in Fig. 35. It shows that, in the surface water regime where the salinity normalized total $\mathrm{CO}_{2}$ concentration values range between 1950 and $2050 \mu \mathrm{mol} / \mathrm{kg}$, the total alkalinity is nearly constant. In the deeper waters where the total $\mathrm{CO}_{2}$ concentration range between 2100 and $2200 \mu \mathrm{mol} / \mathrm{kg}$, the curve has a $\Delta \mathrm{TALK} / \Delta \mathrm{TCO}_{2}$ slope of $26 / 100 \mu \mathrm{eq} / \mu \mathrm{mol}$. As illustrated in Fig. 35, this slope corresponds to a 1 to 8 ratio (or $11 \%$ to $89 \%$ ) for the calcium carbonate dissolution to the respiratory production of $\mathrm{CO}_{2}$ by the oxidation of organic carbon. This implies that calcium carbonate is dissolved in the upper 800 meters. Since seawaters are supersaturated with respect to calcite in the upper oceans down to 2000 meters in the South Pacific (Broecker and Takahashi, 1978), the increase in alkalinity cannot be attributed to the dissolution of sinking biogenic calcite, but may be due to the dissolution of sinking biogenic aragonite. Alternatively; the increase in the alkalinity and total $\mathrm{CO}_{2}$ may be attributed to the northward spreading of polar waters high in these quantities. On the other hand, since neither the total $\mathrm{CO}_{2}$ concentration nor the alkalinity are linearly related to 
Fig. 35 - The relationship between the total alkalinity and total $\mathrm{CO}_{2}$ concentration for a constant Revelle factor of 10 at $20^{\circ} \mathrm{C}$ and 35 PSU. The arrows indicate respectively (clockwise from the near vertical one) the effect of the dissolution of $\mathrm{CaCO}_{3}$, the mean trend in the study area and the effect of respiration (i. e. the oxidation of organic carbon).

\section{CONSTANT REVELLE FACTOR AT 10.0}

$$
T=20.00 \mathrm{C} \quad \mathrm{Sal}=35.00
$$

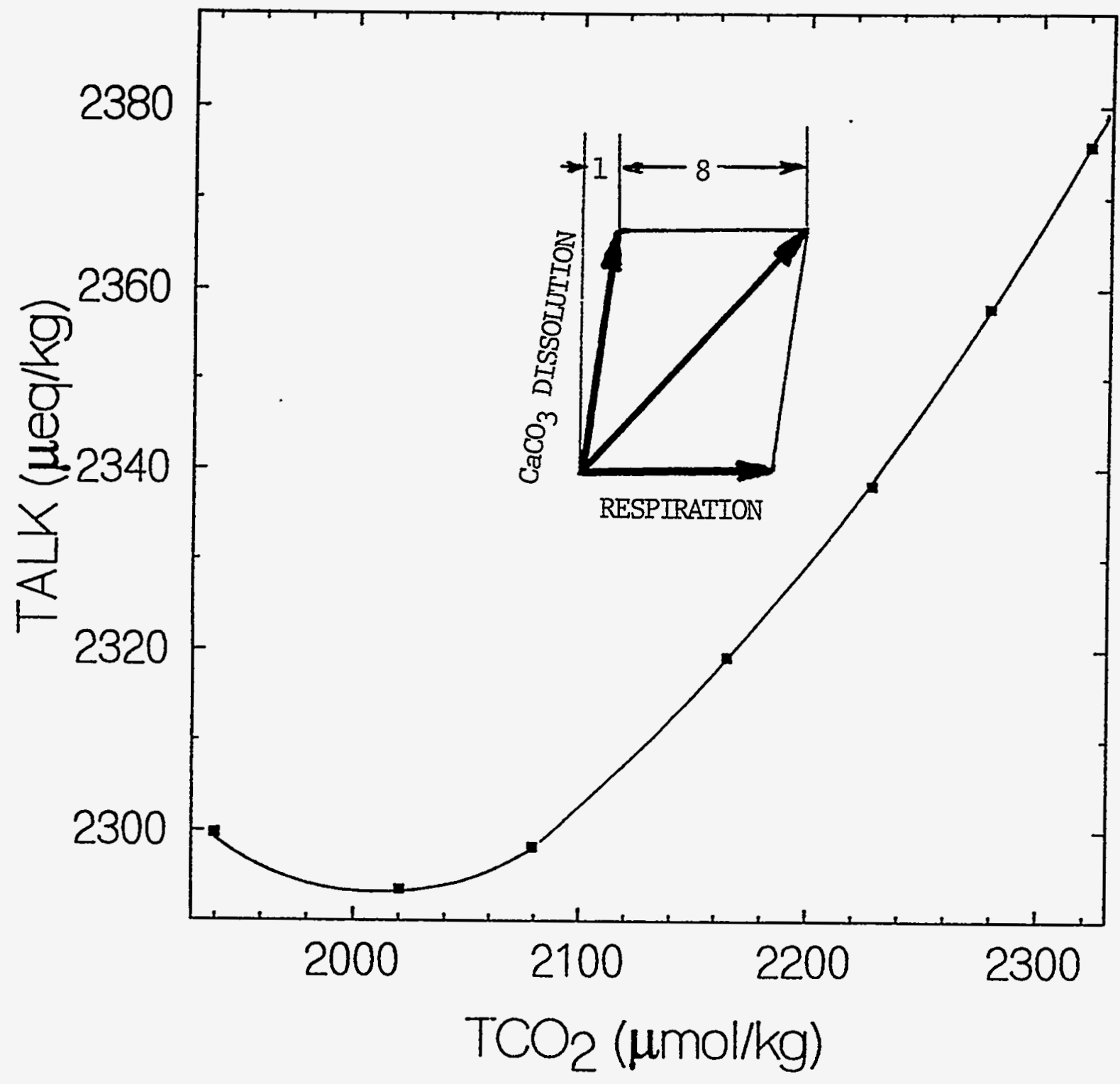


VI-c) $\mathrm{CO}_{2}$-Oxygen Relationships:

Figs. 36-A \& B show the relationships between the concentrations of total $\mathrm{CO}_{2}$ and oxygen dissolved in seawater observed along the $150^{\circ} \mathrm{W}(\mathrm{P}-16 \mathrm{C})$ and $135^{\circ} \mathrm{W}(\mathrm{P}-17 \mathrm{C})$ sections respectively. A vector representing the Redfield $-\mathrm{O}_{2} / \mathrm{C}$ respiration ratio of $175 / 106$ observed in thermocline waters (Takahashi et al., 1985) is indicated by an arrow. A point representing AABW observed in the southernmost Drake Passage area (Chipman et al., 1992) is indicated in each diagram.

The surface waters of the subtropical gyre (see the open circles for the data between $16^{\circ} \mathrm{S}$ and $37.5^{\circ} \mathrm{S}$ ) are closely saturated with atmospheric oxygen, whereas those north of $16^{\circ} \mathrm{S}$ (see Fig. 36-B), which represent the South Equatorial Current, are supersaturated due to the photosynthetic production of oxygen in the nutrient rich water. The variation of $\mathrm{CO}_{2}$ and oxygen in the subsurface waters is strongly affected by the water masses and the respiration which occurred in the water column. The chemical characteristics for AAIW, Lower Oxygen-Minimum Water, North Pacific Deep Waters and AABW are clearly identifiable and indicated in these plots. Points for waters originated in the Southern Oceans are located on the right hand side of the plots, whereas those for tropical and North Pacific tend to be located on the left side of the plots. A linear trend is observed along a depth of 800 meter and another between the North Pacific Waters and AABW. Although these trends are parallel to the respiration vector, they could also indicate a mixing line between two water masses. Therefore, without further analysis of the associated data, these trends cannot be simply attributed to respiration.

VI-d) Relationships between Alkalinity and Silicate:

Fig. 37-A \& B indicate the relationships between the potential alkalinity and silicate. The potential alkalinity (total alkalinity + nitrate) is used to include the contribution of nitrate to the total alkalinity (Brewer and Goldman, 1976). A simple linear relationship is observed between the AAIW located at about 800 meters and the North Pacific Deep Water (located between 2500 and 3500 meters) over a very wide range of silicate values ranging between 15 and $140 \mu \mathrm{mol} / \mathrm{kg}$. This linear relationship suggests (1) that both the alkalinity and silicate concentrations are governed by mixing between the two water masses, and (2) that the dissolution rates of calcium carbonate and silicic tests of organisms are similar. However, as 
shown in Figs. 38-A \& B, the potential alkalinity changes linearly with salinity between AAIW and NPDW, indicating that changes in the alkalinity is due mainly to mixing between two water masses. This supports the first of the above explanations.

$A A B W$ is represented by a point located significantly below the linear trend, and waters below about 3500 meters are represented by a downward hook seen at the extreme right. The observed trend appears to represent mixing between the North Pacific Deep Water located south of the Tuamotu Archipelago and the AABW. The solid circle in each figure indicates the $\mathrm{AABW}$ values $\left(\theta=0.6^{\circ} \mathrm{C}\right.$, Salinity $=34.705 \mathrm{PSU}$, total alkalinity $=2368 \mathrm{ueq} / \mathrm{kg}$, nitrate $=31.7 \mu \mathrm{mol} / \mathrm{kg}$, potential alkalinity at 35.00 salinity $=2420 \mu \mathrm{eq} / \mathrm{kg}$, and silicate $=$ $127.1 \mu \mathrm{mol} / \mathrm{kg}$ ) observed along the WOCE S-4 section at $67^{\circ} \mathrm{S}$ and $139.6^{\circ} \mathrm{W}$.

VI-e) Relationships between Phosphate and Nitrate:

The phosphate-nitrate relationships observed along the $150^{\circ} \mathrm{W}$ and $135^{\circ} \mathrm{W}$ sections provide insight into the biogeochemical processes occurring in the oceans.

Four approximately linear segments are observed in the phosphate and nitrate plots (Figs. 39-A \& B): 1) the surface water segment where nitrate is nearly zero, 2) the main thermocline segment (nitrate concentrations up to $25 \mu \mathrm{mol} / \mathrm{kg}$ ), where the $\mathrm{N} / \mathrm{P}$ ratio is 16.6 and is consistent with the classic Redfield value, 3 ) the deep water regime (nitrate concentrations between 25 and $35 \mu \mathrm{mol} / \mathrm{kg}$ ) where the $N / P$ ratio is about 13.5 , and 4 ) the North Pacific Deep Water and Lower Oxygen-Minimum water regimes (nitrate concentrations above $35 \mu \mathrm{mol} / \mathrm{kg}$ ), where the $\mathrm{N} / \mathrm{P}$ ratio is about 12.3. In addition, a number of data points are located significantly below these trend lines, especially in the $135^{\circ} \mathrm{W}$ section (Fig. 39-B). Since the deviations far exceed the precision of measurements, they are significant. Those data points which fall below the trend lines are from the Lower Oxygen-Minimum Water of tropical origin and having oxygen values smaller than $160 \mu \mathrm{mol} / \mathrm{kg}$. Since the magnitude of the deviation and the number of deviating data points increase significantly from west $\left(150^{\circ} \mathrm{W}\right)$ to east $\left(135^{\circ} \mathrm{W}\right)$, it is concluded that the Lower Oxygen-Minimum Water originated in the eastern tropical Pacific. The observed deviations are due most likely to denitrification processes which occurred in the low oxygen waters of the eastern tropical Pacific. Similar deviations of nitrate from the Redfield N/P ratio have been observed in the low oxygen waters of the Persian Gulf in the Indian Ocean (Takahashi et al, 1985). The observed differences in the slopes of the trend lines may be due to differences in the preformed concentrations of 
Fig. 36 - The relationships between the total $\mathrm{CO}_{2}$ concentration and oxygen in seawater observed along (A) the $150^{\circ} \mathrm{W}(\mathrm{P}-16 \mathrm{C})$ and $(\mathrm{B}) 135^{\circ} \mathrm{W}(\mathrm{P}-17 \mathrm{C})$ sections. The arrow indicates the Redfield ratio for the respiration of $-\mathrm{O}_{2} / \mathrm{CO}_{2}=175 / 106$.

(A)

TUNES/2 WOCE P16C - 1991

Stations $180-220$

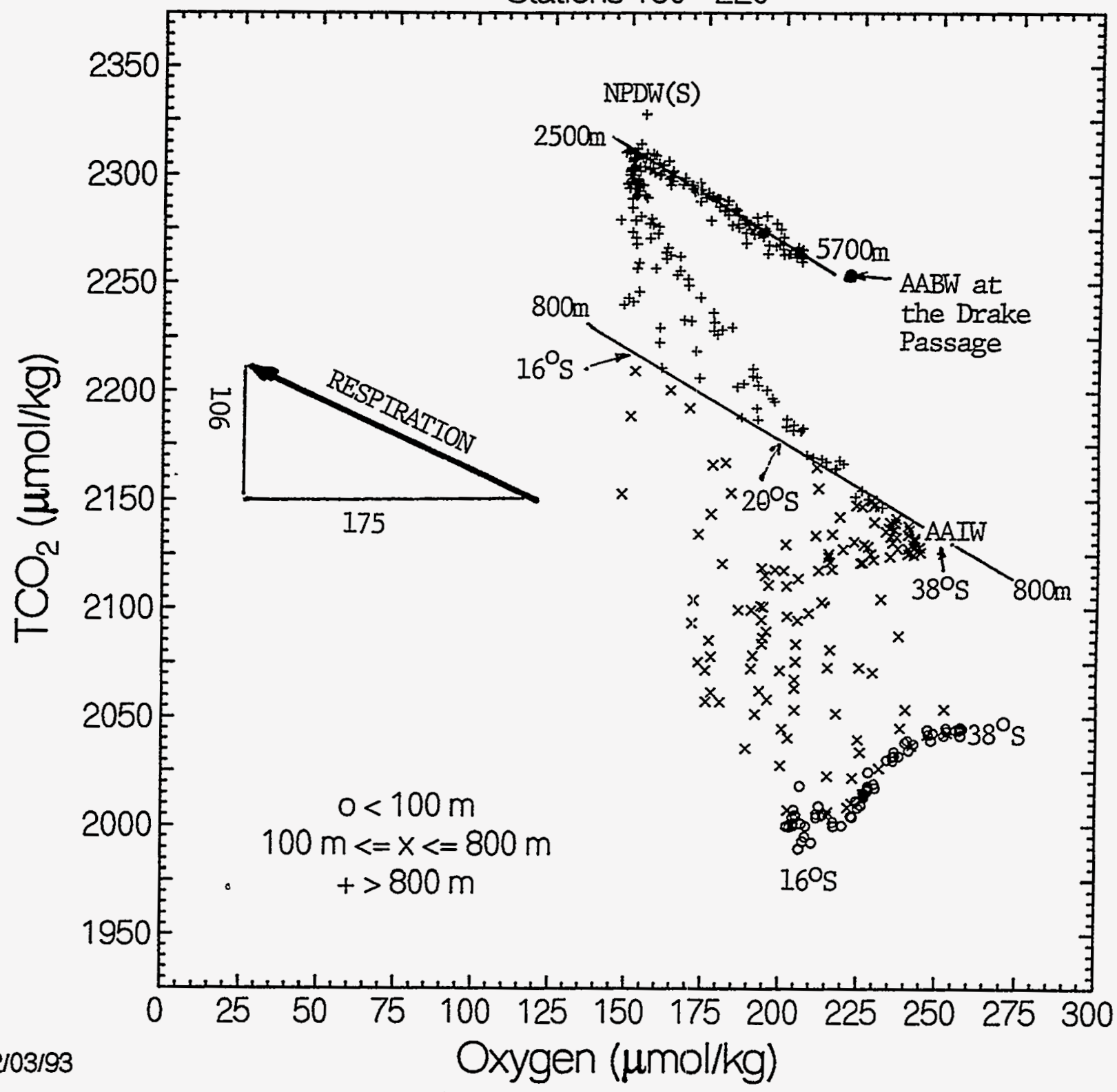


(B)

\section{TUNES/2 WOCE P17C - 1991}

Stations 124 - 179

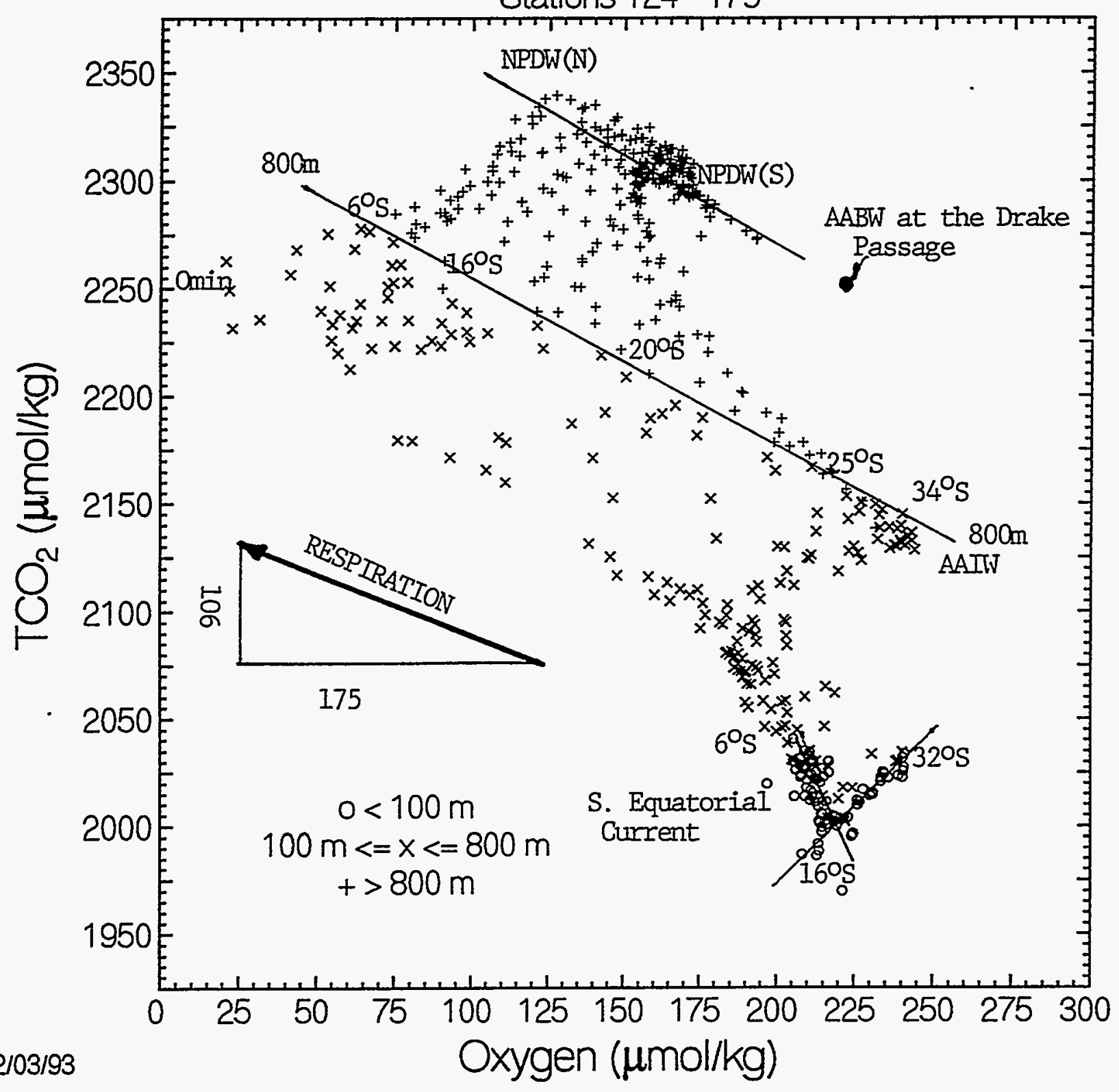


Fig. 37 - The relationships between the potential alkalinity (= (total alkalinity) + (nitrate)) and dissolved silicate in seawater along (A) the $150^{\circ} \mathrm{W}(\mathrm{P}-16 \mathrm{C})$ and $(\mathrm{B}) 135^{\circ} \mathrm{W}$ (P-17C) sections. The observations made at $67^{\circ} \mathrm{S}$ and $140^{\circ} \mathrm{W}$ for the $\mathrm{AABW}$ with a potential temperature of $0.6^{\circ} \mathrm{C}$ are indicated with the solid circles.

(A)

TUNES/2 WOCE P16C - 1991

Stations $180-220$

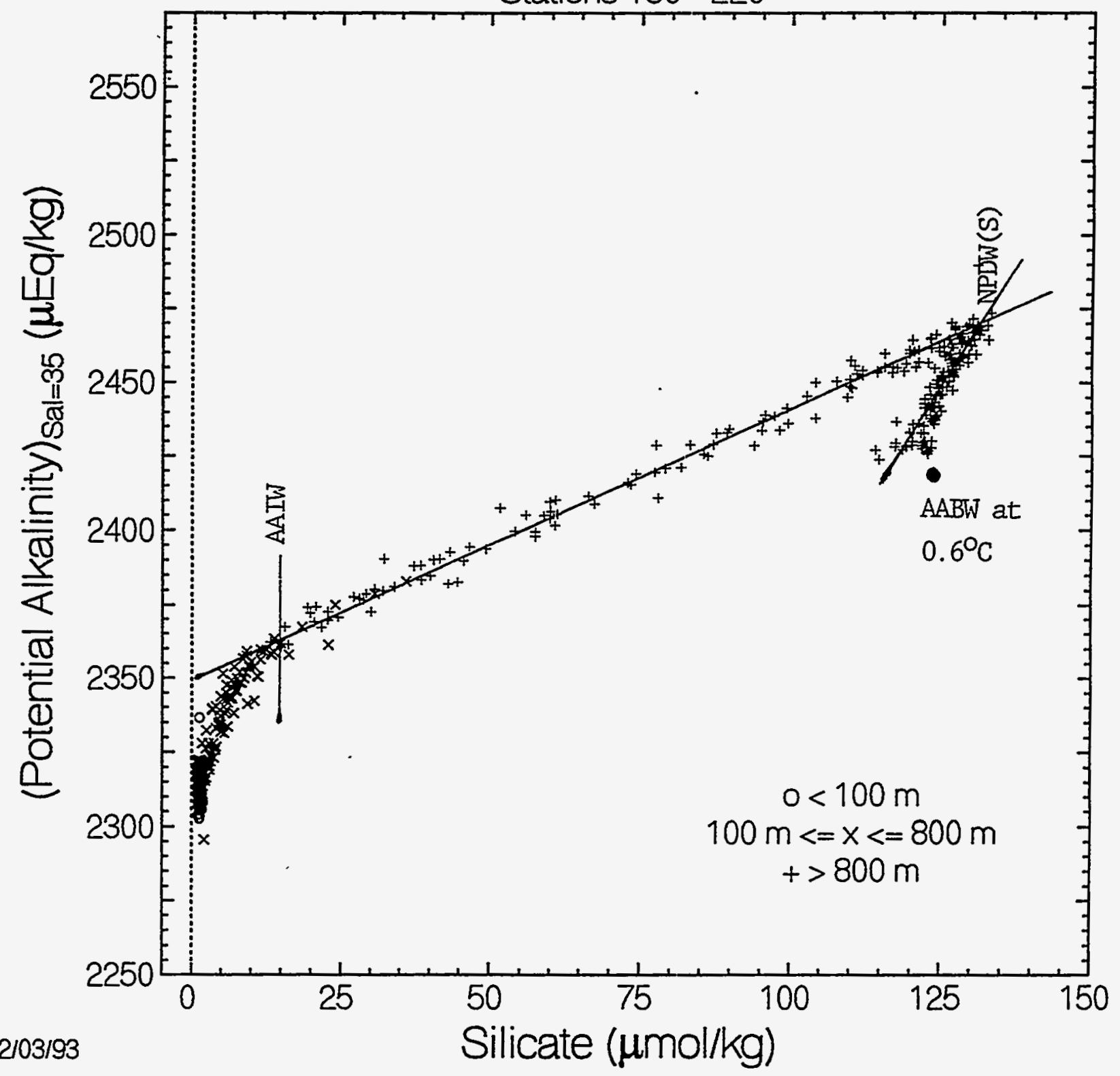




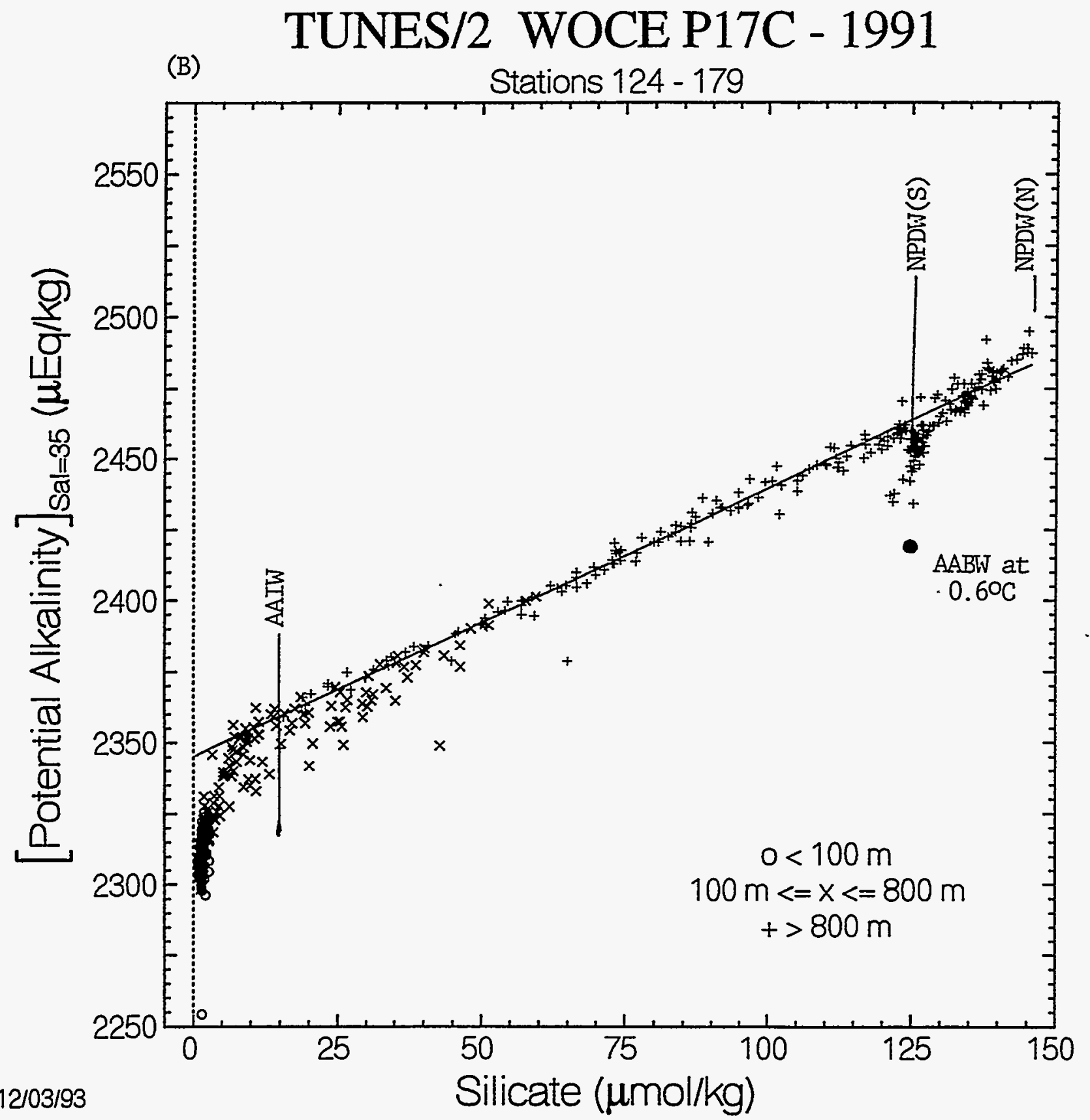


Fig. 38 - The relationships between the potential alkalinity and salinity observed along (A) the $150^{\circ} \mathrm{W}(\mathrm{P}-16 \mathrm{C})$ and (B) $135^{\circ} \mathrm{W}$ (P-17C) sections. In the $135^{\circ} \mathrm{W}$ section, the North Pacific Deep Water located north of the Tuamotu Archipelago, which has been named NPDW(N), is clearly distinguished from that located south of the Archipelago, NPDW(S).

(A)

\section{TUNES/2 WOCE P16C - 1991}

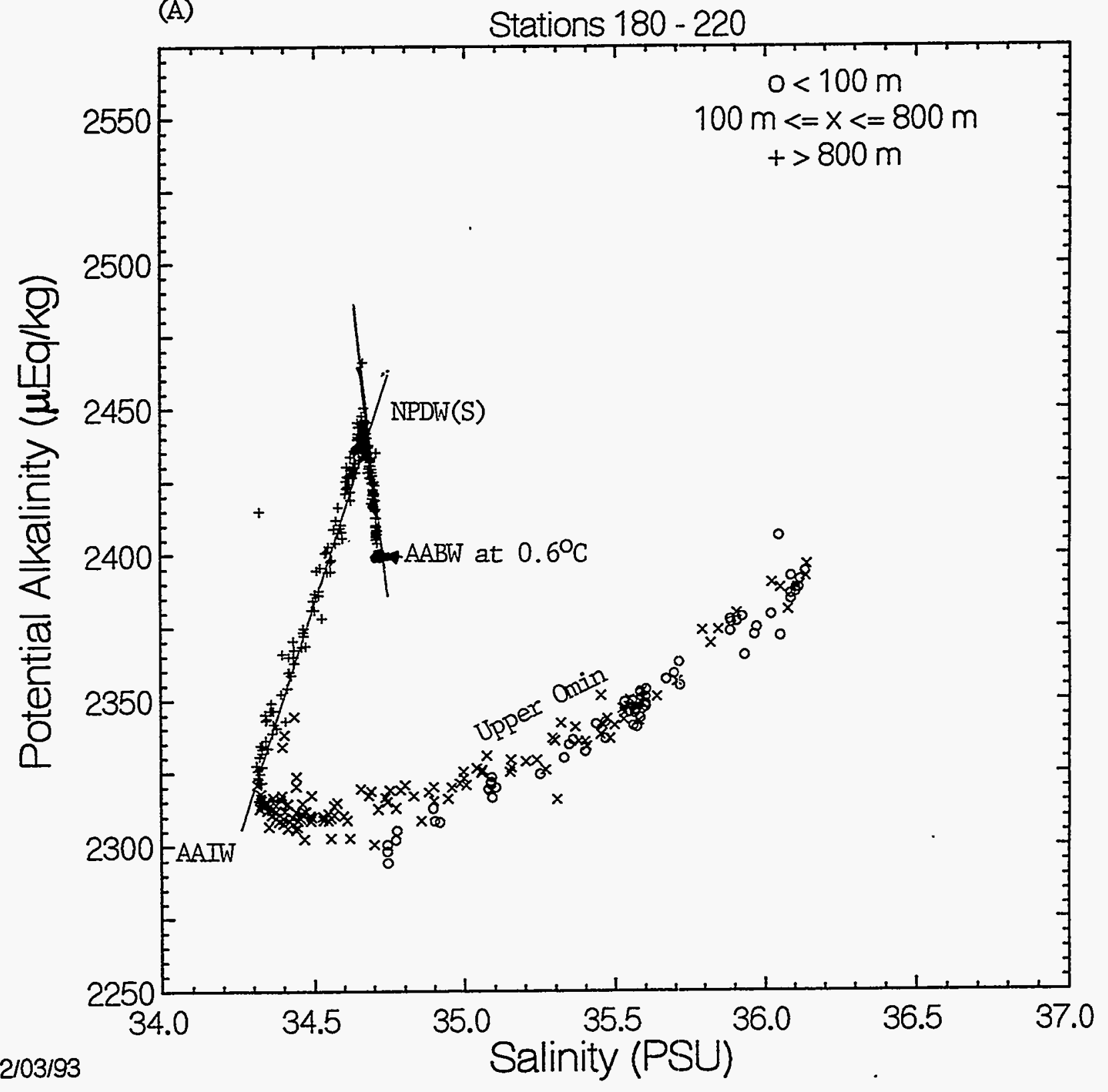


(B)

TUNES/2 WOCE P17C - 1991 Stations 124 - 179

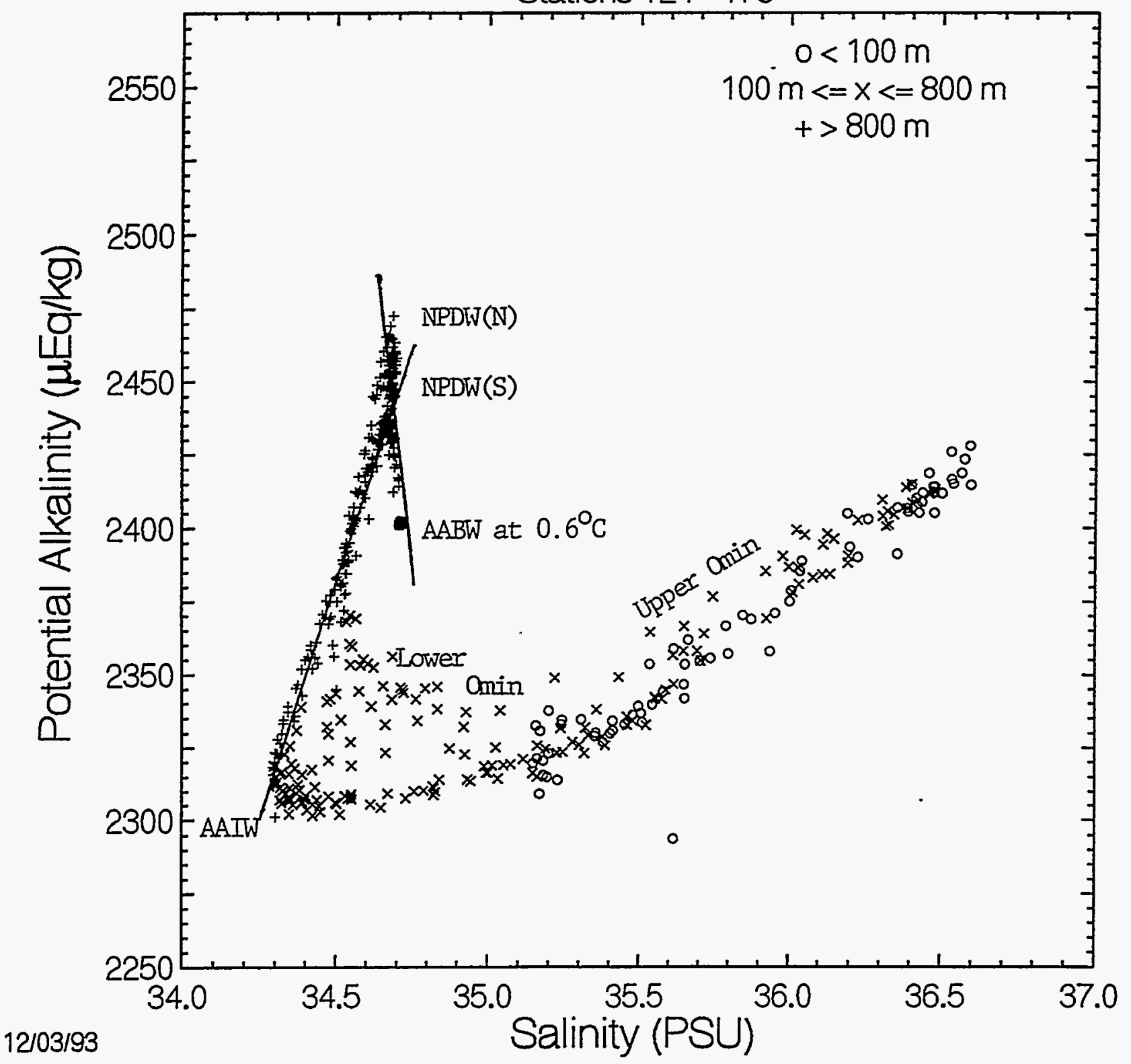


Fig. 39 - The relationships between the concentrations of nitrate and phosphate in seawater observed along (A) the $150^{\circ} \mathrm{W}(\mathrm{P}-16 \mathrm{C})$ and $(\mathrm{B}) 135^{\circ} \mathrm{W}(\mathrm{P}-17 \mathrm{C})$ sections. The data points located below the linear trends are from the lowoxygen waters from the eastern tropical Pacific.

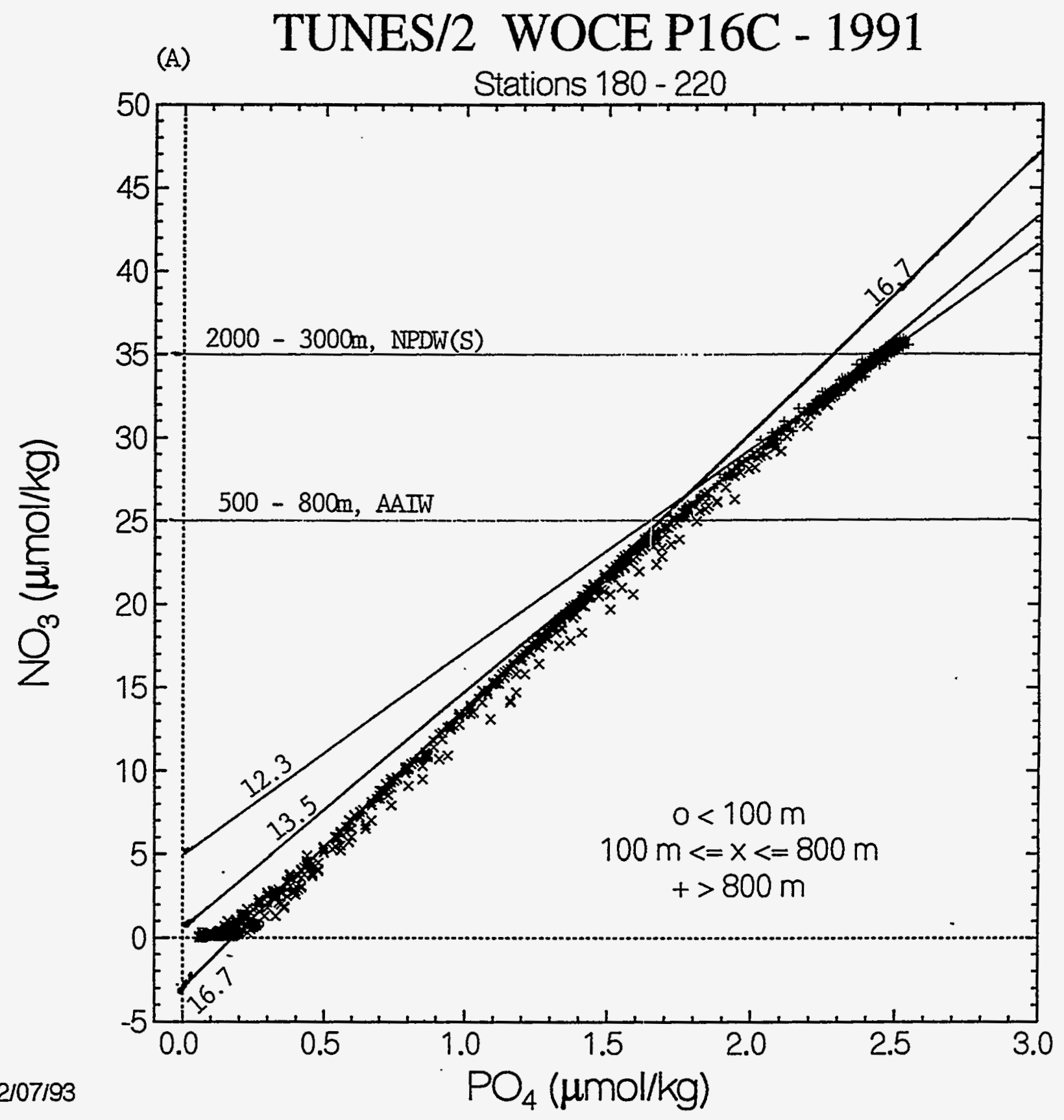




\section{TUNES/2 WOCE P17C - 1991}

(B)

Stations 124 - 179

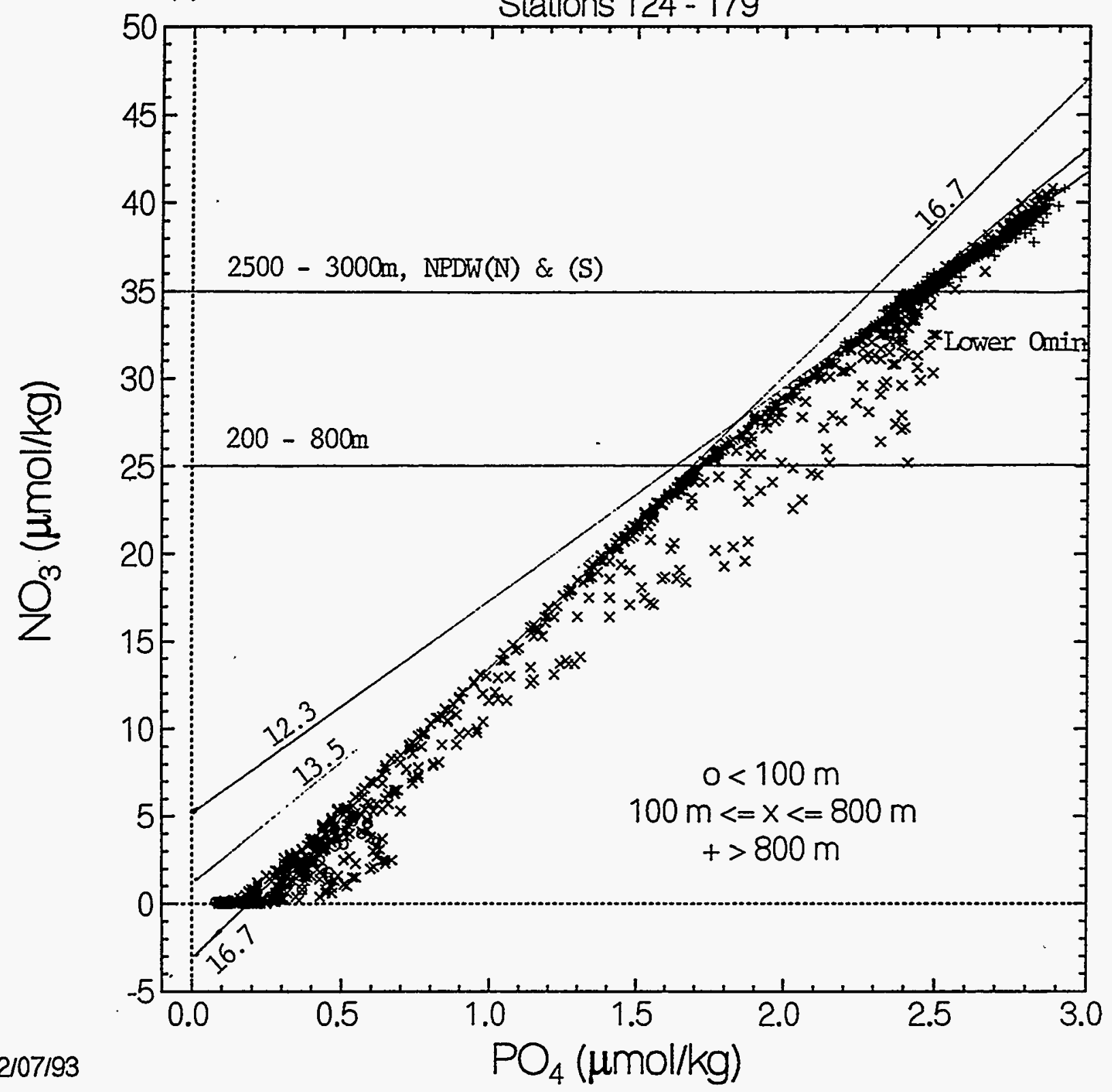


phosphate and nitrate in the source waters and/or to differences in the remineralization rate of organic debris with varying $N / P$ ratios.

\section{V.SUMMARY AND CONCLUSIONS}

1) Measurements for the total $\mathrm{CO}_{2}$ concentration and $\mathrm{pCO}_{2}$ in discrete water samples were made along the WOCE P-16C $\left(150^{\circ} \mathrm{W}\right)$ and $\mathrm{P}-17 \mathrm{C}\left(135^{\circ} \mathrm{W}\right)$ sections in the South Pacific Ocean during the TUNES/2 Expedition. During the 40-day expedition, July 16 through August 25, 1991, the total $\mathrm{CO}_{2}$ concentration in 1000 seawater samples and the $\mathrm{pCO}_{2}$ in 940 samples were determined. Using these data, the alkalinity values in 900 water samples were computed. The results are listed along with the hydrographic data in two tables; one for the surface waters and the other for the water columns.

2) During the expedition, 156 coulometric measurements were made for the Certified Reference Solutions (Batch \#6) supplied by Andrew Drickson of SIO. Our shipboard measurements yielded a mean value of $2303.2 \pm 1.5 \mu \mathrm{mol} / \mathrm{kg}$, which compares with $2304.6 \pm 1.6$ $\mu \mathrm{mol} / \mathrm{kg}(\mathrm{N}=9)$ determined manometrically by the staff of C. D. Keeling, SIO. Although our values are smaller than the Keeling value by $1.4 \mu \mathrm{mol} / \mathrm{kg}$, these mean values overlap within one standard deviation. The total $\mathrm{CO}_{2}$ values listed in this report are based upon our pure $\mathrm{CO}_{2}$ gas calibration and are not corrected for this difference.

3) The total $\mathrm{CO}_{2}$ concentration in surface waters increased southward from about 1990 $\mu \mathrm{mol} / \mathrm{kg}$ at $6^{\circ} \mathrm{S}$ to $2050 \mu \mathrm{mol} / \mathrm{kg}$ at $37.5^{\circ} \mathrm{S}$. The $\mathrm{pCO}_{2}$ in the surface water decreased southward from about $410 \mu \mathrm{atm}$ at $6^{\circ} \mathrm{S}$ to $290 \mu \mathrm{atm}$ at $27 \circ \mathrm{S}$ and then increased to $310 \mu \mathrm{atm}$ at $37.5^{\circ} \mathrm{S}$. The mean atmospheric $\mathrm{CO}_{2}$ concentration in dry air during the expedition was $351.3 \pm 1.0 \mathrm{ppm}$. These data indicate that the tropical waters located north of about $12^{\circ} \mathrm{S}$ were sources for atmospheric $\mathrm{CO}_{2}$, whereas the waters located south of this latitude to $37.5^{\circ} \mathrm{S}$, the southern extreme of this study, were strong sinks for atmospheric $\mathrm{CO}_{2}$, with negative $\Delta \mathrm{pCO}_{2}$ values ranging between -40 and $-50 \mu$ atm.

4) The distribution of the following properties has been presented along the $135^{\circ} \mathrm{W}$ and $150^{\circ} \mathrm{W}$ sections; potential temperature, salinity, potential density, the total $\mathrm{CO}_{2}$ concentration, $\mathrm{pCO}_{2}$ at $20^{\circ} \mathrm{C}$, the alkalinity, the concentration of dissolved oxygen, apparent oxygen utilization, and 
the concentrations of phosphate, nitrate and silicate. The positions of the maxima and minima in these properties and their relationships with respective water masses have been identified. The North Pacific Deep Water (NPDW) located north of the Tuamotu Archipelago has been found to have different chemical characteristics in the total $\mathrm{CO}_{2}$, alkalinity, silicate and oxygen from that located south of the Archipelago. This has been attributed to differences in circulation paths caused by the presence of the high topographic barrier for deep water circulation. The distribution of these chemical properties as well as the other chemical properties in deep waters has been found to be broadly consistent with the geostrophic circulation patterns proposed by Reid (1986).

5) Property-property relationships have been analyzed. The $\theta-S$ relationships (Figs. 31 through 33) show the South Equatorial Current water, South Pacific subtropical gyre waters, Eastern South Pacific Central Waters, AAIW, NPDW, AABW. The $\theta-S$ trend observed at each station along $135^{\circ} \mathrm{W}$ and $150^{\circ} \mathrm{W}$ passes through a common point at sigma- $\theta$ density of 25.7 with a temperature of $17.5-18.0^{\circ} \mathrm{C}$ and salinity of $35.4-35.55$ PSU. The waters having this density are found along the base of the seasonal thermocline, and appear to indicate a subtropical Mode Water.

In the upper 1000 meters of water columns located south of about $20^{\circ} \mathrm{S}$, the Revelle factor is found to be uniformly 10.0. An alkalinity/total $\mathrm{CO}_{2}$ concentration relationship has been calculated for a constant Revelle factor in seawater and shows that the $\mathrm{CO}_{2}$ increase in seawater is due by 8 parts to the oxidation of organic debris and 1 part to the dissolution of calcareous tests.

The N/P ratios observed in the low-oxygen waters are found to be much lower than the general trend observed for well oxygenated waters. This may be attributed to denitrification which occurred in the low oxygen environments in the eastern tropical Pacific. 


\section{REFERENCES CITED}

Armstrong, F. A. J., C. R. Sterns and J. D. H. Strickland (1967). The measurement of upwelling and subsequent biological processes by means of the Technicon Autoanalyzer and associated equipment. Deep-Sea Res., 14, 381-389.

Atlas, E. L., S. W. Hager, L. I. Gordon, and P. K. Park (1971). A Practical Manual for Use of the Technicon(R) in Seawater Nutrient Analyses; Revised. Technical Report 215, Reference 71-22, Oregon State Univ., Dept. of Oceanography, 49 pp.

Bernhardt, H. and A. Wilhelms (1967). The continuous determination of low level iron, soluble phosphate and total phosphate with the Autoanalyzer. Technicon Symposia, Vol. $1,385-389$.

Broecker, W. S. and T. Takahashi (1978). The relationship between lysocline depth and in situ carbonate ion concentration. Deep-Sea Res. 25, 65-95.

Brewer, P. G. and J. C. Goldman (1976). Alkalinity changes generated by phytoplankton growth. Lim. and Oceanogr., 21, 108-117.

Carpenter, J. H. (1965). The Chesapeake Bay Institute technique for the Winkler dissolved oxygen method. Limnol. \& Oceanogr., 10, 141-143.

Chipman, D. W., T. Takahashi, D. Breger, and S. C. Sutherland (1992). Investigation of carbon dioxide in the South Atlantic and Northern Weddell Sea areas (WOCE Sections A-12 and A-21) during the Meteor Expedition 11/5, January-March, 1990. Final Technical Report to DOE, Lamont-Doherty Geological Obs., Palisades, NY, 157 pp.

Chipman, D. W., J. Marra, and T. Takahashi (1993). Primary production at $47{ }^{\circ} \mathrm{N}$ and $20^{\circ} \mathrm{W}$ in the North Atlantic Ocean: A comparison between the ${ }^{14} \mathrm{C}$ incubation method and the mixed layer carbon budget. Deep-Sea. Res. 40, 151-169.

Culberson, C. H. and R. M. Pytkowicz (1973). Ionization of water in seawater. Mar. Chem., I, 403-417.

Culberson, C. H. and R. T. Williams (1991). A comparison of methods for the determination of dissolved oxygen in seawater. WHP Office Report, WHPO 91-2, August, 1991.

Hager, S. W., E. L. Atlas, L. D. Gordon, A. W. Mantyla and P. K. Park (1972). A comparison at sea of manual and autoanalyzer analyses of phosphate, nitrate and silicate. Limnol. \& Oceanogr., 17, 931-937.

Ingri, N. (1959). Equilibrium studies of polyanions, IV. Silicate ions in $\mathrm{NaCl}$ medium. Acta Chem Scand., 13, 758-775. 
Johnson, K. M., A. E. King and J. McN. Sieburth (1985). Coulometric $\mathrm{TCO}_{2}$ analyses for marine studies: an introduction. Mar. Chem., 16, 61-82.

Kester, D. R. (1975). Dissolved gases other than $\mathrm{CO}_{2}$. In "Chemical Oceanography", Vol. 1, edited by J. P. Riley and G. Skirrow, Academic Press, London, 498-556.

Kester, D. R. and Pytkowicz, R. M. (1967). Determination of the apparent dissociation constants of phosphoric acid in seawater. Limnol. Oceanogr., 12, 243-252.

Lyman, J. (1956). Buffer mechanism of sea water. Ph. D. Thesis, UCLA, pp. 196.

McCartney, M. S. (1982). The subtropical recirculation of Model Waters. Jour. Marine Res., 40 (supplement), 427-464.

Mehrbach, C., C. Culberson, J. E. Hawley, and R. M. Pytkowicz (1973). Measurement of the apparent dissociation constants of carbonic acid in seawater at atmospheric pressure. Limnol. and Oceanogr., 18, 897-907.

Millero, F. J. (1979). The thermodynamics of the carbonate system in seawater. Geochim. et Cosmochim. Acta, 43, 1651-1661.

Millero, F. J., C.-T. Chen, A. Bradshaw and K. Schleicher (1980). A new high pressure equation of state for seawater. Deep-Sea Res., 27, 255-264.

Murphy, P. P., R. A. Feely, R. H. Gammon, D. E. Harrison, K. C. Kelly and L. S. Waterman (1991). Assessment of the air-sea exchange of $\mathrm{CO}_{2}$ in the South Pacific during austral autumn. Jour. Geophys. Res., 96, 20455-20465.

Murray, N. N. and J. P. Riley (1969). The solubility of gases in distilled water and seawater II. Oxygen. Deep-Sea Res., 16, 311-320.

Peng, T.-H., T. Takahashi, W. S. Broecker and J. Olafsson (1987). Seasonal variability of carbon dioxide, nutrients and oxygen in the northern North Atlantic surface water. Observations and a model. Tellus, 39B, 439-458.

Reid, J. L. (1986). On the total geostrophic circulation of the South Pacific Ocean: Flow patterns, tracers and transports. Prog. Oceanog., 16, 1-61.

Sverdrup, H. U., M. W. Johnson and R. H. Fleming (1942). THE OCEANS. Prentice-Hall, Inc., Englewood Cliffs, N. J. pp. 1087.

Takahashi, T., W.S. Broecker and A. E. Bainbridge (1981-a). Supplement to the alkalinity and total carbon dioxide concentration in the world oceans. in "Carbon Cycle Modeling", SCOPE Vol. 16, B. Bolin editor, J. Wiley \& Sons, NY, 159-199. 
Takahashi, T., W. S. Broecker and A. E. Bainbridge (1981-b). The alkalinity and total carbon dioxide concentration in the world oceans, in "Carbon Cycle Modelling", SCOPE Vol. 16, B. Bolin editor, J. Wiley \& Sons, NY, 271-286.

Takahashi T., D. Chipman, N. Schechtman, J. Goddard and R. Wanninkof (1982). Measurements of the partial pressure of $\mathrm{CO}_{2}$ in discrete water samples during the North Atlantic Expedition, the Transient Tracers of Oceans Project. Technical Report to NSF, Lamont-Doherty Geol. Obs., Palisades, NY, 268 pp.

Takahashi, T., W. S. Broecker, and S. Langer (1985). Redfield ratio based on chemical data from isopycnal surfaces. J. Geophys. Res., 90, 6907-6924.

UNESCO, (1981). Background papers and supporting data on the Practical Salinity Scale, 1978. UNESCO Technical Papers in Marine Science, No. 37, 144 pp.

Weiss, R.F. (1981). Determinations of $\mathrm{CO}_{2}$ and methane by dual catalyst flame ionization chromatography and nitrous oxide by electron capture chromatography. Jour. of Chromatogr. Sci., 19, 611-616.

Worthington, L. V. (1959). The $18^{\circ}$ water in the Sargasso Sea. Deep-Sea Res., 5, 297-305.

Worthington, L. V. (1976). "On the North Atlantic Circulation". Johns Hopkins Oceanographic Studies, Vol. VI. Johns Hopkins University Press, Baltimore and London, 110 pp. 


\section{IIV. DATA TABLES}

\section{IIV-a) Surface Water Data}

The following quantities are given in this table. The salinity, temperature, the concentrations of oxygen, phosphate, nitrate and silicates were measured by the staff of ODF/SIO.

\begin{tabular}{|c|c|c|}
\hline Station No. & $=$ & The WOCE station number. \\
\hline Date & $=$ & Sampling date given in MM/DD/YY. \\
\hline Lat & $=$ & Latitude in degrees and minutes. \\
\hline Long & $=$ & Longitude in degrees and minutes. \\
\hline InSitu Temp & $=$ & The in situ temperature of water in ${ }^{\circ} \mathrm{C}$. \\
\hline Sal & $=$ & Salinity in PSU (o/oo). \\
\hline Seawater pCO2 $20 \mathrm{Deg}$ & & $\mathrm{pCO}_{2}(\mu \mathrm{atm})$ in seawater measured at $20.0^{\circ} \mathrm{C}$ \\
\hline Seawater pCO2 inSitu & $=$ & $\mathrm{pCO} 2$ ( $\mu \mathrm{atm})$ in seawater corrected to the in situ temperature. \\
\hline Atmosphere VCO2 & $=$ & $\begin{array}{l}\text { Mole fraction concentration (ppm) of } \mathrm{CO}_{z} \text { in dry air. Throughout } \\
\text { the expedition, the value is taken to be } 351.3 \mathrm{ppm} \text { which represents } \\
\text { the mean of } 20 \text { measurements made during this expedition. }\end{array}$ \\
\hline Atmosphere $\mathrm{pCO} 2$ & $=$ & $\begin{array}{l}\text { Partial pressure of } \mathrm{CO}_{2}(\mu \mathrm{atm}) \text { in the atmosphere saturated with } \\
\text { water vapor at the seawater temperature. }\end{array}$ \\
\hline Delta pCO2 sw-air & $=$ & $\begin{array}{l}\text { Difference between the } \mathrm{pCO}_{2} \text { in seawater and that in the overlying } \\
\text { atmosphere ( } \mu \text { atm). Positive values indicate that the seawater is } \\
\text { supersaturated with respect to atmospheric } \mathrm{CO}_{2} \text {, and negative } \\
\text { values indicate that the seawater is undersaturated. }\end{array}$ \\
\hline $\mathrm{TCO} 2$ & $=$ & The total $\mathrm{CO}_{2}$ concentration in seawater $(\mu \mathrm{mol} / \mathrm{kg})$. \\
\hline Oxy, PO4, NO3, SiO3 & $=$ & $\begin{array}{l}\text { The concentrations ( } \mu \mathrm{mol} / \mathrm{kg} \text { ) of dissolved oxygen, phosphate, } \\
\text { nitrate and silicate in seawater. }\end{array}$ \\
\hline Alkalinity Total & - & $\begin{array}{l}\text { Total alkalinity }(\mu \mathrm{eq} / \mathrm{kg}) \text { computed using the total } \mathrm{CO}_{2} \\
\text { concentration and } \mathrm{pCO}_{2} \text { data. }\end{array}$ \\
\hline Alkalinity Pot. & $=$ & Potential alkalinity $(\mu \mathrm{eq} / \mathrm{kg})$, [Total alkalinity] $+[$ Nitrate $]$. \\
\hline
\end{tabular}


Lamont-Doherty Earth Observatory of Columbia University

WOCE Line P17 Expedition -Doherty Earth Observatory 0 Pot. Alkalinity $=$ Total Alkalintty $+($ PO4 $\times 15.5)$ Mean VCO2 of Dry Air 351.3
pCO2 of air calculated from vCO2 of dry air at 1008 relative humidity using the mean for this leg.

\begin{tabular}{|c|c|c|c|c|c|c|c|c|c|c|c|c|c|c|c|c|c|}
\hline $\begin{array}{l}\text { Sta } \\
\text { No. }\end{array}$ & $\begin{array}{c}\text { Date } \\
M M / D D / Y Y\end{array}$ & $\begin{array}{r}\text { Lat } \\
D D-M M\end{array}$ & $\begin{array}{l}\text { Long } \\
\text { DDD-MM }\end{array}$ & $\begin{array}{r}\text { Insitu } \\
\text { Temp } \\
\text { Deg C }\end{array}$ & $\begin{array}{r}\text { Sal } \\
0 / 00\end{array}$ & $\begin{array}{l}\text { Seawa } \\
\text { pCO2 } \\
\text { Insitu }\end{array}$ & $\begin{array}{l}\text { ater } \\
\text { (uatm) } \\
20 \mathrm{Deg}\end{array}$ & $\begin{array}{l}\text { Atmos } \\
\text { veO2 } \\
\text { ppm }\end{array}$ & $\begin{array}{l}\text { phere } \\
\text { pco2 } \\
\text { uatm }\end{array}$ & $\begin{array}{l}\text { Delta pCo2 } \\
\text { sw-air } \\
\text { uatm }\end{array}$ & $\mathrm{TCO}^{\mathrm{TC}}$ & $0 x y$ & $\begin{array}{l}\text { PO4 } \\
\mathrm{uM} / \mathrm{kg}\end{array}$ & $\begin{array}{l}\text { NO3 } \\
---\end{array}$ & Sio3 & $\begin{array}{c}\text { Alkal } \\
\text { uEQ } \\
\text { Total }\end{array}$ & $\begin{array}{l}\text { ity } \\
\text { Pot. }\end{array}$ \\
\hline $\begin{array}{l}124 \\
125 \\
126 \\
127 \\
128 \\
129 \\
130\end{array}$ & $\begin{array}{l}7 / 21 / 91 \\
7 / 22 / 91 \\
7 / 22 / 91 \\
7 / 22 / 91 \\
7 / 23 / 91 \\
7 / 23 / 91 \\
7 / 23 / 91\end{array}$ & $\begin{array}{l}6-0 s \\
6-30 s \\
6-60 s \\
7-30 s \\
7-60 s \\
8-30 s \\
9-0 S\end{array}$ & $\begin{array}{l}135-\text { OW } \\
135-\text { OW } \\
135-\text { OW } \\
135-\text { OW } \\
135-\text { OW } \\
134-59 \mathrm{~W} \\
135-\text { OW }\end{array}$ & $\begin{array}{l}27.48 \\
27.46 \\
27.55 \\
27.62 \\
27.82 \\
27.69 \\
27.61\end{array}$ & $\begin{array}{l}35.172 \\
35.241 \\
35.183 \\
35.160 \\
35.243 \\
35.343 \\
35.636\end{array}$ & $\begin{array}{l}409 \\
414 \\
401 \\
401 \\
393 \\
387 \\
371\end{array}$ & $\begin{array}{l}298 \\
302 \\
292 \\
290 \\
282 \\
280 \\
269\end{array}$ & & $\begin{array}{l}339 \\
339 \\
339 \\
339 \\
338 \\
338 \\
339\end{array}$ & $\begin{array}{l}70 \\
76 \\
63 \\
62 \\
54 \\
49 \\
33\end{array}$ & $\begin{array}{l}1997 \\
2001 \\
1989 \\
1989 \\
1987 \\
1996\end{array}$ & $\begin{array}{l}215 \\
214 \\
211 \\
213 \\
214 \\
209 \\
224\end{array}$ & $\begin{array}{l}0.54 \\
0.55 \\
0.49 \\
0.48 \\
0.47 \\
0.45 \\
0.45\end{array}$ & $\begin{array}{l}4.7 \\
5.0 \\
4.1 \\
4.2 \\
3.9 \\
3.7 \\
3.5\end{array}$ & $\begin{array}{l}2.7 \\
2.5 \\
2.4 \\
2.3 \\
2.0 \\
1.8 \\
1.9\end{array}$ & $\begin{array}{l}2326 \\
2328 \\
2323 \\
2331 \\
2331 \\
2355\end{array}$ & $\begin{array}{l}2334 \\
2336 \\
2330 \\
2338 \\
2338 \\
2362\end{array}$ \\
\hline $\begin{array}{l}131 \\
132 \\
133 \\
134 \\
135 \\
136 \\
137 \\
138 \\
139 \\
140\end{array}$ & $\begin{array}{l}7 / 23 / 91 \\
7 / 24 / 91 \\
7 / 24 / 91 \\
7 / 25 / 91 \\
7 / 25 / 91 \\
7 / 25 / 91 \\
7 / 26 / 91 \\
7 / 26 / 91 \\
7 / 26 / 91 \\
7 / 26 / 91\end{array}$ & $\begin{array}{r}9-30 s \\
10-2 s \\
10-29 s \\
10-59 s \\
11-28 s \\
11-58 s \\
12-27 s \\
12-56 s \\
13-26 s \\
13-55 s\end{array}$ & $\begin{array}{l}135-0 W \\
134-58 W \\
134-54 W \\
134-48 W \\
134-42 W \\
134-36 W \\
134-30 W \\
134-24 W \\
134-17 w \\
134-11 W\end{array}$ & $\begin{array}{l}27.63 \\
27.42 \\
27.37 \\
27.29 \\
27.20 \\
26.99 \\
26.91 \\
26.88 \\
26.73 \\
27.00\end{array}$ & $\begin{array}{l}35.600 \\
35.827 \\
35.990 \\
36.117 \\
36.100 \\
35.918 \\
36.311 \\
36.296 \\
36.407 \\
36.438\end{array}$ & $\begin{array}{l}378 \\
370 \\
358 \\
\\
354 \\
\\
350 \\
343 \\
\\
338\end{array}$ & $\begin{array}{l}274 \\
270 \\
263 \\
\\
261 \\
261 \\
257 \\
250\end{array}$ & & $\begin{array}{l}338 \\
339 \\
339 \\
339 \\
339 \\
339 \\
339\end{array}$ & $\begin{array}{r}39 \\
31 \\
20 \\
16 \\
11 \\
4 \\
-1\end{array}$ & $\begin{array}{l}1998 \\
2002 \\
2007 \\
2015 \\
2001 \\
1990 \\
2023 \\
2018 \\
2022 \\
2020\end{array}$ & $\begin{array}{l}220 \\
216 \\
215 \\
212 \\
211 \\
213 \\
211 \\
212 \\
214 \\
214\end{array}$ & $\begin{array}{l}0.45 \\
0.43 \\
0.41 \\
0.38 \\
0.38 \\
0.36 \\
0.32 \\
0.33 \\
0.29 \\
0.26\end{array}$ & $\begin{array}{l}3.5 \\
3.3 \\
2.8 \\
2.3 \\
2.1 \\
1.9 \\
1.2 \\
1.2 \\
0.6 \\
0.4\end{array}$ & $\begin{array}{l}1.5 \\
1.5 \\
2.0 \\
1.9 \\
2.0 \\
1.4 \\
2.0 \\
1.8 \\
1.7 \\
2.2\end{array}$ & $\begin{array}{l}2406 \\
2402 \\
2414\end{array}$ & $\begin{array}{l}2411 \\
2407 \\
2418\end{array}$ \\
\hline $\begin{array}{l}141 \\
142 \\
143 \\
144 \\
145 \\
146 \\
147 \\
148 \\
149 \\
150\end{array}$ & $\begin{array}{l}7 / 27 / 91 \\
7 / 27 / 91 \\
7 / 28 / 91 \\
7 / 28 / 91 \\
7 / 28 / 91 \\
7 / 28 / 91 \\
7 / 29 / 91 \\
7 / 29 / 91 \\
7 / 29 / 91 \\
7 / 29 / 91\end{array}$ & $\begin{array}{l}14-25 s \\
14-54 s \\
15-23 s \\
15-53 s \\
16-22 s \\
16-52 s \\
17-21 s \\
17-50 s \\
18-20 s \\
18-49 s\end{array}$ & $\begin{array}{l}134-5 w \\
133-59 w \\
133-53 w \\
133-47 w \\
133-40 w \\
133-34 w \\
133-28 w \\
133-22 w \\
133-15 w \\
133-9 w\end{array}$ & $\begin{array}{l}26.89 \\
26.56 \\
26.54 \\
26.51 \\
26.54 \\
26.20 \\
26.04 \\
25.77 \\
25.60 \\
25.63\end{array}$ & $\begin{array}{l}36.474 \\
36.532 \\
36.605 \\
36.553 \\
36.535 \\
36.596 \\
36.576 \\
36.479 \\
36.503 \\
36.476\end{array}$ & $\begin{array}{l}329 \\
328 \\
338 \\
334 \\
344 \\
334 \\
330 \\
333 \\
345\end{array}$ & $\begin{array}{l}248 \\
256 \\
253 \\
265 \\
259 \\
259 \\
263 \\
270\end{array}$ & & $\begin{array}{l}339 \\
\\
339 \\
339 \\
339 \\
340 \\
340 \\
340 \\
340 \\
340\end{array}$ & $\begin{array}{r}-10 \\
-11 \\
-2 \\
-5 \\
5 \\
-6 \\
-10 \\
-7 \\
5\end{array}$ & $\begin{array}{l}2023 \\
2023 \\
\\
2027 \\
2024 \\
2033 \\
2034 \\
2027 \\
2030 \\
2030\end{array}$ & $\begin{array}{l}215 \\
213 \\
210 \\
209 \\
210 \\
211 \\
211 \\
209 \\
212 \\
213\end{array}$ & $\begin{array}{l}0.23 \\
0.23 \\
0.23 \\
0.23 \\
0.22 \\
0.23 \\
0.21 \\
0.20 \\
0.19 \\
0.19\end{array}$ & $\begin{array}{l}0.1 \\
0.1 \\
0.1 \\
0.1 \\
0.1 \\
0.1 \\
0.1 \\
0.1 \\
0.0 \\
0.1\end{array}$ & $\begin{array}{l}2.4 \\
1.6 \\
1.4 \\
1.5 \\
1.5 \\
1.4 \\
1.6 \\
1.5 \\
1.4 \\
1.4\end{array}$ & $\begin{array}{l}2417 \\
2416 \\
2415 \\
2423 \\
2413 \\
2412 \\
2405\end{array}$ & $\begin{array}{l}2420 \\
2420 \\
2418 \\
2427 \\
2416 \\
2415 \\
2408\end{array}$ \\
\hline $\begin{array}{l}151 \\
152 \\
153 \\
154 \\
155 \\
156 \\
157 \\
158 \\
159 \\
160\end{array}$ & $\begin{array}{l}7 / 30 / 91 \\
7 / 30 / 91 \\
7 / 30 / 91 \\
7 / 31 / 91 \\
7 / 31 / 91 \\
7 / 31 / 91 \\
8 / 11 / 91 \\
8 / 1 / 91 \\
8 / 1 / 91 \\
8 / 1 / 91\end{array}$ & $\begin{array}{l}19-19 s \\
19-48 s \\
20-17 s \\
20-47 s \\
21-16 s \\
21-46 s \\
22-15 s \\
22-42 s \\
23-14 s \\
23-43 s\end{array}$ & $\begin{array}{l}133-3 w \\
132-57 w \\
132-50 w \\
132-44 w \\
132-37 w \\
132-31 w \\
132-25 w \\
132-17 w \\
132-26 w \\
132-33 w\end{array}$ & $\begin{array}{l}25.42 \\
25.35 \\
25.11 \\
24.93 \\
24.89 \\
24.29 \\
23.25 \\
23.43 \\
24.12 \\
23.41\end{array}$ & $\begin{array}{l}36.475 \\
36.439 \\
36.404 \\
36.358 \\
36.394 \\
36.226 \\
35.891 \\
35.951 \\
36.203 \\
36.007\end{array}$ & $\begin{array}{l}329 \\
329 \\
329 \\
341 \\
329 \\
328 \\
318 \\
320 \\
313\end{array}$ & $\begin{array}{l}262 \\
262 \\
264 \\
277 \\
268 \\
274 \\
\\
275 \\
269 \\
271\end{array}$ & & $\begin{array}{l}340 \\
340 \\
340 \\
340 \\
340 \\
341 \\
\\
341 \\
341 \\
341\end{array}$ & $\begin{array}{r}-11 \\
-11 \\
-12 \\
1 \\
-11 \\
-13 \\
\\
-24 \\
-20 \\
-28\end{array}$ & $\begin{array}{l}2031 \\
2028 \\
2030 \\
2026 \\
2030 \\
2024 \\
\\
2011 \\
2023 \\
2012\end{array}$ & $\begin{array}{l}216 \\
215 \\
206 \\
206 \\
208 \\
213 \\
214 \\
208 \\
212\end{array}$ & $\begin{array}{l}0.18 \\
0.19 \\
0.18 \\
0.19 \\
0.19 \\
0.17 \\
0.13 \\
0.14 \\
0.17 \\
0.15\end{array}$ & $\begin{array}{l}0.1 \\
0.1 \\
0.0 \\
0.1 \\
0.0 \\
0.1 \\
0.0 \\
0.1 \\
0.1 \\
0.1\end{array}$ & $\begin{array}{l}1.5 \\
1.9 \\
1.6 \\
1.9 \\
1.2 \\
1.4 \\
1.5 \\
1.5 \\
1.3 \\
1.2\end{array}$ & $\begin{array}{l}2414 \\
2410 \\
2410 \\
2391 \\
2406 \\
2390 \\
\\
2371 \\
2393 \\
2377\end{array}$ & $\begin{array}{l}2417 \\
2413 \\
2413 \\
2394 \\
2408 \\
2393 \\
\\
2373 \\
2396 \\
2379\end{array}$ \\
\hline $\begin{array}{l}161 \\
162 \\
163\end{array}$ & $\begin{array}{ll}8 / 2 / 91 \\
8 / 2 / 91 \\
8 / & 2 / 91\end{array}$ & $\begin{array}{l}24-125 \\
24-41 s \\
25-11 s\end{array}$ & $\begin{array}{l}132-40 W \\
132-48 W \\
132-55 W\end{array}$ & $\begin{array}{l}22.09 \\
22.47 \\
21.81\end{array}$ & $\begin{array}{l}35.701 \\
35.799 \\
35.699\end{array}$ & $\begin{array}{l}307 \\
310\end{array}$ & $\begin{array}{l}281 \\
280\end{array}$ & & $\begin{array}{l}342 \\
342\end{array}$ & $\begin{array}{l}-36 \\
-32\end{array}$ & 2005 & $\begin{array}{l}218 \\
215 \\
218\end{array}$ & $\begin{array}{l}0.12 \\
0.11\end{array}$ & $\begin{array}{l}0.1 \\
0.1\end{array}$ & $\begin{array}{l}1.3 \\
1.6 \\
1.5\end{array}$ & $\begin{array}{l}2355 \\
2357\end{array}$ & $\begin{array}{l}2356 \\
2359\end{array}$ \\
\hline
\end{tabular}


wocE Line P17

Lamont-Doherty Earth Observatory of Columbia University

Printed on $12 / 07 / 93$ Mean VCO2 of Dry Air $=351.3$ Expedition TUNES/2 WOCE P17C/P16C 1991 Pot. Alkalinity $=$ Total Alkalinity $+\langle$ PO4 $\times 15.5\rangle$ pCO2 of air calculated from vCO2 of dry air at 1008 relative humidity using the mean for this leg.

\begin{tabular}{|c|c|c|c|c|c|c|c|c|c|c|c|c|c|c|c|c|c|}
\hline $\begin{array}{l}\text { Sta } \\
\text { No. }\end{array}$ & $\begin{array}{c}\text { Date } \\
\text { MM/DD/YY }\end{array}$ & $\begin{array}{r}\text { Lat } \\
D D-M M\end{array}$ & $\begin{array}{l}\text { Long } \\
\text { DDD-MM }\end{array}$ & $\begin{array}{l}\text { Insitu } \\
\text { Temp } \\
\text { Deg C }\end{array}$ & $\begin{array}{r}\text { Sal } \\
\text { o/00 }\end{array}$ & $\begin{array}{l}\text { Seaw } \\
\text { pco2 } \\
\text { Insitu }\end{array}$ & $\begin{array}{l}\text { ater } \\
\text { (uatm) } \\
20 \text { Deg }\end{array}$ & $\begin{array}{l}\text { Atmos } \\
\text { VCO2 } \\
\text { ppm }\end{array}$ & $\begin{array}{l}\text { phere } \\
\text { pCO2 } \\
\text { uatm }\end{array}$ & $\begin{array}{c}\text { Delta pco2 } \\
\text { sw-air } \\
\text { uatm }\end{array}$ & $\mathrm{TCO} 2$ & $0 x y$ & $\begin{array}{c}\text { PO4 } \\
\mathrm{uM} / \mathrm{kg}\end{array}$ & $\mathrm{NO} 3$ & S103 & $\begin{array}{c}\text { Alk } \\
\text { u } \\
\text { Tot }\end{array}$ & $\begin{array}{l}\text { iity } \\
\text { sg } \\
\text { Pot. }\end{array}$ \\
\hline 64 & $\begin{array}{ll}8 / & 2 / 91 \\
8 / & 3 / 91 \\
8 / & 3 / 91 \\
8 / & 4 / 91 \\
8 / & 4 / 91 \\
8 / & 4 / 91 \\
8 / & 5 / 91\end{array}$ & $\begin{array}{l}25-40 S \\
26-7 S \\
26-38 s \\
27-7 s \\
27-37 s \\
28-6 s \\
28-35 S\end{array}$ & $\begin{array}{l}133-3 w \\
133-5 w \\
133-18 w \\
133-26 w \\
133-32 W \\
133-41 w \\
133-49 w\end{array}$ & $\begin{array}{l}21.57 \\
20.52 \\
20.63 \\
19.55 \\
19.12 \\
19.50 \\
18.96\end{array}$ & $\begin{array}{l}35.654 \\
35.576 \\
35.581 \\
35.507 \\
35.502 \\
35.534 \\
35.449\end{array}$ & $\begin{array}{l}304 \\
312 \\
298 \\
300 \\
309 \\
299 \\
302\end{array}$ & $\begin{array}{l}284 \\
299 \\
290 \\
306 \\
320 \\
305 \\
316\end{array}$ & & $\begin{array}{l}342 \\
343 \\
343 \\
343 \\
344 \\
343\end{array}$ & $\begin{array}{l}-39 \\
-31 \\
-45 \\
-44 \\
-34 \\
-44 \\
-42\end{array}$ & & $\begin{array}{l}219 \\
223 \\
223 \\
226 \\
227 \\
227 \\
230\end{array}$ & $\begin{array}{l}0 . \\
0 .\end{array}$ & $\begin{array}{l}0.1 \\
0.1 \\
0.0 \\
0.0 \\
0.1 \\
0.1\end{array}$ & $\begin{array}{l}1.5 \\
1.5 \\
1.2 \\
1.7 \\
1.4\end{array}$ & & \\
\hline $\begin{array}{l}172 \\
173 \\
174 \\
175 \\
176 \\
177 \\
178\end{array}$ & $\begin{array}{ll}8 / & 5 / 91 \\
8 / & 5 / 91 \\
8 / & 6 / 91 \\
8 / & 6 / 91 \\
8 / & 6 / 91 \\
8 / & 7 / 91 \\
8 / & 7 / 91 \\
8 / & 7 / 91 \\
8 / & 8 / 91\end{array}$ & $\begin{array}{l}29-4 S \\
29-34 S \\
30-3 S \\
30-32 S \\
31-1 S \\
31-30 S \\
32-0 S \\
32-29 S \\
33-1 S\end{array}$ & $\begin{array}{l}133-56 W \\
134-4 W \\
134-12 W \\
134-20 W \\
134-28 W \\
134-36 W \\
134-43 W \\
134-51 W \\
135-1 W\end{array}$ & $\begin{array}{l}18.05 \\
17.67 \\
17.78 \\
16.78 \\
16.78 \\
16.63 \\
16.80 \\
16.48\end{array}$ & $\begin{array}{l}35.412 \\
35.397 \\
35.353 \\
35.380 \\
35.170 \\
35.167 \\
35.190 \\
35.229 \\
35.197\end{array}$ & $\begin{array}{l}297 \\
304 \\
300 \\
309 \\
311 \\
313\end{array}$ & $\begin{array}{l}315 \\
329 \\
331 \\
340 \\
354 \\
358\end{array}$ & & $\begin{array}{l}344 \\
344 \\
344 \\
345\end{array}$ & $\begin{array}{l}-4 \\
-4 \\
-4 \\
-3 \\
-3 \\
-3\end{array}$ & 2030 & $\begin{array}{l}231 \\
234 \\
236 \\
234 \\
240 \\
241 \\
243 \\
239 \\
241\end{array}$ & $\begin{array}{l}0.11 \\
0.11 \\
0.13 \\
0.12 \\
0.12 \\
0.12 \\
0.13\end{array}$ & $\begin{array}{l}0.1 \\
0.0 \\
0.1 \\
0.1 \\
0.1 \\
0.0 \\
0.1 \\
0.1 \\
0.1\end{array}$ & $\begin{array}{l}1.7 \\
1.5 \\
1.2 \\
1.1 \\
0.7 \\
1.4 \\
1.1 \\
1.3 \\
1.1\end{array}$ & $\begin{array}{l}2334 \\
2330 \\
2330 \\
2327 \\
2315 \\
2309 \\
2314 \\
2319\end{array}$ & $\begin{array}{l}2331 \\
2332 \\
2329 \\
2317 \\
2311\end{array}$ \\
\hline
\end{tabular}


Lamont-Doherty Earth Observatory of Columbia University

Printed on $12 / 07 / 93$ WOCE Line P16 Lamont-Doherty Earth Observatory of
Expedition TUNES/2 WOCE P17C/P16C 1991

Pot. Alkalinity $=$ Total Alkalinity $+($ PO4 $\times$ Page 15.5$)$ Mean VCO2 of Dry Air a 351.3
pCO2 of air calculated from vCO2 of dry air at 1008 relative humidity using the mean for this leg.

\begin{tabular}{|c|c|c|c|c|c|c|c|c|c|c|c|c|c|c|c|c|c|}
\hline $\begin{array}{l}\text { Sta } \\
\text { No. }\end{array}$ & $\begin{array}{c}\text { Date } \\
\text { MM/DD/YY }\end{array}$ & $\begin{array}{r}\text { Lat } \\
D D-M M\end{array}$ & $\begin{array}{l}\text { Long } \\
\text { DDD-MM }\end{array}$ & $\begin{array}{l}\text { Insitu } \\
\text { Temp } \\
\text { Deg C }\end{array}$ & $\begin{array}{r}\text { Sal } \\
0 / 00\end{array}$ & $\begin{array}{r}\text { seawa } \\
\text { pco2 } \\
\text { Insitu }\end{array}$ & $\begin{array}{l}\text { ter } \\
\text { uatm) } \\
20 \mathrm{Deg}\end{array}$ & $\begin{array}{l}\text { Atmos } \\
\text { VCO2 } \\
\text { ppm }\end{array}$ & $\begin{array}{l}\text { lere } \\
\text { CO2 } \\
\text { latm }\end{array}$ & $\begin{array}{l}\text { Delta pCO2 } \\
\text { sw-a1r } \\
\text { uatm }\end{array}$ & $\begin{array}{l}\mathrm{TCO} 2 \\
---\end{array}$ & Oxy & $\begin{array}{c}\mathrm{PO4} \\
\mathrm{uM} / \mathrm{kg}\end{array}$ & No3 & sio3 & $\begin{array}{l}\text { Alka } \\
\text { u } \\
\text { Tote }\end{array}$ & $\begin{array}{l}\text { itty } \\
\text { got. }\end{array}$ \\
\hline $\begin{array}{l}180 \\
181 \\
182 \\
183 \\
184 \\
185 \\
186 \\
187 \\
188 \\
189 \\
190\end{array}$ & $\begin{array}{l}8 / 12 / 91 \\
8 / 12 / 91 \\
8 / 13 / 91 \\
8 / 13 / 91 \\
8 / 13 / 91 \\
8 / 14 / 91 \\
8 / 14 / 91 \\
8 / 14 / 91 \\
8 / 15 / 91 \\
8 / 16 / 91 \\
8 / 16 / 91\end{array}$ & $\begin{array}{l}37-30 S \\
36-60 S \\
36-30 S \\
36-0 S \\
35-30 S \\
35-0 S \\
34-30 S \\
34-0 S \\
33-30 S \\
32-60 S \\
32-30 S\end{array}$ & $\begin{array}{l}150-30 \mathrm{~W} \\
150-30 \mathrm{~W} \\
150-30 \mathrm{~W} \\
150-30 \mathrm{~W} \\
150-30 \mathrm{~W} \\
150-30 \mathrm{~W} \\
150-30 \mathrm{~W} \\
150-30 \mathrm{~W} \\
150-30 \mathrm{~W} \\
150-30 \mathrm{~W} \\
150-30 \mathrm{~W}\end{array}$ & $\begin{array}{l}13.38 \\
13.41 \\
13.69 \\
14.12 \\
14.30 \\
14.96 \\
15.02 \\
15.04 \\
15.13 \\
15.93 \\
16.40\end{array}$ & $\begin{array}{l}34.745 \\
34.771 \\
34.776 \\
34.901 \\
34.918 \\
35.080 \\
35.092 \\
35.090 \\
35.104 \\
35.248 \\
35.346\end{array}$ & $\begin{array}{l}314 \\
309 \\
308 \\
309 \\
309 \\
306 \\
310 \\
306 \\
303 \\
306 \\
303\end{array}$ & $\begin{array}{l}415 \\
408 \\
402 \\
397 \\
393 \\
379 \\
383 \\
378 \\
372 \\
363 \\
352\end{array}$ & & $\begin{array}{l}346 \\
346 \\
346 \\
346 \\
346 \\
345 \\
345 \\
345 \\
345 \\
345 \\
345\end{array}$ & $\begin{array}{l}-32 \\
-37 \\
-38 \\
-36 \\
-37 \\
-39 \\
-35 \\
-39 \\
-43 \\
-39 \\
-42\end{array}$ & $\begin{array}{l}2044 \\
2044 \\
2044 \\
2044 \\
2042 \\
2043 \\
2042 \\
2044 \\
2039 \\
2038 \\
2039\end{array}$ & $\begin{array}{l}257 \\
257 \\
256 \\
253 \\
252 \\
249 \\
247 \\
247 \\
248 \\
243 \\
241\end{array}$ & $\begin{array}{l}0.25 \\
0.26 \\
0.25 \\
0.21 \\
0.20 \\
0.17 \\
0.18 \\
0.20 \\
0.17 \\
0.15 \\
0.13\end{array}$ & $\begin{array}{l}0.9 \\
0.8 \\
0.6 \\
0.5 \\
0.3 \\
0.1 \\
0.2 \\
0.3 \\
0.1 \\
0.1 \\
0.1\end{array}$ & $\begin{array}{l}1.5 \\
1.4 \\
1.9 \\
1.6 \\
1.3 \\
1.3 \\
1.7 \\
1.3 \\
1.5 \\
1.8 \\
1.4\end{array}$ & $\begin{array}{l}2296 \\
2301 \\
2305 \\
2308 \\
2308 \\
2319 \\
2316 \\
2322 \\
2320 \\
2324 \\
2335\end{array}$ & $\begin{array}{l}2300 \\
2305 \\
2309 \\
2311 \\
2311 \\
2322 \\
2319 \\
2325 \\
2322 \\
2327 \\
2337\end{array}$ \\
\hline $\begin{array}{l}191 \\
192 \\
193 \\
194 \\
195 \\
196 \\
197 \\
198 \\
199 \\
200\end{array}$ & $\begin{array}{l}8 / 16 / 91 \\
8 / 16 / 91 \\
8 / 17 / 91 \\
8 / 17 / 91 \\
8 / 17 / 91 \\
8 / 18 / 91 \\
8 / 18 / 91 \\
8 / 18 / 91 \\
8 / 19 / 91 \\
8 / 19 / 91\end{array}$ & $\begin{array}{l}32-\text { os } \\
31-30 s \\
30-60 s \\
30-30 s \\
30-0 s \\
29-30 s \\
28-60 s \\
28-30 s \\
27-60 s \\
27-30 s\end{array}$ & $\begin{array}{l}150-30 \mathrm{~W} \\
150-30 \mathrm{~W} \\
150-31 \mathrm{~W} \\
150-30 \mathrm{~W} \\
150-31 \mathrm{~W} \\
150-30 \mathrm{~W} \\
150-30 \mathrm{~W} \\
150-30 \mathrm{~W} \\
150-30 \mathrm{~W} \\
150-30 \mathrm{~W}\end{array}$ & $\begin{array}{l}16.52 \\
16.96 \\
17.25 \\
17.38 \\
17.94 \\
18.73 \\
19.16 \\
19.31 \\
18.97 \\
19.31\end{array}$ & $\begin{array}{l}35.359 \\
35.397 \\
35.436 \\
35.468 \\
35.524 \\
35.572 \\
35.564 \\
35.587 \\
35.568 \\
35.571\end{array}$ & $\begin{array}{l}301 \\
303 \\
295 \\
300 \\
295 \\
296 \\
293 \\
297 \\
295 \\
295\end{array}$ & $\begin{array}{l}349 \\
344 \\
332 \\
335 \\
321 \\
312 \\
304 \\
306 \\
308 \\
304\end{array}$ & & $\begin{array}{l}345 \\
345 \\
345 \\
344 \\
344 \\
344 \\
344 \\
344 \\
344 \\
344\end{array}$ & $\begin{array}{l}-44 \\
-42 \\
-49 \\
-45 \\
-50 \\
-48 \\
-50 \\
-46 \\
-49 \\
-48\end{array}$ & $\begin{array}{l}2038 \\
2032 \\
2032 \\
2032 \\
2030 \\
2017 \\
2016 \\
2017 \\
2019 \\
2017\end{array}$ & $\begin{array}{l}240 \\
238 \\
237 \\
236 \\
234 \\
230 \\
228 \\
228 \\
230 \\
228\end{array}$ & $\begin{array}{l}0.13 \\
0.14 \\
0.11 \\
0.10 \\
0.08 \\
0.07 \\
0.07 \\
0.08 \\
0.07 \\
0.08\end{array}$ & $\begin{array}{l}0.1 \\
0.2 \\
0.1 \\
0.1 \\
0.1 \\
0.1 \\
0.1 \\
0.2 \\
0.1 \\
0.0\end{array}$ & $\begin{array}{l}1.3 \\
1.6 \\
1.6 \\
1.7 \\
1.6 \\
1.2 \\
1.7 \\
1.2 \\
1.8 \\
1.2\end{array}$ & $\begin{array}{l}2336 \\
2332 \\
2342 \\
2339 \\
2349 \\
2341 \\
2346 \\
2345 \\
2347 \\
2347\end{array}$ & $\begin{array}{l}2338 \\
2334 \\
2343 \\
2341 \\
2350 \\
2342 \\
2347 \\
2346 \\
2348 \\
2348\end{array}$ \\
\hline $\begin{array}{l}201 \\
202 \\
203 \\
204 \\
205 \\
206 \\
207 \\
208 \\
209 \\
210\end{array}$ & $\begin{array}{l}8 / 19 / 91 \\
8 / 20 / 91 \\
8 / 20 / 91 \\
8 / 20 / 91 \\
8 / 20 / 91 \\
8 / 21 / 91 \\
8 / 21 / 91 \\
8 / 21 / 91 \\
8 / 21 / 91 \\
8 / 22 / 91\end{array}$ & $\begin{array}{l}27-\text { OS } \\
26-30 S \\
25-60 S \\
25-30 S \\
25-0 S \\
24-30 S \\
24-0 S \\
23-30 S \\
23-0 S \\
22-30 S\end{array}$ & $\begin{array}{l}150-30 \mathrm{~W} \\
150-30 \mathrm{~W} \\
150-30 \mathrm{~W} \\
150-30 \mathrm{~W} \\
150-30 \mathrm{~W} \\
150-30 \mathrm{~W} \\
150-30 \mathrm{~W} \\
150-30 \mathrm{~W} \\
150-30 \mathrm{~W} \\
150-30 \mathrm{~W}\end{array}$ & $\begin{array}{l}19.99 \\
19.73 \\
19.73 \\
20.02 \\
21.80 \\
21.35 \\
21.90 \\
22.09 \\
22.73 \\
23.47\end{array}$ & $\begin{array}{l}35.578 \\
35.584 \\
35.585 \\
35.591 \\
35.690 \\
35.636 \\
35.700 \\
35.700 \\
35.843 \\
35.906\end{array}$ & $\begin{array}{l}288 \\
294 \\
292 \\
293 \\
294 \\
294 \\
299 \\
295 \\
303 \\
302\end{array}$ & $\begin{array}{l}286 \\
297 \\
296 \\
290 \\
271 \\
278 \\
275 \\
269 \\
265 \\
261\end{array}$ & & $\begin{array}{l}343 \\
343 \\
343 \\
343 \\
342 \\
343 \\
342 \\
342 \\
342 \\
341\end{array}$ & $\begin{array}{l}-56 \\
-50 \\
-51 \\
-51 \\
-49 \\
-49 \\
-43 \\
-47 \\
-39 \\
-40\end{array}$ & $\begin{array}{l}2008 \\
2012 \\
2015 \\
2011 \\
2000 \\
2002 \\
2000 \\
2002 \\
2009 \\
2005\end{array}$ & $\begin{array}{l}226 \\
226 \\
227 \\
225 \\
218 \\
222 \\
218 \\
217 \\
214 \\
212\end{array}$ & $\begin{array}{l}0.08 \\
0.07 \\
0.07 \\
0.08 \\
0.10 \\
0.08 \\
0.09 \\
0.08 \\
0.12 \\
0.13\end{array}$ & $\begin{array}{l}0.1 \\
0.3 \\
0.1 \\
0.1 \\
0.1 \\
0.2 \\
0.2 \\
0.1 \\
0.1 \\
0.1\end{array}$ & $\begin{array}{l}1.0 \\
1.4 \\
1.5 \\
1.5 \\
1.6 \\
1.4 \\
1.6 \\
1.5 \\
1.4 \\
1.7\end{array}$ & $\begin{array}{l}2353 \\
2347 \\
2352 \\
2353 \\
2359 \\
2354 \\
2355 \\
2363 \\
2377 \\
2377\end{array}$ & $\begin{array}{l}2354 \\
2348 \\
2353 \\
2355 \\
2360 \\
2355 \\
2356 \\
2364 \\
2379 \\
2379\end{array}$ \\
\hline $\begin{array}{l}211 \\
212 \\
213 \\
214 \\
215 \\
216 \\
217 \\
218 \\
219 \\
220\end{array}$ & $\begin{array}{l}8 / 22 / 91 \\
8 / 23 / 91 \\
8 / 23 / 91 \\
8 / 23 / 91 \\
8 / 24 / 91 \\
8 / 24 / 91 \\
8 / 24 / 91 \\
8 / 24 / 91 \\
8 / 25 / 91 \\
8 / 25 / 91\end{array}$ & $\begin{array}{l}22-15 \\
21-30 S \\
21-0 S \\
20-30 S \\
20-0 S \\
19-30 S \\
19-0 S \\
18-30 S \\
18-0 S \\
17-30 S\end{array}$ & $\begin{array}{l}150-30 \mathrm{~W} \\
150-30 \mathrm{~W} \\
150-30 \mathrm{~W} \\
150-30 \mathrm{~W} \\
150-30 \mathrm{~W} \\
150-30 \mathrm{~W} \\
150-30 \mathrm{~W} \\
150-30 \mathrm{~W} \\
150-30 \mathrm{~W} \\
150-30 \mathrm{~W}\end{array}$ & $\begin{array}{l}23.73 \\
24.56 \\
25.13 \\
24.91 \\
25.42 \\
25.69 \\
25.41 \\
25.44 \\
26.11 \\
26.43\end{array}$ & $\begin{array}{l}35.910 \\
35.960 \\
36.049 \\
35.993 \\
36.111 \\
36.085 \\
36.105 \\
36.131 \\
36.096 \\
36.113\end{array}$ & $\begin{array}{l}306 \\
309 \\
311 \\
317 \\
319 \\
319 \\
320 \\
316 \\
321 \\
322\end{array}$ & $\begin{array}{l}258 \\
255 \\
251 \\
256 \\
253 \\
251 \\
254 \\
251 \\
247 \\
245\end{array}$ & & $\begin{array}{l}341 \\
341 \\
340 \\
340 \\
340 \\
340 \\
340 \\
340 \\
340 \\
339\end{array}$ & $\begin{array}{l}-35 \\
-31 \\
-29 \\
-24 \\
-21 \\
-21 \\
-20 \\
-24 \\
-18 \\
-17\end{array}$ & $\begin{array}{l}1992 \\
1995 \\
2004 \\
2001 \\
2005 \\
2001 \\
2004 \\
2007 \\
1999 \\
2000\end{array}$ & $\begin{array}{l}210 \\
209 \\
206 \\
208 \\
205 \\
205 \\
205 \\
205 \\
204 \\
202\end{array}$ & $\begin{array}{l}0.13 \\
0.15 \\
0.16 \\
0.15 \\
0.17 \\
0.18 \\
0.17 \\
0.17 \\
0.19 \\
0.19\end{array}$ & $\begin{array}{l}0.1 \\
0.1 \\
0.1 \\
0.1 \\
0.1 \\
0.2 \\
0.1 \\
0.1 \\
0.1 \\
0.2\end{array}$ & $\begin{array}{l}0.9 \\
1.5 \\
1.3 \\
0.9 \\
1.0 \\
1.4 \\
1.4 \\
1.2 \\
1.1 \\
1.2\end{array}$ & $\begin{array}{l}2365 \\
2372 \\
2389 \\
2379 \\
2388 \\
2385 \\
2387 \\
2394 \\
2388 \\
2391\end{array}$ & $\begin{array}{l}2367 \\
2374 \\
2391 \\
2381 \\
2391 \\
2388 \\
2390 \\
2397 \\
2391 \\
2394\end{array}$ \\
\hline
\end{tabular}


IIV-b) Hydrographic and $\mathrm{CO}_{2}$ Chemistry Data

The following hydrographic and $\mathrm{CO}_{2}$ chemistry data are listed in this table for each station. The station number, positions, date of station occupation and the sea floor depth (m) are listed in each heading. The temperature, salinity and the concentrations of dissolved oxygen, phosphate, nitrate and silicate were measured by the staff of ODF/SIO.

Bot No. $\quad=\quad$ Niskin bottle number of each sample.

Depth $\mathrm{m} \quad=\quad$ Depth (meters) of sample computed from the measured pressure.

Temp deg C $\quad=$ Temperature of water $\left({ }^{\circ} \mathrm{C}\right)$.

Pot Temp deg C $\quad=\quad$ Potential temperature of water $\left({ }^{\circ} \mathrm{C}\right)$ computed for the sea surface.

Salinity $0 / 00 \quad=\quad$ Measured salinity (PSU).

Sigma Theta $\quad=$ Potential density (ppt) of seawater at sea surface.

Oxy, PO4, NO3, SiO3 = Measured concentrations $(\mu \mathrm{mol} / \mathrm{kg})$ of dissolved oxygen, phosphate, nitrate and silicate in seawater.

AOU $=$ Apparent oxygen utilization $(\mu \mathrm{mol} / \mathrm{kg})$ computed for the potential temperature.

TCO2 Obs and $\mathrm{S}=35=$ The total $\mathrm{CO}_{2}$ concentration $(\mu \mathrm{mol} / \mathrm{kg})$ dissolved in seawater observed and normalized to a salinity of 35.00 PSU.

$\mathrm{pCO} 2 @ 20$ and @Theta $=\quad \mathrm{pCO}_{2}$ in seawater $(\mu \mathrm{atm})$ observed at $20.0^{\circ} \mathrm{C}$ and that corrected to the potential temperature.

Total Alk. Calc $=$ Total alkalinity $(\mu \mathrm{eq} / \mathrm{kg})$ computed using the measured total $\mathrm{CO}_{2}$ concentration and $\mathrm{pCO}_{2}$ at $20.0^{\circ} \mathrm{C}$.

(PALK)s $\quad=$ Potential alkalinity (=[total alkalinity $]+[$ nitrate $]$ ) normalized to a salinity of 35.00 PSU. 
Lamont-Doherty Earth Observatory of Columbia University

(TCO2) $5=35$ roject/Expedition is TUNES/2 WOCE P17C/P16C 1991 woCE Line P17C Station 124 Latitude 6-00.3S Longitude 135-00.2W Date 7/21/91 Bottom Depth 4562

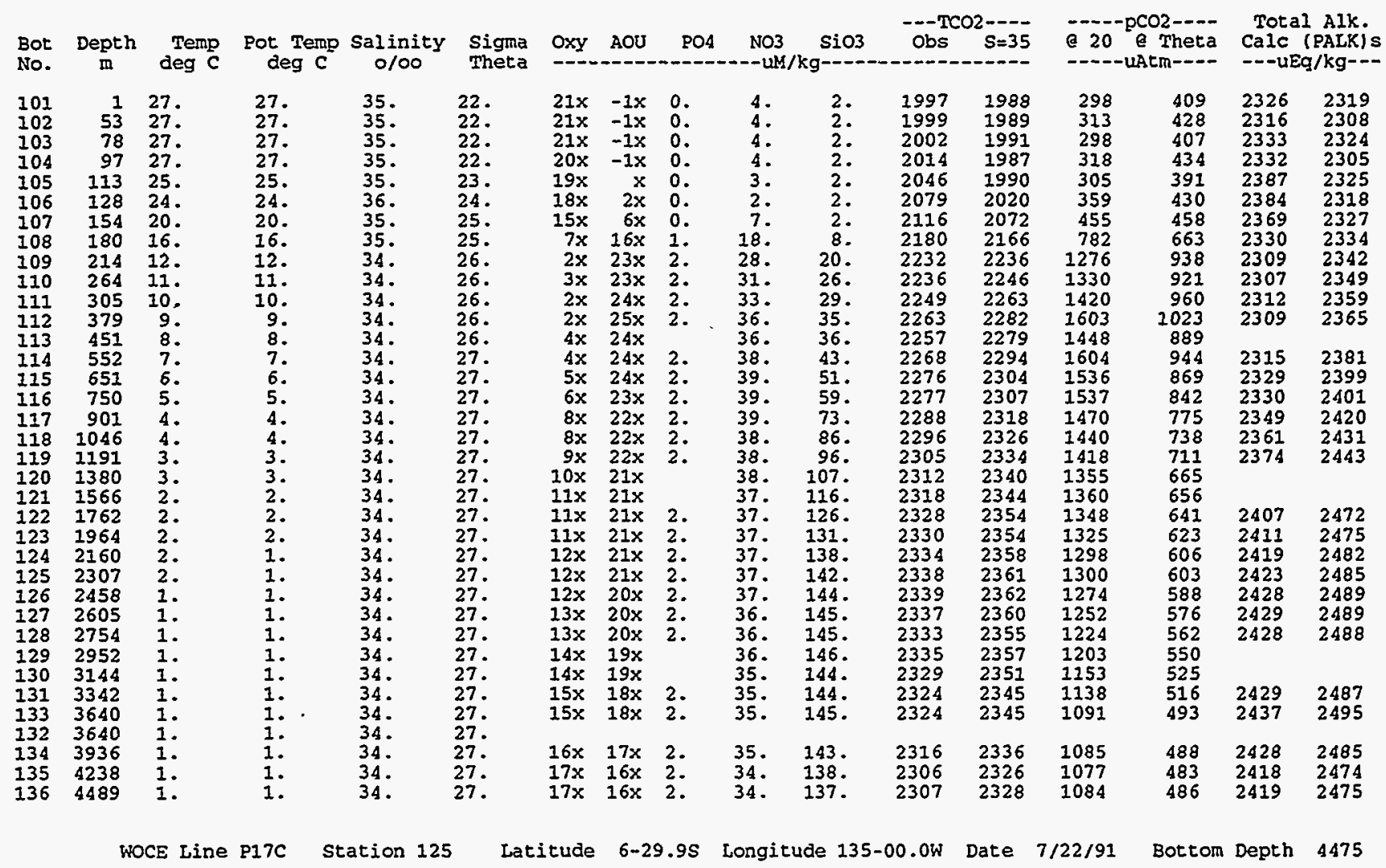

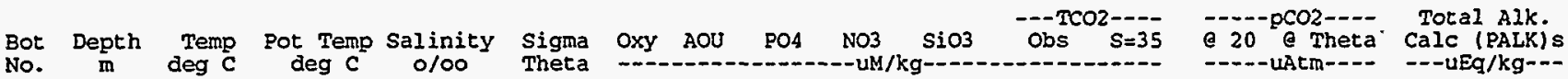

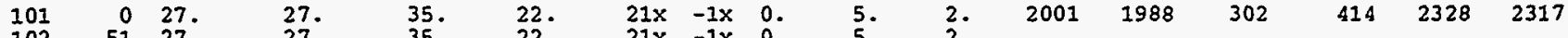

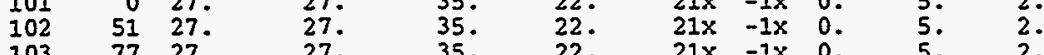

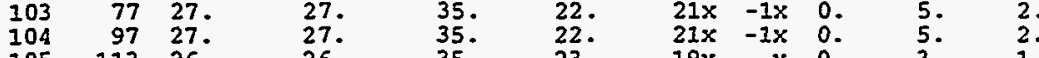

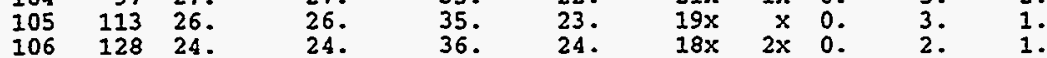

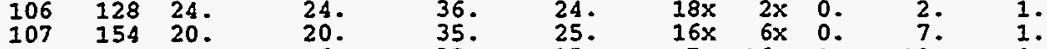

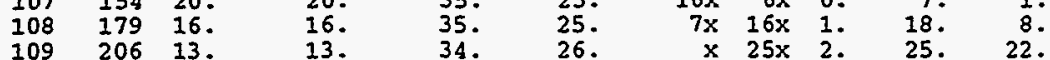

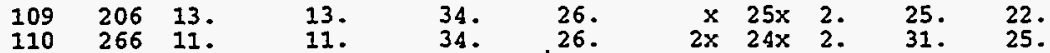

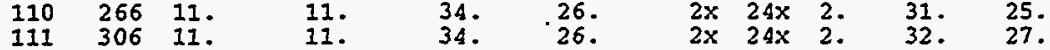

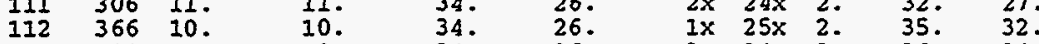

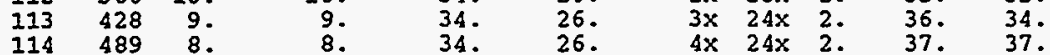

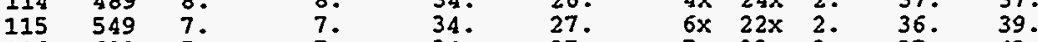

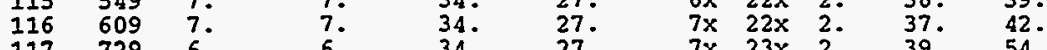

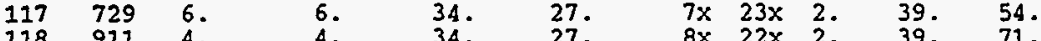

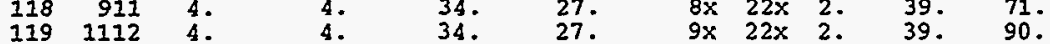

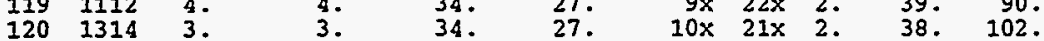

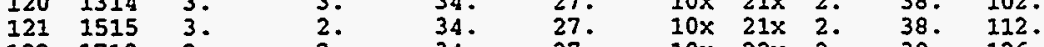

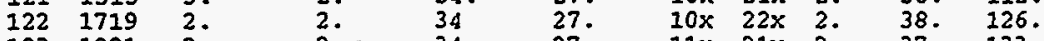

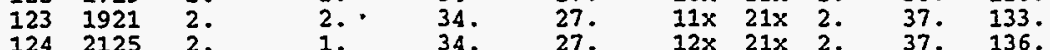

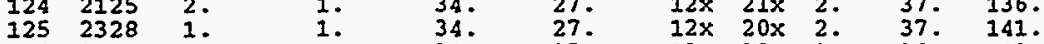

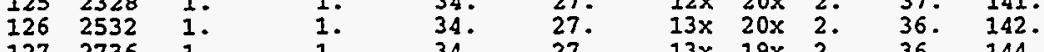

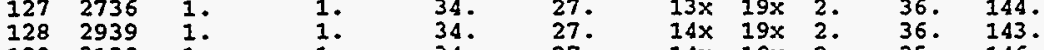

$\begin{array}{lllllllll}129 & 3138 & 1 . & 1 . & 34 . & 27 . & 14 \times 18 \times 2 . & 35 . & 146 . \\ 130 & 3335 & 1 . & 1 . & 34 . & 27 . & 15 \times 18 \times 2 . & 35 . & 144 .\end{array}$

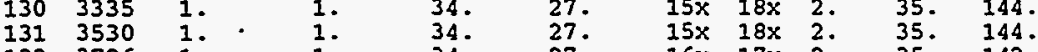

$\begin{array}{lllllllll}132 & 3726 & 1 . & 1 . & 34 . & 27 . & 16 \times 17 \times 2 . & 35 . & 142 .\end{array}$

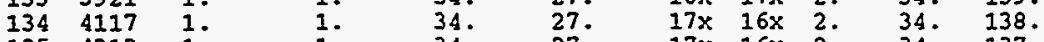

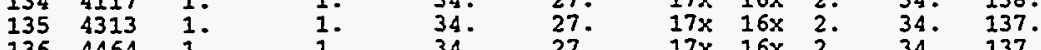


Lamont-Doherty Earth Observatory of Columbia University

Printed on $12 / 06 / 93$

Page 2

(TCO2) $\mathrm{s}=35=\mathrm{TCO} 2$ obs $\mathrm{X}(35, \mathrm{Sa})$

(PALK) $s=$ Potential Alkalinity $=($ TALK + NO3) $\times(35 / \mathrm{Sal})$

WOCE Line P17C Station 126 Latitude 6-59.9S Longitude 135-00.2W Date 7/22/91 Bottom Depth 4393

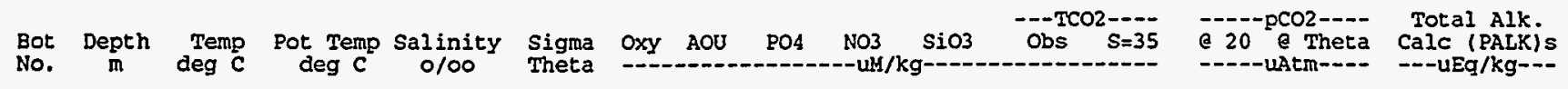

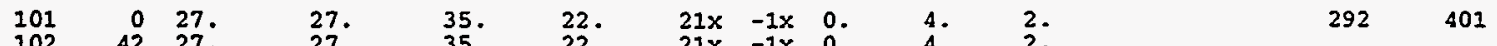

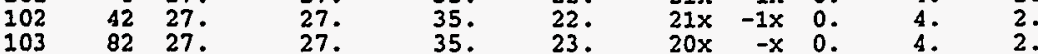

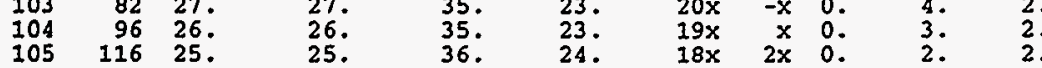

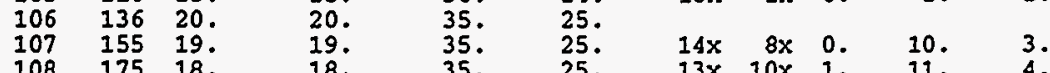

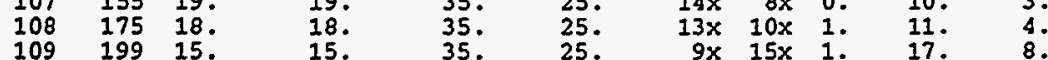

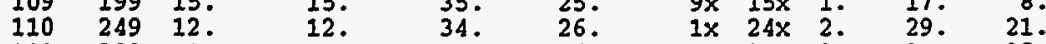

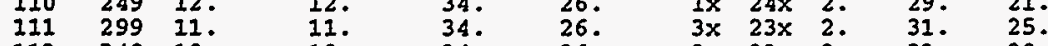

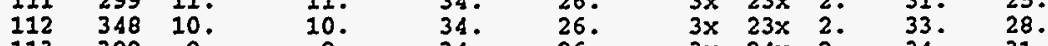

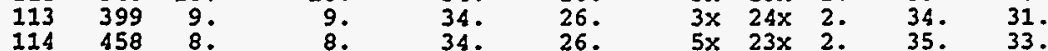

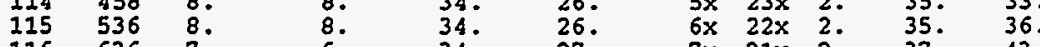

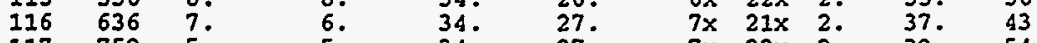

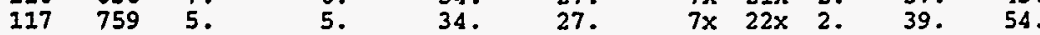

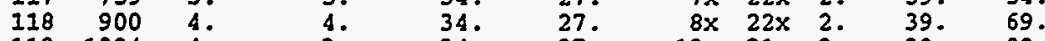

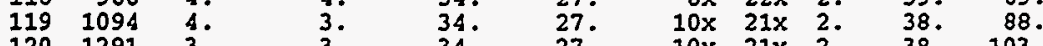

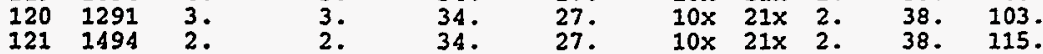

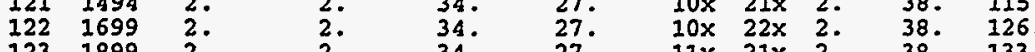

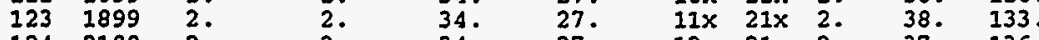

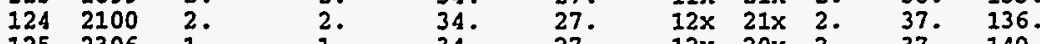

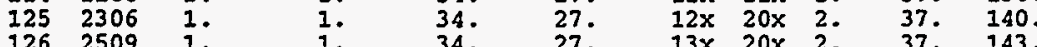

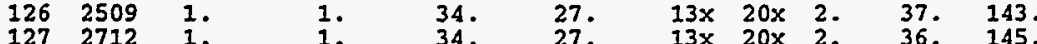

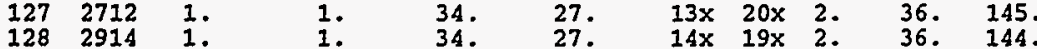

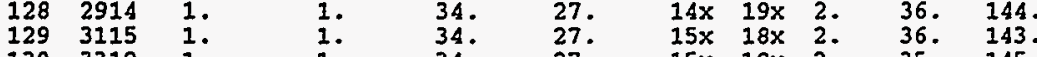

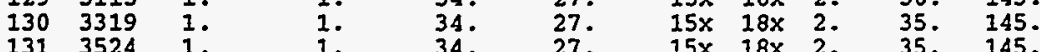

$\begin{array}{lllllllll}131 & 3524 & 1 . & 1 . & 34 . & 27 . & 15 \times 18 \times 2 . & 35 . & 145 .\end{array}$

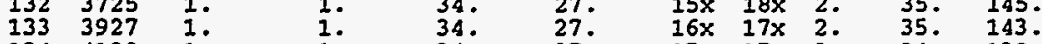

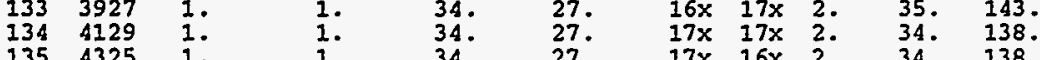

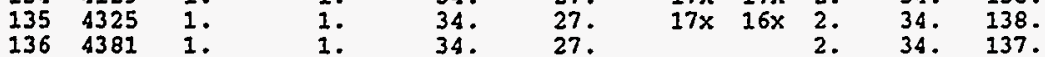

WOCE Line P17C Station 127 Latitude 7-30.2S Longitude 135-00.1W Date 7/22/91 Bottom Depth 4400

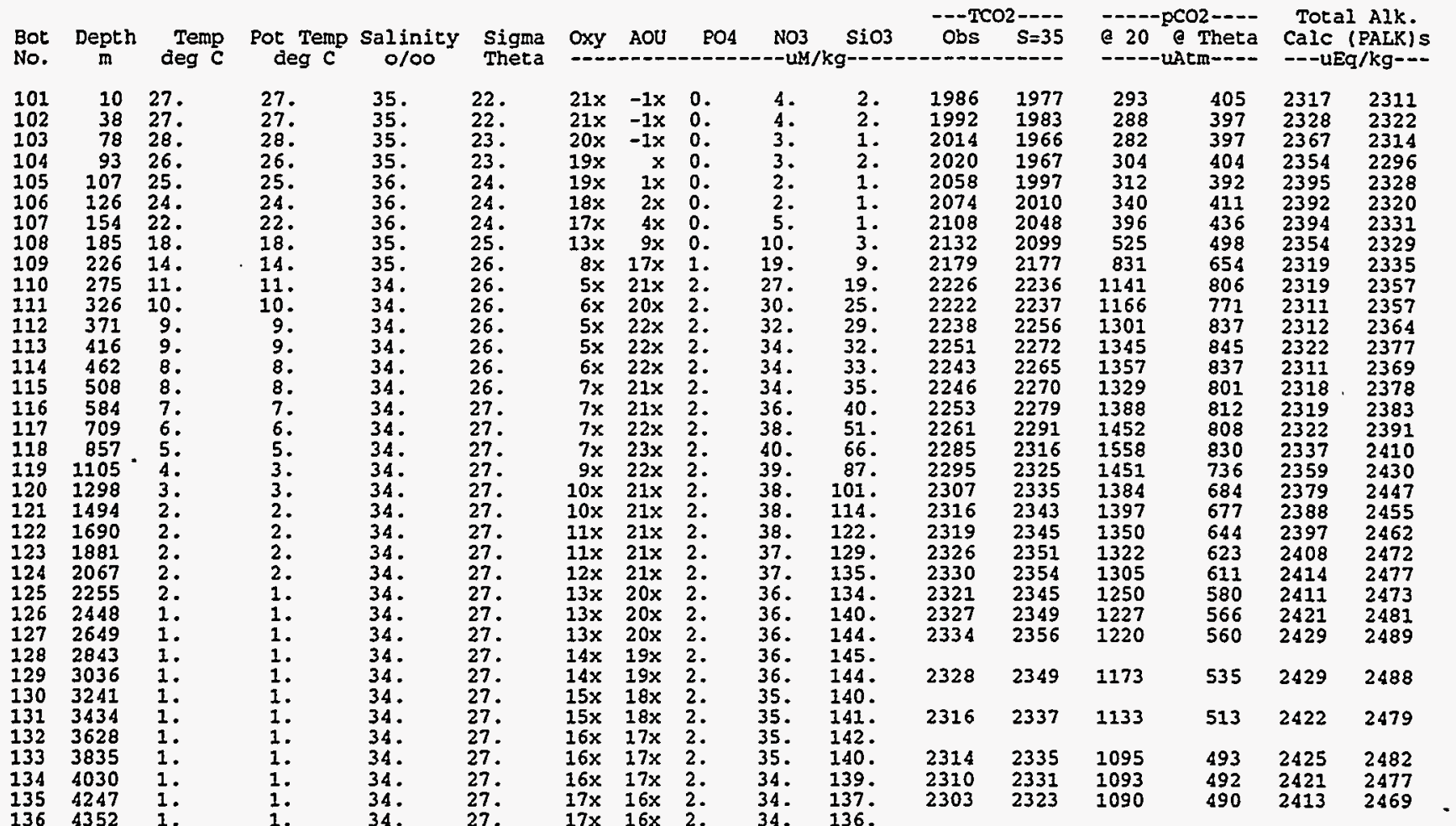


Lamont-Doherty Earth Observatory of Columbia University

Printed on $12 / 06 / 93$

Page 3 Project/Expedition is TUN

(TCO2) $s=35=$ TCO2 Obs $X(35 / \mathrm{Sal}) \quad$ (PALK) $s=$ Potential Alkalinity = (TALK + NO3) X (35 / Sal) HOCE Line P17C station 128 Latitude 7-59.9S Longitude 135-00.0W Date 7/23/91 Bottom Depth 4525

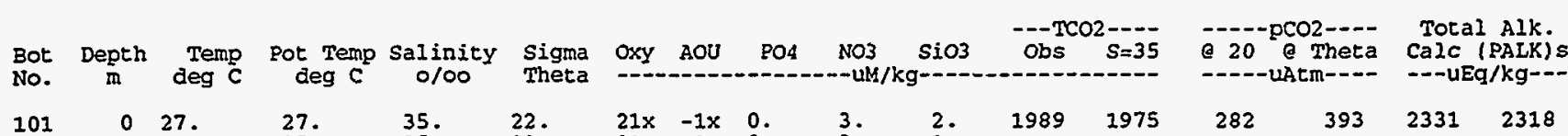

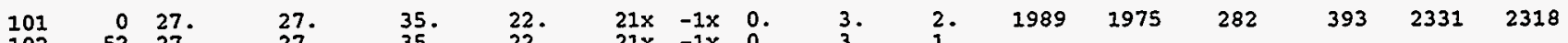

102

103

$\begin{array}{lll}104 & 102 & 26 . \\ 105 & 143 & 22\end{array}$

10618419.

10723013.

$108282 \quad 11$.

109332

$110 \quad 3$

112

113

1145847.

1156616 .

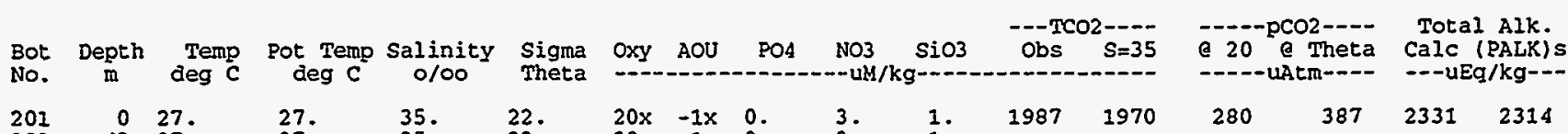


Lamont-Doherty Earth Observatory of Columbia University

Printed on $12 / 06 / 93$

Page 4

$(\mathrm{TCO} 2)_{\mathrm{s}=35}=\mathrm{TCO} 2$ obs $\mathrm{X}(35, \mathrm{Sal})$

(PALK)s = Potential Alkalinity $=($ TALK + NO3) $\times(35$ ( Sal)

WoCE Line P17C Station 130 Latitude 9-00.0s Longitude 135-00.1W Date $7 / 23 / 91$ Bottom Depth 4494

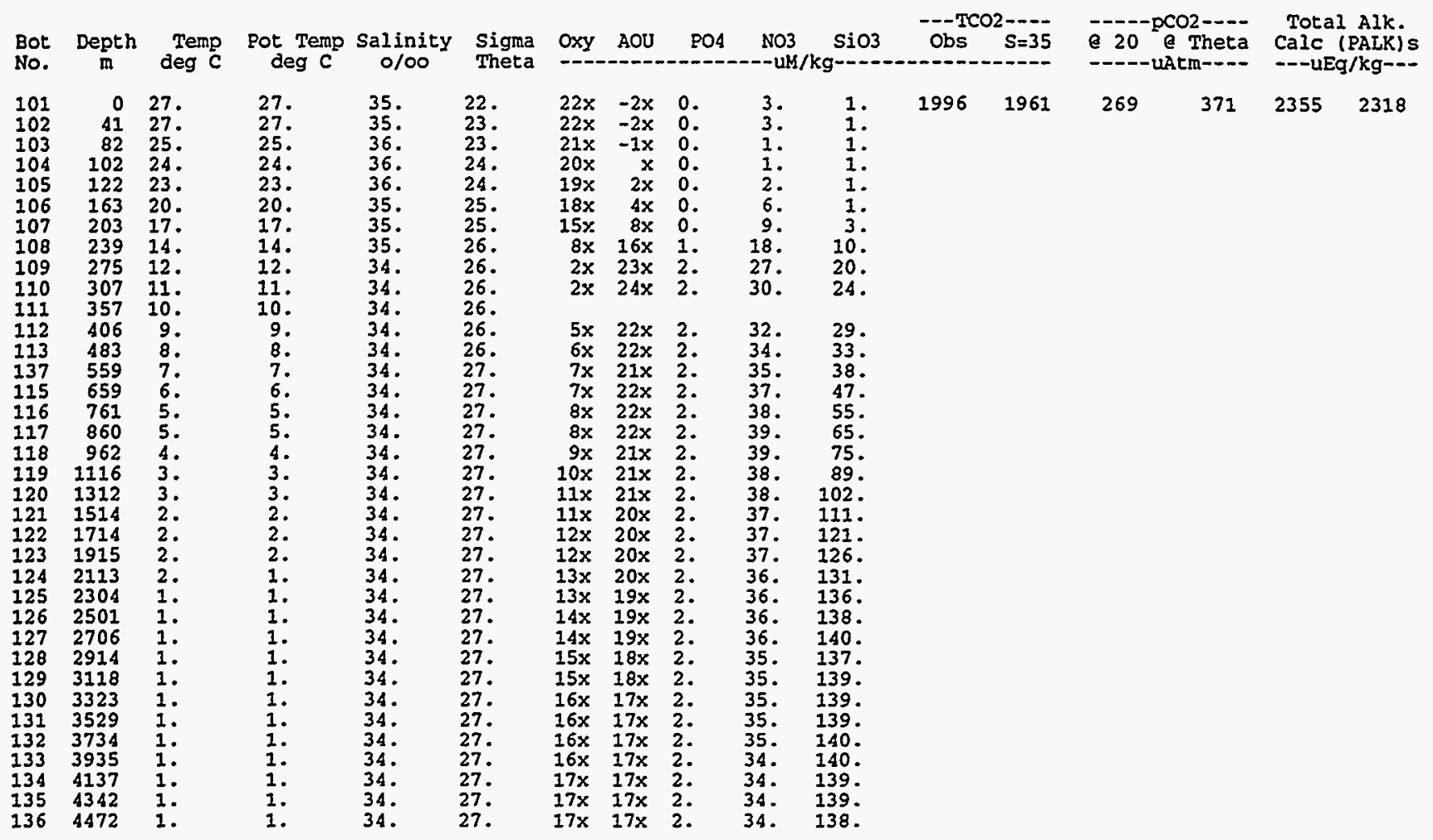

WOCE Line P17C Station 131 Latitude 9-30.1S Longitude 135-00.0W Date 7/23/91 Bottom Depth 4527

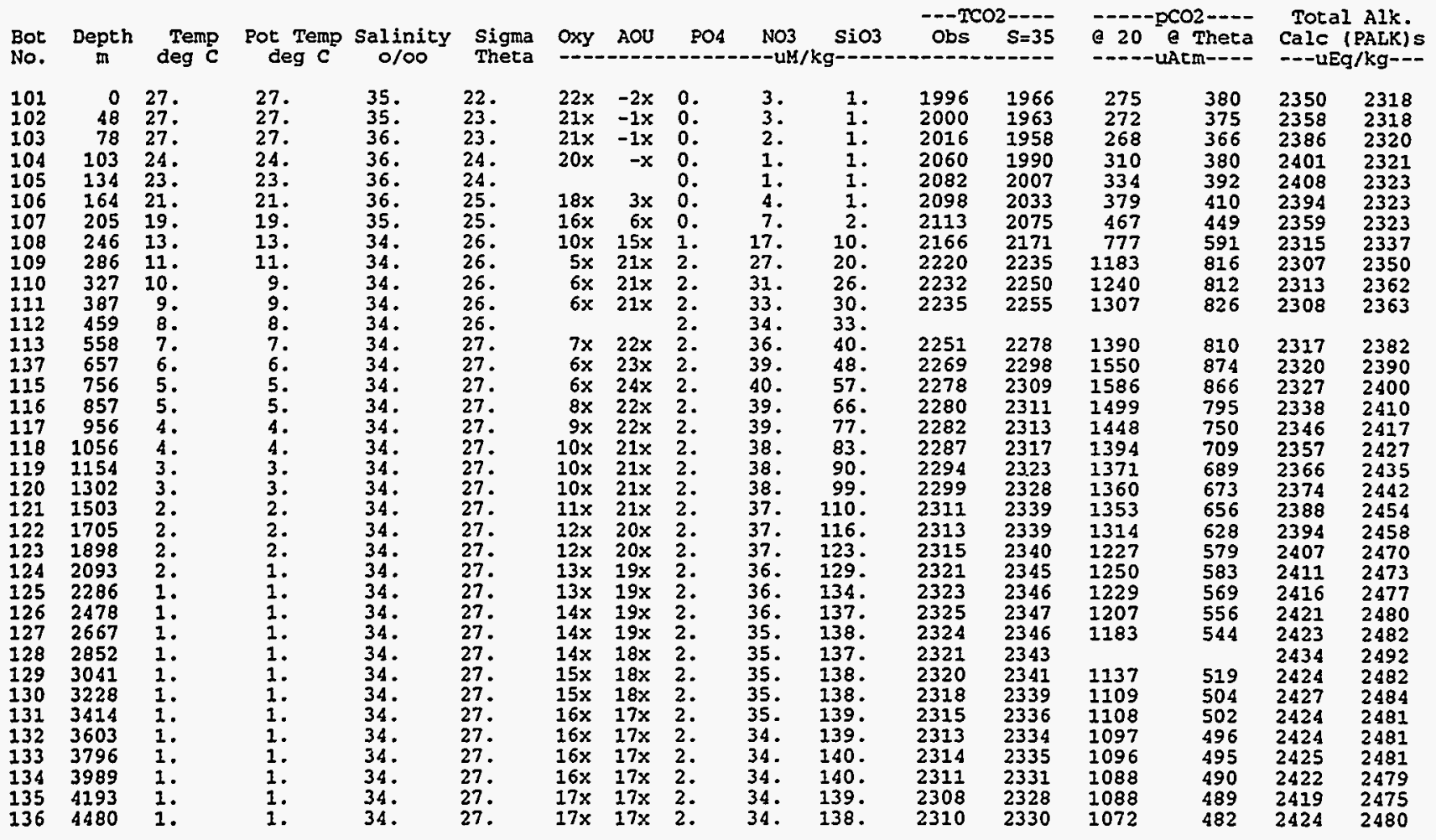


Iamont-Doherty Earth Observatory of Columbia University

Printed on $12 / 06 / 93$

Page 5

(TCO2) $s=35=$ Project/Expedition is TUNES/2 WOCE P17C/ Pl6C 19 (PALK) $=$ Potential Alkalinity = (TALK + NO3) $\mathrm{X}$ (35/Sal)

WOCE Line P17C station 132 Latitude 10-02.4S Longitude 134-57.6W Date 7/24/91 Bottom Depth 4450

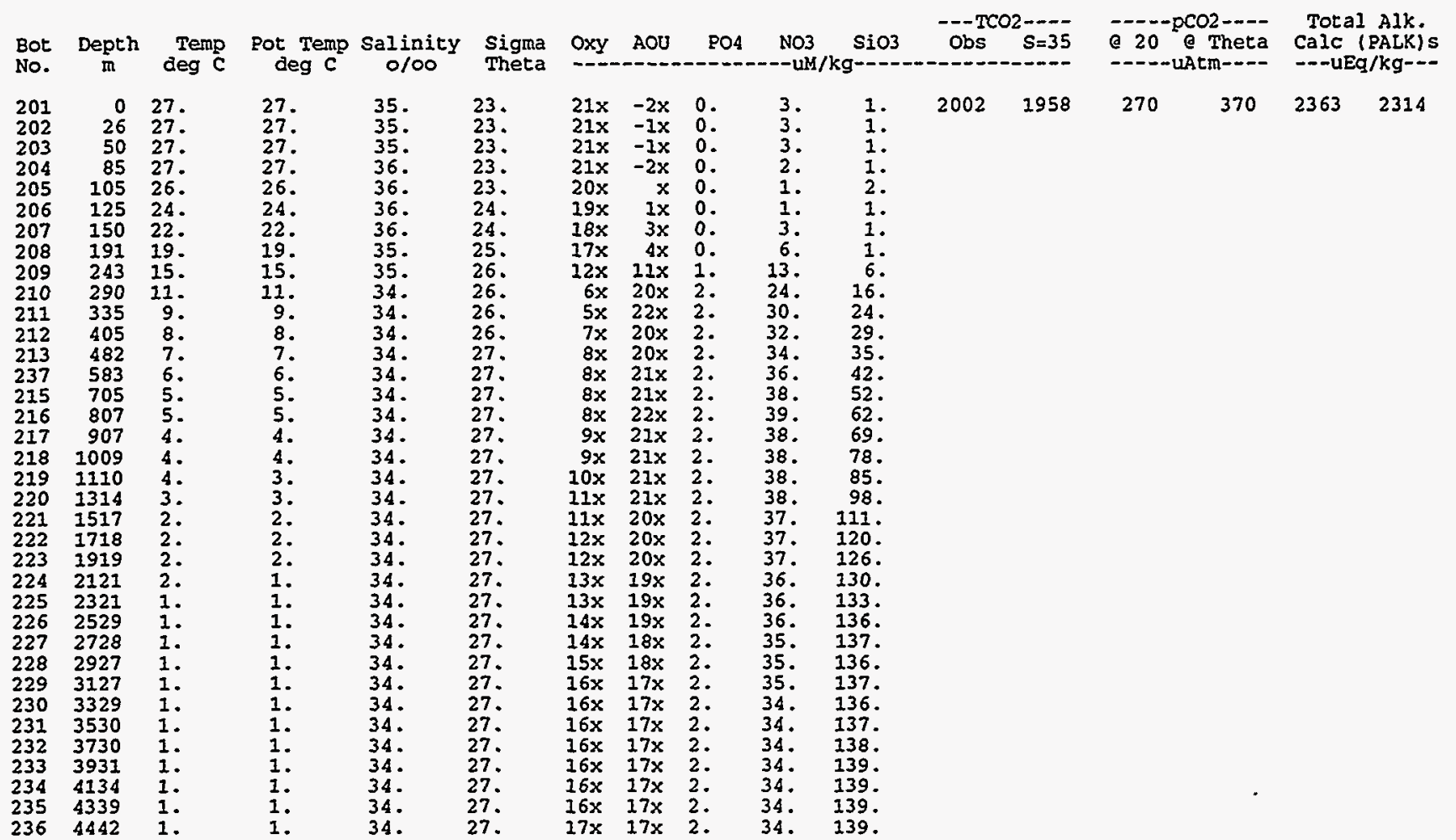

WOCE Line P17C Station 133 Latitude 10-29.0S Longitude 134-53.9W Date 7/24/91 Bottom Depth 4320

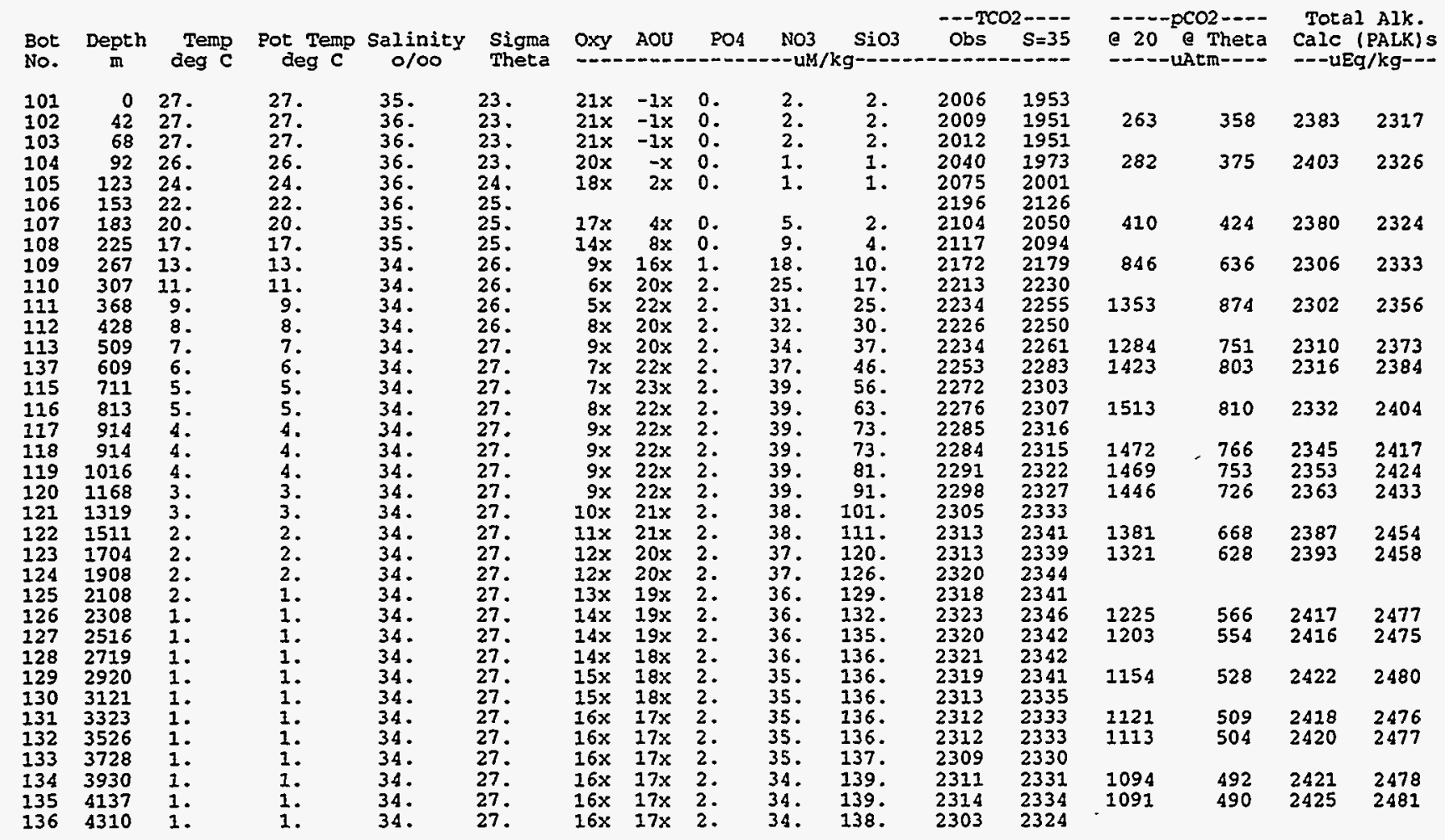


Lamont-Doherty Earth Observatory of Columbia University

Printed on $12 / 06 / 93$

Page 6

Project/Expedition is TUNES/2 WOCE P17C/P16C 1991

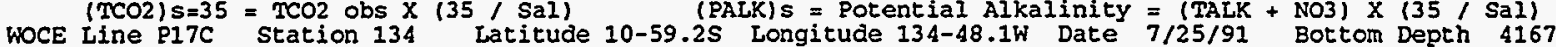

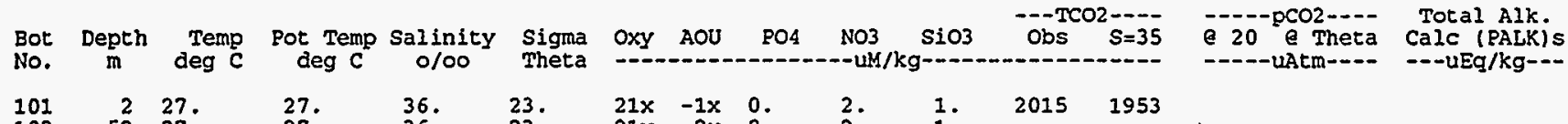

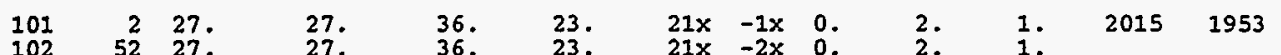

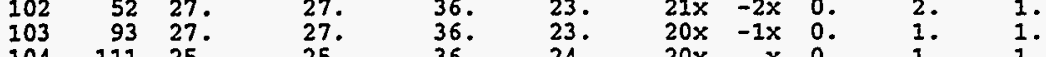

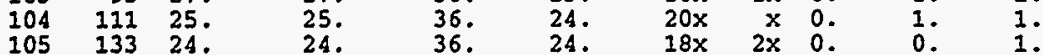

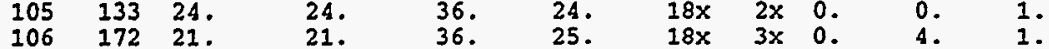

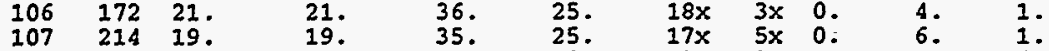

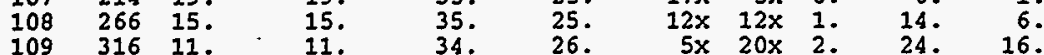

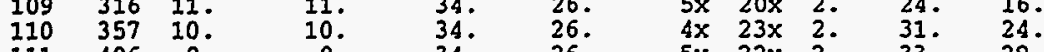

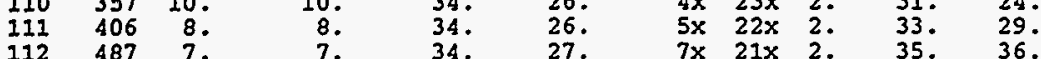

$\begin{array}{lllllllllll}112 & 487 & 7 . & 7 . & 34 . & 27 . & 7 \times & 21 \times & 2 . & 35 . & 36 . \\ 113 & 557 & 6 . & 6 . & 34 . & 27 . & 7 \times & 22 \times & 2 . & 37 . & 42 .\end{array}$

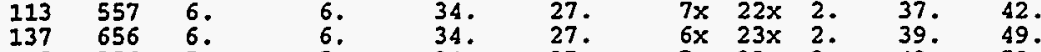

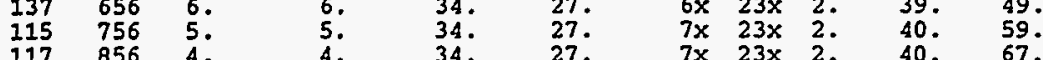

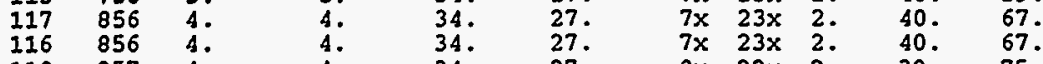

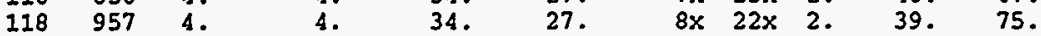

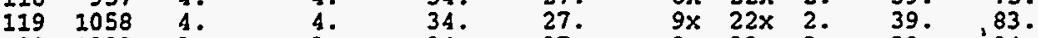

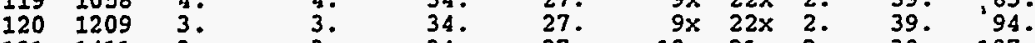

$121 \quad 141$

1221613

1231814

1252216

2367

2518
2670

\begin{tabular}{|c|c|c|c|c|c|c|c|c|c|c|}
\hline $\begin{array}{l}\text { Bot } \\
\text { No. }\end{array}$ & $\underset{\mathrm{m}}{\text { Depth }}$ & $\begin{array}{l}\text { Temp } \\
\operatorname{deg} C\end{array}$ & $\begin{array}{l}\text { Pot Temp } \\
\operatorname{deg} c\end{array}$ & $\begin{array}{c}\text { Salinity } \\
0 / 00\end{array}$ & $\begin{array}{l}\text { Sigma } \\
\text { Theta }\end{array}$ & Oxy & $A O U$ & PO4 & $\mathrm{NO} 3$ & \\
\hline $\begin{array}{l}01 \\
02 \\
03 \\
04 \\
05 \\
06 \\
07 \\
08 \\
09 \\
10 \\
11 \\
12 \\
13 \\
37\end{array}$ & $\begin{array}{r}0 \\
31 \\
66 \\
101 \\
122 \\
153 \\
182 \\
213 \\
265 \\
315 \\
315 \\
367 \\
427 \\
509 \\
611 \\
711 \\
814 \\
915 \\
1017 \\
1220 \\
1423 \\
1624 \\
1828 \\
2032 \\
2236 \\
2439 \\
2643 \\
2845 \\
3049 \\
3252 \\
3455 \\
3658 \\
3859 \\
4055\end{array}$ & $\begin{array}{l}27 . \\
27 . \\
27 . \\
24 . \\
23 . \\
22 . \\
20 . \\
17 . \\
13 . \\
11 . \\
11 . \\
9 . \\
8 . \\
7 . \\
6 . \\
5 . \\
5 . \\
4 . \\
4 . \\
3 . \\
3 . \\
2 . \\
2 . \\
2 . \\
2 . \\
1 . \\
1 . \\
1 . \\
1 . \\
1 . \\
1 . \\
1 . \\
1 . \\
1 . \\
1 .\end{array}$ & $\begin{array}{l}27 . \\
27 . \\
27 . \\
24 . \\
23 . \\
21 . \\
20 . \\
17 . \\
13 . \\
11 . \\
11 . \\
9 . \\
8 . \\
7 . \\
6 . \\
5 . \\
5 . \\
4 . \\
4 . \\
3 . \\
2 . \\
2 . \\
2 . \\
2 . \\
1 . \\
1 . \\
1 . \\
1 . \\
1 . \\
1 . \\
1 . \\
1 . \\
1 . \\
1 . \\
1 . \\
1 .\end{array}$ & $\begin{array}{l}36 . \\
36 . \\
36 . \\
36 . \\
36 . \\
36 . \\
35 . \\
35 . \\
34 . \\
34 . \\
34 . \\
34 . \\
34 . \\
34 . \\
34 . \\
34 . \\
34 . \\
34 . \\
34 . \\
34 . \\
34 . \\
34 . \\
34 . \\
34 . \\
34 . \\
34 . \\
34 . \\
34 . \\
34 . \\
34 . \\
34 . \\
34 . \\
34 . \\
34 . \\
34\end{array}$ & $\begin{array}{l}23 . \\
23 . \\
23 . \\
24 . \\
24 . \\
25 . \\
25 . \\
25 . \\
26 . \\
26 . \\
26 . \\
26 . \\
26 . \\
27 . \\
27 . \\
27 . \\
27 . \\
27 . \\
27 . \\
27 . \\
27 . \\
27 . \\
27 . \\
27 . \\
27 . \\
27 . \\
27 . \\
27 . \\
27 . \\
27 . \\
27 . \\
27 . \\
27 . \\
27 . \\
27 .\end{array}$ & $\begin{array}{r}21 x \\
21 x \\
19 x \\
19 x \\
18 x \\
17 x \\
15 x \\
8 x \\
3 x \\
3 x \\
4 x \\
6 x \\
7 x \\
6 x \\
6 x \\
7 x \\
7 x \\
8 x \\
9 x \\
10 x \\
11 x \\
12 x \\
13 x \\
14 x \\
14 x \\
14 x \\
15 x \\
15 x \\
16 x \\
16 x \\
16 x \\
16 x \\
16 x \\
17 x \\
17 x\end{array}$ & $\begin{array}{r}-1 x \\
-1 x \\
1 x \\
1 x \\
3 x \\
5 x \\
8 x \\
17 x \\
23 x \\
23 x \\
23 x \\
22 x \\
21 x \\
23 x \\
23 x \\
23 x \\
23 x \\
23 x \\
22 x \\
21 x \\
21 x \\
20 x \\
19 x \\
19 x \\
19 x \\
18 x \\
18 x \\
18 x \\
17 x \\
17 x \\
17 x \\
17 x \\
17 x \\
16 x \\
16 x\end{array}$ & $\begin{array}{l}0 . \\
0 . \\
0 . \\
0 . \\
0 . \\
0 . \\
0 . \\
1 . \\
2 . \\
2 . \\
2 . \\
2 . \\
2 . \\
2 . \\
2 . \\
2 . \\
2 . \\
2 . \\
2 . \\
2 . \\
2 . \\
2 . \\
2 . \\
2 . \\
2 . \\
2 . \\
2 . \\
2 . \\
2 . \\
2 . \\
2 . \\
2 . \\
2 .\end{array}$ & $\begin{array}{l}2 . \\
1 . \\
0 . \\
1 . \\
4 . \\
5 . \\
9 . \\
19 . \\
27 . \\
27 . \\
31 . \\
33 . \\
35 . \\
38 . \\
40 . \\
40 . \\
40 . \\
40 . \\
39 . \\
38 . \\
37 . \\
37 . \\
36 . \\
36 . \\
35 . \\
35 . \\
35 . \\
35 . \\
35 . \\
34 . \\
34 . \\
34 . \\
34 . \\
34 . \\
34 .\end{array}$ & $\begin{array}{r}9 \\
10 \\
11 \\
12 \\
12 \\
12 \\
13 \\
13 \\
13 \\
13 \\
13 \\
13 \\
13 \\
13\end{array}$ \\
\hline
\end{tabular}


Iamont-Doherty Earth Observatory of Columbia University

Printed on $12 / 06 / 93$

Page 7

$(T C O 2) s=35=T C O 2$ obs $X(35 / S a l) \quad$ (PALK) = Potential Alkalinity = (TALK + NO3) X (35/Sal) wOCE Line P17C Station 136 Latitude 11-58.2S Longitude 134-35.8W Date 7/25/91 Bottom Depth 4140

\begin{tabular}{|c|c|c|c|c|c|c|c|c|c|c|}
\hline $\begin{array}{l}\text { Bot } \\
\text { No. }\end{array}$ & $\begin{array}{l}\text { Depth } \\
\text { In }\end{array}$ & $\begin{array}{l}\text { Temp } \\
\text { deg C }\end{array}$ & $\begin{array}{c}\text { Pot Temp } \\
\text { deg } c\end{array}$ & $\begin{array}{c}\text { Salinity } \\
0 / 00\end{array}$ & $\begin{array}{l}\text { Sigma } \\
\text { Theta }\end{array}$ & oxy & AOU & PO4 & $\begin{array}{l}\text { NO3 } \\
-- \text { UM/ }\end{array}$ & $\mathrm{SiO}$ \\
\hline $\begin{array}{l}101 \\
102 \\
103 \\
104 \\
105 \\
106 \\
107 \\
108 \\
109 \\
110 \\
111 \\
112 \\
113 \\
137 \\
115 \\
116 \\
117 \\
118 \\
119 \\
120 \\
121 \\
122 \\
123 \\
124 \\
125 \\
126 \\
127 \\
128 \\
129 \\
130 \\
131 \\
132 \\
133 \\
134 \\
135\end{array}$ & $\begin{array}{r}0 \\
38 \\
73 \\
103 \\
144 \\
195 \\
245 \\
285 \\
326 \\
365 \\
426 \\
486 \\
545 \\
605 \\
701 \\
799 \\
897 \\
995 \\
1095 \\
1195 \\
1295 \\
1494 \\
1693 \\
1892 \\
2091 \\
2287 \\
2481 \\
2678 \\
2874 \\
3071 \\
3270 \\
3468 \\
3668 \\
3870 \\
4000 \\
4147\end{array}$ & $\begin{array}{r}26 . \\
27 . \\
27 . \\
27 . \\
23 . \\
19 . \\
15 . \\
12 . \\
10 . \\
9 . \\
8 . \\
8 . \\
7 . \\
6 . \\
6 . \\
5 . \\
4 . \\
4 . \\
4 . \\
3 . \\
3 . \\
3 . \\
2 . \\
2 . \\
2 . \\
1 . \\
1 . \\
1 . \\
1 . \\
1 . \\
1 . \\
1 . \\
1 . \\
1 . \\
1 . \\
1 .\end{array}$ & $\begin{array}{l}26 . \\
27 . \\
27 . \\
26 . \\
23 . \\
19 . \\
15 . \\
12 . \\
10 . \\
9 . \\
8 . \\
8 . \\
7 . \\
6 . \\
6 . \\
5 . \\
4 . \\
4 . \\
3 . \\
3 . \\
3 . \\
2 . \\
2 . \\
2 . \\
1 . \\
1 . \\
1 . \\
1 . \\
1 . \\
1 . \\
1 . \\
1 . \\
1 . \\
1 . \\
1 . \\
1 .\end{array}$ & $\begin{array}{l}35 . \\
36 . \\
36 . \\
36 . \\
36 . \\
35 . \\
35 . \\
34 . \\
34 . \\
34 . \\
34 . \\
34 . \\
34 . \\
34 . \\
34 . \\
34 . \\
34 . \\
34 . \\
34 . \\
34 . \\
34 . \\
34 . \\
34 . \\
34 . \\
34 . \\
34 . \\
34 . \\
34 . \\
34 . \\
34 . \\
34 . \\
34 . \\
34 . \\
34 . \\
34 . \\
34 .\end{array}$ & $\begin{array}{l}23 . \\
23 . \\
23 . \\
23 \\
24 . \\
25 . \\
25 . \\
26 . \\
26 . \\
26 . \\
26 . \\
26 . \\
27 . \\
27 . \\
27 . \\
27 . \\
27 . \\
27 . \\
27 . \\
27 . \\
27 . \\
27 . \\
27 . \\
27 . \\
27 . \\
27 . \\
27 . \\
27 . \\
27 . \\
27 . \\
27 . \\
27 . \\
27 . \\
27 . \\
27 . \\
27 .\end{array}$ & $\begin{array}{r}21 x \\
21 x \\
21 x \\
18 x \\
12 x \\
8 x \\
5 x \\
4 x \\
6 x \\
8 x \\
7 x \\
7 x \\
7 x \\
8 x \\
7 x \\
8 x \\
9 x \\
10 x \\
10 x \\
11 x \\
12 x \\
13 x \\
14 x \\
14 x \\
14 x \\
14 x \\
15 x \\
15 x \\
15 x \\
16 x \\
16 x \\
16 x \\
17 x \\
17 x\end{array}$ & $\begin{array}{r}-1 x \\
-1 x \\
-1 x \\
2 x \\
12 x \\
17 x \\
22 x \\
23 x \\
21 x \\
20 x \\
21 x \\
22 x \\
23 x \\
22 x \\
23 x \\
23 x \\
21 x \\
21 x \\
22 x \\
21 x \\
20 x \\
19 x \\
19 x \\
19 x \\
19 x \\
19 x \\
18 x \\
18 x \\
17 x \\
17 x \\
17 x \\
17 x \\
17 x \\
16 x\end{array}$ & $\begin{array}{l}0 . \\
0 . \\
0 . \\
0 . \\
1 . \\
1 . \\
2 . \\
2 . \\
2 . \\
2 . \\
2 . \\
2 . \\
2 . \\
2 . \\
2 . \\
2 . \\
2 . \\
2 . \\
2 . \\
2 . \\
2 . \\
2 . \\
2 . \\
2 . \\
2 . \\
2 . \\
2 . \\
2 . \\
2 . \\
2 . \\
2 . \\
2 . \\
2 . \\
2 .\end{array}$ & $\begin{array}{l}1 . \\
1 . \\
1 . \\
2 . \\
13 . \\
20 . \\
27 . \\
30 . \\
32 . \\
33 . \\
35 . \\
37 . \\
39 . \\
39 . \\
40 . \\
40 . \\
38 . \\
38 . \\
39 . \\
38 . \\
37 . \\
36 . \\
36 . \\
36 . \\
36 . \\
35 . \\
35 . \\
35 . \\
35 . \\
35 . \\
34 . \\
34 . \\
34 . \\
34 .\end{array}$ & $\begin{array}{r}1 . \\
1 . \\
1 . \\
2 . \\
5 . \\
12 . \\
20 . \\
23 . \\
29 . \\
32 . \\
36 . \\
41 . \\
49 . \\
56 . \\
67 . \\
76 . \\
83 . \\
90 . \\
96 . \\
107 . \\
113 . \\
118 . \\
126 . \\
131 . \\
133 . \\
136 . \\
136 . \\
136 . \\
136 . \\
135 . \\
134 . \\
133 . \\
133 . \\
132 .\end{array}$ \\
\hline
\end{tabular}

WOCE Line P17C Station 137 Latitude 12-26.9S Longitude 134-30.0W Date 7/26/91 Bottom Depth 4237

\begin{tabular}{|c|c|c|c|c|c|c|c|c|c|c|c|c|c|c|c|c|}
\hline $\begin{array}{l}\text { Bot } \\
\text { No. }\end{array}$ & $\begin{array}{l}\text { Depth } \\
\text { m }\end{array}$ & $\begin{array}{l}\text { Temp } \\
\text { deg C }\end{array}$ & $\begin{array}{l}\text { Pot Temp } \\
\text { deg } c\end{array}$ & $\begin{array}{c}\text { Salinity } \\
0 / 00\end{array}$ & $\begin{array}{l}\text { Sigme } \\
\text { Theta }\end{array}$ & Oxy & AOU & PO4 & NO3 & $\mathrm{SiO} 3$ & \multicolumn{2}{|c|}{$\begin{array}{ll}--\mathrm{TCO} 2---- \\
\text { Obs } \quad S=35\end{array}$} & \multicolumn{2}{|c|}{$\begin{array}{l}---p C O 2--- \\
\text { e } 20 \text { Theta }\end{array}$} & \multicolumn{2}{|c|}{$\begin{array}{l}\text { Total Alk. } \\
\text { Calc (PALK)s } \\
-- \text {-uEg/kg- }\end{array}$} \\
\hline $\begin{array}{l}101 \\
102 \\
103 \\
104 \\
105 \\
106 \\
107 \\
108 \\
109 \\
110 \\
111 \\
112 \\
113 \\
137 \\
115 \\
116 \\
117 \\
118 \\
119 \\
120 \\
121 \\
122 \\
123 \\
124 \\
125 \\
126 \\
127 \\
128 \\
129 \\
130 \\
131 \\
132 \\
133 \\
134 \\
135 \\
136\end{array}$ & $\begin{array}{r}1 \\
42 \\
73 \\
104 \\
130 \\
155 \\
186 \\
205 \\
257 \\
307 \\
358 \\
409 \\
460 \\
511 \\
612 \\
713 \\
815 \\
917 \\
1018 \\
1119 \\
1272 \\
1425 \\
1626 \\
1831 \\
2033 \\
2236 \\
2439 \\
2643 \\
2847 \\
3052 \\
3253 \\
3455 \\
3659 \\
3862 \\
4064 \\
4222\end{array}$ & $\begin{array}{l}26 . \\
26 . \\
26 . \\
26 . \\
24 . \\
23 . \\
21 . \\
21 . \\
17 . \\
13 . \\
10 . \\
9 . \\
8 . \\
7 . \\
6 . \\
6 . \\
5 . \\
4 . \\
4 . \\
4 . \\
3 . \\
3 . \\
2 . \\
2 . \\
2 . \\
1 . \\
1 . \\
1 . \\
1 . \\
1 . \\
1 . \\
1 . \\
1 . \\
1 . \\
1 . \\
1 .\end{array}$ & $\begin{array}{l}26 . \\
26 . \\
26 . \\
26 . \\
24 . \\
23 . \\
21 . \\
20 . \\
17 . \\
13 . \\
10 . \\
9 . \\
8 . \\
7 . \\
6 . \\
6 . \\
5 . \\
4 . \\
4 . \\
4 . \\
3 . \\
2 . \\
2 . \\
2 . \\
1 . \\
1 . \\
1 . \\
1 . \\
1 . \\
1 . \\
1 . \\
1 . \\
1 . \\
1 . \\
1 . \\
1 .\end{array}$ & $\begin{array}{l}36 . \\
36 . \\
36 . \\
36 . \\
36 . \\
36 . \\
36 . \\
35 . \\
35 . \\
34 . \\
34 . \\
34 . \\
34 . \\
34 . \\
34 . \\
34 . \\
34 . \\
34 . \\
34 . \\
34 . \\
34 . \\
34 . \\
34 . \\
34 . \\
34 . \\
34 . \\
34 . \\
34 . \\
34 . \\
34 . \\
34 . \\
34 . \\
34 . \\
34 . \\
34 . \\
34 .\end{array}$ & $\begin{array}{l}23 . \\
23 . \\
23 . \\
23 . \\
24 . \\
24 . \\
25 . \\
25 . \\
25 . \\
26 . \\
26 . \\
26 . \\
26 . \\
27 . \\
27 . \\
27 . \\
27 . \\
27 . \\
27 . \\
27 . \\
27 . \\
27 . \\
27 . \\
27 . \\
27 . \\
27 . \\
27 . \\
27 . \\
27 . \\
27 . \\
27 . \\
27 . \\
27 . \\
27 . \\
27 .\end{array}$ & $\begin{array}{r}21 x \\
21 x \\
20 x \\
20 x \\
19 x \\
18 x \\
18 x \\
17 x \\
16 x \\
11 x \\
\\
5 x \\
7 x \\
7 x \\
7 x \\
7 x \\
8 x \\
8 x \\
9 x \\
9 x \\
11 x \\
12 x \\
12 x \\
13 x \\
14 x \\
14 x \\
14 x \\
14 x \\
15 x \\
15 x \\
16 x \\
16 x \\
16 x \\
16 x \\
17 x \\
17 x\end{array}$ & $\begin{array}{r}-1 x \\
-1 x \\
-x \\
-x \\
1 x \\
2 x \\
3 x \\
4 x \\
7 x \\
14 x \\
23 x \\
21 x \\
21 x \\
22 x \\
22 x \\
22 x \\
22 x \\
22 x \\
22 x \\
20 x \\
20 x \\
20 x \\
19 x \\
19 x \\
19 x \\
19 x \\
19 x \\
18 x \\
18 x \\
17 x \\
17 x \\
17 x \\
17 x \\
16 x \\
16 x\end{array}$ & $\begin{array}{l}0 . \\
0 . \\
0 . \\
0 . \\
0 . \\
0 . \\
0 . \\
0 . \\
0 . \\
1 . \\
2 . \\
2 . \\
2 . \\
2 . \\
2 . \\
2 . \\
2 . \\
2 . \\
2 . \\
2 . \\
2 . \\
2 . \\
2 . \\
2 . \\
2 . \\
2 . \\
2 . \\
2 . \\
2 . \\
2 . \\
2 . \\
2 .\end{array}$ & $\begin{array}{r}1 . \\
1 . \\
1 . \\
0 . \\
0 . \\
1 . \\
3 . \\
4 . \\
8 . \\
17 . \\
32 . \\
33 . \\
34 . \\
37 . \\
39 . \\
40 . \\
40 . \\
39 . \\
39 . \\
37 . \\
37 . \\
37 . \\
36 . \\
36 . \\
36 . \\
36 . \\
36 . \\
35 . \\
35 . \\
35 . \\
35 . \\
34 . \\
34 . \\
34 . \\
34 .\end{array}$ & $\begin{array}{r}2 . \\
2 . \\
2 . \\
2 . \\
2 . \\
1 . \\
1 . \\
1 . \\
2 . \\
10 . \\
26 . \\
30 . \\
34 . \\
42 . \\
49 . \\
58 . \\
66 . \\
72 . \\
79 . \\
88 . \\
100 . \\
110 . \\
117 . \\
125 . \\
130 . \\
135 . \\
137 . \\
136 . \\
136 . \\
135 . \\
135 . \\
135 . \\
135 . \\
133 . \\
133 .\end{array}$ & $\begin{array}{l}2021 \\
2024 \\
2028 \\
2039 \\
2066 \\
2080 \\
2095 \\
2098 \\
2108 \\
2160 \\
2240 \\
2235 \\
2235 \\
2223 \\
2261 \\
2274 \\
2279 \\
2282 \\
2287 \\
2286 \\
2296 \\
2303 \\
2308 \\
2312 \\
2315 \\
2317 \\
2320 \\
2318 \\
2313 \\
2311 \\
2310 \\
2307 \\
2309 \\
2301 \\
2298\end{array}$ & $\begin{array}{l}1951 \\
1948 \\
1952 \\
1960 \\
1987 \\
2002 \\
2028 \\
2043 \\
2082 \\
2172 \\
2265 \\
2260 \\
2262 \\
2252 \\
2291 \\
2306 \\
2311 \\
2313 \\
2318 \\
2316 \\
2325 \\
2329 \\
2333 \\
2336 \\
2338 \\
2339 \\
2342 \\
2340 \\
2334 \\
2332 \\
2331 \\
2328 \\
2329 \\
2322 \\
2318\end{array}$ & $\begin{array}{l}1336 \\
1446 \\
1531 \\
1476 \\
1466 \\
1322 \\
1272\end{array}$ & $\begin{array}{l}816 \\
825 \\
823 \\
765 \\
749 \\
643 \\
600\end{array}$ & $\begin{array}{l}2305 \\
2281 \\
2328 \\
2342 \\
2349 \\
2375 \\
2393\end{array}$ & $\begin{array}{l}2365 \\
2349 \\
2401 \\
2424 \\
2421 \\
2442 \\
2457\end{array}$ \\
\hline
\end{tabular}


Lamont-Doherty Earth Observatory of Columbia University

(TCO2) $\mathrm{s}=35=\mathrm{TCO} 2$ obs $\mathrm{X}(35 / \mathrm{Sal}) \quad$ (PALK) $=$ Potential Alkalinity = (TALK + NO3) X (35 / Sal) WOCE Line P17C Station 138 Latitude 12-55.9S Longitude 134-23.8W Date 7/26/91 Bottom Depth 4414

\begin{tabular}{|c|c|c|c|c|c|c|c|c|c|c|}
\hline $\begin{array}{l}\text { Bot } \\
\text { No. }\end{array}$ & $\underset{\text { m }}{\text { Depth }}$ & $\begin{array}{l}\text { Temp } \\
\text { deg C }\end{array}$ & $\begin{array}{c}\text { Pot Temp } \\
\operatorname{deg} c\end{array}$ & $\begin{array}{c}\text { Salinity } \\
0 / 00\end{array}$ & $\begin{array}{l}\text { Sigma } \\
\text { Theta }\end{array}$ & Oxy & AOU & PO4 & & \\
\hline $\begin{array}{l}101 \\
102 \\
103 \\
104 \\
105 \\
106 \\
107 \\
108 \\
109 \\
110 \\
111 \\
112 \\
113 \\
137 \\
115 \\
116 \\
117 \\
118 \\
119 \\
120 \\
121 \\
122 \\
123 \\
124 \\
125 \\
126 \\
127 \\
128 \\
129 \\
130 \\
131 \\
132 \\
133 \\
134 \\
135\end{array}$ & $\begin{array}{r}2 \\
45 \\
85 \\
106 \\
126 \\
167 \\
207 \\
258 \\
334 \\
410 \\
460 \\
532 \\
613 \\
714 \\
816 \\
917 \\
1018 \\
1121 \\
1272 \\
1423 \\
1626 \\
1828 \\
2032 \\
2233 \\
2387 \\
2539 \\
2691 \\
2842 \\
3044 \\
3248 \\
3450 \\
3653 \\
3855 \\
4058 \\
4260 \\
4387\end{array}$ & $\begin{array}{l}26 . \\
26 . \\
26 . \\
25 . \\
24 . \\
22 . \\
20 . \\
17 . \\
11 . \\
9 . \\
8 . \\
7 . \\
6 . \\
5 . \\
5 . \\
4 . \\
4 . \\
3 . \\
3 . \\
3 . \\
2 . \\
2 . \\
2 . \\
1 . \\
1 . \\
1 . \\
1 . \\
1 . \\
1 . \\
1 . \\
1 . \\
1 . \\
1 . \\
1 . \\
1 . \\
1 .\end{array}$ & $\begin{array}{l}26 . \\
26 . \\
26 . \\
25 . \\
24 . \\
22 . \\
20 . \\
17 . \\
11 . \\
9 . \\
8 . \\
7 . \\
6 . \\
5 . \\
5 . \\
4 . \\
4 . \\
3 . \\
3 . \\
3 . \\
2 . \\
2 . \\
1 . \\
1 . \\
1 . \\
1 . \\
1 . \\
1 . \\
1 . \\
1 . \\
1 . \\
1 . \\
1 . \\
1 . \\
1 . \\
1 .\end{array}$ & $\begin{array}{l}36 . \\
36 . \\
36 . \\
36 . \\
36 . \\
36 . \\
35 . \\
35 . \\
34 . \\
34 . \\
34 . \\
34 . \\
34 . \\
34 . \\
34 . \\
34 . \\
34 . \\
34 . \\
34 . \\
34 . \\
34 . \\
34 . \\
34 . \\
34 . \\
34 . \\
34 . \\
34 . \\
34 . \\
34 . \\
34 . \\
34 . \\
34 . \\
34 . \\
34 . \\
34 . \\
34 .\end{array}$ & $\begin{array}{l}23 . \\
23 . \\
23 . \\
24 . \\
24 . \\
24 . \\
25 . \\
25 . \\
26 . \\
26 . \\
26 . \\
26 . \\
27 . \\
27 . \\
27 . \\
27 . \\
27 . \\
27 . \\
27 . \\
27 . \\
27 . \\
27 . \\
27 . \\
27 . \\
27 . \\
27 . \\
27 . \\
27 . \\
27 . \\
27 . \\
27 . \\
27 . \\
27 . \\
27 . \\
27 . \\
27 .\end{array}$ & $\begin{array}{r}21 x \\
21 x \\
20 x \\
19 x \\
19 x \\
18 x \\
17 x \\
16 x \\
6 x \\
4 x \\
\\
9 x \\
11 x \\
10 x \\
11 x \\
11 x \\
11 x \\
11 x \\
11 x \\
11 x \\
12 x \\
13 x \\
14 x \\
14 x \\
14 x \\
14 x \\
14 x \\
15 x \\
15 x \\
15 x \\
16 x \\
16 x \\
16 x \\
17 x \\
17 x \\
17 x\end{array}$ & $\begin{array}{r}-1 x \\
-1 x \\
-x \\
x \\
1 x \\
2 x \\
4 x \\
6 x \\
19 x \\
23 x \\
\\
19 x \\
18 x \\
19 x \\
19 x \\
19 x \\
19 x \\
20 x \\
20 x \\
20 x \\
20 x \\
19 x \\
19 x \\
19 x \\
19 x \\
19 x \\
18 x \\
18 x \\
18 x \\
17 x \\
17 x \\
17 x \\
17 x \\
16 x \\
16 x \\
16 x\end{array}$ & $\begin{array}{l}0 . \\
0 . \\
0 . \\
0 . \\
0 . \\
0 . \\
0 . \\
0 . \\
2 . \\
2 . \\
2 . \\
2 . \\
2 . \\
2 . \\
2 . \\
2 . \\
2 . \\
2 . \\
2 . \\
2 . \\
2 . \\
2 . \\
2 . \\
2 . \\
2 . \\
2 . \\
2 . \\
2 . \\
2 . \\
2 . \\
2 . \\
2 . \\
2 . \\
2 . \\
2 .\end{array}$ & $\begin{array}{l}1 . \\
1 . \\
0 . \\
0 . \\
0 . \\
2 . \\
4 . \\
7 . \\
23 . \\
32 . \\
33 . \\
33 . \\
35 . \\
36 . \\
36 . \\
37 . \\
37 . \\
37 . \\
37 . \\
37 . \\
36 . \\
36 . \\
36 . \\
36 . \\
35 . \\
35 . \\
35 . \\
35 . \\
35 . \\
35 . \\
34 . \\
34 . \\
34 . \\
34 . \\
34 .\end{array}$ & $\begin{array}{r}2 . \\
16 . \\
26 . \\
32 . \\
38 . \\
47 . \\
55 . \\
63 . \\
72 . \\
82 . \\
91 . \\
100 . \\
108 . \\
118 . \\
124 . \\
130 . \\
133 . \\
136 . \\
136 . \\
136 . \\
136 . \\
136 . \\
136 . \\
136 . \\
135 . \\
133 . \\
132 . \\
131 .\end{array}$ \\
\hline
\end{tabular}

WOCE Line P17C Station 139 Latitude 13-26.0S Longitude 134-16.8W Date 7/26/91 Botcon Depth 4294

\begin{tabular}{|c|c|c|c|c|c|c|c|c|c|c|c|c|}
\hline $\begin{array}{l}\text { Bot } \\
\text { No. }\end{array}$ & $\underset{\text { Depth }}{\text { Deph }}$ & $\begin{array}{l}\text { Temp } \\
\text { deg } C\end{array}$ & $\begin{array}{c}\text { Pot Temp } \\
\text { deg } c\end{array}$ & $\begin{array}{c}\text { Salinity } \\
0 / 00\end{array}$ & $\begin{array}{l}\text { Sigma } \\
\text { Theta }\end{array}$ & Oxy & AOU & PO4 & $\begin{array}{r}\text { NO3 } \\
--4 M\end{array}$ & $\mathrm{SiO3}$ & $\begin{array}{l}-T C \\
\text { Obs }\end{array}$ & $\begin{array}{r}S--- \\
S=35 \\
-\end{array}$ \\
\hline $\begin{array}{l}101 \\
102 \\
103 \\
104 \\
105 \\
106 \\
107 \\
108 \\
109 \\
110 \\
111 \\
112 \\
113 \\
137 \\
115 \\
116 \\
117 \\
118 \\
119 \\
120 \\
121 \\
122 \\
123 \\
124 \\
125 \\
126 \\
127 \\
128 \\
129 \\
130 \\
131 \\
132 \\
133 \\
134 \\
135 \\
136\end{array}$ & $\begin{array}{r}2 \\
34 \\
75 \\
116 \\
156 \\
206 \\
257 \\
318 \\
350 \\
379 \\
409 \\
460 \\
512 \\
563 \\
614 \\
716 \\
817 \\
918 \\
1020 \\
1223 \\
1425 \\
1627 \\
1831 \\
2036 \\
2238 \\
2441 \\
2644 \\
2847 \\
3050 \\
3254 \\
3457 \\
3660 \\
3861 \\
4064 \\
4164 \\
4256\end{array}$ & $\begin{array}{l}26 . \\
26 . \\
26 . \\
26 . \\
23 . \\
21 . \\
17 . \\
13 . \\
12 . \\
11 . \\
9 . \\
8 . \\
7 . \\
6 . \\
6 . \\
5 . \\
5 . \\
4 . \\
4 . \\
3 . \\
3 . \\
2 . \\
2 . \\
2 . \\
1 . \\
1 . \\
1 . \\
1 . \\
1 . \\
1 . \\
1 . \\
1 . \\
1 . \\
1 . \\
1 . \\
1 .\end{array}$ & $\begin{array}{l}26 . \\
26 . \\
26 . \\
26 . \\
23 . \\
21 . \\
17 . \\
13 . \\
11 . \\
11 . \\
9 . \\
8 . \\
7 . \\
6 . \\
6 . \\
5 . \\
5 . \\
4 . \\
4 . \\
3 . \\
3 . \\
2 . \\
2 . \\
1 . \\
1 . \\
1 . \\
1 . \\
1 . \\
1 . \\
1 . \\
1 . \\
1 . \\
1 . \\
1 . \\
1 . \\
1 .\end{array}$ & $\begin{array}{l}36 . \\
36 . \\
36 . \\
36 . \\
36 . \\
36 . \\
35 . \\
34 . \\
34 . \\
34 . \\
34 . \\
34 . \\
34 . \\
34 . \\
34 . \\
34 . \\
34 . \\
34 . \\
34 . \\
34 . \\
34 . \\
34 . \\
34 . \\
34 . \\
34 . \\
34 . \\
34 . \\
34 . \\
34 . \\
34 . \\
34 . \\
34 . \\
34 . \\
34 . \\
34 . \\
34 .\end{array}$ & $\begin{array}{l}23 . \\
23 . \\
23 . \\
23 . \\
24 . \\
25 . \\
25 . \\
26 . \\
26 . \\
26 . \\
26 . \\
26 . \\
27 . \\
27 . \\
27 . \\
27 . \\
27 . \\
27 . \\
27 . \\
27 . \\
27 . \\
27 . \\
27 . \\
27 . \\
27 . \\
27 . \\
27 . \\
27 . \\
27 . \\
27 . \\
27 . \\
27 . \\
27 . \\
27 . \\
27 . \\
27 .\end{array}$ & $\begin{array}{r}21 x \\
21 x \\
21 x \\
21 x \\
18 x \\
18 x \\
17 x \\
11 x \\
7 x \\
5 x \\
\\
9 x \\
11 x \\
12 x \\
12 x \\
12 x \\
12 x \\
11 x \\
12 x \\
11 x \\
12 x \\
13 x \\
13 x \\
14 x \\
14 x \\
14 x \\
15 x \\
15 x \\
15 x \\
16 x \\
16 x \\
16 x \\
16 x \\
17 x \\
17 x \\
17 x\end{array}$ & $\begin{array}{r}-1 x \\
-1 x \\
-1 x \\
-1 x \\
2 x \\
3 x \\
6 x \\
14 x \\
19 x \\
21 x \\
19 x \\
17 x \\
17 x \\
17 x \\
18 x \\
18 x \\
19 x \\
19 x \\
20 x \\
20 x \\
19 x \\
19 x \\
19 x \\
18 x \\
18 x \\
18 x \\
18 x \\
17 x \\
17 x \\
17 x \\
17 x \\
17 x \\
16 x \\
16 x \\
16 x\end{array}$ & $\begin{array}{l}0 . \\
0 . \\
0 . \\
0 . \\
0 . \\
0 . \\
0 . \\
1 . \\
2 . \\
2 . \\
2 . \\
2 . \\
2 . \\
2 . \\
2 . \\
2 . \\
2 . \\
2 . \\
2 . \\
2 . \\
2 . \\
2 . \\
2 . \\
2 . \\
2 . \\
2 . \\
2 . \\
2 . \\
2 . \\
2 . \\
2 . \\
2 . \\
2 . \\
2 . \\
2 . \\
2 .\end{array}$ & $\begin{array}{r}0 . \\
0 . \\
0 . \\
0 . \\
1 . \\
3 . \\
6 . \\
17 . \\
22 . \\
26 . \\
29 . \\
31 . \\
31 . \\
32 . \\
33 . \\
34 . \\
35 . \\
36 . \\
36 . \\
37 . \\
37 . \\
37 . \\
36 . \\
36 . \\
35 . \\
35 . \\
35 . \\
35 . \\
35 . \\
35 . \\
34 . \\
34 . \\
34 . \\
34 . \\
34 . \\
34 .\end{array}$ & $\begin{array}{r}1 . \\
1 . \\
1 . \\
1 . \\
1 . \\
1 . \\
2 . \\
9 . \\
15 . \\
19 . \\
21 . \\
27 . \\
32 . \\
36 . \\
39 . \\
46 . \\
54 . \\
63 . \\
70 . \\
85 . \\
98 . \\
107 . \\
117 . \\
123 . \\
128 . \\
132 . \\
133 . \\
134 . \\
135 . \\
136 . \\
136 . \\
135 . \\
134 . \\
133 . \\
133 . \\
133 .\end{array}$ & 2022 & 1947 \\
\hline
\end{tabular}


Iamont-Doherty Earth Observatory of Columbia University

(TCO2) $s=35$ Project/Expedition is TUNES/2 WOCE P17C/P16C 1991 Alkalinity = (TALK + NO3) X (35/Sal) WOCE Iine PI7C Station 140 Latitude 13-55.2S Longitude 134-11.1W Date 7/26/91 Bottom Depth 4423

\begin{tabular}{|c|c|c|c|c|c|c|c|c|c|c|c|c|c|c|c|c|}
\hline $\begin{array}{l}\text { Bot } \\
\text { No. }\end{array}$ & $\underset{\mathrm{m}}{\text { Depth }}$ & $\begin{array}{r}\text { Temp } \\
\text { deg } c\end{array}$ & $\begin{array}{c}\text { Pot Temp } \\
\text { deg } c\end{array}$ & $\begin{array}{c}\text { Salinity } \\
0 / 00\end{array}$ & $\begin{array}{l}\text { Sigma } \\
\text { Theta }\end{array}$ & OXY & AOU & PO4 & $\begin{array}{r}\text { NO3 } \\
-- \text { uM }\end{array}$ & $\mathrm{siO3}$ & Obs & $S=35$ & 20 & hera & $\begin{array}{l}\text { Tot } \\
\text { Calc } \\
-- \text { uE }\end{array}$ & $\begin{array}{l}\text { Alk. } \\
\text { ALK) s } \\
(\mathrm{kg}--\end{array}$ \\
\hline $\begin{array}{l}101 \\
102 \\
103 \\
104 \\
105 \\
106 \\
107 \\
108 \\
109 \\
110 \\
111 \\
112 \\
113 \\
137 \\
115 \\
116 \\
117 \\
118 \\
119 \\
120 \\
121 \\
122 \\
123 \\
124 \\
125 \\
126 \\
127 \\
128 \\
129 \\
130 \\
131 \\
132 \\
133 \\
134 \\
135 \\
136\end{array}$ & $\begin{array}{r}2 \\
42 \\
79 \\
109 \\
150 \\
190 \\
252 \\
312 \\
372 \\
403 \\
424 \\
484 \\
565 \\
667 \\
769 \\
870 \\
971 \\
1072 \\
1224 \\
1428 \\
1629 \\
1832 \\
2036 \\
2239 \\
2391 \\
2544 \\
2697 \\
2849 \\
3052 \\
3254 \\
3457 \\
3660 \\
3862 \\
4116 \\
4319 \\
4400\end{array}$ & $\begin{array}{r}27 . \\
26 . \\
26 . \\
25 . \\
23 . \\
22 . \\
19 . \\
14 . \\
10 . \\
9 . \\
8 . \\
7 . \\
6 . \\
5 . \\
5 . \\
4 . \\
4 . \\
4 . \\
3 . \\
3 . \\
2 . \\
2 . \\
2 . \\
1 . \\
1 . \\
1 . \\
1 . \\
1 . \\
1 . \\
1 . \\
1 . \\
1 . \\
1 . \\
1 . \\
1 . \\
1 .\end{array}$ & $\begin{array}{l}27 . \\
26 . \\
26 . \\
25 . \\
23 . \\
22 . \\
18 . \\
14 . \\
10 . \\
9 . \\
8 . \\
7 . \\
6 . \\
5 . \\
5 . \\
4 . \\
4 . \\
3 . \\
3 . \\
2 . \\
2 . \\
2 . \\
1 . \\
1 . \\
1 . \\
1 . \\
1 . \\
1 . \\
1 . \\
1 . \\
1 . \\
1 . \\
1 . \\
1 . \\
1 . \\
1 .\end{array}$ & $\begin{array}{l}36 . \\
36 . \\
36 . \\
36 . \\
36 . \\
36 . \\
35 . \\
34 . \\
34 . \\
34 . \\
34 . \\
34 . \\
34 . \\
34 . \\
34 . \\
34 . \\
34 . \\
34 . \\
34 . \\
34 . \\
34 . \\
34 . \\
34 . \\
34 . \\
34 . \\
34 . \\
34 . \\
34 . \\
34 . \\
34 . \\
34 . \\
34 . \\
34 . \\
34 . \\
34 . \\
34 .\end{array}$ & $\begin{array}{l}23 . \\
23 \\
23 \\
24 . \\
24 . \\
25 \\
25 . \\
26 . \\
26 . \\
26 . \\
26 . \\
26 . \\
27 . \\
27 . \\
27 . \\
27 . \\
27 . \\
27 . \\
27 . \\
27 . \\
27 . \\
27 . \\
27 . \\
27 . \\
27 . \\
27 . \\
27 . \\
27 . \\
27 . \\
27 . \\
27 . \\
27 . \\
27 . \\
27 . \\
27 . \\
27 .\end{array}$ & $\begin{array}{r}21 x \\
21 x \\
21 x \\
20 x \\
18 x \\
18 x \\
17 x \\
13 x \\
8 x \\
7 x \\
7 x \\
10 x \\
12 x \\
12 x \\
12 x \\
12 x \\
11 x \\
11 x \\
11 x \\
12 x \\
13 x \\
13 x \\
14 x \\
14 x \\
14 x \\
15 x \\
15 x \\
15 x \\
15 x \\
16 x \\
16 x \\
16 x \\
16 x \\
17 x \\
17 x \\
17 x\end{array}$ & $\begin{array}{r}-1 x \\
-1 x \\
-1 x \\
-x \\
2 x \\
2 x \\
5 x \\
11 x \\
19 x \\
20 x \\
20 x \\
18 x \\
17 x \\
18 x \\
18 x \\
19 x \\
19 x \\
19 x \\
20 x \\
20 x \\
19 x \\
19 x \\
18 x \\
18 x \\
18 x \\
18 x \\
18 x \\
18 x \\
17 x \\
17 x \\
17 x \\
17 x \\
17 x \\
16 x \\
16 x \\
16 x\end{array}$ & 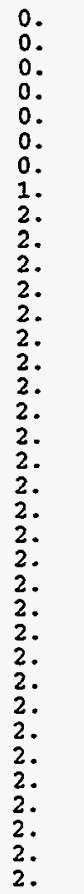 & $\begin{array}{c}0 . \\
0 . \\
0 . \\
0 . \\
1 . \\
3 . \\
5 . \\
13 . \\
26 . \\
29 . \\
30 . \\
31 . \\
32 . \\
34 . \\
35 . \\
36 . \\
36 . \\
37 . \\
37 . \\
37 . \\
36 . \\
36 . \\
35 . \\
35 . \\
35 . \\
35 . \\
35 . \\
35 . \\
35 . \\
34 . \\
34 . \\
34 . \\
34 . \\
34 . \\
34 . \\
34 .\end{array}$ & $\begin{array}{r}2 . \\
2 . \\
1 . \\
1 . \\
2 . \\
1 . \\
1 . \\
6 . \\
17 . \\
21 . \\
24 . \\
28 . \\
35 . \\
44 . \\
51 . \\
60 . \\
69 . \\
76 . \\
87 . \\
100 . \\
108 . \\
117 . \\
123 . \\
127 . \\
130 . \\
132 . \\
132 . \\
132 . \\
135 . \\
135 . \\
136 . \\
135 . \\
134 . \\
134 . \\
132 . \\
132 .\end{array}$ & 2020 & 1942 & 250 & 338 & 2414 & 2322 \\
\hline
\end{tabular}

WOCE Iine P17C Station 141 Latitude 14-25.1S Longitude 134-05.0W Date 7/27/91 Bottom Depth 4245

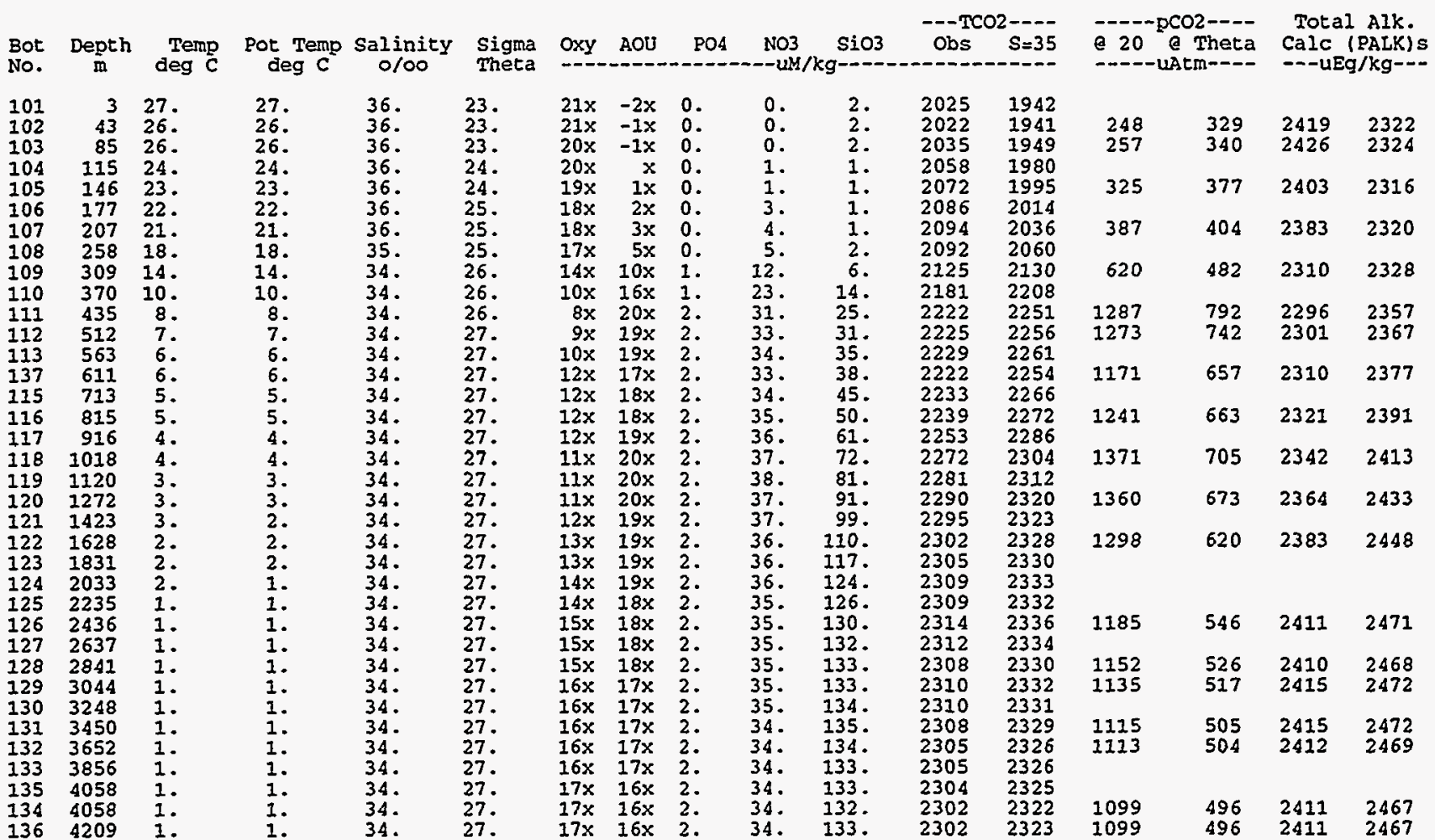


Lamont-Doherty Earth Observatory of Columbia University

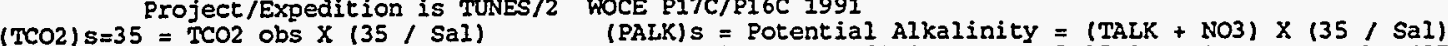
woce Line P17C station 142 Latitude 14-53.9S Longitude 133-59.0W Date 7/27/91 Bottom Depth 4270

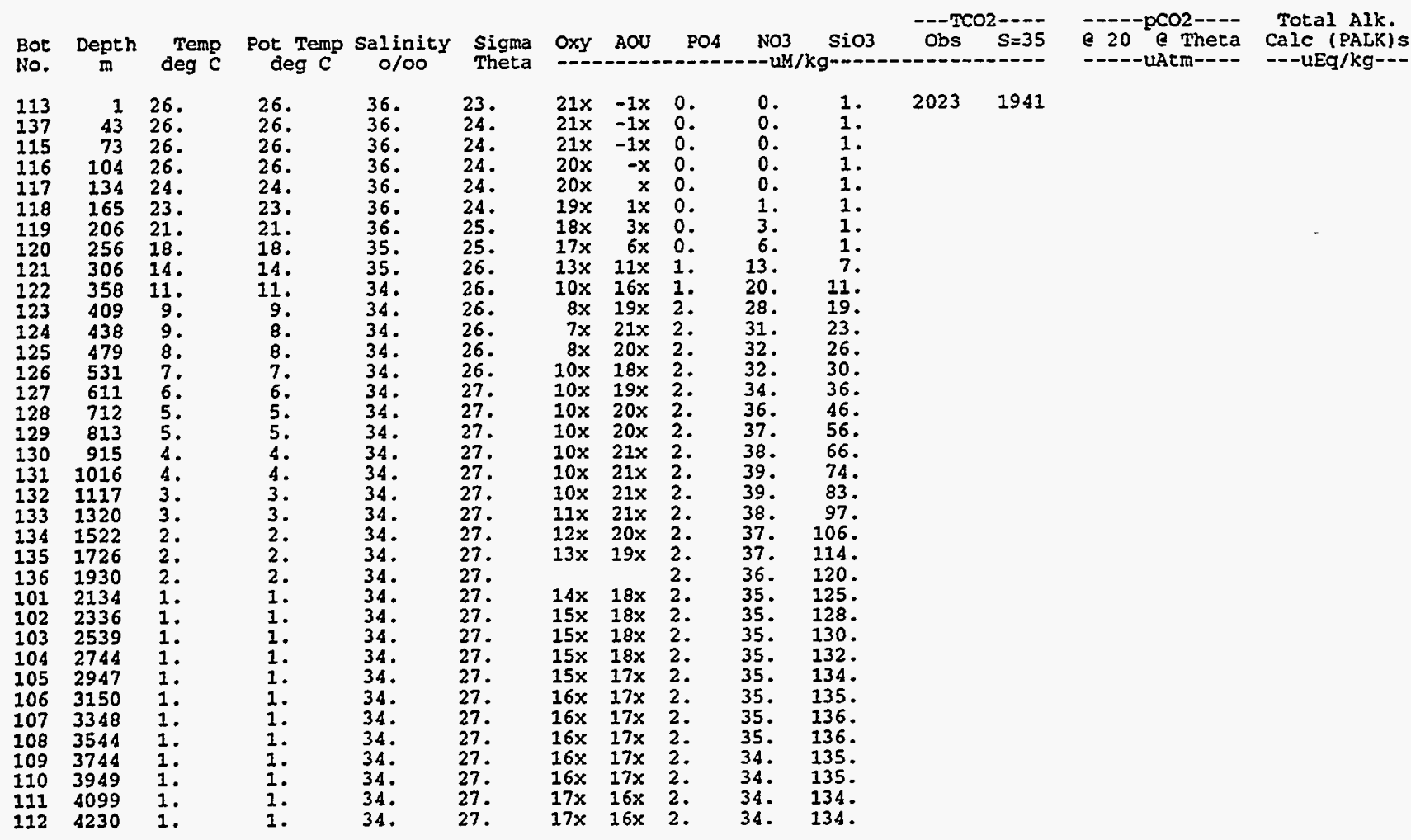

WOCE Line P17C Station 143 Latitude 15-22.9S Longicude 133-52.9W Date 7/28/91 Bottom Depth 4258

\begin{tabular}{|c|c|c|c|c|c|c|c|c|c|c|c|c|c|c|}
\hline $\begin{array}{l}\text { Bot } \\
\text { No. }\end{array}$ & $\underset{\text { Depth }}{\text { Deph }}$ & $\begin{array}{l}\text { Temp } \\
\text { deg } \mathbf{C}\end{array}$ & $\begin{array}{l}\text { Pot Temp } \\
\operatorname{deg} c\end{array}$ & $\begin{array}{c}\text { Salinity } \\
0 / 00\end{array}$ & $\begin{array}{l}\text { Sigma } \\
\text { Theta }\end{array}$ & Oxy & AOU & PO4 & $\begin{array}{l}\text { NO3 } \\
--U M\end{array}$ & $\mathrm{SiO} 3$ & Obs $\quad \mathrm{S}=35$ & 20 & heta & $\begin{array}{l}\text { Total Alk. } \\
\text { Calc (PALK)s } \\
-- \text { UEg/kg--- }\end{array}$ \\
\hline $\begin{array}{l}301 \\
302 \\
303 \\
304 \\
305 \\
306 \\
307 \\
308 \\
309 \\
310 \\
311 \\
312 \\
313 \\
337 \\
315 \\
316 \\
317 \\
318 \\
319 \\
320 \\
321 \\
322 \\
323 \\
324 \\
325 \\
326 \\
327 \\
328 \\
329 \\
330 \\
331 \\
332 \\
333 \\
335 \\
334 \\
336\end{array}$ & $\begin{array}{r}3 \\
47 \\
87 \\
121 \\
143 \\
172 \\
199 \\
245 \\
293 \\
343 \\
394 \\
445 \\
494 \\
598 \\
705 \\
806 \\
911 \\
1015 \\
1117 \\
1219 \\
1424 \\
1629 \\
1833 \\
2034 \\
2230 \\
2430 \\
2633 \\
2833 \\
3033 \\
3234 \\
3434 \\
3632 \\
3833 \\
4036 \\
4037 \\
4211\end{array}$ & $\begin{array}{l}26 . \\
26 . \\
26 . \\
25 . \\
23 . \\
22 . \\
21 . \\
19 . \\
16 . \\
12 . \\
10 . \\
8 . \\
7 . \\
6 . \\
5 . \\
5 . \\
4 . \\
4 . \\
3 . \\
3 . \\
3 . \\
2 . \\
2 . \\
2 . \\
1 . \\
1 . \\
1 . \\
1 . \\
1 . \\
1 . \\
1 . \\
1 . \\
1 . \\
1 . \\
1 . \\
1 .\end{array}$ & $\begin{array}{l}26 . \\
26 . \\
26 . \\
25 . \\
23 . \\
22 . \\
21 . \\
19 . \\
16 . \\
12 . \\
10 . \\
8 . \\
7 . \\
6 . \\
5 . \\
5 . \\
4 . \\
4 . \\
3 . \\
3 . \\
3 . \\
2 . \\
2 . \\
1 . \\
1 . \\
1 . \\
1 . \\
1 . \\
1 . \\
1 . \\
1 . \\
1 . \\
1 . \\
1 . \\
1 . \\
1 .\end{array}$ & $\begin{array}{l}36 . \\
36 . \\
36 . \\
36 . \\
36 . \\
36 . \\
36 . \\
35 . \\
35 . \\
34 . \\
34 . \\
34 . \\
34 . \\
34 . \\
34 . \\
34 . \\
34 . \\
34 . \\
34 . \\
34 . \\
34 . \\
34 . \\
34 . \\
34 . \\
34 . \\
34 . \\
34 . \\
34 . \\
34 . \\
34 . \\
34 . \\
34 . \\
34 . \\
34 . \\
34 . \\
34 .\end{array}$ & $\begin{array}{l}24 . \\
24 . \\
24 . \\
24 . \\
24 . \\
25 . \\
25 . \\
25 . \\
25 . \\
26 . \\
26 . \\
26 . \\
26 . \\
27 . \\
27 . \\
27 . \\
27 . \\
27 . \\
27 . \\
27 . \\
27 . \\
27 . \\
27 . \\
27 . \\
27 . \\
27 . \\
27 . \\
27 . \\
27 . \\
27 . \\
27 . \\
27 . \\
27 . \\
27 . \\
27 . \\
27 .\end{array}$ & $\begin{array}{r}20 x \\
21 x \\
20 x \\
20 x \\
19 x \\
18 x \\
18 x \\
17 x \\
13 x \\
9 x \\
8 x \\
8 x \\
10 x \\
10 x \\
10 x \\
9 x \\
9 x \\
9 x \\
10 x \\
11 x \\
12 x \\
13 x \\
14 x \\
15 x \\
15 x \\
15 x \\
15 x \\
15 x \\
16 x \\
16 x \\
16 x \\
16 x \\
17 x \\
17 x \\
17 x\end{array}$ & $\begin{array}{r}-1 x \\
-1 x \\
-1 x \\
x \\
1 x \\
2 x \\
4 x \\
7 x \\
12 x \\
18 x \\
20 x \\
20 x \\
19 x \\
20 x \\
20 x \\
21 x \\
22 x \\
22 x \\
22 x \\
21 x \\
20 x \\
19 x \\
18 x \\
18 x \\
18 x \\
18 x \\
18 x \\
17 x \\
17 x \\
17 x \\
17 x \\
17 x \\
17 x \\
17 x \\
16 x\end{array}$ & $\begin{array}{l}0 . \\
0 . \\
0 . \\
0 . \\
0 . \\
0 . \\
0 . \\
0 . \\
1 . \\
2 . \\
2 . \\
2 . \\
2 . \\
2 . \\
2 . \\
2 . \\
2 . \\
2 . \\
2 . \\
2 . \\
2 . \\
2 . \\
2 . \\
2 . \\
2 . \\
2 . \\
2 . \\
2 . \\
2 . \\
2 . \\
2 . \\
2 . \\
2 . \\
2 . \\
2 .\end{array}$ & $\begin{array}{c}0 . \\
0 . \\
0 . \\
0 . \\
0 . \\
\\
2 . \\
3 . \\
76 \\
16 . \\
24 . \\
31 . \\
33 . \\
34 . \\
36 . \\
37 . \\
38 . \\
39 . \\
39 . \\
39 . \\
38 . \\
37 . \\
36 . \\
35 . \\
35 . \\
35 . \\
35 . \\
35 . \\
34 . \\
34 . \\
34 . \\
34 . \\
34 . \\
34 . \\
34 . \\
34 .\end{array}$ & $\begin{array}{r}1 . \\
1 . \\
1 . \\
1 . \\
1 . \\
1 . \\
1 . \\
2 . \\
8 . \\
16 . \\
24 . \\
26 . \\
36 . \\
46 . \\
54 . \\
64 . \\
73 . \\
83 . \\
90 . \\
101 . \\
109 . \\
116 . \\
120 . \\
123 . \\
127 . \\
129 . \\
130 . \\
132 . \\
133 . \\
133 . \\
132 . \\
132 . \\
132 . \\
132 . \\
131 .\end{array}$ & & 248 & 328 & \\
\hline
\end{tabular}


Lamont-Doherty Earth Observatory of Columbia University Project/Expedition is TUNES/2 WOCE P17C/P16C 199:
(TCO2) $s=35=$ TCO2 obs $x(35, \mathrm{Sal})$
(PALK) $=$ Potential Alkalinity = (TALK + NO3) $\mathrm{X}$ (35/Sal)

Printed on $12 / 06 / 93 \quad$ Page 11 wOCE Line PI7C Station 144 Latitude 15-52.9S Longitude 133-47.1W Date 7/28/91 Bottom Depth 4260

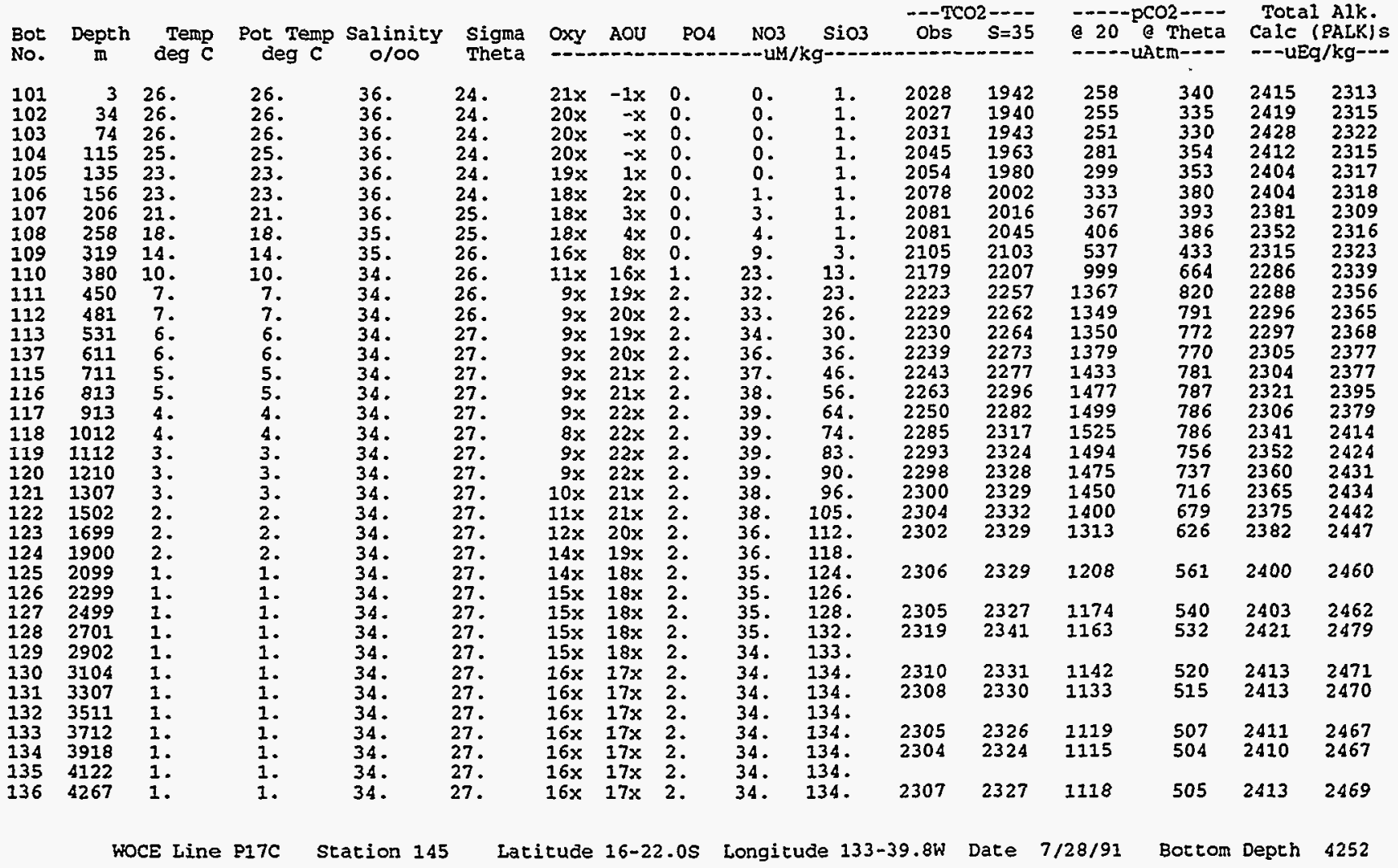

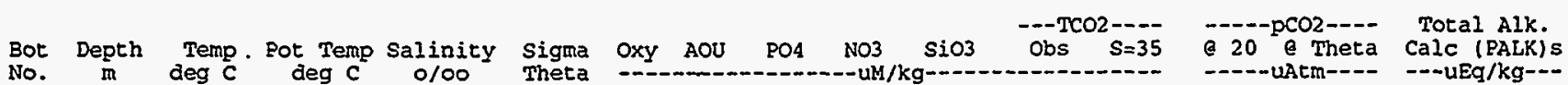

\begin{tabular}{|c|c|c|c|c|c|c|c|c|}
\hline $\begin{array}{rr}101 & 2 \\
102 & 35 \\
103 & 60 \\
104 & 96 \\
105 & 121 \\
106 & 147 \\
107 & 167 \\
108 & 218 \\
109 & 270 \\
110 & 320 \\
111 & 372 \\
112 & 422 \\
113 & 472 \\
137 & 533 \\
115 & 613 \\
116 & 715 \\
117 & 818 \\
118 & 919 \\
119 & 1020 \\
120 & 1122 \\
121 & 1325 \\
122 & 1529 \\
123 & 1732 \\
124 & 1935 \\
125 & 2138 \\
126 & 2341 \\
127 & 2544 \\
128 & 2747 \\
129 & 2949 \\
130 & 3151 \\
131 & 3350 \\
132 & 3550 \\
133 & 3752 \\
134 & 3956 \\
135 & 4110 \\
136 & 4235\end{array}$ & $\begin{array}{l}26 . \\
26 . \\
26 . \\
26 . \\
24 . \\
23 . \\
22 . \\
20 . \\
18 . \\
15 . \\
11 . \\
9 . \\
7 . \\
6 . \\
6 . \\
5 . \\
5 . \\
4 . \\
4 . \\
3 . \\
3 . \\
2 . \\
2 . \\
2 . \\
1 . \\
1 . \\
1 . \\
1 . \\
1 . \\
1 . \\
1 . \\
1 . \\
1 . \\
1 . \\
1 . \\
1 .\end{array}$ & $\begin{array}{l}26 . \\
26 . \\
26 . \\
26 . \\
24 . \\
23 . \\
22 . \\
20 . \\
18 . \\
15 . \\
11 . \\
9 . \\
7 . \\
6 . \\
6 . \\
5 . \\
5 . \\
4 . \\
4 . \\
3 . \\
3 . \\
2 . \\
2 . \\
1 . \\
1 . \\
1 . \\
1 . \\
1 . \\
1 . \\
1 . \\
1 . \\
1 . \\
1 . \\
1 . \\
1 . \\
1 .\end{array}$ & $\begin{array}{l}36 . \\
36 . \\
36 . \\
36 . \\
36 . \\
36 . \\
36 . \\
36 . \\
35 . \\
35 . \\
34 . \\
34 . \\
34 . \\
34 . \\
34 . \\
34 . \\
34 . \\
34 . \\
34 . \\
34 . \\
34 . \\
34 . \\
34 . \\
34 . \\
34 . \\
34 . \\
34 . \\
34 . \\
34 . \\
34 . \\
34 . \\
34 . \\
34 . \\
34 . \\
34 . \\
34 .\end{array}$ & $\begin{array}{l}24 . \\
24 . \\
24 . \\
24 . \\
24 . \\
24 . \\
24 . \\
25 . \\
25 . \\
25 . \\
26 . \\
26 . \\
26 . \\
27 . \\
27 . \\
27 . \\
27 . \\
27 . \\
27 . \\
27 . \\
27 . \\
27 . \\
27 . \\
27 . \\
27 . \\
27 . \\
27 . \\
27 . \\
27 . \\
27 . \\
27 . \\
27 . \\
27 . \\
27 . \\
27 . \\
27 .\end{array}$ & $\begin{array}{r}21 x \\
20 x \\
21 x \\
20 x \\
19 x \\
19 x \\
18 x \\
18 x \\
18 x \\
17 x \\
13 x \\
9 x \\
9 x \\
10 x \\
10 x \\
9 x \\
9 x \\
8 x \\
8 x \\
9 x \\
10 x \\
11 x \\
13 x \\
14 x \\
14 x \\
15 x \\
15 x \\
15 x \\
15 x \\
16 x \\
16 x \\
16 x \\
16 x \\
17 x \\
17 x \\
17 x\end{array}$ & $\begin{array}{r}-1 x \\
-1 x \\
-1 x \\
-x \\
1 x \\
1 x \\
2 x \\
3 x \\
4 x \\
7 x \\
13 x \\
18 x \\
19 x \\
19 x \\
19 x \\
20 x \\
21 x \\
22 x \\
22 x \\
22 x \\
22 x \\
21 x \\
19 x \\
19 x \\
18 x \\
18 x \\
18 x \\
17 x \\
17 x \\
17 x \\
17 x \\
17 x \\
17 x \\
16 x \\
16 x \\
16 x\end{array}$ & $\begin{array}{l}0 . \\
0 . \\
0 . \\
0 . \\
0 . \\
0 . \\
0 . \\
0 . \\
0 . \\
0 . \\
1 . \\
2 . \\
2 . \\
2 . \\
2 . \\
2 . \\
2 . \\
2 . \\
2 . \\
2 . \\
2 . \\
2 . \\
2 . \\
2 . \\
2 . \\
2 . \\
2 . \\
2 . \\
2 . \\
2 . \\
2 . \\
2 . \\
2 . \\
2 . \\
2 . \\
2 .\end{array}$ & $\begin{array}{l}0 . \\
0 . \\
0 . \\
0 . \\
0 . \\
0 . \\
2 . \\
3 . \\
4 . \\
9 . \\
18 . \\
27 . \\
32 . \\
34 . \\
35 . \\
37 . \\
38 . \\
39 . \\
39 . \\
39 . \\
38 . \\
37 . \\
36 . \\
36 . \\
35 . \\
35 . \\
34 . \\
34 . \\
34 . \\
34 . \\
34 . \\
34 . \\
34 . \\
34 . \\
34 . \\
34 .\end{array}$ \\
\hline
\end{tabular}


Lamont-Doherty Earth Observatory of Columbia University

Printed on $12 / 06 / 93$

Project/Expedition is TUNES/2 WOCE P17C/P16C 1991

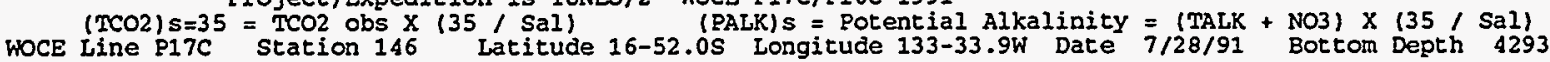

$\begin{array}{rrrll}\text { Bot } & \begin{array}{c}\text { Depth } \\ \text { No. }\end{array} & \begin{array}{c}\text { Temp } \\ \text { deg C }\end{array} & \begin{array}{c}\text { Pot Temp Salinity } \\ \text { deg C }\end{array} \\ & & & & \\ 101 & 3 & 26 . & 26 . & 36 . \\ 102 & 44 & 26 . & 26 . & 36 . \\ 103 & 86 & 26 . & 26 . & 36 . \\ 104 & 126 & 26 . & 26 . & 36 . \\ 105 & 157 & 24 . & 24 . & 36 . \\ 106 & 187 & 22 . & 22 . & 36 . \\ 107 & 239 & 20 . & 20 . & 35 . \\ 108 & 289 & 18 . & 17 . & 35 . \\ 109 & 350 & 13 . & 13 . & 34 . \\ 110 & 410 & 9 . & 9 . & 34 . \\ 111 & 461 & 8 . & 8 . & 34 . \\ 112 & 512 & 7 . & 7 . & 34 . \\ 113 & 562 & 6 . & 6 . & 34 . \\ 137 & 614 & 6 . & 6 . & 34 . \\ 115 & 715 & 5 . & 5 . & 34 . \\ 116 & 816 & 5 . & .5 & 34 . \\ 117 & 917 & 4 . & 4 . & 34 . \\ 118 & 1019 & 4 . & 4 . & 34 . \\ 119 & 1118 & 4 . & 3 . & 34 . \\ 120 & 1219 & 3 . & 3 . & 34 . \\ 121 & 1419 & 3 . & 3 . & 34 . \\ 122 & 1622 & 2 . & 2 . & 34 . \\ 123 & 1828 & 2 . & 2 . & 34 . \\ 124 & 2033 & 2 . & 1 . & 34 . \\ 125 & 2236 & 1 . & 1 . & 34 . \\ 126 & 2388 & 1 . & 1 . & 34 . \\ 127 & 2542 & 1 . & 1 . & 34 . \\ 128 & 2694 & 1 . & 1 . & 34 . \\ 129 & 2846 & 1 . & 1 . & 34 . \\ 130 & 3051 & 1 . & 1 . & 34 . \\ 131 & 3253 & 1 . & 1 . & 34 . \\ 132 & 3457 & 1 . & 1 . & 34 . \\ 133 & 3659 & 1 . & 1 . & 34 . \\ 134 & 3862 & 1 . & 1 . & 34 . \\ 135 & 4063 & 1 . & 1 . & 34 . \\ 136 & 4257 & 1 . & 1 . & 34 . \\ & & & & \\ 13 & \end{array}$

Sigma
Theta
24.
24.
24.
24.
24.
24.
25.
25.
26.
26.
26.
26.
27.
27.
27.
27.
27.
27.
27.
27.
27.
27.
27.
27.
27.
27.
27.
27.
27.
27.
27.
27.
27.
27.
27.
27.

\begin{tabular}{|c|c|c|c|c|}
\hline$x y$ & AOU & PO4 & & \\
\hline $\begin{array}{l}21 x \\
21 x \\
21 x \\
20 x \\
19 x \\
19 x \\
18 x \\
18 x \\
15 x \\
11 x \\
10 x \\
13 x \\
14 x \\
12 x \\
10 x \\
9 x \\
9 x \\
8 x \\
9 x \\
9 x \\
10 x \\
12 x \\
14 x \\
14 x \\
14 x \\
15 x \\
15 x \\
15 x \\
15 x \\
16 x \\
16 x \\
16 x \\
16 x \\
17 x \\
17\end{array}$ & $\begin{array}{r}-1 x \\
-1 x \\
-1 x \\
-x \\
1 x \\
2 x \\
3 x \\
5 x \\
10 x \\
16 x \\
18 x \\
16 x \\
16 x \\
17 x \\
19 x \\
21 x \\
21 x \\
22 x \\
22 x \\
22 x \\
21 x \\
20 x \\
19 x \\
18 x \\
18 x \\
18 x \\
18 x \\
18 x \\
18 x \\
17 x \\
17 x \\
17 x \\
17 x \\
17 x\end{array}$ & $\begin{array}{l}0 . \\
0 . \\
0 . \\
0 . \\
0 . \\
0 . \\
0 . \\
0 . \\
1 . \\
1 . \\
2 . \\
2 . \\
2 . \\
2 . \\
2 . \\
2 . \\
2 . \\
2 . \\
2 . \\
2 . \\
2 . \\
2 . \\
2 .\end{array}$ & $\begin{array}{l}0 . \\
0 . \\
0 . \\
0 . \\
0 . \\
1 . \\
2 . \\
5 . \\
12 . \\
24 . \\
29 . \\
30 . \\
32 . \\
34 . \\
36 . \\
38 . \\
38 . \\
39 . \\
39 . \\
39 . \\
38 . \\
37 . \\
35 . \\
35 . \\
35 . \\
34 . \\
34 . \\
34 . \\
34 . \\
34 . \\
34 . \\
34 . \\
34 . \\
34 .\end{array}$ & $\begin{array}{l}1 \\
1 \\
1 \\
12 \\
12 \\
12 \\
12 \\
12 \\
12 \\
13 \\
13 \\
13 \\
13\end{array}$ \\
\hline
\end{tabular}

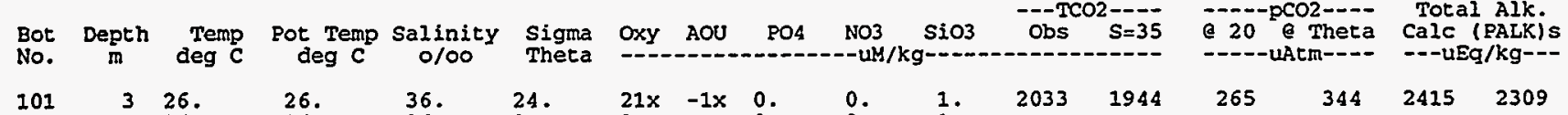

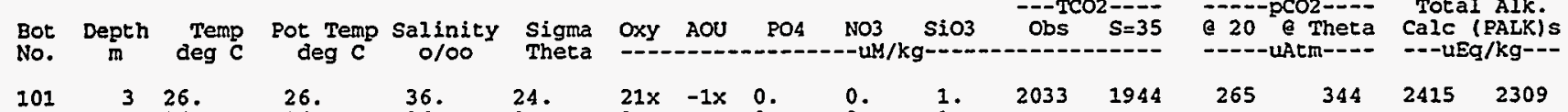

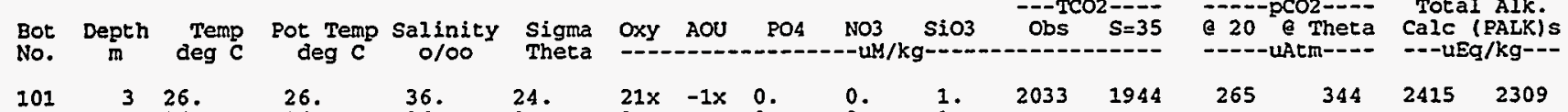

WOCE Line P17C Station 147 Latitude 17-20.9s Longitude 133-28.0W Date 7/29/91 Bottom Depth 4404

\begin{tabular}{|c|c|c|c|c|c|c|c|c|c|c|c|c|c|c|c|c|}
\hline $\begin{array}{l}\text { Bot } \\
\text { No. }\end{array}$ & $\underset{\text { m }}{\text { Depth }}$ & $\begin{array}{l}\text { Temp } \\
\text { deg } C\end{array}$ & $\begin{array}{c}\text { Pot Temp } \\
\text { deg } c\end{array}$ & $\begin{array}{c}\text { Salinity } \\
0 / 00\end{array}$ & $\begin{array}{l}\text { Sigma } \\
\text { Theta }\end{array}$ & Oxy & AOU & PO4 & $\begin{array}{r}\text { NO3 } \\
---U M\end{array}$ & $\mathrm{SiO3}$ & Obs & $\begin{array}{r}2--- \\
S=35\end{array}$ & 20 & Mhera & $\begin{array}{l}\text { Tot } \\
\text { Calc }\end{array}$ & $\begin{array}{l}\text { Alk. } \\
\text { PALK S } \\
/ \mathrm{kg}--\end{array}$ \\
\hline $\begin{array}{l}101 \\
102 \\
103 \\
104 \\
105 \\
106 \\
107 \\
108 \\
109 \\
110 \\
111 \\
112 \\
113 \\
137 \\
115 \\
116 \\
117 \\
118 \\
119 \\
120 \\
121 \\
122 \\
123 \\
124 \\
125 \\
126 \\
127 \\
128 \\
129 \\
130 \\
131 \\
132 \\
133 \\
134 \\
135 \\
136\end{array}$ & $\begin{array}{r}3 \\
55 \\
106 \\
131 \\
156 \\
181 \\
208 \\
234 \\
283 \\
335 \\
386 \\
436 \\
492 \\
553 \\
613 \\
715 \\
817 \\
918 \\
1070 \\
1222 \\
1426 \\
1630 \\
1832 \\
2034 \\
2237 \\
2440 \\
2643 \\
2846 \\
3050 \\
3253 \\
3455 \\
3658 \\
3860 \\
4063 \\
4216 \\
4367\end{array}$ & $\begin{array}{l}26 . \\
25 . \\
25 . \\
25 . \\
23 . \\
23 . \\
22 . \\
21 . \\
18 . \\
15 . \\
11 . \\
9 . \\
7 . \\
6 . \\
5 . \\
5 . \\
5 . \\
4 . \\
4 . \\
3 . \\
3 . \\
2 . \\
2 . \\
2 . \\
1 . \\
1 . \\
1 . \\
1 . \\
1 . \\
1 . \\
1 . \\
1 . \\
1 . \\
1 . \\
1 . \\
1 .\end{array}$ & $\begin{array}{l}26 . \\
25 . \\
25 . \\
25 . \\
23 . \\
23 . \\
22 . \\
21 . \\
18 . \\
15 . \\
11 . \\
9 . \\
7 . \\
6 . \\
5 . \\
5 . \\
5 . \\
4 . \\
4 . \\
3 . \\
2 . \\
2 . \\
2 . \\
1 . \\
1 . \\
1 . \\
1 . \\
1 . \\
1 . \\
1 . \\
1 . \\
1 . \\
1 . \\
1 . \\
1 . \\
1 .\end{array}$ & $\begin{array}{l}36 . \\
36 . \\
36 . \\
36 . \\
36 . \\
36 . \\
36 . \\
36 . \\
35 . \\
35 . \\
34 . \\
34 . \\
34 . \\
34 . \\
34 . \\
34 . \\
34 . \\
34 . \\
34 . \\
34 . \\
34 . \\
34 . \\
34 . \\
34 . \\
34 . \\
34 . \\
34 . \\
34 . \\
34 . \\
34 . \\
34 . \\
34 . \\
34 . \\
34 . \\
34 . \\
34 .\end{array}$ & $\begin{array}{l}24 . \\
24 . \\
24 . \\
24 . \\
24 . \\
24 . \\
25 . \\
25 . \\
25 . \\
25 . \\
26 . \\
26 . \\
26 . \\
27 . \\
27 . \\
27 . \\
27 . \\
27 . \\
27 . \\
27 . \\
27 . \\
27 . \\
27 . \\
27 . \\
27 . \\
27 . \\
27 . \\
27 . \\
27 . \\
27 . \\
27 . \\
27 . \\
27 . \\
27 . \\
27 . \\
27 .\end{array}$ & $\begin{array}{l}21 x \\
21 x \\
21 x \\
20 x \\
19 x \\
19 x \\
18 x \\
18 x \\
18 x \\
17 x \\
15 x \\
14 x \\
12 x \\
15 x \\
14 x \\
12 x \\
12 x \\
11 x \\
11 x \\
12 x \\
13 x \\
13 x \\
14 x \\
14 x \\
14 x \\
15 x \\
15 x \\
15 x \\
15 x \\
15 x \\
16 x \\
16 x \\
16 x \\
17 x \\
17 x \\
17 x\end{array}$ & $\begin{array}{r}-1 x \\
-1 x \\
-x \\
-x \\
1 x \\
2 x \\
2 x \\
3 x \\
4 x \\
6 x \\
11 x \\
14 x \\
16 x \\
14 x \\
15 x \\
18 x \\
18 x \\
19 x \\
19 x \\
19 x \\
18 x \\
19 x \\
19 x \\
18 x \\
18 x \\
18 x \\
18 x \\
17 x \\
17 x \\
17 x \\
17 x \\
17 x \\
17 x \\
16 x \\
16 x \\
16 x\end{array}$ & $\begin{array}{l}0 . \\
0 . \\
0 . \\
0 . \\
0 . \\
0 . \\
0 . \\
0 . \\
0 . \\
0 . \\
1 . \\
1 . \\
2 . \\
2 . \\
2 . \\
2 . \\
2 . \\
2 . \\
2 . \\
2 . \\
2 . \\
2 . \\
2 . \\
2 . \\
2 . \\
2 . \\
2 . \\
2 . \\
2 . \\
2 . \\
2 . \\
2 . \\
2 . \\
2 . \\
2 . \\
2 .\end{array}$ & $\begin{array}{l}0 . \\
0 . \\
0 . \\
0 . \\
0 . \\
1 . \\
2 . \\
2 . \\
3 . \\
7 . \\
17 . \\
24 . \\
30 . \\
30 . \\
32 . \\
34 . \\
35 . \\
36 . \\
37 . \\
37 . \\
36 . \\
36 . \\
36 . \\
35 . \\
35 . \\
35 . \\
35 . \\
35 . \\
35 . \\
34 . \\
34 . \\
34 . \\
34 . \\
34 . \\
34 . \\
34 .\end{array}$ & $\begin{array}{r}1 . \\
1 . \\
1 . \\
1 . \\
1 . \\
1 . \\
1 . \\
1 . \\
1 . \\
2 . \\
7 . \\
13 . \\
19 . \\
20 . \\
27 . \\
43 . \\
54 . \\
62 . \\
74 . \\
83 . \\
94 . \\
106 . \\
115 . \\
120 . \\
125 . \\
127 . \\
128 . \\
130 . \\
131 . \\
134 . \\
134 . \\
134 . \\
134 . \\
132 . \\
132 . \\
132 .\end{array}$ & 2034 & 1947 & 258 & 334 & 2423 & 2319 \\
\hline
\end{tabular}


Iamont-Doherty Earth Observatory of Columbia University

Printed on $12 / 06 / 93$

Page 13

(TCO2) $s=35$ roject/Expedition is TUNES/2 WOCE P17C/P16C 1991 (PALK) $=$ Potential Alkalinity = (TALK + NO3) X (35/Sal) WOCE Iine P17C Station 148 Latitude 17-50.0s Longitude 133-22.0 Date $7 / 29 / 91$ Bottom Depth 3970

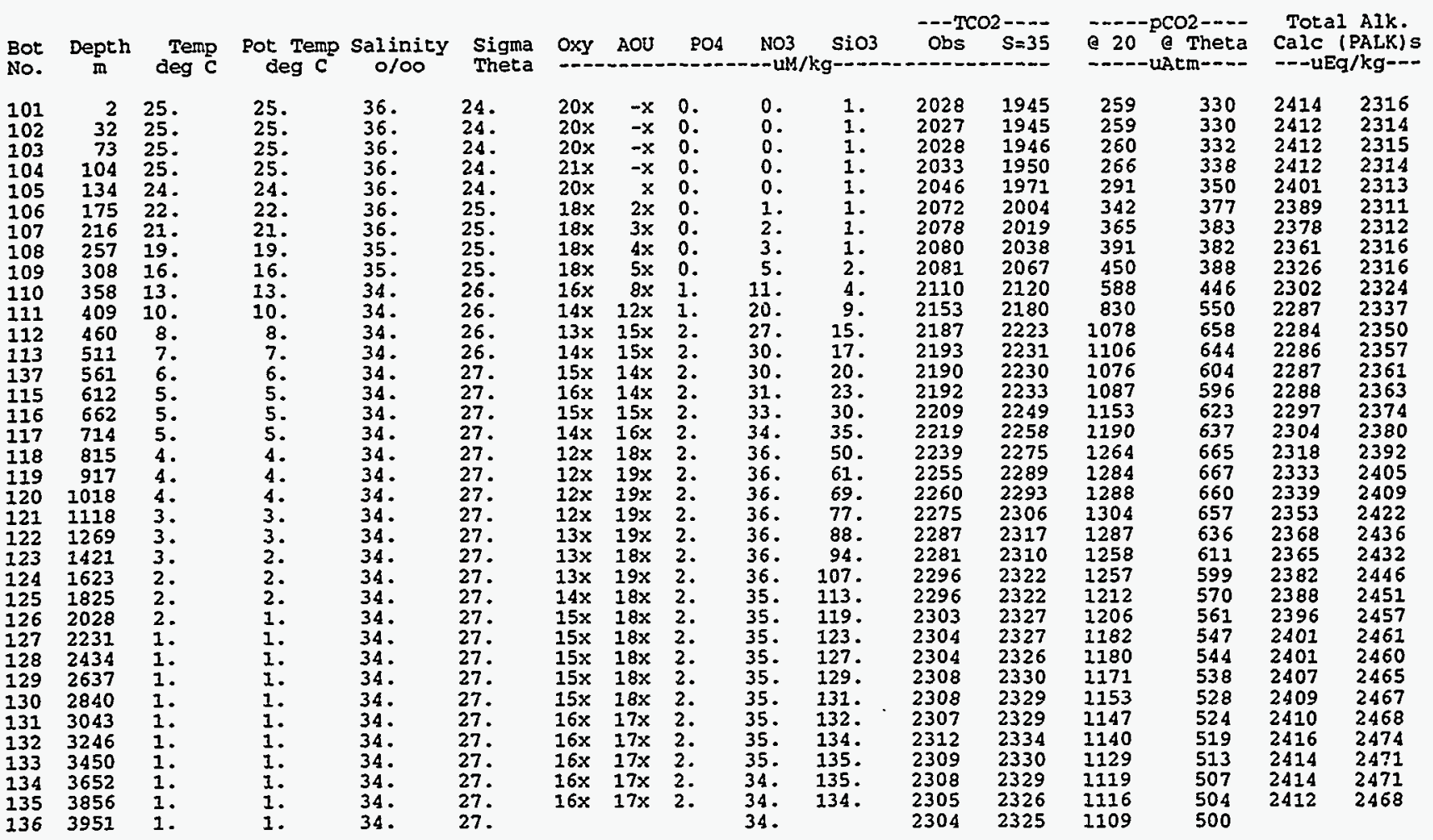

WOCE Line P17C Station 149 Latitude 18-19.8S Longitude 133-15.0W Date 7/29/91 Bottom Depth 4107

\begin{tabular}{|c|c|c|c|c|c|c|c|c|c|c|c|c|c|c|c|c|}
\hline $\begin{array}{l}\text { Bot } \\
\text { No. }\end{array}$ & $\underset{\text { Depth }}{\text { m }}$ & $\begin{array}{l}\text { Tenp } \\
\text { deg C }\end{array}$ & $\begin{array}{l}\text { Pot Temp } \\
\text { deg } c\end{array}$ & $\begin{array}{c}\text { Salinity } \\
0 / 00\end{array}$ & $\begin{array}{l}\text { Sigma } \\
\text { Theta }\end{array}$ & Oxy & AOU & PO4 & $\begin{array}{r}\text { NO3 } \\
--\mathrm{UM}\end{array}$ & SiO3 & Obs & $s=35$ & a 20 & $\begin{array}{r}\text { pco2---- } \\
\text { a Theta } \\
\text {-uAcm---- }\end{array}$ & $\begin{array}{l}\text { Tota } \\
\text { Calc } \\
---u E\end{array}$ & $\begin{array}{l}\text { Alk. } \\
\text { PALKis } \\
\text { /kg-- }\end{array}$ \\
\hline $\begin{array}{l}101 \\
102 \\
103 \\
104 \\
105 \\
106 \\
107 \\
108 \\
109 \\
110 \\
111 \\
112 \\
113 \\
137 \\
115 \\
116 \\
117 \\
118 \\
119 \\
120 \\
121 \\
122 \\
123 \\
124 \\
125 \\
126 \\
127 \\
128 \\
129 \\
130 \\
131 \\
132 \\
133 \\
134 \\
135 \\
138\end{array}$ & $\begin{array}{r}1 \\
44 \\
85 \\
116 \\
136 \\
172 \\
207 \\
257 \\
308 \\
359 \\
409 \\
460 \\
511 \\
560 \\
611 \\
662 \\
711 \\
812 \\
913 \\
1014 \\
1216 \\
1418 \\
1620 \\
1823 \\
2026 \\
2227 \\
2431 \\
2634 \\
2838 \\
3043 \\
3247 \\
3452 \\
3656 \\
3808 \\
3961 \\
4083\end{array}$ & 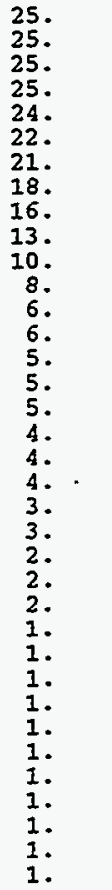 & $\begin{array}{l}25 . \\
25 . \\
25 . \\
25 . \\
24 . \\
22 . \\
21 . \\
18 . \\
16 . \\
12 . \\
10 . \\
8 . \\
6 . \\
6 . \\
5 . \\
5 . \\
5 . \\
4 . \\
4 . \\
4 . \\
3 . \\
2 . \\
2 . \\
2 . \\
1 . \\
1 . \\
1 . \\
1 . \\
1 . \\
1 . \\
1 . \\
1 . \\
1 . \\
1 . \\
1 . \\
1 .\end{array}$ & $\begin{array}{l}36 . \\
36 . \\
36 . \\
36 . \\
36 . \\
36 . \\
36 . \\
35 . \\
35 . \\
34 . \\
34 . \\
34 . \\
34 . \\
34 . \\
34 . \\
34 . \\
34 . \\
34 . \\
34 . \\
34 . \\
34 . \\
34 . \\
34 . \\
34 . \\
34 . \\
34 . \\
34 . \\
34 . \\
34 . \\
34 . \\
34 . \\
34 . \\
34 . \\
34 . \\
34 . \\
34 .\end{array}$ & $\begin{array}{l}24 . \\
24 . \\
24 . \\
24 . \\
24 . \\
24 . \\
25 . \\
25 . \\
25 . \\
26 . \\
26 . \\
26 . \\
26 . \\
27 . \\
27 . \\
27 . \\
27 . \\
27 . \\
27 . \\
27 . \\
27 . \\
27 . \\
27 . \\
27 . \\
27 . \\
27 . \\
27 . \\
27 . \\
27 . \\
27 . \\
27 . \\
27 . \\
27 . \\
27 . \\
27 . \\
27 .\end{array}$ & $\begin{array}{l}21 x \\
21 x \\
21 x \\
21 x \\
20 x \\
19 x \\
18 x \\
18 x \\
18 x \\
17 x \\
15 x \\
15 x \\
17 x \\
19 x \\
18 x \\
16 x \\
14 x \\
12 x \\
12 x \\
12 x \\
12 x \\
13 x \\
14 x \\
14 x \\
15 x \\
15 x \\
15 x \\
15 x \\
15 x \\
15 x \\
16 x \\
16 x \\
16 x \\
16 x \\
17 x \\
17 x\end{array}$ & $\begin{array}{r}-1 x \\
-1 x \\
-x \\
-x \\
x \\
1 x \\
2 x \\
4 x \\
5 x \\
8 x \\
11 x \\
13 x \\
12 x \\
11 x \\
12 x \\
14 x \\
16 x \\
18 x \\
19 x \\
19 x \\
19 x \\
18 x \\
18 x \\
18 x \\
18 x \\
18 x \\
18 x \\
18 x \\
17 x \\
17 x \\
17 x \\
17 x \\
17 x \\
17 x \\
17 x \\
16 x \\
19\end{array}$ & $\begin{array}{l}0 . \\
0 . \\
0 . \\
0 . \\
0 . \\
0 . \\
0 . \\
0 . \\
0 . \\
1 . \\
1 . \\
1 . \\
1 . \\
1 . \\
2 . \\
2 . \\
2 . \\
2 . \\
2 . \\
2 . \\
2 . \\
2 . \\
2 . \\
2 . \\
2 . \\
2 . \\
2 . \\
2 . \\
2 . \\
2 . \\
2 . \\
2 . \\
2 . \\
2 . \\
2 . \\
2 .\end{array}$ & $\begin{array}{l}0 . \\
0 . \\
0 . \\
0 . \\
0 . \\
0 . \\
2 . \\
3 . \\
5 . \\
12 . \\
19 . \\
25 . \\
28 . \\
28 . \\
29 \\
32 . \\
34 . \\
36 . \\
36 . \\
37 . \\
37 . \\
36 . \\
35 . \\
35 . \\
35 . \\
35 . \\
35 . \\
35 . \\
35 . \\
34 . \\
35 . \\
35 . \\
34 . \\
34 . \\
34 . \\
34 .\end{array}$ & $\begin{array}{r}1 . \\
1 . \\
1 . \\
1 . \\
1 . \\
1 . \\
1 . \\
1 . \\
1 . \\
4 . \\
9 . \\
12 . \\
14 . \\
15 . \\
19 . \\
26 . \\
33 . \\
50 . \\
63 . \\
72 . \\
85 . \\
95 . \\
104 . \\
112 . \\
118 . \\
122 . \\
125 . \\
128 . \\
130 . \\
131 . \\
134 . \\
136 . \\
135 . \\
134 . \\
134 . \\
133 .\end{array}$ & 2030 & 1946 & 263 & 333 & 2412 & 2313 \\
\hline
\end{tabular}


Lamont-Doherty Earth Observatory of Columbia University Project/Expedition is TUNES/2 WOCE P17C/P16C 1991

$(T C O 2) s=35=T C O 2$ obs $X(35 / \mathrm{Sal}) \quad$ (PALK) $s=$ Potential Alkalinity $=($ TALK + NO3) X (35 $/$ SaI) woce Line P17C station 150 Latitude 18-48.9s Longitude 133-09.0W Date 7/29/91 Bottom Depth 3884

\begin{tabular}{|c|c|c|c|c|c|c|c|c|c|c|c|c|c|c|c|c|}
\hline $\begin{array}{l}\text { Bot } \\
\text { No. }\end{array}$ & $\underset{m}{\text { Depth }}$ & $\begin{array}{l}\text { Temp } \\
\text { deg } c\end{array}$ & $\begin{array}{c}\text { Pot Temp } \\
\text { deg } C\end{array}$ & $\begin{array}{c}\text { Salinity } \\
0 / 00\end{array}$ & $\begin{array}{l}\text { Sigma } \\
\text { Theta }\end{array}$ & Oxy & AOU & PO4 & $\begin{array}{r}\text { NO3 } \\
--U M\end{array}$ & $\mathrm{SiO3}$ & $\begin{array}{c}--T C \\
\text { Obs }\end{array}$ & $S=35$ & 20 & heta & $\begin{array}{l}\text { Tota } \\
\text { Calc } \\
-- \text {-uE }\end{array}$ & $\begin{array}{l}\text { Alk. } \\
\text { ALKis } \\
\mathrm{kg}-\end{array}$ \\
\hline $\begin{array}{l}101 \\
102 \\
103 \\
104 \\
105 \\
106 \\
107 \\
108 \\
109 \\
110 \\
111 \\
112 \\
113 \\
137 \\
115 \\
116 \\
117 \\
118 \\
119 \\
120 \\
121 \\
122 \\
123 \\
124 \\
125 \\
126 \\
127 \\
128 \\
129 \\
130 \\
131 \\
133 \\
132 \\
135 \\
134 \\
138\end{array}$ & 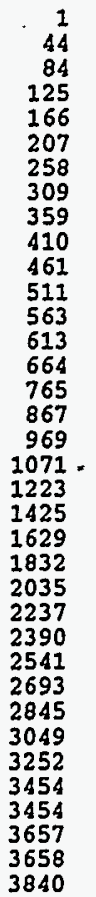 & $\begin{array}{l}25 . \\
25 . \\
25 . \\
25 . \\
23 . \\
21 . \\
19 . \\
16 . \\
13 . \\
10 . \\
8 . \\
6 . \\
6 . \\
5 . \\
5 . \\
5 . \\
4 . \\
4 . \\
3 . \\
3 . \\
3 . \\
2 . \\
2 . \\
2 . \\
1 . \\
1 . \\
1 . \\
1 . \\
1 . \\
1 . \\
1 . \\
1 . \\
1 . \\
1 . \\
1 . \\
1 .\end{array}$ & $\begin{array}{l}25 . \\
25 . \\
25 . \\
25 . \\
23 . \\
21 . \\
19 . \\
16 . \\
13 . \\
10 . \\
8 . \\
6 . \\
6 . \\
5 . \\
5 . \\
4 . \\
4 . \\
4 . \\
3 . \\
3 . \\
2 . \\
2 . \\
2 . \\
1 . \\
1 . \\
1 . \\
1 . \\
1 . \\
1 . \\
1 . \\
1 . \\
1 . \\
1 . \\
1 . \\
1 . \\
1 .\end{array}$ & $\begin{array}{l}36 . \\
36 . \\
36 . \\
36 . \\
36 . \\
36 . \\
35 . \\
35 . \\
34 . \\
34 . \\
34 . \\
34 . \\
34 . \\
34 . \\
34 . \\
34 . \\
34 . \\
34 . \\
34 . \\
34 . \\
34 . \\
34 . \\
34 . \\
34 . \\
34 . \\
34 . \\
34 . \\
34 . \\
34 . \\
34 . \\
34 . \\
34 . \\
34 . \\
34 . \\
34 . \\
34 .\end{array}$ & $\begin{array}{l}24 . \\
24 . \\
24 . \\
24 . \\
24 . \\
25 . \\
25 . \\
25 . \\
26 . \\
26 . \\
26 . \\
26 . \\
27 . \\
27 . \\
27 . \\
27 . \\
27 . \\
27 . \\
27 . \\
27 . \\
27 . \\
27 . \\
27 . \\
27 . \\
27 . \\
27 . \\
27 . \\
27 . \\
27 . \\
27 . \\
27 . \\
27 . \\
27 . \\
27 . \\
27 . \\
27 .\end{array}$ & $\begin{array}{l}21 x \\
21 x \\
21 x \\
21 x \\
20 x \\
19 x \\
19 x \\
18 x \\
17 x \\
16 x \\
15 x \\
17 x \\
20 x \\
19 x \\
16 x \\
13 x \\
12 x \\
12 x \\
12 x \\
12 x \\
13 x \\
14 x \\
15 x \\
15 x \\
15 x \\
15 x \\
15 x \\
15 x \\
15 x \\
16 x \\
16 x \\
16 x \\
16 x \\
16 x \\
16 x\end{array}$ & $\begin{array}{r}-1 x \\
-1 x \\
-1 x \\
-x \\
x \\
2 x \\
3 x \\
5 x \\
8 x \\
11 x \\
13 x \\
12 x \\
9 x \\
10 x \\
13 x \\
17 x \\
19 x \\
19 x \\
19 x \\
19 x \\
18 x \\
18 x \\
18 x \\
18 x \\
17 x \\
18 x \\
18 x \\
18 x \\
18 x \\
17 x \\
17 x \\
17 x \\
17 x \\
17 x \\
17 x\end{array}$ & $\begin{array}{l}0 . \\
0 . \\
0 . \\
0 . \\
0 . \\
0 . \\
0 . \\
0 . \\
1 . \\
1 . \\
1 . \\
1 . \\
1 . \\
1 . \\
2 . \\
2 . \\
2 . \\
2 . \\
2 . \\
2 . \\
2 . \\
2 . \\
2 . \\
2 . \\
2 . \\
2 . \\
2 . \\
2 . \\
2 . \\
2 . \\
2 . \\
2 . \\
2 . \\
2 . \\
2 .\end{array}$ & $\begin{array}{l}0 . \\
0 . \\
0 . \\
0 . \\
0 . \\
2 . \\
3 . \\
5 . \\
11 . \\
19 . \\
25 . \\
27 . \\
27 . \\
28 . \\
31 . \\
35 . \\
36 . \\
36 . \\
36 . \\
36 . \\
36 . \\
35 . \\
35 . \\
35 . \\
35 . \\
35 . \\
35 . \\
35 . \\
35 . \\
34 . \\
34 . \\
34 . \\
34 . \\
34 . \\
34 .\end{array}$ & $\begin{array}{r}1 . \\
1 . \\
1 . \\
0 . \\
1 . \\
1 . \\
1 . \\
2 . \\
4 . \\
9 . \\
13 . \\
14 . \\
13 . \\
18 . \\
25 . \\
43 . \\
59 . \\
68 . \\
76 . \\
84 . \\
90 . \\
103 . \\
110 . \\
117 . \\
121 . \\
125 . \\
126 . \\
129 . \\
131 . \\
130 . \\
130 . \\
132 . \\
132 . \\
133 . \\
133 .\end{array}$ & 2030 & 1948 & 269 & 345 & 2405 & 2308 \\
\hline
\end{tabular}

WOCE Line P17C Station 151 Latitude 19-18.7S Longitude 133-03.1W Date 7/30/91 Bottom Depth 3629

\begin{tabular}{|c|c|c|c|c|c|c|c|c|c|c|c|c|c|c|c|c|}
\hline $\begin{array}{l}\text { Bot } \\
\text { No. }\end{array}$ & $\underset{\text { mepth }}{\text { Depth }}$ & $\begin{array}{r}\text { Temp } \\
\operatorname{deg} \mathrm{C}\end{array}$ & $\begin{array}{c}\text { Pot Temp } \\
\text { deg } c\end{array}$ & $\begin{array}{c}\text { Salinity } \\
0 / 00\end{array}$ & $\begin{array}{l}\text { Sigma } \\
\text { Theta }\end{array}$ & Oxy & AOU & PO4 & $\begin{array}{r}\text { NO3 } \\
-- \text { UM }\end{array}$ & $\mathrm{SiO3}$ & Obs & $\begin{array}{l}2---35 \\
S=35\end{array}$ & 20 & Pheta & $\begin{array}{l}\text { Tot } \\
\text { Calc } \\
--- \text { u }\end{array}$ & $\begin{array}{l}\text { Alk. } \\
\text { PALKIs } \\
/ \mathrm{kg}=-\end{array}$ \\
\hline $\begin{array}{l}101 \\
102 \\
103 \\
104 \\
105 \\
106 \\
107 \\
108 \\
109 \\
110 \\
111 \\
112 \\
113 \\
137 \\
115 \\
116 \\
117 \\
118 \\
119 \\
120 \\
121 \\
122 \\
123 \\
124 \\
125 \\
126 \\
127 \\
128 \\
129 \\
130 \\
131 \\
132 \\
133 \\
135 \\
134 \\
138\end{array}$ & $\begin{array}{r}3 \\
44 \\
85 \\
127 \\
146 \\
166 \\
187 \\
207 \\
258 \\
310 \\
386 \\
472 \\
533 \\
613 \\
664 \\
715 \\
817 \\
918 \\
1019 \\
1121 \\
1274 \\
1426 \\
1629 \\
1833 \\
2035 \\
2239 \\
2441 \\
2644 \\
2847 \\
3050 \\
3050 \\
3253 \\
3253 \\
3456 \\
3456 \\
3593\end{array}$ & $\begin{array}{l}25 . \\
25 . \\
25 . \\
25 . \\
23 . \\
23 . \\
22 . \\
21 . \\
19 . \\
17 . \\
13 . \\
8 . \\
7 . \\
6 . \\
5 . \\
5 . \\
4 . \\
4 . \\
4 . \\
3 . \\
3 . \\
2 . \\
2 . \\
2 . \\
2 . \\
1 . \\
1 . \\
1 . \\
1 . \\
1 . \\
1 . \\
1 . \\
1 . \\
1 . \\
1 . \\
1 .\end{array}$ & $\begin{array}{l}25 . \\
25 . \\
25 . \\
25 . \\
23 . \\
23 . \\
22 . \\
21 . \\
19 . \\
17 . \\
13 . \\
8 . \\
7 . \\
6 . \\
5 . \\
5 . \\
4 . \\
4 . \\
4 . \\
3 . \\
3 . \\
2 . \\
2 . \\
2 . \\
1 . \\
1 . \\
1 . \\
1 . \\
1 . \\
1 . \\
1 . \\
1 . \\
1 . \\
1 . \\
1 . \\
1 .\end{array}$ & $\begin{array}{l}36 . \\
36 . \\
36 . \\
36 . \\
36 . \\
36 . \\
36 . \\
36 . \\
35 . \\
35 . \\
34 . \\
34 . \\
34 . \\
34 . \\
34 . \\
34 . \\
34 . \\
34 . \\
34 . \\
34 . \\
34 . \\
34 . \\
34 . \\
34 . \\
34 . \\
34 . \\
34 . \\
34 . \\
34 . \\
34 . \\
34 . \\
34 . \\
34 . \\
34 . \\
34 . \\
34 .\end{array}$ & $\begin{array}{l}24 . \\
24 . \\
24 . \\
24 . \\
24 . \\
24 . \\
24 . \\
25 . \\
25 . \\
25 . \\
26 . \\
26 . \\
26 . \\
27 . \\
27 . \\
27 . \\
27 . \\
27 . \\
27 . \\
27 . \\
27 . \\
27 . \\
27 . \\
27 . \\
27 . \\
27 . \\
27 . \\
27 . \\
27 . \\
27 . \\
27 . \\
27 . \\
27 . \\
27 . \\
27 . \\
27 .\end{array}$ & $\begin{array}{l}21 x \\
21 x \\
21 x \\
20 x \\
19 x \\
19 x \\
18 x \\
18 x \\
16 x \\
14 x \\
16 x \\
19 x \\
18 x \\
16 x \\
13 x \\
12 x \\
12 x \\
13 x \\
14 x \\
14 x \\
15 x \\
15 x \\
15 x \\
15 x \\
15 x \\
16 x \\
16 x \\
16 x \\
16 x \\
16 x \\
16 x \\
16 x \\
16 x \\
16 x\end{array}$ & $\begin{array}{r}-1 x \\
-1 x \\
x \\
x \\
2 x \\
2 x \\
3 x \\
4 x \\
9 x \\
14 x \\
12 x \\
10 x \\
12 x \\
14 x \\
17 x \\
18 x \\
19 x \\
18 x \\
18 x \\
18 x \\
18 x \\
17 x \\
17 x \\
17 x \\
17 x \\
17 x \\
17 x \\
17 x \\
17 x \\
17 x \\
17 x \\
17 x \\
17 x \\
17 x\end{array}$ & $\begin{array}{l}0 . \\
0 . \\
0 . \\
0 . \\
0 . \\
0 . \\
0 . \\
0 . \\
0 . \\
0 . \\
1 . \\
1 . \\
1 . \\
1 . \\
2 . \\
2 . \\
2 . \\
2 . \\
2 . \\
2 . \\
2 . \\
2 . \\
2 . \\
2 . \\
2 . \\
2 . \\
2 . \\
2 . \\
2 . \\
2 . \\
2 . \\
2 . \\
2 . \\
2 . \\
2 . \\
2 .\end{array}$ & $\begin{array}{l}0 . \\
0 . \\
0 . \\
0 . \\
0 . \\
0 . \\
0 . \\
1 . \\
2 . \\
3 . \\
13 . \\
25 . \\
27 . \\
28 . \\
30 . \\
33 . \\
35 . \\
36 . \\
36 . \\
36 . \\
35 . \\
35 . \\
35 . \\
35 . \\
35 . \\
35 . \\
34 . \\
34 . \\
34 . \\
34 . \\
34 . \\
34 . \\
34 . \\
34 . \\
34 . \\
34 .\end{array}$ & $\begin{array}{r}1 . \\
1 . \\
1 . \\
1 . \\
1 . \\
1 . \\
1 . \\
1 . \\
1 . \\
2 . \\
5 . \\
13 . \\
15^{\circ} \\
16 . \\
21 . \\
29 . \\
48 . \\
60 . \\
69 . \\
76 . \\
87 . \\
98 . \\
108 . \\
112 . \\
117 . \\
1210^{\circ} \\
123 . \\
126 . \\
126 . \\
127 . \\
128 . \\
128 . \\
1290^{\circ} \\
130 . \\
130 . \\
130 .\end{array}$ & 2031 & 1949 & 262 & 329 & 2414 & 2317 \\
\hline
\end{tabular}


Lamont-Doherty Earth Observatory of Columbia University

Printed on $12 / 06 / 93$

Page 15

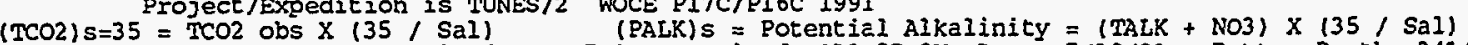
woCE Line P17C station 152 Latitude 19-47.95 Longitude 132-57.0W Date 7/30/91 Bottom Depth 3414

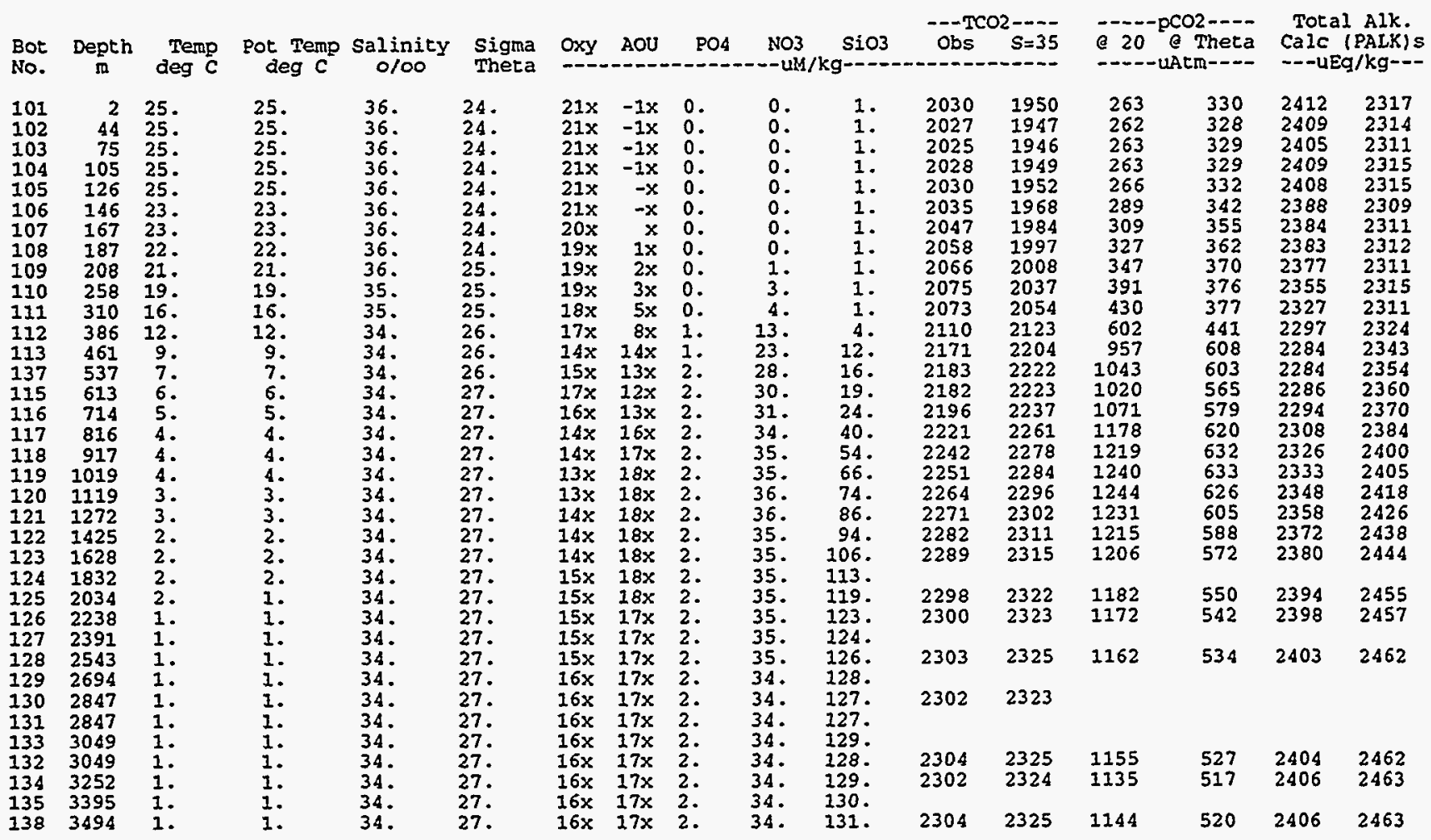

WOCE Line P17C Station 153 Latitude 20-17.0S Longitude 132-50.0W Date 7/30/91 Bottom Depth 4430

\begin{tabular}{|c|c|c|c|c|c|c|c|c|c|c|c|c|c|c|c|c|}
\hline $\begin{array}{l}\text { Bot } \\
\text { No. }\end{array}$ & $\begin{array}{l}\text { Depth } \\
\text { m }\end{array}$ & $\begin{array}{l}\text { Temp } \\
\text { deg C }\end{array}$ & $\begin{array}{l}\text { Pot Tenp } \\
\text { deg } c\end{array}$ & $\begin{array}{c}\text { Salinity } \\
0 / 00\end{array}$ & $\begin{array}{l}\text { Sigma } \\
\text { Theta }\end{array}$ & Oxy & AOU & PO4 & $\begin{array}{l}\text { NO3 } \\
--\mathrm{UM} / 1\end{array}$ & $\mathrm{SiO3}$ & $\begin{array}{c}- \text { TC } \\
\text { Obs }\end{array}$ & $S=35$ & a 20 & heta & $\begin{array}{l}\text { Tota } \\
\text { Calc } \\
--- \text { uE }\end{array}$ & $\begin{array}{l}\text { Alk. } \\
\text { ALKis } \\
\mathrm{kg}=-\end{array}$ \\
\hline $\begin{array}{l}201 \\
202 \\
203 \\
204 \\
205 \\
206 \\
207 \\
208 \\
209 \\
210 \\
211 \\
212 \\
213 \\
237 \\
215 \\
216 \\
217 \\
218 \\
219 \\
220 \\
221 \\
222 \\
223 \\
224 \\
225 \\
226 \\
227 \\
228 \\
229 \\
230 \\
231 \\
232 \\
233 \\
234 \\
235 \\
238\end{array}$ & $\begin{array}{r}3 \\
44 \\
85 \\
131 \\
157 \\
181 \\
208 \\
259 \\
310 \\
371 \\
432 \\
492 \\
552 \\
624 \\
684 \\
745 \\
816 \\
917 \\
1019 \\
1222 \\
1426 \\
1629 \\
1832 \\
2035 \\
2237 \\
2440 \\
2643 \\
2846 \\
3050 \\
3253 \\
3456 \\
3659 \\
3862 \\
4065 \\
4267 \\
4414\end{array}$ & $\begin{array}{l}25 . \\
25 . \\
25 . \\
24 . \\
23 . \\
22 . \\
21 . \\
19 . \\
16 . \\
14 . \\
10 . \\
8 . \\
6 . \\
6 . \\
5 . \\
5 . \\
5 . \\
4 . \\
4 . \\
3 . \\
2 . \\
2 . \\
2 . \\
2 . \\
1 . \\
1 . \\
1 . \\
1 . \\
1 . \\
1 . \\
1 . \\
1 . \\
1 . \\
1 . \\
1 . \\
1 .\end{array}$ & $\begin{array}{l}25 . \\
25 . \\
25 . \\
24 . \\
23 . \\
22 . \\
21 . \\
18 . \\
16 . \\
14 . \\
10 . \\
8 . \\
6 . \\
6 . \\
5 . \\
5 . \\
5 . \\
4 . \\
4 . \\
3 . \\
2 . \\
2 . \\
2 . \\
1 . \\
1 . \\
1 . \\
1 . \\
1 . \\
1 . \\
1 . \\
1 . \\
1 . \\
1 . \\
1 . \\
1 . \\
1 .\end{array}$ & $\begin{array}{l}36 . \\
36 . \\
36 . \\
36 . \\
36 . \\
36 . \\
36 . \\
35 . \\
35 . \\
34 . \\
34 . \\
34 . \\
34 . \\
34 . \\
34 . \\
34 . \\
34 . \\
34 . \\
34 . \\
34 . \\
34 . \\
34 . \\
34 . \\
34 . \\
34 . \\
34 . \\
34 . \\
34 . \\
34 . \\
34 . \\
34 . \\
34 . \\
34 . \\
34 . \\
34 . \\
34 .\end{array}$ & $\begin{array}{l}24 . \\
24 . \\
24 . \\
24 . \\
24 . \\
24 . \\
25 . \\
25 \\
25 . \\
26 . \\
26 . \\
26 . \\
26 . \\
27 . \\
27 . \\
27 . \\
27 . \\
27 . \\
27 . \\
27 . \\
27 . \\
27 . \\
27 . \\
27 . \\
27 . \\
27 . \\
27 . \\
27 . \\
27 . \\
27 . \\
27 . \\
27 . \\
27 . \\
27 . \\
27 . \\
27 .\end{array}$ & $\begin{array}{l}21 x \\
21 x \\
21 x \\
20 x \\
20 x \\
19 x \\
18 x \\
18 x \\
18 x \\
18 x \\
17 x \\
17 x \\
18 x \\
19 x \\
17 x \\
16 x \\
13 x \\
13 x \\
13 x \\
14 x \\
14 x \\
14 x \\
15 x \\
15 x \\
15 x \\
15 x \\
16 x \\
16 x \\
16 x \\
16 x \\
16 x \\
16 x \\
16 x \\
16 x \\
16 x \\
\end{array}$ & $\begin{array}{r}-1 x \\
-x \\
-x \\
-x \\
1 x \\
2 x \\
3 x \\
4 x \\
5 x \\
6 x \\
9 x \\
11 x \\
11 x \\
10 x \\
12 x \\
14 x \\
17 x \\
17 x \\
18 x \\
18 x \\
18 x \\
18 x \\
18 x \\
18 x \\
17 x \\
17 x \\
17 x \\
17 x \\
17 x \\
17 x \\
17 x \\
17 x \\
17 x \\
17 x \\
17 x\end{array}$ & $\begin{array}{l}0 . \\
0 . \\
0 . \\
0 . \\
0 . \\
0 . \\
0 . \\
0 . \\
0 . \\
0 . \\
1 . \\
1 . \\
1 . \\
1 . \\
2 . \\
2 . \\
2 . \\
2 . \\
2 . \\
2 . \\
2 . \\
2 . \\
2 . \\
2 . \\
2 . \\
2 . \\
2 . \\
2 . \\
2 . \\
2 . \\
2 . \\
2 . \\
2 . \\
2 . \\
2 .\end{array}$ & $\begin{array}{l}0 . \\
0 . \\
0 . \\
0 . \\
0 . \\
0 . \\
1 . \\
3 . \\
5 . \\
9 . \\
16 . \\
24 . \\
27 . \\
28 . \\
30 . \\
32 . \\
34 . \\
35 . \\
35 . \\
35 . \\
35 . \\
35 . \\
35 . \\
35 . \\
34 . \\
34 . \\
34 . \\
34 . \\
34 . \\
34 . \\
34 . \\
34 . \\
34 . \\
34 . \\
34 .\end{array}$ & $\begin{array}{r}1 . \\
1 . \\
1 . \\
1 . \\
1 . \\
1 . \\
1 . \\
1 . \\
1 . \\
3 . \\
6 . \\
11 . \\
14 . \\
16 . \\
21 . \\
28 . \\
38 . \\
53 . \\
64 . \\
82 . \\
97 . \\
105 . \\
114 . \\
118 . \\
122 . \\
125 . \\
125 . \\
125 . \\
127 . \\
127 . \\
128 . \\
129 . \\
129 . \\
129 . \\
129 .\end{array}$ & 2030 & 1951 & 264 & 329 & 2410 & 2316 \\
\hline
\end{tabular}


Lamont-Doherty Earth Observatory of Columbia University

(TCO2) $s=35$ roject/Expedition is TUNES/2 HOCE P17C/PI6C 1991 A WOCE Line P17C Station 154 Latitude 20-47.2S Longitude 132-44.0W Date 7/31/91 Bottom Depth 4250

\begin{tabular}{|c|c|c|c|c|c|c|c|c|c|c|c|c|c|c|c|c|}
\hline $\begin{array}{l}\text { Bot } \\
\text { No. }\end{array}$ & $\underset{m}{\text { Depth }}$ & $\begin{array}{l}\text { Temp } \\
\text { deg } C\end{array}$ & $\begin{array}{c}\text { Pot Temp } \\
\text { deg } c\end{array}$ & $\begin{array}{c}\text { Salinity } \\
0 / 00\end{array}$ & $\begin{array}{l}\text { Sigma } \\
\text { Theta }\end{array}$ & Oxy & AOU & PO4 & $\begin{array}{c}\text { NO3 } \\
-- \text { UM }\end{array}$ & $\mathrm{SiO3}$ & $\begin{array}{r}--T C \\
\text { Obs }\end{array}$ & $S=35$ & 20 & Theta & $\begin{array}{l}\text { Tota } \\
\text { Calc } \\
---u E\end{array}$ & $\begin{array}{l}\text { Alk. } \\
\text { ALKis } \\
\text { kg- }\end{array}$ \\
\hline $\begin{array}{l}101 \\
102 \\
103 \\
104 \\
105 \\
106 \\
107 \\
108 \\
109 \\
110 \\
111 \\
112 \\
113 \\
137 \\
115 \\
116 \\
117 \\
118 \\
119 \\
120 \\
121 \\
122 \\
123 \\
124 \\
125 \\
126 \\
127 \\
128 * \\
129 \\
130 \\
131 \\
132 \\
133 \\
134 \\
135 \\
138\end{array}$ & $\begin{array}{r}2 \\
45 \\
86 \\
131 \\
148 \\
167 \\
187 \\
207 \\
228 \\
248 \\
310 \\
387 \\
462 \\
538 \\
639 \\
716 \\
816 \\
917 \\
1019 \\
1121 \\
1273 \\
1424 \\
1628 \\
1830 \\
2034 \\
2237 \\
2440 \\
2642 \\
2847 \\
3049 \\
3254 \\
3458 \\
3660 \\
3864 \\
4067 \\
4270\end{array}$ & $\begin{array}{l}24 . \\
24 . \\
24 . \\
24 . \\
24 . \\
22 . \\
21 . \\
21 . \\
20 . \\
20 . \\
17 . \\
13 . \\
9 . \\
7 . \\
5 . \\
5 . \\
4 . \\
4 . \\
4 . \\
3 . \\
3 . \\
2 . \\
2 . \\
2 . \\
2 . \\
1 . \\
1 . \\
1 . \\
1 . \\
1 . \\
1 . \\
1 . \\
1 . \\
1 . \\
1 . \\
1 .\end{array}$ & $\begin{array}{l}24 . \\
24 . \\
24 . \\
24 . \\
24 . \\
22 . \\
21 . \\
21 . \\
20 . \\
20 . \\
17 . \\
13 . \\
9 . \\
7 . \\
5 . \\
5 . \\
4 . \\
4 . \\
4 . \\
3 . \\
3 . \\
2 . \\
2 . \\
2 . \\
1 . \\
1 . \\
1 . \\
1 . \\
1 . \\
1 . \\
1 . \\
1 . \\
1 . \\
1 . \\
1 . \\
1 .\end{array}$ & $\begin{array}{l}36 . \\
36 . \\
36 . \\
36 . \\
36 . \\
35 . \\
35 . \\
35 . \\
35 . \\
35 . \\
35 . \\
34 . \\
34 . \\
34 . \\
34 . \\
34 . \\
34 . \\
34 . \\
34 . \\
34 . \\
34 . \\
34 . \\
34 . \\
34 . \\
34 . \\
34 . \\
34 . \\
34 . \\
34 . \\
34 . \\
34 . \\
34 . \\
34 . \\
34 . \\
34 . \\
34 .\end{array}$ & $\begin{array}{l}24 . \\
24 . \\
24 . \\
24 . \\
24 . \\
24 . \\
24 . \\
25 . \\
25 . \\
25 . \\
25 . \\
26 . \\
26 . \\
26 . \\
27 . \\
27 . \\
27 . \\
27 . \\
27 . \\
27 . \\
27 . \\
27 . \\
27 . \\
27 . \\
27 . \\
27 . \\
27 . \\
27 . \\
27 . \\
27 . \\
27 . \\
27 . \\
27 . \\
27 . \\
27 . \\
27 .\end{array}$ & $\begin{array}{l}20 x \\
20 x \\
20 x \\
20 x \\
20 x \\
20 x \\
19 x \\
19 x \\
18 x \\
18 x \\
19 x \\
18 x \\
17 x \\
17 x \\
19 x \\
18 x \\
15 x \\
13 x \\
13 x \\
13 x \\
14 x \\
14 x \\
14 x \\
15 x \\
15 x \\
15 x \\
15 x \\
15 x \\
16 x \\
16 x \\
16 x \\
16 x \\
16 x \\
16 x \\
16 x\end{array}$ & $\begin{array}{r}-x \\
-x \\
-x \\
-x \\
x \\
1 x \\
1 x \\
2 x \\
3 x \\
3 x \\
4 x \\
7 x \\
10 x \\
11 x \\
10 x \\
12 x \\
15 x \\
17 x \\
18 x \\
18 x \\
18 x \\
18 x \\
18 x \\
18 x \\
18 x \\
18 x \\
17 x \\
17 x \\
17 x \\
17 x \\
17 x \\
17 x \\
17 x \\
17 x \\
17 x \\
1 \\
\end{array}$ & $\begin{array}{l}0 . \\
0 . \\
0 . \\
0 . \\
0 . \\
0 . \\
0 . \\
0 . \\
0 . \\
0 . \\
0 . \\
0 . \\
1 . \\
1 . \\
1 . \\
2 . \\
2 . \\
2 . \\
2 . \\
2 . \\
2 . \\
2 . \\
2 . \\
2 . \\
2 . \\
2 . \\
2 . \\
2 . \\
2 . \\
2 . \\
2 . \\
2 . \\
2 . \\
2 . \\
2 .\end{array}$ & $\begin{array}{l}0 . \\
0 . \\
0 . \\
0 . \\
0 . \\
0 . \\
0 . \\
1 . \\
2 . \\
2 . \\
4 . \\
10 . \\
20 . \\
26 . \\
28 . \\
30 . \\
34 . \\
35 . \\
36 . \\
36 . \\
36 . \\
35 . \\
35 . \\
35 . \\
35 . \\
35 . \\
35 . \\
35 . \\
35 . \\
34 . \\
34 . \\
34 . \\
34 . \\
34 . \\
34 .\end{array}$ & $\begin{array}{r}1 . \\
1 . \\
1 . \\
1 . \\
1 . \\
1 . \\
1 . \\
1 . \\
1 . \\
1 . \\
2 . \\
3 . \\
8 . \\
12 . \\
16 . \\
23 . \\
38 . \\
53 . \\
68 . \\
77 . \\
86 . \\
95 . \\
105 . \\
112 . \\
119 . \\
123 . \\
125 . \\
126 . \\
128 . \\
128 . \\
129 . \\
131 . \\
132 . \\
132 . \\
132 .\end{array}$ & 2026 & 1951 & 277 & 341 & 2391 & 2302 \\
\hline
\end{tabular}

WOCE Line P17C Station 155 Latitude 21-15.8S Longitude 132-37.1W Date 7/31/91 Bottom Depth 3959

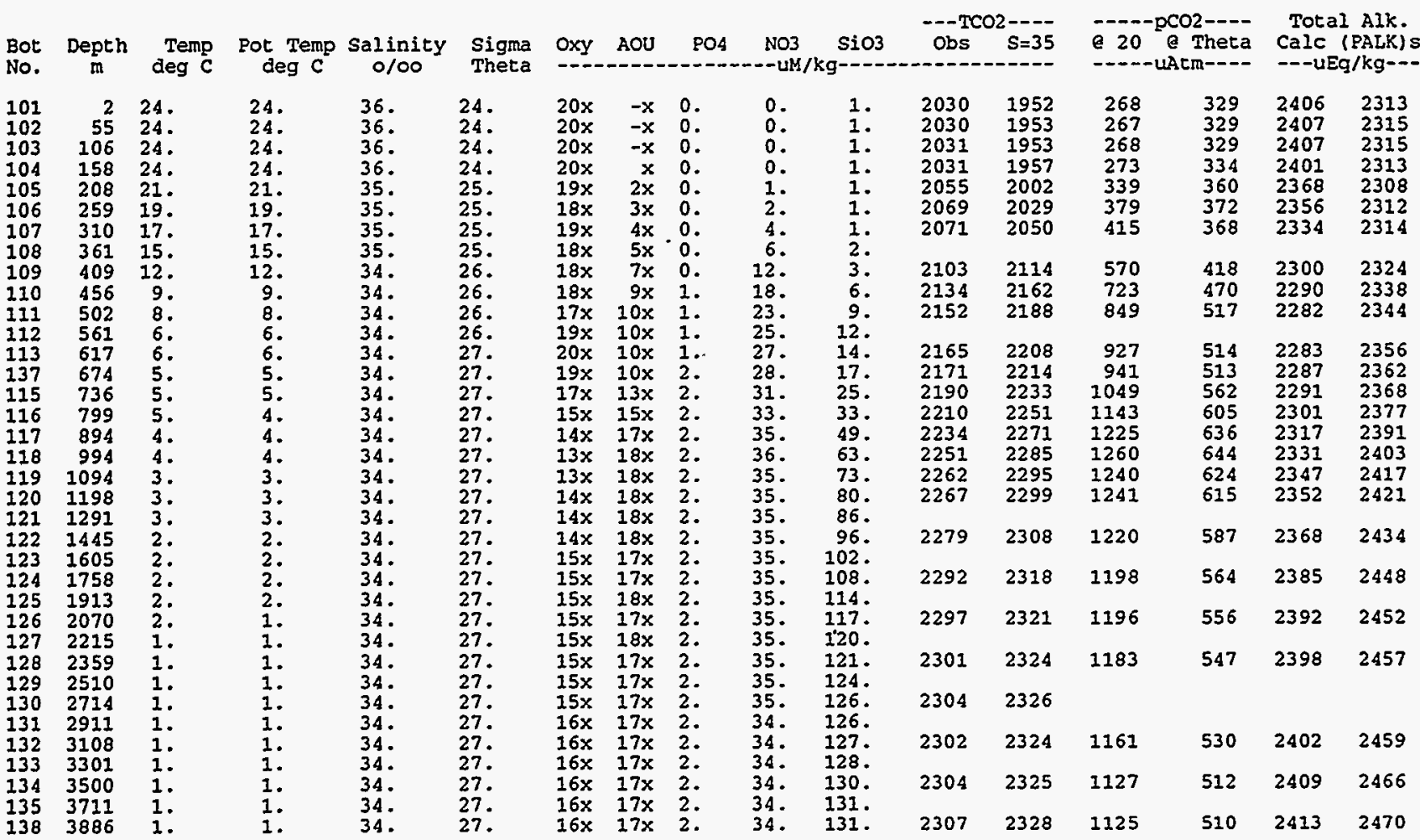


Lamont-Doherty Earth Observatory of Columbia University

$(\mathrm{TCO}) \mathrm{s}=35$ (TALK + NO3) $\mathrm{X}(35 / \mathrm{Sal})$ WOCE Line P17C station 156 Latitude 21-46.0S Longitude 132-31.1W Date 7/31/91 Botrom Depth 3837

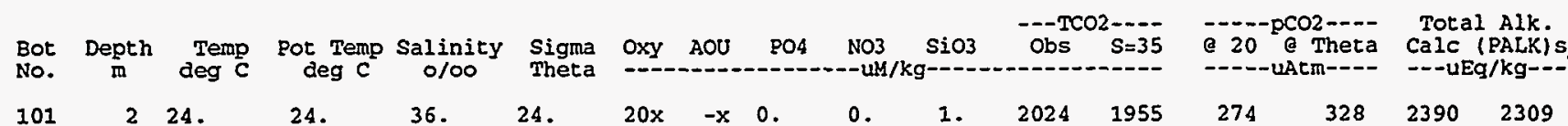

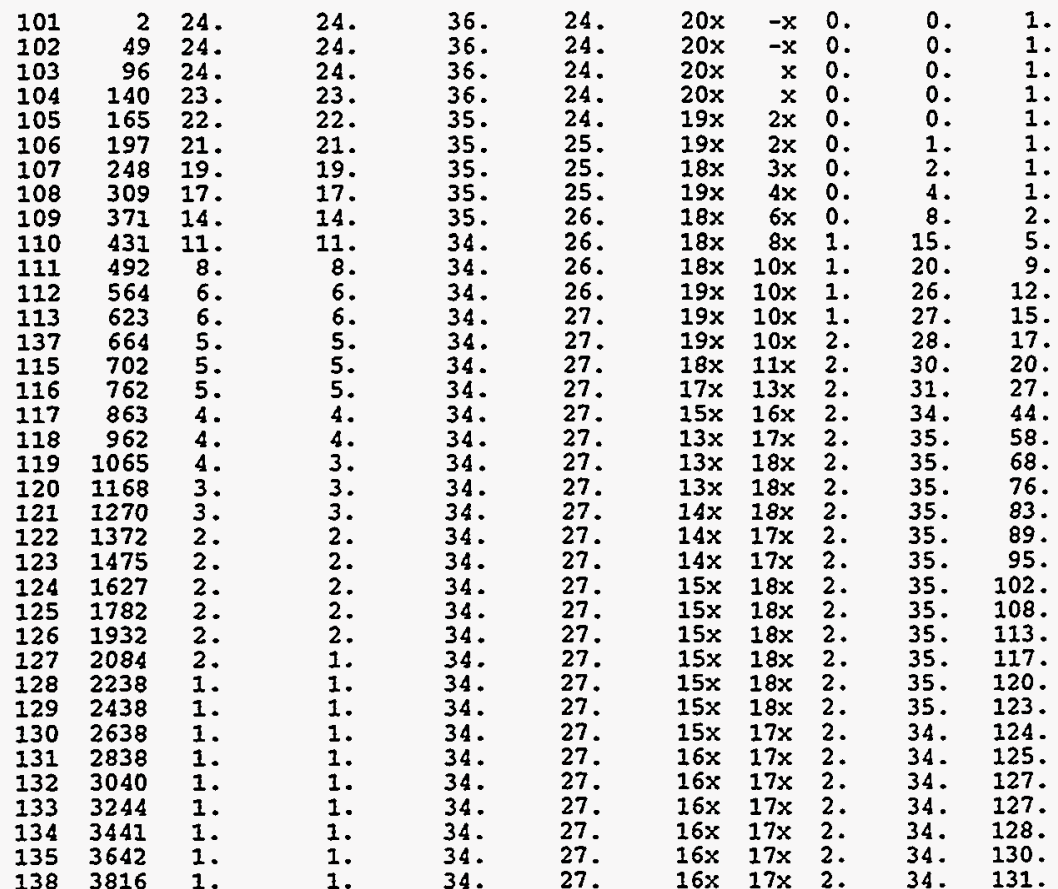

WoCE Line P17C Station 157 Latitude 22-15.3S Longitude 132-25.IW Date $8 / 1 / 91$ Bottom Depth 3512

Bot Depth Temp Pot Temp Salinity Sigma oxy AOU PO4 No3 SiO3 obs S=35 e 20 e Theta cal Alk.

No. $m$ deg $C$ deg $C$ o/O0 Theta

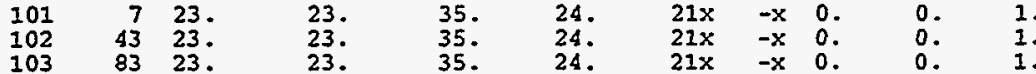

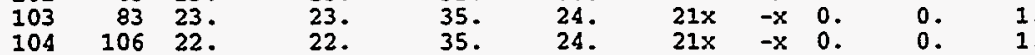

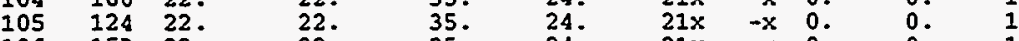

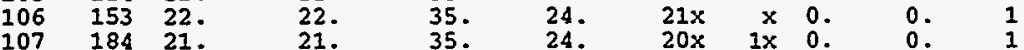

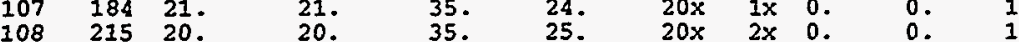

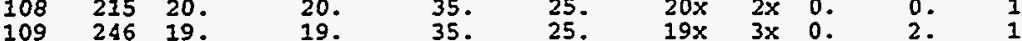

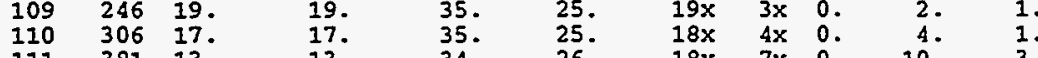

111381 13.

1124569.

$\begin{array}{lll}113 & 506 & 7 \\ 137 & 584 & 6\end{array}$

1156605

$\begin{array}{lll}116 & 731 & 5 .\end{array}$

1178005.

$\begin{array}{lll}118 & 899 & 4\end{array}$

$120 \quad 10934$.

$121 \quad 119133$.

$122 \quad 1336 \quad 3$.

12416902 .

$\begin{array}{lll}125 & 1892 & 2\end{array}$

$\begin{array}{lll}126 & 2099 & 1\end{array}$

$\begin{array}{lll}127 & 2304 & 1\end{array}$

$\begin{array}{lll}128 & 2503 & 1\end{array}$

$1292706 \quad 1$.

$\begin{array}{lll}131 & 2917 & 1 \\ 130 & 2917 & 1\end{array}$

$\begin{array}{lll}132 & 3121 & 1\end{array}$

$\begin{array}{lll}133 & 3122 & 1\end{array}$

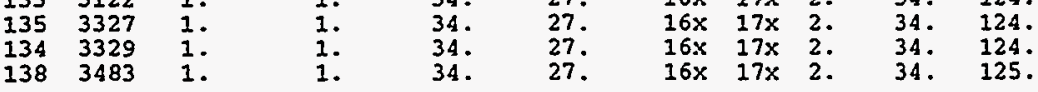

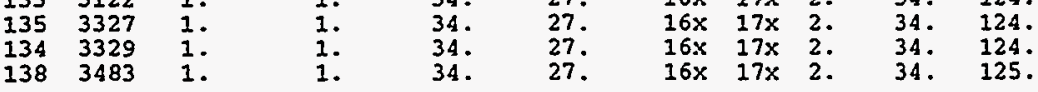

$18 \times \quad 7 \times \quad 0$

$\begin{array}{lll}18 x & 9 x & 1 \\ 18 x & 10 x & 1\end{array}$

24.10.

$19 x$ 10x 1.

$20 x \quad 10 x \quad 1.28 .216$.

$16 \times 14 \times 2$.

$14 \times 16 \times 2 . \quad 34.47$

$13 \times 17 \times 2 . \quad 35 . \quad 59$.

$13 \times 18 \times 2 . \quad 35.67$

$13 \times 18 \times 2 . \quad 35.76$

$\begin{array}{lllll}14 x & 18 x & 2 . & 35 . & 84 .\end{array}$

$15 x \quad 17 x \quad 2$.

$15 \times 18 \times 2$.

$15 \mathrm{x} 17 \mathrm{x}, 2.35 .118$.

$15 x \quad 17 x \times 2 . \quad 35, \quad 121$.

$15 \times 17 x$ 2. 34. 122.

$16 \times 17 x \quad 2.34 . \quad 124$.

$16 x \quad 17 x \quad 2 . \quad 34 . \quad 123$.

$16 x \quad 17 x \quad 2 . \quad 34 . \quad 124$.

$\begin{array}{lllll}16 x & 17 x & 2 . & 34 . & 124 .\end{array}$

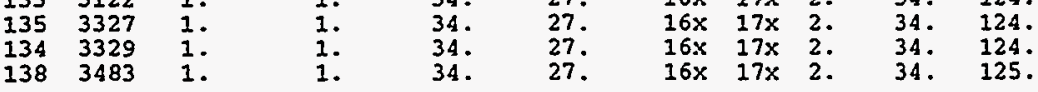


Lamont-Doherty Earth Observatory of Columbia University

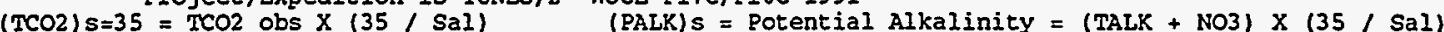
Woce Line P17C Station 158 Latitude 22-42.5S Longitude 132-17.1W Date 8/ 1/91 Bottom Depth 3398

\begin{tabular}{|c|c|c|c|c|c|c|c|c|c|c|}
\hline ot & $\underset{\text { In }}{\text { Depth }}$ & $\begin{array}{l}\text { Temp } \\
\text { deg C }\end{array}$ & $\begin{array}{c}\text { Pot Temp } \\
\operatorname{deg} c\end{array}$ & $\begin{array}{c}\text { Salinity } \\
0 / 00\end{array}$ & $\begin{array}{l}\text { Sigma } \\
\text { Theta }\end{array}$ & Oxy & AOU & PO4 & $\begin{array}{l}\text { NO3 } \\
-- \text { UM/ }\end{array}$ & \\
\hline $\begin{array}{l}101 \\
102 \\
103 \\
104 \\
105 \\
106 \\
107 \\
108 \\
109 \\
110 \\
111 \\
112 \\
113 \\
137 \\
115 \\
116 \\
117 \\
118 \\
119 \\
120 \\
121 \\
122 \\
123 \\
124 \\
125 \\
126 \\
127 \\
128 \\
129 \\
130 \\
131 \\
132 \\
127\end{array}$ & $\begin{array}{r}2 \\
39 \\
80 \\
114 \\
156 \\
176 \\
196 \\
215 \\
256 \\
305 \\
352 \\
401 \\
444 \\
496 \\
556 \\
619 \\
672 \\
741 \\
792 \\
858 \\
958 \\
1049 \\
1108 \\
1157 \\
1254 \\
1350 \\
1552 \\
1759 \\
1966 \\
2171 \\
2381 \\
2586 \\
2791 \\
3000 \\
3193 \\
3374\end{array}$ & $\begin{array}{l}23 . \\
23 . \\
23 . \\
23 . \\
23 . \\
22 . \\
22 . \\
20 . \\
19 . \\
16 . \\
14 . \\
12 . \\
10 . \\
8 . \\
6 . \\
6 . \\
5 . \\
5 . \\
5 . \\
4 . \\
4 . \\
4 . \\
4 . \\
3 . \\
3 . \\
3 . \\
2 . \\
2 . \\
2 . \\
1 . \\
1 . \\
1 . \\
1 . \\
1 . \\
1 .\end{array}$ & $\begin{array}{l}23 . \\
23 . \\
23 . \\
23 . \\
23 . \\
22 . \\
22 . \\
20 . \\
18 . \\
16 . \\
14 . \\
12 . \\
10 . \\
8 . \\
6 . \\
6 . \\
5 . \\
5 . \\
5 . \\
4 . \\
4 . \\
4 . \\
3 . \\
3 . \\
3 . \\
3 . \\
2 . \\
2 . \\
1 . \\
1 . \\
1 . \\
1 . \\
1 . \\
1 . \\
1 . \\
1 .\end{array}$ & $\begin{array}{l}35 . \\
35 . \\
35 . \\
35 . \\
35 . \\
35 . \\
35 . \\
35 . \\
35 . \\
35 . \\
35 . \\
34 . \\
34 . \\
34 . \\
34 . \\
34 . \\
34 . \\
34 . \\
34 . \\
34 . \\
34 . \\
34 . \\
34 . \\
34 . \\
34 . \\
34 . \\
34 . \\
34 . \\
34 . \\
34 . \\
34 . \\
34 . \\
34 . \\
34 . \\
34 .\end{array}$ & $\begin{array}{l}24 . \\
24 . \\
24 . \\
24 . \\
24 . \\
24 . \\
24 . \\
25 . \\
25 . \\
25 . \\
26 . \\
26 . \\
26 . \\
26 . \\
26 . \\
26 . \\
27 . \\
27 . \\
27 . \\
27 . \\
27 . \\
27 . \\
27 . \\
27 . \\
27 . \\
27 . \\
27 . \\
27 . \\
27 . \\
27 . \\
27 . \\
27 . \\
27 . \\
27 .\end{array}$ & $\begin{array}{l}21 x \\
21 x \\
21 x \\
21 x \\
21 x \\
21 x \\
20 x \\
19 x \\
19 x \\
19 x \\
19 x \\
18 x \\
18 x \\
17 x \\
21 x \\
19 x \\
19 x \\
18 x \\
17 x \\
16 x \\
14 x \\
14 x \\
13 x \\
14 x \\
14 x \\
14 x \\
15 x \\
15 x \\
15 x \\
15 x \\
15 x \\
16 x \\
16 x \\
16 x \\
16 x \\
17 x\end{array}$ & $\begin{array}{r}-x \\
-x \\
-x \\
-x \\
-x \\
x \\
1 x \\
3 x \\
3 x \\
4 x \\
6 x \\
7 x \\
9 x \\
10 x \\
8 x \\
10 x \\
11 x \\
11 x \\
13 x \\
15 x \\
16 x \\
17 x \\
18 x \\
17 x \\
17 x \\
17 x \\
17 x \\
17 x \\
18 x \\
17 x \\
17 x \\
17 x \\
17 x \\
17 x \\
17 x \\
16 x\end{array}$ & $\begin{array}{l}0 . \\
0 . \\
0 . \\
0 . \\
0 . \\
0 . \\
0 . \\
0 . \\
0 . \\
0 . \\
0 . \\
1 . \\
1 . \\
1 . \\
1 . \\
1 . \\
2 . \\
2 . \\
2 . \\
2 . \\
2 . \\
2 . \\
2 . \\
2 . \\
2 . \\
2 . \\
2 . \\
2 . \\
2 . \\
20 \\
2 . \\
2 . \\
2 . \\
2 . \\
2 .\end{array}$ & $\begin{array}{l}0 . \\
0 . \\
0 . \\
0 . \\
0 . \\
0 . \\
0 . \\
1 . \\
2 . \\
4 . \\
8 . \\
12 . \\
17 . \\
22 . \\
24 . \\
27 . \\
29 . \\
30 . \\
32 . \\
33 . \\
34 . \\
35 . \\
35 . \\
35 . \\
35 . \\
35 . \\
35 . \\
35 . \\
35 . \\
35 . \\
35 . \\
34 . \\
34 . \\
34 . \\
34 . \\
34 .\end{array}$ & $\begin{array}{r}8 \\
9 \\
10 \\
11 \\
12 \\
12 \\
12 \\
12 \\
12\end{array}$ \\
\hline
\end{tabular}

WOCE Line P17C Station 159 Latitude 23-14.0S Longitude 132-26.1W Date $8 / 1 / 91$ Bottom Depth 3619

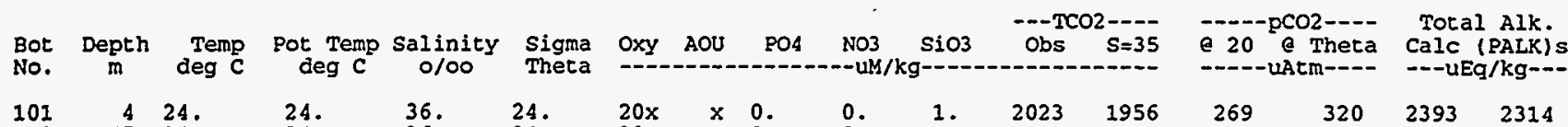

$\begin{array}{rrrrrrrrrrr}101 & 4 & 24 . & 24 . & 36 . & 24 . & 20 \times & \times & 0 . & 0 . & 1 . \\ 102 & 45 & 24 . & 24 . & 36 . & 24 . & 20 \times & -\times & 0 . & 0 . & 1 . \\ 103 & 86 & 24 . & 24 . & 36 . & 24 . & 20 \times & \times & 0 . & 0 . & 1 . \\ 104 & 115 & 24 . & 24 . & 36 . & 24 . & 20 \times & \times & 0 . & 0 . & 1 . \\ 105 & 129 & 22 . & 22 . & 35 . & 24 . & 19 \times & 1 \times & 0 . & 0 . & 1 . \\ 106 & 140 & 22 . & 22 . & 36 . & 24 . & 19 \times & 1 \times & 0 . & 1 . & 1 . \\ 107 & 162 & 22 . & 22 . & 36 . & 24 . & 19 \times & 2 \times & 0 . & 1 . & 1 . \\ 108 & 177 & 21 . & 21 . & 35 . & 25 . & 19 \times & 2 \times & 0 . & 1 . & 1 . \\ 109 & 208 & 20 . & 20 . & 35 . & 25 . & 19 \times & 3 \times & 0 . & 3 . & 1 . \\ 110 & 259 & 17 . & 17 . & 35 . & 25 . & 19 \times & 4 \times & 0 . & 5 . & 1 . \\ 111 & 309 & 16 . & 15 . & 35 . & 25 . & 19 \times & 5 \times & 0 . & 10 . & 2 . \\ 112 & 367 & 13 . & 13 . & 34 . & 26 . & 18 \times & 6 \times & 0 . & 15 . & 4 . \\ 113 & 424 & 10 . & 10 . & 34 . & 26 . & 19 \times & 7 \times & 1 . & 18 . & 6 . \\ 137 & 467 & 9 . & 9 . & 34 . & 26 . & 19 \times & 8 \times & 1 . & 21 . & 7 . \\ 115 & 517 & 7 . & 7 . & 34 . & 26 . & 20 \times & 8 \times & 1 . & 23 . & 9 . \\ 116 & 563 & 6 . & 6 . & 34 . & 26 . & 21 \times & 7 \times & 1 . & 24 . & 10 . \\ 117 & 602 & 6 . & 6 . & 34 . & 26 . & 22 \times & 7 \times & 1 . & 25 . & 12 . \\ 118 & 655 & 6 . & 5 . & 34 . & 27 . & 22 \times & 7 \times & 1 . & 27 . & 15 . \\ 119 & 718 & 5 . & 5 . & 34 . & 27 . & 21 \times & 8 \times & 1 . & 29 . & 21 . \\ 120 & 773 & 5 . & 5 . & 34 . & 27 . & 20 \times & 10 \times & 2 . & 31 . & 30 . \\ 121 & 856 & 4 . & 4 . & 34 . & 27 . & 18 \times & 12 \times & 2 . & 33 . & 42 . \\ 122 & 939 & 4 . & 4 . & 34 . & 27 . & 16 \times & 14 \times & 2 . & 35 . & 57 . \\ 123 & 1028 & 3 . & 3 . & 34 . & 27 . & 15 \times & 16 \times & 2 . & 35 . \\ 124 & 1189 & 3 . & 3 . & 34 . & 27 . & 14 \times & 17 \times & 2 . & 35 . & 76 . \\ 125 & 1343 & 2 . & 2 . & 34 . & 27 . & 14 \times & 17 \times & 2 . & 35 . & 88 . \\ 126 & 1529 & 2 . & 2 . & 34 . & 27 . & 15 \times & 17 \times & 2 . & 35 . & 100 . \\ 127 & 1732 & 2 . & 2 . & 34 . & 27 . & 15 \times & 18 \times & 2 . & 35 . & 108 . \\ 128 & 1941 & 2 . & 1 . & 34 . & 27 . & 15 \times & 17 \times & 2 . & 35 . & 115 . \\ 129 & 2125 & 1 . & 1 . & 34 . & 27 . & 15 \times & 17 \times & 2 . & 35 . & 119 . \\ 130 & 2321 & 1 . & 1 . & 34 . & 27 . & 15 \times & 17 \times & 2 . & 35 . & 121 . \\ 131 & 2517 & 1 . & 1 . & 34 . & 27 . & 16 \times & 17 \times & 2 . & 35 . & 123 . \\ 132 & 2707 & 1 . & 1 . & 34 . & 27 . & 16 \times & 17 \times & 2 . & 34 . & 124 . \\ 133 & 2895 & 1 . & 1 . & 34 . & 27 . & 16 \times & 17 \times & 2 . & 34 . & 125 . \\ 134 & 3121 & 1 . & 1 . & 34 . & 27 . & 16 \times & 17 \times & 2 . & 34 . & 125 . \\ 135 & 3358 & 1 . & 1 . & 34 . & 27 . & 17 \times & 16 \times & 2 . & 34 . & 125 . \\ 138 & 3581 & 1 . & 1 . & 34 . & 27 . & 17 \times & 16 \times & 2 . & 34 . & 125 .\end{array}$


Lamont-Doherty Earth Observatory of Columbia University

Printed on $12 / 06 / 93$

Page 19

(PALK)s = Potential Alkalinity $=($ TALK + NO3) $\times(35 / \mathrm{Sal})$

wOCE Line P17C Station 160 Latitude 23-43.3s Longitude 132-33.0W Date $8 / 1 / 91$ Bottom Depth 3664

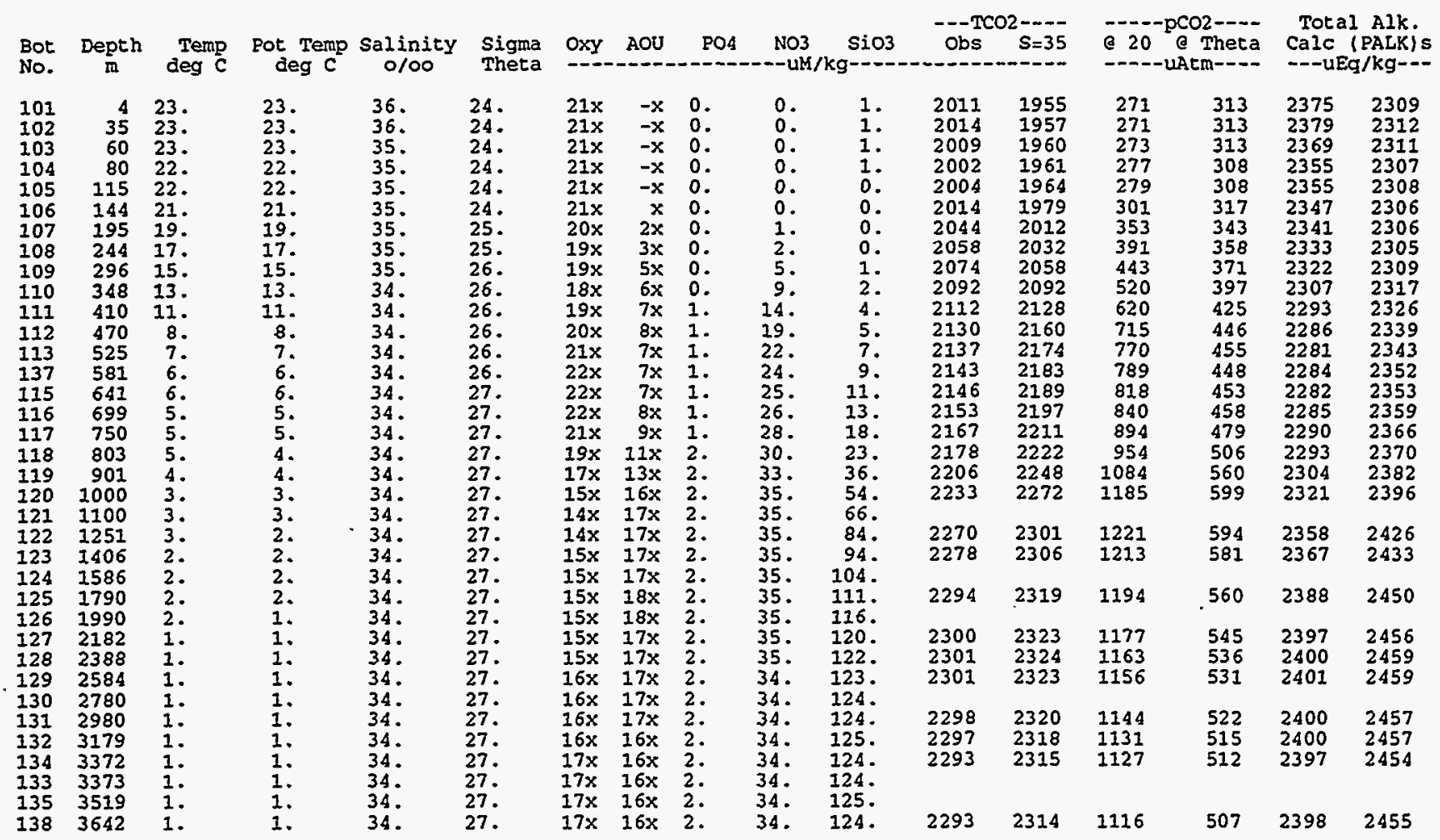

WOCE Iine P17C Station 161 Latitude 24-12.1S Longitude 132-40.1W Date 8/ 2/91 Bottom Depth 3777

\begin{tabular}{|c|c|c|c|c|c|c|c|c|c|c|c|c|c|c|c|c|}
\hline $\begin{array}{l}\text { Bot } \\
\text { No. }\end{array}$ & Depth & $\begin{array}{l}\text { Temp } \\
\text { deg C }\end{array}$ & $\begin{array}{c}\text { Pot Temp } \\
\text { deg } C\end{array}$ & $\begin{array}{c}\text { Salinity } \\
0 / 00\end{array}$ & $\begin{array}{l}\text { Sigma } \\
\text { Theta }\end{array}$ & Oxy & AOU & PO4 & $\begin{array}{r}\mathrm{NO} 3 \\
--\mathrm{UM}\end{array}$ & $\mathrm{SiO3}$ & $\begin{array}{c}--T C \\
\text { Obs }\end{array}$ & $S=35$ & 20 & heta & $\begin{array}{l}\text { Tota } \\
\text { Calc } \\
--- \text { e }\end{array}$ & $\begin{array}{l}\text { Alk. } \\
\text { ALK) S } \\
\mathrm{kg}--\end{array}$ \\
\hline $\begin{array}{l}101 \\
102 \\
103 \\
104 \\
105 \\
106 \\
107 \\
108 \\
109 \\
110 \\
111 \\
112 \\
113 \\
137 \\
115 \\
116 \\
117 \\
118 \\
119 \\
120 \\
121 \\
122 \\
123 \\
124 \\
125 \\
126 \\
127 \\
128 \\
129 \\
130 \\
131 \\
132 \\
133 \\
134 \\
135 \\
138\end{array}$ & $\begin{array}{r}4 \\
45 \\
86 \\
107 \\
116 \\
128 \\
138 \\
148 \\
168 \\
206 \\
254 \\
299 \\
347 \\
400 \\
502 \\
602 \\
708 \\
811 \\
910 \\
1003 \\
1098 \\
1235 \\
1375 \\
1580 \\
1792 \\
1987 \\
2179 \\
2375 \\
2592 \\
2794 \\
3003 \\
3210 \\
3412 \\
3611 \\
3611 \\
3800\end{array}$ & $\begin{array}{l}22 . \\
22 . \\
22 . \\
22 . \\
22 . \\
21 . \\
20 . \\
20 . \\
19 . \\
18 . \\
17 . \\
15 . \\
13 . \\
11 . \\
8 . \\
6 . \\
5 . \\
5 . \\
4 . \\
4 . \\
3 . \\
3 . \\
2 . \\
2 . \\
2 . \\
2 . \\
1 . \\
1 . \\
1 . \\
1 . \\
1 . \\
1 . \\
1 . \\
1 . \\
1 . \\
1 .\end{array}$ & $\begin{array}{l}22 . \\
22 . \\
22 . \\
22 . \\
22 . \\
21 . \\
20 . \\
20 . \\
19 . \\
18 . \\
17 . \\
15 . \\
13 . \\
11 . \\
8 . \\
6 . \\
5 . \\
4 . \\
4 . \\
3 . \\
3 . \\
3 . \\
2 . \\
2 . \\
2 . \\
1 . \\
1 . \\
1 . \\
1 . \\
1 . \\
1 . \\
1 . \\
1 . \\
1 . \\
1 . \\
1 .\end{array}$ & $\begin{array}{l}35 . \\
35 . \\
35 . \\
35 . \\
35 . \\
35 . \\
35 . \\
35 . \\
35 . \\
35 . \\
35 . \\
35 . \\
35 . \\
34 . \\
34 . \\
34 . \\
34 . \\
34 . \\
34 . \\
34 . \\
34 . \\
34 . \\
34 . \\
34 . \\
34 . \\
34 . \\
34 . \\
34 . \\
34 . \\
34 . \\
34 . \\
34 . \\
34 . \\
34 . \\
34 . \\
34 .\end{array}$ & $\begin{array}{l}24 . \\
24 . \\
24 . \\
24 . \\
24 . \\
24 . \\
25 . \\
25 . \\
25 . \\
25 . \\
25 . \\
25 . \\
26 . \\
26 . \\
26 . \\
27 . \\
27 . \\
27 . \\
27 . \\
27 . \\
27 . \\
27 . \\
27 . \\
27 . \\
27 . \\
27 . \\
27 . \\
27 . \\
27 . \\
27 . \\
27 . \\
27 . \\
27 . \\
27 . \\
27 . \\
27 .\end{array}$ & $\begin{array}{l}21 x \\
21 x \\
21 x \\
21 x \\
21 x \\
21 x \\
20 x \\
20 x \\
20 x \\
20 x \\
19 x \\
19 x \\
19 x \\
19 x \\
20 x \\
22 x \\
22 x \\
20 x \\
17 x \\
15 x \\
15 x \\
14 x \\
14 x \\
15 x \\
15 x \\
15 x \\
15 x \\
15 x \\
16 x \\
16 x \\
16 x \\
17 x \\
17 x \\
17 x \\
17 x \\
17 x\end{array}$ & $\begin{array}{r}-x \\
-x \\
-x \\
-x \\
-x \\
x \\
1 x \\
2 x \\
2 x \\
3 x \\
4 x \\
4 x \\
6 x \\
7 x \\
8 x \\
8 x \\
7 x \\
10 x \\
13 x \\
16 x \\
16 x \\
17 x \\
17 x \\
17 x \\
17 x \\
18 x \\
17 x \\
17 x \\
17 x \\
17 x \\
16 x \\
16 x \\
16 x \\
16 x \\
16 x \\
16 x\end{array}$ & $\begin{array}{l}0 . \\
0 . \\
0 . \\
0 . \\
0 . \\
0 . \\
0 . \\
0 . \\
0 . \\
0 . \\
0 . \\
0 . \\
0 . \\
1 . \\
1 . \\
1 . \\
1 . \\
2 . \\
2 . \\
2 . \\
2 . \\
2 . \\
2 . \\
2 . \\
2 . \\
2 . \\
2 . \\
2 . \\
2 . \\
2 . \\
2 . \\
2 . \\
2 . \\
2 . \\
2 . \\
2 .\end{array}$ & $\begin{array}{c}0 . \\
0 . \\
0 . \\
0 . \\
0 . \\
0 . \\
0 . \\
0 . \\
0 . \\
1 . \\
3 . \\
5 . \\
9 . \\
14 . \\
21 . \\
23 . \\
26 . \\
29 . \\
32 . \\
34 . \\
35 . \\
36 . \\
35 . \\
35 . \\
35 . \\
35 . \\
35 . \\
35 . \\
35 . \\
34 . \\
34 . \\
34 . \\
34 . \\
34 . \\
34 . \\
34 .\end{array}$ & $\begin{array}{r}1 . \\
1 . \\
1 . \\
1 . \\
1 . \\
1 . \\
1 . \\
1 . \\
1 . \\
1 . \\
1 . \\
1 . \\
2 . \\
4 . \\
7 . \\
9 . \\
13 . \\
21 . \\
36 . \\
51 . \\
63 . \\
77 . \\
89 . \\
101 . \\
110 . \\
118 . \\
122 . \\
123 . \\
124 . \\
126 . \\
126 . \\
126 . \\
126 . \\
125 . \\
125 . \\
126 .\end{array}$ & 2005 & 1965 & 281 & 307 & 2355 & 2308 \\
\hline
\end{tabular}


Lamont-Doherty Earth Observatory of Columbia University

(TCO2) $s=35$ Project/Expedition is TUNES/2 WOCE P17C/P16C 1991 Plkalinity = (TALK + NO3) $\mathrm{X}(35 / \mathrm{Sa} 1)$

wOCE Line P17C station 162 Latitude 24-41.3S Longitude 132-48.0W Date $8 / 2 / 91$ Bottom Depth 4047

\begin{tabular}{|c|c|c|c|c|c|c|c|c|c|c|c|c|c|c|c|c|}
\hline $\begin{array}{l}\text { Bot } \\
\text { No. }\end{array}$ & $\underset{\text { m }}{\text { Depth }}$ & $\begin{array}{l}\text { Temp } \\
\text { deg C }\end{array}$ & $\begin{array}{l}\text { Pot Temp } \\
\text { deg } C\end{array}$ & $\begin{array}{c}\text { Salinity } \\
0 / 00\end{array}$ & $\begin{array}{l}\text { Sigma } \\
\text { Theta }\end{array}$ & Oxy & AOU & PO4 & $\begin{array}{r}\text { NO3 } \\
-- \text { uM }\end{array}$ & $\mathrm{SiO} 3$ & Obs & $\begin{array}{r}s=--- \\
s=35\end{array}$ & e 20 & $\begin{array}{l}\text { Theta } \\
\text { nhe-- }\end{array}$ & $\begin{array}{l}\text { Tota } \\
\text { Calc } \\
---u E\end{array}$ & $\begin{array}{l}\text { Alk. } \\
\text { PALKis } \\
\text { (kg- }\end{array}$ \\
\hline $\begin{array}{l}101 \\
102 \\
103 \\
104 \\
105 \\
106 \\
107 \\
108 \\
109 \\
110 \\
111 \\
112 \\
113 \\
137 \\
115 \\
116 \\
117 \\
118 \\
119 \\
120 \\
121 \\
122 \\
123 \\
124 \\
125 \\
126 \\
127 \\
128 \\
129 \\
130 \\
131 \\
132 \\
133 \\
134 \\
135 \\
138\end{array}$ & $\begin{array}{r}2 \\
47 \\
89 \\
129 \\
149 \\
180 \\
220 \\
261 \\
321 \\
382 \\
436 \\
490 \\
557 \\
617 \\
634 \\
649 \\
691 \\
752 \\
834 \\
913 \\
1003 \\
1098 \\
1282 \\
1473 \\
1671 \\
1858 \\
2042 \\
2244 \\
2463 \\
2663 \\
2884 \\
3096 \\
3304 \\
3534 \\
3751 \\
3981\end{array}$ & $\begin{array}{l}22 . \\
22 . \\
22 . \\
22 . \\
21 . \\
19 . \\
18 . \\
17 . \\
15 . \\
13 . \\
10 . \\
8 . \\
7 . \\
6 . \\
6 . \\
6 . \\
5 . \\
5 . \\
4 . \\
4 . \\
4 . \\
3 . \\
3 . \\
2 . \\
2 . \\
2 . \\
2 . \\
1 . \\
1 . \\
1 . \\
1 . \\
1 . \\
1 . \\
1 . \\
1 . \\
1 .\end{array}$ & $\begin{array}{l}22 . \\
22 . \\
22 . \\
22 . \\
21 . \\
19 . \\
18 . \\
17 . \\
15 . \\
13 . \\
10 . \\
8 . \\
7 . \\
6 . \\
6 . \\
6 . \\
5 . \\
5 . \\
4 . \\
4 . \\
4 . \\
3 . \\
3 . \\
2 . \\
2 . \\
2 . \\
1 . \\
1 . \\
1 . \\
1 . \\
1 . \\
1 . \\
1 . \\
1 . \\
1 . \\
1 .\end{array}$ & $\begin{array}{l}35 . \\
35 . \\
35 . \\
35 . \\
35 . \\
35 . \\
35 . \\
35 . \\
35 . \\
34 . \\
34 . \\
34 . \\
34 . \\
34 . \\
34 . \\
34 . \\
34 . \\
34 . \\
34 . \\
34 . \\
34 . \\
34 . \\
34 . \\
34 . \\
34 . \\
34 . \\
34 . \\
34 . \\
34 . \\
34 . \\
34 . \\
34 . \\
34 . \\
34 . \\
34 . \\
34 .\end{array}$ & $\begin{array}{l}24 . \\
24 . \\
24 . \\
24 . \\
25 . \\
25 . \\
25 . \\
25 . \\
26 . \\
26 . \\
26 . \\
26 . \\
26 . \\
26 . \\
26 . \\
27 . \\
27 . \\
27 . \\
27 . \\
27 . \\
27 . \\
27 . \\
27 . \\
27 . \\
27 . \\
27 . \\
27 . \\
27 . \\
27 . \\
27 . \\
27 . \\
27 . \\
27 . \\
27 . \\
27 . \\
27 .\end{array}$ & $\begin{array}{l}21 x \\
21 x \\
21 x \\
21 x \\
19 x \\
19 x \\
19 x \\
20 x \\
19 x \\
19 x \\
19 x \\
19 x \\
20 x \\
21 x \\
22 x \\
\\
22 x \\
21 x \\
20 x \\
18 x \\
16 x \\
15 x \\
14 x \\
15 x \\
15 x \\
15 x \\
15 x \\
15 x \\
15 x \\
16 x \\
16 x \\
16 x \\
17 x \\
17 x \\
17 x \\
17 x\end{array}$ & $\begin{array}{r}-x \\
-x \\
-x \\
x \\
2 x \\
2 x \\
3 x \\
3 x \\
4 x \\
6 x \\
8 x \\
8 x \\
8 x \\
8 x \\
8 x \\
\\
8 x \\
9 x \\
10 x \\
13 x \\
15 x \\
16 x \\
17 x \\
17 x \\
17 x \\
17 x \\
18 x \\
18 x \\
17 x \\
17 x \\
17 x \\
16 x \\
16 x \\
16 x \\
16 x \\
16 x\end{array}$ & 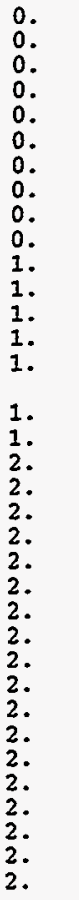 & $\begin{array}{l}0 . \\
0 . \\
0 . \\
0 . \\
0 . \\
1 . \\
2 . \\
2 . \\
5 . \\
10 . \\
16 . \\
21 . \\
23 . \\
25 . \\
25 . \\
\\
26 . \\
27 . \\
29 . \\
32 . \\
34 . \\
35 . \\
35 . \\
35 . \\
35 . \\
35 . \\
35 . \\
35 . \\
35 . \\
34 . \\
34 . \\
34 . \\
34 . \\
34 . \\
34 . \\
34 .\end{array}$ & 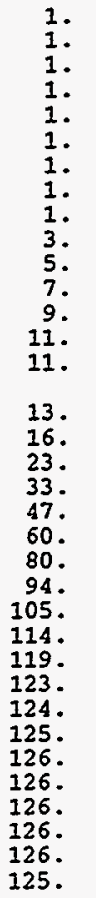 & 2005 & 1960 & 280 & 310 & 2357 & 2305 \\
\hline
\end{tabular}

WOCE Line P17C Station 163 Latitude 25-10.9S Longitude 132-55.2W Date $8 / 2 / 91 \quad$ Bottom Depth 4178

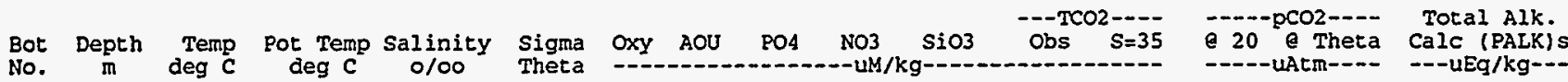

$\begin{array}{rrrrll}101 & 2 & 21 . & 21 . & 35 . & 24 . \\ 102 & 47 & 21 . & 21 . & 35 . & 24 . \\ 103 & 88 & 21 . & 21 . & 35 . & 24 . \\ 104 & 128 & 21 . & 21 . & 35 . & 24 . \\ 105 & 165 & 19 . & 19 . & 35 . & 25 . \\ 106 & 220 & 18 . & 17 . & 35 . & 25 . \\ 107 & 292 & 15 . & 15 . & 35 . & 25 . \\ 108 & 367 & 13 . & 12 . & 34 . & 26 . \\ 109 & 431 & 10 . & 10 . & 34 . & 26 . \\ 110 & 497 & 8 . & 8 . & 34 . & 26 . \\ 111 & 573 & 6 . & 6 . & 34 . & 26 . \\ 112 & 631 & 6 . & 6 . & 34 . & 26 . \\ 113 & 666 & 5 . & 5 . & 34 . & 27 . \\ 137 & 703 & 5 . & 5 . & 34 . & 27 . \\ 115 & 760 & 5 . & 5 . & 34 . & 27 . \\ 116 & 816 & 5 . & 4 . & 34 . & 27 . \\ 117 & 909 & 4 . & 4 . & 34 . & 27 . \\ 118 & 1002 & 4 . & 3 . & 34 . & 27 . \\ 119 & 1091 & 3 . & 3 . & 34 . & 27 . \\ 120 & 1178 & 3 . & 3 . & 34 . & 27 . \\ 121 & 1270 & 3 . & 3 . & 34 . & 27 . \\ 122 & 1357 & 2 . & 2 . & 34 . & 27 . \\ 123 & 1534 & 2 . & 2 . & 34 . & 27 . \\ 124 & 1715 & 2 . & 2 . & 34 . & 27 . \\ 125 & 1910 & 2 . & 1 . & 34 . & 27 . \\ 126 & 2108 & 1 . & 1 . & 34 . & 27 . \\ 127 & 2320 & 1 . & 1 . & 34 . & 27 . \\ 128 & 2513 & 1 . & 1 . & 34 . & 27 . \\ 129 & 2704 & 1 . & 1 . & 34 . & 27 . \\ 130 & 2925 & 1 . & 1 . & 34 . & 27 . \\ 131 & 3124 & 1 . & 1 . & 34 . & 27 . \\ 132 & 3300 & 1 . & 1 . & 34 . & 27 . \\ 133 & 3521 & 1 . & 1 . & 34 . & 27 . \\ 134 & 3757 & 1 . & 1 . & 34 . & 27 . \\ 135 & 3938 & 1 . & 1 . & 34 . & 27 . \\ 138 & 4150 & 1 . & 1 . & 34 . & 27 .\end{array}$

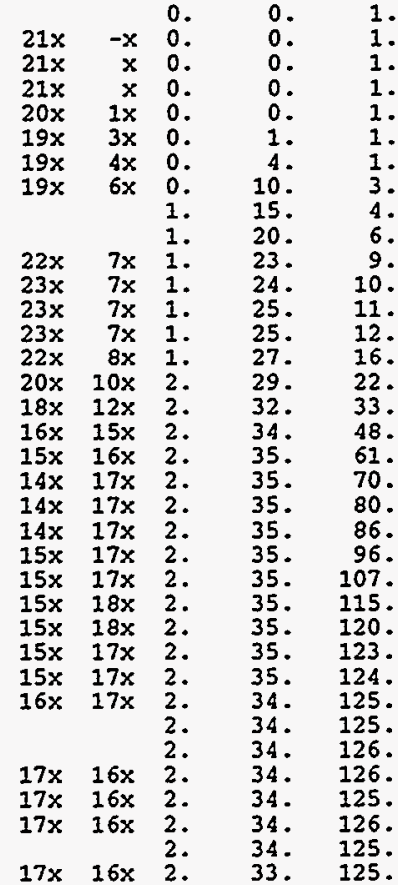


Lamont-Doherty Earth Observatory of Columbia University

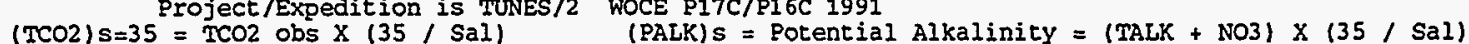
wOCE Line P17C Station 164 Latitude 25-40.4S Longitude 133-02.7W Date 8/2/91 Bottom Depth 3845

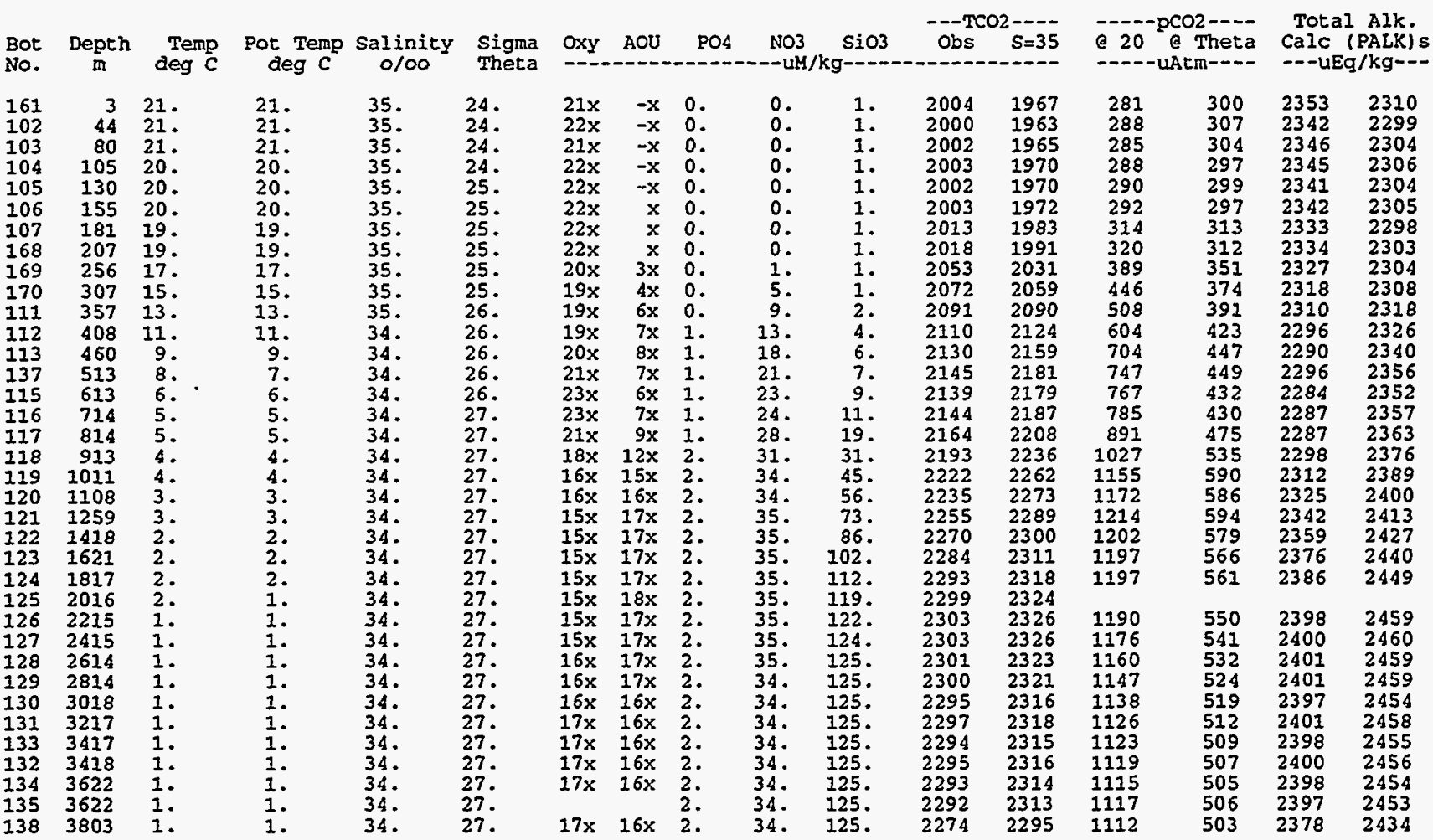

WoCE Line Pi7C Station 165. Latitude 26-06.6S Longitude 133-05.3w Date 8/3/91 Bottom Depth 4187

103 ---TCO2--- - - - pco2---- Toral Alk.

Bot Depth Temp Pot Temp Salinity Sigma Oxy AOU PO4 NO3 SiO3 Obs S=35 e 20 a Theta Calc (PALK)
No. $\mathrm{d}$ deg C

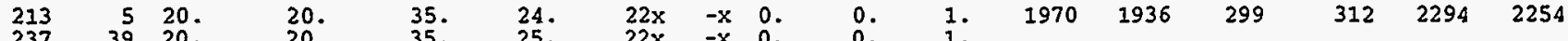

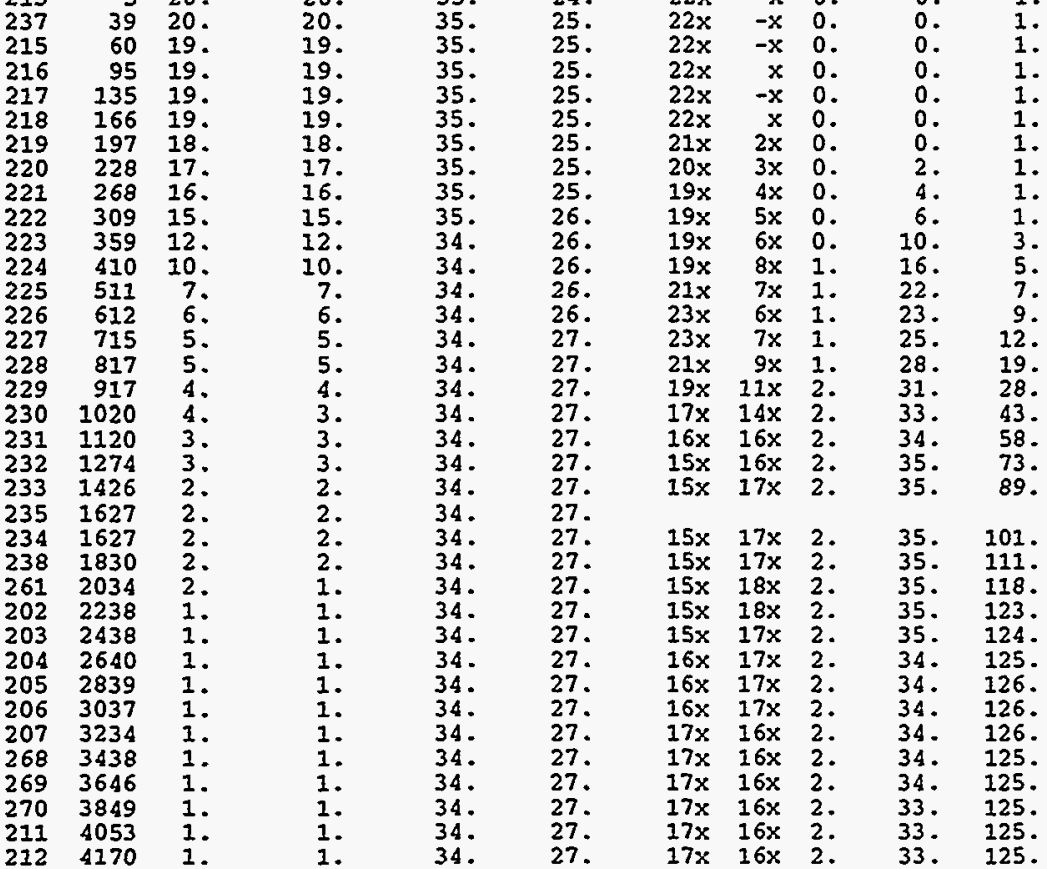


Lamont-Doherty Earth Observatory of Columbia University Project/Expedition is TUNES/2 WOCE P17C/P16C 1991 $(T C O 2) s=35=T C O 2$ obs $x(35 / \mathrm{Sal})$

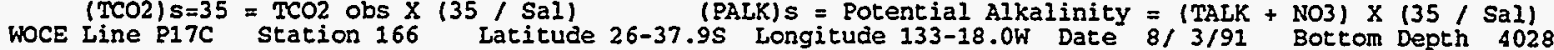

\begin{tabular}{|c|c|c|c|c|c|c|c|c|c|c|c|c|c|c|c|c|}
\hline $\begin{array}{l}\text { Bot } \\
\text { No. }\end{array}$ & $\begin{array}{l}\text { Depth } \\
\text { m }\end{array}$ & $\begin{array}{l}\text { Temp } \\
\text { deg } c\end{array}$ & $\begin{array}{l}\text { Pot Ternp } \\
\text { deg } c\end{array}$ & $\begin{array}{c}\text { Salinity } \\
0 / 00\end{array}$ & $\begin{array}{l}\text { Sigma } \\
\text { Theta }\end{array}$ & $\begin{array}{l}\text { Oxy } \\
-\end{array}$ & AOU & POA & $\begin{array}{c}\mathrm{NO} 3 \\
--\mathrm{uM} /\end{array}$ & SiO3 & Obs & $S=35$ & 20 & $\begin{array}{l}2---- \\
\text { Thera } \\
\text { m---- }\end{array}$ & $\begin{array}{l}\text { Tota } \\
\text { Calc }\end{array}$ & $\begin{array}{l}\text { Alk. } \\
\text { ALKis } \\
\text { kg- }\end{array}$ \\
\hline $\begin{array}{l}261 \\
202 \\
203 \\
204 \\
205 \\
206 \\
207 \\
268 \\
269 \\
270 \\
211 \\
212 \\
213 \\
237 \\
215 \\
216 \\
217 \\
218 \\
219 \\
220 \\
221 \\
222 \\
223 \\
224 \\
225 \\
226 \\
227 \\
228 \\
229 \\
230 \\
231 \\
232 \\
233 \\
235 \\
234 \\
238\end{array}$ & $\begin{array}{r}8 \\
52 \\
78 \\
118 \\
169 \\
220 \\
280 \\
338 \\
397 \\
461 \\
522 \\
589 \\
666 \\
717 \\
768 \\
819 \\
920 \\
1022 \\
1121 \\
1218 \\
1362 \\
1504 \\
1697 \\
1894 \\
2095 \\
2297 \\
2503 \\
2712 \\
2918 \\
3125 \\
3332 \\
3535 \\
3738 \\
3892 \\
3892 \\
4034\end{array}$ & $\begin{array}{r}20 . \\
20 . \\
19 . \\
19 . \\
19 . \\
17 . \\
15 . \\
13 . \\
11 . \\
8 . \\
7 . \\
6 . \\
6 . \\
5 . \\
5 . \\
5 . \\
4 . \\
4 . \\
3 . \\
3 . \\
2 . \\
2 . \\
2 . \\
2 . \\
2 . \\
1 . \\
1 . \\
1 . \\
1 . \\
1 . \\
1 . \\
1 . \\
1 . \\
1 . \\
1 . \\
1 .\end{array}$ & $\begin{array}{l}20 . \\
20 . \\
19 . \\
19 . \\
19 . \\
17 . \\
15 . \\
13 . \\
11 . \\
8 . \\
7 . \\
6 . \\
6 . \\
5 . \\
5 . \\
5 . \\
4 . \\
4 . \\
3 . \\
3 . \\
2 . \\
2 . \\
2 . \\
2 . \\
1 . \\
1 . \\
1 . \\
1 . \\
1 . \\
1 . \\
1 . \\
1 . \\
1 . \\
1 . \\
1 . \\
1 .\end{array}$ & $\begin{array}{l}35 . \\
35 . \\
35 . \\
35 . \\
35 . \\
35 . \\
35 . \\
35 . \\
34 . \\
34 . \\
34 . \\
34 . \\
34 . \\
34 . \\
34 . \\
34 . \\
34 . \\
34 . \\
34 . \\
34 . \\
34 . \\
34 . \\
34 . \\
34 . \\
34 . \\
34 . \\
34 . \\
34 . \\
34 . \\
34 . \\
34 . \\
34 . \\
34 . \\
34 . \\
34 . \\
34 .\end{array}$ & 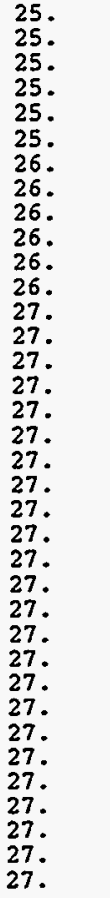 & $\begin{array}{l}22 x \\
22 x \\
22 x \\
22 x \\
21 x \\
20 x \\
19 x \\
19 x \\
19 x \\
20 x \\
23 x \\
24 x \\
24 x \\
23 x \\
23 x \\
22 x \\
19 x \\
17 x \\
16 x \\
15 x \\
15 x \\
15 x \\
15 x \\
15 x \\
15 x \\
15 x \\
15 x \\
16 x \\
16 x \\
17 x \\
17 x \\
17 x \\
17 x \\
17 x \\
17 x \\
17 x\end{array}$ & $\begin{array}{r}-x \\
x \\
-x \\
x \\
1 x \\
3 x \\
4 x \\
6 x \\
7 x \\
7 x \\
6 x \\
5 x \\
6 x \\
6 x \\
7 x \\
8 x \\
11 x \\
13 x \\
15 x \\
16 x \\
17 x \\
17 x \\
17 x \\
17 x \\
18 x \\
18 x \\
17 x \\
17 x \\
17 x \\
16 x \\
16 x \\
16 x \\
16 x \\
16 x \\
16 x \\
16 x\end{array}$ & $\begin{array}{l}0 . \\
0 . \\
0 . \\
0 . \\
0 . \\
0 . \\
0 . \\
0 . \\
1 . \\
1 . \\
1 . \\
1 . \\
1 . \\
1 . \\
1 . \\
1 . \\
2 . \\
2 . \\
2 . \\
2 . \\
2 . \\
2 . \\
2 . \\
2 . \\
2 . \\
2 . \\
2 . \\
2 . \\
2 . \\
2 . \\
2 . \\
2 . \\
2 . \\
2 . \\
2 . \\
2 .\end{array}$ & $\begin{array}{l}0 . \\
0 . \\
0 . \\
0 . \\
0 . \\
2 . \\
5 . \\
8 . \\
13 . \\
18 . \\
21 . \\
22 . \\
23 . \\
24 . \\
25 . \\
27 . \\
30 . \\
33 . \\
34 . \\
35 . \\
35 . \\
35 . \\
35 . \\
35 . \\
35 . \\
35 . \\
35 . \\
35 . \\
34 . \\
34 . \\
34 . \\
34 . \\
33 . \\
33 . \\
33 . \\
33 .\end{array}$ & $\begin{array}{r}1 . \\
1 . \\
1 . \\
1 . \\
1 . \\
0 . \\
1 . \\
2 . \\
3 . \\
5 . \\
6 . \\
7 . \\
9 . \\
11 . \\
13 . \\
17 . \\
28 . \\
40 . \\
54 . \\
67 . \\
80 . \\
91 . \\
103 . \\
113 . \\
119 . \\
123 . \\
124 . \\
125 . \\
125 . \\
125 . \\
125 \circ \\
125 . \\
125 \circ \\
125 . \\
125 .\end{array}$ & 2004 & 1971 & 290 & 298 & 2344 & 2306 \\
\hline
\end{tabular}

WOCE Line P17C Station 167 Latitude 27-07.1S Longitude 133-26.1W Date $8 / 4 / 91$ Bottom Depth 3758

\begin{tabular}{|c|c|c|c|c|c|c|c|c|c|c|c|c|c|c|c|c|}
\hline $\begin{array}{l}\text { Bot } \\
\text { No. }\end{array}$ & $\begin{array}{l}\text { Depth } \\
\text { m }\end{array}$ & $\begin{array}{l}\text { Temp } \\
\text { deg C }\end{array}$ & $\begin{array}{l}\text { Pot Temp } \\
\text { deg } c\end{array}$ & $\begin{array}{c}\text { Salinity } \\
0 / 00\end{array}$ & $\begin{array}{l}\text { Sigma } \\
\text { Theta }\end{array}$ & Oxy & AOU & PO4 & $\begin{array}{l}\text { NO3 } \\
--\mathrm{UM}\end{array}$ & $\mathrm{SiO} 3$ & $\begin{array}{l}-- \text { TC } \\
\text { Obs }\end{array}$ & $S=35$ & e 20 & Theta & $\begin{array}{r}\text { To } \\
\mathrm{Cal} \\
-\end{array}$ & $\begin{array}{l}\text { Alk. } \\
\text { sg }\end{array}$ \\
\hline $\begin{array}{l}161 \\
102 \\
103 \\
104 \\
105 \\
106 \\
107 \\
168 \\
169 \\
170 \\
111 \\
112 \\
113 \\
137 \\
115 \\
116 \\
117 \\
118 \\
119\end{array}$ & $\begin{array}{r}4 \\
51 \\
97 \\
148 \\
197 \\
259 \\
320 \\
351 \\
381 \\
442 \\
513 \\
583 \\
653 \\
693 \\
733 \\
803 \\
865 \\
926 \\
1018\end{array}$ & $\begin{array}{l}19 . \\
19 . \\
19 . \\
19 . \\
17 . \\
16 . \\
14 . \\
13 . \\
11 . \\
9 . \\
7 . \\
7 . \\
6 . \\
6 . \\
6 . \\
5 . \\
5 . \\
4 . \\
4 .\end{array}$ & $\begin{array}{l}19 . \\
19 . \\
19 . \\
19 . \\
17 . \\
16 . \\
14 . \\
13 . \\
11 . \\
9 . \\
7 . \\
6 . \\
6 . \\
6 . \\
5 . \\
5 . \\
5 . \\
4 . \\
4 .\end{array}$ & $\begin{array}{l}35 . \\
35 . \\
35 . \\
35 . \\
35 . \\
35 . \\
35 . \\
35 . \\
34 . \\
34 . \\
34 . \\
34 . \\
34 . \\
34 . \\
34 . \\
34 . \\
34 . \\
34 . \\
34 .\end{array}$ & $\begin{array}{l}25 . \\
25 . \\
25 . \\
25 . \\
25 . \\
25 . \\
26 . \\
26 . \\
26 . \\
26 . \\
26 . \\
26 . \\
26 . \\
27 . \\
27 . \\
27 . \\
27 . \\
27 . \\
27 .\end{array}$ & $\begin{array}{l}22 x \\
22 x \\
22 x \\
22 x \\
21 x \\
19 x \\
19 x \\
19 x \\
19 x \\
20 x \\
22 x \\
23 x \\
24 x \\
23 x \\
23 x \\
22 x \\
21 x \\
20 x\end{array}$ & $\begin{array}{r}x \\
x \\
x \\
x \\
2 x \\
4 x \\
5 x \\
6 x \\
7 x \\
7 x \\
6 x \\
5 x \\
6 x \\
6 x \\
6 x \\
7 x \\
9 x \\
10 x\end{array}$ & $\begin{array}{l}0 . \\
0 . \\
0 . \\
0 . \\
0 . \\
0 . \\
0 . \\
0 . \\
0 . \\
1 . \\
1 . \\
1 . \\
1 . \\
1 . \\
1 . \\
1 . \\
1 . \\
2 .\end{array}$ & $\begin{array}{r}0 . \\
0 . \\
0 . \\
0 . \\
0 . \\
4 . \\
7 . \\
9 . \\
13 . \\
17 . \\
20 . \\
21 . \\
23 . \\
23 . \\
24 . \\
26 . \\
28 . \\
30 .\end{array}$ & $\begin{array}{r}1 . \\
1 . \\
1 . \\
1 . \\
1 . \\
1 . \\
2 . \\
2 . \\
3 . \\
4 . \\
6 . \\
7 . \\
9 . \\
9 . \\
11 . \\
15 . \\
20 . \\
27 .\end{array}$ & $\begin{array}{l}2010 \\
2010 \\
2012 \\
2018 \\
2046 \\
2068 \\
2086 \\
2094 \\
2106 \\
2119 \\
2130 \\
2130 \\
2133 \\
2138 \\
2139 \\
2151 \\
2166 \\
2176\end{array}$ & $\begin{array}{l}1981 \\
1981 \\
1984 \\
1992 \\
2027 \\
2050 \\
2079 \\
2094 \\
2116 \\
2142 \\
2165 \\
2168 \\
2173 \\
2179 \\
2181 \\
2195 \\
2210 \\
2220\end{array}$ & $\begin{array}{l}305 \\
305 \\
306 \\
321 \\
374 \\
428 \\
488 \\
526 \\
584 \\
661 \\
715 \\
724 \\
743 \\
759 \\
776 \\
827 \\
882 \\
949\end{array}$ & $\begin{array}{l}300 \\
299 \\
299 \\
311 \\
336 \\
365 \\
386 \\
397 \\
412 \\
428 \\
426 \\
417 \\
418 \\
423 \\
428 \\
446 \\
468 \\
495\end{array}$ & $\begin{array}{l}2337 \\
2337 \\
2339 \\
2333 \\
2329 \\
2322 \\
2313 \\
2307 \\
2298 \\
2288 \\
2287 \\
2284 \\
2283 \\
2286 \\
2283 \\
2285 \\
2292 \\
2292\end{array}$ & $\begin{array}{l}2303 \\
2303 \\
2306 \\
2302 \\
2308 \\
2306 \\
2313 \\
2316 \\
2323 \\
2331 \\
2345 \\
2347 \\
2350 \\
2354 \\
2353 \\
2359 \\
2367 \\
2369\end{array}$ \\
\hline
\end{tabular}


Lamont-Doherty Earth Observatory of Columbia University

Printed on $12 / 06 / 93$

Page 23

(TCO2) $s=35=$ TCO2 obs $x(35$, Sal)

WOCE Line PI7C station 168 Latitude 27-37.1s Longitude 133-32.4W Date 8/4/91 Bottom Depth 4130

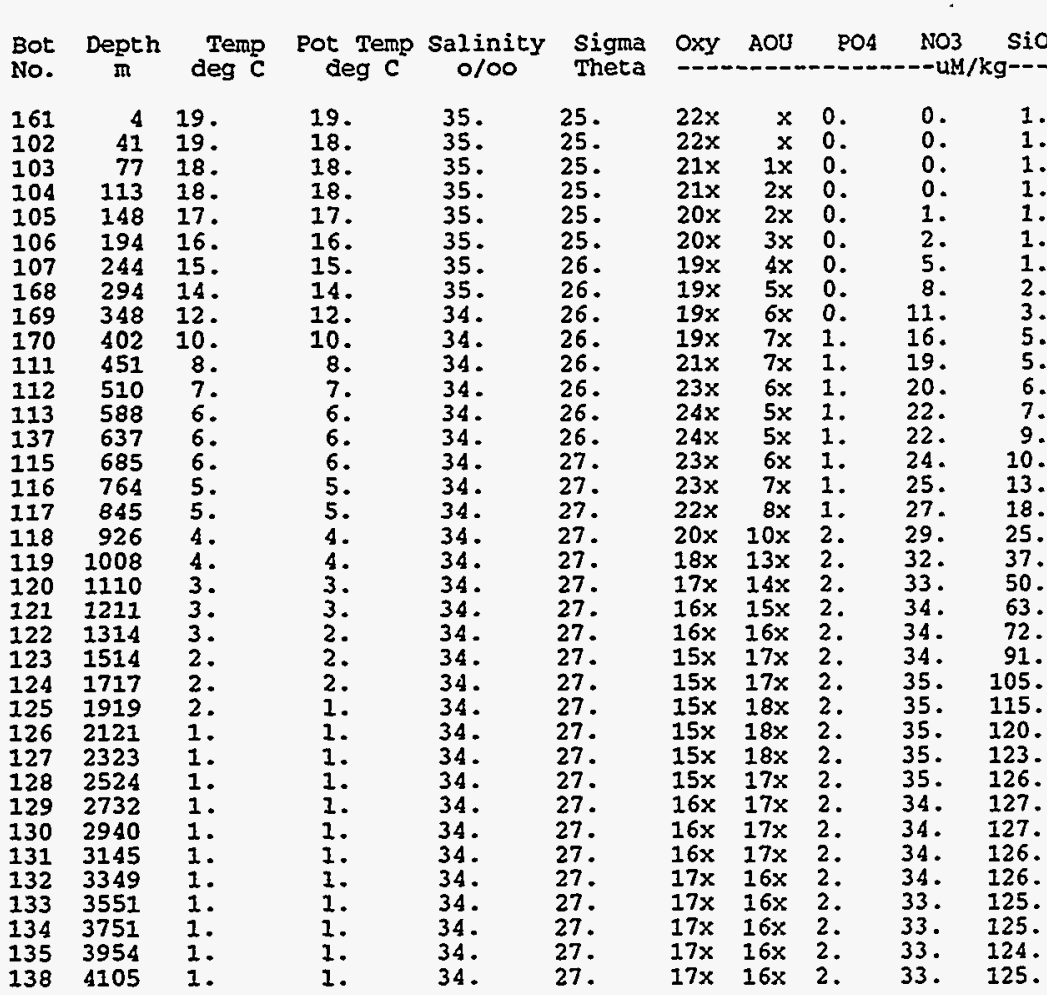

WOCE Line PI7C Station 169 Latitude 28-05.8S Longitude 133-40.9W Date 8/4/91 Bortom Depth 4230

\begin{tabular}{|c|c|c|c|c|c|c|c|c|c|c|c|c|c|c|c|c|}
\hline $\begin{array}{l}\text { Bot } \\
\text { No. }\end{array}$ & Depth & Temp & $\begin{array}{c}\text { Pot Temp } \\
\text { deg } C\end{array}$ & $\begin{array}{l}\text { Salinity } \\
0 / 00\end{array}$ & $\begin{array}{l}\text { Signa } \\
\text { Theta }\end{array}$ & Oxy & AOU & PO4 & $\begin{array}{r}\mathrm{NO} 3 \\
--\mathrm{uH}\end{array}$ & $\mathrm{SiO} 3$ & Obs & $\begin{array}{r}S=35 \\
----\end{array}$ & 20 & Theta & $\begin{array}{l}\text { Tot } \\
\text { Calc }\end{array}$ & $\begin{array}{l}\text { ALk. } \\
\text { PALKis } \\
\text { /kg- }\end{array}$ \\
\hline $\begin{array}{l}161 \\
102 \\
103 \\
104 \\
105 \\
106 \\
107 \\
168 \\
169 \\
170 \\
111 \\
112 \\
113 \\
137 \\
115 \\
116 \\
117 \\
118 \\
119 \\
120 \\
121 \\
122 \\
123 \\
124 \\
125 \\
126 \\
127 \\
128 \\
129 \\
130 \\
131 \\
132 \\
133 \\
134 \\
135 \\
138\end{array}$ & $\begin{array}{r}3 \\
25 \\
54 \\
80 \\
106 \\
142 \\
176 \\
218 \\
259 \\
335 \\
410 \\
486 \\
561 \\
663 \\
765 \\
865 \\
967 \\
1018 \\
1069 \\
1120 \\
1172 \\
1324 \\
1527 \\
1730 \\
1931 \\
2129 \\
2391 \\
2643 \\
2841 \\
3041 \\
3246 \\
3452 \\
3659 \\
3863 \\
4066 \\
4182\end{array}$ & $\begin{array}{l}19 . \\
19 . \\
18 . \\
18 . \\
18 . \\
17 . \\
16 . \\
15 . \\
14 . \\
12 . \\
9 . \\
7 . \\
6 . \\
6 . \\
5 . \\
4 . \\
4 . \\
4 . \\
3 . \\
3 . \\
3 . \\
2 . \\
2 . \\
2 . \\
2 . \\
1 . \\
1 . \\
1 . \\
1 . \\
1 . \\
1 . \\
1 . \\
1 . \\
1 . \\
1 . \\
1 .\end{array}$ & $\begin{array}{r}19 . \\
19 . \\
18 . \\
18 . \\
18 . \\
17 . \\
16 . \\
15 . \\
14 . \\
12 . \\
9 . \\
7 . \\
6 . \\
6 . \\
5 . \\
4 . \\
4 . \\
4 . \\
3 . \\
3 . \\
3 . \\
2 . \\
2 . \\
2 . \\
1 . \\
1 . \\
1 . \\
1 . \\
1 . \\
1 . \\
1 . \\
1 . \\
1 . \\
1 . \\
1 . \\
1 .\end{array}$ & $\begin{array}{l}35 . \\
35 . \\
35 . \\
35 . \\
35 . \\
35 . \\
35 . \\
35 . \\
35 . \\
34 . \\
34 . \\
34 . \\
34 . \\
34 . \\
34 . \\
34 . \\
34 . \\
34 . \\
34 . \\
34 . \\
34 . \\
34 . \\
34 . \\
34 . \\
34 . \\
34 . \\
34 . \\
34 . \\
34 . \\
34 . \\
34 . \\
34 . \\
34 . \\
34 . \\
34 . \\
34 .\end{array}$ & 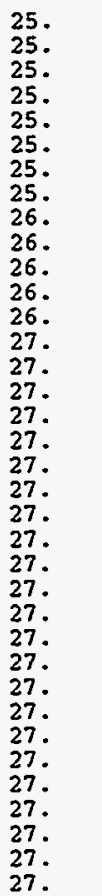 & $\begin{array}{l}22 x \\
22 x \\
23 x \\
23 x \\
22 x \\
21 x \\
20 x \\
19 x \\
19 x \\
19 x \\
20 x \\
22 x \\
23 x \\
23 x \\
22 x \\
21 x \\
19 x \\
18 x \\
17 x \\
17 x \\
17 x \\
16 x \\
15 x \\
15 x \\
15 x \\
15 x \\
15 x \\
15 x \\
16 x \\
16 x \\
16 x \\
17 x \\
17 x \\
17 x \\
17 x \\
18 x\end{array}$ & $\begin{array}{r}-x \\
-x \\
-x \\
-x \\
x \\
2 x \\
3 x \\
4 x \\
5 x \\
6 \mathrm{x} \\
7 \mathrm{x} \\
6 \mathrm{x} \\
6 \mathrm{x} \\
6 \mathrm{x} \\
8 \mathrm{x} \\
10 \mathrm{x} \\
11 \mathrm{x} \\
12 \mathrm{x} \\
13 \mathrm{x} \\
14 \mathrm{x} \\
15 \mathrm{x} \\
16 \mathrm{x} \\
17 \mathrm{x} \\
17 \mathrm{x} \\
18 \mathrm{x} \\
18 \mathrm{x} \\
18 \mathrm{x} \\
17 \mathrm{x} \\
17 \mathrm{x} \\
17 \mathrm{x} \\
17 \mathrm{x} \\
16 \mathrm{x} \\
16 \mathrm{x} \\
16 \mathrm{x} \\
16 \mathrm{x} \\
16 \mathrm{x}\end{array}$ & $\begin{array}{l}0 . \\
0 . \\
0 . \\
0 . \\
0 . \\
0 . \\
0 . \\
0 . \\
0 . \\
0 . \\
1 . \\
1 . \\
1 . \\
1 . \\
1 . \\
2 . \\
2 . \\
2 . \\
2 . \\
2 . \\
2 . \\
2 . \\
2 . \\
2 . \\
2 . \\
2 . \\
2 . \\
2 . \\
2 . \\
2 . \\
2 . \\
2 . \\
2 . \\
2 . \\
2 . \\
2 .\end{array}$ & $\begin{array}{l}0 . \\
0 . \\
0 . \\
0 . \\
0 . \\
0 . \\
2 . \\
4 . \\
7 . \\
12 . \\
17 . \\
20 . \\
22 . \\
24 . \\
26 . \\
29 . \\
31 . \\
32 . \\
33 . \\
33 . \\
34 . \\
34 . \\
34 . \\
35 . \\
35 . \\
35 . \\
35 . \\
35 . \\
34 . \\
34 . \\
34 . \\
34 . \\
33 . \\
33 . \\
33 . \\
33 .\end{array}$ & $\begin{array}{r}1 . \\
1 . \\
1 . \\
1 . \\
1 . \\
1 . \\
1 . \\
1 . \\
1 . \\
3 . \\
5 . \\
6 . \\
7 . \\
10 . \\
15 . \\
23 . \\
33 . \\
37 . \\
45 . \\
52 . \\
60 . \\
76 . \\
92 . \\
106 . \\
115 . \\
120 . \\
124 . \\
126 . \\
127 . \\
127 . \\
126 . \\
126 . \\
125 . \\
124 . \\
124 . \\
124 .\end{array}$ & 2011 & 1981 & 304 & 299 & 2340 & 2304 \\
\hline
\end{tabular}


Lamont-Doherty Earth Observatory of Columbia University

(Tco2) Project/Expedition is Tun

WOCE Line P17C Station 170 (PALK)s = Potential Alkalinity $=(T A L K+$ NO3) $X$ (35 / Sal)
Latitude 28-34.95 Longitude 133-49.0W Date $8 / 5 / 91$
Bottom Depth 3885

\begin{tabular}{|c|c|c|c|c|c|c|c|c|c|c|c|c|c|c|c|c|}
\hline $\begin{array}{l}\text { Bot } \\
\text { No. }\end{array}$ & $\underset{\text { Depth }}{\text { Depth }}$ & $\begin{array}{l}\text { Temp } \\
\text { deg } c\end{array}$ & $\begin{array}{c}\text { Pot Temp } \\
\text { deg } c\end{array}$ & $\begin{array}{c}\text { Salinity } \\
0 / 00\end{array}$ & $\begin{array}{l}\text { Sigma } \\
\text { Theta }\end{array}$ & Oxy & AOU & PO4 & $\begin{array}{c}\text { NO3 } \\
-- \text { UM/l }\end{array}$ & $\mathrm{siO3}$ & Obs & $S=35$ & 20 & $\begin{array}{r}\mathrm{pO} 2---- \\
\text { a Theta }\end{array}$ & $\begin{array}{l}\text { Tota } \\
\text { Calc } \\
--\mathrm{uE}\end{array}$ & $\begin{array}{l}\text { AIK. } \\
\text { PALKIs } \\
/ \mathrm{kg}^{--}\end{array}$ \\
\hline $\begin{array}{l}161 \\
102 \\
103 \\
104 \\
105 \\
106 \\
107 \\
168 \\
169 \\
170 \\
111 \\
112 \\
113 \\
137 \\
115 \\
116 \\
117 \\
118 \\
119 \\
120 \\
121 \\
122 \\
123 \\
124 \\
125 \\
126 \\
127 \\
128 \\
129 \\
130 \\
131 \\
132 \\
134 \\
133 \\
135 \\
138\end{array}$ & $\begin{array}{r}6 \\
47 \\
76 \\
107 \\
132 \\
155 \\
180 \\
204 \\
252 \\
304 \\
351 \\
394 \\
462 \\
531 \\
604 \\
679 \\
749 \\
820 \\
916 \\
1011 \\
1105 \\
1256 \\
1453 \\
1657 \\
1862 \\
2076 \\
2272 \\
2469 \\
2680 \\
2883 \\
3089 \\
3297 \\
3507 \\
3508 \\
3708 \\
3850\end{array}$ & $\begin{array}{l}18 . \\
18 . \\
18 . \\
18 . \\
18 . \\
17 . \\
16 . \\
16 . \\
14 . \\
13 . \\
11 . \\
9 . \\
7 . \\
6 . \\
6 . \\
5 . \\
5 . \\
5 . \\
4 . \\
4 . \\
3 . \\
3 . \\
2 . \\
2 . \\
2 . \\
2 . \\
1 . \\
1 . \\
1 . \\
1 . \\
1 . \\
1 . \\
1 . \\
1 . \\
1 . \\
1 .\end{array}$ & $\begin{array}{l}18 . \\
18 . \\
18 . \\
18 . \\
18 . \\
17 . \\
16 . \\
16 . \\
14 . \\
13 . \\
11 . \\
9 . \\
7 . \\
6 . \\
6 . \\
5 . \\
5 . \\
5 . \\
4 . \\
4 . \\
3 . \\
3 . \\
2 . \\
2 . \\
2 . \\
1 . \\
1 . \\
1 . \\
1 . \\
1 . \\
1 . \\
1 . \\
1 . \\
1 . \\
1 . \\
1 .\end{array}$ & $\begin{array}{l}35 . \\
35 . \\
35 . \\
35 . \\
35 . \\
35 . \\
35 . \\
35 . \\
35 . \\
34 . \\
34 . \\
34 . \\
34 . \\
34 . \\
34 . \\
34 . \\
34 . \\
34 . \\
34 . \\
34 . \\
34 . \\
34 . \\
34 . \\
34 . \\
34 . \\
34 . \\
34 . \\
34 . \\
34 . \\
34 . \\
34 . \\
34 . \\
34 . \\
34 . \\
34 . \\
34 .\end{array}$ & 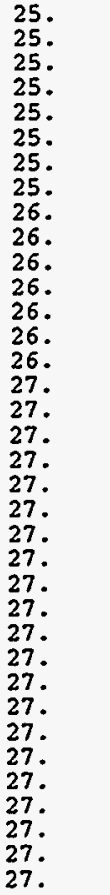 & $\begin{array}{l}23 x \\
23 x \\
23 x \\
23 x \\
22 x \\
20 x \\
20 x \\
19 x \\
19 x \\
19 x \\
19 x \\
20 x \\
22 x \\
23 x \\
23 x \\
23 x \\
23 x \\
22 x \\
18 x \\
17 x \\
16 x \\
16 x \\
15 x \\
15 x \\
15 x \\
15 x \\
15 x \\
16 x \\
16 x \\
16 x \\
17 x \\
17 x \\
17 x \\
17 x \\
17 x\end{array}$ & $\begin{array}{r}-x \\
-x \\
-x \\
x \\
1 x \\
2 x \\
3 x \\
4 x \\
5 x \\
6 x \\
7 x \\
7 x \\
6 x \\
5 x \\
6 x \\
6 x \\
7 x \\
8 x \\
\\
13 x \\
14 x \\
15 x \\
16 x \\
17 x \\
17 x \\
18 x \\
18 x \\
18 x \\
17 x \\
17 x \\
17 x \\
16 x \\
16 x \\
16 x \\
16 x \\
16 x\end{array}$ & 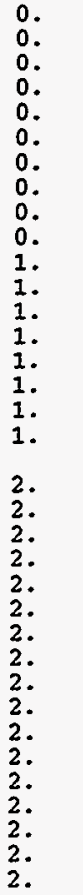 & $\begin{array}{l}0 . \\
0 . \\
0 . \\
0 . \\
0 . \\
1 . \\
2 . \\
3 . \\
6 . \\
9 . \\
13 . \\
17 . \\
20 . \\
21 . \\
23 . \\
24 . \\
25 . \\
27 . \\
32 . \\
33 . \\
34 . \\
34 . \\
35 . \\
35 . \\
35 . \\
35 . \\
35 . \\
35 . \\
34 . \\
34 . \\
34 . \\
34 . \\
34 . \\
33 . \\
33 .\end{array}$ & $\begin{array}{r}1 . \\
1 . \\
1 . \\
1 . \\
1 . \\
1 . \\
1 . \\
1 . \\
1 . \\
2 . \\
3 . \\
5 . \\
6 . \\
7 . \\
9 . \\
11 . \\
13 . \\
18 . \\
38 . \\
50 . \\
67 . \\
86 . \\
101 . \\
110^{\circ} \\
118 . \\
123 . \\
125 . \\
127 . \\
126 . \\
126 . \\
126 . \\
125 . \\
125 . \\
125 . \\
124 .\end{array}$ & 2014 & 1989 & 316 & 302 & 2333 & 2303 \\
\hline
\end{tabular}

WOCE Line P17C Station 171 Latitude 29-04.1S Longitude 133-55.9W Date $8 / 5 / 91$ Bottom Depth 4206

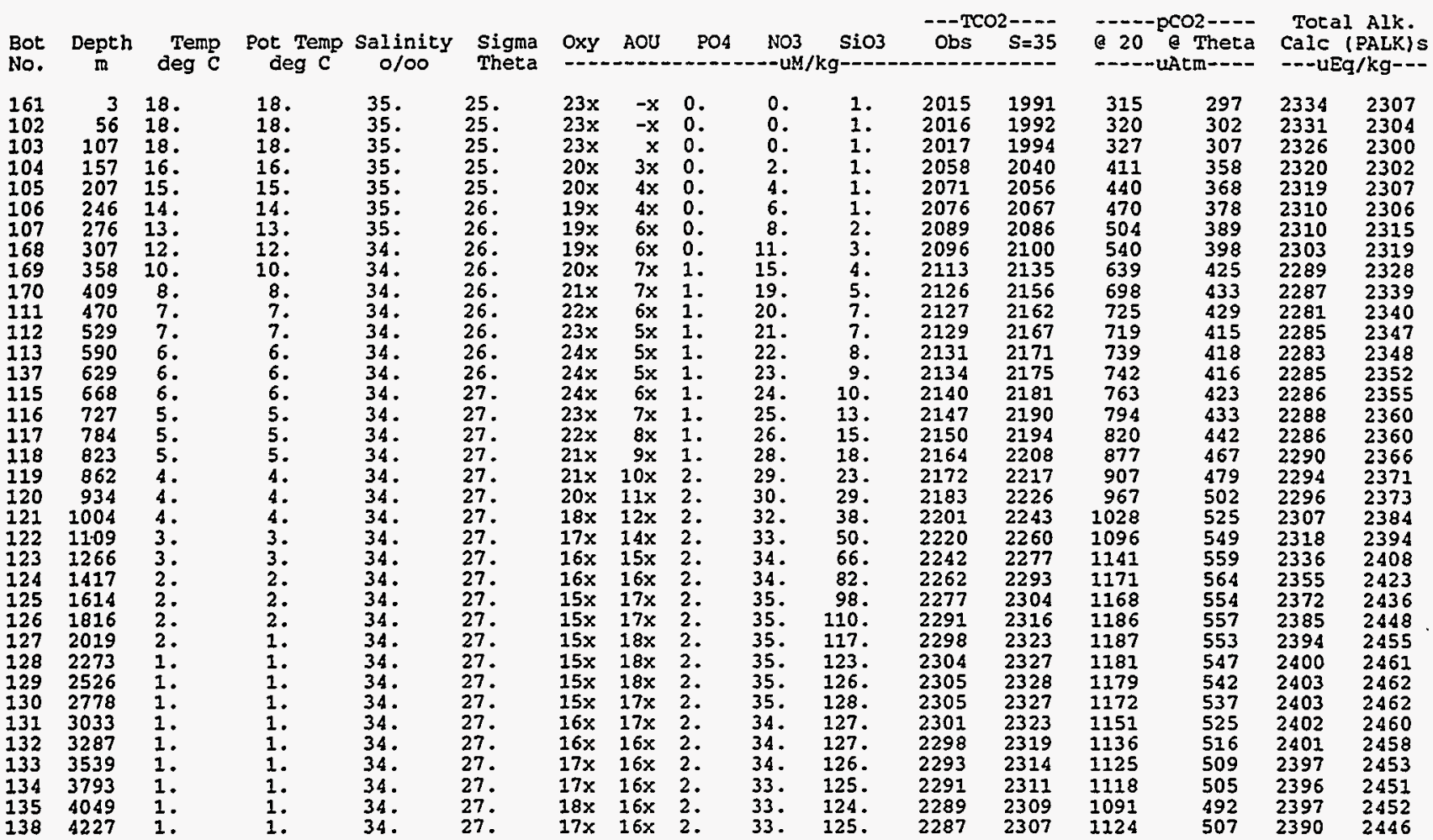


Lamont-Doherty Earth Observatory of Columbia University

Printed on $12 / 06 / 93$

Page 25

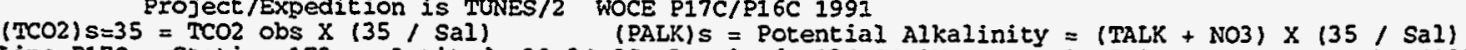
wOCE Iine P17C Station 172 Latitude 29-34.OS Longitude 134-04.2W Date 8/5/91 Bottom Depth 4183

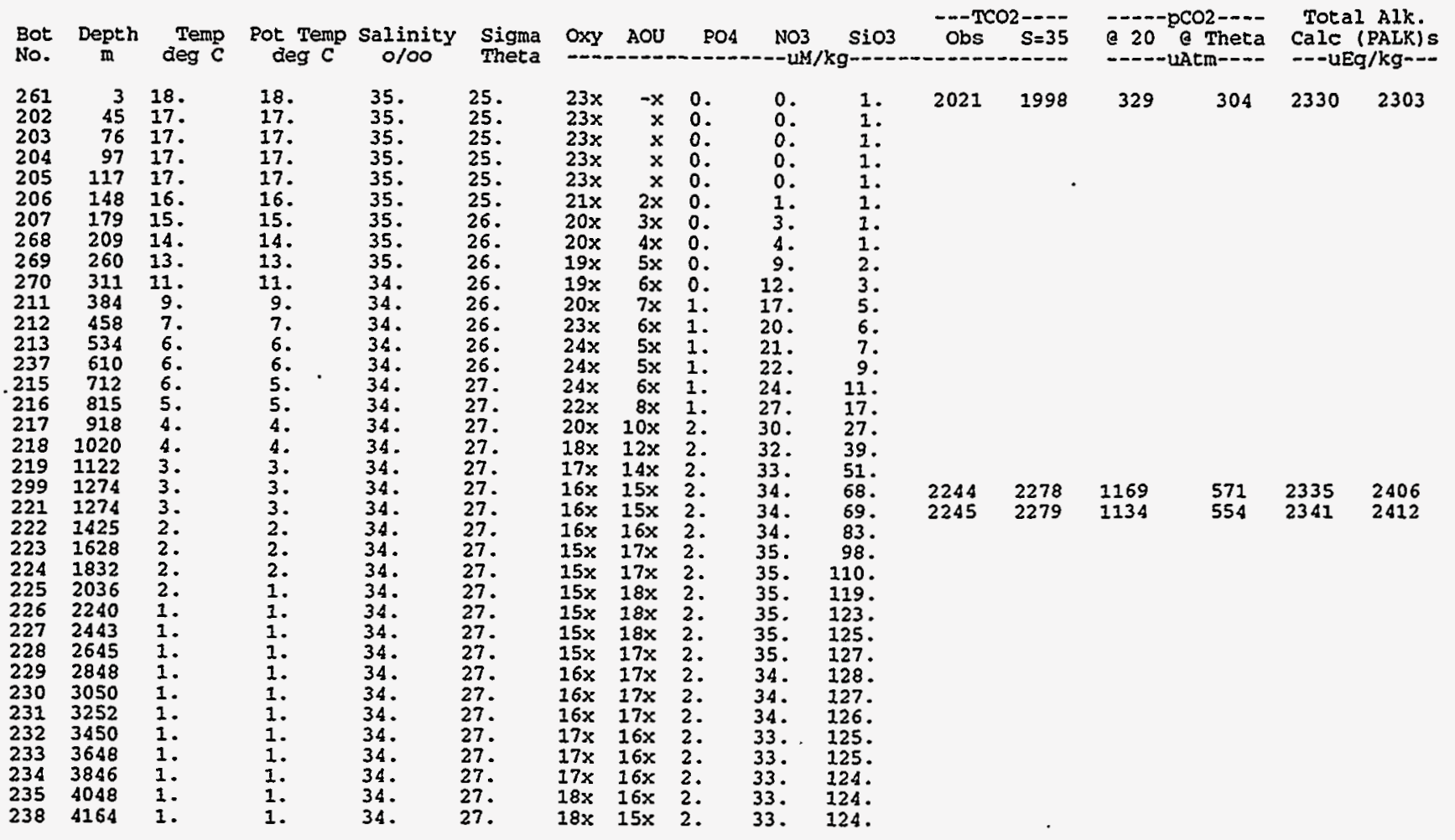

WOCE Line P17C Station 173 Latitude 30-02.9S Longitude 134-12.2W Date 8/6/91 Bottom Depth 4190

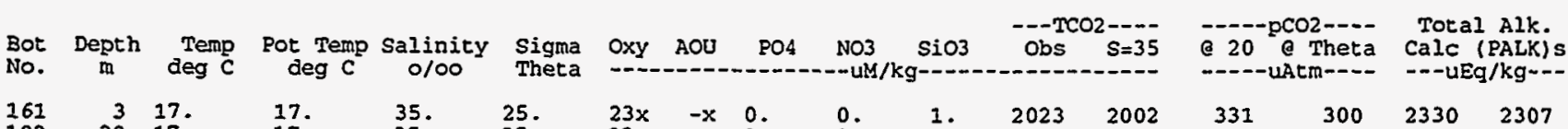

\begin{tabular}{|c|c|c|c|c|c|c|c|c|}
\hline $\begin{array}{rr}161 & 3 \\
102 & 29 \\
103 & 54 \\
104 & 80 \\
105 & 106 \\
106 & 131 \\
107 & 157 \\
168 & 182 \\
169 & 207 \\
170 & 259 \\
111 & 309 \\
112 & 360 \\
113 & 435 \\
137 & 511 \\
115 & 587 \\
116 & 663 \\
117 & 764 \\
118 & 866 \\
119 & 967 \\
120 & 1069 \\
121 & 1221 \\
122 & 1424 \\
123 & 1628 \\
124 & 1832 \\
125 & 2035 \\
126 & 2238 \\
127 & 2441 \\
128 & 2645 \\
129 & 2847 \\
130 & 3051 \\
131 & 3253 \\
132 & 3457 \\
133 & 3660 \\
134 & 3863 \\
135 & 4066 \\
138 & 4177\end{array}$ & $\begin{array}{l}17 . \\
17 . \\
17 . \\
17 . \\
27 . \\
16 . \\
16 . \\
15 . \\
14 . \\
13 . \\
11 . \\
10 . \\
8 . \\
7 . \\
6 . \\
6 . \\
5 . \\
5 . \\
4 . \\
4 . \\
3 . \\
2 . \\
2 . \\
2 . \\
2 . \\
1 . \\
1 . \\
1 . \\
1 . \\
1 . \\
1 . \\
1 . \\
1 . \\
1 . \\
1 . \\
1 .\end{array}$ & $\begin{array}{l}17 . \\
17 . \\
17 . \\
17 . \\
17 . \\
16 . \\
16 . \\
15 . \\
14 . \\
13 . \\
11 . \\
10 . \\
8 . \\
7 . \\
6 . \\
6 . \\
5 . \\
5 . \\
4 . \\
3 . \\
3 . \\
2 . \\
2 . \\
2 . \\
1 . \\
1 . \\
1 . \\
1 . \\
1 . \\
1 . \\
1 . \\
1 . \\
1 . \\
1 . \\
1 . \\
1 .\end{array}$ & $\begin{array}{l}35 . \\
35 . \\
35 . \\
35 . \\
35 . \\
35 . \\
35 . \\
35 . \\
35 . \\
35 . \\
34 . \\
34 . \\
34 . \\
34 . \\
34 . \\
34 . \\
34 . \\
34 . \\
34 . \\
34 . \\
34 . \\
34 . \\
34 . \\
34 . \\
34 . \\
34 . \\
34 . \\
34 . \\
34 . \\
34 . \\
34 . \\
34 . \\
34 . \\
34 . \\
34 . \\
34 .\end{array}$ & $\begin{array}{l}25 . \\
25 . \\
25 . \\
25 . \\
25 . \\
25 . \\
25 . \\
26 . \\
26 . \\
26 . \\
26 . \\
26 . \\
26 . \\
26 . \\
26 . \\
27 . \\
27 . \\
27 . \\
27 . \\
27 . \\
27 . \\
27 . \\
27 . \\
27 . \\
27 . \\
27 . \\
27 . \\
27 . \\
27 . \\
27 . \\
27 . \\
27 . \\
27 . \\
27 . \\
27 . \\
27 .\end{array}$ & $\begin{array}{l}23 x \\
23 x \\
23 x \\
23 x \\
23 x \\
22 x \\
21 x \\
21 x \\
20 x \\
19 x \\
20 x \\
20 x \\
21 x \\
23 x \\
23 x \\
23 x \\
23 x \\
22 x \\
20 x \\
18 x \\
17 x \\
16 x \\
15 x \\
15 x \\
15 x \\
15 x \\
15 x \\
15 x \\
16 x \\
16 x \\
16 x \\
17 x \\
17 x \\
18 x \\
18 x \\
18 x \\
18 x\end{array}$ & $\begin{array}{r}-x \\
-x \\
-x \\
x \\
x \\
1 x \\
2 x \\
3 x \\
4 x \\
5 x \\
6 x \\
7 x \\
7 x \\
6 x \\
6 x \\
6 x \\
7 x \\
9 x \\
11 x \\
13 x \\
15 x \\
16 x \\
17 x \\
17 x \\
18 x \\
18 x \\
18 x \\
17 x \\
17 x \\
17 x \\
17 x \\
16 x \\
16 x \\
16 x \\
15 x \\
15 x\end{array}$ & $\begin{array}{l}0 . \\
0 . \\
0 . \\
0 . \\
0 . \\
0 . \\
0 . \\
0 . \\
0 . \\
0 . \\
0 . \\
1 . \\
1 . \\
1 . \\
1 . \\
1 . \\
1 . \\
1 . \\
2 . \\
2 . \\
2 . \\
2 . \\
2 . \\
2 . \\
2 . \\
2 . \\
2 . \\
2 . \\
2 . \\
2 . \\
2 . \\
2 . \\
2 . \\
2 . \\
2 . \\
2 .\end{array}$ & $\begin{array}{r}0 . \\
0 . \\
0 . \\
0 . \\
0 . \\
0 . \\
2 . \\
3 . \\
4 . \\
8 . \\
12 . \\
15 . \\
19 . \\
21 . \\
23 . \\
24 . \\
25 . \\
28 . \\
30 . \\
32 . \\
33 . \\
34 . \\
34 . \\
35 . \\
35 . \\
35 . \\
35 . \\
34 . \\
34 . \\
34 . \\
34 . \\
33 . \\
33 . \\
33 . \\
33 . \\
33 .\end{array}$ \\
\hline
\end{tabular}


Lamont-Doherty Earth Observatory of Columbia University

Printed on $12 / 06 / 93$

$(T C O 2) s=35=T C O 2$ obs $x(35, \mathrm{Sal}$ ) (PALK)s = Potential Alkalinity $=$ (TALK + NO3) $\mathrm{X}(35 / \mathrm{Sal}$ )

wOCE Line P17C Station 174 Latitude 30-31.9S Longitude 134-20.0W Date $8 / 6 / 91$ Bottom Depth 3711

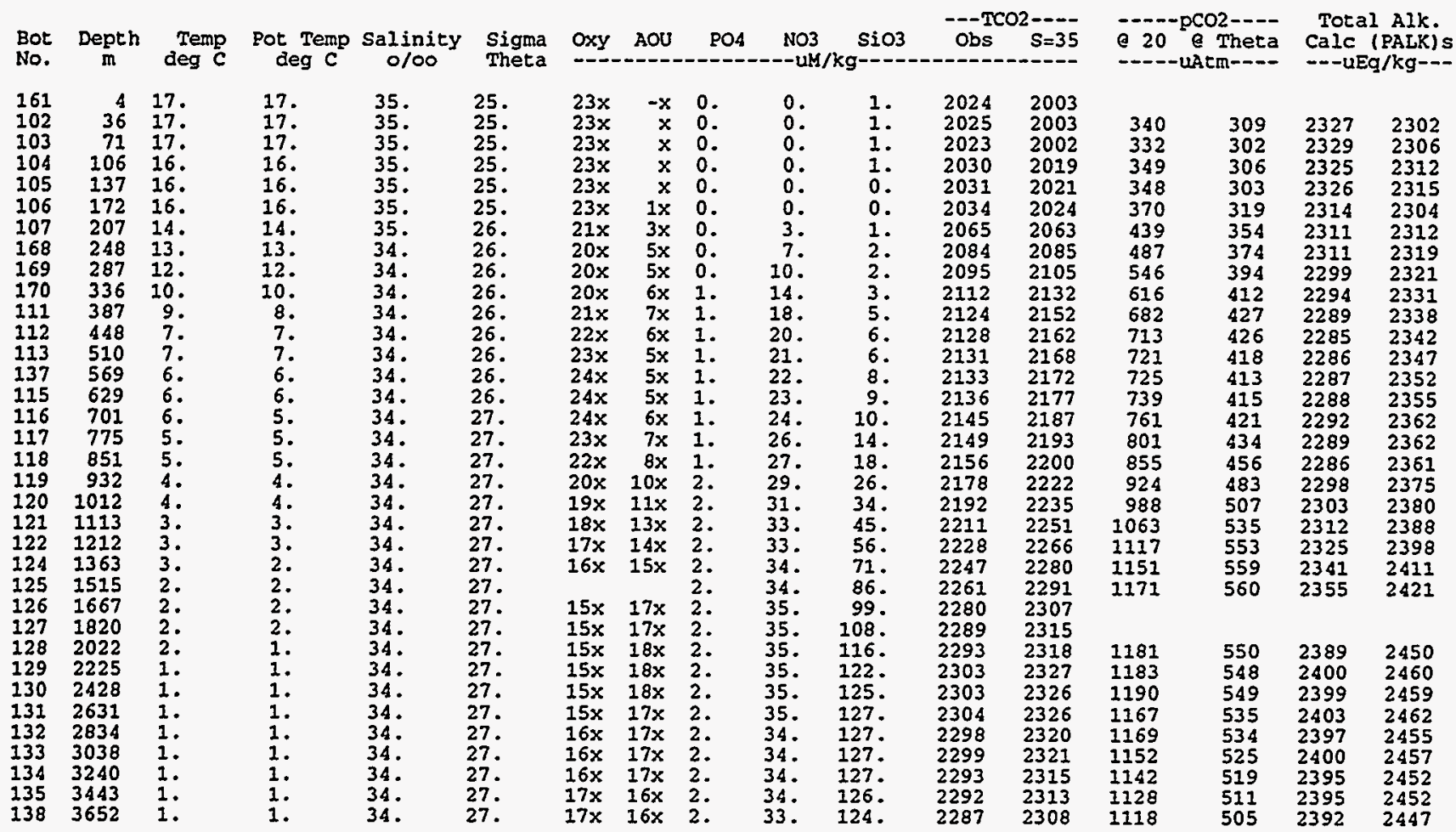

WOCE Line P17C Station 175 Latitude 31-01.3S Longitude 134-27.9W Date 8/ 6/91 Bottom Depth 4258

\begin{tabular}{|c|c|c|c|c|c|c|c|c|c|c|c|c|c|c|c|c|}
\hline $\begin{array}{l}\text { Bot } \\
\text { No. }\end{array}$ & $\underset{\text { m }}{\text { Depth }}$ & $\begin{array}{r}\text { Temp } \\
\text { deg C }\end{array}$ & $\begin{array}{c}\text { Pot Temp } \\
\text { deg } c\end{array}$ & $\begin{array}{c}\text { Salinity } \\
0 / 00\end{array}$ & $\begin{array}{l}\text { Sigma } \\
\text { Theta }\end{array}$ & Oxy & AOU & PO4 & $\begin{array}{r}\mathrm{NO3} \\
-\mathrm{UM}\end{array}$ & $\mathrm{SiO} 3$ & Obs & $\begin{array}{r}2-5=35 \\
S=--\end{array}$ & 20 & heta & $\begin{array}{l}\text { Tota } \\
\text { Calc } \\
---u E\end{array}$ & $\begin{array}{l}\text { Alk. } \\
\text { ALKis } \\
\mathrm{kg}\end{array}$ \\
\hline $\begin{array}{l}161 \\
102 \\
103 \\
104 \\
105 \\
106 \\
107 \\
168 \\
169 \\
170 \\
111 \\
112 \\
113 \\
137 \\
115 \\
116 \\
117 \\
118 \\
119 \\
120 \\
121 \\
122 \\
124 \\
125 \\
126 \\
127 \\
128 \\
129 \\
130 \\
131 \\
132 \\
133 \\
134 \\
135 \\
138\end{array}$ & $\begin{array}{r}3 \\
46 \\
92 \\
137 \\
173 \\
217 \\
280 \\
342 \\
391 \\
455 \\
529 \\
593 \\
658 \\
733 \\
811 \\
891 \\
969 \\
1048 \\
1147 \\
1245 \\
1343 \\
1442 \\
1592 \\
1741 \\
1893 \\
2045 \\
2251 \\
2458 \\
2665 \\
2872 \\
3134 \\
3396 \\
3662 \\
3926 \\
4182\end{array}$ & $\begin{array}{r}16 . \\
16 . \\
16 . \\
16 . \\
15 . \\
13 . \\
12 . \\
9 . \\
8 . \\
7 . \\
7 . \\
6 . \\
6 . \\
5 . \\
5 . \\
5 . \\
4 . \\
4 . \\
3 . \\
3 . \\
3 . \\
2 . \\
2 . \\
2 . \\
2 . \\
2 . \\
1 . \\
1 . \\
1 . \\
1 . \\
1 . \\
1 . \\
1 . \\
1 . \\
1 .\end{array}$ & $\begin{array}{r}16 . \\
16 . \\
16 . \\
16 . \\
15 . \\
13 . \\
12 . \\
9 . \\
8 . \\
7 . \\
6 . \\
6 . \\
6 . \\
5 . \\
5 . \\
5 . \\
4 . \\
4 . \\
3 . \\
3 . \\
2 . \\
2 . \\
2 . \\
2 . \\
2 . \\
1 . \\
1 . \\
1 . \\
1 . \\
1 . \\
1 . \\
1 . \\
1 . \\
1 . \\
1 .\end{array}$ & $\begin{array}{l}35 . \\
35 \\
35 . \\
35 . \\
35 . \\
34 . \\
34 . \\
34 . \\
34 . \\
34 . \\
34 . \\
34 . \\
34 . \\
34 \\
34 . \\
34 . \\
34 . \\
34 . \\
34 . \\
34 . \\
34 . \\
34 . \\
34 . \\
34 . \\
34 . \\
34 . \\
34 . \\
34 . \\
34 . \\
34 . \\
34 . \\
34 . \\
34 . \\
34 . \\
34 .\end{array}$ & $\begin{array}{l}25 . \\
25 . \\
25 . \\
25 . \\
25 . \\
26 . \\
26 . \\
26 . \\
26 . \\
26 . \\
26 . \\
26 . \\
27 . \\
27 . \\
27 . \\
27 . \\
27 . \\
27 . \\
27 . \\
27 . \\
27 . \\
27 . \\
27 . \\
27 . \\
27 . \\
27 . \\
27 . \\
27 . \\
27 . \\
27 . \\
27 . \\
27 . \\
27 . \\
27 . \\
27 .\end{array}$ & $\begin{array}{l}24 x \\
24 x \\
24 x \\
23 x \\
21 x \\
20 x \\
20 x \\
20 x \\
21 x \\
22 x \\
24 x \\
24 x \\
24 x \\
24 x \\
23 x \\
22 x \\
20 x \\
19 x \\
18 x \\
17 x \\
16 x \\
16 x \\
16 x \\
15 x \\
15 x \\
15 x \\
15 x \\
15 x \\
16 x \\
16 x \\
17 x \\
17 x \\
18 x \\
18 x\end{array}$ & $\begin{array}{r}-x \\
x \\
x \\
x \\
3 x \\
4 x \\
6 x \\
6 x \\
6 x \\
6 x \\
5 x \\
5 x \\
5 x \\
6 x \\
7 x \\
9 x \\
10 x \\
12 x \\
13 x \\
14 x \\
15 x \\
16 x \\
17 x \\
17 x \\
17 x \\
18 x \\
18 x \\
18 x \\
17 x \\
17 x \\
17 x \\
16 x \\
16 x \\
15 x \\
15 x\end{array}$ & $\begin{array}{l}0 . \\
0 . \\
0 . \\
0 . \\
0 . \\
0 . \\
0 . \\
1 . \\
1 . \\
1 . \\
1 . \\
1 . \\
1 . \\
1 . \\
1 . \\
1 . \\
2 . \\
2 . \\
2 . \\
2 . \\
2 . \\
2 . \\
2 . \\
2 . \\
2 . \\
2 . \\
2 . \\
2 . \\
2 . \\
2 . \\
2 . \\
2 . \\
2 . \\
2 . \\
2 .\end{array}$ & $\begin{array}{l}0 . \\
0 . \\
0 . \\
0 . \\
3 . \\
6 . \\
11 . \\
15 . \\
18 . \\
20 . \\
21 . \\
22 . \\
23 . \\
24 . \\
26 . \\
28 . \\
30 . \\
32 . \\
33 . \\
33 . \\
34 . \\
34 . \\
34 . \\
35 . \\
35 . \\
35 . \\
35 . \\
35 . \\
34 . \\
34 . \\
34 . \\
34 . \\
33 . \\
33 . \\
33 .\end{array}$ & $\begin{array}{r}0 . \\
0 . \\
0 . \\
0 . \\
0 . \\
1 . \\
2 . \\
4 . \\
4 . \\
6 . \\
6 . \\
8 . \\
9 . \\
11 . \\
15 . \\
20 . \\
27 . \\
39 . \\
48 . \\
58 . \\
69 . \\
81 . \\
93 . \\
103 . \\
110 . \\
117 . \\
122 . \\
125 . \\
126 . \\
126 . \\
127 . \\
126 . \\
125 . \\
124 . \\
123 .\end{array}$ & 2026 & 2015 & 354 & 311 & 2315 & 2304 \\
\hline
\end{tabular}


Lamont-Doherty Earth Observatory of Columbia University Project/Expedition is TUNES/2 WOCE P17C/PI6C 1991

Printed on $12 / 06 / 93$

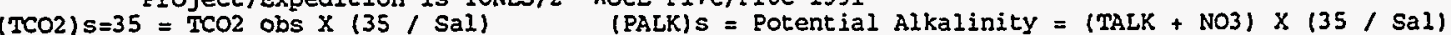

WOCE Iine P17C Station 176 Latitude 31-30.0S Longitude 134-36.0W Date 8/7/91 Bottom Depth 4290

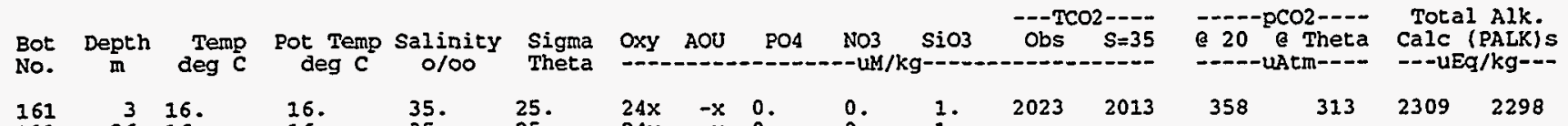

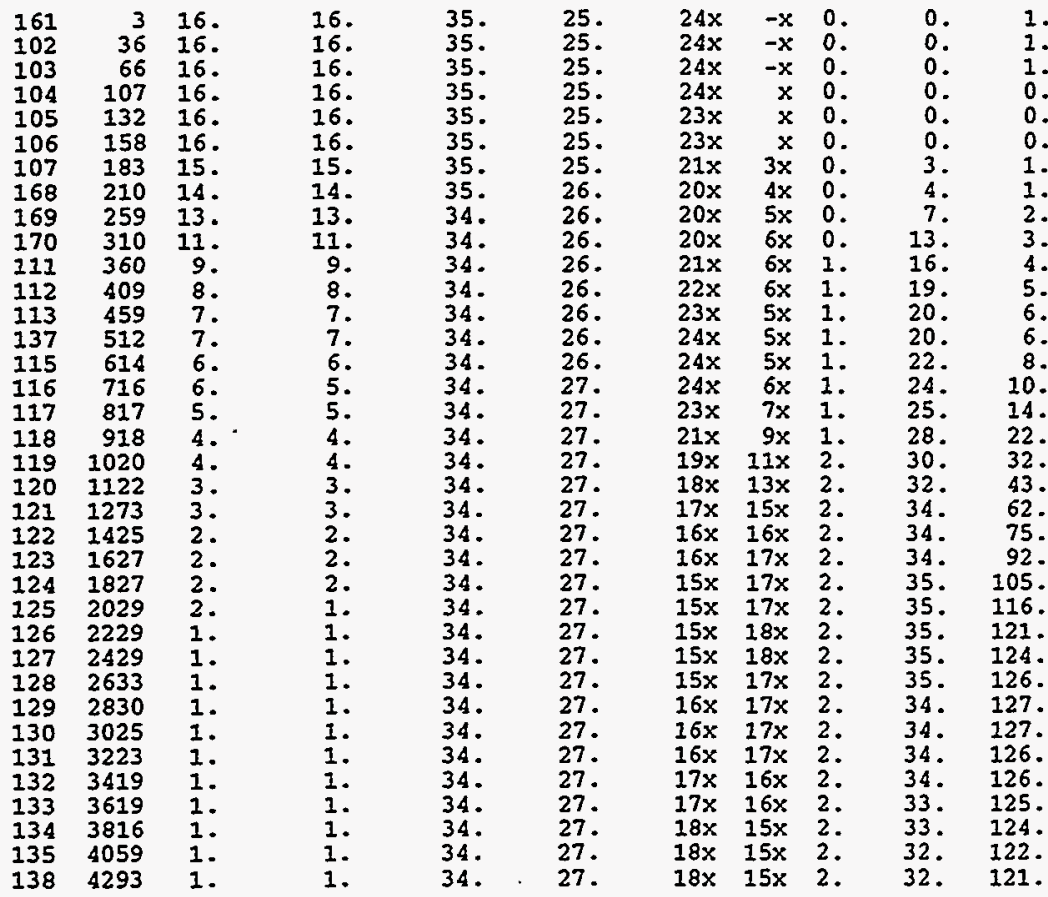

WOCE Line P17C Station 177 Latitude 32-00.2S Longitude 134-42.9W Date 8/7/91 Bottom Depth 4156

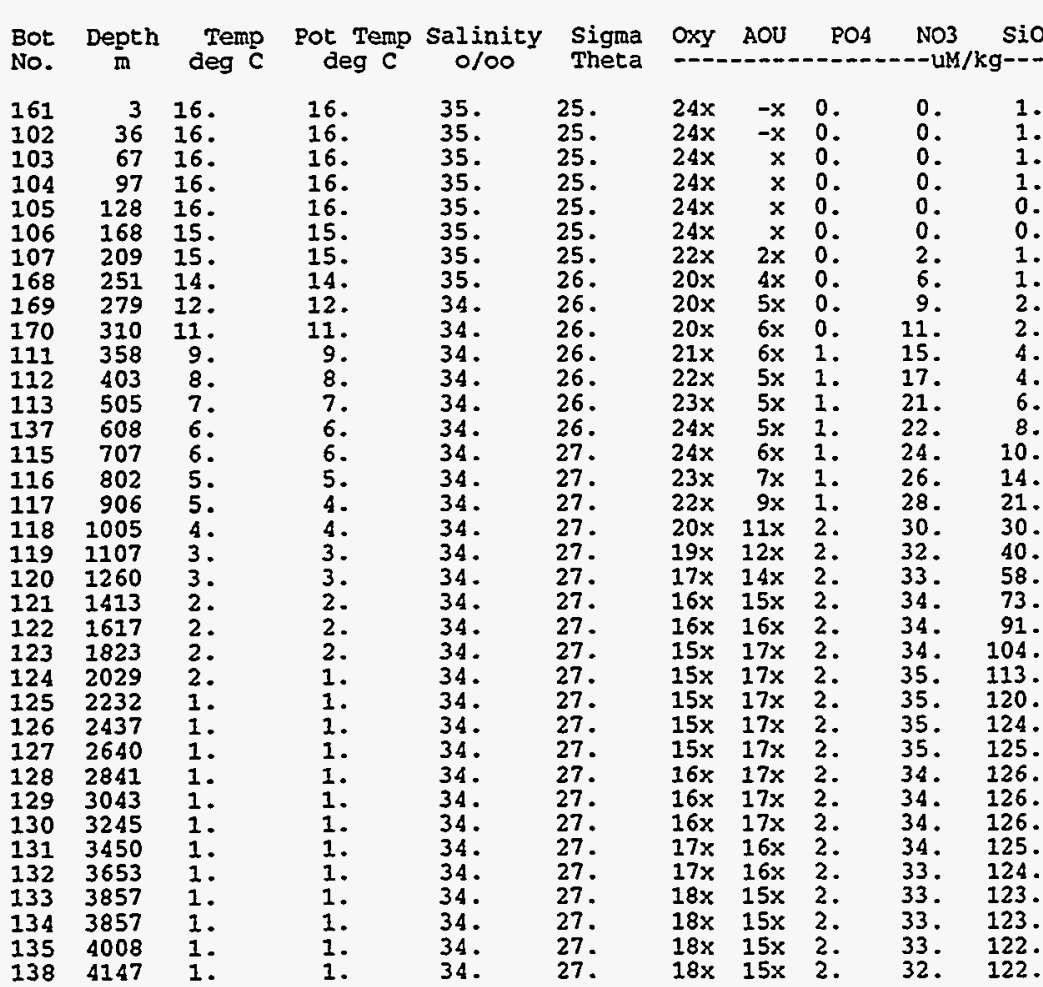


Lamont-Doherty Earth Observatory of Columbia University

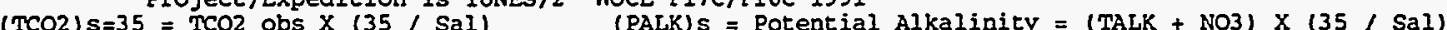
WOCE Line PI7C Station 178 Latitude 32-28.9S Longitude 134-50.9W Date $8 / 7 / 91$ Bottom Depth 4337

\begin{tabular}{|c|c|c|c|c|c|c|c|c|c|c|c|c|c|c|c|c|}
\hline $\begin{array}{l}\text { Bot } \\
\text { No. }\end{array}$ & Depth & $\begin{array}{l}\text { Temp } \\
\text { deg } C\end{array}$ & $\begin{array}{l}\text { Pot Temp } \\
\text { deg } c\end{array}$ & $\begin{array}{c}\text { Salinity } \\
0 / 00\end{array}$ & $\begin{array}{l}\text { Sigma } \\
\text { Theta }\end{array}$ & Oxy & AOU & PO4 & $\begin{array}{r}\text { NO3 } \\
--- \text { UH }\end{array}$ & SiO3 & Obs & $\begin{array}{r}2---- \\
S=35\end{array}$ & e 20 & $\begin{array}{l}\text { 2---- } \\
\text { Theta } \\
\text { n---- }\end{array}$ & $\begin{array}{l}\text { Tota } \\
\text { Calc } \\
---u E\end{array}$ & $\begin{array}{l}\text { AIK. } \\
\text { PALK) } \\
\text { / kg--- }\end{array}$ \\
\hline $\begin{array}{l}161 \\
102 \\
103 \\
104 \\
105 \\
106 \\
107 \\
168 \\
169 \\
170 \\
111 \\
112 \\
113 \\
137 \\
115 \\
116 \\
117 \\
118 \\
119 \\
120 \\
121 \\
122 \\
123 \\
124 \\
125 \\
126 \\
127 \\
128 \\
129 \\
130 \\
131 \\
132 \\
133 \\
134 \\
135 \\
138\end{array}$ & $\begin{array}{r}5 \\
51 \\
96 \\
143 \\
183 \\
224 \\
260 \\
310 \\
360 \\
411 \\
461 \\
512 \\
562 \\
611 \\
672 \\
742 \\
811 \\
912 \\
1011 \\
1109 \\
1309 \\
1508 \\
1708 \\
1908 \\
2104 \\
2299 \\
2494 \\
2687 \\
2887 \\
3095 \\
3308 \\
3518 \\
3728 \\
3939 \\
4142 \\
4270\end{array}$ & 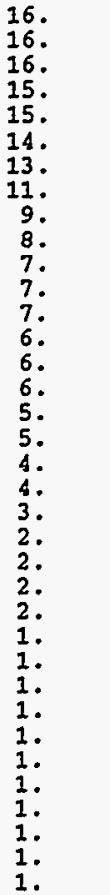 & $\begin{array}{l}16 . \\
16 . \\
16 . \\
15 . \\
15 . \\
14 . \\
13 . \\
11 . \\
9 . \\
8 . \\
7 . \\
7 . \\
7 . \\
6 . \\
6 . \\
6 . \\
5 . \\
5 . \\
4 . \\
3 . \\
3 . \\
2 . \\
2 . \\
2 . \\
1 . \\
1 . \\
1 . \\
1 . \\
1 . \\
1 . \\
1 . \\
1 . \\
1 . \\
1 . \\
0 . \\
0 .\end{array}$ & $\begin{array}{l}35 . \\
35 . \\
35 . \\
35 . \\
35 . \\
35 . \\
34 . \\
34 . \\
34 . \\
34 . \\
34 . \\
34 . \\
34 . \\
34 . \\
34 . \\
34 . \\
34 . \\
34 . \\
34 . \\
34 . \\
34 . \\
34 . \\
34 . \\
34 . \\
34 . \\
34 . \\
34 . \\
34 . \\
34 . \\
34 . \\
34 . \\
34 . \\
34 . \\
34 . \\
34 . \\
34 .\end{array}$ & 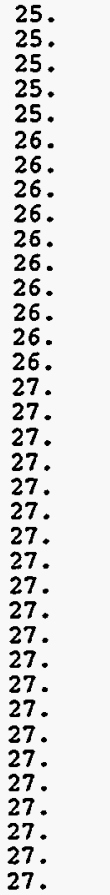 & $\begin{array}{l}23 x \\
23 x \\
23 x \\
24 x \\
21 x \\
20 x \\
20 x \\
20 x \\
21 x \\
22 x \\
24 x \\
24 x \\
24 x \\
24 x \\
24 x \\
24 x \\
23 x \\
22 x \\
20 x \\
19 x \\
17 x \\
16 x \\
15 x \\
15 x \\
15 x \\
15 x \\
15 x \\
16 x \\
16 x \\
16 x \\
17 x \\
17 x \\
17 x \\
18 x \\
19 x \\
19 x\end{array}$ & $\begin{array}{r}x \\
x \\
x \\
x \\
2 x \\
4 x \\
5 x \\
6 x \\
6 x \\
5 x \\
5 x \\
4 x \\
4 x \\
4 x \\
5 x \\
6 x \\
7 x \\
9 x \\
10 x \\
12 x \\
15 x \\
16 x \\
17 x \\
17 x \\
17 x \\
17 x \\
17 x \\
17 x \\
17 x \\
17 x \\
16 x \\
16 x \\
16 x \\
15 x \\
15 x \\
15 x\end{array}$ & $\begin{array}{l}0 . \\
0 . \\
0 . \\
0 . \\
0 . \\
0 . \\
0 . \\
0 . \\
1 . \\
1 . \\
1 . \\
1 . \\
1 . \\
1 . \\
1 . \\
1 . \\
1 . \\
1 . \\
2 . \\
2 . \\
2 . \\
2 . \\
2 . \\
2 . \\
2 . \\
2 . \\
2 . \\
2 . \\
2 . \\
2 . \\
2 . \\
2 . \\
2 . \\
2 . \\
2 . \\
2 .\end{array}$ & $\begin{array}{l}0 . \\
0 . \\
0 . \\
0 . \\
2 . \\
6 . \\
9 . \\
12 . \\
16 . \\
18 . \\
19 . \\
19 . \\
20 . \\
21 . \\
22 . \\
24 . \\
25 . \\
27 . \\
29 . \\
31 . \\
34 . \\
34 . \\
34 . \\
35 . \\
35 . \\
35 . \\
35 . \\
34 . \\
34 . \\
34 . \\
34 . \\
34 . \\
33 . \\
33 . \\
32 . \\
32 .\end{array}$ & $\begin{array}{r}1 . \\
1 . \\
1 . \\
1 . \\
1 . \\
1 . \\
2 . \\
3 . \\
4 . \\
4 . \\
5 . \\
6 . \\
6 . \\
7 . \\
9 . \\
11 . \\
14 . \\
20 . \\
29 . \\
38 . \\
63 . \\
82 . \\
99 . \\
109 . \\
116 . \\
121 . \\
124 . \\
125 . \\
125 . \\
125 . \\
126 . \\
125 . \\
124 . \\
122 . \\
122 . \\
121 .\end{array}$ & 2024 & 2010 & 353 & 309 & 2314 & 2299 \\
\hline
\end{tabular}

WOCE Line P17C Station 179 Latitude 33-00.6S Longitude 135-01.3W Date 8/ 8/91 Botton Depth 4493

\begin{tabular}{|c|c|c|c|c|c|c|c|c|c|c|c|c|c|c|c|c|}
\hline $\begin{array}{l}\text { Bot } \\
\text { No. }\end{array}$ & $\underset{\mathbf{m}}{\text { Depth }}$ & $\begin{array}{l}\text { Temp } \\
\text { deg C }\end{array}$ & $\begin{array}{c}\text { Pot Temp } \\
\text { deg } c\end{array}$ & $\begin{array}{c}\text { Salinity } \\
0 / 00\end{array}$ & $\begin{array}{l}\text { Sigma } \\
\text { Theta }\end{array}$ & Oxy & AOU & PO4 & $\begin{array}{r}\text { NO3 } \\
-- \text { uk }\end{array}$ & SiO3 & Obs & $\begin{array}{r}S=35 \\
S=--\end{array}$ & 20 & $\begin{array}{l}\text { 2---- } \\
\text { Theta } \\
\text { m-- }\end{array}$ & $\begin{array}{l}\text { Tot } \\
\text { Calc } \\
---4\end{array}$ & $\begin{array}{l}\text { Alk } \\
\text { ALK) } \\
\mathrm{kg}\end{array}$ \\
\hline $\begin{array}{l}261 \\
202 \\
203 \\
204 \\
205 \\
206 \\
207 \\
268 \\
269 \\
270 \\
211 \\
212 \\
213 \\
237 \\
215 \\
216 \\
217 \\
218 \\
219 \\
220 \\
221 \\
222 \\
223 \\
224 \\
225 \\
226 \\
227 \\
228 \\
229 \\
230 \\
231 \\
232 \\
233 \\
234 \\
235 \\
238\end{array}$ & $\begin{array}{r}8 \\
40 \\
79 \\
120 \\
161 \\
189 \\
227 \\
267 \\
309 \\
360 \\
409 \\
457 \\
510 \\
613 \\
711 \\
815 \\
918 \\
1015 \\
1117 \\
1274 \\
1430 \\
1624 \\
1825 \\
2029 \\
2231 \\
2441 \\
2646 \\
2844 \\
3045 \\
3244 \\
3450 \\
3658 \\
3857 \\
4059 \\
4259 \\
4460\end{array}$ & $\begin{array}{r}16 . \\
16 . \\
16 . \\
16 . \\
15 . \\
14 . \\
13 . \\
12 . \\
10 . \\
8 . \\
7 . \\
7 . \\
6 . \\
6 . \\
6 . \\
5 . \\
4 . \\
4 . \\
3 . \\
3 . \\
2 . \\
2 . \\
2 . \\
2 . \\
1 . \\
1 . \\
1 . \\
1 . \\
1 . \\
1 . \\
1 . \\
1 . \\
1 . \\
1 . \\
1 . \\
1 .\end{array}$ & $\begin{array}{r}16 . \\
16 . \\
16 . \\
16 . \\
15 . \\
14 . \\
13 . \\
12 . \\
10 . \\
8 . \\
7 . \\
7 . \\
6 . \\
6 . \\
5 . \\
5 . \\
4 . \\
4 . \\
3 . \\
3 . \\
2 . \\
2 . \\
2 . \\
1 . \\
1 . \\
1 . \\
1 . \\
1 . \\
1 . \\
1 . \\
1 . \\
1 . \\
1 . \\
1 . \\
0 . \\
0 .\end{array}$ & $\begin{array}{l}35 . \\
35 . \\
35 . \\
35 . \\
35 . \\
35 . \\
34 . \\
34 . \\
34 . \\
34 . \\
34 . \\
34 . \\
34 . \\
34 . \\
34 . \\
34 . \\
34 . \\
34 . \\
34 . \\
34 . \\
34 . \\
34 . \\
34 . \\
34 . \\
34 . \\
34 . \\
34 . \\
34 . \\
34 . \\
34 . \\
34 . \\
34 . \\
34 . \\
34 . \\
34 . \\
34 .\end{array}$ & $\begin{array}{l}25 . \\
25 . \\
25 . \\
25 . \\
25 . \\
26 . \\
26 . \\
26 . \\
26 . \\
26 . \\
26 . \\
26 . \\
26 . \\
26 . \\
27 . \\
27 . \\
27 . \\
27 . \\
27 . \\
27 . \\
27 . \\
27 . \\
27 . \\
27 . \\
27 . \\
27 . \\
27 . \\
27 . \\
27 . \\
27 . \\
27 . \\
27 . \\
27 . \\
27 . \\
27 . \\
27 .\end{array}$ & $\begin{array}{l}24 x \\
24 x \\
24 x \\
24 x \\
21 x \\
20 x \\
20 x \\
21 x \\
22 x \\
22 x \\
23 x \\
24 x \\
24 x \\
24 x \\
23 x \\
21 x \\
20 x \\
18 x \\
17 x \\
16 x \\
16 x \\
15 x \\
15 x \\
15 x \\
15 x \\
15 x \\
16 x \\
16 x \\
16 x \\
17 x \\
17 x \\
18 x \\
19 x \\
19 x \\
19 x\end{array}$ & $\begin{array}{r}x \\
-x \\
x \\
x \\
2 x \\
5 x \\
6 x \\
6 x \\
6 x \\
6 x \\
6 x \\
5 x \\
5 x \\
6 x \\
7 x \\
9 x \\
11 x \\
13 x \\
14 x \\
15 x \\
16 x \\
17 x \\
17 x \\
18 x \\
17 x \\
17 x \\
17 x \\
17 x \\
16 x \\
16 x \\
16 x \\
15 x \\
15 x \\
14 x \\
14 x\end{array}$ & $\begin{array}{l}0 . \\
0 . \\
0 . \\
0 . \\
0 . \\
0 . \\
0 . \\
1 . \\
1 . \\
1 . \\
1 . \\
1 . \\
1 . \\
1 . \\
1 . \\
2 . \\
2 . \\
2 . \\
2 . \\
2 . \\
2 . \\
2 . \\
2 . \\
2 . \\
2 . \\
2 . \\
2 . \\
2 . \\
2 . \\
2 . \\
2 . \\
2 . \\
2 . \\
2 . \\
2 .\end{array}$ & $\begin{array}{r}0 . \\
0 . \\
0 \\
0 . \\
2 . \\
8 . \\
11 . \\
14 . \\
17 . \\
19 \\
21 . \\
21 . \\
22 . \\
24 . \\
26 . \\
28 . \\
30 . \\
32 . \\
33 . \\
34 . \\
34 . \\
34 . \\
35 . \\
35 . \\
35 . \\
35 . \\
34 . \\
34 . \\
34 . \\
34 . \\
33 . \\
33 . \\
33 . \\
32 . \\
32 .\end{array}$ & $\begin{array}{r}1 . \\
1 . \\
1 . \\
1 . \\
1 . \\
2 . \\
2 . \\
3 . \\
4 . \\
5 . \\
6 . \\
7 . \\
8 . \\
10 . \\
15 . \\
24 . \\
33 . \\
44 . \\
59 . \\
73 . \\
89 . \\
102 . \\
112 . \\
119 . \\
123 . \\
125 . \\
126 . \\
126 . \\
125 . \\
125 . \\
124 . \\
123 . \\
122 . \\
121 . \\
121 .\end{array}$ & $\begin{array}{l}2032 \\
2027 \\
2034 \\
2035 \\
2062 \\
2044 \\
2089 \\
2096 \\
2125 \\
2118 \\
2124 \\
2133 \\
2131 \\
2128 \\
2135 \\
2139 \\
2173 \\
2190 \\
2202 \\
2228 \\
2258 \\
2264 \\
2274 \\
2292 \\
2298 \\
2306 \\
2300 \\
2301 \\
2291 \\
2298 \\
2294 \\
2283 \\
2282 \\
2277 \\
2273 \\
2274\end{array}$ & $\begin{array}{l}2020 \\
2016 \\
2025 \\
2026 \\
2057 \\
2041 \\
2092 \\
2107 \\
2145 \\
2148 \\
2157 \\
2170 \\
2169 \\
2169 \\
2177 \\
2182 \\
2217 \\
2232 \\
2242 \\
2264 \\
2290 \\
2292 \\
2300 \\
2316 \\
2321 \\
2329 \\
2323 \\
2323 \\
2313 \\
2319 \\
2315 \\
2303 \\
2302 \\
2296 \\
2292 \\
2293\end{array}$ & $\begin{array}{r}355 \\
358 \\
362 \\
369 \\
422 \\
381 \\
513 \\
553 \\
615 \\
674 \\
700 \\
728 \\
709 \\
738 \\
761 \\
810 \\
912 \\
974 \\
1059 \\
1130 \\
1182 \\
1182 \\
1179 \\
1190 \\
1185 \\
1185 \\
1174 \\
1162 \\
1155 \\
1137 \\
1132 \\
1118 \\
1098 \\
1089 \\
1079 \\
1071\end{array}$ & $\begin{array}{l}306 \\
309 \\
307 \\
312 \\
346 \\
303 \\
385 \\
397 \\
411 \\
420 \\
420 \\
425 \\
407 \\
414 \\
420 \\
437 \\
480 \\
500 \\
531 \\
553 \\
569 \\
561 \\
555 \\
555 \\
549 \\
546 \\
538 \\
531 \\
526 \\
517 \\
513 \\
505 \\
494 \\
487 \\
482 \\
478\end{array}$ & $\begin{array}{l}2323 \\
2315 \\
2319 \\
2316 \\
2317 \\
2305 \\
2298 \\
2309 \\
2284 \\
2283 \\
2287 \\
2289 \\
2279 \\
2282 \\
2275 \\
2294 \\
2302 \\
2303 \\
2322 \\
2349 \\
2356 \\
2368 \\
2386 \\
2394 \\
2403 \\
2398 \\
2401 \\
2390 \\
2400 \\
2397 \\
2387 \\
2388 \\
2384 \\
2381 \\
2384\end{array}$ & $\begin{array}{l}2310 \\
2302 \\
2310 \\
2307 \\
2314 \\
2317 \\
2320 \\
2346 \\
2334 \\
2340 \\
2349 \\
2352 \\
2346 \\
2351 \\
2348 \\
2370 \\
2379 \\
2379 \\
2395 \\
2417 \\
2421 \\
2430 \\
2447 \\
2453 \\
2462 \\
2457 \\
2459 \\
2448 \\
2457 \\
2453 \\
2442 \\
2443 \\
2438 \\
2435 \\
2437\end{array}$ \\
\hline
\end{tabular}


Lamont-Doherty Earth Observatory of Columbia University

Printed on $12 / 06 / 93$

Page 29

(PALK) $s$ Potential Alkalinity $=($ TALK + NO3) $x(35 / \mathrm{Sal})$

WOCE tine P16C Station 180 Latitude 37-29.9S Longitude 150-30.1W Date 8/12/91 Bottom Depth 5533

\begin{tabular}{|c|c|c|c|c|c|c|c|c|c|c|c|c|c|c|c|c|}
\hline $\begin{array}{l}\text { Bot } \\
\text { No. }\end{array}$ & $\underset{\text { m }}{\text { Depth }}$ & $\begin{array}{l}\text { Temp } \\
\text { deg C }\end{array}$ & $\begin{array}{c}\text { Pot Temp } \\
\text { deg } C\end{array}$ & $\begin{array}{c}\text { Salinity } \\
0 / 00\end{array}$ & $\begin{array}{l}\text { Sigma } \\
\text { Theta }\end{array}$ & OXY & AOU & PO4 & & $\mathrm{SiO}_{3}$ & Obs & $S=35$ & 20 & Cheta & $\begin{array}{r}\text { To } \\
\text { Cal } \\
--1\end{array}$ & $\begin{array}{l}\text { Alk } \\
\text { ALKis } \\
\mathrm{kg}=-\end{array}$ \\
\hline $\begin{array}{l}261 \\
202 \\
203 \\
204 \\
205 \\
206 \\
207 \\
268 \\
269 \\
270 \\
211 \\
212 \\
213 \\
237 \\
215 \\
216 \\
217 \\
218 \\
219 \\
220 \\
221 \\
222 \\
223 \\
224 \\
225 \\
226 \\
227 \\
228 \\
229 \\
230 \\
231 \\
232 \\
233 \\
234 \\
235\end{array}$ & $\begin{array}{r}4 \\
49 \\
95 \\
131 \\
171 \\
201 \\
231 \\
261 \\
312 \\
389 \\
465 \\
541 \\
616 \\
718 \\
820 \\
922 \\
1023 \\
1175 \\
1327 \\
1526 \\
1778 \\
2027 \\
2268 \\
2520 \\
2770 \\
3006 \\
3241 \\
3474 \\
3717 \\
3956 \\
4204 \\
4465 \\
4721 \\
5014\end{array}$ & $\begin{array}{l}13 . \\
13 . \\
13 . \\
12 . \\
11 . \\
9 . \\
9 . \\
8 . \\
8 . \\
7 . \\
7 . \\
7 . \\
6 . \\
6 . \\
5 . \\
5 . \\
4 . \\
3 . \\
3 . \\
2 . \\
2 . \\
2 . \\
2 . \\
2 . \\
1 . \\
1 . \\
1 . \\
1 . \\
1 . \\
1 . \\
1 . \\
1 . \\
1 . \\
1 . \\
1 . \\
1 .\end{array}$ & $\begin{array}{r}13 . \\
13 . \\
13 . \\
12 . \\
11 . \\
9 . \\
9 . \\
8 . \\
8 . \\
7 . \\
7 . \\
7 . \\
6 . \\
6 . \\
5 . \\
5 . \\
4 . \\
3 . \\
3 . \\
2 . \\
2 . \\
2 . \\
1 . \\
1 . \\
1 . \\
1 . \\
1 . \\
1 . \\
1 . \\
1 . \\
0 . \\
0 . \\
0 . \\
0 . \\
0 . \\
0 .\end{array}$ & $\begin{array}{l}34 . \\
34 . \\
34 . \\
34 . \\
34 . \\
34 . \\
34 . \\
34 . \\
34 . \\
34 . \\
34 . \\
34 . \\
34 . \\
34 . \\
34 . \\
34 . \\
34 . \\
34 . \\
34 . \\
34 . \\
34 . \\
34 . \\
34 . \\
34 . \\
34 . \\
34 . \\
34 . \\
34 . \\
34 . \\
34 . \\
34 . \\
34 . \\
34 . \\
34 . \\
34\end{array}$ & $\begin{array}{l}26 . \\
26 . \\
26 . \\
26 . \\
26 . \\
26 . \\
26 . \\
26 . \\
26 . \\
26 . \\
26 . \\
26 . \\
26 . \\
27 . \\
27 . \\
27 . \\
27 . \\
27 . \\
27 . \\
27 . \\
27 . \\
27 . \\
27 . \\
27 . \\
27 . \\
27 . \\
27 . \\
27 . \\
27 . \\
27 . \\
27 . \\
27 . \\
27 . \\
27 . \\
27 .\end{array}$ & $\begin{array}{l}25 x \\
25 x \\
25 x \\
25 x \\
23 x \\
23 x \\
22 x \\
22 x \\
24 x \\
24 x \\
24 x \\
24 x \\
24 x \\
23 x \\
22 x \\
21 x \\
20 x \\
19 x \\
18 x \\
16 x \\
15 x \\
15 x \\
15 x \\
15 x \\
15 x \\
15 x \\
16 x \\
17 x \\
18 x \\
19 x \\
20 x \\
20 x \\
20 x \\
20 x \\
20 x \\
20 x\end{array}$ & $\begin{array}{r}-x \\
-x \\
-x \\
x \\
3 x \\
4 x \\
5 x \\
5 x \\
4 x \\
4 x \\
4 x \\
5 x \\
5 x \\
6 x \\
7 x \\
9 x \\
11 x \\
12 x \\
14 x \\
16 x \\
17 x \\
18 x \\
18 x \\
18 x \\
18 x \\
18 x \\
17 x \\
16 x \\
15 x \\
14 x \\
14 x \\
14 x \\
14 x \\
13 x \\
13 x \\
13 x\end{array}$ & $\begin{array}{l}0 . \\
0 . \\
0 . \\
0 . \\
0 . \\
0 . \\
1 . \\
1 . \\
1 . \\
1 . \\
1 . \\
1 . \\
1 . \\
1 . \\
1 . \\
1 . \\
2 . \\
2 . \\
2 . \\
2 . \\
2 . \\
2 . \\
2 . \\
2 . \\
2 . \\
2 . \\
2 . \\
2 . \\
2 . \\
2 . \\
2 . \\
2 . \\
2 . \\
2 . \\
2 . \\
2 .\end{array}$ & $\begin{array}{l}0 . \\
0 . \\
0 . \\
2 . \\
8 . \\
12 . \\
15 . \\
16 . \\
17 . \\
19 . \\
20 . \\
21 . \\
22 . \\
23 . \\
25 . \\
28 . \\
30 . \\
32 . \\
33 . \\
34 . \\
34 . \\
35 . \\
35 . \\
35 . \\
35 . \\
35 . \\
34 . \\
33 . \\
32 . \\
32 . \\
32 . \\
32 . \\
32 . \\
32 . \\
32 .\end{array}$ & $\begin{array}{r}1 . \\
1 . \\
1 . \\
1 . \\
1 . \\
2 . \\
3 . \\
4 . \\
4 . \\
5 . \\
6 . \\
7 . \\
8 . \\
11 . \\
15 . \\
21 . \\
30 . \\
43 . \\
57 . \\
78 . \\
98 . \\
109 . \\
117 . \\
122 . \\
127 . \\
128 . \\
125 . \\
117 . \\
114 . \\
114 . \\
117 . \\
119 . \\
120 . \\
122 . \\
122 . \\
123 .\end{array}$ & $\begin{array}{l}2042 \\
2045 \\
2045 \\
2054 \\
2087 \\
2104 \\
2121 \\
2123 \\
2126 \\
2125 \\
2126 \\
2128 \\
2133 \\
2137 \\
2151 \\
2167 \\
2182 \\
2203 \\
2229 \\
2254 \\
2278 \\
2290 \\
2298 \\
2303 \\
2303 \\
2304 \\
2296 \\
2279 \\
2269 \\
2264 \\
2266 \\
2265 \\
2265 \\
2266 \\
2262 \\
2263\end{array}$ & $\begin{array}{l}2057 \\
2060 \\
2060 \\
2071 \\
2110 \\
2131 \\
2148 \\
2152 \\
2157 \\
2158 \\
2161 \\
2165 \\
2171 \\
2177 \\
2193 \\
2210 \\
2225 \\
2244 \\
2266 \\
2285 \\
2304 \\
2315 \\
2322 \\
2326 \\
2326 \\
2326 \\
2316 \\
2299 \\
2287 \\
2283 \\
2285 \\
2284 \\
2284 \\
2285 \\
2281 \\
2282\end{array}$ & $\begin{array}{l}417 \\
414 \\
417 \\
434 \\
531 \\
599 \\
646 \\
663 \\
675 \\
707 \\
702 \\
714 \\
729 \\
762 \\
805 \\
880 \\
955 \\
1045 \\
1116 \\
1187 \\
1184 \\
1196 \\
1192 \\
1203 \\
1197 \\
1186 \\
1155 \\
1113 \\
1089 \\
1073 \\
1058 \\
1056 \\
1046 \\
1054 \\
1052 \\
1048\end{array}$ & $\begin{array}{l}315 \\
312 \\
314 \\
322 \\
366 \\
392 \\
410 \\
411 \\
408 \\
420 \\
412 \\
413 \\
415 \\
426 \\
441 \\
470 \\
496 \\
526 \\
547 \\
571 \\
562 \\
562 \\
556 \\
558 \\
552 \\
544 \\
528 \\
507 \\
493 \\
482 \\
472 \\
469 \\
463 \\
465 \\
464 \\
462\end{array}$ & $\begin{array}{l}2293 \\
2300 \\
2297 \\
2298 \\
2294 \\
2290 \\
2295 \\
2292 \\
2292 \\
2283 \\
2286 \\
2285 \\
2286 \\
2283 \\
2289 \\
2294 \\
2297 \\
2307 \\
2325 \\
2344 \\
2371 \\
2384 \\
2393 \\
2397 \\
2398 \\
2400 \\
2395 \\
2383 \\
2375 \\
2372 \\
2377 \\
2376 \\
2378 \\
2378 \\
2374 \\
2375\end{array}$ & $\begin{array}{l}2311 \\
2317 \\
2315 \\
2320 \\
2328 \\
2332 \\
2340 \\
2340 \\
2344 \\
2338 \\
2343 \\
2346 \\
2350 \\
2350 \\
2360 \\
2367 \\
2373 \\
2382 \\
2398 \\
2411 \\
2434 \\
2445 \\
2454 \\
2457 \\
2457 \\
2458 \\
2452 \\
2437 \\
2427 \\
2424 \\
2428 \\
2428 \\
2430 \\
2430 \\
2426 \\
2427\end{array}$ \\
\hline
\end{tabular}

WOCE Line P16C Station 181 Latitude 36-59.9S Longitude 150-29.9W Date 8/12/91 Bottom Depth 5686

\begin{tabular}{|c|c|c|c|c|c|c|c|c|c|c|c|c|c|c|c|c|}
\hline $\begin{array}{l}\text { Bot } \\
\text { No. }\end{array}$ & $\underset{\text { Depth }}{\text { m }}$ & $\begin{array}{l}\text { Temp } \\
\text { deg } C\end{array}$ & $\begin{array}{l}\text { Pot Temp } \\
\text { deg } C\end{array}$ & $\begin{array}{c}\text { Salinity } \\
0 / 00\end{array}$ & $\begin{array}{l}\text { Sigma } \\
\text { Theta }\end{array}$ & Oxy & AOU & $\mathrm{PO} 4$ & $\begin{array}{r}\text { NO3 } \\
--U M /\end{array}$ & SiO3 & Obs & $s=35$ & 20 & Theta & $\begin{array}{l}\text { Tota } \\
\text { Calc } \\
---U E\end{array}$ & $\begin{array}{l}\text { ALk. } \\
\text { pALK) s } \\
/ \mathrm{kg}^{--}\end{array}$ \\
\hline $\begin{array}{l}161 \\
102 \\
103 \\
104 \\
105 \\
106 \\
107 \\
168 \\
169 \\
170 \\
111 \\
112 \\
113 \\
137 \\
115 \\
116 \\
117 \\
118 \\
119 \\
120 \\
121 \\
122 \\
123 \\
124 \\
125 \\
126 \\
127 \\
128 \\
129 \\
130 \\
131 \\
132 \\
133 \\
134 \\
135 \\
138\end{array}$ & $\begin{array}{r}3 \\
48 \\
89 \\
136 \\
176 \\
215 \\
271 \\
337 \\
412 \\
514 \\
614 \\
716 \\
815 \\
913 \\
1018 \\
1117 \\
1266 \\
1419 \\
1625 \\
1826 \\
2026 \\
2273 \\
2520 \\
2769 \\
3007 \\
3259 \\
3518 \\
3756 \\
3989 \\
4224 \\
4483 \\
4729 \\
4985 \\
5228 \\
5485 \\
5683\end{array}$ & $\begin{array}{r}13 . \\
13 . \\
13 . \\
12 . \\
10 . \\
9 . \\
8 . \\
7 . \\
7 . \\
7 . \\
6 . \\
6 . \\
5 . \\
5 . \\
4 . \\
4 . \\
3 . \\
2 . \\
2 . \\
2 . \\
2 . \\
2 . \\
1 . \\
1 . \\
1 . \\
1 . \\
1 . \\
1 . \\
1 . \\
1 . \\
1 . \\
1 . \\
1 . \\
1 . \\
1 . \\
1 .\end{array}$ & $\begin{array}{r}13 . \\
13 . \\
13 . \\
12 . \\
10 . \\
9 . \\
8 . \\
7 . \\
7 . \\
7 . \\
6 . \\
6 . \\
5 . \\
5 . \\
4 . \\
3 . \\
3 . \\
2 . \\
2 . \\
2 . \\
2 . \\
1 . \\
1 . \\
1 . \\
1 . \\
1 . \\
1 . \\
1 . \\
1 . \\
0 . \\
0 . \\
0 . \\
0 . \\
0 . \\
0 . \\
0 .\end{array}$ & $\begin{array}{l}34 . \\
34 . \\
34 . \\
34 . \\
34 . \\
34 . \\
34 . \\
34 . \\
34 . \\
34 . \\
34 . \\
34 . \\
34 . \\
34 . \\
34 . \\
34 . \\
34 . \\
34 . \\
34 . \\
34 . \\
34 . \\
34 . \\
34 . \\
34 . \\
34 . \\
34 . \\
34 . \\
34 . \\
34 . \\
34 . \\
34 . \\
34 . \\
34 . \\
34 . \\
34 . \\
34 .\end{array}$ & $\begin{array}{l}26 . \\
26 . \\
26 . \\
26 . \\
26 . \\
26 . \\
26 . \\
26 . \\
26 . \\
26 . \\
26 . \\
27 . \\
27 . \\
27 . \\
27 . \\
27 . \\
27 . \\
27 . \\
27 . \\
27 . \\
27 . \\
27 . \\
27 . \\
27 . \\
27 . \\
27 . \\
27 . \\
27 . \\
27 . \\
27 . \\
27 . \\
27 . \\
27 . \\
27 . \\
27 . \\
27 .\end{array}$ & $\begin{array}{l}25 x \\
25 x \\
25 x \\
24 x \\
22 x \\
22 x \\
22 x \\
24 x \\
24 x \\
24 x \\
24 x \\
23 x \\
22 x \\
21 x \\
20 x \\
19 x \\
18 x \\
27 x \\
16 x \\
15 x \\
15 x \\
15 x \\
15 x \\
15 x \\
15 x \\
16 x \\
17 x \\
18 x \\
19 x \\
19 x \\
20 x \\
20 x \\
20 x \\
20 x \\
20 x \\
20 x\end{array}$ & $\begin{array}{r}-x \\
-x \\
x \\
1 x \\
4 x \\
5 x \\
5 x \\
4 x \\
4 x \\
5 x \\
5 x \\
6 x \\
7 x \\
9 x \\
11 x \\
12 x \\
14 x \\
15 x \\
16 x \\
17 x \\
18 x \\
18 x \\
18 x \\
18 x \\
18 x \\
17 x \\
16 x \\
15 x \\
14 x \\
14 x \\
14 x \\
14 x \\
13 x \\
13 x \\
13 x \\
13 x\end{array}$ & 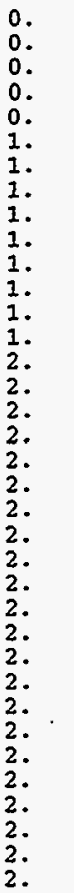 & $\begin{array}{r}0 . \\
0 . \\
0 . \\
2 . \\
10 . \\
14 . \\
17 . \\
18 . \\
19 . \\
20 . \\
22 . \\
23 . \\
25 . \\
28 . \\
30 . \\
31 . \\
33 . \\
34 . \\
34 . \\
34 . \\
35 . \\
35 . \\
35 . \\
35 . \\
35 . \\
34 . \\
34 . \\
33 . \\
32 . \\
32 . \\
32 . \\
32 . \\
32 . \\
32 . \\
32 . \\
32 .\end{array}$ & $\begin{array}{r}1 . \\
1 . \\
1 . \\
1 . \\
2 . \\
3 . \\
4 . \\
5 . \\
6 . \\
7 . \\
8 . \\
10 . \\
15 . \\
21 . \\
30 . \\
39 . \\
54 . \\
69 . \\
87 . \\
101 . \\
110 . \\
118 . \\
124 . \\
1290^{\circ} \\
130 . \\
129 . \\
124 . \\
118 . \\
114 . \\
116 . \\
118 . \\
120 . \\
121 . \\
122 . \\
122 . \\
122 .\end{array}$ & 2044 & 2058 & 408 & 309 & 2301 & 2317 \\
\hline
\end{tabular}


Lamont-Doherty Earth Observatory of Columbia University Project/Expedition is TUNES/2 WOCE P17C/P16C 1991

(TCO2) $s=35=$ TCO2 obs $x(35 /$ SaI) $\quad$ (PALK) $s=$ Potential Alkalinity $=$ (TALK + NO3) $X(35 / \mathrm{Sal})$ WOCE Line P16C Station 182 Latitude 36-30.0s Longitude 150-30.0W Date 8/13/91 Bottom Depth 5590

\begin{tabular}{|c|c|c|c|c|c|c|c|c|c|c|c|c|c|c|c|c|}
\hline $\begin{array}{l}\text { Bot } \\
\text { No. }\end{array}$ & $\underset{\text { Im }}{\text { Depth }}$ & $\begin{array}{l}\text { Temp } \\
\text { deg } c\end{array}$ & $\begin{array}{l}\text { Pot Temp } \\
\text { deg } C\end{array}$ & $\begin{array}{c}\text { Salinity } \\
0 / 00\end{array}$ & $\begin{array}{l}\text { Sigma } \\
\text { Theta }\end{array}$ & Oxy & AOU & PO4 & $\begin{array}{r}\text { NO3 } \\
--U M\end{array}$ & $\mathrm{SiO3}$ & $\begin{array}{c}--\mathrm{TC} \\
\text { Obs }\end{array}$ & $\begin{array}{r}S=35 \\
S=--\end{array}$ & 20 & heta & $\begin{array}{l}\text { Tot } \\
\text { Calc } \\
---4\end{array}$ & $\begin{array}{l}\text { Alk. } \\
\text { PALK) } \\
\text { /kg-- }\end{array}$ \\
\hline $\begin{array}{l}213 \\
237 \\
215 \\
216 \\
217 \\
218 \\
219 \\
220 \\
221 \\
222 \\
223 \\
224 \\
225 \\
226 \\
227 \\
228 \\
229 \\
230 \\
231 \\
232 \\
233 \\
234 \\
235 \\
238\end{array}$ & $\begin{array}{r}4 \\
33 \\
62 \\
93 \\
122 \\
154 \\
184 \\
226 \\
266 \\
325 \\
385 \\
445 \\
507 \\
607 \\
707 \\
807 \\
906 \\
1006 \\
1101 \\
1251 \\
1403 \\
1610 \\
1814 \\
2017\end{array}$ & $\begin{array}{r}13 . \\
13 . \\
13 . \\
13 . \\
13 . \\
12 . \\
11 . \\
9 . \\
8 . \\
8 . \\
7 . \\
7 . \\
7 . \\
6 . \\
6 . \\
5 . \\
5 . \\
4 . \\
4 . \\
3 . \\
2 . \\
2 . \\
2 . \\
2 .\end{array}$ & $\begin{array}{r}13 . \\
13 . \\
13 . \\
13 . \\
13 . \\
12 . \\
11 . \\
9 . \\
8 . \\
8 . \\
7 . \\
7 . \\
7 . \\
6 . \\
6 . \\
5 . \\
5 . \\
4 . \\
3 . \\
3 . \\
2 . \\
2 . \\
2 . \\
2 .\end{array}$ & $\begin{array}{l}34 . \\
34 . \\
34 . \\
34 . \\
34 . \\
34 . \\
34 . \\
34 . \\
34 . \\
34 . \\
34 . \\
34 . \\
34 . \\
34 . \\
34 . \\
34 . \\
34 . \\
34 . \\
34 . \\
34 . \\
34 . \\
34 . \\
34 . \\
34 .\end{array}$ & $\begin{array}{l}26 . \\
26 . \\
26 . \\
26 . \\
26 . \\
26 . \\
26 . \\
26 . \\
26 . \\
26 . \\
26 . \\
26 . \\
26 . \\
26 . \\
27 . \\
27 . \\
27 . \\
27 . \\
27 . \\
27 . \\
27 . \\
27 . \\
27 . \\
27 .\end{array}$ & $\begin{array}{l}25 x \\
25 x \\
25 x \\
25 x \\
25 x \\
23 x \\
23 x \\
22 x \\
23 x \\
24 x \\
24 x \\
24 x \\
24 x \\
24 x \\
23 x \\
22 x \\
21 x \\
20 x \\
19 x \\
18 x \\
17 x \\
16 x \\
15 x \\
15 x\end{array}$ & $\begin{array}{r}-x \\
-x \\
-x \\
x \\
x \\
2 x \\
3 x \\
5 x \\
5 x \\
4 x \\
4 x \\
4 x \\
4 x \\
5 x \\
6 x \\
7 x \\
9 x \\
11 x \\
12 x \\
13 x \\
15 x \\
16 x \\
17 x \\
18 x\end{array}$ & $\begin{array}{l}0 . \\
0 . \\
0 . \\
0 . \\
0 . \\
0 . \\
0 . \\
1 . \\
1 . \\
1 . \\
1 . \\
1 . \\
1 . \\
1 . \\
1 . \\
1 . \\
1 . \\
2 . \\
2 . \\
2 . \\
2 . \\
2 . \\
2 . \\
2 .\end{array}$ & $\begin{array}{l}0 . \\
0 . \\
0 . \\
0 . \\
0 . \\
5 . \\
8 . \\
13 . \\
16 . \\
17 . \\
19 . \\
19 . \\
20 . \\
22 . \\
24 . \\
26 . \\
28 . \\
30 . \\
31 . \\
33 . \\
34 . \\
34 . \\
35 . \\
35 .\end{array}$ & $\begin{array}{r}2 . \\
1 . \\
1 . \\
1 . \\
1 . \\
1 . \\
2 . \\
3 . \\
4 . \\
5 . \\
5 . \\
6 . \\
7 . \\
9 . \\
11 . \\
15 . \\
23 . \\
31 . \\
40 . \\
53 . \\
68 . \\
88 . \\
104 . \\
111 .\end{array}$ & 2044 & 2057 & 402 & 308 & 2305 & 2320 \\
\hline
\end{tabular}

WOCE Line PI6C Station 183 Latitude 36-00.0S Longitude 150-29.8w Date 8/13/91 Bottom Depth 5293

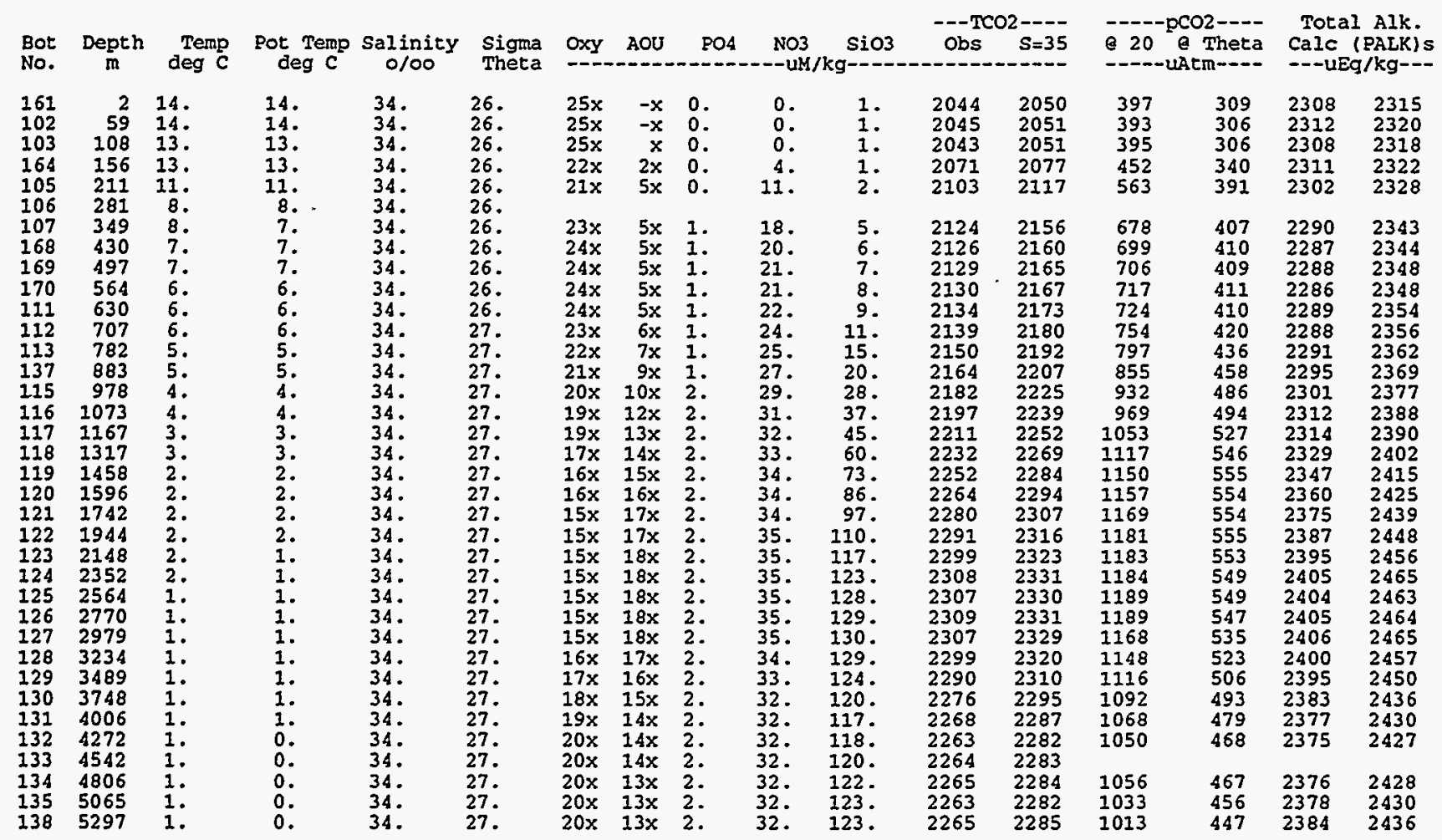


Lamont-Doherty Earth Observatory of Columbia University

$(T C O 2) s=35=T C O 2$ obs $X(35 / \mathrm{Sal}$ (PALK) $=$ Potential Alkalinity $=(\mathrm{TALK}+\mathrm{NO}) \mathrm{X}(35 / \mathrm{Sa})$ wOCE Iine P16C station 184 Latitude 35-29.8S Longitude 150-29.9W Date 8/13/91 Bottom Depth 5383

\begin{tabular}{|c|c|c|c|c|c|c|c|c|c|c|}
\hline $\begin{array}{l}\text { ot } \\
0 .\end{array}$ & $\begin{array}{l}\text { Depth } \\
\text { m }\end{array}$ & $\begin{array}{r}\text { Temp } \\
\text { deg C }\end{array}$ & $\begin{array}{l}\text { ot Temp } \\
\text { deg } C\end{array}$ & $\begin{array}{c}\text { Salinity } \\
0 / 00\end{array}$ & $\begin{array}{l}\text { Sigma } \\
\text { Theta }\end{array}$ & oxy & $\mathrm{AOU}$ & PO4 & NO3 & \\
\hline $\begin{array}{l}02 \\
03 \\
64 \\
05 \\
06 \\
07 \\
68 \\
69 \\
69\end{array}$ & $\begin{array}{r}7 \\
51 \\
98 \\
143 \\
188 \\
237 \\
286 \\
349 \\
411 \\
481 \\
553 \\
633 \\
713 \\
811 \\
908 \\
1009 \\
1110 \\
1256 \\
1403 \\
1591 \\
1777 \\
1968 \\
2159 \\
2346 \\
2539 \\
2802 \\
3065 \\
3323 \\
3580 \\
3832 \\
4080 \\
4329 \\
4565 \\
4814 \\
5065\end{array}$ & $\begin{array}{r}14 . \\
14 . \\
14 . \\
12 . \\
11 . \\
9 . \\
8 . \\
8 . \\
7 . \\
7 . \\
7 . \\
6 . \\
6 . \\
5 . \\
5 . \\
4 . \\
4 . \\
3 . \\
2 . \\
2 . \\
2 . \\
2 . \\
2 . \\
2 . \\
1 . \\
1 . \\
1 . \\
1 . \\
1 . \\
1 . \\
1 . \\
1 . \\
1 . \\
1 . \\
1 .\end{array}$ & $\begin{array}{r}14 . \\
14 . \\
14 . \\
12 . \\
11 . \\
9 . \\
8 . \\
8 . \\
7 . \\
7 . \\
7 . \\
6 . \\
6 . \\
5 . \\
5 . \\
4 . \\
3 . \\
3 . \\
2 . \\
2 . \\
2 . \\
2 . \\
1 . \\
1 . \\
1 . \\
1 . \\
1 . \\
1 . \\
1 . \\
1 . \\
0 . \\
0 . \\
0 . \\
0 .\end{array}$ & $\begin{array}{l}34 . \\
34 . \\
34 . \\
34 . \\
34 . \\
34 . \\
34 . \\
34 . \\
34 . \\
34 . \\
34 . \\
34 . \\
34 . \\
34 . \\
34 . \\
34 . \\
34 . \\
34 . \\
34 . \\
34 . \\
34 . \\
34 . \\
34 . \\
34 . \\
34 . \\
34 . \\
34 . \\
34 . \\
34 . \\
34 . \\
34 . \\
34 . \\
34 . \\
34 . \\
34\end{array}$ & $\begin{array}{l}26 . \\
26 . \\
26 . \\
26 . \\
26 . \\
26 . \\
26 . \\
26 . \\
26 . \\
26 . \\
26 . \\
26 . \\
27 . \\
27 . \\
27 . \\
27 . \\
27 . \\
27 . \\
27 . \\
27 . \\
27 . \\
27 . \\
27 . \\
27 . \\
27 . \\
27 . \\
27 . \\
27 . \\
27 . \\
27 . \\
27 . \\
27 . \\
27 . \\
27 . \\
27 .\end{array}$ & $\begin{array}{l}25 x \\
25 x \\
25 x \\
23 x \\
22 x \\
22 x \\
22 x \\
23 x \\
23 x \\
24 x \\
24 x \\
24 x \\
23 x \\
22 x \\
21 x \\
20 x \\
19 x \\
18 x \\
17 x \\
16 x \\
15 x \\
15 x \\
15 x \\
15 x \\
15 x \\
15 x \\
15 x \\
16 x \\
17 x \\
18 x \\
19 x \\
20 x \\
20 x \\
20 x \\
20 x\end{array}$ & $\begin{array}{r}-x \\
-x \\
-x \\
2 x \\
4 x \\
5 x \\
5 x \\
5 x \\
5 x \\
5 x \\
5 x \\
5 x \\
6 x \\
7 x \\
9 x \\
11 x \\
12 x \\
13 x \\
15 x \\
16 x \\
17 x \\
17 x \\
18 x \\
18 x \\
18 x \\
18 x \\
17 x \\
17 x \\
16 x \\
15 x \\
14 x \\
14 x \\
14 x \\
14 x \\
13 x \\
13 x\end{array}$ & $\begin{array}{l}0 . \\
0 . \\
0 . \\
0 . \\
0 . \\
1 . \\
1 . \\
1 . \\
1 . \\
1 . \\
1 . \\
1 . \\
1 . \\
1 . \\
1 . \\
2 . \\
2 . \\
2 . \\
2 . \\
2 . \\
2 . \\
2 . \\
2 . \\
2 . \\
2 . \\
2 . \\
2 . \\
2 . \\
2 . \\
2 . \\
2 . \\
2 . \\
2 . \\
2 . \\
2 . \\
2 .\end{array}$ & 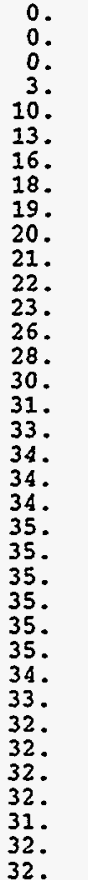 & $\begin{array}{r}1 \\
1 \\
2 \\
3 \\
3 \\
5 \\
6 \\
8 \\
10 \\
10 \\
11 \\
12 \\
12 \\
13 \\
13 \\
12 \\
12 \\
11 \\
11 \\
11 \\
12 \\
12\end{array}$ \\
\hline
\end{tabular}

WOCE Line 216C Station 185 Latitude 35-00.0S Longitude 150-29.9W Date 8/14/91 Bottom Depth 5470

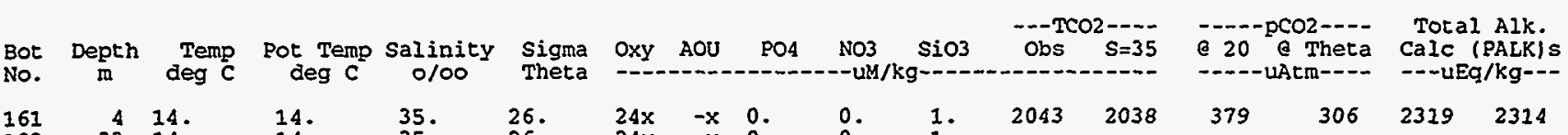

$\begin{array}{rrrrlllllll}161 & 4 & 14 . & 14 . & 35 . & 26 . & 24 \times & -\times & 0 . & 0 . & 1 . \\ 102 & 33 & 14 . & 14 . & 35 . & 26 . & 24 \times & -\times & 0 . & 0 . & 1 . \\ 103 & 68 & 14 . & 14 . & 35 . & 26 . & 25 \times & -\times & 0 . & 0 . & 1 . \\ 164 & 109 & 14 . & 14 . & 35 . & 26 . & 24 \times & -\times & 0 . & 0 . & 1 . \\ 105 & 155 & 14 . & 14 . & 35 . & 26 . & 24 \times & \times & 0 . & 0 . & 1 . \\ 106 & 185 & 12 . & 12 . & 34 . & 26 . & 22 \times & 3 \times & 0 . & 5 . & 2 . \\ 107 & 234 & 11 . & 11 . & 34 . & 26 . & 21 \times & 5 \times & 0 . & 11 . & 3 . \\ 168 & 286 & 9 . & 9 . & 34 . & 26 . & 22 \times & 5 \times & 1 . & 15 . & 4 . \\ 169 & 338 & 8 . & 8 . & 34 . & 26 . & 22 \times & 6 \times & 1 . & 17 . & 5 . \\ 170 & 415 & 7 . & 7 . & 34 . & 26 . & 23 \times & 5 \times & 1 . & 19 . & 6 . \\ 111 & 515 & 7 . & 7 . & 34 . & 26 . & 24 \times & 5 \times & 1 . & 20 . & 8 . \\ 112 & 616 & 6 . & 6 . & 34 . & 26 . & 24 \times & 5 \times & 1 . & 22 . & 10 . \\ 113 & 716 & 6 . & 6 . & 34 . & 27 . & 23 \times & 6 \times & 1 . & 23 . & 15 . \\ 137 & 818 & 5 . & 5 . & 34 . & 27 . & 22 \times & 7 \times & 1 . & 26 . & 28 . \\ 115 & 917 & 5 . & 5 . & 34 . & 27 . & 21 \times & 9 \times & 1 . & 30 . & 30 . \\ 116 & 1018 & 4 . & 4 . & 34 . & 27 . & 20 \times & 11 \times & 2 . & 31 . & 39 . \\ 117 & 1119 & 4 . & 3 . & 34 . & 27 . & 19 \times & 12 \times & 2 . & 33 . & 55 . \\ 118 & 1271 & 3 . & 3 . & 34 . & 27 . & 18 \times & 14 \times & 2 . & 34 . & 71 . \\ 119 & 1424 & 2 . & 2 . & 34 . & 27 . & 17 \times & 15 \times & 2 . & 34 . & 90 . \\ 120 & 1626 & 2 . & 2 . & 34 . & 27 . & 16 \times & 16 \times & 2 . & 35 . & 104 . \\ 121 & 1832 & 2 . & 2 . & 34 . & 27 . & 15 \times & 17 \times & 2 . & 35 . & 113 . \\ 122 & 2034 & 2 . & 2 . & 34 . & 27 . & 15 \times & 18 \times & 2 . & 35 . & 121 . \\ 123 & 2290 & 2 . & 1 . & 34 . & 27 . & 15 \times & 18 \times & 2 . & 35 . & 127 . \\ 124 & 2543 & 1 . & 1 . & 34 . & 27 . & 15 \times & 18 \times & 2 . & 35 . & 130 . \\ 125 & 2800 & 1 . & 1 . & 34 . & 27 . & 15 \times & 18 \times & 2 . & 35 . & 131 . \\ 126 & 3055 & 1 . & 1 . & 34 . & 27 . & 15 \times & 18 \times & 2 . & 34 . & 127 . \\ 127 & 3308 & 1 . & 1 . & 34 . & 27 . & 16 \times & 17 \times & 2 . & 33 . & 123 . \\ 128 & 3561 & 1 . & 1 . & 34 . & 27 . & 17 \times & 16 \times & 2 . & 32 . & 120 . \\ 129 & 3816 & 1 . & 1 . & 34 . & 27 . & 18 \times & 15 \times & 2 . & 32 . & 119 . \\ 130 & 4068 & 1 . & 0 . & 34 . & 27 . & 19 \times & 14 \times & 2 . & 32 . & 120 . \\ 131 & 4322 & 1 . & 0 . & 34 . & 27 . & 20 \times & 14 \times & 2 . & 32 . & 121 . \\ 132 & 4575 & 1 . & 0 . & 34 . & 27 . & 20 \times & 14 \times & 2 . & 32 . & 122 . \\ 133 & 4825 & 1 . & 0 . & 34 . & 27 . & 20 \times & 14 \times & 2 . & 32 . & 122 . \\ 134 & 5078 & 1 . & 0 . & 34 . & 27 . & 20 \times & 13 \times & 2 . & 32 . & 122 . \\ 135 & 5284 & 1 . & 0 . & 34 . & 27 . & 20 \times & 13 \times & 2 . & 32 . & 123 . \\ 138 & 5437 & 1 . & 0 . & 34 . & 27 . & & & 2 . & & \end{array}$

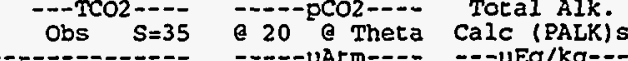


Lamont-Doherty Earth Observatory of Columbia University

Printed on $12 / 06 / 93$

Page 32

(PALK)s = POLential Alkalinity $=($ TALK + NO3) $\times(35 / \mathrm{Sal})$

WOCE Line P16C Station 186 Latitude 34-29.8S Longitude 150-30.3W Date 8/14/91 Bottom Depth 5348

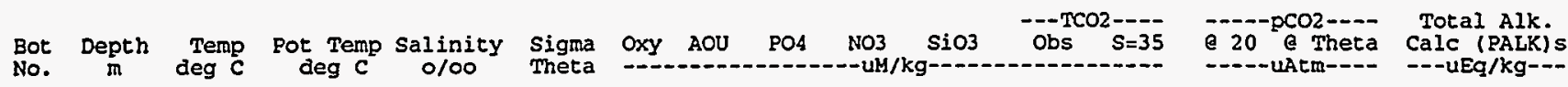

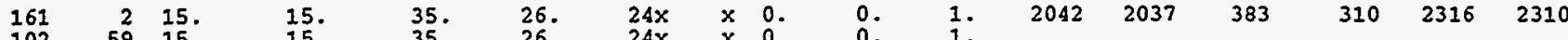

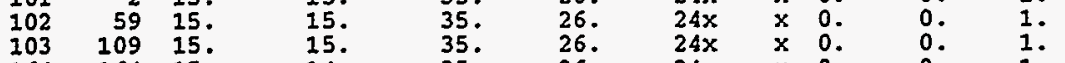

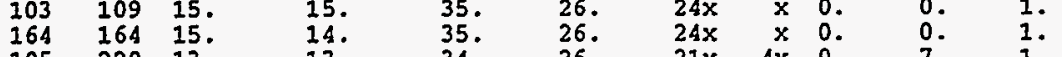

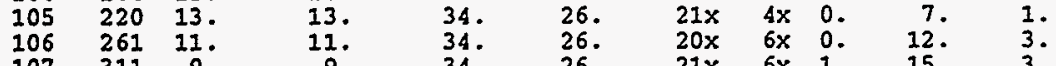

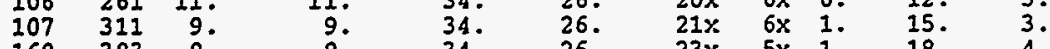

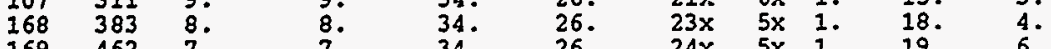

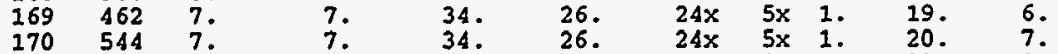

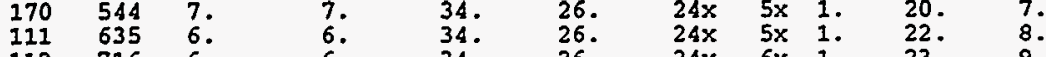

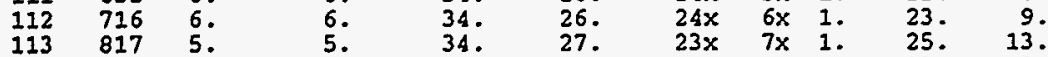

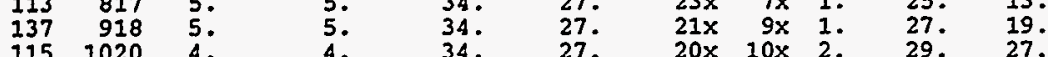

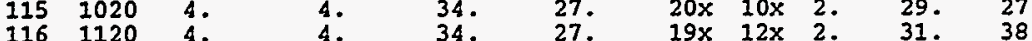

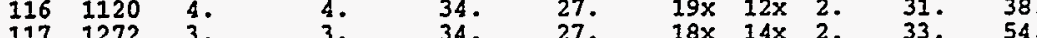

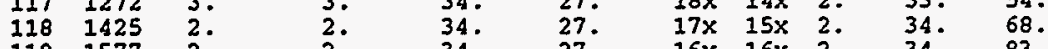

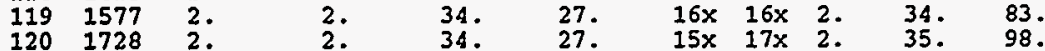

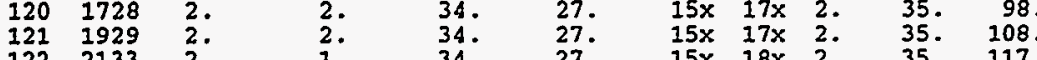

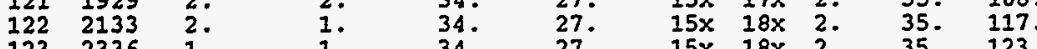

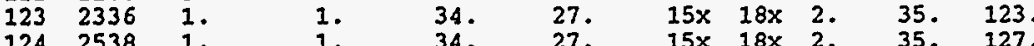

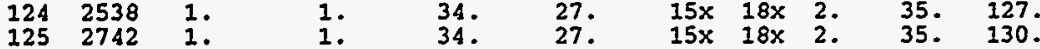

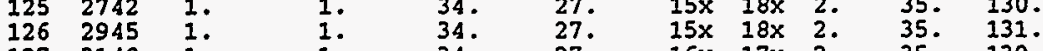

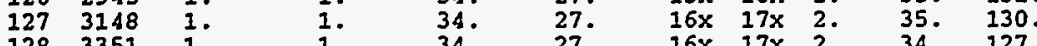

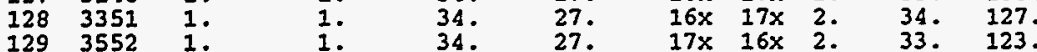

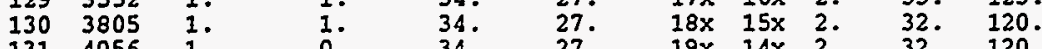

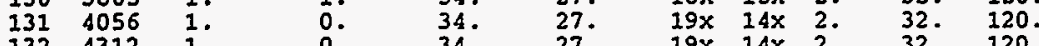

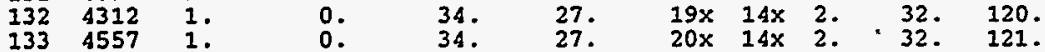

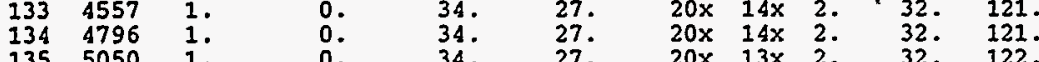

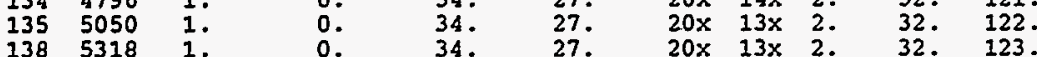

WOCE Line P16C Station 187 Latitude 34-00.1S Longitude 150-30.0W Date 8/14/91 Bottom Depth 5318

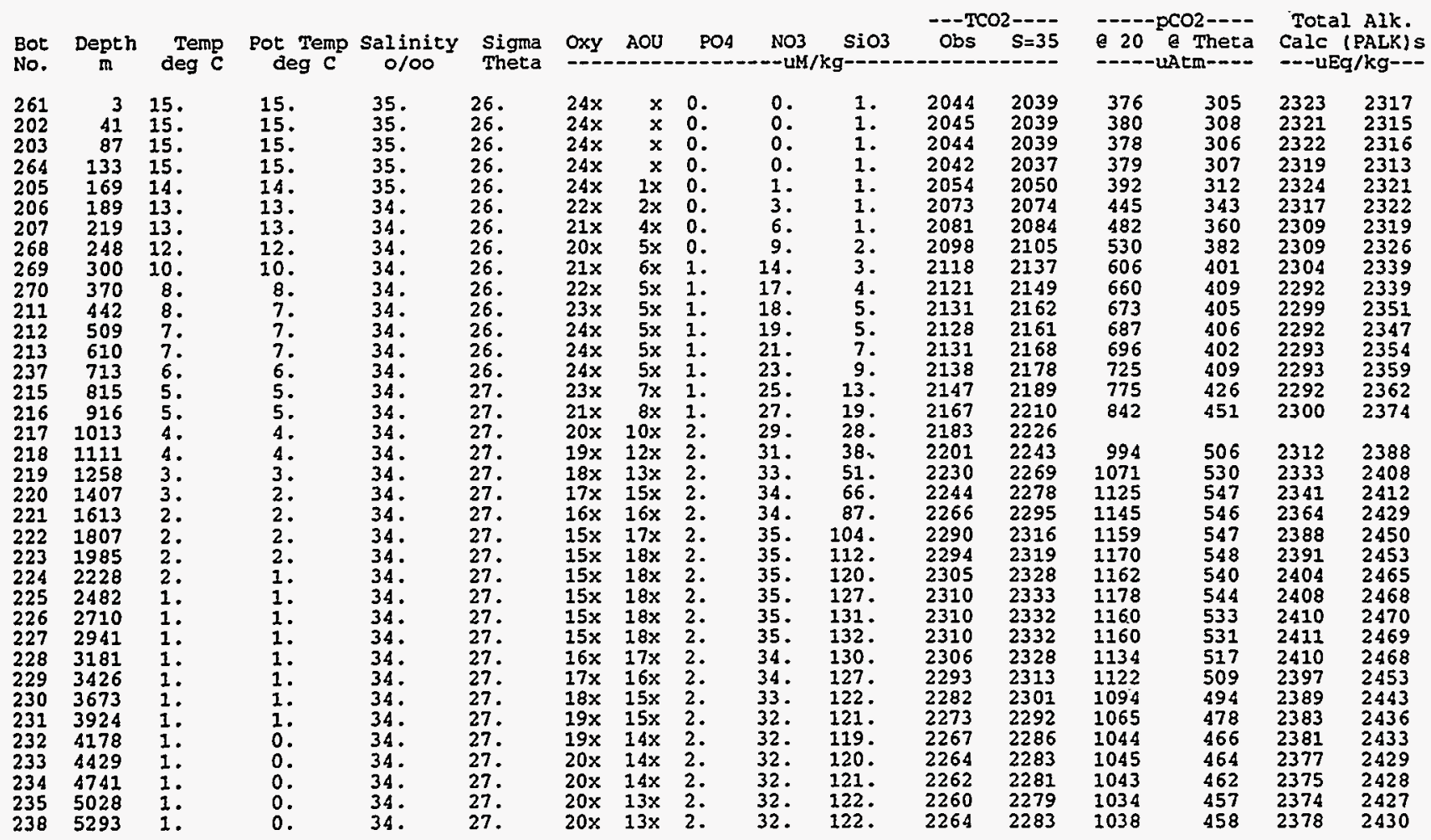


Lamont-Doherty Earth Observatory of Columbia University

Projes 12 WCE $17 \mathrm{C}$ (P16C 199

(TCO2) $s=35=\mathrm{TCO}$ obs $\mathrm{X}(35 / \mathrm{Sal}) \quad$ (PALK) $s=$ Potential Alkalinity $=$ (TALK + NO3) X (35/ Sal) WOCE line P16C Station 188 Latitude 33-29.8S Longitude 150-30.3W Date 8/15/91 Bottom Depth 5236

\begin{tabular}{|c|c|c|c|c|c|c|c|c|c|c|}
\hline $\begin{array}{l}\text { sot } \\
\text { So. }\end{array}$ & $\underset{\text { mepth }}{\text { Des }}$ & $\begin{array}{l}\text { Temp } \\
\text { deg C }\end{array}$ & $\begin{array}{c}\text { Pot Temp } \\
\text { deg } C\end{array}$ & $\begin{array}{c}\text { Salinity } \\
0 / \infty 0\end{array}$ & $\begin{array}{l}\text { Signa } \\
\text { Theta }\end{array}$ & Oxy & AOU & PO4 & $\begin{array}{l}\mathrm{NO} 3 \\
--\mathrm{UM} /\end{array}$ & si \\
\hline $\begin{array}{l}161 \\
102 \\
103 \\
164 \\
105 \\
106 \\
107 \\
168 \\
169 \\
170 \\
111 \\
112 \\
113 \\
137 \\
115 \\
116 \\
117 \\
118 \\
119 \\
120 \\
121 \\
122 \\
123 \\
124 \\
125 \\
126 \\
127 \\
128 \\
129 \\
130 \\
131 \\
132 \\
133 \\
134 \\
135\end{array}$ & $\begin{array}{r}4 \\
51 \\
96 \\
141 \\
192 \\
243 \\
298 \\
360 \\
431 \\
503 \\
574 \\
655 \\
736 \\
816 \\
918 \\
1018 \\
1118 \\
1270 \\
1421 \\
1623 \\
1825 \\
2030 \\
2233 \\
2436 \\
2639 \\
2839 \\
3035 \\
3237 \\
3442 \\
3699 \\
3952 \\
4206 \\
4454 \\
4708 \\
4956\end{array}$ & $\begin{array}{l}15 . \\
15 . \\
15 . \\
15 . \\
13 . \\
11 . \\
10 . \\
8 . \\
7 . \\
7 . \\
6 . \\
6 . \\
6 . \\
5 . \\
5 . \\
4 . \\
3 . \\
3 . \\
2 . \\
2 . \\
2 . \\
2 . \\
2 . \\
1 . \\
1 . \\
1 . \\
1 . \\
1 . \\
1 . \\
1 . \\
1 . \\
1 . \\
1 . \\
1 . \\
1 . \\
1 .\end{array}$ & $\begin{array}{r}15 . \\
15 . \\
15 . \\
14 . \\
13 . \\
11 . \\
10 . \\
8 . \\
7 . \\
7 . \\
6 . \\
6 . \\
6 . \\
5 . \\
4 . \\
4 . \\
3 . \\
3 . \\
2 . \\
2 . \\
2 . \\
2 . \\
1 . \\
1 . \\
1 . \\
1 . \\
1 . \\
1 . \\
1 . \\
1 . \\
1 . \\
0 . \\
0 . \\
0 . \\
0 . \\
0 .\end{array}$ & $\begin{array}{l}35 . \\
35 \\
35 \\
35 \\
34 . \\
34 . \\
34 . \\
34 . \\
34 . \\
34 . \\
34 . \\
34 . \\
34 . \\
34 . \\
34 . \\
34 . \\
34 . \\
34 . \\
34 . \\
34 . \\
34 . \\
34 . \\
34 . \\
34 . \\
34 . \\
34 . \\
34 . \\
34 . \\
34 . \\
34 . \\
34 . \\
34 . \\
34 . \\
34 . \\
34 .\end{array}$ & $\begin{array}{l}26 . \\
26 . \\
26 . \\
26 . \\
26 . \\
26 . \\
26 . \\
26 . \\
26 . \\
26 . \\
26 . \\
26 . \\
27 . \\
27 . \\
27 . \\
27 . \\
27 . \\
27 . \\
27 . \\
27 . \\
27 . \\
27 . \\
27 . \\
27 . \\
27 . \\
27 . \\
27 . \\
27 . \\
27 . \\
27 . \\
27 . \\
27 . \\
27 . \\
27 . \\
27\end{array}$ & $\begin{array}{l}24 x \\
24 x \\
24 x \\
24 x \\
22 x \\
20 x \\
21 x \\
23 x \\
23 x \\
24 x \\
24 x \\
24 x \\
23 x \\
22 x \\
21 x \\
20 x \\
19 x \\
17 x \\
16 x \\
16 x \\
15 x \\
15 x \\
14 x \\
14 x \\
15 x \\
15 x \\
15 x \\
16 x \\
17 x \\
18 x \\
19 x \\
19 x \\
20 x \\
20 x \\
20 x \\
20 x\end{array}$ & $\begin{array}{r}-x \\
-x \\
-x \\
x \\
3 x \\
5 x \\
6 x \\
5 x \\
5 x \\
5 x \\
5 x \\
5 x \\
6 x \\
8 x \\
9 x \\
11 x \\
12 x \\
14 x \\
15 x \\
16 x \\
17 x \\
18 x \\
18 x \\
18 x \\
18 x \\
18 x \\
18 x \\
17 x \\
16 x \\
15 x \\
14 x \\
14 x \\
14 x \\
13 x \\
13 x \\
13 x\end{array}$ & $\begin{array}{l}0 . \\
0 . \\
0 . \\
0 . \\
0 . \\
0 . \\
1 . \\
1 . \\
1 . \\
1 . \\
1 . \\
1 . \\
1 . \\
1 . \\
1 . \\
2 . \\
2 . \\
2 . \\
2 . \\
2 . \\
2 . \\
2 . \\
2 . \\
2 . \\
2 . \\
2 . \\
2 . \\
2 . \\
2 . \\
2 . \\
2 . \\
2 . \\
2 . \\
2 . \\
2 . \\
2 .\end{array}$ & $\begin{array}{l}0 . \\
0 . \\
0 . \\
0 . \\
5 . \\
11 . \\
14 . \\
17 . \\
19 . \\
20 . \\
21 . \\
22 . \\
24 . \\
26 . \\
28 . \\
30 . \\
32 . \\
33 . \\
34 . \\
34 . \\
35 . \\
35 . \\
35 . \\
35 . \\
35 . \\
35 . \\
35 . \\
34 . \\
34 . \\
33 . \\
32 . \\
32 . \\
32 . \\
32 . \\
32 . \\
32 .\end{array}$ & $\begin{array}{r}1 \\
1 \\
2 \\
32 \\
42 \\
58 \\
72 \\
91 \\
10 \\
11 \\
12 \\
128 \\
132 \\
132 \\
131 \\
130 \\
126 \\
121 \\
118 \\
119 \\
120 \\
122\end{array}$ \\
\hline
\end{tabular}

WOCE Line P16C Station 189 Latitude 32-59.7S Longitude 150-29.5W Date 8/16/91 Bottom Depth 5401

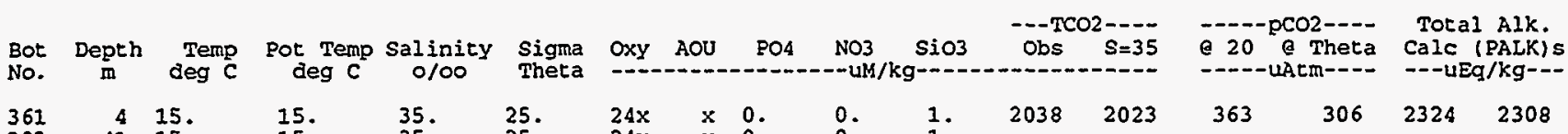

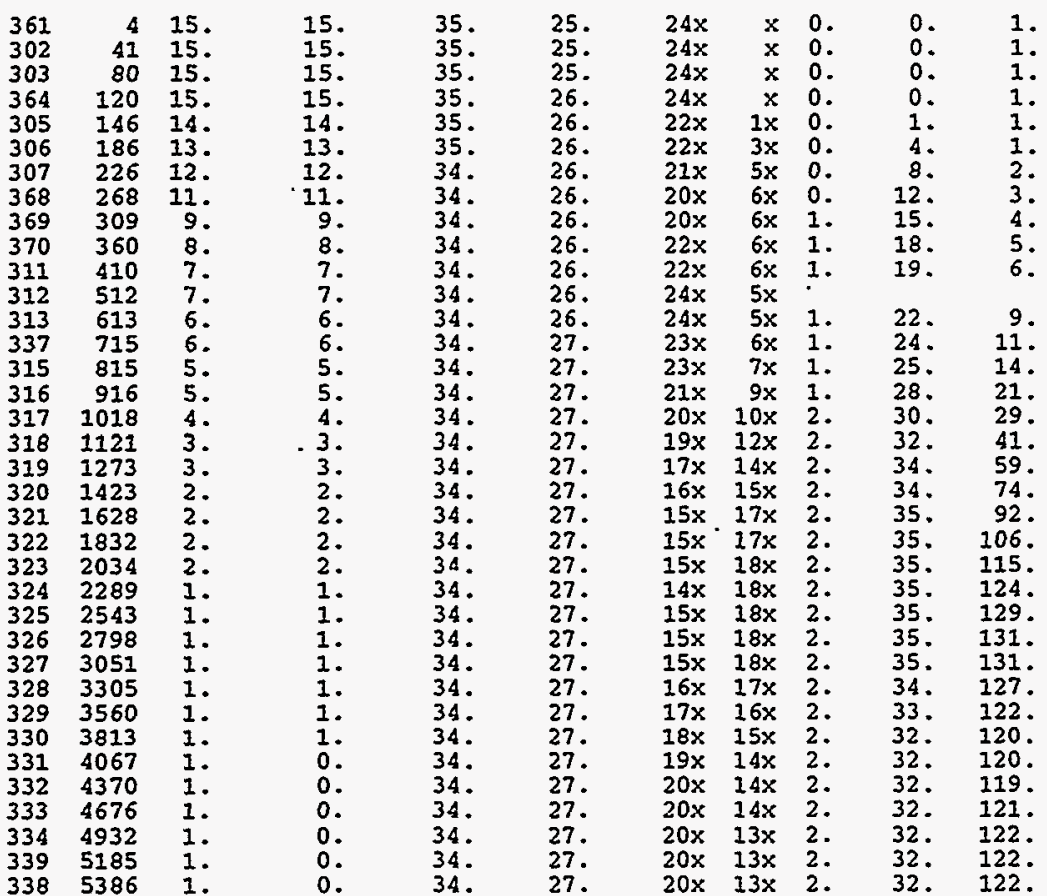


Lamont-Doherty Earth Observatory of Columbia University

Printed on $12 / 06 / 93$

Page 34

Potential Alkalinity = (TALK + N03) X (35/ Sal)

wOCE Line P16C station 190 Latitude 32-29.9s Longitude 150-30.0W Date 8/16/91 Bottom Depth 5179

\begin{tabular}{|c|c|c|c|c|c|c|c|c|c|c|c|c|c|c|c|c|}
\hline $\begin{array}{l}\text { Bot } \\
\text { No. }\end{array}$ & $\underset{\text { m }}{\text { Depth }}$ & $\begin{array}{r}\text { Temp } \\
\text { deg C }\end{array}$ & $\begin{array}{c}\text { Pot Temp } \\
\text { deg } C\end{array}$ & $\begin{array}{c}\text { Salinity } \\
0 / 00\end{array}$ & $\begin{array}{l}\text { Sigma } \\
\text { Theta }\end{array}$ & $O x y$ & AOU & PO4 & $\begin{array}{r}\text { NO3 } \\
--U M\end{array}$ & Sio3 & Obs & $\begin{array}{r}S=--- \\
s=35\end{array}$ & 20 & Theta & $\begin{array}{c}\text { To } \\
\text { cal }\end{array}$ & Alk. \\
\hline $\begin{array}{l}161 \\
102 \\
103 \\
164 \\
105 \\
106 \\
107 \\
168 \\
169 \\
170 \\
111 \\
112 \\
113 \\
137 \\
115 \\
116 \\
117 \\
118 \\
119 \\
120 \\
121 \\
122 \\
123 \\
124 \\
125 \\
126 \\
127 \\
128 \\
129 \\
130 \\
131 \\
132 \\
133 \\
134 \\
139 \\
138\end{array}$ & $\begin{array}{r}2 \\
72 \\
117 \\
142 \\
192 \\
248 \\
309 \\
369 \\
426 \\
485 \\
544 \\
604 \\
703 \\
804 \\
904 \\
1006 \\
1105 \\
1258 \\
1411 \\
1567 \\
1718 \\
1925 \\
2132 \\
2336 \\
2537 \\
2737 \\
2935 \\
3128 \\
3385 \\
3641 \\
3897 \\
4151 \\
4412 \\
4670 \\
4924 \\
5168\end{array}$ & $\begin{array}{r}16 . \\
16 . \\
16 . \\
15 . \\
14 . \\
12 . \\
11 . \\
9 . \\
8 . \\
7 . \\
7 . \\
6 . \\
6 . \\
5 . \\
5 . \\
4 . \\
3 . \\
3 . \\
2 . \\
2 . \\
2 . \\
2 . \\
2 . \\
1 . \\
1 . \\
1 . \\
1 . \\
1 . \\
1 . \\
1 . \\
1 . \\
1 . \\
1 . \\
1 . \\
1 . \\
1 .\end{array}$ & $\begin{array}{l}16 . \\
16 . \\
16 . \\
15 . \\
14 . \\
12 . \\
11 . \\
9 . \\
8 . \\
7 . \\
6 . \\
6 . \\
6 . \\
5 . \\
5 . \\
4 . \\
3 . \\
3 . \\
2 . \\
2 . \\
2 . \\
2 . \\
1 . \\
1 . \\
1 . \\
1 . \\
1 . \\
1 . \\
1 . \\
1 . \\
1 . \\
0 . \\
0 . \\
0 . \\
0 . \\
0 .\end{array}$ & $\begin{array}{l}35 . \\
35 . \\
35 . \\
35 . \\
35 . \\
35 . \\
34 . \\
34 . \\
34 . \\
34 . \\
34 . \\
34 . \\
34 . \\
34 . \\
34 . \\
34 . \\
34 . \\
34 . \\
34 . \\
34 . \\
34 . \\
34 . \\
34 . \\
34 . \\
34 . \\
34 . \\
34 . \\
34 . \\
34 . \\
34 . \\
34 . \\
34 . \\
34 . \\
34 . \\
34 . \\
34 .\end{array}$ & $\begin{array}{l}25 . \\
25 . \\
25 . \\
25 . \\
26 . \\
26 . \\
26 . \\
26 . \\
26 . \\
26 . \\
26 . \\
26 . \\
27 . \\
27 . \\
27 . \\
27 . \\
27 . \\
27 . \\
27 . \\
27 . \\
27 . \\
27 . \\
27 . \\
27 . \\
27 . \\
27 . \\
27 . \\
27 . \\
27 . \\
27 . \\
27 . \\
27 . \\
27 . \\
27 . \\
27 . \\
27 .\end{array}$ & $\begin{array}{l}24 x \\
24 x \\
24 x \\
23 x \\
21 x \\
20 x \\
20 x \\
21 x \\
22 x \\
22 x \\
23 x \\
23 x \\
23 x \\
22 x \\
21 x \\
20 x \\
19 x \\
17 x \\
16 x \\
16 x \\
15 x \\
15 x \\
15 x \\
15 x \\
15 x \\
15 x \\
15 x \\
16 x \\
17 x \\
18 x \\
18 x \\
19 x \\
19 x \\
20 x \\
20 x \\
20 x\end{array}$ & $\begin{array}{r}x \\
x \\
x \\
x \\
3 x \\
5 x \\
6 x \\
6 x \\
6 x \\
6 x \\
6 x \\
6 x \\
6 x \\
8 x \\
9 x \\
11 x \\
12 x \\
14 x \\
15 x \\
16 x \\
17 x \\
17 x \\
18 x \\
18 x \\
18 x \\
18 x \\
17 x \\
17 x \\
16 x \\
15 x \\
15 x \\
14 x \\
14 x \\
14 x \\
13 x \\
13 x\end{array}$ & $\begin{array}{l}0 . \\
0 . \\
0 . \\
0 . \\
0 . \\
0 . \\
0 . \\
1 . \\
1 . \\
1 . \\
1 . \\
1 . \\
1 . \\
1 . \\
1 . \\
2 . \\
2 . \\
2 . \\
2 . \\
2 . \\
2 . \\
2 . \\
2 . \\
2 . \\
2 . \\
2 . \\
2 . \\
2 . \\
2 . \\
2 . \\
2 . \\
2 . \\
2 . \\
2 . \\
2 . \\
2 .\end{array}$ & $\begin{array}{l}0 . \\
0 . \\
0 . \\
0 . \\
4 . \\
9 . \\
13 . \\
16 . \\
19 . \\
21 . \\
21 . \\
22 . \\
24 . \\
26 . \\
28 . \\
30 . \\
32 . \\
33 . \\
34 . \\
34 . \\
34 . \\
35 . \\
35 . \\
35 . \\
35 . \\
35 . \\
35 . \\
34 . \\
34 . \\
33 . \\
33 . \\
32 . \\
32 . \\
32 . \\
32 . \\
32 .\end{array}$ & $\begin{array}{r}1 . \\
1 . \\
1 . \\
1 . \\
1 . \\
3 . \\
3 . \\
4 . \\
6 . \\
7 . \\
8 . \\
9 . \\
11 . \\
15 . \\
22 . \\
32 . \\
43 . \\
57 . \\
73 . \\
85 . \\
99 . \\
110 . \\
119 . \\
126 . \\
129 . \\
131 . \\
131 . \\
130 . \\
126 . \\
124 . \\
123 . \\
122 . \\
121 . \\
121 . \\
122 . \\
123 .\end{array}$ & $\begin{array}{l}2039 \\
2035 \\
2037 \\
2045 \\
2073 \\
2096 \\
2110 \\
2118 \\
2128 \\
2131 \\
2133 \\
2133 \\
2140 \\
2154 \\
2169 \\
2187 \\
2207 \\
2227 \\
2249 \\
2263 \\
2277 \\
2296 \\
2298 \\
2306 \\
2311 \\
2308 \\
2309 \\
2300 \\
2293 \\
2283 \\
2277 \\
2274 \\
2268 \\
2264 \\
2267 \\
2262\end{array}$ & $\begin{array}{l}2019 \\
2016 \\
2021 \\
2031 \\
2064 \\
2096 \\
2121 \\
2142 \\
2157 \\
2165 \\
2170 \\
2172 \\
2181 \\
2197 \\
2212 \\
2230 \\
2249 \\
2264 \\
2282 \\
2293 \\
2304 \\
2321 \\
2322 \\
2329 \\
2333 \\
2330 \\
2331 \\
2321 \\
2313 \\
2303 \\
2297 \\
2293 \\
2287 \\
2283 \\
2286 \\
2281\end{array}$ & $\begin{array}{r}352 \\
351 \\
360 \\
370 \\
440 \\
521 \\
584 \\
645 \\
689 \\
713 \\
717 \\
729 \\
745 \\
798 \\
866 \\
950 \\
1011 \\
1091 \\
1125 \\
1148 \\
1164 \\
1162 \\
1172 \\
1174 \\
1168 \\
1167 \\
1154 \\
1136 \\
1111 \\
1091 \\
1068 \\
1057 \\
1052 \\
1047 \\
1039 \\
1036\end{array}$ & $\begin{array}{l}303 \\
300 \\
305 \\
311 \\
350 \\
385 \\
403 \\
411 \\
421 \\
421 \\
414 \\
414 \\
414 \\
435 \\
461 \\
491 \\
510 \\
538 \\
544 \\
549 \\
551 \\
545 \\
545 \\
543 \\
538 \\
535 \\
527 \\
517 \\
503 \\
492 \\
479 \\
472 \\
468 \\
465 \\
460 \\
458\end{array}$ & $\begin{array}{l}2335 \\
2330 \\
2326 \\
2329 \\
2321 \\
2311 \\
2304 \\
2293 \\
2291 \\
2289 \\
2290 \\
2287 \\
2291 \\
2295 \\
2298 \\
2304 \\
2317 \\
2326 \\
2347 \\
2359 \\
2373 \\
2394 \\
2396 \\
2404 \\
2410 \\
2407 \\
2410 \\
2403 \\
2399 \\
2391 \\
2388 \\
2386 \\
2380 \\
2376 \\
2381 \\
2376\end{array}$ & $\begin{array}{l}2312 \\
2308 \\
2308 \\
2313 \\
2315 \\
2320 \\
2328 \\
2335 \\
2342 \\
2346 \\
2352 \\
2352 \\
2360 \\
2367 \\
2373 \\
2380 \\
2393 \\
2400 \\
2416 \\
2426 \\
2436 \\
2456 \\
2457 \\
2465 \\
2470 \\
2466 \\
2469 \\
2460 \\
2455 \\
2446 \\
2442 \\
2439 \\
2433 \\
2429 \\
2433 \\
2428\end{array}$ \\
\hline
\end{tabular}

WOCE Line P16C Station 191 Latitude 32-00.0S Longitude 150-30.1W Date 8/16/91 Bottom Depth 5170

\begin{tabular}{|c|c|c|c|c|c|c|c|c|c|c|c|c|c|c|c|c|}
\hline $\begin{array}{l}\text { Bot } \\
\text { No. }\end{array}$ & $\underset{\text { m }}{\text { Depth }}$ & $\begin{array}{r}\text { Temp } \\
\text { deg C }\end{array}$ & $\begin{array}{l}\text { Pot Temp } \\
\text { deg } C\end{array}$ & $\begin{array}{c}\text { Salinity } \\
0 / 00\end{array}$ & $\begin{array}{l}\text { Sigma } \\
\text { Theta }\end{array}$ & Oxy & AOU & PO4 & $\begin{array}{r}\text { NO3 } \\
---4 M\end{array}$ & $\mathrm{SiO} 3$ & Obs & $\begin{array}{l}S=35 \\
----\end{array}$ & 20 & $\begin{array}{l}\text { Theta } \\
\text { m-- }\end{array}$ & $\begin{array}{l}\text { Tot } \\
\text { Calc } \\
\text { - }\end{array}$ & $\begin{array}{l}\text { Alk. } \\
\text { PALKIs } \\
\text { (kg- }\end{array}$ \\
\hline $\begin{array}{l}161 \\
102 \\
103 \\
164 \\
105 \\
106 \\
107 \\
168 \\
169 \\
170 \\
111 \\
112 \\
113 \\
137 \\
115 \\
116 \\
117 \\
118 \\
119 \\
120 \\
121 \\
122 \\
123 \\
124 \\
125 \\
126 \\
127 \\
128 \\
129 \\
130 \\
131 \\
132 \\
133 \\
134 \\
139 \\
138\end{array}$ & $\begin{array}{r}3 \\
58 \\
114 \\
169 \\
215 \\
252 \\
302 \\
361 \\
421 \\
480 \\
540 \\
600 \\
669 \\
750 \\
830 \\
912 \\
1002 \\
1102 \\
1202 \\
1356 \\
1508 \\
1711 \\
1916 \\
2120 \\
2373 \\
2627 \\
2884 \\
3141 \\
3397 \\
3652 \\
3907 \\
4161 \\
4410 \\
4665 \\
4921 \\
5157\end{array}$ & $\begin{array}{l}16 . \\
16 . \\
16 . \\
15 . \\
14 . \\
13 . \\
11 . \\
9 . \\
8 . \\
7 . \\
7 . \\
7 . \\
6 . \\
6 . \\
5 . \\
5 . \\
4 . \\
4 . \\
3 . \\
3 . \\
2 . \\
2 . \\
2 . \\
2 . \\
1 . \\
1 . \\
1 . \\
1 . \\
1 . \\
1 . \\
1 . \\
1 . \\
1 . \\
1 . \\
1 . \\
1 .\end{array}$ & $\begin{array}{l}16 . \\
16 . \\
16 . \\
15 . \\
14 . \\
13 . \\
11 . \\
9 . \\
8 . \\
7 . \\
7 . \\
6 . \\
6 . \\
6 . \\
5 . \\
5 . \\
4 . \\
4 . \\
3 . \\
2 . \\
2 . \\
2 . \\
2 . \\
1 . \\
1 . \\
1 . \\
1 . \\
1 . \\
1 . \\
1 . \\
1 . \\
0 . \\
0 . \\
0 . \\
0 . \\
0 .\end{array}$ & $\begin{array}{l}35 . \\
35 . \\
35 . \\
35 . \\
35 . \\
35 . \\
34 . \\
34 . \\
34 . \\
34 . \\
34 . \\
34 . \\
34 . \\
34 . \\
34 . \\
34 . \\
34 . \\
34 . \\
34 . \\
34 . \\
34 . \\
34 . \\
34 . \\
34 . \\
34 . \\
34 . \\
34 . \\
34 . \\
34 . \\
34 . \\
34 . \\
34 . \\
34 . \\
34 . \\
34 . \\
34 .\end{array}$ & $\begin{array}{l}25 . \\
25 . \\
25 . \\
26 . \\
26 . \\
26 . \\
26 . \\
26 . \\
26 . \\
26 . \\
26 . \\
26 . \\
26 . \\
27 . \\
27 . \\
27 . \\
27 . \\
27 . \\
27 . \\
27 . \\
27 . \\
27 . \\
27 . \\
27 . \\
27 . \\
27 . \\
27 . \\
27 . \\
27 . \\
27 . \\
27 . \\
27 . \\
27 . \\
27 . \\
27 . \\
27 .\end{array}$ & $\begin{array}{l}24 x \\
24 x \\
24 x \\
21 x \\
20 x \\
20 x \\
20 x \\
20 x \\
22 x \\
23 x \\
24 x \\
23 x \\
23 x \\
23 x \\
22 x \\
21 x \\
20 x \\
19 x \\
18 x \\
17 x \\
16 x \\
15 x \\
15 x \\
15 x \\
15 x \\
15 x \\
15 x \\
16 x \\
17 x \\
18 x \\
18 x \\
19 x \\
19 x \\
20 x \\
20 x\end{array}$ & $\begin{array}{r}x \\
x \\
x \\
2 x \\
4 x \\
5 x \\
6 x \\
7 x \\
6 x \\
5 x \\
5 x \\
6 x \\
5 x \\
6 x \\
8 x \\
9 x \\
10 x \\
12 x \\
13 x \\
15 x \\
16 x \\
17 x \\
17 x \\
18 x \\
18 x \\
18 x \\
18 x \\
17 x \\
16 x \\
15 x \\
15 x \\
14 x \\
14 x \\
14 x \\
14 x\end{array}$ & $\begin{array}{l}0 . \\
0 . \\
0 . \\
0 . \\
0 . \\
0 . \\
0 . \\
1 . \\
1 . \\
1 . \\
1 . \\
1 . \\
1 . \\
1 . \\
1 . \\
1 . \\
2 . \\
2 . \\
2 . \\
2 . \\
2 . \\
2 . \\
2 . \\
2 . \\
2 . \\
2 . \\
2 . \\
2 . \\
2 . \\
2 . \\
2 . \\
2 . \\
2 . \\
2 . \\
2 .\end{array}$ & $\begin{array}{l}0 . \\
0 . \\
0 . \\
3 . \\
6 . \\
8 . \\
12 . \\
16 . \\
18 . \\
19 . \\
20 . \\
21 . \\
22 . \\
24 . \\
26 . \\
27 . \\
29 . \\
31 . \\
33 . \\
34 . \\
34 . \\
35 . \\
35 . \\
35 . \\
35 . \\
35 . \\
35 . \\
34 . \\
33 . \\
33 . \\
33 . \\
32 . \\
32 . \\
32 . \\
32 .\end{array}$ & $\begin{array}{r}1 . \\
1 . \\
1 . \\
1 . \\
2 . \\
2 . \\
3 . \\
4 . \\
5 . \\
5 . \\
6 . \\
8 . \\
9 . \\
11 . \\
15 . \\
20 . \\
28 . \\
37 . \\
48 . \\
67 . \\
81 . \\
98 . \\
111 . \\
119 . \\
127 . \\
130 . \\
132 . \\
131 . \\
127 . \\
124 . \\
124 . \\
122 . \\
121 . \\
121 . \\
121 .\end{array}$ & 2038 & 2018 & 349 & 301 & 2336 & 2313 \\
\hline
\end{tabular}


Iamont-Doherty Earth Observatory of Columbia University

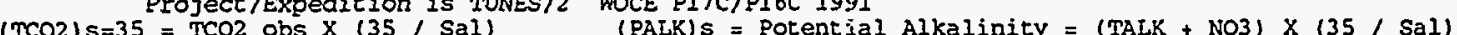
WOCE Line P16C Station 192 Latitude 31-30.0S Longitude 150-30.2W Date 8/16/91 Bottom Depth 4928

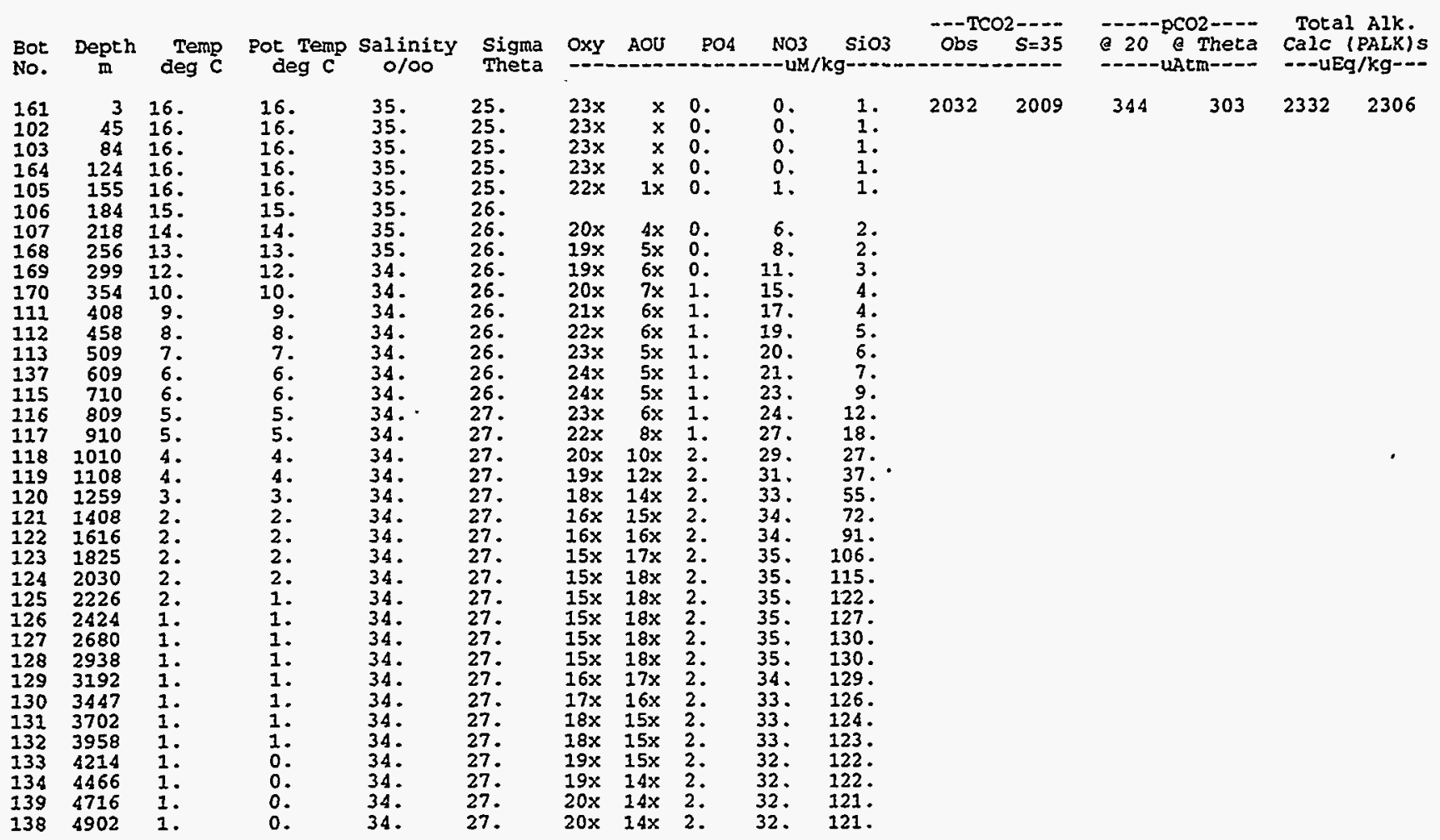

WoCE Line P16C Station 193 Latitude 30-59.8S Longitude 150-30.6W Date 8/17/91 Bottom Depth 4547

\begin{tabular}{|c|c|c|c|c|c|c|c|c|c|c|c|c|c|c|c|c|}
\hline $\begin{array}{l}\text { Bot } \\
\text { No. }\end{array}$ & $\underset{\text { Depth }}{\text { Dept }}$ & $\begin{array}{l}\text { Temp } \\
\text { deg C }\end{array}$ & $\begin{array}{c}\text { Pot Temp } \\
\operatorname{deg~} c\end{array}$ & $\begin{array}{c}\text { Salinity } \\
0 / 00\end{array}$ & $\begin{array}{l}\text { Sigma } \\
\text { Theta }\end{array}$ & Oxy & AOU & PO4 & $\begin{array}{c}\mathrm{NO3} \\
--\mathrm{uM} /\end{array}$ & $\mathrm{SiO}_{3}$ & Obs & $\begin{array}{r}2---- \\
S=35\end{array}$ & \multicolumn{2}{|c|}{ e 20 e Theta } & \multicolumn{2}{|c|}{$\begin{array}{l}\text { Total Alk. } \\
\text { Calc (PALK) } \\
\text { - - -uEg/kg- }\end{array}$} \\
\hline $\begin{array}{l}161 \\
102 \\
103 \\
164 \\
105 \\
106 \\
107 \\
168 \\
169 \\
170 \\
111 \\
112 \\
113 \\
137 \\
115 \\
116 \\
117 \\
118 \\
119 \\
121 \\
120 \\
122 \\
123 \\
124 \\
125 \\
126 \\
127 \\
128 \\
129 \\
130 \\
131 \\
132 \\
133 \\
134 \\
139 \\
138\end{array}$ & $\begin{array}{r}3 \\
33 \\
74 \\
104 \\
129 \\
155 \\
185 \\
215 \\
256 \\
307 \\
356 \\
408 \\
507 \\
607 \\
705 \\
804 \\
908 \\
1012 \\
1112 \\
1263 \\
1412 \\
1611 \\
1810 \\
2009 \\
2210 \\
2409 \\
2605 \\
2797 \\
2997 \\
3248 \\
3503 \\
3760 \\
4012 \\
4266 \\
4524 \\
4772\end{array}$ & $\begin{array}{l}17 . \\
17 . \\
17 . \\
17 . \\
15 . \\
14 . \\
14 . \\
14 . \\
13 . \\
11 . \\
10 . \\
9 . \\
7 . \\
6 . \\
6 . \\
5 . \\
5 . \\
4 . \\
4 . \\
3 . \\
2 . \\
2 . \\
2 . \\
2 . \\
1 . \\
1 . \\
1 . \\
1 . \\
1 . \\
1 . \\
1 . \\
1 . \\
1 . \\
1 . \\
1 . \\
1 .\end{array}$ & $\begin{array}{l}17 . \\
17 . \\
17 . \\
17 . \\
15 . \\
14 . \\
14 . \\
14 . \\
13 . \\
11 . \\
10 . \\
9 . \\
7 . \\
6 . \\
6 . \\
5 . \\
5 . \\
4 . \\
4 . \\
3 . \\
2 . \\
2 . \\
2 . \\
2 . \\
1 . \\
1 . \\
1 . \\
1 . \\
1 . \\
1 . \\
1 . \\
1 . \\
0 . \\
0 . \\
0 . \\
0 .\end{array}$ & $\begin{array}{l}35 . \\
35 . \\
35 . \\
35 . \\
35 . \\
35 . \\
35 . \\
35 . \\
35 . \\
34 . \\
34 . \\
34 . \\
34 . \\
34 . \\
34 . \\
34 . \\
34 . \\
34 . \\
34 . \\
34 . \\
34 . \\
34 . \\
34 . \\
34 . \\
34 . \\
34 . \\
34 . \\
34 . \\
34 . \\
34 . \\
34 . \\
34 . \\
34 . \\
34 . \\
34 . \\
34 .\end{array}$ & $\begin{array}{l}25 . \\
25 . \\
25 . \\
25 . \\
25 . \\
26 . \\
26 . \\
26 . \\
26 . \\
26 . \\
26 . \\
26 . \\
26 . \\
26 . \\
27 . \\
27 . \\
27 . \\
27 . \\
27 . \\
27 . \\
27 . \\
27 . \\
27 . \\
27 . \\
27 . \\
27 . \\
27 . \\
27 . \\
27 . \\
27 . \\
27 . \\
27 . \\
27 . \\
27 . \\
27 . \\
27 .\end{array}$ & $\begin{array}{l}23 x \\
23 x \\
23 x \\
23 x \\
21 x \\
22 x \\
21 x \\
19 x \\
19 x \\
19 x \\
20 x \\
20 x \\
23 x \\
23 x \\
23 x \\
21 x \\
20 x \\
19 x \\
18 x \\
16 x \\
16 x \\
15 x \\
15 x \\
15 x \\
15 x \\
15 x \\
15 x \\
16 x \\
16 x \\
17 x \\
18 x \\
19 x \\
19 x \\
19 x \\
19 x\end{array}$ & $\begin{array}{r}x \\
x \\
x \\
x \\
2 x \\
2 x \\
3 x \\
5 x \\
6 x \\
6 x \\
7 x \\
7 x \\
5 x \\
5 x \\
6 x \\
7 x \\
8 x \\
10 x \\
12 x \\
14 x \\
15 x \\
16 x \\
17 x \\
18 x \\
18 x \\
18 x \\
18 x \\
18 x \\
17 x \\
17 x \\
16 x \\
15 x \\
15 x \\
14 x \\
14 x \\
14 x\end{array}$ & $\begin{array}{l}0 . \\
0 . \\
0 . \\
0 . \\
0 . \\
0 . \\
0 . \\
0 . \\
0 . \\
0 . \\
1 . \\
1 . \\
1 . \\
1 . \\
1 . \\
1 . \\
2 . \\
2 . \\
2 . \\
2 . \\
2 . \\
2 . \\
2 . \\
2 . \\
2 . \\
2 . \\
2 . \\
2 . \\
2 . \\
2 . \\
2 . \\
2 . \\
2 . \\
2 . \\
2 .\end{array}$ & $\begin{array}{l}0 . \\
0 . \\
0 . \\
0 . \\
2 . \\
2 . \\
4 . \\
8 . \\
9 . \\
13 . \\
16 . \\
17 . \\
21 . \\
23 \cdot \\
25 . \\
27 . \\
29 . \\
31 . \\
33 . \\
34 . \\
34 . \\
34 . \\
35 . \\
35 . \\
35 . \\
35 . \\
35 . \\
34 . \\
34 . \\
33 . \\
33 . \\
32 . \\
32 . \\
32 . \\
32 .\end{array}$ & $\begin{array}{r}1 . \\
1 . \\
1 . \\
1 . \\
1 . \\
1 . \\
1 . \\
2 . \\
3 . \\
4 . \\
5 . \\
5 . \\
8 . \\
10 . \\
13 . \\
20 . \\
28 . \\
38 . \\
54 . \\
73 . \\
91 . \\
105^{\circ} \\
114 . \\
123 . \\
127 . \\
130 . \\
131 . \\
131 . \\
128 . \\
125 . \\
124 . \\
123 . \\
123 . \\
122 . \\
122 .\end{array}$ & 2032 & 2007 & 332 & 295 & 2342 & 2313 \\
\hline
\end{tabular}


Lamont-Doherty Earth Observatory of Columbia University

Printed on $12 / 06 / 93$

Page 36

$(\mathrm{TCO} 2) \mathrm{s}=35=\mathrm{TCO} 2$ obs $\mathrm{X}(35, \mathrm{Sal})$

(PALK) $s=$ Potential Alkalinity $=($ TALK + NO3) $\times(35 / \mathrm{Sa})$

WOCE Line P16C Station 194 Latitude 30-30.2S Longitude 150-30.3W Date 8/17/91 Bottom Depth 4939

\begin{tabular}{|c|c|c|c|c|c|c|c|c|c|c|c|c|c|c|c|c|}
\hline $\begin{array}{l}\text { Bot } \\
\text { No. }\end{array}$ & $\underset{\mathrm{m}}{\text { Depth }}$ & $\begin{array}{l}\text { Temp } \\
\text { deg C }\end{array}$ & $\begin{array}{c}\text { Pot Temp } \\
\text { deg } c\end{array}$ & $\begin{array}{c}\text { Salinity } \\
0 / 00\end{array}$ & $\begin{array}{l}\text { Sigma } \\
\text { Theta }\end{array}$ & Oxy & AOU & $\mathrm{PO} 4$ & $\begin{array}{r}\text { NO3 } \\
-- \text { UM }\end{array}$ & SiO3 & Obs & $\begin{array}{r}2--- \\
S=35\end{array}$ & 20 & Thera & $\begin{array}{r}\text { To } \\
\text { Cal }\end{array}$ & $\begin{array}{l}\text { Alk. } \\
\text { PALKis } \\
\text { /kg- }\end{array}$ \\
\hline $\begin{array}{l}361 \\
302 \\
303 \\
364 \\
305 \\
306 \\
307 \\
368 \\
369 \\
370 \\
311 \\
312 \\
313 \\
337 \\
315 \\
316 \\
317 \\
318 \\
319 \\
320 \\
321 \\
322 \\
323 \\
324 \\
325 \\
326 \\
327 \\
328 \\
329 \\
330 \\
331 \\
332 \\
333 \\
334 \\
339\end{array}$ & $\begin{array}{r}2 \\
46 \\
92 \\
132 \\
172 \\
217 \\
268 \\
319 \\
380 \\
451 \\
523 \\
592 \\
662 \\
743 \\
825 \\
917 \\
1018 \\
1120 \\
1269 \\
1419 \\
1619 \\
1823 \\
2025 \\
2226 \\
2426 \\
2626 \\
2828 \\
3081 \\
3338 \\
3594 \\
3848 \\
4098 \\
4354 \\
4609 \\
4864 \\
5074\end{array}$ & $\begin{array}{r}17 . \\
17 . \\
17 . \\
16 . \\
15 . \\
14 . \\
12 . \\
10 . \\
9 . \\
8 . \\
7 . \\
6 . \\
6 . \\
6 . \\
5 . \\
5 . \\
4 . \\
3 . \\
3 . \\
2 . \\
2 . \\
2 . \\
2 . \\
1 . \\
1 . \\
1 . \\
1 . \\
1 . \\
1 . \\
1 . \\
1 . \\
1 . \\
1 . \\
1 . \\
1 . \\
1 .\end{array}$ & $\begin{array}{l}17 . \\
17 . \\
17 . \\
16 . \\
15 . \\
14 . \\
12 . \\
10 . \\
9 . \\
7 . \\
7 . \\
6 . \\
6 . \\
5 . \\
5 . \\
5 . \\
4 . \\
3 . \\
3 . \\
2 . \\
2 . \\
2 . \\
1 . \\
1 . \\
1 . \\
1 . \\
1 . \\
1 . \\
1 . \\
1 . \\
1 . \\
0 . \\
0 . \\
0 . \\
0 . \\
0 .\end{array}$ & $\begin{array}{l}35 . \\
35 . \\
35 . \\
35 . \\
35 . \\
35 . \\
34 . \\
34 . \\
34 . \\
34 . \\
34 . \\
34 . \\
34 . \\
34 . \\
34 . \\
34 . \\
34 . \\
34 . \\
34 . \\
34 . \\
34 . \\
34 . \\
34 . \\
34 . \\
34 . \\
34 . \\
34 . \\
34 . \\
34 . \\
34 . \\
34 . \\
34 . \\
34 . \\
34 . \\
34 . \\
34 .\end{array}$ & $\begin{array}{l}25 . \\
25 . \\
25 . \\
25 . \\
26 . \\
26 . \\
26 . \\
26 . \\
26 . \\
26 . \\
26 . \\
26 . \\
26 . \\
27 . \\
27 . \\
27 . \\
27 . \\
27 . \\
27 . \\
27 . \\
27 . \\
27 . \\
27 . \\
27 . \\
27 . \\
27 . \\
27 . \\
27 . \\
27 . \\
27 . \\
27 . \\
27 . \\
27 . \\
27 . \\
27 . \\
27 .\end{array}$ & $\begin{array}{l}23 x \\
23 x \\
23 x \\
21 x \\
20 x \\
20 x \\
20 x \\
20 x \\
21 x \\
22 x \\
23 x \\
24 x \\
24 x \\
23 x \\
23 x \\
21 x \\
20 x \\
19 x \\
17 x \\
16 x \\
15 x \\
15 x \\
15 x \\
15 x \\
15 x \\
15 x \\
15 x \\
16 x \\
17 x \\
18 x \\
18 x \\
19 x \\
19 x \\
19 x \\
19 x \\
20 x\end{array}$ & $\begin{array}{r}x \\
-x \\
x \\
2 x \\
3 x \\
4 x \\
5 x \\
6 x \\
6 x \\
6 x \\
5 x \\
5 x \\
5 x \\
6 x \\
7 x \\
9 x \\
11 x \\
12 x \\
14 x \\
16 x \\
17 x \\
17 x \\
18 x \\
18 x \\
18 x \\
18 x \\
18 x \\
17 x \\
16 x \\
15 x \\
15 x \\
15 x \\
14 x \\
14 x \\
14 x \\
14 x\end{array}$ & $\begin{array}{l}0 . \\
0 . \\
0 . \\
0 . \\
0 . \\
0 . \\
0 . \\
1 . \\
1 . \\
1 . \\
1 . \\
1 . \\
1 . \\
1 . \\
1 . \\
1 . \\
2 . \\
2 . \\
2 . \\
2 . \\
2 . \\
2 . \\
2 . \\
2 . \\
2 . \\
2 . \\
2 . \\
2 . \\
2 . \\
2 . \\
2 . \\
2 . \\
2 . \\
2 . \\
2 . \\
2 .\end{array}$ & $\begin{array}{l}0 . \\
0 . \\
0 . \\
1 . \\
4 . \\
6 . \\
9 . \\
13 . \\
17 . \\
19 . \\
20 . \\
21 . \\
22 . \\
24 . \\
26 . \\
27 . \\
30 . \\
32 . \\
33 . \\
34 . \\
34 . \\
35 . \\
35 . \\
35 . \\
35 . \\
35 . \\
35 . \\
34 . \\
34 . \\
33 . \\
33 . \\
33 . \\
32 . \\
32 . \\
32 . \\
32 .\end{array}$ & $\begin{array}{r}1 . \\
1 . \\
1 . \\
1 . \\
2 . \\
2 . \\
2 . \\
4 . \\
4 . \\
5 . \\
6 . \\
7 . \\
9 . \\
12 . \\
15 . \\
20 . \\
30 . \\
41 . \\
60 . \\
77 . \\
95 . \\
107 . \\
115 . \\
123 . \\
128 . \\
130 . \\
131 . \\
130 . \\
127 . \\
126 . \\
124 . \\
123 . \\
123 . \\
1220^{\circ} \\
1220^{\circ} \\
121 .\end{array}$ & $\begin{array}{l}2030 \\
2034 \\
2032 \\
2052 \\
2076 \\
2084 . \\
2095 \\
2114 \\
2122 \\
2126 \\
2128 \\
2128 \\
2136 \\
2141 \\
2147 \\
2168 \\
2185 \\
2207 \\
2237 \\
2256 \\
2276 \\
2291 \\
2297 \\
2307 \\
2308 \\
2308 \\
2310 \\
2302 \\
2293 \\
2287 \\
2279 \\
2277 \\
2281 \\
2278 \\
2275 \\
2271\end{array}$ & $\begin{array}{l}2003 \\
2007 \\
2006 \\
2029 \\
2058 \\
2074 \\
2097 \\
2127 \\
2146 \\
2157 \\
2163 \\
2165 \\
2176 \\
2183 \\
2190 \\
2212 \\
2228 \\
2248 \\
2273 \\
2287 \\
2304 \\
2316 \\
2322 \\
2331 \\
2330 \\
2330 \\
2332 \\
2323 \\
2314 \\
2307 \\
2299 \\
2297 \\
2301 \\
2297 \\
2294 \\
2290\end{array}$ & $\begin{array}{r}335 \\
334 \\
333 \\
376 \\
468 \\
467 \\
517 \\
590 \\
657 \\
679 \\
689 \\
702 \\
724 \\
758 \\
788 \\
852 \\
931 \\
1021 \\
1096 \\
1144 \\
1156 \\
1164 \\
1175 \\
1179 \\
1175 \\
1164 \\
1165 \\
1133 \\
1122 \\
1098 \\
1071 \\
1069 \\
1065 \\
1048 \\
1047 \\
1058\end{array}$ & $\begin{array}{l}300 \\
299 \\
298 \\
330 \\
389 \\
366 \\
379 \\
402 \\
415 \\
409 \\
404 \\
403 \\
408 \\
419 \\
429 \\
454 \\
483 \\
516 \\
537 \\
550 \\
549 \\
547 \\
548 \\
546 \\
542 \\
534 \\
533 \\
516 \\
508 \\
494 \\
480 \\
478 \\
475 \\
466 \\
465 \\
470\end{array}$ & $\begin{array}{l}2337 \\
2342 \\
2340 \\
2334 \\
2311 \\
2320 \\
2310 \\
2306 \\
2293 \\
2291 \\
2291 \\
2288 \\
2292 \\
2289 \\
2289 \\
2300 \\
2304 \\
2314 \\
2337 \\
2352 \\
2373 \\
2388 \\
2394 \\
2405 \\
2406 \\
2408 \\
2410 \\
2405 \\
2398 \\
2394 \\
2389 \\
2388 \\
2393 \\
2392 \\
2389 \\
2383\end{array}$ & $\begin{array}{l}2306 \\
2312 \\
2310 \\
2309 \\
2296 \\
2316 \\
2323 \\
2333 \\
2337 \\
2345 \\
2349 \\
2350 \\
2358 \\
2359 \\
2362 \\
2374 \\
2380 \\
2390 \\
2410 \\
2420 \\
2437 \\
2451 \\
2455 \\
2465 \\
2466 \\
2467 \\
2468 \\
2463 \\
2454 \\
2449 \\
2444 \\
2442 \\
2446 \\
2445 \\
2442 \\
2436\end{array}$ \\
\hline
\end{tabular}

WOCE Line P16C Station 195 Latitude 30-00.2S Longitude 150-30.7W Date 8/17/91 Bottom Depth 5029

\begin{tabular}{|c|c|c|c|c|c|c|c|c|c|c|c|c|c|c|c|c|}
\hline $\begin{array}{l}\text { Bot } \\
\text { No. }\end{array}$ & $\begin{array}{l}\text { Depth } \\
\text { m }\end{array}$ & $\begin{array}{l}\text { Temp } \\
\text { deg C }\end{array}$ & $\begin{array}{c}\text { Pot Temp } \\
\text { deg } c\end{array}$ & $\begin{array}{c}\text { Salinity } \\
0 / 00\end{array}$ & $\begin{array}{l}\text { Sigma } \\
\text { Theta }\end{array}$ & Oxy & AOU & PO4 & $\begin{array}{l}\text { NO3 } \\
-- \text { UN/ }\end{array}$ & $\mathrm{SiO3}$ & Obs & $\begin{array}{l}S=35 \\
S-D-\end{array}$ & a 20 & heta & $\begin{array}{c}\text { To } \\
\mathrm{CaI} \\
---2\end{array}$ & $\begin{array}{l}\text { Alk. } \\
\text { ALKis } \\
\mathrm{kg}=-\end{array}$ \\
\hline $\begin{array}{l}161 \\
102 \\
103 \\
164 \\
105 \\
106 \\
107 \\
168 \\
169 \\
170 \\
111 \\
112 \\
113 \\
137 \\
115 \\
116 \\
117 \\
118 \\
119 \\
120 \\
121 \\
122 \\
124 \\
123 \\
125 \\
126 \\
127 \\
128 \\
129 \\
130 \\
131 \\
132 \\
133 \\
134 \\
139 \\
138\end{array}$ & $\begin{array}{r}1 \\
34 \\
64 \\
114 \\
143 \\
193 \\
240 \\
297 \\
353 \\
403 \\
468 \\
532 \\
609 \\
685 \\
763 \\
861 \\
1010 \\
1157 \\
1354 \\
1553 \\
1752 \\
1958 \\
2160 \\
2162 \\
2356 \\
2557 \\
2766 \\
2973 \\
3182 \\
3389 \\
3593 \\
3802 \\
3803 \\
4005 \\
4207 \\
4367\end{array}$ & $\begin{array}{r}18 . \\
17 . \\
17 . \\
17 . \\
17 . \\
15 . \\
14 . \\
12 . \\
10 . \\
9 . \\
8 . \\
7 . \\
6 . \\
6 . \\
6 . \\
5 . \\
4 . \\
3 . \\
3 . \\
2 . \\
2 . \\
2 . \\
2 . \\
2 . \\
1 . \\
1 . \\
1 . \\
1 . \\
1 . \\
1 . \\
1 . \\
1 . \\
1 . \\
1 . \\
1 . \\
1 .\end{array}$ & $\begin{array}{r}18 . \\
17 . \\
17 . \\
17 . \\
17 . \\
15 . \\
14 . \\
12 . \\
10 . \\
9 . \\
8 . \\
7 . \\
6 . \\
6 . \\
6 . \\
5 . \\
4 . \\
3 . \\
3 . \\
2 . \\
2 . \\
2 . \\
1 . \\
1 . \\
1 . \\
1 . \\
1 . \\
1 . \\
1 . \\
1 . \\
1 . \\
1 . \\
1 . \\
1 . \\
0 . \\
0 .\end{array}$ & $\begin{array}{l}35 . \\
35 \\
35 . \\
35 . \\
35 . \\
35 \\
35 . \\
34 . \\
34 . \\
34 . \\
34 . \\
34 . \\
34 . \\
34 . \\
34 . \\
34 . \\
34 . \\
34 . \\
34 . \\
34 . \\
34 . \\
34 . \\
34 . \\
34 . \\
34 . \\
34 . \\
34 . \\
34 . \\
34 . \\
34 . \\
34 . \\
34 . \\
34 . \\
34 . \\
34 . \\
34 .\end{array}$ & $\begin{array}{l}25 . \\
25 . \\
25 . \\
25 . \\
25 . \\
26 . \\
26 . \\
26 . \\
26 . \\
26 . \\
26 . \\
26 . \\
26 . \\
26 . \\
27 . \\
27 . \\
27 . \\
27 . \\
27 . \\
27 . \\
27 . \\
27 . \\
27 . \\
27 . \\
27 . \\
27 . \\
27 . \\
27 . \\
27 . \\
27 . \\
27 . \\
27 . \\
27 . \\
27 . \\
27 . \\
27 .\end{array}$ & $\begin{array}{l}23 x \\
23 x \\
23 x \\
23 x \\
23 x \\
21 x \\
20 x \\
19 x \\
20 x \\
20 x \\
22 x \\
23 x \\
24 x \\
24 x \\
23 x \\
22 x \\
20 x \\
18 x \\
17 x \\
16 x \\
15 x \\
15 x \\
15 x \\
15 x \\
15 x \\
15 x \\
15 x \\
15 x \\
16 x \\
17 x \\
18 x \\
18 x \\
18 x \\
18 x \\
19 x \\
19 x\end{array}$ & $\begin{array}{r}-x \\
-x \\
x \\
x \\
x \\
2 x \\
4 x \\
6 x \\
7 x \\
7 x \\
6 x \\
5 x \\
5 x \\
5 x \\
6 x \\
7 x \\
11 x \\
13 x \\
15 x \\
16 x \\
17 x \\
18 x \\
18 x \\
18 x \\
18 x \\
18 x \\
18 x \\
17 x \\
17 x \\
16 x \\
16 x \\
15 x \\
15 x \\
15 x \\
15 x \\
14 x\end{array}$ & $\begin{array}{l}0 . \\
0 . \\
0 . \\
0 . \\
0 . \\
0 . \\
0 . \\
0 . \\
1 . \\
1 . \\
1 . \\
1 . \\
1 . \\
1 . \\
1 . \\
1 . \\
2 . \\
2 . \\
2 . \\
2 . \\
2 . \\
2 . \\
2 . \\
2 . \\
2 . \\
2 . \\
2 . \\
2 . \\
2 . \\
2 . \\
2 . \\
2 . \\
2 . \\
2 . \\
2 . \\
2 .\end{array}$ & $\begin{array}{l}0 . \\
0 . \\
0 . \\
0 . \\
0 . \\
2 . \\
5 . \\
10 . \\
14 . \\
18 . \\
19 . \\
20 . \\
21 . \\
22 . \\
24 . \\
25 . \\
30 . \\
32 . \\
34 . \\
34 . \\
34 . \\
35 . \\
35 . \\
35 . \\
35 . \\
35 . \\
35 . \\
35 . \\
34 . \\
34 . \\
33 . \\
33 . \\
33 . \\
32 . \\
32 . \\
32 .\end{array}$ & $\begin{array}{r}1 . \\
1 . \\
1 . \\
1 . \\
1 . \\
1 . \\
2 . \\
3 . \\
4 . \\
5 . \\
6 . \\
7 . \\
8 . \\
9 . \\
11 . \\
15 . \\
30 . \\
48 . \\
67 . \\
87 . \\
103 . \\
113 . \\
121 . \\
121 . \\
128^{\circ} \\
130 . \\
132 . \\
129 . \\
127 . \\
1250^{\circ} \\
125^{\circ} \\
124^{\circ} \\
123^{\circ} \\
123^{\circ} \\
123^{\circ}\end{array}$ & 2030 & 2000 & 320 & 295 & 2349 & 2314 \\
\hline
\end{tabular}


Lamont-Doherty Earth Observatory of Columbia University Project /Expedition is TUNES/2 WOCE P17C/P16C 1991

(TCO2) $5=35=$ TCO2 obs $X(35$ (Sal) (PALK) $=$ Potential Alkalinity $=(T A L K+N O 3) X(35 / S a 1)$ WOCE Line PI6C Station 196 Latitude 29-30.2S Longitude 150-30.2W Date 8/18/91 Bottom Depth 4579

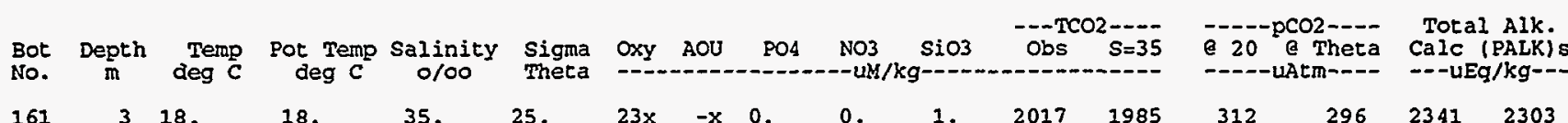

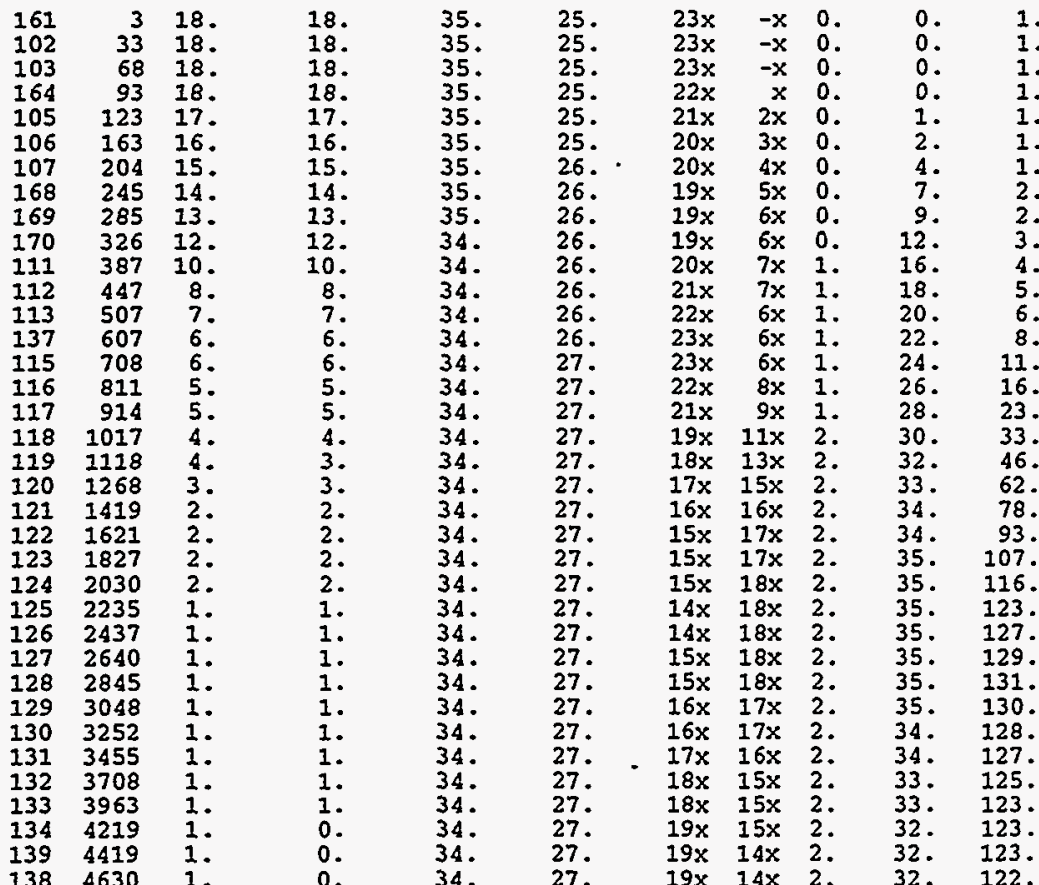

WOCE Line P16C Station 197 Latitude 28-59.9S Longitude 150-30.2W Date 8/18/91 Bottom Depth 4772

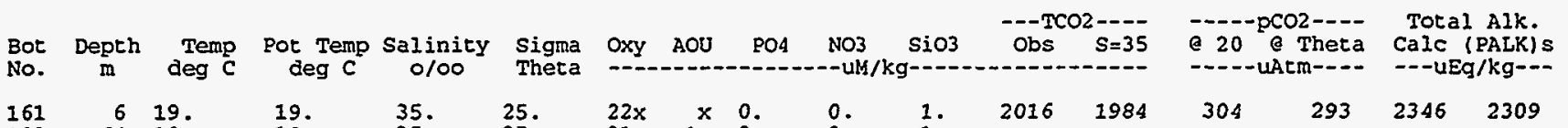

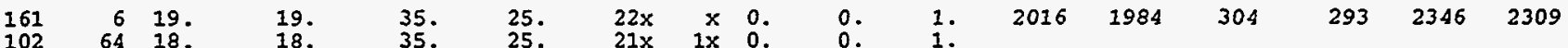

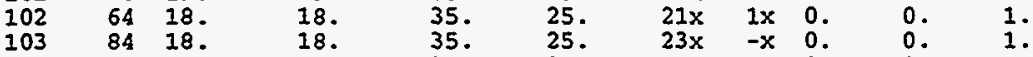

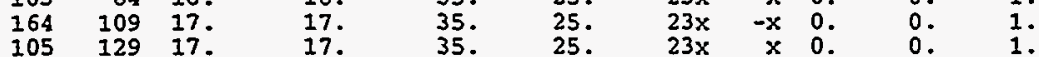

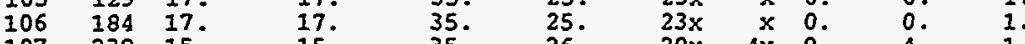

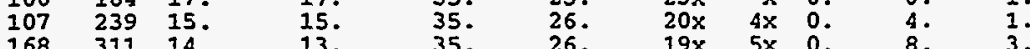

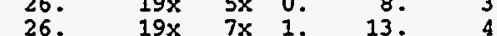

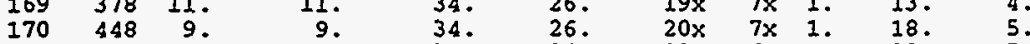

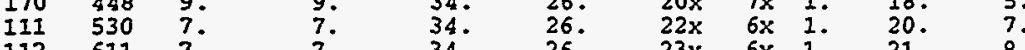

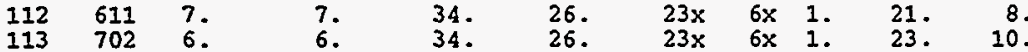

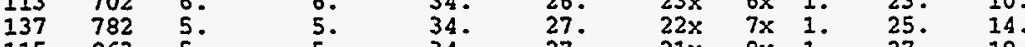

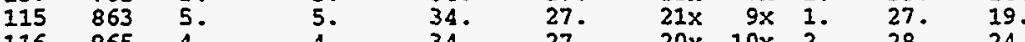

$\begin{array}{lllllllll}116 & 965 & 4 . & 4 . & 34 . & 27 . & 20 \times 10 \times 2 . & 24 .\end{array}$

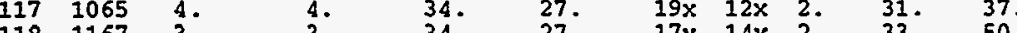$$
\text { . }
$$
. .

. 
Lamont-Doherty Earth Observatory of Columbia University

Princed on $12 / 06 / 93$

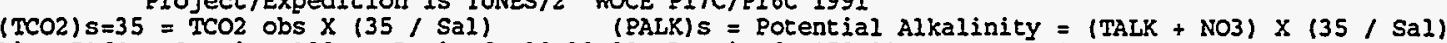
wOCE Line P16C station 198 Latitude 28-30.0S Longitude 150-29.8W Date 8/18/91 Bottom Depth 4897

\begin{tabular}{|c|c|c|c|c|c|c|c|c|c|c|c|c|c|c|c|c|}
\hline $\begin{array}{l}\text { Bot } \\
\text { No. }\end{array}$ & $\underset{\text { mepth }}{\text { Deth }}$ & $\begin{array}{l}\text { Temp } \\
\text { deg C }\end{array}$ & $\begin{array}{l}\text { Pot Temp } \\
\text { deg } \mathbf{c}\end{array}$ & $\begin{array}{c}\text { Salinity } \\
0 / 00\end{array}$ & $\begin{array}{l}\text { Sigma } \\
\text { Theta }\end{array}$ & Oxy & AOU & PO4 & $\begin{array}{l}\mathrm{NO3} \\
--\mathrm{UM} / 1\end{array}$ & SiO3 & $\begin{array}{c}\cdots \text { TC } \\
\text { Obs }\end{array}$ & $S=35$ & 20 & rheta & $\begin{array}{l}\text { Tot } \\
\text { Calc } \\
---4\end{array}$ & $\begin{array}{l}\text { alk. } \\
\text { ILK) s }\end{array}$ \\
\hline $\begin{array}{l}261 \\
202 \\
203 \\
264 \\
205 \\
206 \\
207 \\
268 \\
269 \\
270 \\
211 \\
212 \\
213 \\
237 \\
215 \\
216 \\
217 \\
218 \\
219 \\
220 \\
221 \\
222 \\
224 \\
225 \\
226 \\
227 \\
228 \\
229 \\
230 \\
231 \\
232 \\
233 \\
234 \\
239\end{array}$ & $\begin{array}{r}1 \\
44 \\
74 \\
114 \\
153 \\
184 \\
226 \\
267 \\
307 \\
357 \\
409 \\
484 \\
561 \\
638 \\
713 \\
815 \\
917 \\
1018 \\
1120 \\
1272 \\
1425 \\
1628 \\
1831 \\
2034 \\
2289 \\
2542 \\
2797 \\
3049 \\
3304 \\
3559 \\
3812 \\
4117 \\
4421 \\
4676 \\
4938\end{array}$ & 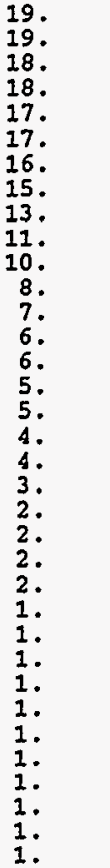 & $\begin{array}{l}19 . \\
19 . \\
18 . \\
18 . \\
17 . \\
17 . \\
16 . \\
14 . \\
13 . \\
11 . \\
10 . \\
8 . \\
7 . \\
6 . \\
6 . \\
5 . \\
4 . \\
4 . \\
3 . \\
3 . \\
2 . \\
2 . \\
2 . \\
1 . \\
1 . \\
1 . \\
1 . \\
1 . \\
1 . \\
1 . \\
10 \\
0 . \\
0 . \\
0 . \\
0 .\end{array}$ & $\begin{array}{l}35 . \\
35 . \\
35 . \\
35 . \\
35 . \\
35 . \\
35 . \\
35 . \\
35 . \\
34 . \\
34 . \\
34 . \\
34 . \\
34 . \\
34 . \\
34 . \\
34 . \\
34 . \\
34 . \\
34 . \\
34 . \\
34 . \\
34 . \\
34 . \\
34 . \\
34 . \\
34 . \\
34 . \\
34 . \\
34 . \\
34 . \\
34 . \\
34 . \\
34 . \\
34 .\end{array}$ & 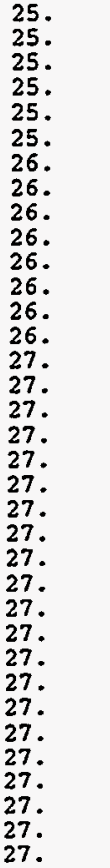 & $\begin{array}{l}22 x \\
22 x \\
22 x \\
23 x \\
22 x \\
22 x \\
20 x \\
19 x \\
19 x \\
19 x \\
20 x \\
21 x \\
22 x \\
23 x \\
23 x \\
22 x \\
20 x \\
19 x \\
18 x \\
17 x \\
16 x \\
15 x \\
15 x \\
15 x \\
14 x \\
15 x \\
15 x \\
15 x \\
17 x \\
17 x \\
18 x \\
19 x \\
19 x \\
19 x \\
19 x\end{array}$ & $\begin{array}{r}-x \\
-x \\
x \\
x \\
x \\
1 x \\
3 x \\
5 x \\
6 x \\
6 x \\
7 x \\
6 x \\
6 x \\
6 x \\
6 x \\
8 x \\
10 x \\
11 x \\
13 x \\
14 x \\
16 x \\
17 x \\
17 x \\
18 x \\
18 x \\
18 x \\
18 x \\
17 x \\
16 x \\
16 x \\
15 x \\
15 x \\
15 x \\
14 x \\
14 x\end{array}$ & $\begin{array}{l}0 . \\
0 . \\
0 . \\
0 . \\
0 . \\
0 . \\
0 . \\
0 . \\
0 . \\
0 . \\
1 . \\
1 . \\
1 \\
1 \\
1 . \\
1 \\
2 . \\
2 . \\
2 . \\
2 . \\
2 . \\
2 . \\
2 . \\
2 . \\
2 . \\
2 . \\
2 . \\
2 . \\
2 . \\
2 . \\
2 . \\
2 . \\
2 . \\
2 . \\
2 .\end{array}$ & 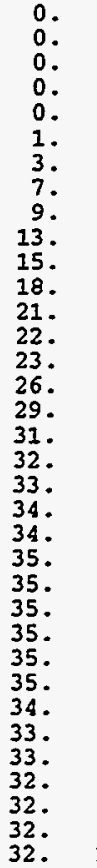 & $\begin{array}{r}1 . \\
1 . \\
1 . \\
1 . \\
1 . \\
1 . \\
1 . \\
2 . \\
3 . \\
4 . \\
4 . \\
5 . \\
7 . \\
8 . \\
10 . \\
16 . \\
24 . \\
32 . \\
44 . \\
55 . \\
77 . \\
95^{\circ} \\
110 . \\
119 . \\
127 . \\
131 . \\
133 . \\
132 . \\
129 . \\
126 . \\
1250^{\circ} \\
124 . \\
124 . \\
123 . \\
124 .\end{array}$ & $\begin{array}{l}2016 \\
2018 \\
2025 \\
2026 \\
2034 \\
2040 \\
2067 \\
2087 \\
2095 \\
2111 \\
2118 \\
2124 \\
2129 \\
2137 \\
2136 \\
2151 \\
2171 \\
2196 \\
2202 \\
2228 \\
2263 \\
2273 \\
2293 \\
2302 \\
2311 \\
2310 \\
2314 \\
2305 \\
2295 \\
2290 \\
2278 \\
2277 \\
2274 \\
2272 \\
2274\end{array}$ & $\begin{array}{l}1983 \\
1984 \\
1993 \\
1996 \\
2006 \\
2014 \\
2044 \\
2069 \\
2086 \\
2117 \\
2133 \\
2151 \\
2163 \\
2175 \\
2175 \\
2194 \\
2213 \\
2238 \\
2242 \\
2266 \\
2295 \\
2301 \\
2318 \\
2326 \\
2335 \\
2332 \\
2336 \\
2327 \\
2316 \\
2310 \\
2297 \\
2296 \\
2293 \\
2291 \\
2293\end{array}$ & $\begin{array}{r}306 \\
306 \\
312 \\
322 \\
343 \\
351 \\
413 \\
457 \\
497 \\
577 \\
623 \\
675 \\
706 \\
723 \\
741 \\
812 \\
890 \\
942 \\
1035 \\
1066 \\
1135 \\
1157 \\
1171 \\
1180 \\
1189 \\
1177 \\
1162 \\
1152 \\
1100 \\
1087 \\
1082 \\
1060 \\
1069 \\
1057 \\
1057\end{array}$ & $\begin{array}{l}299 \\
296 \\
297 \\
298 \\
311 \\
314 \\
353 \\
369 \\
382 \\
406 \\
417 \\
418 \\
415 \\
414 \\
416 \\
441 \\
472 \\
490 \\
524 \\
525 \\
548 \\
550 \\
550 \\
550 \\
550 \\
541 \\
532 \\
525 \\
499 \\
490 \\
486 \\
474 \\
478 \\
472 \\
472\end{array}$ & $\begin{array}{l}2344 \\
2347 \\
2350 \\
2343 \\
2336 \\
2337 \\
2330 \\
2330 \\
2320 \\
2307 \\
2299 \\
2291 \\
2288 \\
2293 \\
2287 \\
2289 \\
2296 \\
2314 \\
2308 \\
2332 \\
2360 \\
2369 \\
2389 \\
2399 \\
2408 \\
2408 \\
\mid\end{array}$ & $\begin{array}{l}2305 \\
2308 \\
2313 \\
2308 \\
2305 \\
2308 \\
2307 \\
2318 \\
2319 \\
2327 \\
2332 \\
2339 \\
2346 \\
2357 \\
2354 \\
2361 \\
2371 \\
2390 \\
2383 \\
2405 \\
2429 \\
2434 \\
2451 \\
2460 \\
2469 \\
2468 \\
2474 \\
2464 \\
2460 \\
2454 \\
2441 \\
2442 \\
2438 \\
2437 \\
2439\end{array}$ \\
\hline
\end{tabular}

WOCE Line P16C Station 199 Latitude 27-59.8S Longitude 150-29.8W Date 8/19/91 Botton Depth 3452

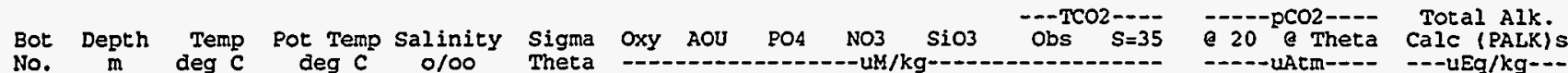

$\begin{array}{lllllllllllllllll}161 & 1 & 18 . & 18 . & 35 . & 25 & 23 \times & -\times & 0 . & 0 . & 1 . & 2019 & 1987 & 308 & 295 & 2347 & 2309\end{array}$

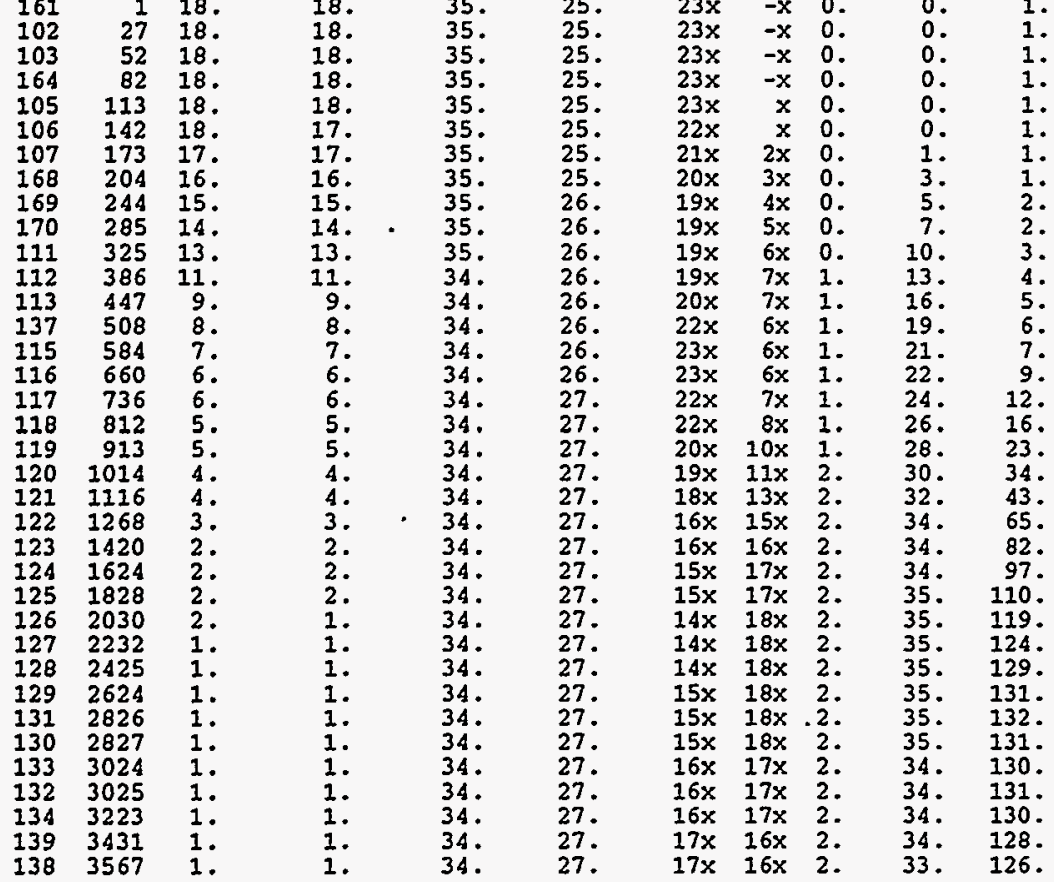


Lamont-Doherty Earth Observatory of Columbia University Project/Expedition is TUNES/2 WOCE P17C/P16C 1991

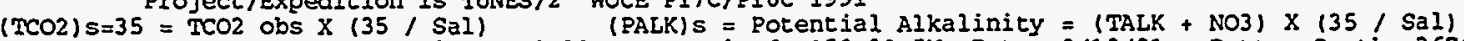
WOCE Line P16C Station 200 Latitude 27-30.15 Longitude 150-29.5W Date 8/19/91 Bottom Depth 3678

\begin{tabular}{|c|c|c|c|c|c|c|c|c|c|c|}
\hline $\begin{array}{l}\text { 3ot } \\
\text { io. }\end{array}$ & $\begin{array}{l}\text { Depth } \\
\text { m }\end{array}$ & $\begin{array}{l}\text { Temp } \\
\text { deg C }\end{array}$ & $\begin{array}{l}\text { ot Temp } \\
\text { deg C }\end{array}$ & $\begin{array}{c}\text { Salinity } \\
0 / 00\end{array}$ & $\begin{array}{l}\text { Sigma } \\
\text { Theta }\end{array}$ & Oxy & AOU & PO4 & $\begin{array}{c}\text { NO3 } \\
-- \text { UN/ }\end{array}$ & \\
\hline $\begin{array}{l}161 \\
102 \\
103 \\
164 \\
105 \\
106 \\
107 \\
168 \\
169 \\
170 \\
111 \\
112 \\
113 \\
137 \\
115 \\
116 \\
117 \\
118 \\
119 \\
120 \\
121 \\
122 \\
124 \\
125 \\
126 \\
127 \\
128 \\
129 \\
130 \\
131 \\
132 \\
133 \\
134\end{array}$ & $\begin{array}{r}3 \\
52 \\
102 \\
153 \\
203 \\
249 \\
295 \\
340 \\
386 \\
437 \\
508 \\
590 \\
671 \\
763 \\
854 \\
944 \\
1036 \\
1126 \\
1214 \\
1314 \\
1417 \\
1519 \\
1642 \\
1776 \\
1928 \\
2081 \\
2236 \\
2388 \\
2539 \\
2667 \\
2841 \\
2988 \\
3139\end{array}$ & $\begin{array}{l}19 . \\
19 . \\
19 . \\
17 . \\
16 . \\
15 . \\
14 . \\
12 . \\
11 . \\
9 . \\
8 . \\
7 . \\
6 . \\
5 . \\
5 . \\
4 . \\
4 . \\
3 . \\
3 . \\
3 . \\
2 . \\
2 . \\
2 . \\
2 . \\
2 . \\
2 . \\
2 . \\
1 . \\
1 . \\
1 . \\
1 . \\
1 . \\
1 . \\
1 .\end{array}$ & $\begin{array}{l}19 . \\
19 . \\
19 . \\
17 . \\
16 . \\
15 . \\
14 . \\
12 . \\
11 . \\
9 . \\
8 . \\
7 . \\
6 . \\
5 . \\
5 . \\
4 . \\
4 . \\
3 . \\
3 . \\
3 . \\
2 . \\
2 . \\
2 . \\
2 . \\
2 . \\
1 . \\
1 . \\
1 . \\
1 . \\
1 . \\
1 . \\
1 . \\
1 . \\
1 .\end{array}$ & $\begin{array}{l}35 . \\
35 . \\
35 . \\
35 . \\
35 . \\
35 . \\
35 . \\
35 . \\
34 . \\
34 . \\
34 . \\
34 . \\
34 . \\
34 . \\
34 . \\
34 . \\
34 . \\
34 . \\
34 . \\
34 . \\
34 . \\
34 . \\
34 . \\
34 . \\
34 . \\
34 . \\
34 . \\
34 . \\
34 . \\
34 . \\
34 . \\
34 . \\
34 . \\
34\end{array}$ & $\begin{array}{l}25 . \\
25 . \\
25 . \\
25 . \\
25 . \\
26 . \\
26 . \\
26 . \\
26 . \\
26 . \\
26 . \\
26 . \\
26 . \\
27 . \\
27 . \\
27 . \\
27 . \\
27 . \\
27 . \\
27 . \\
27 . \\
27 . \\
27 . \\
27 . \\
27 . \\
27 . \\
27 . \\
27 . \\
27 . \\
27 . \\
27 . \\
27 . \\
27 .\end{array}$ & $\begin{array}{l}22 x \\
22 x \\
22 x \\
21 x \\
20 x \\
19 x \\
19 x \\
19 x \\
19 x \\
20 x \\
21 x \\
22 x \\
23 x \\
22 x \\
21 x \\
20 x \\
18 x \\
17 x \\
17 x \\
16 x \\
16 x \\
16 x \\
15 x \\
15 x \\
15 x \\
14 x \\
14 x \\
14 x \\
15 x \\
15 x \\
15 x \\
15 x \\
16 x \\
16 x \\
17 x\end{array}$ & $\begin{array}{r}-x \\
-x \\
x \\
2 x \\
4 x \\
5 x \\
5 x \\
6 x \\
7 x \\
7 x \\
7 x \\
6 x \\
6 x \\
7 x \\
9 x \\
11 x \\
12 x \\
14 x \\
15 x \\
15 x \\
16 x \\
16 x \\
17 x \\
17 x \\
18 x \\
18 x \\
18 x \\
18 x \\
18 x \\
18 x \\
18 x \\
17 x \\
17 x \\
17 x \\
16 x\end{array}$ & $\begin{array}{l}0 . \\
0 . \\
0 . \\
0 . \\
0 . \\
0 . \\
0 . \\
0 . \\
1 . \\
1 . \\
1 . \\
1 . \\
1 . \\
1 . \\
1 . \\
2 . \\
2 . \\
2 . \\
2 . \\
2 . \\
2 . \\
2 . \\
2 . \\
2 . \\
2 . \\
2 . \\
2 . \\
2 . \\
2 . \\
2 . \\
2 . \\
2 . \\
2 . \\
2 . \\
2 .\end{array}$ & $\begin{array}{l}0 . \\
0 . \\
0 . \\
1 . \\
4 . \\
6 . \\
8 . \\
11 . \\
14 . \\
17 . \\
19 . \\
21 . \\
23 . \\
25 . \\
27 . \\
29 . \\
31 . \\
32 . \\
33 . \\
34 . \\
34 . \\
34 . \\
35 . \\
35 . \\
35 . \\
35 . \\
35 . \\
35 . \\
35 . \\
35 . \\
35 . \\
35 . \\
34 . \\
34 . \\
34 .\end{array}$ & $\begin{array}{l}9 \\
10 \\
11 \\
12 \\
12 \\
12 \\
13 \\
13 \\
13 \\
13 \\
13 \\
12 \\
12\end{array}$ \\
\hline
\end{tabular}

$-\cdots \mathrm{TCO} 2---\overline{2}$

--------

20 -

-.---UAtm--

$\begin{array}{lllllll}2017 & 1984 & 304 & 295 & 2347 & 2309\end{array}$

$\begin{array}{lllllll}\text {. } & 2017 & 1984 & 304 & 295 & 2347 & 2309\end{array}$

.

2.

3.

6 .

9.

30.

29.

39.

60.

72 .

98.

106 .

121.

125.

30.

.

27.

WOCE Line P16C Station 201 Latitude 27-00.0S Longitude 150-29.7W Date 8/19/91 Bottom Depth 4753

\begin{tabular}{|c|c|c|c|c|c|c|c|c|c|c|c|c|c|c|c|c|}
\hline $\begin{array}{l}\text { Bot } \\
\text { No. }\end{array}$ & $\underset{\text { Depth }}{\text { Den }}$ & $\begin{array}{l}\text { Temp } \\
\text { deg c }\end{array}$ & $\begin{array}{c}\text { Pot Temp } \\
\text { deg } c\end{array}$ & $\begin{array}{c}\text { Salinity } \\
0 / 00\end{array}$ & $\begin{array}{l}\text { Sigma } \\
\text { Theta }\end{array}$ & Oxy & AOU & $\begin{array}{r}\mathrm{PO4} \\
-\end{array}$ & $\begin{array}{r}\mathrm{NO} 3 \\
--\mathrm{uM}\end{array}$ & $\mathrm{SiO3}$ & Obs & $\begin{array}{r}S=35 \\
S=--\end{array}$ & 20 & heta & $\begin{array}{l}\text { Tot } \\
\text { Calc } \\
---u\end{array}$ & $\begin{array}{l}\text { Alk } \\
\text { ALK) } \\
\mathrm{kg}-\end{array}$ \\
\hline $\begin{array}{l}161 \\
102 \\
103 \\
164 \\
105 \\
106 \\
107 \\
168 \\
169 \\
170 \\
111 \\
112 \\
113 \\
137 \\
115 \\
116 \\
117 \\
118 \\
119 \\
120 \\
121 \\
122 \\
124 \\
125 \\
126 \\
127 \\
128 \\
129 \\
130 \\
131 \\
132 \\
133 \\
134 \\
139 \\
138\end{array}$ & $\begin{array}{r}1 \\
44 \\
84 \\
123 \\
163 \\
222 \\
282 \\
352 \\
414 \\
486 \\
556 \\
625 \\
685 \\
765 \\
854 \\
956 \\
1053 \\
1148 \\
1246 \\
1399 \\
1553 \\
1706 \\
1912 \\
2113 \\
2321 \\
2533 \\
2731 \\
2975 \\
3230 \\
3481 \\
3735 \\
3981 \\
4235 \\
4490 \\
4697\end{array}$ & $\begin{array}{l}20 . \\
19 . \\
19 . \\
19 . \\
18 . \\
16 . \\
14 . \\
12 . \\
11 . \\
9 . \\
7 . \\
6 . \\
6 . \\
5 . \\
5 . \\
4 . \\
4 . \\
3 . \\
3 . \\
2 . \\
2 . \\
2 . \\
2 . \\
2 . \\
1 . \\
1 . \\
1 . \\
1 . \\
1 . \\
1 . \\
1 . \\
1 . \\
1 . \\
1 . \\
1 .\end{array}$ & $\begin{array}{l}20 . \\
19 . \\
19 . \\
19 . \\
18 . \\
16 . \\
14 . \\
12 . \\
11 . \\
9 . \\
7 . \\
6 . \\
6 . \\
5 . \\
5 . \\
4 . \\
4 . \\
3 . \\
3 . \\
2 . \\
2 . \\
2 . \\
2 . \\
1 . \\
1 . \\
1 . \\
1 . \\
1 . \\
1 . \\
1 . \\
1 . \\
1 . \\
0 . \\
0 . \\
0 .\end{array}$ & $\begin{array}{l}35 . \\
35 . \\
35 . \\
35 . \\
35 . \\
35 . \\
35 . \\
35 . \\
34 . \\
34 . \\
34 . \\
34 . \\
34 . \\
34 . \\
34 . \\
34 . \\
34 . \\
34 . \\
34 . \\
34 . \\
34 . \\
34 . \\
34 . \\
34 . \\
34 . \\
34 . \\
34 . \\
34 . \\
34 . \\
34 . \\
34 . \\
34 . \\
34 . \\
34 . \\
34 .\end{array}$ & $\begin{array}{l}25 . \\
25 . \\
25 . \\
25 . \\
25 . \\
25 . \\
26 . \\
26 . \\
26 . \\
26 . \\
26 . \\
26 . \\
26 . \\
27 . \\
27 . \\
27 . \\
27 . \\
27 . \\
27 . \\
27 . \\
27 . \\
27 . \\
27 . \\
27 . \\
27 . \\
27 . \\
27 . \\
27 . \\
27 . \\
27 . \\
27 . \\
27 . \\
27 . \\
27 . \\
27 .\end{array}$ & $\begin{array}{l}22 x \\
22 x \\
22 x \\
22 x \\
21 x \\
20 x \\
19 x \\
19 x \\
19 x \\
20 x \\
22 x \\
23 x \\
23 x \\
22 x \\
21 x \\
19 x \\
18 x \\
17 x \\
16 x \\
16 x \\
15 x \\
15 x \\
15 x \\
14 x \\
14 x \\
15 x \\
15 x \\
15 x \\
16 x \\
17 x \\
18 x \\
18 x \\
19 x \\
19 x \\
19 x\end{array}$ & $\begin{array}{c}-x \\
-x \\
-x \\
-x \\
1 x \\
3 x \\
5 x \\
6 x \\
7 x \\
7 x \\
6 x \\
6 x \\
6 x \\
7 x \\
9 x \\
11 x \\
13 x \\
14 x \\
15 x \\
16 x \\
17 x \\
17 x \\
18 x \\
18 x \\
18 x \\
18 x \\
18 x \\
18 x \\
17 x \\
16 x \\
15 x \\
15 x \\
14 x \\
14 x \\
14 x\end{array}$ & $\begin{array}{l}0 . \\
0 . \\
0 . \\
0 . \\
0 . \\
0 . \\
0 . \\
0 . \\
1 . \\
1 . \\
1 . \\
1 . \\
1 . \\
1 . \\
1 . \\
2 . \\
2 . \\
2 . \\
2 . \\
2 . \\
2 . \\
2 . \\
2 . \\
2 . \\
2 . \\
2 . \\
2 . \\
2 . \\
2 . \\
2 . \\
2 . \\
2 . \\
2 . \\
2 . \\
2 .\end{array}$ & 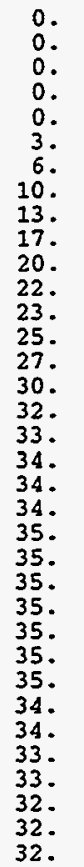 & $\begin{array}{r}1 . \\
0 . \\
0 . \\
0 . \\
0 . \\
1 . \\
2 . \\
3 . \\
3 . \\
5 . \\
6 . \\
8 . \\
9 . \\
14 . \\
20 . \\
30 . \\
42 . \\
54 . \\
64 . \\
80 . \\
91 . \\
103 . \\
113 . \\
121 . \\
127 . \\
129 . \\
131 . \\
131 . \\
129 . \\
126 . \\
123 . \\
123 . \\
122 . \\
121 . \\
121 .\end{array}$ & 2008 & 1975 & 286 & 288 & 2353 & 2314 \\
\hline
\end{tabular}


Lamont-Doherty Earth Observatory of Columbia University

Printed on $12 / 06 / 93$

Page 40

$(\mathrm{TCO}) \mathrm{s}=35=\mathrm{TCO} 2$ obs $\mathrm{x}(35 / \mathrm{Sal}) \quad$ (PALK)s $=$ Potential Alkalinity $=$ (TALK + NO3) $\mathrm{X}(35 / \mathrm{Sal})$ woce Line P16C Station 202 Latitude 26-30.2S Longitude 150-30.2W Date 8/20/91 Bottom Depth 4777

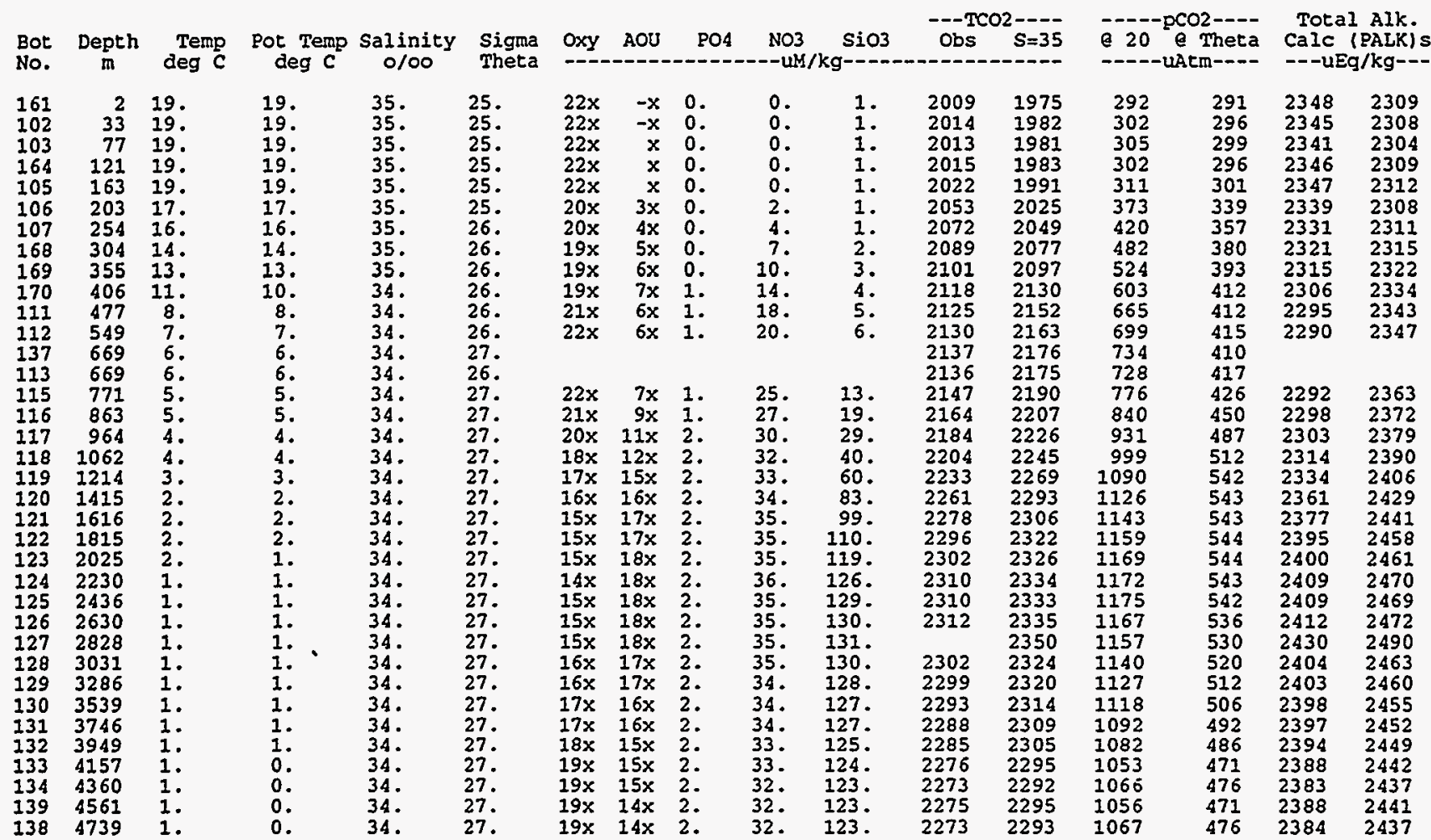

WOCE Line P16C Station 203 Latitude 25-59.9S Longitude 150-29.9W Date 8/20/91 Bottom Depth 4628

Bot Depth Temp pot Temp Salinity sigma oxy AOU PO4 NO3 SiO3 Obs

Bot Depth Temp pot Temp Salinity Sigma Oxy AOU POA NO3 SiO3 Obs S=35 20 a Theta Calc (PALK)

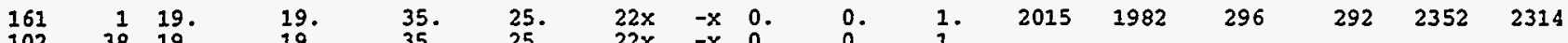

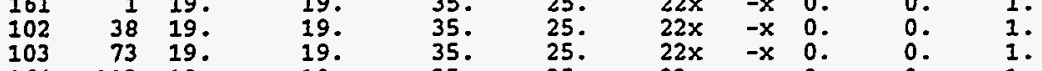

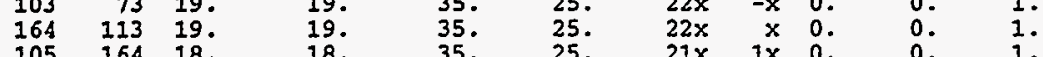

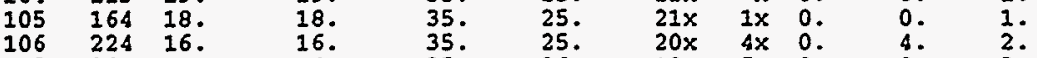

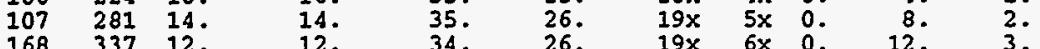

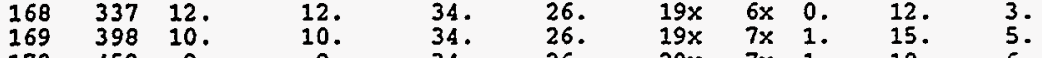

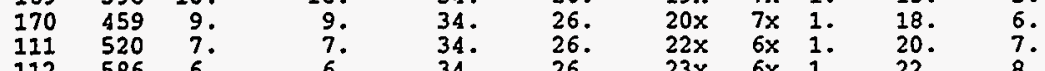

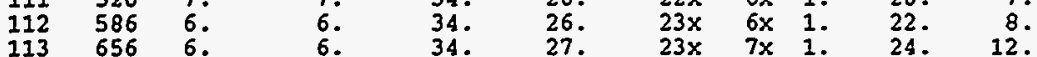

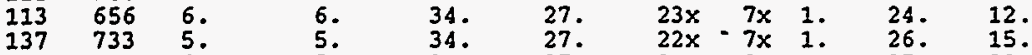

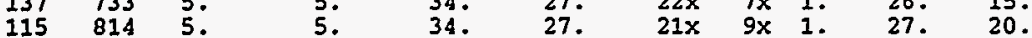

$\begin{array}{llllllll}116 & 893 & 4 . & 4 . & 4 . & 34 . & 27 . & 20 \times \\ 11 \times & 2 . & 30 . & 29 .\end{array}$

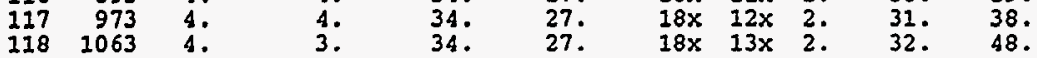

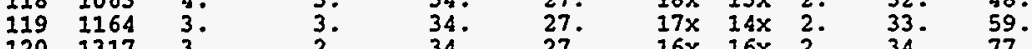

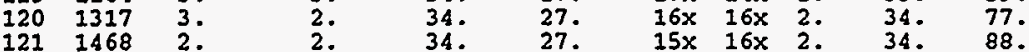

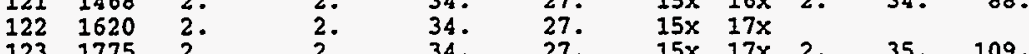

1231775 2. $\quad 2.034 .27$.

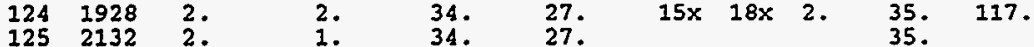

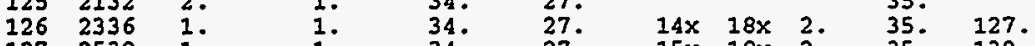

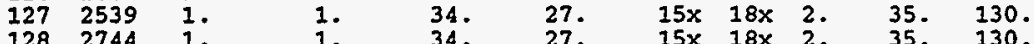

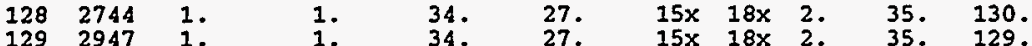

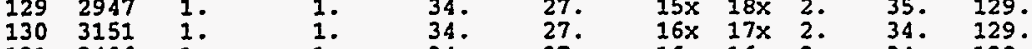

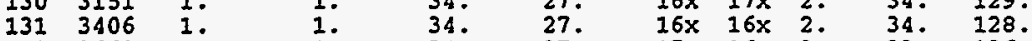

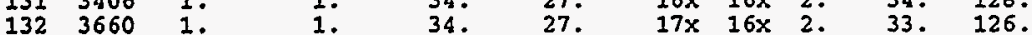

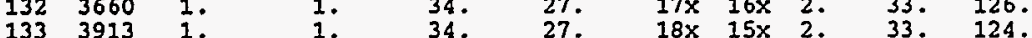

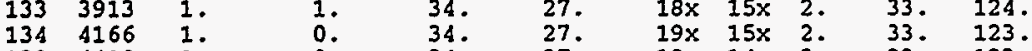

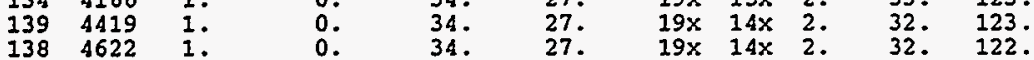


Lamont-Doherty Earth Observatory of Columbia University

Printed on $12 / 06 / 93$

Page 41

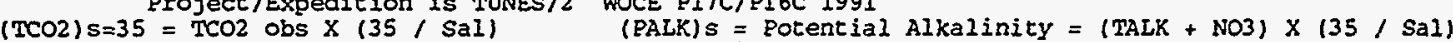

WOCE Line P16C Station 204 Latitude 25-30.2S Iongitude 150-29.8W Date 8/20/91 Bottom Depth 2541

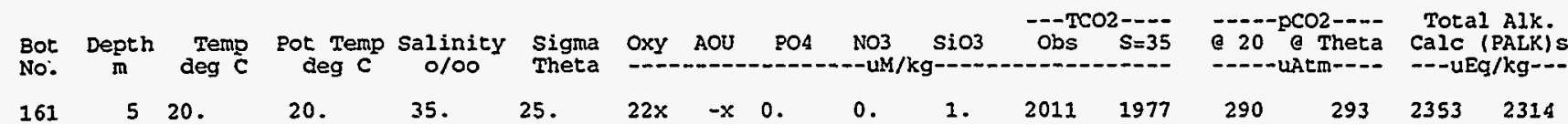

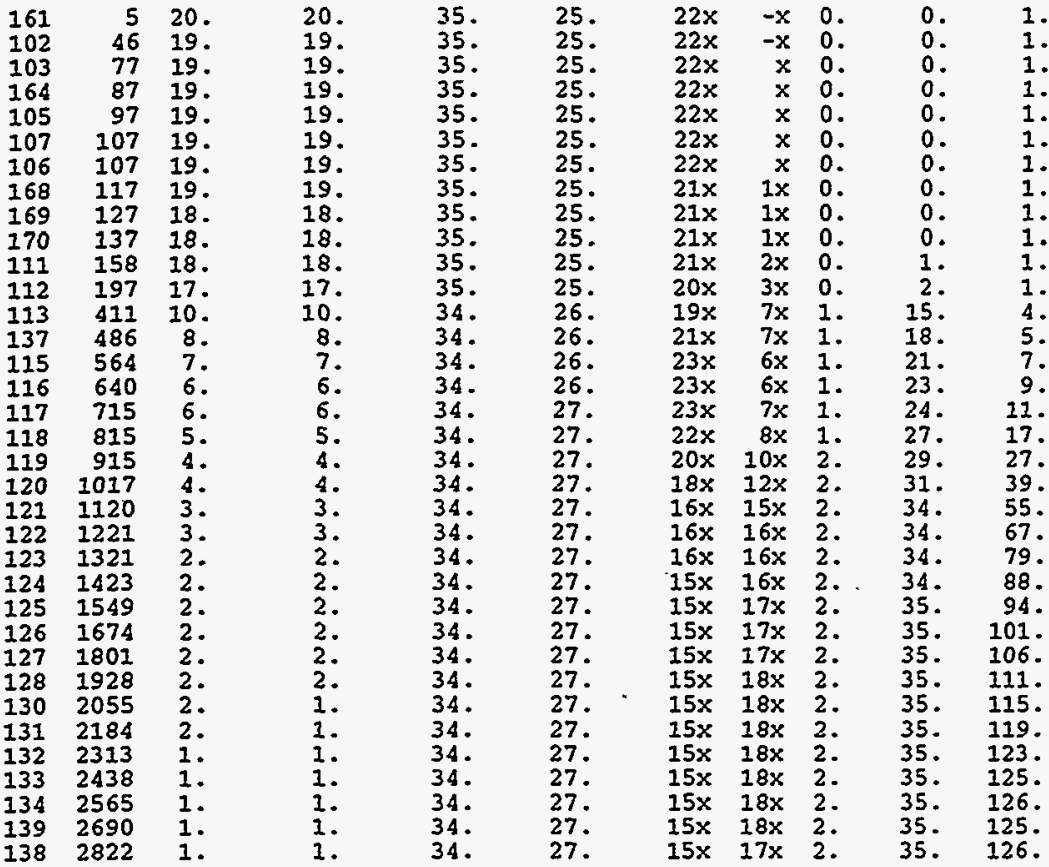

WOCE Line P16C

Station 205

Latitude 25-00.0S Longitude 150-29.9W Date 8/20/91 Bottom Depth 4749

\begin{tabular}{|c|c|c|c|c|c|c|c|c|c|c|}
\hline Bot & $\underset{\mathrm{m}}{\text { Depth }}$ & $\begin{array}{l}\text { Teng } \\
\text { deg C }\end{array}$ & $\begin{array}{l}\text { Pot Temp } \\
\text { deg } c\end{array}$ & $\begin{array}{l}\text { Salinity } \\
0 / 00\end{array}$ & $\begin{array}{l}\text { Sigma } \\
\text { Theta }\end{array}$ & Oxy & $\mathrm{AOU}$ & PO4 & $\mathrm{NO} 3$ & \\
\hline $\begin{array}{l}102 \\
103 \\
164 \\
105 \\
106 \\
107 \\
168 \\
169 \\
170 \\
111 \\
112 \\
113 \\
137 \\
115 \\
116 \\
117\end{array}$ & $\begin{array}{r}3 \\
34 \\
74 \\
115 \\
155 \\
179 \\
203 \\
255 \\
307 \\
357 \\
404 \\
503 \\
602 \\
703 \\
804 \\
904 \\
1003 \\
1102 \\
1254 \\
1405 \\
1605 \\
1807 \\
2009 \\
2214 \\
2427 \\
2633 \\
2832 \\
3019 \\
3265 \\
3514 \\
3756 \\
3964 \\
4224\end{array}$ & $\begin{array}{l}21 . \\
21 . \\
20 . \\
20 . \\
20 . \\
19 . \\
18 . \\
16 . \\
14 . \\
13 . \\
12 . \\
8 . \\
6 . \\
5 . \\
5 . \\
4 . \\
4 . \\
3 . \\
3 . \\
2 . \\
2 . \\
2 . \\
2 . \\
1 . \\
1 . \\
1 . \\
1 . \\
1 . \\
1 . \\
1 . \\
1 . \\
1 . \\
1 . \\
1 . \\
1 .\end{array}$ & $\begin{array}{l}21 . \\
21 . \\
20 . \\
20 . \\
20 . \\
19 . \\
18 . \\
16 . \\
14 . \\
13 . \\
11 . \\
8 . \\
6 . \\
5 . \\
5 . \\
4 . \\
4 . \\
3 . \\
3 . \\
2 . \\
2 . \\
2 . \\
1 . \\
1 . \\
1 . \\
1 . \\
1 . \\
1 . \\
1 . \\
1 . \\
1 . \\
1 . \\
1 . \\
0 . \\
0 .\end{array}$ & $\begin{array}{l}35 . \\
35 . \\
35 . \\
35 . \\
35 . \\
35 . \\
35 . \\
35 . \\
35 . \\
35 . \\
34 . \\
34 . \\
34 . \\
34 . \\
34 . \\
34 . \\
34 . \\
34 . \\
34 . \\
34 . \\
34 . \\
34 . \\
34 . \\
34 . \\
34 . \\
34 . \\
34 . \\
34 . \\
34 . \\
34 . \\
34 . \\
34 . \\
34 . \\
34\end{array}$ & $\begin{array}{l}24 . \\
24 . \\
25 . \\
25 . \\
25 . \\
25 . \\
25 . \\
25 . \\
26 . \\
26 . \\
26 . \\
26 . \\
26 . \\
27 . \\
27 . \\
27 . \\
27 . \\
27 . \\
27 . \\
27 . \\
27 . \\
27 . \\
27 . \\
27 . \\
27 . \\
27 . \\
27 . \\
27 . \\
27 . \\
27 . \\
27 . \\
27 . \\
27 .\end{array}$ & $\begin{array}{l}21 x \\
21 x \\
22 x \\
22 x \\
22 x \\
22 x \\
21 x \\
20 x \\
19 x \\
19 x \\
19 x \\
20 x \\
22 x \\
22 x \\
20 x \\
19 x \\
17 x \\
17 x \\
16 x \\
15 x \\
15 x \\
15 x \\
15 x \\
15 x \\
15 x \\
16 x \\
16 x \\
16 x \\
17 x \\
17 x \\
18 x \\
18 x\end{array}$ & $\begin{array}{r}-x \\
x \\
x \\
-x \\
-x \\
x \\
1 x \\
3 x \\
5 x \\
6 x \\
6 x \\
8 x \\
7 x \\
7 x \\
10 x \\
12 x \\
14 x \\
15 x \\
16 x \\
16 x \\
17 x \\
18 x \\
18 x \\
18 x \\
18 x \\
18 x \\
17 x \\
17 x \\
17 x \\
16 x \\
16 x \\
15 x \\
15 x \\
15 x \\
15 x\end{array}$ & $\begin{array}{l}0 . \\
0 . \\
0 . \\
0 . \\
0 . \\
0 . \\
0 . \\
0 . \\
0 . \\
0 . \\
0 . \\
1 . \\
1 . \\
1 \\
1 \\
2 . \\
2 . \\
2 . \\
2 . \\
2 . \\
2 . \\
2 . \\
2 . \\
2 . \\
2 . \\
2 . \\
2 . \\
2 . \\
2 . \\
2 . \\
2 . \\
2 . \\
2 .\end{array}$ & $\begin{array}{l}0 . \\
0 . \\
0 . \\
0 . \\
0 . \\
0 . \\
0 . \\
3 . \\
7 . \\
10 . \\
12 . \\
20 . \\
23 . \\
25 . \\
28 . \\
31 . \\
33 . \\
34\end{array}$ & $\begin{array}{l}1 \\
1 \\
1 \\
1 \\
1 \\
1 \\
1 \\
1 \\
1 \\
1 \\
1 \\
1\end{array}$ \\
\hline
\end{tabular}


Lamont-Doherty Earth Observatory of Columbia University

Printed on $12 / 06 / 93$

Page 42 Project/Expedition is TU

$(P A L K) s=$ Potential Alkalinity $=($ TALK + NO3) $\times(35 / \mathrm{Sal}$

(TCO2) $s=35=$ TCO2 obs $X$ (35/Sal) (PALK)s = Potential Alkalinity = (TALK + NO3) X (35 / Sal)

WOCE Line P16C Station 206 Latitude 24-30.1S Longitude 150-29.9W

\begin{tabular}{|c|c|c|c|c|c|c|c|c|c|c|c|c|c|c|c|c|}
\hline $\begin{array}{l}\text { Bot } \\
\text { No. }\end{array}$ & $\underset{\mathbb{m}}{\operatorname{Depth}}$ & deg C & $\begin{array}{l}\text { Pot Temp } \\
\text { deg } c\end{array}$ & $\begin{array}{c}\text { Salinity } \\
0 / 00\end{array}$ & $\begin{array}{l}\text { Sigma } \\
\text { Theta }\end{array}$ & $O X Y$ & AOU & PO4 & $\mathrm{NO} 3$ & $\mathrm{SiO}_{3}$ & $\begin{array}{c}--T C \\
\text { Obs }\end{array}$ & $\begin{array}{r}S=--- \\
S=--\end{array}$ & \multicolumn{2}{|c|}{$\bar{e} 20$ e Theta } & \multicolumn{2}{|c|}{$\begin{array}{l}\text { Total Alk. } \\
\text { Calc (PALK) } \\
\text { - -uEg/kg-- }\end{array}$} \\
\hline $\begin{array}{l}161 \\
102 \\
103 \\
164 \\
105 \\
106 \\
107 \\
168 \\
169 \\
170 \\
111 \\
112 \\
113 \\
137 \\
115 \\
116 \\
117 \\
118 \\
119 \\
120 \\
121 \\
122\end{array}$ & $\begin{array}{r}3 \\
33 \\
73 \\
123 \\
179 \\
214 \\
254 \\
285 \\
324 \\
374 \\
427 \\
479 \\
549 \\
630 \\
710 \\
810 \\
909 \\
1009 \\
1112 \\
1264 \\
1408 \\
1610\end{array}$ & $\begin{array}{l}21 . \\
20 . \\
20 . \\
20 . \\
20 . \\
19 . \\
18 . \\
17 . \\
15 . \\
13 . \\
11 . \\
9 . \\
7 . \\
6 . \\
5 . \\
5 . \\
4 . \\
4 . \\
3 . \\
3 . \\
2 . \\
2 .\end{array}$ & $\begin{array}{l}21 . \\
20 . \\
20 . \\
20 . \\
20 . \\
19 . \\
18 . \\
17 . \\
15 . \\
13 . \\
11 . \\
9 . \\
7 . \\
6 . \\
5 . \\
5 . \\
4 . \\
3 . \\
3 . \\
2 . \\
2 . \\
2 .\end{array}$ & $\begin{array}{l}35 . \\
35 . \\
35 . \\
35 . \\
35 . \\
35 . \\
35 . \\
35 . \\
35 . \\
35 . \\
34 . \\
34 . \\
34 . \\
34 . \\
34 . \\
34 . \\
34 . \\
34 . \\
34 . \\
34 . \\
34 . \\
34 .\end{array}$ & 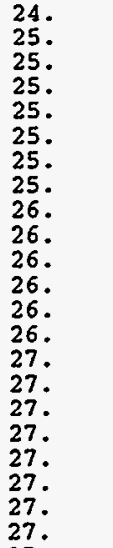 & $\begin{array}{l}22 x \\
22 x \\
22 x \\
22 x \\
22 x \\
20 x \\
19 x \\
20 x \\
19 x \\
19 x \\
19 x \\
20 x \\
21 x \\
23 x \\
22 x \\
21 x \\
19 x \\
17 x \\
16 x \\
15 x \\
15 x \\
15 x\end{array}$ & $\begin{array}{r}-x \\
-x \\
-x \\
-x \\
x \\
2 x \\
3 x \\
3 x \\
5 x \\
6 x \\
7 x \\
7 x \\
7 x \\
6 x \\
7 x \\
10 x \\
12 x \\
14 x \\
15 x \\
16 x \\
17 x \\
17 x\end{array}$ & $\begin{array}{l}0 . \\
0 . \\
0 . \\
0 . \\
0 . \\
0 . \\
0 . \\
0 . \\
0 . \\
0 . \\
1 . \\
1 . \\
1 . \\
1 . \\
1 . \\
1 . \\
2 . \\
2 . \\
2 . \\
2 . \\
2 . \\
2 .\end{array}$ & $\begin{array}{c}0 . \\
0 . \\
0 . \\
0 . \\
0 . \\
1 . \\
2 . \\
2 . \\
6 . \\
10 . \\
15 . \\
18 . \\
21 . \\
23 . \\
25 . \\
28 . \\
31 . \\
33 . \\
33 . \\
34 . \\
34 . \\
35 .\end{array}$ & $\begin{array}{r}1 . \\
1 . \\
1 . \\
1 . \\
1 . \\
1 . \\
1 . \\
1 . \\
2 . \\
3 . \\
4 . \\
6 . \\
8 . \\
10 . \\
13 . \\
22 . \\
34 . \\
49 . \\
60 . \\
79 . \\
89 . \\
105 .\end{array}$ & $\begin{array}{l}2000 \\
2004 \\
2004 \\
2010 \\
2008 \\
2041 \\
2058 \\
2063 \\
2084 \\
2101 \\
2119 \\
2130 \\
2134 \\
2140 \\
2147 \\
2169 \\
2192 \\
2219 \\
2233 \\
2257 \\
2271 \\
2281\end{array}$ & $\begin{array}{l}1962 \\
1970 \\
1971 \\
1977 \\
1976 \\
2008 \\
2028 \\
2037 \\
2066 \\
2099 \\
2134 \\
2156 \\
2170 \\
2180 \\
2190 \\
2213 \\
2234 \\
2258 \\
2270 \\
2289 \\
2301 \\
2308\end{array}$ & $\begin{array}{r}273 \\
283 \\
287 \\
289 \\
297 \\
341 \\
376 \\
392 \\
450 \\
524 \\
613 \\
680 \\
730 \\
754 \\
798 \\
887 \\
976 \\
1082 \\
1110 \\
1151 \\
1160\end{array}$ & $\begin{array}{l}295 \\
293 \\
294 \\
295 \\
301 \\
331 \\
347 \\
345 \\
367 \\
392 \\
419 \\
432 \\
431 \\
426 \\
438 \\
472 \\
507 \\
549 \\
554 \\
560 \\
557\end{array}$ & $\begin{array}{l}2357 \\
2351 \\
2348 \\
2353 \\
2343 \\
2346 \\
2343 \\
2339 \\
2330 \\
2316 \\
2304 \\
2296 \\
2288 \\
2289 \\
2287 \\
2295 \\
2305 \\
2319 \\
2331 \\
2352 \\
2366\end{array}$ & $\begin{array}{l}2313 \\
2311 \\
2308 \\
2314 \\
2305 \\
2310 \\
2311 \\
2311 \\
2316 \\
2324 \\
2335 \\
2343 \\
2348 \\
2356 \\
2359 \\
2370 \\
2381 \\
2394 \\
2404 \\
2421 \\
2433\end{array}$ \\
\hline $\begin{array}{l}123 \\
124 \\
125 \\
126 \\
127 \\
128 \\
129\end{array}$ & $\begin{array}{l}1817 \\
2009 \\
2204 \\
2400 \\
2647 \\
2900 \\
3151\end{array}$ & $\begin{array}{l}2 . \\
2 . \\
1 . \\
1 . \\
1 . \\
1 . \\
1 .\end{array}$ & $\begin{array}{l}2 . \\
1 . \\
1 . \\
1 . \\
1 . \\
1 . \\
1 .\end{array}$ & $\begin{array}{l}34 . \\
34 . \\
34 . \\
34 \\
34 \\
34 \\
34 .\end{array}$ & $\begin{array}{l}27 \\
27 \\
27 \\
27 \\
27 \\
27 \\
27\end{array}$ & $\begin{array}{l}15 x \\
15 x \\
15 x \\
15 x \\
15 x \\
16 x\end{array}$ & $\begin{array}{l}18 x \\
18 x \\
18 x \\
18 x \\
17 x \\
17 x\end{array}$ & $\begin{array}{l}2 . \\
2 . \\
2 . \\
2 . \\
2 . \\
2 .\end{array}$ & $\begin{array}{l}35 \\
35 \\
35 \\
35 \\
35 \\
34\end{array}$ & $\begin{array}{l}114 . \\
121 . \\
124 . \\
127 . \\
129 . \\
128 .\end{array}$ & $\begin{array}{l}2294 \\
2300 \\
2303 \\
2304 \\
2303 \\
2298\end{array}$ & $\begin{array}{l}2319 \\
2324 \\
2327 \\
2327 \\
2326 \\
2320\end{array}$ & $\begin{array}{l}1170 \\
1186 \\
1169 \\
1172 \\
1148 \\
1136\end{array}$ & $\begin{array}{l}549 \\
552 \\
542 \\
541 \\
527 \\
519\end{array}$ & $\begin{array}{l}2391 \\
2396 \\
2402 \\
2402 \\
2405 \\
2401\end{array}$ & $\begin{array}{l}2454 \\
2457 \\
2462 \\
2462 \\
2464 \\
2459\end{array}$ \\
\hline $\begin{array}{l}130 \\
131 \\
132 \\
133 \\
134 \\
139 \\
138\end{array}$ & $\begin{array}{l}3404 \\
3665 \\
3925 \\
4178 \\
4429 \\
4690 \\
4894\end{array}$ & $\begin{array}{l}1 . \\
1 . \\
1 . \\
1 . \\
1 . \\
1 .\end{array}$ & $\begin{array}{l}1 . \\
1 . \\
1 . \\
1 . \\
0 . \\
0 . \\
0 .\end{array}$ & $\begin{array}{l}34 . \\
34 . \\
34 . \\
34 . \\
34 . \\
34 . \\
34 .\end{array}$ & $\begin{array}{l}27 \\
27 \\
27 \\
27 \\
27 \\
27 \\
27\end{array}$ & $\begin{array}{l}17 x \\
17 x \\
18 x \\
18 x \\
18 x \\
19 x \\
19 x\end{array}$ & $\begin{array}{l}16 x \\
16 x \\
16 x \\
15 x \\
15 x \\
15 x \\
15 x\end{array}$ & $\begin{array}{l}2 . \\
2 . \\
2 . \\
2 . \\
2 . \\
2 . \\
2 .\end{array}$ & $\begin{array}{l}34 . \\
33 . \\
33 . \\
33 . \\
33 . \\
32 . \\
32 .\end{array}$ & $\begin{array}{l}126 . \\
127 . \\
127 . \\
125 . \\
123 . \\
124^{\circ} \\
124^{\circ}\end{array}$ & $\begin{array}{l}2293 \\
2292 \\
2284 \\
2282 \\
2278 \\
2280 \\
2273\end{array}$ & $\begin{array}{l}2314 \\
2313 \\
2304 \\
2301 \\
2297 \\
2300 \\
2293\end{array}$ & $\begin{array}{l}1102 \\
1103 \\
1086 \\
1073 \\
1073 \\
1064 \\
1059\end{array}$ & $\begin{array}{l}499 \\
498 \\
489 \\
481 \\
480 \\
476 \\
473\end{array}$ & $\begin{array}{l}2400 \\
2399 \\
2393 \\
2392 \\
2388 \\
2392 \\
2385\end{array}$ & $\begin{array}{l}2457 \\
2455 \\
2448 \\
2446 \\
2442 \\
2446 \\
2438\end{array}$ \\
\hline
\end{tabular}

HOCE Line P16C Station 207 Latitude 24-00.0S Longitude 150-30.0W Date 8/21/91 Botcon Depth 4910

\begin{tabular}{|c|c|c|c|c|c|c|c|c|c|c|c|c|c|c|c|c|}
\hline $\begin{array}{l}\text { Bot } \\
\text { No. }\end{array}$ & $\underset{\text { mepth }}{\text { Def }}$ & $\begin{array}{l}\text { Temp } \\
\text { deg } C\end{array}$ & $\begin{array}{l}\text { Pot Temp } \\
\text { deg } c\end{array}$ & $\begin{array}{c}\text { Salinity } \\
0 / 00\end{array}$ & $\begin{array}{l}\text { Sigma } \\
\text { Theta }\end{array}$ & Oxy & AOU & PO4 & $\begin{array}{r}\mathrm{NO} 3 \\
--\mathrm{UM}\end{array}$ & SiO3 & Obs & $S=35$ & 20 & Theta & $\begin{array}{l}\text { Tot } \\
\text { Calc } \\
--U\end{array}$ & $\begin{array}{l}\text { Alk. } \\
\text { PALK) } \\
\text { /kg- }\end{array}$ \\
\hline $\begin{array}{l}161 \\
102 \\
103 \\
164 \\
105 \\
106 \\
107 \\
168 \\
169 \\
170 \\
111 \\
112 \\
113 \\
137 \\
115 \\
116 \\
117 \\
118 \\
119 \\
120 \\
121 \\
122 \\
123 \\
124 \\
125 \\
126 \\
127 \\
128 \\
129 \\
130 \\
131 \\
132 \\
133 \\
134 \\
139 \\
138\end{array}$ & $\begin{array}{r}2 \\
39 \\
75 \\
109 \\
145 \\
185 \\
215 \\
239 \\
277 \\
327 \\
398 \\
489 \\
581 \\
668 \\
766 \\
855 \\
952 \\
1052 \\
1199 \\
1398 \\
1596 \\
1791 \\
1986 \\
2189 \\
2389 \\
2592 \\
2794 \\
2990 \\
3191 \\
3393 \\
3644 \\
3898 \\
4147 \\
4402 \\
4652 \\
4899\end{array}$ & $\begin{array}{l}21 . \\
21 . \\
21 . \\
21 . \\
20 . \\
19 . \\
19 . \\
19 . \\
17 . \\
15 . \\
12 . \\
9 . \\
7 . \\
6 . \\
5 . \\
5 . \\
4 . \\
3 . \\
3 . \\
2 . \\
2 . \\
2 . \\
2 . \\
2 . \\
1 . \\
1 . \\
1 . \\
1 . \\
1 . \\
1 . \\
1 . \\
1 . \\
1 . \\
1 . \\
1 . \\
1 .\end{array}$ & $\begin{array}{l}21 . \\
21 . \\
21 . \\
21 . \\
20 . \\
19 . \\
19 . \\
18 . \\
17 . \\
15 . \\
12 . \\
9 . \\
7 . \\
6 . \\
5 . \\
5 . \\
4 . \\
3 . \\
3 . \\
2 . \\
2 . \\
2 . \\
1 . \\
1 . \\
1 . \\
1 . \\
1 . \\
1 . \\
1 . \\
1 . \\
1 . \\
1 . \\
1 . \\
0 . \\
0 . \\
0 .\end{array}$ & $\begin{array}{l}35 . \\
35 . \\
35 . \\
35 . \\
35 . \\
35 . \\
35 . \\
35 . \\
35 . \\
35 . \\
34 . \\
34 . \\
34 . \\
34 . \\
34 . \\
34 . \\
34 . \\
34 . \\
34 . \\
34 . \\
34 . \\
34 . \\
34 . \\
34 . \\
34 . \\
34 . \\
34 . \\
34 . \\
34 . \\
34 . \\
34 . \\
34 . \\
34 . \\
34 . \\
34 . \\
34 .\end{array}$ & $\begin{array}{l}24 . \\
24 . \\
24 . \\
24 . \\
25 . \\
25 . \\
25 . \\
25 . \\
25 . \\
26 . \\
26 . \\
26 . \\
26 . \\
26 . \\
27 . \\
27 . \\
27 . \\
27 . \\
27 . \\
27 . \\
27 . \\
27 . \\
27 . \\
27 . \\
27 . \\
27 . \\
27 . \\
27 . \\
27 . \\
27 . \\
27 . \\
27 . \\
27 . \\
27 . \\
27 . \\
27 .\end{array}$ & $\begin{array}{l}21 x \\
21 x \\
21 x \\
22 x \\
22 x \\
22 x \\
20 x \\
19 x \\
18 x \\
19 x \\
19 x \\
20 x \\
22 x \\
22 x \\
22 x \\
20 x \\
18 x \\
17 x \\
16 x \\
15 x \\
15 x \\
15 x \\
15 x \\
15 x \\
15 x \\
15 x \\
15 x \\
15 x \\
16 x \\
16 x \\
17 x \\
18 x \\
18 x \\
19 x \\
19 x \\
19 x\end{array}$ & $\begin{array}{r}-x \\
-x \\
-x \\
-x \\
x \\
x \\
2 x \\
3 x \\
4 x \\
5 x \\
6 x \\
7 x \\
7 x \\
7 x \\
8 x \\
10 x \\
13 x \\
14 x \\
16 x \\
17 x \\
17 x \\
18 x \\
18 x \\
18 x \\
18 x \\
18 x \\
18 x \\
17 x \\
17 x \\
17 x \\
16 x \\
15 x \\
15 x \\
15 x \\
15 x \\
15 x\end{array}$ & $\begin{array}{l}0 . \\
0 . \\
0 . \\
0 . \\
0 . \\
0 . \\
0 . \\
0 . \\
0 . \\
0 . \\
0 . \\
1 . \\
1 . \\
1 . \\
1 . \\
2 . \\
2 . \\
2 . \\
2 . \\
2 . \\
2 . \\
2 . \\
2 . \\
2 . \\
2 . \\
2 . \\
2 . \\
2 . \\
2 . \\
2 . \\
2 . \\
2 . \\
2 . \\
2 . \\
2 . \\
2 .\end{array}$ & $\begin{array}{l}0 . \\
0 . \\
0 . \\
0 . \\
0 . \\
0 . \\
1 . \\
2 . \\
4 . \\
6 . \\
11 . \\
18 . \\
22 . \\
23 . \\
26 . \\
29 . \\
32 . \\
33 . \\
34 . \\
34 . \\
35 . \\
35 . \\
35 . \\
35 . \\
35 . \\
35 . \\
35 . \\
35 . \\
34 . \\
34 . \\
34 . \\
33 . \\
32 . \\
32 . \\
32 . \\
32 .\end{array}$ & $\begin{array}{r}1 . \\
1 . \\
1 . \\
1 . \\
1 . \\
1 . \\
1 . \\
1 . \\
1 . \\
2 . \\
3 . \\
6 . \\
8 . \\
10 . \\
15 . \\
24 . \\
38 . \\
52 . \\
66 . \\
88 . \\
103 . \\
113 . \\
118 . \\
122 . \\
126 . \\
130 . \\
131 . \\
130 . \\
130 . \\
130 . \\
128 . \\
125 . \\
123 . \\
123 . \\
123 . \\
122 .\end{array}$ & 2000 & 1960 & 275 & 299 & 2355 & 2308 \\
\hline
\end{tabular}


Lamont-Doherty Earth Observatory of Columbia University

(TCO2) $5=35$ roject/Expedition is TUNES/2 WOCE P17C/P16C 1991 WOCE Line P16C Station 208 Latitude 23-30.35 Longitude 150-30.0W Date 8/21/91 Bottom Depth 4439

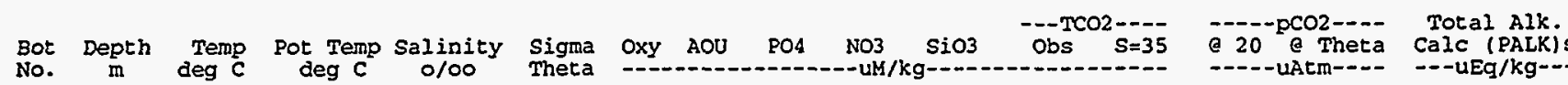

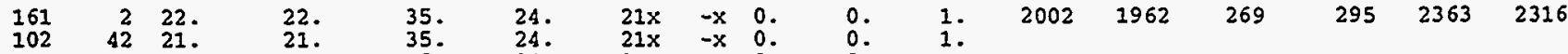

$\begin{array}{lll}102 & 42 & 21 .\end{array}$

$\begin{array}{lrr}164 & 122 & 21\end{array}$

$105 \quad 16320$.

10621319.

$\begin{array}{lll}107 & 263 & 18 \\ 168 & 314 & 16\end{array}$

16936416.

$\begin{array}{lll}169 & 424 & 14 .\end{array}$

1114869.

$\begin{array}{lll}112 & 557 & 8 . \\ 113 & 628 & 7\end{array}$

1376976 .

$\begin{array}{lll}115 & 767 & 5 .\end{array}$

117929

$118 \quad 1010$

1181010

12011133.

12115202 .

$122 \quad 1521$

$123 \quad 1722$

$124 \quad 19232$.

$125 \quad 2125$

$127 \quad 2534$

1272534

$\begin{array}{ll}128 & 2739 \\ 129 & 2943\end{array}$

$130 \quad 3148$

$131 \quad 3352$

$132 \quad 3555$

$1333759 \quad 1$.

$1343987 \quad 1$.

13844131.

$\begin{array}{ll}22 . & 35 . \\ 21 . & 35 . \\ 21 . & 35 . \\ 21 . & 35 . \\ 20 . & 35 . \\ 19 . & 35 . \\ 17 . & 35 . \\ 16 . & 35 . \\ 14 . & 35 . \\ 12 . & 34 . \\ 9 . & 34 . \\ 8 . & 34 . \\ 6 . & 34 . \\ 6 . & 34 . \\ 5 . & 34 . \\ 5 . & 34 . \\ 4 . & 34 . \\ 4 . & 34 . \\ 3 . & 34 . \\ 2 . & 34 . \\ 2 . & 34 . \\ 2 . & 34 . \\ 2 . & 34 . \\ 2 . & 34 . \\ 1 . & 34 . \\ 1 . & 34 . \\ 1 . & 34 . \\ 1 . & 34 . \\ 1 . & 34 . \\ 1 . & 34 . \\ 1 . & 34 . \\ 1 . & 34 . \\ 1 . & 34 . \\ 1 . & 34 . \\ 1 . & 34 . \\ 0 . & 34 . \\ & \end{array}$

$\begin{array}{lll}21 \mathrm{x} & -\mathrm{x} & 0\end{array}$

$\begin{array}{rrrrr}21 \times & -x & 0 . & 0 . & 1 \\ 21 \times & x & 0 . & 0 . & 1 .\end{array}$

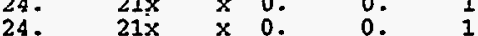

25. $19 x$ 2x $0 . \quad 1 . \quad 1$

25. $19 x \quad 3 \times \quad 0 . \quad 2 . \quad 1$.

25. $19 \times \quad 5 \times 0$

26. $19 x \quad 5 \times 0$.

26. $19 \times \quad 7 \times 0$

26. $20 \times \quad 7 \times 1$.

26. $21 \times \quad 7 \times 1$.

26. $22 x \quad 7 x \quad 1$.

27. $\quad 22 x \quad 7 x \quad 1$.

27. $19 \times 11 \times 2$.

$18 \times 13 x 2$.

$16 x \quad 14 x \quad 2$

$\begin{array}{lll}16 \mathrm{x} & 16 \mathrm{x} & 2 \\ 15 \mathrm{x} & 16 \mathrm{x} & 2\end{array}$

$\begin{array}{lll}15 x & 16 x & 2 \\ 15 x & 17 x & 2\end{array}$

$15 \mathrm{x} 17 \mathrm{x} 2$

$15 x \quad 18 x \quad 2$.

$15 \mathrm{x} \quad 18 \mathrm{x} \quad 2$

$15 \mathrm{x} 18 \mathrm{x} 2$.

$15 \times \quad 18 x \quad 2$

$\begin{array}{lllll}15 x & 18 \times & 2 . & 35 . & 131 . \\ 16 x & 17 x & 2 . & 35 . & 132 .\end{array}$

$16 \times \quad 17 x \quad 2 . \quad 34 . \quad 132$.

$\begin{array}{lllll}17 \times & 16 x & 2 . & 34 . & 129 .\end{array}$

$18 \times 16 \times 2 . \quad 33.126$.

$18 \times 15 \times 2 x^{\circ} \quad 33.0125$.

WOCE Line P16C Station 209

$19 \times 15 \times 2$. 32. 123 .

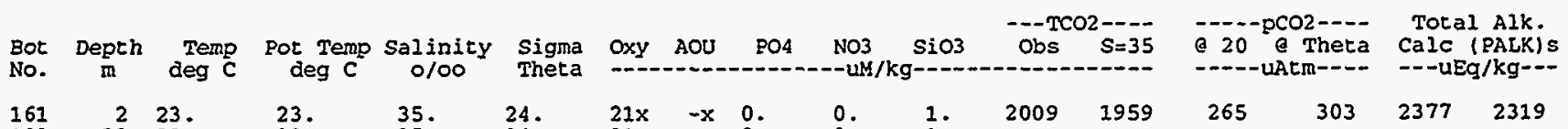

$\begin{array}{rrr}161 & 2 & 23 . \\ 102 & 33 & 22 . \\ 103 & 73 & 22 . \\ 164 & 103 & 21 . \\ 105 & 143 & 20 . \\ 106 & 184 & 20 . \\ 107 & 223 & 18 . \\ 168 & 264 & 17 . \\ 169 & 306 & 15 . \\ 170 & 357 & 14 . \\ 111 & 402 & 12 . \\ 112 & 474 & 9 . \\ 113 & 549 & 7 . \\ 137 & 648 & 6 . \\ 115 & 746 & 5 . \\ 116 & 844 & 5 . \\ 117 & 942 & 4 . \\ 118 & 1039 & 3 . \\ 119 & 1136 & 3 . \\ 120 & 1280 & 3 . \\ 121 & 1479 & 2 . \\ 122 & 1678 & 2 . \\ 123 & 1878 & 2 . \\ 124 & 2079 & 2 . \\ 125 & 2281 & 1 . \\ 126 & 2485 & 1 . \\ 127 & 2739 & 1 . \\ 128 & 2996 & 1 . \\ 129 & 3251 & 1 . \\ 130 & 3509 & 1 . \\ 131 & 3766 & 1 . \\ 132 & 4023 & 1 . \\ 133 & 4233 & 1 . \\ 134 & 4438 & 1 . \\ 139 & 4642 & 1 . \\ 138 & 4875 & 1 .\end{array}$

23.
22.
22.
21.
20.
20.
18.
17.
15.
14.
12.
9.
7.
6.
5.
4.
4.
3.
3.
2.
2.
2.
2.
1.
1.
1.
1.
1.
1.
1.
1.
1.
1.
1.
0.
0.

35.
35.
35.
35.
35.
35.
35.
35.
35.
35.
34.
34.
34.
34.
34.
34.
34.
34.
34.
34.
34.
34.
34.
34.
34.
34.
34.
34.
34.
34.
34.
34.
34.
34.
34.
34.

24. $\quad 21 x \quad-x \quad 0$.

24. $21 \mathrm{x} \quad \mathrm{x} \quad 0$.

$21 x \times 0$

$20 x \quad 2 x \quad 0$.

$19 \times 3 \times \quad 0$

$19 \times \quad 4 \times \quad 0$.

$19 x \quad 5 x \quad 0$

$19 \mathrm{x} \quad 6 \mathrm{x} \quad 0$

$19 x \quad 7 x \quad 0$

$\begin{array}{lll}20 x & 7 x & 1 \\ 21 x & 7 x & 1\end{array}$

$21 \times 8 \times 1$

$21 \times 9 \times 1$.

$19 \times 11 x \quad 2$

$17 \times \quad 13 x \quad 2$

$16 \mathrm{x} \quad 15 \mathrm{x} \quad 2$

$15 \times 16 \times 2$.

$15 \mathrm{x} 17 \mathrm{x} \quad 2$.

$15 \times 17 x \quad 2$

$15 \times 18 \times 2$.

$15 \times 18 \times 2$.

$15 x \quad 18 x \quad 2$

$15 x \quad 18 x \quad 2$

$15 x \quad 18 x \quad 2$

$16 x \quad 17 x \quad 2$

$16 \times \quad 17 x \quad 2$.

$\begin{array}{lll}17 x & 16 x & 2 \\ 17 x & 16 x & 2\end{array}$

$18 \times 16 x 2$

$18 \times 15 \times 2$.

$18 \mathrm{x} \quad 15 \mathrm{x} \quad 2$.

$18 \mathrm{x} 15 \mathrm{x} 2$.

33.124

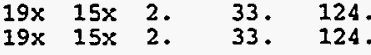


Lamont-Doherty Earth Observatory of Columbia University

Printed on $12 / 06 / 93$

$(T C O 2) s=35=$ TCO2 obs $X(35 / \mathrm{Sal}) \quad$ (PALK) $=$ Potential Alkalinity $=$ (TALK + NO3) X (35/Sal) WOCE Line P16C station 210 Latitude 22-30.1S Longitude 150-30.1W Date 8/22/91 Bottom Depth 4578

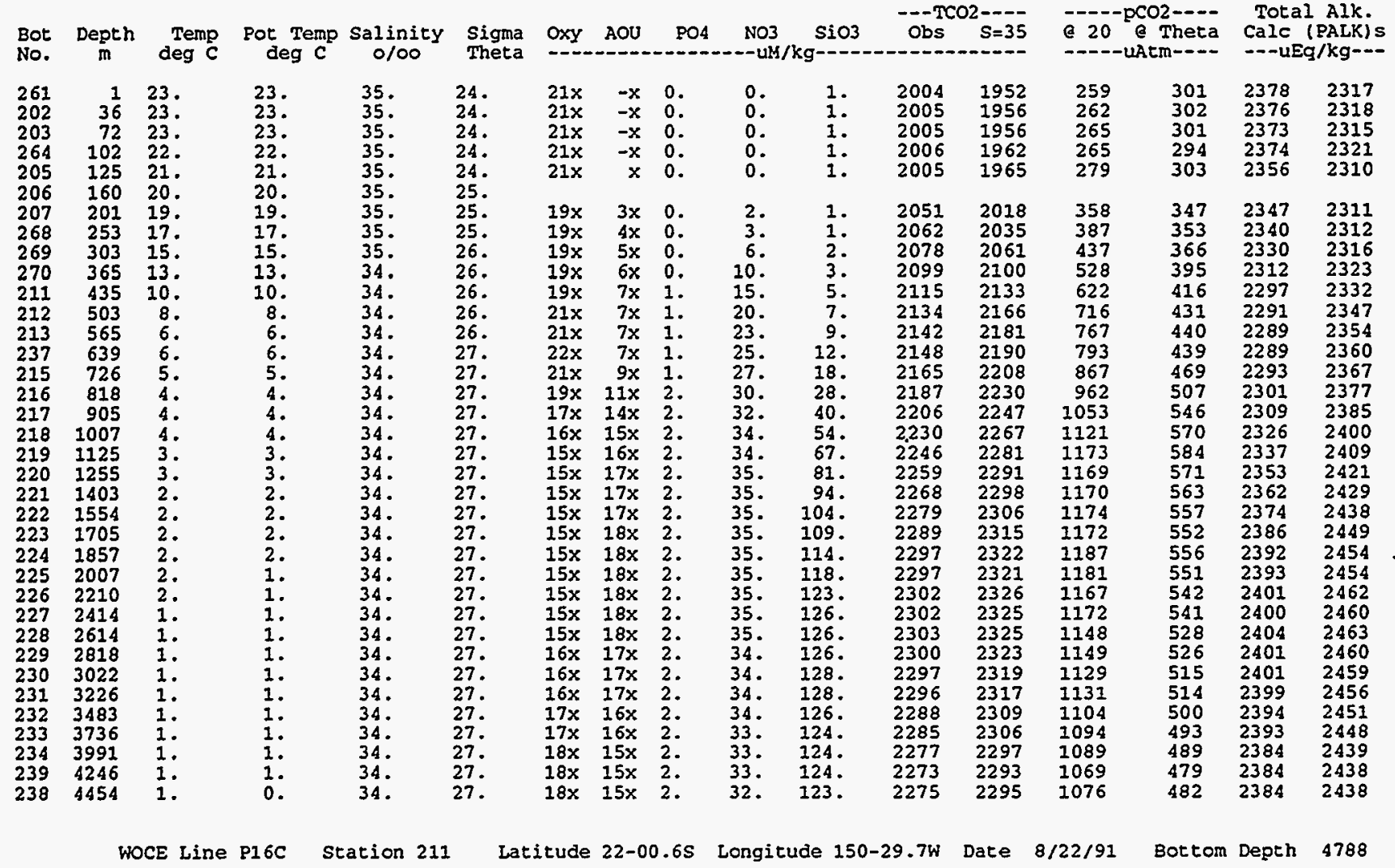

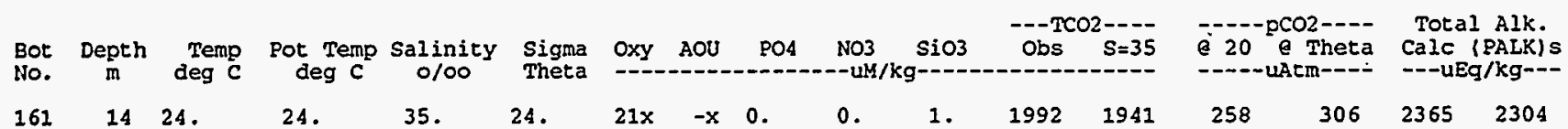

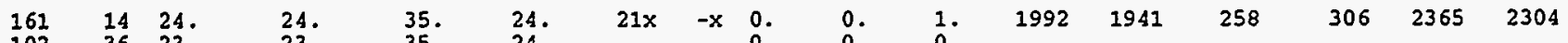

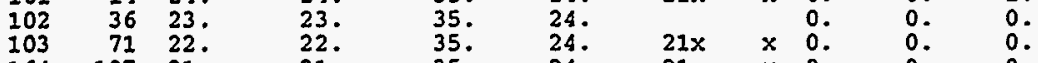

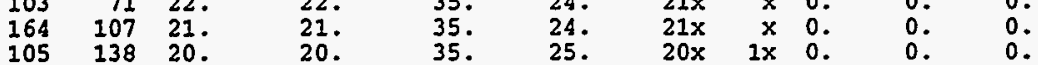

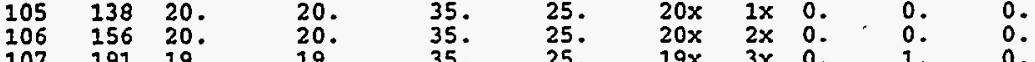

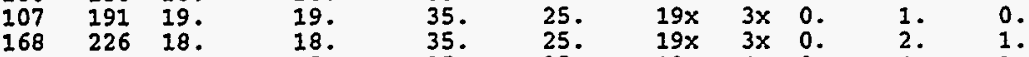

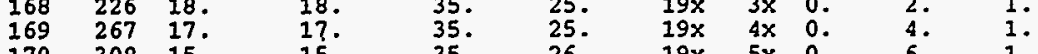

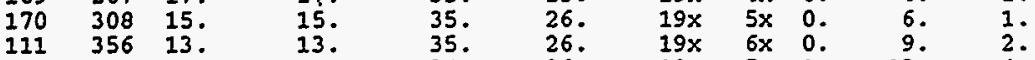

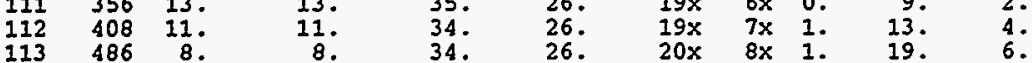

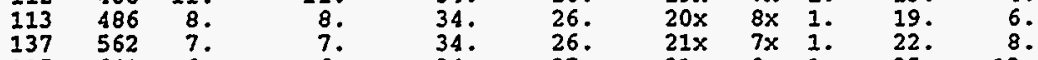

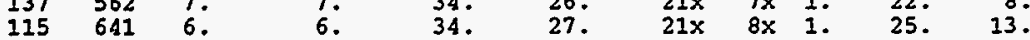

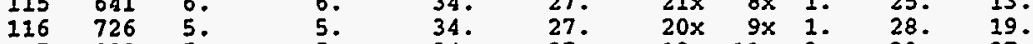

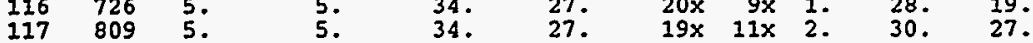

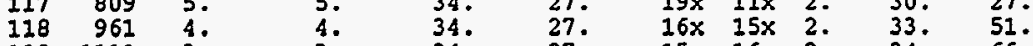

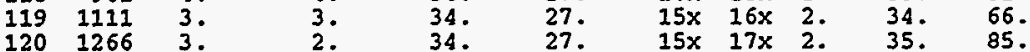

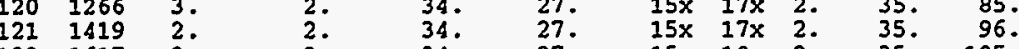

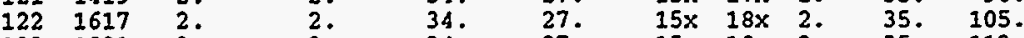

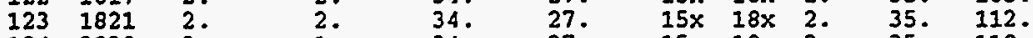

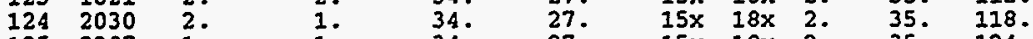

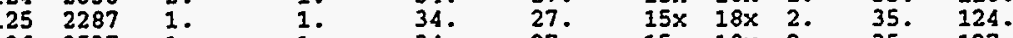

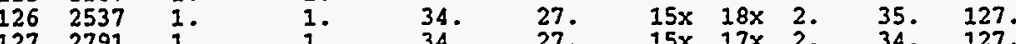

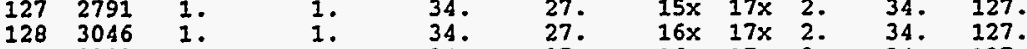

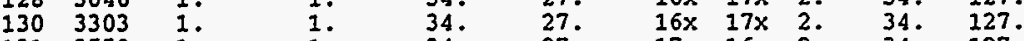

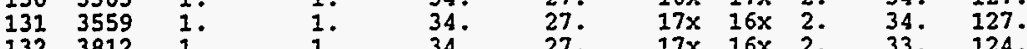

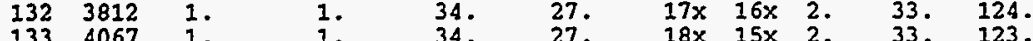

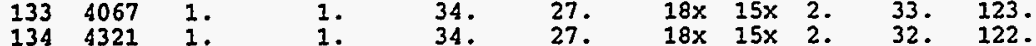

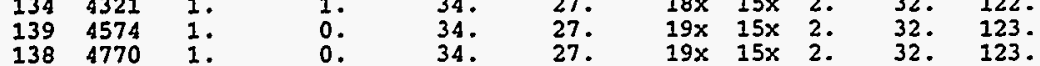


Lamont-Doherty Earth Observatory of Columbia University

(TCO2) $s=35=$ TCO2 obs $X(35, \mathrm{Sal}$ ) (PALK) $=$ Potential Alkalinity $=$ (TALK + NO3) X (35/ Sal) wOCE Iine P16C station 212 Iatitude 21-29.9S Longitude 150-30.4W Date 8/23/91 Bottom Depth 4285

\begin{tabular}{|c|c|c|c|c|c|c|c|c|c|c|c|c|c|c|c|c|}
\hline $\begin{array}{l}\text { Bot } \\
\text { No. }\end{array}$ & $\begin{array}{l}\text { Depth } \\
\text { m }\end{array}$ & $\begin{array}{l}\text { Tenp } \\
\text { deg C }\end{array}$ & $\begin{array}{l}\text { Pot Temp } \\
\text { deg } c\end{array}$ & $\begin{array}{c}\text { Salinity } \\
0 / 00\end{array}$ & $\begin{array}{l}\text { Sigma } \\
\text { Theta }\end{array}$ & Oxy & AOU & $\mathrm{PO4}$ & $\begin{array}{r}\text { NO3 } \\
---U M\end{array}$ & $\mathrm{SiO3}$ & $\begin{array}{c}--T C \\
\text { Obs }\end{array}$ & $S=35$ & a 20 & Theta & $\begin{array}{l}\text { Tota } \\
\text { Calc } \\
---U E\end{array}$ & $\begin{array}{l}\text { ALk. } \\
\text { (PALK) } \\
\text { / } / \mathrm{kg}\end{array}$ \\
\hline $\begin{array}{l}161 \\
162 \\
103 \\
164 \\
105 \\
106 \\
107 \\
168 \\
169 \\
170 \\
111 \\
112 \\
113 \\
137 \\
115 \\
116 \\
117 \\
118 \\
119 \\
120 \\
121 \\
122 \\
123 \\
124 \\
125 \\
126 \\
127 \\
128 \\
129 \\
130 \\
131 \\
132 \\
133 \\
134 \\
139 \\
138\end{array}$ & $\begin{array}{r}2 \\
31 \\
62 \\
96 \\
132 \\
152 \\
183 \\
213 \\
253 \\
304 \\
355 \\
405 \\
481 \\
558 \\
629 \\
684 \\
758 \\
857 \\
957 \\
1106 \\
1258 \\
1410 \\
1611 \\
1813 \\
2014 \\
2216 \\
2415 \\
2613 \\
2812 \\
3013 \\
3220 \\
3429 \\
3640 \\
3840 \\
4038 \\
4241\end{array}$ & $\begin{array}{l}24 . \\
24 . \\
24 . \\
23 . \\
22 . \\
21 . \\
20 . \\
19 . \\
18 . \\
16 . \\
14 . \\
12 . \\
9 . \\
7 . \\
6 . \\
5 . \\
5 . \\
4 . \\
4 . \\
3 . \\
3 . \\
2 . \\
2 . \\
2 . \\
2 . \\
1 . \\
1 . \\
1 . \\
1 . \\
1 . \\
1 . \\
1 . \\
1 . \\
1 . \\
1 . \\
1 .\end{array}$ & $\begin{array}{l}24 . \\
24 . \\
24 . \\
23 . \\
22 . \\
21 . \\
20 . \\
19 . \\
18 . \\
16 . \\
14 . \\
12 . \\
9 . \\
7 . \\
6 . \\
5 . \\
5 . \\
4 . \\
4 . \\
3 . \\
3 . \\
2 . \\
2 . \\
2 . \\
1 . \\
1 . \\
1 . \\
1 . \\
1 . \\
1 . \\
1 . \\
1 . \\
1 . \\
1 . \\
1 . \\
1 .\end{array}$ & $\begin{array}{l}35 . \\
35 . \\
35 . \\
35 . \\
35 . \\
35 . \\
35 . \\
35 . \\
35 . \\
35 . \\
35 . \\
34 . \\
34 . \\
34 . \\
34 . \\
34 . \\
34 . \\
34 . \\
34 . \\
34 . \\
34 . \\
34 . \\
34 . \\
34 . \\
34 . \\
34 . \\
34 . \\
34 . \\
34 . \\
34 . \\
34 . \\
34 . \\
34 . \\
34 . \\
34 . \\
34 .\end{array}$ & $\begin{array}{l}24 . \\
24 . \\
24 . \\
24 . \\
24 . \\
24 . \\
25 \\
25 \\
25 . \\
25 . \\
26 . \\
26 . \\
26 . \\
26 . \\
27 . \\
27 . \\
27 . \\
27 . \\
27 . \\
27 . \\
27 . \\
27 . \\
27 . \\
27 . \\
27 . \\
27 . \\
27 . \\
27 . \\
27 . \\
27 . \\
27 . \\
27 . \\
27 . \\
27 . \\
27 . \\
27 .\end{array}$ & $\begin{array}{l}20 x \\
20 x \\
20 x \\
21 x \\
20 x \\
19 x \\
20 x \\
20 x \\
18 x \\
19 x \\
19 x \\
19 x \\
20 x \\
21 x \\
22 x \\
21 x \\
20 x \\
18 x \\
16 x \\
15 x \\
15 x \\
15 x \\
15 x \\
15 x \\
15 x \\
15 x \\
16 x \\
16 x \\
16 x \\
17 x \\
17 x \\
18 x \\
18 x\end{array}$ & $\begin{array}{r}-x \\
-x \\
x \\
-x \\
x \\
2 x \\
1 x \\
2 x \\
4 x \\
4 x \\
6 x \\
7 x \\
8 x \\
7 x \\
8 x \\
8 x \\
10 x \\
12 x \\
14 x \\
16 x \\
17 x \\
18 x \\
18 x \\
18 x \\
18 x \\
18 x \\
17 x \\
17 x \\
17 x \\
16 x \\
16 x \\
15 x \\
15 x\end{array}$ & $\begin{array}{l}0 . \\
0 . \\
0 . \\
0 . \\
0 . \\
0 . \\
0 . \\
0 . \\
0 . \\
0 . \\
0 . \\
0 . \\
1 . \\
1 . \\
1 . \\
1 . \\
1 . \\
2 . \\
2 . \\
2 . \\
2 . \\
2 . \\
2 . \\
2 . \\
2 . \\
2 . \\
2 . \\
2 . \\
2 . \\
2 . \\
2 . \\
2 . \\
2 . \\
2 .\end{array}$ & $\begin{array}{l}0 . \\
0 . \\
0 . \\
0 . \\
0 . \\
0 . \\
0 . \\
0 . \\
3 . \\
5 . \\
9 . \\
12 . \\
19 . \\
22 . \\
24 . \\
26 . \\
28 . \\
31 . \\
33 . \\
34 . \\
\\
35 . \\
35 . \\
35 . \\
35 . \\
35 . \\
35 . \\
35 . \\
34 . \\
34 . \\
34 . \\
33 . \\
33 . \\
33 . \\
33 . \\
3 .\end{array}$ & $\begin{array}{r}1 . \\
1 . \\
1 . \\
1 . \\
1 . \\
1 . \\
1 . \\
1 . \\
1 . \\
1 . \\
2 . \\
4 . \\
6 . \\
8 . \\
11 . \\
15 . \\
20 . \\
30 . \\
45 . \\
64 . \\
94 . \\
106 . \\
114 . \\
119 . \\
122 . \\
124 . \\
125 . \\
127 . \\
127 . \\
126 . \\
126 . \\
124 . \\
124 . \\
123 .\end{array}$ & 1995 & 1942 & 255 & 309 & 2372 & 2309 \\
\hline
\end{tabular}

WoCE Line Pi6C Station 213 Latitude 21-00.0S Longitude 150-29.9W Date $8 / 23 / 91$ Botton Depth 4714

\begin{tabular}{|c|c|c|c|c|c|c|c|c|c|c|c|c|c|c|c|c|}
\hline $\begin{array}{l}\text { Bot } \\
\text { No. }\end{array}$ & $\underset{\text { m }}{\text { Depth }}$ & $\begin{array}{l}\text { Temp } \\
\text { deg C }\end{array}$ & $\begin{array}{c}\text { Pot Temp } \\
\text { deg } c\end{array}$ & $\begin{array}{c}\text { Salinity } \\
\text { o/oo }\end{array}$ & $\begin{array}{l}\text { Sigma } \\
\text { Theta }\end{array}$ & Oxy & $\mathrm{AOU}$ & PO4 & $\begin{array}{r}\mathrm{NO3} \\
--\mathrm{UM}\end{array}$ & $\mathrm{SiO} 3$ & Obs & $S=35$ & e 20 & heta & $\begin{array}{r}\text { To } \\
\text { Cal } \\
---\end{array}$ & $\begin{array}{l}\text { Alk } \\
\text { ALK) } \\
\mathrm{kg}\end{array}$ \\
\hline $\begin{array}{l}161 \\
162 \\
103 \\
164 \\
105 \\
106 \\
107 \\
168 \\
169 \\
170 \\
111 \\
112 \\
113 \\
137 \\
115 \\
116 \\
117 \\
118 \\
119 \\
120 \\
121 \\
122 \\
123 \\
124 \\
125 \\
126 \\
127 \\
128 \\
129 \\
130 \\
131 \\
132 \\
133 \\
134 \\
139\end{array}$ & $\begin{array}{r}1 \\
32 \\
62 \\
96 \\
136 \\
176 \\
217 \\
258 \\
305 \\
356 \\
407 \\
465 \\
527 \\
588 \\
647 \\
725 \\
806 \\
908 \\
1011 \\
1164 \\
1319 \\
1522 \\
1722 \\
1920 \\
2118 \\
2319 \\
2525 \\
2723 \\
2971 \\
3221 \\
3486 \\
3735 \\
3988 \\
4251 \\
4500 \\
4741\end{array}$ & $\begin{array}{l}25 . \\
25 . \\
24 . \\
24 . \\
22 . \\
21 . \\
19 . \\
19 . \\
16 . \\
13 . \\
11 . \\
9 . \\
7 . \\
6 . \\
6 . \\
5 . \\
5 . \\
4 . \\
4 . \\
3 . \\
3 . \\
2 . \\
2 . \\
2 . \\
2 . \\
1 . \\
1 . \\
1 . \\
1 . \\
1 . \\
1 . \\
1 . \\
1 . \\
1 . \\
1 . \\
1 .\end{array}$ & $\begin{array}{l}25 . \\
25 . \\
24 . \\
24 . \\
22 . \\
21 . \\
19 . \\
19 . \\
16 . \\
13 . \\
11 . \\
9 . \\
7 . \\
6 . \\
6 . \\
5 . \\
5 . \\
4 . \\
3 . \\
3 . \\
2 . \\
2 . \\
2 . \\
2 . \\
1 . \\
1 . \\
1 . \\
1 . \\
1 . \\
1 . \\
1 . \\
1 . \\
1 . \\
1 . \\
1 . \\
1 .\end{array}$ & $\begin{array}{l}36 . \\
36 . \\
35 . \\
35 . \\
35 . \\
35 . \\
35 . \\
35 . \\
35 . \\
34 . \\
34 . \\
34 . \\
34 . \\
34 . \\
34 . \\
34 . \\
34 . \\
34 . \\
34 . \\
34 . \\
34 . \\
34 . \\
34 . \\
34 . \\
34 . \\
34 . \\
34 . \\
34 . \\
34 . \\
34 . \\
34 . \\
34 . \\
34 . \\
34 . \\
34 . \\
34 .\end{array}$ & $\begin{array}{l}24 . \\
24 . \\
24 . \\
24 . \\
24 . \\
24 . \\
25 . \\
25 . \\
25 . \\
26 . \\
26 . \\
26 . \\
26 . \\
26 . \\
27 . \\
27 . \\
27 . \\
27 . \\
27 . \\
27 . \\
27 . \\
27 . \\
27 . \\
27 . \\
27 . \\
27 . \\
27 . \\
27 . \\
27 . \\
27 . \\
27 . \\
27 . \\
27 . \\
27 . \\
27\end{array}$ & $\begin{array}{l}20 x \\
20 x \\
20 x \\
20 x \\
18 x \\
20 x \\
21 x \\
20 x \\
19 x \\
18 x \\
18 x \\
17 x \\
17 x \\
18 x \\
17 x \\
16 x \\
16 x \\
16 x \\
15 x \\
15 x \\
15 x \\
15 x \\
15 x \\
15 x \\
15 x \\
15 x \\
15 x \\
15 x \\
16 x \\
16 x \\
17 x \\
17 x \\
18 x \\
18 x \\
18 x\end{array}$ & $\begin{array}{r}-x \\
-x \\
-x \\
-x \\
2 x \\
1 x \\
1 x \\
2 x \\
4 x \\
6 x \\
8 x \\
10 x \\
11 x \\
11 x \\
13 x \\
14 x \\
14 x \\
15 x \\
16 x \\
17 x \\
17 x \\
17 x \\
18 x \\
18 x \\
18 x \\
18 x \\
18 x \\
18 x \\
17 x \\
17 x \\
16 x \\
16 x \\
15 x \\
15 x \\
15 x \\
15 x\end{array}$ & $\begin{array}{l}0 . \\
0 . \\
0 . \\
0 . \\
0 . \\
0 . \\
0 . \\
0 . \\
0 . \\
0 . \\
1 . \\
1 . \\
1 . \\
1 . \\
2 . \\
2 . \\
2 . \\
2 . \\
2 . \\
2 . \\
2 . \\
2 . \\
2 . \\
2 . \\
2 . \\
2 . \\
2 . \\
2 . \\
2 . \\
2 . \\
2 . \\
2 . \\
2 . \\
2 . \\
2 . \\
2 .\end{array}$ & $\begin{array}{l}0 . \\
0 . \\
0 . \\
0 . \\
0 . \\
0 . \\
0 . \\
1 . \\
5 . \\
10 . \\
15 . \\
21 . \\
25 . \\
27 . \\
29 . \\
30 . \\
32 . \\
33 . \\
34 . \\
34 . \\
35 . \\
35 . \\
35 . \\
35 . \\
35 . \\
35 . \\
35 . \\
35 . \\
34 . \\
34 . \\
33 . \\
33 . \\
33 . \\
33 . \\
32 . \\
32 .\end{array}$ & $\begin{array}{r}1 . \\
1 . \\
1 . \\
2 . \\
1 . \\
1 . \\
0 . \\
0 . \\
1 . \\
3 . \\
6 . \\
9 . \\
13 . \\
16 . \\
24 . \\
30 . \\
38 . \\
46 . \\
61 . \\
74 . \\
87 . \\
102 . \\
111 . \\
115 . \\
120 . \\
124 . \\
127 . \\
128 . \\
128 . \\
126 . \\
125 . \\
125 . \\
124 . \\
123 . \\
122 . \\
122 .\end{array}$ & $\begin{array}{l}1990 \\
2018 \\
1993 \\
2000 \\
2036 \\
2028 \\
2023 \\
2045 \\
2072 \\
2099 \\
2121 \\
2144 \\
2166 \\
2167 \\
2192 \\
2201 \\
2211 \\
2223 \\
2242 \\
2257 \\
2271 \\
2285 \\
2294 \\
2300 \\
2303 \\
2307 \\
2310 \\
2308 \\
2304 \\
2297 \\
2297 \\
2291 \\
2288 \\
2284 \\
2270\end{array}$ & $\begin{array}{l}1932 \\
1960 \\
1939 \\
1949 \\
1989 \\
1991 \\
1993 \\
2013 \\
2051 \\
2100 \\
2137 \\
2172 \\
2201 \\
2205 \\
2231 \\
2239 \\
2249 \\
2261 \\
2277 \\
2290 \\
2302 \\
2313 \\
2320 \\
2325 \\
2327 \\
2330 \\
2333 \\
2330 \\
2326 \\
2319 \\
2317 \\
2311 \\
2308 \\
2304 \\
2299 \\
2298\end{array}$ & $\begin{array}{l}250 \\
251 \\
251 \\
256 \\
308 \\
316 \\
312 \\
344 \\
415 \\
522 \\
631 \\
769 \\
862 \\
897 \\
978 \\
1021 \\
1077 \\
1097 \\
1157 \\
1170 \\
1169 \\
1170 \\
1180 \\
1171 \\
1180 \\
1166 \\
1165 \\
1164 \\
1140 \\
1125 \\
1109 \\
1097 \\
1093 \\
1072 \\
1084\end{array}$ & $\begin{array}{l}311 \\
312 \\
307 \\
309 \\
345 \\
332 \\
310 \\
332 \\
360 \\
397 \\
437 \\
487 \\
512 \\
515 \\
546 \\
558 \\
575 \\
570 \\
587 \\
579 \\
567 \\
557 \\
556 \\
549 \\
549 \\
540 \\
536 \\
534 \\
521 \\
511 \\
502 \\
495 \\
492 \\
481 \\
486 \\
478\end{array}$ & $\begin{array}{l}2372 \\
2406 \\
2375 \\
2376 \\
2369 \\
2350 \\
2347 \\
2349 \\
2336 \\
2315 \\
2300 \\
2290 \\
2295 \\
2290 \\
2305 \\
2307 \\
2311 \\
2321 \\
2334 \\
2349 \\
2366 \\
2381 \\
2390 \\
2398 \\
2400 \\
2406 \\
2410 \\
2408 \\
2407 \\
2402 \\
2403 \\
2398 \\
2396 \\
2394 \\
2388 \\
2389\end{array}$ & $\begin{array}{l}2303 \\
2337 \\
2311 \\
2317 \\
2315 \\
2309 \\
2312 \\
2314 \\
2316 \\
2325 \\
2334 \\
2341 \\
2358 \\
2358 \\
2375 \\
2379 \\
2383 \\
2395 \\
2405 \\
2419 \\
2433 \\
2446 \\
2453 \\
2460 \\
2461 \\
2466 \\
2469 \\
2467 \\
2465 \\
2459 \\
2459 \\
2454 \\
2451 \\
2449 \\
2442 \\
2443\end{array}$ \\
\hline
\end{tabular}


Lamont-Doherty Earth Observatory of Columbia University

Printed on $12 / 06 / 93$

$(\mathrm{TCO} 2) \mathrm{s}=35=\mathrm{TCO} 2$ obs $\mathrm{X}(35 / \mathrm{Sal}) \quad$ (PALK) $\mathrm{s}=$ Potential Alkalinity $=(\mathrm{TALK}+\mathrm{NO} 3) \mathrm{X}(35 / \mathrm{Sal})$

WOCE Line P16C Station 214 Latitude 20-29.8S Longitude 150-29.8W Date 8/23/91 Bottom Depth 4619

\begin{tabular}{|c|c|c|c|c|c|c|c|c|c|c|c|c|c|c|c|c|}
\hline $\begin{array}{l}\text { Bot } \\
\text { No. }\end{array}$ & $\underset{\text { m }}{\text { Depth }}$ & $\begin{array}{l}\text { Temp } \\
\text { deg C }\end{array}$ & $\begin{array}{c}\text { Pot Temp } \\
\text { deg } C\end{array}$ & $\begin{array}{c}\text { Salinity } \\
0 / 00\end{array}$ & $\begin{array}{l}\text { Sigma } \\
\text { Theta }\end{array}$ & $O X Y$ & AOU & PO4 & $\begin{array}{r}\mathrm{NO} 3 \\
--\mathrm{UM}\end{array}$ & $\mathrm{SiO3}$ & Obs & $S=35$ & 20 & heta & $\begin{array}{l}\text { Tot } \\
\text { Calc } \\
---u\end{array}$ & $\begin{array}{l}\text { Alk, } \\
\text { ALKis } \\
\mathrm{kg}---\end{array}$ \\
\hline $\begin{array}{l}161 \\
162 \\
103 \\
164 \\
105 \\
106 \\
107 \\
168 \\
169 \\
170 \\
111 \\
112 \\
113 \\
137 \\
115 \\
116 \\
117 \\
118 \\
119 \\
120 \\
121 \\
122 \\
123 \\
124 \\
125 \\
126 \\
127 \\
128 \\
129 \\
130 \\
131 \\
132 \\
133 \\
134 \\
139 \\
138\end{array}$ & $\begin{array}{r}4 \\
49 \\
95 \\
140 \\
160 \\
190 \\
231 \\
277 \\
326 \\
386 \\
446 \\
508 \\
570 \\
642 \\
723 \\
813 \\
913 \\
1014 \\
1141 \\
1268 \\
1419 \\
1569 \\
1719 \\
1924 \\
2124 \\
2325 \\
2527 \\
2719 \\
2926 \\
3126 \\
3377 \\
3627 \\
3871 \\
4135 \\
4392 \\
4614\end{array}$ & $\begin{array}{l}25 . \\
24 . \\
24 . \\
23 . \\
22 . \\
22 . \\
20 . \\
18 . \\
16 . \\
13 . \\
11 . \\
9 . \\
7 . \\
6 . \\
5 . \\
5 . \\
4 . \\
4 . \\
3 . \\
3 . \\
2 . \\
2 . \\
2 . \\
2 . \\
2 . \\
1 . \\
1 . \\
1 . \\
1 . \\
1 . \\
1 . \\
1 . \\
1 . \\
1 . \\
1 . \\
1 .\end{array}$ & $\begin{array}{l}25 . \\
24 . \\
24 . \\
23 . \\
22 . \\
22 . \\
20 . \\
18 . \\
16 . \\
13 . \\
11 . \\
8 . \\
7 . \\
6 . \\
5 . \\
5 . \\
4 . \\
4 . \\
3 . \\
2 . \\
2 . \\
2 . \\
2 . \\
2 . \\
1 . \\
1 . \\
1 . \\
1 . \\
1 . \\
1 . \\
1 . \\
1 . \\
1 . \\
1 . \\
1 . \\
1 .\end{array}$ & $\begin{array}{l}36 . \\
35 \\
35 . \\
35 . \\
35 . \\
35 . \\
35 . \\
35 . \\
35 . \\
35 . \\
34 . \\
34 . \\
34 . \\
34 . \\
34 . \\
34 . \\
34 . \\
34 . \\
34 . \\
34 . \\
34 . \\
34 . \\
34 . \\
34 . \\
34 . \\
34 . \\
34 . \\
34 . \\
34 . \\
34 . \\
34 . \\
34 . \\
34 . \\
34 . \\
34 . \\
34 .\end{array}$ & $\begin{array}{l}24 . \\
24 . \\
24 . \\
24 . \\
24 . \\
24 . \\
25 . \\
25 . \\
25 . \\
26 . \\
26 . \\
26 . \\
26 . \\
27 . \\
27 . \\
27 . \\
27 . \\
27 . \\
27 . \\
27 . \\
27 . \\
27 . \\
27 . \\
27 . \\
27 . \\
27 . \\
27 . \\
27 . \\
27 . \\
27 . \\
27 . \\
27 . \\
27 . \\
27 . \\
27 . \\
27 .\end{array}$ & $\begin{array}{l}20 x \\
20 x \\
20 x \\
20 x \\
18 x \\
17 x \\
18 x \\
18 x \\
19 x \\
18 x \\
17 x \\
17 x \\
18 x \\
17 x \\
15 x \\
15 x \\
15 x \\
15 x \\
15 x \\
15 x \\
14 x \\
14 x \\
14 x \\
15 x \\
15 x \\
15 x \\
15 x \\
15 x \\
16 x \\
16 x \\
17 x \\
17 x \\
17 x \\
18 x \\
18 x \\
18 x\end{array}$ & $\begin{array}{r}-x \\
-x \\
-x \\
x \\
2 x \\
3 x \\
4 x \\
4 x \\
5 x \\
6 x \\
9 x \\
10 x \\
11 x \\
12 x \\
14 x \\
15 x \\
16 x \\
16 x \\
17 x \\
17 x \\
17 x \\
18 x \\
18 x \\
18 x \\
18 x \\
18 x \\
18 x \\
17 x \\
17 x \\
17 x \\
16 x \\
16 x \\
16 x \\
15 x \\
15 x \\
15 x\end{array}$ & $\begin{array}{l}0 . \\
0 . \\
0 . \\
0 . \\
0 . \\
0 . \\
0 . \\
0 . \\
0 . \\
0 . \\
1 \\
1 . \\
1 . \\
2 . \\
2 . \\
2 . \\
2 . \\
2 . \\
2 . \\
2 . \\
2 . \\
2 . \\
2 . \\
2 . \\
2 . \\
2 . \\
2 . \\
2 . \\
2 . \\
2 . \\
2 . \\
2 . \\
2 . \\
2 . \\
2 . \\
2 .\end{array}$ & $\begin{array}{l}0 . \\
0 . \\
0 . \\
0 . \\
0 . \\
2 . \\
2 . \\
3 . \\
5 . \\
10 . \\
16 . \\
22 . \\
25 . \\
28 . \\
31 . \\
32 . \\
34 . \\
34 . \\
34 . \\
35 . \\
35 . \\
35 . \\
35 . \\
35 . \\
35 . \\
35 . \\
35 . \\
34 . \\
34 . \\
34 . \\
34 . \\
33 . \\
33 . \\
33 . \\
33 . \\
33 .\end{array}$ & $\begin{array}{r}1 . \\
0 . \\
0 . \\
0 . \\
0 . \\
0 . \\
0 . \\
1 . \\
1 . \\
2 . \\
6 . \\
10 . \\
14 . \\
21 . \\
33 . \\
38 . \\
53 . \\
61 . \\
74 . \\
85 . \\
95 . \\
104 . \\
110 . \\
115 . \\
118 . \\
122 . \\
123 . \\
126 . \\
125 . \\
125 . \\
125 . \\
126 . \\
125 . \\
123 . \\
122 . \\
122 .\end{array}$ & 2001 & 1944 & 256 & 317 & 2379 & 2312 \\
\hline
\end{tabular}

WOCE Line PI6C Station 215 Latitude 20-00.0S Longitude 150-29.9W Date 8/24/91 Bottom Depth 3777

\begin{tabular}{|c|c|c|c|c|c|c|c|c|c|c|c|c|c|c|c|c|}
\hline $\begin{array}{l}\text { Bot } \\
\text { No. }\end{array}$ & $\begin{array}{c}\text { Depth } \\
\text { m }\end{array}$ & $\begin{array}{l}\text { Temp } \\
\text { deg C }\end{array}$ & $\begin{array}{c}\text { Pot Temp } \\
\text { deg } c\end{array}$ & $\begin{array}{c}\text { Salinity } \\
0 / 00\end{array}$ & $\begin{array}{l}\text { Sigma } \\
\text { Theta }\end{array}$ & Oxy & AOU & PO4 & $\begin{array}{l}\text { NO3 } \\
-- \text { UH }\end{array}$ & $\mathrm{SiO3}$ & $\begin{array}{l}- \text { TC } \\
\text { Obs }\end{array}$ & $\begin{array}{r}S=35 \\
-\end{array}$ & e 20 & Theta & $\begin{array}{c}\text { Tota } \\
\text { Calc } \\
---U E\end{array}$ & $\begin{array}{l}\text { Alk. } \\
\text { PALKis } \\
\text { kg-- }\end{array}$ \\
\hline $\begin{array}{l}161 \\
162 \\
103 \\
164 \\
105 \\
106 \\
107 \\
168 \\
169 \\
170 \\
111 \\
112 \\
113 \\
137 \\
115 \\
116 \\
117 \\
118 \\
119 \\
120 \\
121 \\
122 \\
123 \\
124 \\
125 \\
126 \\
128 \\
127 \\
129 \\
130 \\
131 \\
132 \\
133 \\
134 \\
139 \\
138\end{array}$ & $\begin{array}{r}1 \\
33 \\
78 \\
123 \\
153 \\
176 \\
200 \\
222 \\
246 \\
294 \\
349 \\
402 \\
454 \\
503 \\
548 \\
650 \\
753 \\
854 \\
954 \\
1053 \\
1205 \\
1408 \\
1604 \\
1800 \\
2001 \\
2201 \\
2400 \\
2401 \\
2595 \\
2797 \\
3001 \\
3205 \\
3205 \\
3407 \\
3572 \\
3720\end{array}$ & $\begin{array}{l}25 . \\
25 . \\
25 . \\
24 . \\
23 . \\
22 . \\
21 . \\
20 . \\
19 . \\
18 . \\
15 . \\
12 . \\
10 . \\
9 . \\
7 . \\
6 . \\
5 . \\
4 . \\
4 . \\
3 . \\
3 . \\
2 . \\
2 . \\
2 . \\
2 . \\
1 . \\
1 . \\
1 . \\
1 . \\
1 . \\
1 . \\
1 . \\
1 . \\
1 . \\
1 . \\
1 .\end{array}$ & $\begin{array}{l}25 . \\
25 . \\
25 . \\
24 . \\
23 . \\
22 . \\
21 . \\
20 . \\
19 . \\
18 . \\
15 . \\
12 . \\
10 . \\
9 . \\
7 . \\
6 . \\
5 . \\
4 . \\
4 . \\
3 . \\
3 . \\
2 . \\
2 . \\
2 . \\
1 . \\
1 . \\
1 . \\
1 . \\
1 . \\
1 . \\
1 . \\
1 . \\
1 . \\
1 . \\
1 . \\
1 .\end{array}$ & $\begin{array}{l}36 . \\
36 . \\
36 . \\
35 . \\
35 . \\
35 . \\
35 . \\
35 . \\
35 . \\
35 . \\
35 . \\
34 . \\
34 . \\
34 . \\
34 . \\
34 . \\
34 . \\
34 . \\
34 . \\
34 . \\
34 . \\
34 . \\
34 . \\
34 . \\
34 . \\
34 . \\
34 . \\
34 . \\
34 . \\
34 . \\
34 . \\
34 . \\
34 . \\
34 . \\
34 . \\
34 .\end{array}$ & $\begin{array}{l}24 . \\
24 . \\
24 . \\
24 . \\
24 . \\
24 . \\
25 . \\
25 . \\
25 . \\
25 . \\
26 . \\
26 . \\
26 . \\
26 . \\
26 . \\
27 . \\
27 . \\
27 . \\
27 . \\
27 . \\
27 . \\
27 . \\
27 . \\
27 . \\
27 . \\
27 . \\
27 . \\
27 . \\
27 . \\
27 . \\
27 . \\
27 . \\
27 . \\
27 . \\
27 . \\
27 .\end{array}$ & $\begin{array}{l}20 x \\
20 x \\
20 x \\
20 x \\
18 x \\
17 x \\
17 x \\
17 x \\
17 x \\
17 x \\
17 x \\
17 x \\
17 x \\
18 x \\
19 x \\
17 x \\
16 x \\
15 x \\
15 x \\
14 x \\
15 x \\
15 x \\
14 x \\
14 x \\
15 x \\
15 x \\
15 x \\
15 x \\
15 x \\
16 x \\
16 x \\
16 x \\
16 x \\
17 x \\
17 x \\
17 x\end{array}$ & $\begin{array}{r}-x \\
-x \\
-x \\
x \\
2 x \\
3 x \\
3 x \\
4 x \\
4 x \\
5 x \\
7 x \\
9 x \\
9 x \\
9 x \\
10 x \\
12 x \\
14 x \\
15 x \\
16 x \\
16 x \\
17 x \\
17 x \\
18 x \\
18 x \\
18 x \\
18 x \\
18 x \\
17 x \\
17 x \\
17 x \\
17 x \\
17 x \\
17 x \\
16 x \\
16 x \\
16 x\end{array}$ & $\begin{array}{l}0 . \\
0 . \\
0 . \\
0 . \\
0 . \\
0 . \\
0 . \\
0 . \\
0 . \\
0 . \\
0 . \\
1 . \\
1 . \\
1 . \\
1 . \\
2 . \\
2 . \\
2 . \\
2 . \\
2 . \\
2 . \\
2 . \\
2 . \\
2 . \\
2 . \\
2 . \\
2 . \\
2 . \\
2 . \\
2 . \\
2 . \\
2 . \\
2 . \\
2 . \\
2 . \\
2 .\end{array}$ & $\begin{array}{r}0 . \\
0 . \\
0 . \\
0 . \\
0 . \\
2 . \\
2 . \\
3 . \\
3 . \\
5 . \\
9 . \\
14 . \\
17 . \\
20 . \\
23 . \\
29 . \\
31 . \\
33 . \\
34 . \\
34 . \\
35 . \\
35 . \\
35 . \\
35 . \\
35 . \\
35 . \\
35 . \\
35 . \\
35 . \\
34 . \\
34 . \\
34 . \\
34 . \\
34 . \\
34 . \\
33 .\end{array}$ & $\begin{array}{r}1 . \\
0 . \\
0 . \\
0 . \\
0 . \\
0 . \\
0 . \\
0 . \\
0 . \\
1 . \\
2 . \\
5 . \\
6 . \\
8 . \\
10 . \\
21 . \\
33 . \\
46 . \\
56 . \\
66 . \\
80 . \\
94 . \\
104 . \\
110 . \\
118 . \\
121 . \\
122 . \\
123 . \\
126 . \\
126 . \\
125 . \\
125 . \\
125 . \\
126 . \\
125 . \\
125 .\end{array}$ & 2005 & 1943 & 253 & 319 & 2388 & 2315 \\
\hline
\end{tabular}


Lamont-Doherty Earth Observatory of Columbia University

Printed on $12 / 06 / 93$

Page 47

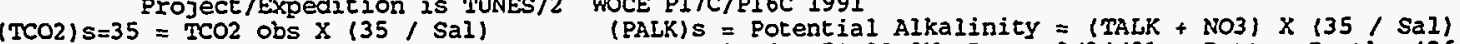
WOCE Line P16C Station 216 Latitude 19-30.0S Longitude 150-29.9W Date 8/24/91 Bottom Depth 4264

\begin{tabular}{|c|c|c|}
\hline $\begin{array}{l}\text { Bot } \\
\text { No. }\end{array}$ & $\begin{array}{l}\text { Depth } \\
\mathbf{m}\end{array}$ & $\begin{array}{r}\text { Temp } \\
\text { deg } C\end{array}$ \\
\hline $\begin{array}{l}161 \\
162 \\
103 \\
164 \\
105 \\
106 \\
107 \\
168 \\
169 \\
170 \\
111 \\
112 \\
113 \\
137 \\
115 \\
116 \\
117 \\
118 \\
119 \\
120 \\
121 \\
122 \\
123 \\
124 \\
125 \\
126 \\
127 \\
128 \\
129 \\
130 \\
131 \\
132 \\
133 \\
134 \\
139 \\
138\end{array}$ & $\begin{array}{r}3 \\
32 \\
62 \\
102 \\
136 \\
150 \\
189 \\
242 \\
304 \\
361 \\
433 \\
507 \\
568 \\
629 \\
712 \\
813 \\
915 \\
1016 \\
1168 \\
1321 \\
1523 \\
1726 \\
1929 \\
2131 \\
2335 \\
2538 \\
2739 \\
2939 \\
3139 \\
3344 \\
3547 \\
3749 \\
3749 \\
3951 \\
4106 \\
4276\end{array}$ & $\begin{array}{r}25 . \\
25 . \\
25 . \\
25 . \\
23 . \\
23 . \\
22 . \\
20 . \\
17 . \\
14 . \\
10 . \\
8 . \\
6 . \\
6 . \\
5 . \\
5 . \\
4 . \\
4 . \\
3 . \\
2 . \\
2 . \\
2 . \\
2 . \\
2 . \\
1 . \\
1 . \\
1 . \\
1 . \\
1 . \\
1 . \\
1 . \\
1 . \\
1 . \\
1 . \\
1 . \\
1 .\end{array}$ \\
\hline
\end{tabular}

Pot Tem
deg C
25.
25.
25.
25.
23.
23.
22.
20
17
14.
10.
8.
6.
6.
5.
5.
4.
4.
3.
2.
2.
2.
2.
1.
1.
1.
1.
1.
1.
1.
1.
1.
1.
1.
1.
1.

Salinity
o/oo
36.
36.
36.
36.
36.
36.
36.
35.
35.
35.
34.
34.
34.
34.
34.
34.
34.
34.
34.
34.
34.
34.
34.
34.
34.
34.
34.
34.
34.
34.
34.
34.
34.
34.
34.
34.

3.
.5
5

Sigma

Oxy AOU PO4 NO3 SiO3

Obs $\mathrm{S}=35$

e 20 pcos---

Total Alk.

23. $20 \mathrm{x}-\mathrm{x} \quad 0$.

0. 1 .

$\begin{array}{ll}2000 & 1940 \\ 2001 & 1941 \\ 2004 & 1944 \\ 2007 & 1946\end{array}$

- 20 TAtm----

(PALK) s

20x $-x \quad x$.

24. $20 x \times 0$.

24. $17 x \quad 3 x \quad 0$.

25. $17 \times \quad 4 x \quad 0$.

25. $17 \times$ 4x 0 .

25. $17 x$ 5x 0.

26. $17 x$ 9x 1.

26. $18 \times 10 \times 1$.

26. $19 \times 10 \times \quad 1$.

27. $19 \times 10 \times 2$.

$\begin{array}{llll}27 . & 18 \times & 12 \times & 2 . \\ 27 . & 15 \times & 15 \times & 2 .\end{array}$

27. $\quad 15 \times 16 x \quad 2$.

27. $\quad 15 x \quad 17 x \quad 2$.

27. $15 x \quad 17 x \quad 2$.

27. $14 x$ 18x 2.

$\begin{array}{lll}14 \mathrm{x} & 18 \mathrm{x} & 2 \\ 15 \mathrm{x} & 18 \mathrm{x} & 2 \\ & \text {. }\end{array}$

$15 x \quad 18 x \quad 2$.

$\begin{array}{lll}15 \mathrm{x} & 17 \mathrm{x} & 2 \\ 16 \mathrm{x} & 17 \mathrm{x} & 2 \\ 16 \mathrm{x} & 17 \mathrm{x} & 2\end{array}$

$\begin{array}{lll}16 \mathrm{x} & 17 \mathrm{x} & 2 \\ 16 \mathrm{x} & 17 \mathrm{x} & 2 .\end{array}$

$16 x \quad 17 x \quad 2$

$\begin{array}{lll}17 \mathrm{x} & 16 \mathrm{x} & 2 \\ 17 \mathrm{x} & 16 \mathrm{x} & 2\end{array}$

$\begin{array}{lll}17 \mathrm{x} & 16 \mathrm{x} & 2 . \\ 17 \mathrm{x} & 16 \mathrm{x} & 2 .\end{array}$

$17 x$ 16x 2. 33. 125.

$17 \times$ 16x 2. 33. 125 .

$18 x \quad 15 x \quad 2 . \quad 33 . \quad 124$.

249
252
248
255
311

$\begin{array}{lll}317 & 2386 & 2315\end{array}$

$\begin{array}{lll}321 & 2384 & 2313 \\ 314 & 2392 & 2320\end{array}$

$322 \quad 2388 \quad 2315$

$\begin{array}{llllll}2057 & 1992 & 311 & 367 & 2395 & 2321\end{array}$

$\begin{array}{llllll}2062 & 1997 & 323 & 373 & 2391 & 2317 \\ 2 & 231 & 376 & 2385 & 2319\end{array}$

$\begin{array}{llllll}2078 & 2029 & 374 & 381 & 2370 & 2318\end{array}$

$\begin{array}{llllll}2085 & 2059 & 426 & 388 & 2346 & 2322\end{array}$

$\begin{array}{llllll}2085 & 2059 & 426 & 388 & 2346 & 2322 \\ 2104 & 2099 & 523 & 416 & 2320 & 2326\end{array}$

$\begin{array}{llllll}2134 & 2154 & 689 & 464 & 2299 & 2338\end{array}$

$\begin{array}{llllll}2153 & 2187 & 814 & 491 & 2291 & 2351\end{array}$

$\begin{array}{llllll}2155 & 2197 & 841 & 468 & 2288 & 2358\end{array}$

$\begin{array}{llllll}2188 & 2229 & 958 & 508 & 2303 & 2378\end{array}$

$\begin{array}{llllll}2243 & 2278 & 1135 & 579 & 2339 & 2410\end{array}$

$\begin{array}{lllllll}2274 & 2303 & 1173 & 568 & 2368 & 2434\end{array}$

$\begin{array}{llllll}2296 & 2322 & 1186 & 559 & 2391 & 2454\end{array}$

$\begin{array}{llllll}2302 & 2326 & 1168 & 543 & 2401 & 2461\end{array}$

$\begin{array}{llllll}2301 & 2324 & 1156 & 532 & 2401 & 2461\end{array}$

$\begin{array}{llllll}2301 & 2323 & 1145 & 523 & 2403 & 2461\end{array}$

$\begin{array}{llllll}2295 & 2317 & 1114 & 506 & 2401 & 2458\end{array}$

$\begin{array}{llllll}2291 & 2311 & 1109 & 501 & 2397 & 2453\end{array}$

$2289 \quad 2310 \quad 1109$

$500 \quad 2395 \quad 2450$

$\begin{array}{llllll}2288 & 2309 & 1069 & 481 & 2400 \quad 2455\end{array}$

WOCE Line P16C Station 217 Latitude 19-00.0S Longicude 150-30.0W Date $8 / 24 / 91$ Bottom Depth 3356

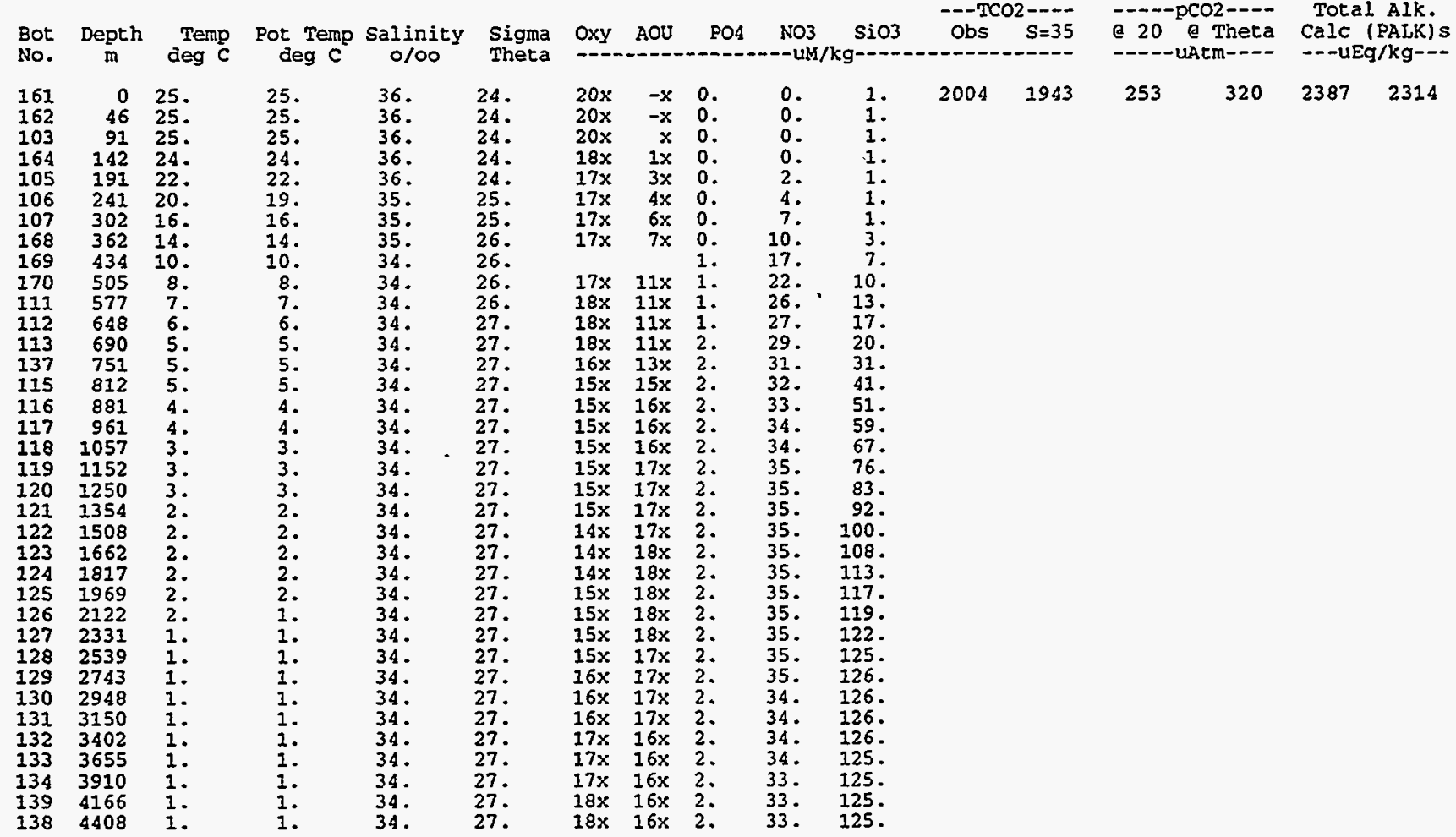


Lamont-Doherty Earth Observatory of Columbia University

(TCO2) $\mathrm{s}=35=$ TCO2 obs $X(35$ / Sal)
WOCE Line PI6C Station 218 Latitude 18-30.5s Longitude 150-29.8W Date 8/24/91

\begin{tabular}{|c|c|c|c|c|c|c|c|c|c|c|c|c|c|c|c|c|}
\hline $\begin{array}{l}\text { Bot } \\
\text { No. }\end{array}$ & $\underset{m}{\text { Depth }}$ & $\begin{array}{l}\text { Temp } \\
\text { deg C }\end{array}$ & $\begin{array}{l}\text { Pot Temp } \\
\text { deg } c\end{array}$ & $\begin{array}{c}\text { Salinity } \\
0 / 00\end{array}$ & $\begin{array}{l}\text { Sigma } \\
\text { Thera }\end{array}$ & Oxy & AOU & PO4 & $\begin{array}{r}\text { NO3 } \\
-- \text { UM }\end{array}$ & $\begin{array}{r}\text { Sio3 } \\
\mathrm{kgg}\end{array}$ & $\begin{array}{l}---T C \\
\text { Obs }\end{array}$ & $\begin{array}{r}2--\overline{-} \\
S=35\end{array}$ & 20 & heta & $\begin{array}{l}\text { Tot } \\
\text { Calc } \\
---u E\end{array}$ & $\begin{array}{l}\text { AlK. } \\
\text { PALK) s } \\
/ \mathrm{kg}^{---}\end{array}$ \\
\hline $\begin{array}{l}161 \\
162 \\
103 \\
164 \\
105 \\
106 \\
107 \\
168 \\
169 \\
170 \\
111 \\
112 \\
113 \\
137 \\
115 \\
116 \\
117 \\
118 \\
119 \\
120 \\
121 \\
122 \\
123 \\
124 \\
125 \\
126 \\
127 \\
128 \\
129 \\
130 \\
131 \\
132 \\
133 \\
134 \\
139 \\
138\end{array}$ & $\begin{array}{r}1 \\
46 \\
96 \\
151 \\
201 \\
252 \\
303 \\
364 \\
424 \\
485 \\
546 \\
607 \\
667 \\
737 \\
808 \\
890 \\
971 \\
1062 \\
1163 \\
1264 \\
1365 \\
1467 \\
1617 \\
1769 \\
1923 \\
2076 \\
2229 \\
2428 \\
2631 \\
2833 \\
3037 \\
3239 \\
3439 \\
3690 \\
3942 \\
4185\end{array}$ & $\begin{array}{r}25 . \\
25 \\
25 . \\
23 . \\
22 . \\
19 . \\
17 . \\
13 . \\
10 . \\
8 . \\
7 . \\
6 . \\
5 . \\
5 . \\
4 . \\
4 . \\
4 . \\
3 . \\
3 . \\
3 . \\
2 . \\
2 . \\
2 . \\
2 . \\
2 . \\
2 . \\
1 . \\
1 . \\
1 . \\
1 . \\
1 . \\
1 . \\
1 . \\
1 . \\
1 . \\
1 .\end{array}$ & $\begin{array}{l}25 . \\
25 . \\
25 . \\
23 . \\
22 . \\
19 . \\
17 . \\
13 . \\
10 . \\
8 . \\
7 . \\
6 . \\
5 . \\
5 . \\
4 . \\
4 . \\
4 . \\
3 . \\
3 . \\
2 . \\
2 . \\
2 . \\
2 . \\
2 . \\
2 . \\
1 . \\
1 . \\
1 . \\
1 . \\
1 . \\
1 . \\
1 . \\
1 . \\
1 . \\
1 . \\
1 .\end{array}$ & $\begin{array}{l}36 . \\
36 . \\
36 . \\
36 . \\
35 . \\
35 . \\
35 . \\
34 . \\
34 . \\
34 . \\
34 . \\
34 . \\
34 . \\
34 . \\
34 . \\
34 . \\
34 . \\
34 . \\
34 . \\
34 . \\
34 . \\
34 . \\
34 . \\
34 . \\
34 . \\
34 . \\
34 . \\
34 . \\
34 . \\
34 . \\
34 . \\
34 . \\
34 . \\
34 . \\
34 . \\
34 .\end{array}$ & $\begin{array}{l}24 . \\
24 . \\
24 . \\
24 . \\
24 . \\
25 . \\
25 . \\
26 . \\
26 . \\
26 . \\
26 . \\
27 . \\
27 . \\
27 . \\
27 . \\
27 . \\
27 . \\
27 . \\
27 . \\
27 . \\
27 . \\
27 . \\
27 . \\
27 . \\
27 . \\
27 . \\
27 . \\
27 . \\
27 . \\
27 . \\
27 . \\
27 . \\
27 . \\
27 . \\
27 . \\
27 .\end{array}$ & $\begin{array}{l}20 \mathrm{x} \\
20 \mathrm{x} \\
20 \mathrm{x} \\
18 \mathrm{x} \\
17 \mathrm{x} \\
18 \mathrm{x} \\
17 \mathrm{x} \\
16 \mathrm{x} \\
15 \mathrm{x} \\
16 \mathrm{x} \\
17 \mathrm{x} \\
18 \mathrm{x} \\
18 \mathrm{x} \\
15 \mathrm{x} \\
15 \mathrm{x} \\
15 \mathrm{x} \\
14 \mathrm{x} \\
15 \mathrm{x} \\
15 \mathrm{x} \\
14 \mathrm{x} \\
14 \mathrm{x} \\
14 \mathrm{x} \\
14 \mathrm{x} \\
14 \mathrm{x} \\
15 \mathrm{x} \\
15 \mathrm{x} \\
15 \mathrm{x} \\
15 \mathrm{x} \\
16 \mathrm{x} \\
16 \mathrm{x} \\
16 \mathrm{x} \\
17 \mathrm{x} \\
17 \mathrm{x} \\
17 \mathrm{x} \\
17 \mathrm{x} \\
17 \mathrm{x}\end{array}$ & $\begin{array}{r}-x \\
-x \\
x \\
2 x \\
3 x \\
4 x \\
6 x \\
9 x \\
11 x \\
12 x \\
11 x \\
11 x \\
12 x \\
14 x \\
15 x \\
16 x \\
16 x \\
16 x \\
17 x \\
17 x \\
17 x \\
18 x \\
18 x \\
18 x \\
18 x \\
18 x \\
18 x \\
17 x \\
17 x \\
17 x \\
17 x \\
16 x \\
16 x \\
16 x \\
16 x \\
16 x\end{array}$ & $\begin{array}{l}0 . \\
0 . \\
0 . \\
0 . \\
0 . \\
0 . \\
0 . \\
1 . \\
1 . \\
1 . \\
1 . \\
1 . \\
2 . \\
2 . \\
2 . \\
2 . \\
2 . \\
2 . \\
2 . \\
2 . \\
2 . \\
2 . \\
2 . \\
2 . \\
2 . \\
2 . \\
2 . \\
2 . \\
2 . \\
2 . \\
2 . \\
2 . \\
2 . \\
2 . \\
2 . \\
2 .\end{array}$ & $\begin{array}{l}0 . \\
0 . \\
0 . \\
0 . \\
2 . \\
3 . \\
6 . \\
14 . \\
19 . \\
23 . \\
26 . \\
28 . \\
29 . \\
32 . \\
33 . \\
34 . \\
34 . \\
35 . \\
35 . \\
35 . \\
35 . \\
35 . \\
35 . \\
35 . \\
35 . \\
35 . \\
35 . \\
35 . \\
35 . \\
35 . \\
35 . \\
34 . \\
34 . \\
34 . \\
34 . \\
34 .\end{array}$ & $\begin{array}{r}1 . \\
1 . \\
1 . \\
1 . \\
1 . \\
1 . \\
2 . \\
6 . \\
9 . \\
12 . \\
14 . \\
18 . \\
23 . \\
38 . \\
48 . \\
55 . \\
60 . \\
69 . \\
81 . \\
89 . \\
95 . \\
100 . \\
105 . \\
111 . \\
116 . \\
118 . \\
120 . \\
123 . \\
125 . \\
128 . \\
127 . \\
127 . \\
127 . \\
127 . \\
127 . \\
126 .\end{array}$ & 2007 & 1944 & 251 & 316 & 2394 & 2319 \\
\hline
\end{tabular}

WOCE Line P16C Station 219 Latitude 18-00.1S Longitude 150-29.9W Date 8/25/91 Botcom Depth 3659

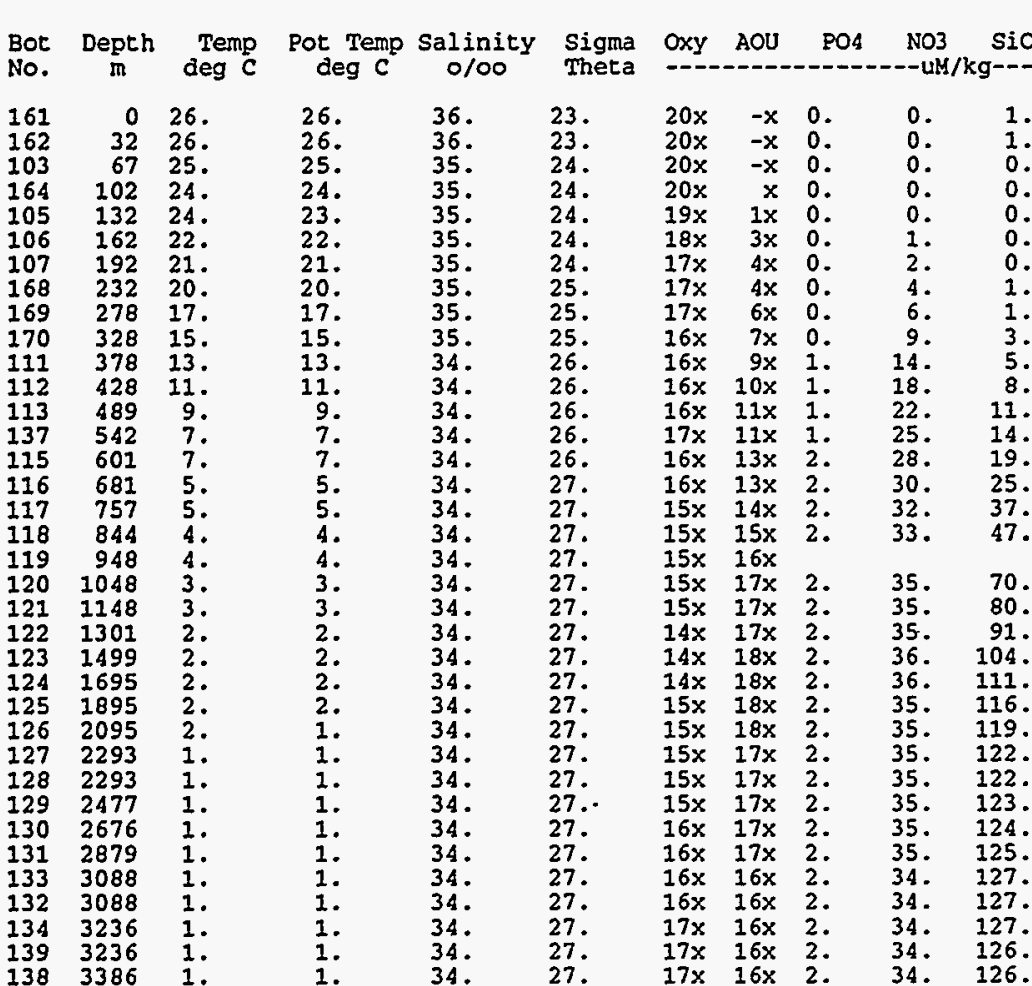


Lamont-Doherty Earth Observatory of Columbia University

Printed on $12 / 06 / 93$

Page 49 Project/Expedition is TUNES/2 WOCE P17C/P16C 1991

(PALK)S = Potent al Alkalinity $=($ TALK + NO3) $\times(35 / \mathrm{Sal})$ WOCE Line P16C station 220 Latilude 17-30.1S Longitude 150-29.9W Date 8/25/91 Bottom Depth 3604

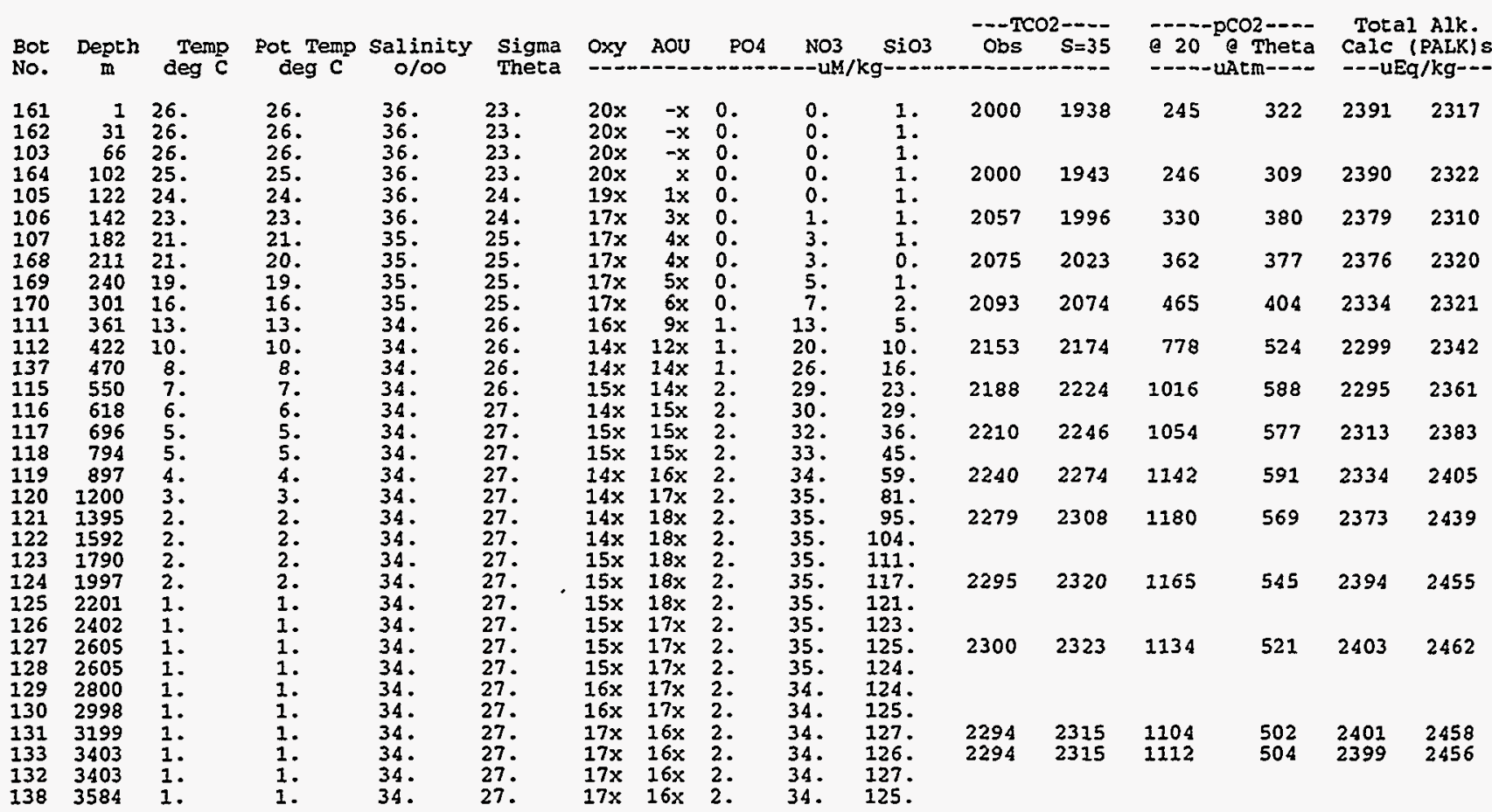




\section{INTERNAL DISTRIBUTION}

1. L. D. Bates

2. B. A. Berven

3. T. A. Boden

4. R. B. Cook

5. J. H. Cushman

6. R. M. Cushman

7. V. H. Dale

8. M. P. Farrell

9. D. E. Fowler

10. R. L. Graham

11. S. G. Hildebrand

12. G. K. Jacobs

13. P. Kanciruk

14. D. P. Kaiser

15. A. Kozyr

16. J. M. Loar

17. D. E. Reichle

18. F. E. Sharples

19. D. E. Shepherd

20-219. CDIAC

221. Central Research Library

222-223. ESD Library

224-225. Laboratory Records Department

226. Laboratory Records, RC

227. ORNL Patent Office

228. ORNL Y-12 Technical Library

\section{EXTERNAL DISTRIBUTION}

229. William Asher, Marine Sciences Laboratory, Pacific Northwest Laboratory, 1529 West Sequim Bay Road, Sequim, WA 98382

230. James R. Akse, Umpqua Research Company, P.O. Box 791-125 Volunteer Way, Myrtle Creek, OR 97457

231. S. S. Alexander, Pennsylvania State University, Department of Geosciences, 503 Deike Building, University Park, PA 16802

232. J. H. Allen, National Oceanic and Atmospheric Administration, National Geophysical Data Center Code E/GC2, 325 Broadway, Boulder, CO 80303 
233. D. Alvic, EERC/UT, Pellissippi Office, Ste. 100, 10521 Research Drive, Knoxville, TN 37932

234. Robert F. Anderson, Lamont-Doherty Earth Observatory, Columbia University, Palisades, NY 10964

235. Colin Attwood, Sea Fisheries Research Institute, Private Bag X2 Roggebaai, 8012, South Africa

236. Donald K. Atwood, NOAA/AOML/OCD, 4301 Rickenbacker Causeway, Miami, FL 33149

237. Rich Barber, Duke University of North Carolina Oceanographic Consortium, Duke University Marine Laboratory, Beaufort, NC 28516

238. R. C. Barry, University of Colorado, World Data Center A, Glaciology, CIRES, Campus Box449, Boulder, CO 80309-0449

239. Jim Bauer, Department of Oceanography, B-169, Florida State University, Tallahassee, FL 32306-3048

240. Robert Bidigare, University of Hawaii, 1000 Pope Road, Honolulu, HI 96822

241. Linda S. Bingler, Pacific Northwest Laboratories, Marine Sciences Laboratory, 1529 West Sequim Bay Road, Sequim, Washington 98382

242. Peter G. Brewer, Monterey Bay Aquarium Research Institute, 160 Central Avenue, Pacific Grove, CA 93950

243. John A. Brimble, UIC, Inc., P.O. Box 83, 1225 Channahon Road, Joliet, IL 60434-0863

244. Jose Joaquin Hernandex Brito, Facultad de Ciencias del Mar, Dep. Quimica, Universidad de las Palmas, AP. 550, Las Palmas 35017, Spain

245. Michelle Broido, Acting Director, Environmental Sciences Division, Office of Health and Environmental Research, Department of Energy, ER-74, 19901 Germantown Road, Germantown, MD 20874-1290

246. Otis B. Brown, University of Miami, 4600 Rickenbacker Causeway, Miami, FL 33149

247. Lutz Brugmann, Department of Geology and Geochemistry, Stockholm University, S-106 91 Stockholm, Sweden

248. Alexander S. Bychkov, Climate Chemistry Laboratory, 43, Baltiyskaya Street, Vladivostok, 690041 Russia

249. Robert H. Byrne, University of South Florida, Department of Marine Science ,140 Seventh Avenue South, St. Petersburg, FL 33701-5016

250. C-T.A. Chen, Institute of Marine Geology, National Sun Yat-Sen University, Kaohsiung, 80424, Taiwan ROC 
251. M. A. Chinnery, National Oceanic and Atmospheric Administration, National Geophysical Data Center Code E/GC2, 325 Broadway, Boulder, CO 80303

252-256. David W. Chipman, Lamont-Doherty Earth Observatory of Columbia University, Climate/Environment/Ocean Division, RT 9W, Palisades, NY 10964-8000

257. Y. Collos, Laboratoire d'Hydrobiologie, Univ. Montpellier, CC093 34095 Montpellier Cedex 5, France

258. Claire Copin-Montegut, Laboratoire de Physique et Chimie Marines, Universite Pierre et Marie Curie, Quai de la Darse BP 8, 06230 Villefranche sur Mer, France

259. Greg Cutter, Department of Oceanography, Old Dominion University, Norfolk, VA 23529-0276

260. Giovanni Daneri, Dept De Oceanografia y Biologia Pesquera, CEA Universidad Del Mar, Amunategui 1838, Vina Del Mar, Chile

261. Hein J. W. de Baar, Netherlands Institute for Sea Research, P.O. Box 59 1790, Ab den Burg, Texel, The Netherlands

262. Thomas Dickey, University of Southern California, Ocean Physics Group, Los Angeles, CA 90007

263. Andrew G. Dickson, University of California, Marine Physical Laboratory-0902 9500 Gilman Drive, La Jolla, CA 92093-0902

264. Scott Doney, Oceanography Section, NCAR, PO Box 3000, Boulder, CO 80307

265. John P. Downing, Battelle Marine Sciences Laboratory, Battelle Pacific Northwest Laboratories, 439 West Sequim Bay Road, Sequim, WA 98382

266. W. Draeger, EROS Data Center, U.S. Geological Survey, Sioux Falls, SD 57198

267. M. Dryer, National Oceanic and Atmospheric Administration, Space Environmental Lab., ERL/OAR, R/E/SE, 320 Broadway, Boulder, CO 80303

268. Hugh W. Ducklow, Woods Hole Oceanographic Institution, Clark 4th Floor, Woods Hole, MA 02543

269. Brian J. Eadie, Great Lakes Environmental Research Laboratory, NOAA U.S. Department of Commerce, 2205 Commonwealth Blvd., Ann Arbor, MI 48105

270. J. F. Farvolden, Professor, Department of Earth Sciences, University of Waterloo, Waterloo, Ontario N2L 3G1 Canada

271. Richard Feely, National Oceanic \& Atmospheric Administration, Pacific Marine Envir. Lab, 7600 Sand Point Way, NE, Seattle, WA 98115

272. Gene C. Feldman, NASA/GSFC, Code 936, Building 28, Room W161B, Goddard Space Flight Center, Greenbelt, MD 20771 
273. J. Filson, National Earthquake Information Center, U.S. Geological Survey, Denver Federal Center, P.O. Box 20546, Denver, CO 80225

274. Martin Q. Fleisher, Dept. of Geochemistry, Lamont-Doherty Earth Observatory, Columbia University, Palisades, NY 10964

275. Jerry F. Franklin, Bloedel Professor of Ecosystem Analysis, College of Forest Resources, University of Washington, Anderson Hall (AR-10), Seattle, WA 98195

276. Diana W. Freckman, Director, College of Natural Resources, 101 Natural Resources Building, Colorado State University, Fort Collins, CO 80523.

277. Richard H. Gammon, University of Washington, Chemistry Department, BG-10, Seattle, WA 98195

278. Wilford D. Gardner, Department of Oceanography, Texas A \& M University, College Station, TX 77843

279. Christopher Garside, Bigelow Laboratory for Ocean Science, McKnown Point, West Boothbay Harbor, ME 04575

280. Jean-Pierre Gattuso, Observatoire Oceanologique European, Avenue Saint-Martin, MC98000 , Monaco

281. Bob Gershey, Bedford Institute of Oceanography, Box 10061 Challenger Drive/Shannon Park, Dartmouth, Nova Scotia, Canada B2Y 4A2

282. Jorunn S. Gislefoss, Radiological Dating Laboratory, The Norwegian Institute of Technology, N-7034 Trondheim-NTH, Norway

283-287. John G. Goddard, Lamont-Doherty Earth Observatory of Columbia University, ClimateEnviornment/Ocean Division, RT 9W, Palisades, NY 10964-8000

288. Lars G. Golmen, Norwegian Institute for Water Research, Regional Office, Bergen, Thormohlensgt. 55 5008, Bergen, Norway

289-293. Catherine Goyet, Chemistry Dept., Woods Hole Oceanographic Institution, Clark 461, Woods Hole, MA 02543

294. S. Graves, National Aeronautics and Space Administration Headquarters Code SED, 600 Independence Avenue, Washington, DC 20546

295. J. L. Green, National Space Science Data Center, NASA Goddard Space Flight Center, Code 630.2, Greenbelt, MD 20771

296. Elizabeth Gross, SCOR, Department of Earth and Planetary Sciences, The John Hopkins University, Baltimore, MD 21218

297. Nicolas Gruber, Climate and Environmental Physics, Physics Insitute, University of Bern, Sidlerstr.5, CH-3012 Bern, Switzerland 
297. Peter Guenther, Scripps Institution of Oceanography, University of California, Geological Research Div. 0220, 9500 Gilman Drive, La Jolla, CA 92093-0220

298. K. D. Hadeen, National Oceanic and Atmospheric Administration, NESDIS/NCDC, Federal Building MC E/CC, Asheville, NC 28801

299. Koh Harada, National Institute for Resources and Environment, 16-3 Onogawa, Tsukuba, Ibaraki 305, Japan

300. Akira Harashima, National Institute for Environmental Studies, 16-2 Onogawa, Tsukuba, Ibaraki 305, Japan

301. R. C. Harriss, Institute for the Study of Earth, Oceans, and Space, Science and Engineering Research Building, University of New Hampshire, Durham, NH 03824

302. Mette Hein, Freshwater Biological Laboratory, Helsingoersgade 51, DK-3400 Hilleroed, Denmark

303. James C. Hendee, Data Manager, NOAA/AOML/OCD, 4301 Rickenbacker Causeway, Miami, FL 33149

304. W. J. Hinze, Purdue University, Department of Earth and Atmospheric Sciences, West Lafayette, IN 47907

305. Hilary Hodgson, DSC, Special Acquisitions, British Library, Boston Spa, Wetherby, West Yorkshire LS23 7BQ, United Kingdom

306. Huasheng Hong, Research Centre, The Hong Kong University of Science \& Technology, Clear Water Bay, Kowloon, Hong Kong

307. Masao Ishii, Meteorological Research Institute, 1-1 Nagamine, Tsukuba, Ibaraki, 305, Japan

308. John Jamerlan, Customer and Applications Support Technician, Europa Scientific, 1776 Mentor Avenue, Cincinnati, OH 45212-3597

309. Kenneth M. Johnson, Brookhaven National Laboratory, OASD Bldg. 318, Upton, NY 11973

310. W. Keith Johnson, Centre For Ocean Climate Chemistry, Institute of Ocean Sciences, 9860 W. Saanich Road, Sidney, BC, Canada V8L 4B2

311. Fortunat Joos, Physics Institute, KUP, Sidlerstr. 5, CH-3012 Bern, Switzerland

312. G. Y. Jordy, Director, Office of Program Analysis, Office of Energy Research, ER-30, G-226, U.S. Department of Energy, Washington, DC 20585

313. Terrence M. Joyce, WOCE Hydrographic Program Office, Woods Hole Oceanographic Institution, Woods Hole, MA 02543

314. Susan Kadar, Clark 461, Woods Hole Oceanographic Institution, Woods Hole, MA 02543 
315. Dong-Jin Kang, Marine Natural Products Chemistry Laboratory, Ansan P.O. Box 29, Seoul 425-600, Korea

316. David Karl, Department of Oceanography, University of Hawaii, 1000 Pope Road, Honolulu, HI 96822

317. Charles D. Keeling, Scripps Institution of Oceanography, University of California San Diego, Geological Research Division, A020, 2314 Ritter Hall, La Jolla, CA 92093-0220

318. Kimberly C. Kelly, PMEL/NOAA, 7600 Sandpoint Way NE, Building 3, Seattle, WA 98115

319. Stephan Kemp, Geologisch-Palaontologisches Institut, H Darmstadt, Schnittspahnstrabe 9, 64287 Darmstadt, Gemany

320. Robert Key, Princeton University, Geology Department, Princeton, NY 08544

321. Kyung-Ryul Kim, Ph.D., Department of Oceanology, Seoul National University, Seoul 151-742, Korea

322. Bert Klein, GIROQ Universite, Laval Pav., Vachon, Quebec PQ, Canada G1K 7P4

323. Anthony H. Knap, BBSR, Inc., Ferry Reach 1-15, Bermuda

324. S. Krishnaswami, Physical Research Laboratory, Navrangpura, Ahmedabad-380009, India

325. D. Lauer, EROS Data Center, U.S. Geological Survey, Sioux Falls, SD 57198

326. Margaret Leinen, Graduate School of Oceanography, University of Rhode Island, Kingston, RI 02882-1197

327. S. Levitus, NOAA/National Oceanographic Data Center, 1825 Connecticut Avenue, NW, Washington, DC 20235

328. Ernie Lewis, Oceanographic Sciences Division, Brookhaven National Laboratory, Upton, NY 11973

329. Marlon Lewis, Department of Oceanography, Dalhousie University, Halifax, Nova Scotia $\mathrm{B} 3 \mathrm{H}$ 4J1, Canada

330. A. M. Linn, Program Officer, BESR, National Academy of Sciences, Harris Building 372, 2101 Constitution Avenue NW, Washington, DC 20418

331. Hugh D. Livingston, Woods Hole Oceanographic Institution, Clark 4, Woods Hole, MA 02543

332. M. S. Loughridge, National Oceanic and Atmospheric Administration, National Geophysical Data Center, Code E/GC3, 325 Broadway, Boulder, CO 80303

333. Clarence Low, NASA-Ames Research Center, Mail Stop 239-4, Moffett Field, CA 94035-1000 
334. Bram Majoor, Netherlands Institute for Sea Research, P.O. Box 59, $1790 \mathrm{Ab}$ den Burg, Texel, The Netherlands

335. H. M. McCammon, Acting Deputy Director, Environmental Sciences Division, Office of Health and Environmental Research, Office of Energy Research, ER-74, U.S. Department of Energy, 19901 Germantown Road, Germantown, MD 20874-1290

336. James J. McCarthy, Museum of Comparative Zoology, Harvard University, 26 Oxford Street, Cambridge, MA 02139

337. Dennis McGillicuddy, Physical Oceanography Department, Woods Hole Oceanographic Institution, Clark 205A, Woods Hole, MA 02543

338. Nicolas Metzl, Universite Pierre et Marie Curie - Paris 6, Laboratoire de Physique et Chimie Marines, T24-25 - Case 134-4, place Jussieu-75252, Cedex 05, France

339. Frank J. Millero, University of Miami, RSMAS, 4600 Rickenbacker Causeway, Miami, FL $33149-1098$

340. DongHa Min, Trace Gas Lab, Department of Oceanography, Seoul National University, Seoul, Korea (151-742)

341. Dr. Ludger Mintrop, Marine Chemist, Institute for Marine Research, Marine Chemistry Department, Duesternbrooker Weg 20, D-214105 Kiel, Germany

342. M. Nicole Momzikoff, Bibliothecaire, Institut Oceanographique Bibliotheque, 195, rue Saint-Jacques, F 75005 Paris, France

343. Pedro M. S. Monteiro, Department of Oceanography, University of Cape Town, Rondebosch 7700, South Africa

344. Lloyd Moore, NOAA/AOML/OCD, 4301 Rickenbacker Causeway, Miami, FL 33149

345. Mary Morris, The Martin Ryan Marine Science Institute, University College, Galway, Ireland

346. John W. Morse, Department of Oceanography, Texas A \& M University, College Station, TX 77843-3148

347. Peter J. Muller, Universitat Bremen, Fachbereich Geowissenschaften, Postfach 330 440, D-28334 Bremen, Germany

348. Shohei Murayama, Atmospheric Environment Division, National Institute for Resources and Environment, 16-3 Onogawa, Tsukuba, Ibaraki 305 Japan

349. Paulette P. Murphy, PMEL/NOAA, 7600 Sandpoint Way NE, Building 3, Seattle, WA 98115

350. James W. Murray, School of Oceanography, WB-10, University of Washington, Seattle, WA 98195 
351. Jae Ryoung Oh, Chemical Oceanography lab, KORDI, An San P.O. Box 29, Seoul $425-$ 600 , Korea

352. Jon 'Olafsson, Marine Research Institute, P.O. Box 1390, Skulagata 4, 121 Reykjavik, Iceland

353. Curtis R. Olsen, US Department of Energy, Environmental Sciences Division, ER-74, Office of Energy Research, 19901 Germantown Road, Germantown, MD 20874-1290

354. R. H. Olsen, Vice President for Research, University of Michigan, Medical Science Building II, \#5605, 1301 East Catherine Street, Ann Arbor, MI 48109-0620

355. Michael J. Orren, Professor, Head. Dept. Of Oceanography, Universtiy College Galway, 80 Harcourt Street, Dublin 2, Ireland

356. Claude Oudot, Centre ORSTOM de Cayenne, B. P. 165-97323, CAYENNE Cedex, French Guyana

357. J. T. Overpeck, National Oceanic and Atmospheric Administration, National Geophysical Data Center, Paleoclimatology Program, 325 Broadway E/EC, Boulder, CO 80303

358. Bobbi Parra, US Department of Energy, Environmental Sciences Division, Office of Health and Environmental Research, 19901 Germantown Road, Germantown, MD 208741290

359. Ari Patrinos, Associate Director, Office of Health and Environmental Research, U.S. Department of Energy, 19901 Germantown Road, Germantown, MD 20874-1290

360. Kay Pegler, Universitat Hamburg, Institut fur Biogeochemie und Meereschemie, Jungiusstrasse, 6, 1000 Hamburg 36, Germany

361. T-H Peng, Ocean Chemistry Division, NOAA/AOML/OCD, 4301 Rickenbacker Causeway, Miami, FL 33149

362. Dr. Fiz F. Perez, Consejo Superior de Investigaciones Cientificas, Instituto de Investigacions Marinas, Eduardo Cabello, 6-36208 VIGO (Espana)

363. Trevor Platt, Department of Fisheries \& Oceans, Bedford Institute of Oceanography, P.O. Box 1006, Dartmouth, Nova Scotia B2Y 4A2, Canada

364. Alain R. H. Poisson, Univ. Pierre et Marie Cuie, Lab de Phys. et Chimie Marines, Case 134, 4 Place Jussieu, 75252 Paris Cedex 05, France

365. Barbara Preselin, Dept. of Biological Sciences, University of California, Santa Barbara, CA 93106

366. Paul Quay, School of Oceanography, WB-10, University of Washington, Seattle, WA 98195

367. S. Ichtiaque Rasool, IGBP Data and Information System Office, Universite Paris, Tour 26, 4 Etage, Aile 26-16, 4 Place Jussieu, 75230 Paris, Cedex 06, France 
368. Clare Reimers, Institute of Marine and Coastal Sciences, Rutgers University, P.O. Box 231, New Brunswick, NJ 08903-0231

369. Joachim Ribbe, Flinders University of S. A., School of Earth Sciences, GPO Box 2100, Adelaide, 5001 S. A., Australia

370. Michael R. Riches, Environmental Sciences Division, Office of Health and Environmental Research, ER-74, U.S. Department of Energy, 19901 Germantown Road, Germantown, MD 20874-1290

371. Aida F. Rios, Consejo Superior de Investigaciones Cientifican, Instituto de Investigacions Marinas, Eduardo Caballo 6-36208, Vigo, Spain

372. Marilyn Roberts, NOAA/PMEL, 7600 Sandpoint Way NE, Building 3, Seattle, WA 98115

373. Jane Robertson, University of Wales, Department of Geology, P.O. Box 914, Cardiff CF1 3YE, United Kingdom

374. Carol Robinson, University of Wales: Bangor, School of Ocean Sciences, Menai Bridge, Gwynedd LL59 5EY, United Kingdom

375-379. Stephany Rubin, Lamont-Doherty Earth Observatory of Columbia University, Ulimate/Environment/Ocean Division, RT 9W, Palisades, NY 10964-8000

380. Christopher Sabine, Princeton University, Geology Dept./Guyot Hall, Princeton, NJ 08544

381. Dan Sadler, Univerrsity of Hawaii, 1000 Pope Road, Honolulu, HI 96822

382. Ray Sambrotto, Lamont-Doherty Earth Observatory, Columbia University, P.O. Box 1000, Palisades, NY 10964

383. Jorge L. Sarmiento, Universitat Bern, Physikalisches Institut, Abteilung KUP, Sidlerstrasse 5, 3012 Bern, Switzerland

384. Tatyana G. Sazhina, P. Shirshov Institute of Oceanology, Russian Academy of Sciences, 23, Krasikova Str., Moscow 117218 Russia

385. Claire L. Schelske, Department of Fisheries and Aquaculture, University of Florida, 7922 W 71st Street, Gainesville, FL 32606

386. Bernd Schneider, Institut fur Ostseeforschung, SeestraBe 15, Rostock-Warnemunde, Germany

387. Alan Shiller, Center for Marine Science, University of Southern Mississippi, Stennis Space Center, MS 39529

388. Kiminori Shitashima, Environmental Science Department, Abiko Research Laboratory, Central Research Institute of Electric Power Industry, 1646, Abiko, Abiko City, Chiba, 270-11, Japan 
389. A. L. Shumbera, National Oceanic and Atmospheric Administration, WDC-A for Meteorology, National Climatic Data Center, Federal Building MC E/CC, Asheville, NC 28801

390. Nelson Silva, Escuela de Ciencias del Mar, Universidad Catolica de Valparaiso, Casilla 1020, Valparaiso, Chile

391. Sharon Smith, RSMAS, University of Miami, 4600 Rickenbacker Causeway, Miami, FL 33149

392. Michel H. C. Stoll, Centre for Environmental and Resources Studies, Hoeyteknologisenteret University of Bergen, N-5020 Bergen, Norway

393. Eric T. Sundquist, U.S. Geological Survey, Branch of Atlantic Marine Geology, Quissett Campus, Woods Hole, MA 02543

394-399. Stewart C. Sutherland, Lamont-Doherty Earth Observatory of Columbia University, Climate/Environment/Ocean Division, RT 9W, Palisades, NY 10964-8000

400. James H. Swift, Scripps Institution of Oceanography, University of California, San Diego Oceanographic Data Facility, 9500 Gilman Drive, La Jolla, CA 92093-0124

401-405. Taro Takahashi, Lamont-Doherty Earth Observatory of Columbia University, Climate/Environment/Ocean Division, RT 9W, Palisades, NY 10964-8000

406. Lynne D. Talley, Scripps Institution of Oceanography, UCSD 0230, 9500 Gilman Drive, La Jolla, CA 92075-0230

407. Pavel Ya. Tishchenko, Ph.D., Senior Researcher, Processes of Mineral formation Laboratory, Pacific Oceanological Institute Far Eastern Branch Russian Academy of Sciences, 43 Baltiyskaya Street, Vladivostok, 690041 Russia

408. James F. Todd, NOAA/OAR Office of Global Programs, Room 4142, SSMC-1, 1335 East-West Highway, Silver Spring, MD 20910

409. Jane Tucker, Marine Biological Laboratory, Woods Hole, MA 02543

410. David Turner, Department of Analytical and Marine Chemistry, University of Goteborg, S-41296 Goteborg, Sweden

411. J. Val Klump, Center for Great Lakes Studies, University of Wisconsin, 600 East Greenfield Avenue, Milwaukee, WI 53204

412. Michiel Rutgers van der Loeff, Alfred Wwegener Institute for Polar and Marine Research, Columbusstrasse 2855, Bremerhaven, Germany

413. Douglas W. R. Wallace, Brookhaven National Laboratory, Oceanographic Sciences Division, Bldg. 318, Upton, NY 11973

414. Richard H. Wanninkhof, NOAA/AOML/OCD, 4301 Rickenbacker Causeway, Miami, FL 33149 
415. Bess B. Ward, Marine Sciences Program, University of California, Santa Cruz, CA 95064

416. Richard Weisburd, National Institute for Environmental Studies, 16-2 Onogawa, Tsukuba, Ibaraki, 305, Japan

417. Ray F. Weiss, University of California, Scripps Institute of Oceanography, Mail code A020, Room 2271, Ritter Hall, La Jolla, CA 92093

418. Richard J. Wilke, Brookhaven National Laboratory, Oceanographic Sciences Division, Bldg. 318, Upton, NY 11973

419. Christopher Winn, Scripps Institution of Oceanography, Marine Physical Lab, 9500 Gilman Drive, La Jolla, CA 92093-0230

420. Amos Winter, Ph.D., Associate Professor, Marine Geology, University of Puetro Rico, Department of Marine Sciences, Mayaguez, Puerto Rico 00681-5000

421. F. J. Wobber, Environmental Sciences Division, Office of Health and Environmental Research, Office of Energy Research, ER-74, U.S. Department of Energy, 19901 Germantown Road, Germantown, MD 20874-1290

422. C. S. Wong, Centre for Ocean Climate Chemistry, Institute of Ocean Sciences, P.O. Box 6000 , Sidney, British Columbia V8L 4B2, Canada

423. L. Xu, Department of Oceanography, Xiamen University, Xiamen, Fujian, Peoples Republic of China

424. Evgeniy V. Yakushev, Ph.D., Senior Associate Scientist, P. P. Shirshov Institute of Oceanology, Russian Academy of Sciences, 26 Krasikova Street, 109017 Moscow, Russia

425. Masumi Yamamuro, Marine Geology Department, Geological Survey of Japan, 1-1-3 Higashi, Tsukuba, Ibaraki 305, Japan

426. D. B. Yang, Korea Ocean Research and Development Institute, Ansan, P.O. Box 29, Seoul, 425-600, Korea

427. Office of Assistant Manager for Energy Research and Development, U.S. Department of Energy Oak Ridge Operations, P. O. Box 2001, Oak Ridge, TN 37831-8600

428-429. Office of Scientific and Technical Information, P. O. Box 62, Oak Ridge, TN 37831 
